\title{
The structure and organisation of EU law in the field of direct taxes
}

Citation for published version (APA):

Schaper, M. G. H. (2012). The structure and organisation of EU law in the field of direct taxes. [Doctoral Thesis, Maastricht University]. IBFD. https://doi.org/10.26481/dis.20121218ms

Document status and date:

Published: 01/01/2012

DOI:

10.26481/dis.20121218ms

Document Version:

Publisher's PDF, also known as Version of record

\section{Please check the document version of this publication:}

- A submitted manuscript is the version of the article upon submission and before peer-review. There can be important differences between the submitted version and the official published version of record.

People interested in the research are advised to contact the author for the final version of the publication, or visit the DOI to the publisher's website.

- The final author version and the galley proof are versions of the publication after peer review.

- The final published version features the final layout of the paper including the volume, issue and page numbers.

Link to publication

\footnotetext{
General rights rights.

- You may freely distribute the URL identifying the publication in the public portal. please follow below link for the End User Agreement:

www.umlib.nl/taverne-license

Take down policy

If you believe that this document breaches copyright please contact us at:

repository@maastrichtuniversity.nl

providing details and we will investigate your claim.
}

Copyright and moral rights for the publications made accessible in the public portal are retained by the authors and/or other copyright owners and it is a condition of accessing publications that users recognise and abide by the legal requirements associated with these

- Users may download and print one copy of any publication from the public portal for the purpose of private study or research.

- You may not further distribute the material or use it for any profit-making activity or commercial gain

If the publication is distributed under the terms of Article $25 \mathrm{fa}$ of the Dutch Copyright Act, indicated by the "Taverne" license above, 
THE STRUCTURE AND ORGANISATION OF EU LAW IN THE FIELD OF DIRECT TAXES 
ISBN: 9789056814007

NUR: 826

Printed in the Netherlands by Océ Business Services.

Cover design by Océ Business Services.

(C) 2012 by M.G.H. Schaper.

All rights reserved. No part of this publication may be reproduced, stored in a retrieval system, or transmitted, in any form or by any means, electronic, mechanical, photocopying, recording, or otherwise, without the prior permission in writing from the author. 


\title{
The Structure and Organisation of EU Law in the Field of Direct Taxes
}

\author{
DISSERTATION \\ to obtain the degree of Doctor at \\ Maastricht University, \\ on the authority of the Rector Magnificus, \\ Prof. dr. L.L.G. Soete \\ in accordance with the decision of the Board of Deans, \\ to be defended in public \\ on Tuesday 18 December 2012, at 14:00 hours
}

by

Marcel Guido Herwig Schaper 
Supervisor:

Prof. dr. R.G. Prokisch

Assessment Committee:

Prof. dr. R.H.C. Luja (Chairman)

Prof. dr. H.T.P.M. van den Hurk

Prof. dr. P. Pistone (Università di Salerno/Wirtschaftsuniversität Wien) 
Voor mijn ouders, mijn zusje en broertje 



\section{Outline Contents}

Acknowledgements ............................................................................ xi

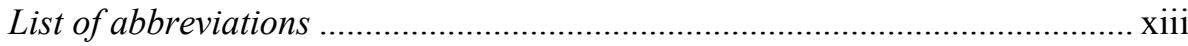

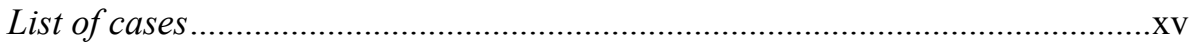

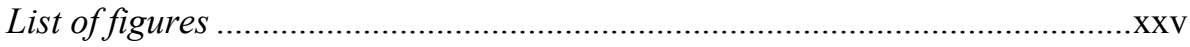

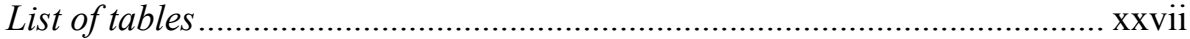

PART I INTRODUCTION

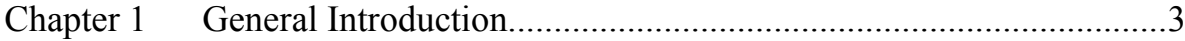

Part II The Structure and Organisation of the CASE LAW

Chapter 2 Introduction to Part II ........................................................ 17

Chapter 3 Properties of the Case Law .........................................................51

Chapter 4 A Network Analysis of the Case Law .....................................121

PART III The BALANCED Allocation of TAXING Powers

Chapter $5 \quad$ Introduction to Part III............................................................223

Chapter 6 The BAOTP Standard as Such ............................................245

Chapter 7 Relations with Other Justifications.........................................295

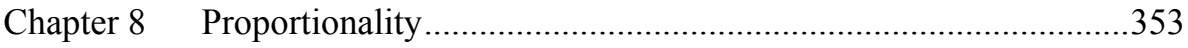

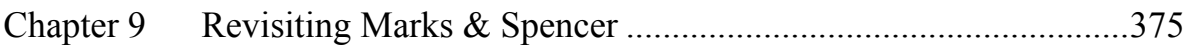

PART IV CONCLUSION

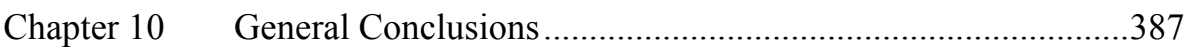

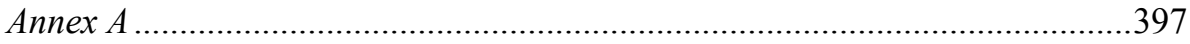

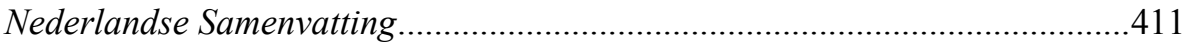

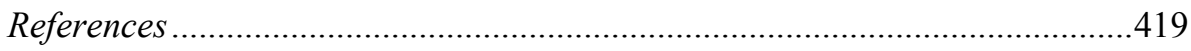

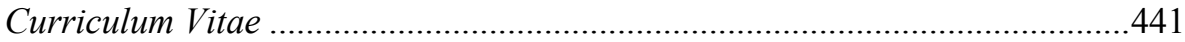





\section{Contents}

Acknowledgements ............................................................................... $\mathrm{xi}$

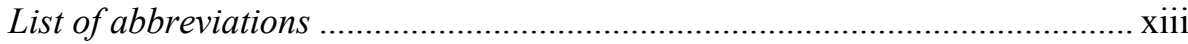

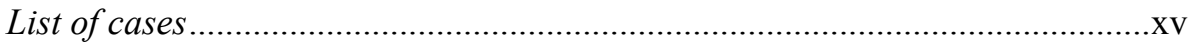

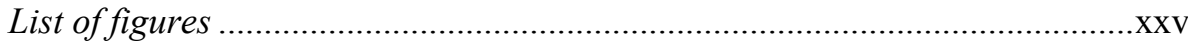

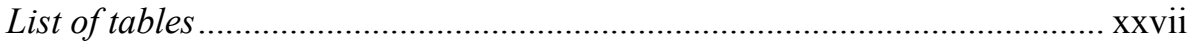

PART I INTRODUCTION

Chapter 1 General Introduction...............................................................

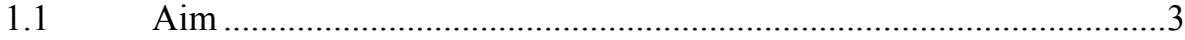

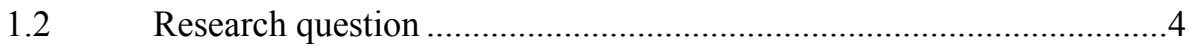

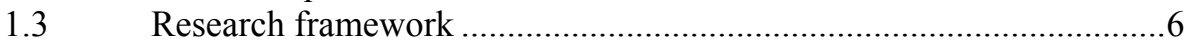

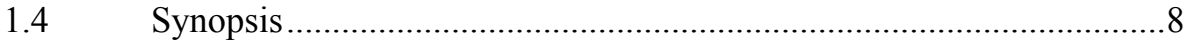

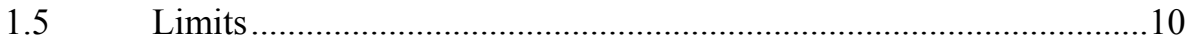

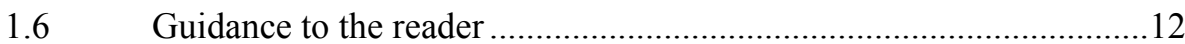

Part II The Structure and Organisation of the CASE LAW

Chapter 2 Introduction to Part II .................................................................

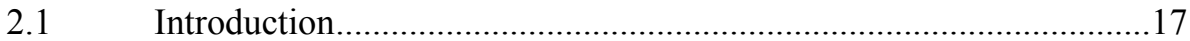

$2.2 \quad$ Research questions........................................................................ 19

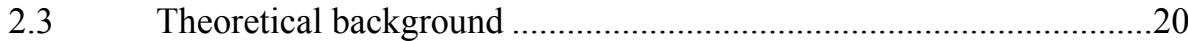

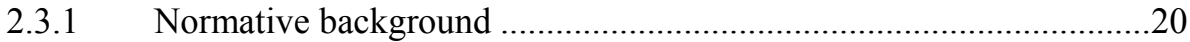

2.3.1.1 Choice against an attitudinal model of judicial decision making........20

2.3.1.2 Montesquieu and the role of the judge............................................20

2.3.1.3 A view from European political science on judicial governance ........23

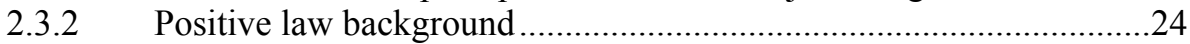

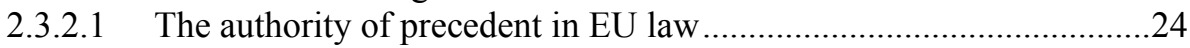

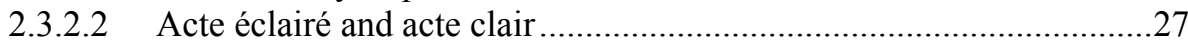

2.3.2.3 Member State liability for disregard of precedent …………..............29

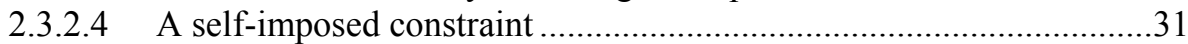

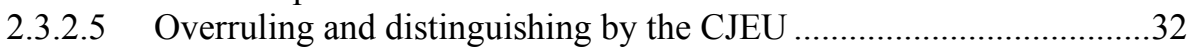

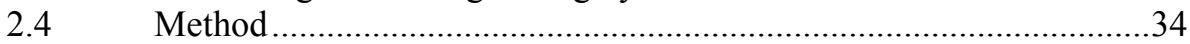

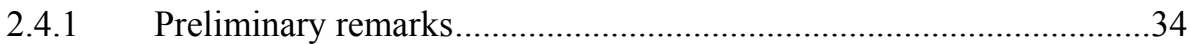

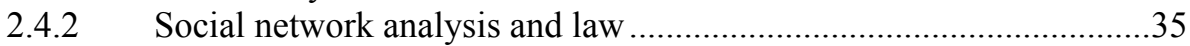

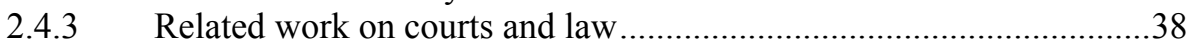

2.4.4 Self-organisation of complex networks ...............................................39 


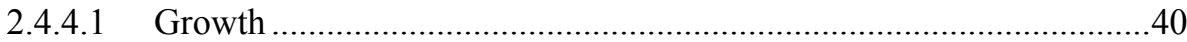

2.4.4.2 Preferential attachment ...............................................................40

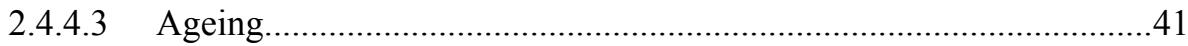

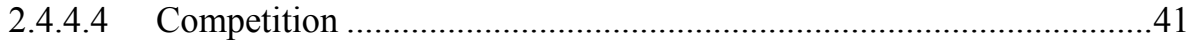

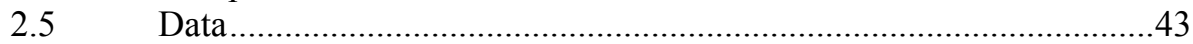

2.5.1 What are direct taxes in EU law?....................................................43

2.5.2 The sample of cases ................................................................. 47

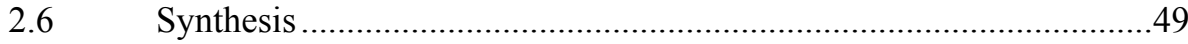

Chapter 3 Properties of the Case Law ......................................................51

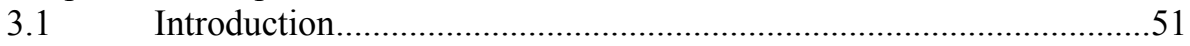

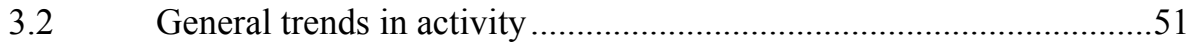

3.3 Member States before the Court ....................................................55

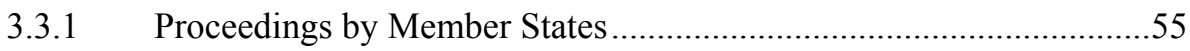

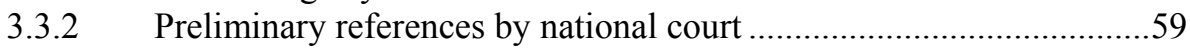

3.4 Subject matter of the proceedings ...........................................61

3.4.1 National subject matter ...................................................................61

3.4.1.1 Subject matter by OECD classification ..........................................61

3.4.1.2 The relevance of DTCs ............................................................6 63

3.4.2 EU law subject matter..................................................................64

3.4.2.1 The interpretation of the TFEU.......................................................65

3.4.2.1.1 The basic rights of Articles 18 and 21 TFEU ..................................65

3.4.2.1.2 The freedom of establishment......................................................69

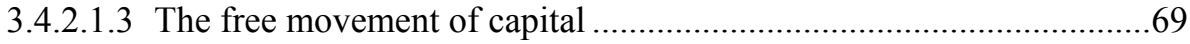

3.4.2.1.4 The third country dimension to freedom of movement ...................... 71

3.4.2.1.5 The freedom to provide services....................................................... 84

3.4.2.1.6 The free movement of workers ....................................................... 85

3.4.2.2 The interpretation of the EU direct tax directives ..............................86

3.4.2.2.1 The Parent-Subsidiary Directive (90/435/EEC) ..............................86

3.4.2.2.2 The Mergers Taxation Directive $(2009 / 133 / \mathrm{EC})$................................8

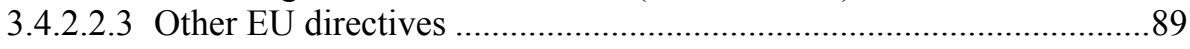

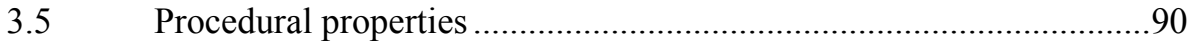

3.5.1 Bench hearing action ............................................................ 90

3.5.2 Opinions of the Advocates General ............................................92

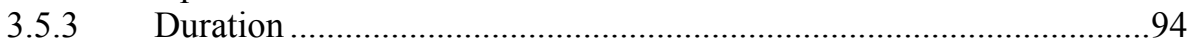

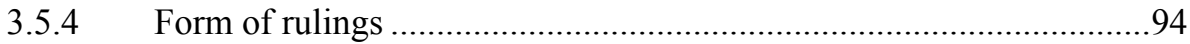

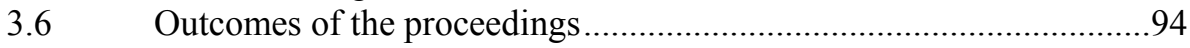

3.6.1 Taxpayer rate of success ...........................................................94

3.6.2 Grounds held against taxpayers ..................................................97

3.6.2.1 EU law does not confer the invoked right........................................98

3.6.2.2 The legal effects do not amount to a restriction...............................102

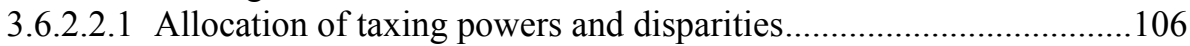

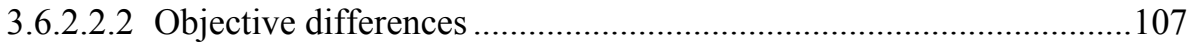

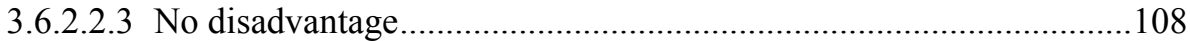

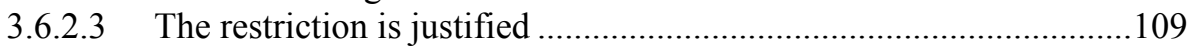

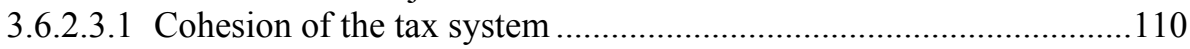




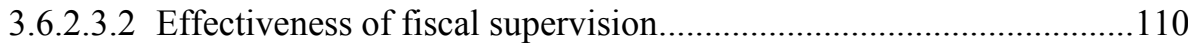

3.6.2.3.3 The balanced allocation of taxing powers......................................112

3.6.2.3.4 The need to prevent tax avoidance and evasion.................................112

3.7 Reception in the academic literature...............................................113

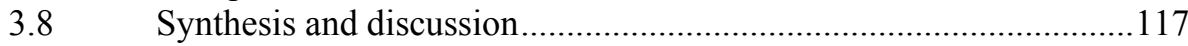

Chapter 4 A Network Analysis of the Case Law ...........................................121

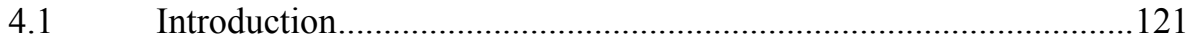

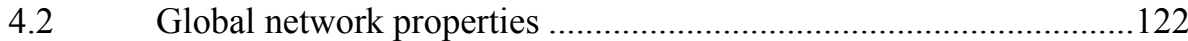

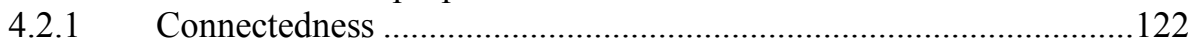

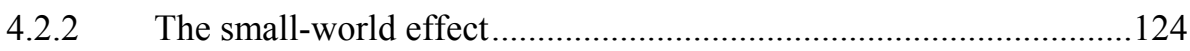

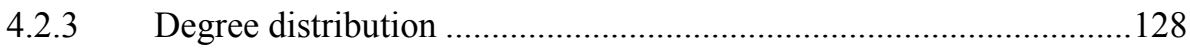

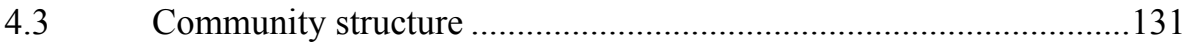

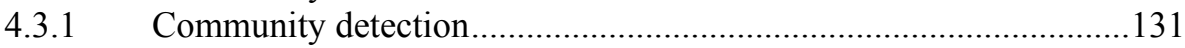

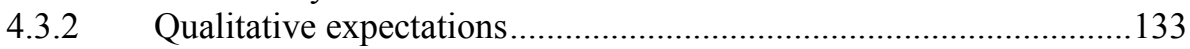

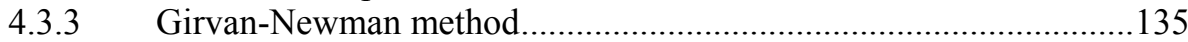

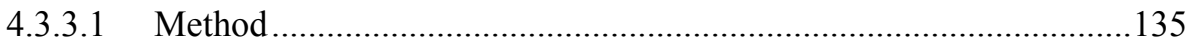

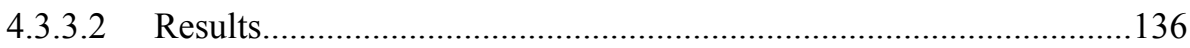

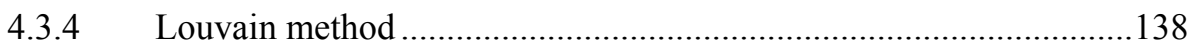

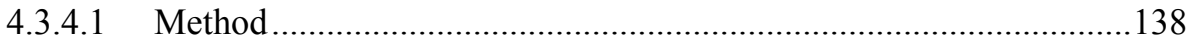

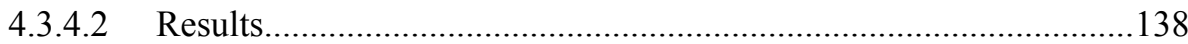

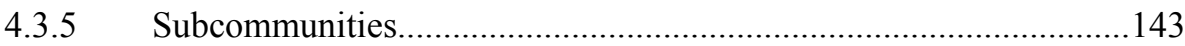

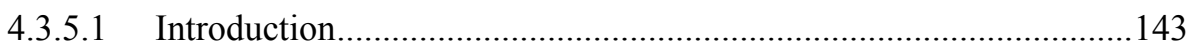

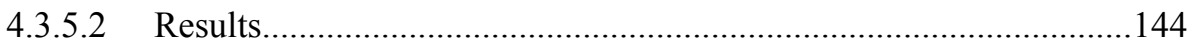

4.3.5.3 Qualitative analysis of community 1 ...............................................146

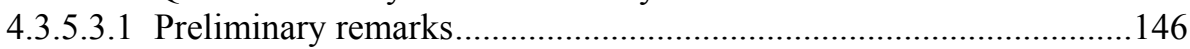

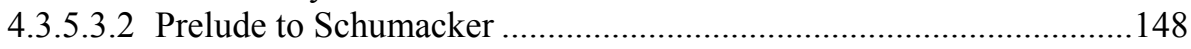

4.3.5.3.3 The Sotgiu/Schumacker line of authority .........................................149

4.3.5.3.4 Capital movement and the EEA Agreement .....................................158

4.3.5.3.5 Preferential tax rates and capital transactions ..................................159

4.3.5.4 Qualitative analysis of community 3 ……......................................160

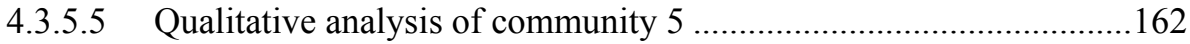

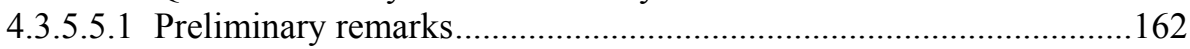

4.3.5.5.2 The Singh/De Groot line of authority ..............................................162

4.3.5.5.3 Negative income and progressivity of tax rates .................................. 165

4.3.5.5.4 Tax benefits for private residences ...................................................167

4.3.5.5.5 Renneberg and Commission v Germany (C-269/07)........................ 168

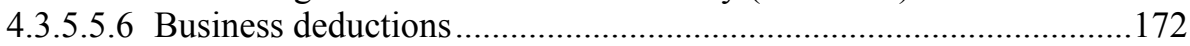

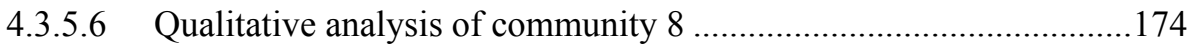

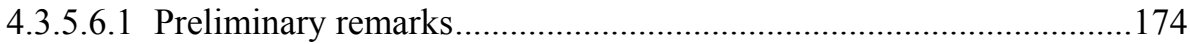

4.3.5.6.2 Concepts of the Parent-Subsidiary Directive .....................................175

4.3.5.6.3 Dividends and liability for damages ...............................................177

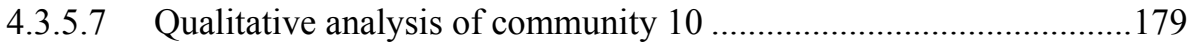

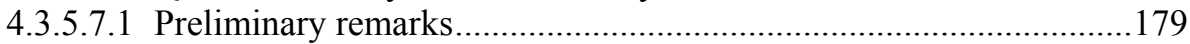

4.3.5.7.2 Taxation of pensions and annuities................................................. 180

4.3.5.7.3 Cross-border investment and fiscal cohesion.....................................183 
4.3.5.7.4 Tax benefits solely for activities on national territory ..................... 188

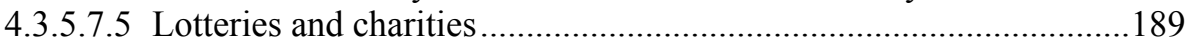

4.3.5.7.6 Effective fiscal supervision and cross-border investments ................189

4.4 The most important precedents ...................................................191

4.4.1 Method ..................................................................................... 191

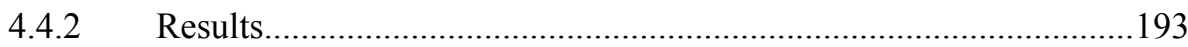

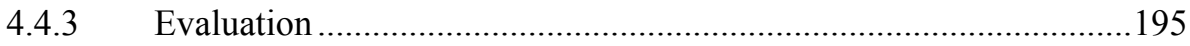

4.5 The most important judicial rules ...........................................196

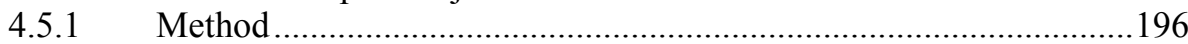

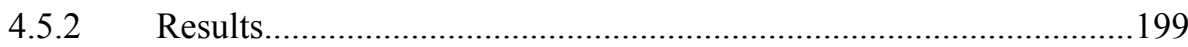

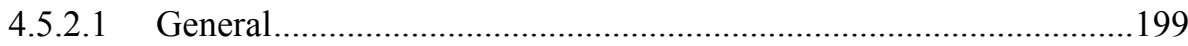

4.5.2.2 DTC neutralisation of restrictive dividend withholding taxes ..........200

4.5.2.2.1 Introduction................................................................................20

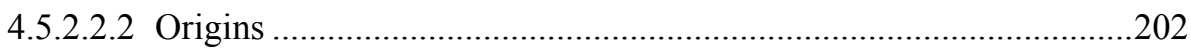

4.5.2.2.3 The criterion of regulatory control...........................................205

4.5.2.2.4 Conditions of effective neutralisation ...........................................207

4.5.2.2.5 The EFTA Court judgment in Fokus Bank ...................................211

4.5.2.2.6 Comparison with prior research....................................................2. 212

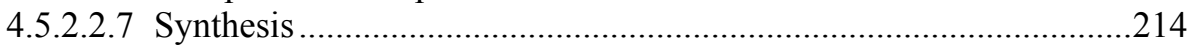

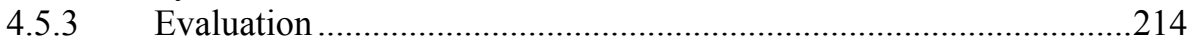

4.6 The reception of rules of general EU law ....................................215

4.6.1 Quantitative analysis ................................................................2. 215

4.6.1.1 Structural openness but organisational closure ...............................215

4.6.1.2 The most important non-tax precedents......................................218

4.6.2 Qualitative analysis...............................................................220

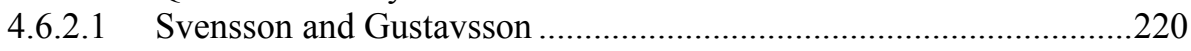

4.6.2.2 Commission v Belgium (C-478/98) .............................................22

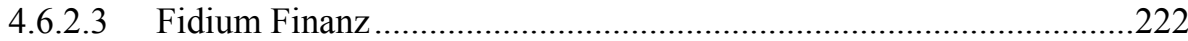

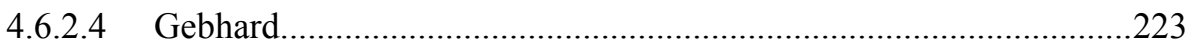

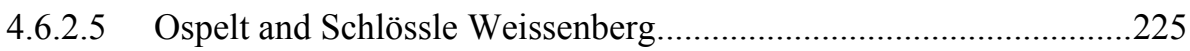

$4.7 \quad$ Synthesis and Discussion.........................................................226

Part III The BAlanced Allocation of TAXing Powers

Chapter 5 Introduction to Part III......................................................231

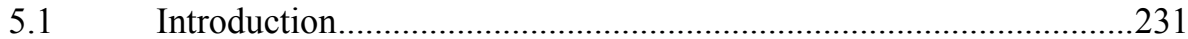

5.2 Survey of prior research...........................................................2232

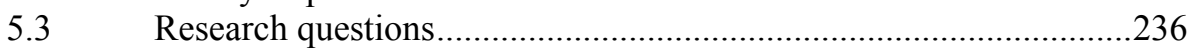

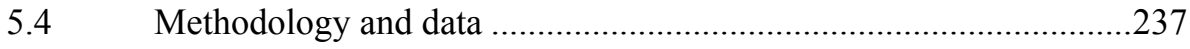

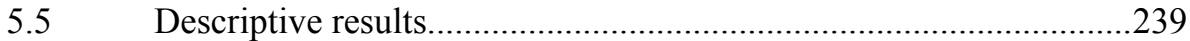

5.5.1 Properties of the network ..........................................................239

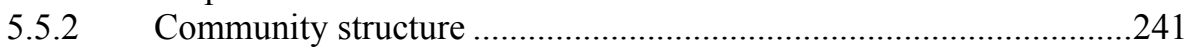

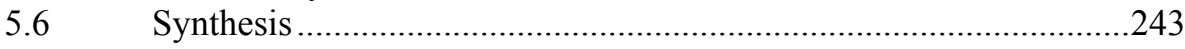

Chapter 6 The BAOTP Standard as Such .................................................245

6.1 Introduction..............................................................................245

The basic framework of the law...................................................246 
6.2.1 The principle of conferral as point of departure ……........................246

6.2.2 The legitimate existence of the power to impose tax.......................248

6.2.3 The constrained exercise of the power to impose tax ........................251

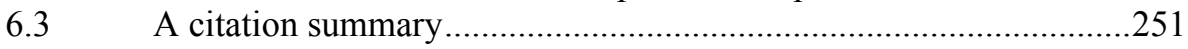

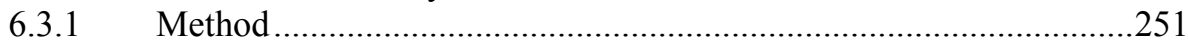

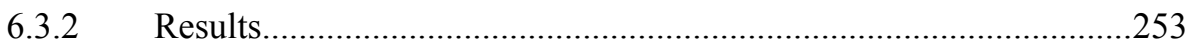

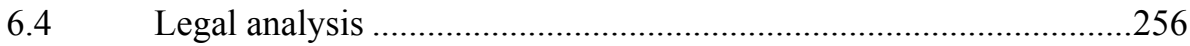

6.4.1 Two periods of legal evolution ...................................................256

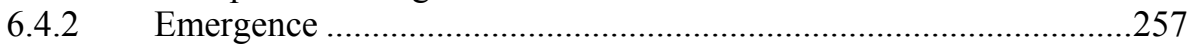

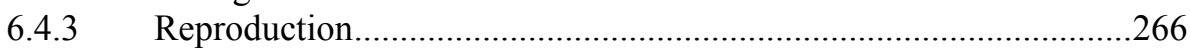

6.5 Fit within the basic framework of the law .......................................279

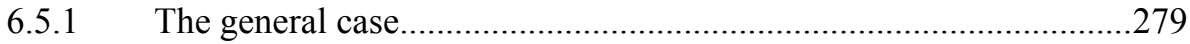

6.5.2 Aims of the measure and the existence of a restriction.....................281

6.5.3 Compensation by other tax advantages..........................................28

6.5.4 The specific case of grouping rules ...............................................290

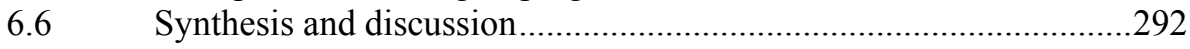

Chapter 7 Relations with Other Justifications...........................................295

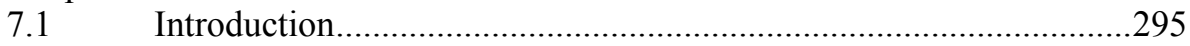

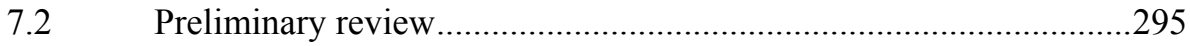

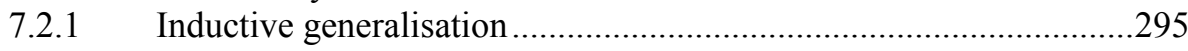

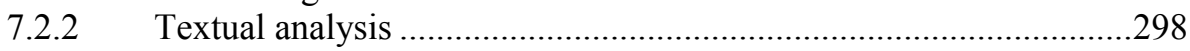

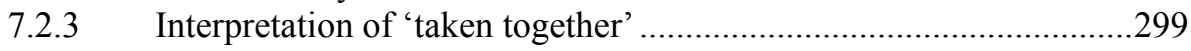

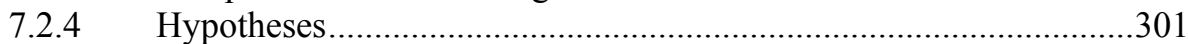

7.3 Relation with the risk of double use of losses...................................302

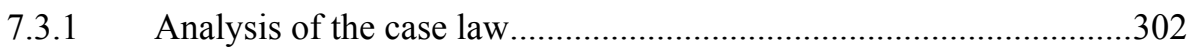

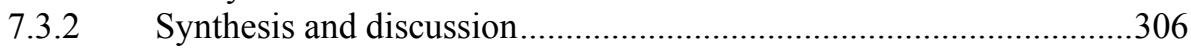

7.4 Relation with the prevention of tax avoidance..................................309

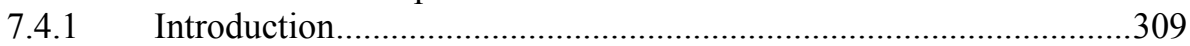

7.4.2 EU law cannot be relied upon for abusive or fraudulent ends ..........311

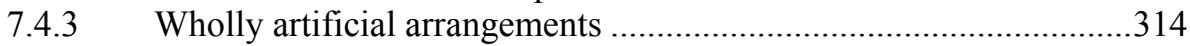

7.4.4 The Emsland-Stärke standard of proof ..............................................320

7.4.5 Prevention of tax avoidance after Cadbury Schweppes......................325

7.4.6 Synthesis and discussion................................................................336

7.5 Relation with the cohesion of the tax system....................................339

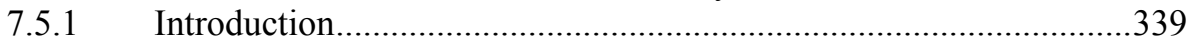

7.5.2 The requirements of the cohesion of the tax system ...........................340

7.5.3 Comparison with the balanced allocation of taxing powers ...............341

7.5.4 Synthesis and discussion...............................................................349

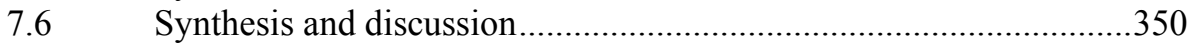

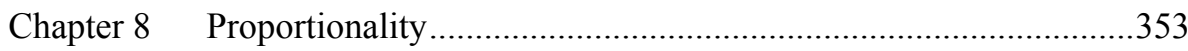

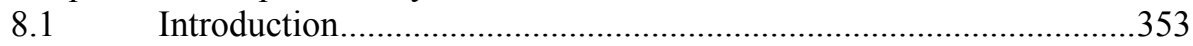

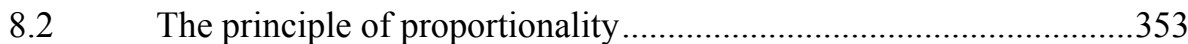

8.2.1 A general and judicial principle of EU law........................................353

8.2.2 Reception in the field of direct taxation..........................................357

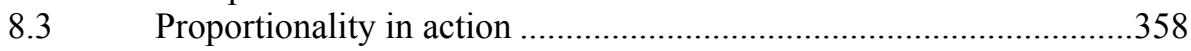




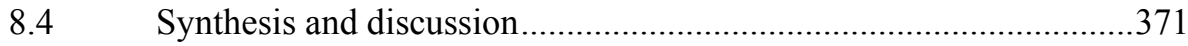

Chapter 9 Revisiting Marks \& Spencer ........................................................375

9.1 Why the Court erred in Marks \& Spencer ........................................375

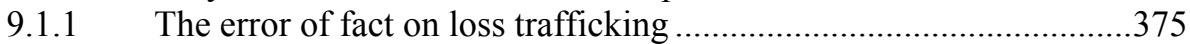

9.1.2 The error cannot be mended by reinterpretation.................................376

9.2 Alternative solution: a system of deferral ..........................................379

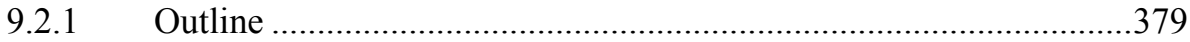

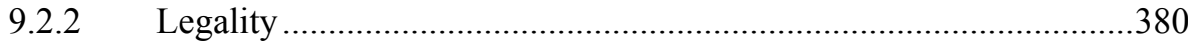

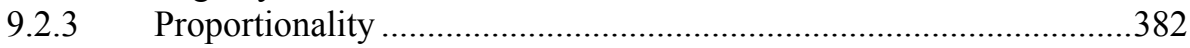

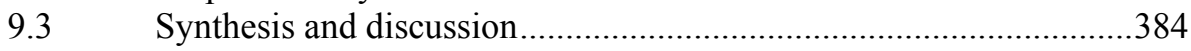

PART IV CONCLUSION

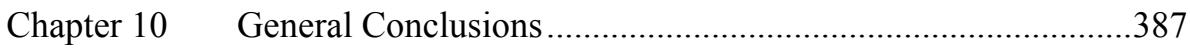

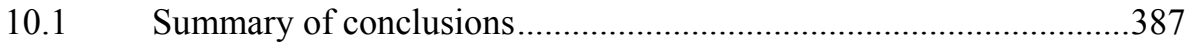

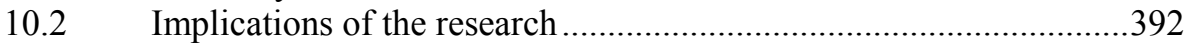

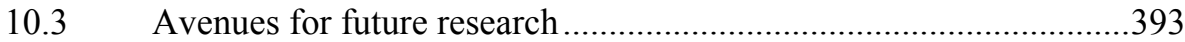

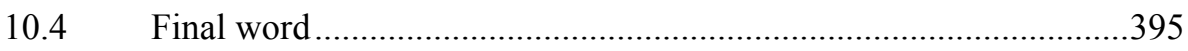

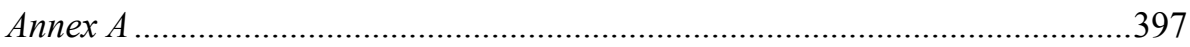

Nederlandse Samenvatting............................................................................411

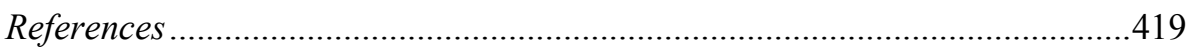

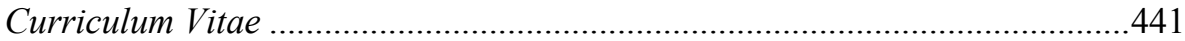




\section{Acknowledgements}

The research for this book started in the fall of 2006 and I completed this book in the fall of 2012. During that research period of six years, the Court of Justice of the European Union decided more cases about the compatibility of national direct taxes with European Union law than the number of cases it had decided in this field before 2006. I owe a debt of gratitude to my family and my friends, colleagues and many other people who have contributed to my sanity over these years. A few must be mentioned here by name.

The person who encouraged me to start this book was my supervisor Professor Rainer Prokisch. I thank him for his trust over the years that we have worked together. I am grateful for the freedom that he gave me in my research. I also thank the members of the assessment committee, Professors Raymond Luja, Hans van den Hurk and Pasquale Pistone, for their readiness to review this book critically.

Professor Arthur Denie encouraged me to pursue an academic career. Even after his retirement from university, he found time to read the summary in Dutch and provided valuable comments. Thank you for your guidance and support .

Carol Ní Ghiollarnáth made this book readable by changing the order of the words in my sentences, by adding definite and indefinite articles, and by substituting proper English words for my gibberish. For that, but even more for all the other things you have said or done over the period that we shared offices and after, I could write many kind words, but most of all I thank you for your friendship.

Many more persons have supported me and took an interest in this book. The tax law department of Maastricht University Faculty of Law is home to many kind people. I consider myself lucky to have you as my colleagues. A special thank you goes to my paranymph Anouk Bollen-Vandenboorn and to Hans Arts for our discussions and his comments on the summary in Dutch.

Professors Gerard-René de Groot and Hildegard Schneider should be acknowledged for the sincere interest they take in young researchers and the advice they give them, including me. I have also enjoyed working with Professor Michael Faure in the context of the Ius Commune Research School.

I thank Professors Lieven Denys and Otto Marres for the discussions and comments on earlier drafts of chapters of this book during the workshops of the Ius Commune Research School in Leuven and Amsterdam. Also the comments of Professor Frans Vanistendael during the IBFD Research Students Meeting helped me to sharpen the analysis and to organise my thoughts. I thank him, his 
team, and the participants during those days for the outstanding discussions and the memorable social talks and activities.

Parts of this book have been researched and written at the Institute for Austrian and International Tax Law of the Wirtschaftsuniversität Wien during a research visit that was made possible by an Ernst Mach Worldwide Grant from the Austrian federal government. I thank Professor Michael Lang and his team for their hospitality.

Finally, my family are the most important people in my life. I dedicate this book to my parents Marie-Louise and Friedrich, my sister Fallon and my brother and paranymph Frédéric. I love you.

The law in this book is stated as at 1 January 2012. Due to research design, subsequent developments have not been taken into account, but are reported in the footnotes on occasion.

Marcel Schaper

Maastricht, 25 October 2012 


\section{List of Abbreviations}

\begin{tabular}{|c|c|}
\hline $\mathrm{ACT}$ & advance corporation tax \\
\hline $\mathrm{AG}$ & Advocate General \\
\hline BAOTP & balanced allocation of the power to impose tax \\
\hline СССТВ & Common Consolidated Corporate Tax Base \\
\hline $\mathrm{CFC}$ & controlled foreign corporation \\
\hline CJEU & Court of Justice of the European Union \\
\hline DTC & Convention for the Avoidance of Double Taxation \\
\hline $\mathrm{EC}$ & European Community/Communities \\
\hline ECR & Reports of cases before the Court \\
\hline ECtHR & European Court of Human Rights \\
\hline EEA & European Economic Area \\
\hline EEC & European Economic Community \\
\hline EFTA & European Free Trade Association \\
\hline $\begin{array}{l}\text { EFTA Court } \\
\text { e.g. }\end{array}$ & $\begin{array}{l}\text { Court of Justice of the European Free Trade Association States } \\
\text { exempli gratia / for example }\end{array}$ \\
\hline EU & European Union \\
\hline EU law & law of the European Union \\
\hline EWCA & Court of Appeal of England and Wales \\
\hline FII & franked investment income \\
\hline FG & Finanzgericht / Finance Court (Germany) \\
\hline GC & Grand Chamber \\
\hline HITS & Hyperlink-Induced Topic Search \\
\hline i.e. & id est / that is \\
\hline IRAP & $\begin{array}{l}\text { L'Imposta Regionale sulle Attività Produttive / Regional Tax } \\
\text { on Productive Activities (Italy) }\end{array}$ \\
\hline MFN & most-favoured-nation \\
\hline nyr & not yet reported \\
\hline OCT & Overseas Countries and Territories \\
\hline OECD & Organisation for Economic Co-operation and Development \\
\hline OECD Model & OECD Model Tax Convention on Income and on Capital \\
\hline $\begin{array}{l}\text { O.J. } \\
\operatorname{para}(s)\end{array}$ & $\begin{array}{l}\text { Official Journal of the European Communities/Union } \\
\operatorname{paragraph}(s)\end{array}$ \\
\hline $\mathrm{PE}$ & permanent establishment \\
\hline P.C.I.J. & Publications of the Permanent Court of International Justice \\
\hline SNA & social network analysis \\
\hline TEC & Treaty establishing the European Community \\
\hline TEU & Treaty on the European Union \\
\hline
\end{tabular}


TFEU Treaty on the Functioning of the European Union

UK

US

VAT

United Kingdom of Great Britain and Northern Ireland

United States of America

value added tax 


\section{List of Cases}

\section{Court of Justice of the European Union}

3M Italia (C-417/10) [2012] ECR nyr 337

A (C-101/05) [2007] ECR I-11531 $71,82,111,142$

A and B (C-102/05) [2007] ECR I-3871 $80,101,161,223$

A.T. (C-285/07) [2008] ECR I-9329 88,140 Aberdeen Property Fininvest Alpha (C-303/07) [2009] ECR I-5145 . 81, 87, 140, $161,270,297,328$

Accor (C-310/09) [2011] ECR nyr 74,139 ACT Group Litigation (C-374/04) [2006] ECR I-11673 ...74, 107, 108, 161, 201, 202, 203, 257, 264, 280, 298, 378

Alpine Investments (C-384/93) [1995] ECR I-1141 ....................................... 104 AMID (C-141/99) [2000] ECR I-11619 ………........................ 115, 116, 160 Amorim Energia (C-38/11) [2012] ECR nyr .............................................. 209 Amurta (C-379/05) [2007] ECR I-9569..............87, 140, 158, 161, 202, 213, 266 Andersen og Jensen (C-43/00) [2002] ECR I-379 ……......................... 88, 140 Arens-Sikken (C-43/07) [2008] ECR I-6887 ………........................... 206, 222 Asscher (C-107/94) [1996] ECR I-3089 …………..........69, 116, 141, 146, 285 Athinaiki Zythopoiia (C-294/99) [2001] ECR I-6797 ...........58, 87, 97, 137, 175 Baars (C-251/98) [2000] ECR I-2787 $81,142,161$ Bachmann (C-204/90) [1992] ECR I-249......57, 85, 97, 110, 115, 181, 195, 197, 339,344

Banca popolare di Cremona (C-475/03) [2006] ECR I-9373 45

Banco Bilbao Vizcaya Argentaria (C-157/10) [2011] ECR nyr .................. 52, 59 Banque Fédérative du Crédit Mutuel (C-27/07) [2008] ECR I-2067 87, 137, 177 Barbier (C-364/01) [2003] ECR I-15013 64

Baumbast (C-413/99) [2002] ECR I-7091 66,217

Bautiaa and Société française maritime (Joined Cases C-197\&252/94) [1996]

ECR I-505

Baxter (C-254/97) [1999] ECR I-4809 $43,61,69$

Beker and Beker (C-168/11) [pending] 164

Bergaderm (C-352/98P) [2000] ECR I-5291 …........................................... 32

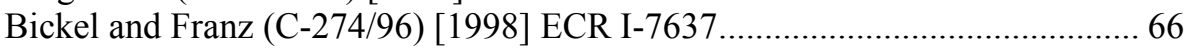

Biehl I (C-175/88) [1990] ECR I-1779.........................33, 57, 85, 148, 162, 215 Blanckaert (C-512/03) [2005] ECR I-7685.......................................... 71, 108 Block (C-67/08) [2009] ECR I-883 $70,106,117$

Bosal (C-168/01) [2003] ECR I-9409.... $87,115,184,283$ 
Bosman (C-415/93) [1995] ECR I-4921 $104,114,163,357$

Bouanich (C-265/04) [2006] ECR I-923

Bouchoucha (C-61/89) [1990] ECR I-3551

Brasserie du Pêcheur and Factortame (Joined Cases C-46\&48/93) [1996] ECR I1029 177,219

Burda (C-284/06) [2008] ECR I-4571 $81,87,108,140,175$

Busley and Cibrian Fernandez (C-35/08) [2009] ECR I-9807 259

Cadbury Schweppes (C-196/04) [2006] ECR I-7995 ....77, 81, 95, 113, 115, 117 , $161,195,224,240,254,261,297,310,317,321,331,377$

CaixaBank (C-442/02) [2004] ECR I-8961 .............................................. 104

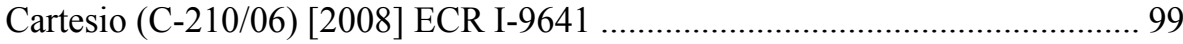

Cassis de Dijon (C-120/78) [1979] ECR 649 ............................................... 34

Centro Equestre da Lezíria Grande (C-345/04) [2007] ECR I-1425 . 85, 107, 173

Centros (C-212/97) [1999] ECR I-1459 ...219, 220, 241, 311, 312, 318, 321, 324

CFC and Dividend Group Litigation (C-201/05) [2008] ECR I-2875 .. 70, 71, 77, $82,108,111,113,142,223,241,377$

CIBA (C-96/08) [2010] ECR I-2911 $57,61,69,161,333$

CILFIT (283/81) [1982] ECR 3415. 28,32

Cobelfret (C-138/07) [2009] ECR I-731 87

Collins (C-138/02) [2004] ECR I-2703 323

Columbus Container Services (C-298/05) [2007] ECR I-10451 .69, 75, 105, 106, $108,142,161,224,287$

Commerzbank (C-330/91) [1993] ECR I-4017 .......................................... 160

Commission v Austria (C-10/10) [2011] ECR nyr ........................................ 159

Commission v Austria (C-387/10) [2011] ECR nyr .................................... 215

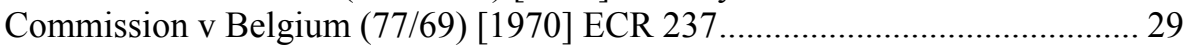

Commission v Belgium (C-250/08) [2011] ECR nyr ....47, 62, 84, 110, 141, 142, $159,284,339,347$

Commission v Belgium (C-300/90) [1992] ECR I-305 ......85, 97, 110, 181, 197, $215,221,339,344$

Commission v Belgium (C-370/11) [2012] ECR nyr .................................... 159

Commission v Belgium (C-387/11) [2012] ECR nyr .................................... 270

Commission v Belgium (C-392/07) [2008] I-72 .............................. 122, 140

Commission v Belgium (C-415/02) [2004] ECR I-7215 ................. 62, 64, 122

Commission v Belgium (C-433/04) [2006] ECR I-10653 ........................... 179

Commission v Belgium (C-478/98) [2000] ECR I-7587 ............... 219, 221, 314

Commission v Belgium (C-522/04) [2007] ECR I-5701 67, 81, 85, 181, 183, 226

Commission v Denmark (C-150/04) [2007] ECR I-1163 ....81, 85, 181, 182, 345

Commission v Denmark (C-261/11) [pending] ............................................ 367

Commission v Denmark (C-464/02) [2005] ECR I-7929 ................................ 219

Commission v Estonia (C-39/10) [2012] ECR nyr ............................. 57, 152

Commission v France (Avoir Fiscal) (270/83) [1986] ECR 273 .. 33, 51, 57, 119 , $123,160,161,193,215,270,285,357$

Commission v France (C-334/02) [2004] ECR I-2229 $85,189,358$

Commission v France (C-34/98) [2000] ECR I-995.

Commission v France (C-381/93) [1994] ECR I-5145 
Commission v France (Joined Cases 6/69 \& 11/69) [1969] ECR 523 ............. 248

Commission v Germany (205/84) [1986] ECR 3755..................................... 219

Commission v Germany (C-152/05) [2008] ECR I-39 ................67, 86, 167, 218

Commission v Germany (C-269/07) [2009] ECR I-7811 ....67, 85, 168, 172, 218

Commission v Germany (C-284/09) [2011] ECR nyr ......140, 161, 209, 225, 277

Commission v Germany (C-318/05) [2007] ECR I-6957 .................. 68, 136, 218

Commission v Germany (Volkswagen) (C-112/05) [2007] ECR I-8995 ........ 219

Commission v Greece (305/87) [1989] ECR 1461 ...................................... 219

Commission v Greece (C-155/09) [2011] ECR I-65 62, 67, 68, 86, 142, 167, 218

Commission v Greece (C-406/07) [2009] ECR I-62 74,161

Commission v Greece (C-8/97) [1998] ECR I-823 ....................57, 88, 122, 140

Commission v Hungary (C-253/09) [2011] ECR nyr 67, 110, 141, 157, 159, 284, 339,347

Commission v Italy (C-129/00) [2003] ECR I-14637 29

Commission v Italy (C-197/03) [2006] ECR I-60 ...............62, 64, 139, 142, 215

Commission v Italy (C-518/06) [2009] ECR I-3491 ……............................. 104

Commission v Italy (C-540/07) [2009] ECR I-1098357, 161, 205, 206, 207, 213, $225,316,328$

Commission v Luxembourg (Biehl II) (C-151/94) [1995] ECR I-3685 ... 85, 148, 162

Commission v Netherlands (C-301/11) [pending] 367

Commission v Netherlands (C-521/07) [2009] ECR I-4873 ...139, 140, 158, 160, 225

Commission v Portugal (C-105/08) [2010] ECR I-5331 $97,109,122$

Commission v Portugal (C-20/09) [2011] ECR nyr. 160,220

Commission v Portugal (C-267/09) [2011] ECR nyr. 190,225

Commission v Portugal (C-345/05) [2006] ECR I-10633 ..............67, 81, 86, 167

Commission v Portugal (C-38/10) [2012] ECR nyr........................................ 367

Commission v Portugal (C-493/09) [2011] ECR nyr....................................... 161

Commission v Spain (C-153/08) [2009] ECR I-9735...................... 59, 189, 224

Commission v Spain (C-154/08) [2009] ECR I-187......................................... 29

Commission v Spain (C-219/03) [2004] not reported........................ 57, 59, 122

Commission v Spain (C-248/06) [2008] ECR I-47......................59, 85, 188, 224

Commission v Spain (C-269/09) [2012] ECR nyr ....................................... 367

Commission v Spain (C-487/08) [2010] ECR I-4843.........59, 161, 205, 207, 213

Commission v Spain (C-562/07) [2009] ECR I-9553 ............................... 59, 160

Commission v Spain (C-64/11) [pending] ……............................................ 367

Commission v Sweden (C-104/06) [2007] I-671 ..........................67, 81, 86, 167

Commission v UK (C-246/89) [1991] ECR I-4585 ……...................... 248, 319

Conijn (C-346/04) [2006] ECR I-6137 ...................................69, 141, 156, 162

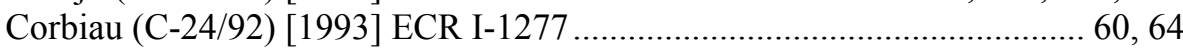

D. (C-376/03) [2005] ECR I-5821 ……...................107, 115, 141, 142, 154, 162

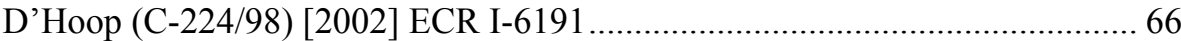

Da Costa (Joined Cases 28-30/62) [1963] ECR 31 .................................. 27, 28

Daily Mail (81/87) [1988] ECR 5483 .....57, 61, 98, 114, 115, 123, 160, 215, 325

Damseaux (C-128/08) [2009] ECR I-6823 …………….........106, 117, 161, 271 
Danner (C-136/00) [2002] ECR I-8147 $57,85,181$

Dassonville (8/74) [1974] ECR 837 .............................................................. 34

De Baeck (C-268/03) [2004] ECR I-5961 ......................................... 69, 74

De Coster (C-17/00) [2001] ECR I-9445 ........................................................ 48

De Cuyper (C-406/04) [2006] ECR I-6947 ............................................. 219

De Groot (C-385/00) [2002] ECR I-11819 ...........................85, 146, 163, 288

De Lasteyrie du Saillant (C-9/02) [2004] ECR I-2409 .....115, 161, 316, 334, 340 Decker (C-8/81) [1982] ECR 53

Denkavit Internationaal and Denkavit France (C-170/05) [2006] ECR I-11949

$161,203,266,271$

Denkavit International, VITIC Amsterdam \& Voormeer (Joined Cases C-283, 291\&292/94) [1996] ECR I-5063 $87,115,137,177,215$

Deutsche Shell (C-293/06) [2008] ECR I-1129 $105,161,224,250$

Dietz (C-435/93) [1996] ECR I-5223 ........................................................ 202

Dijkman and Dijkman-Lavaleije (C-233/09) [2010] ECR I-6649 .................. 161

DIVI Finanziaria SAPA di Diego délia Valle (C-380/11) [2012] ECR nyr .... 367 Eckelkamp (C-11/07) [2008] ECR I-6845 ..................................... 206, 222 ELISA (C-451/05) [2007] ECR I-8251 ................................... 111, 113, 190 Emsland-Stärke (C-110/99) [2000] ECR I-11569 ...................... 241, 320, 328 EPSON Europe (C-375/98) [2000] ECR I-4243 ......................57, 87, 137, 175 Établissements Rimbaud (C-72/09) [2010] ECR I-10659 .............. 64, 111, 225 Eurofood IFSC (C-341/04) [2006] ECR I-3813 .............................. 241, 321 Eurowings (C-294/97) [1999] ECR I-7447.........................160, 173, 286, 289 Factortame (C-213/89) [1990] ECR I-2433 ….............................................. 58 Factortame II (C-221/89) [1991] ECR I-3905 ............................................. 319 Fearon and Company v Irish Land Commission (182/83) [1984] ECR 3677... 52 Ferrero and General Beverage Europe (Joined Cases C-338\&339/08) [2010] ECR I-5743 $87,137,175$

Festeren (C-370/05) [2007] ECR I-1129 219

Fidium Finanz (C-452/04) [2006] ECR I-9521 ....................85, 161, 219, 222 FII Group Litigation (C-446/04) [2006] ECR I-11753 .70, 75, 108, 139, 178, 402 FII Group Litigation II (C-35/11) [pending] ......................................... 73, 84 Filipiak (C-314/08) [2009] ECR I-11049 69,224

FIM Santander Top 25 Euro Fi (Joined Cases C-338-347/11) [2012] ECR nyr61, 270

FOGGIA-SGPS (C-126/10) [2011] ECR nyr ............................................ 140

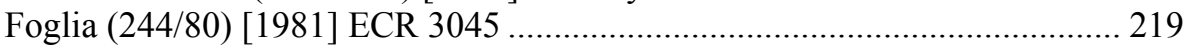

Futura (C-250/95) [1997] ECR I-2471 .....95, 107, 109, 110, 188, 224, 250, 259, 280, 283, 292, 357

Gaz de France (C-247/08) [2009] ECR I-9225 87,177

Gebhard (C-55/94) [1995] ECR I-4165 $104,219,223,319,357$

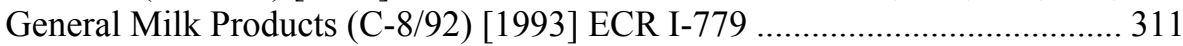

Geraets-Smits and Peerbooms (C-157/99) [2001] ECR I-5473 ...................... 219 Gerritse (C-234/01) [2003] ECR I-5933 .....85, 107, 109, 115, 116, 153, 162, 172 Geurts and Vogten (C-464/05) [2007] ECR I-9325 .......................... 81, 142 Gielen (C-440/08) [2010] ECR I-2323 $69,141,157,162$ 
Gilly (C-336/96) [1998] ECR I-2793 $85,98,101,106,160,248,280,378$ Glaxo Wellcome (C-182/08) [2009] ECR I-8591......84, 112, 113, 255, 272, 297, 336,347

Graf (C-190/98) [2000] ECR I-493 103,163

Grzelczyk (C-184/99) [2001] ECR I-6193 $65,217,219$

Gschwind (C-391/97) [1999] ECR I-5451 $85,107,151,162$

Halifax (C-255/02) [2006] ECR I-1609 241,320

Halley and Others (C-132/10) [2011] ECR nyr ........................................... 84 Halliburton Services (C-1/93) [1994] ECR I-1137 .........57, 62, 69, 139, 142, 175 Haribo Lakritzen and Österreichische Salinen (Joined Cases C-436\&437/08) [2011] ECR nyr $106,108,223,255,275$

Hartmann (C-212/05) [2007] ECR I-6303... 169

Heinrich Bauer Verlag (C-360/06) [2008] ECR I-7333. 142,161

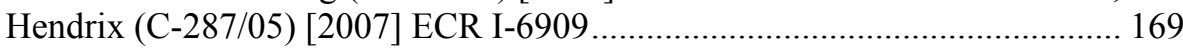

Hengartner and Gasser (C-70/09) [2010] ECR 7233 ..........64, 101, 139, 162, 215 Holböck (C-157/05) [2007] ECR I-4051 ..................................70, 81, 161, 223

Hollmann (C-443/06) [2007] ECR I-8491 ………....................................... 83

Humbel and Edel (263/86) [1988] ECR 5365 ............................................. 219

ICI (C-264/96) [1998] ECR I-4695 ……………........81, 115, 160, 195, 240, 314

Jäger (C-256/06) [2008] ECR I-123 222

Jobra (C-330/07) [2008] ECR I-9099 $.85,188,269,297$

KBC Bank and Beleggen, Risicokapitaal, Beheer (Joined Cases C-439\&499/07) [2009] ECR I-4409 $.78,87,108,140$

Keck and Mithouard (Joined Cases C-267\&268/91) [1993] ECR I-6097 .. 32, 34, 105

Kefalas (C-367/96) [1998] ECR I-2843 311

Keller Holding (C-471/04) [2006] ECR I-2107 ........................81, 161, 225, 226

Kerckhaert and Morres (C-513/04) [2006] ECR I-10967...12, 106, 116, 187, 272, $292,369,375$

Knoors (115/78) [1979] ECR 399 33,311

Köbler (C-224/01) [2003] ECR I-10239 29

Kofoed (C-321/05) [2007] ECR I-5795 113,140

Krankenheim Ruhesitz am Wannsee-Seniorenheimstatt (C-157/07) [2008] ECR I-8061 $64,110,161,225,339,340,347,381$

Krantz (C-69/88) [1990] ECR I-583 103

Kraus (C-19/92) [1993] ECR I-1663 $66,100,147,357$

Laboratoires Fournier (C-39/04) [2005] ECR I-2057 85,187

Lair (39/86) [1988] ECR 3161 311

Lakebrink and Peters-Lakebrink (C-182/06) [2007] ECR I-6705 ............. 85, 165

Lambert (308/86) [1988] ECR 4369 221

Lammers \& Van Cleeff (C-105/07) [2008] ECR I-173 81,328

Lankhorst-Hohorst (C-324/00) [2002] ECR I-11779

Lasertec (C-492/04) [2007] ECR I-3775 115,315

Lawrie-Blum (66/85) [1986] ECR 2121 $. .80,101,161,223$

Leclerc (229/83) [1985] ECR 1 323

Lenz (C-315/02) [2004] ECR I-7063 311 $81,179,186,288$ 
Les Verges du Vieux Tauves (C-48/07) [2008] ECR I-10627 87,140

Leur-Bloem (C-28/95) [1997] ECR I-4161 $88,115,140,215,314$

Levin (53/81) [1982] ECR 1035 324

Levy and Sebag (C-540/11) [2012] ECR nyr ............................................ 106 Lidl Belgium (C-414/06) [2008] ECR I-3601 ...81, 112, 161, 223, 241, 267, 304, $310,333,361,375$

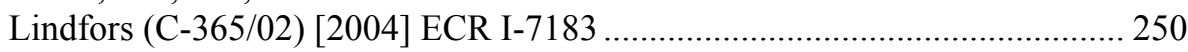

Lindman (C-42/02) [2003] ECR I-13519 ......................................... 189, 224

Luisi and Carbone (Joined Cases 286/82 \& 26/83) [1984] ECR 377 ...... 219, 221

Manninen (C-319/02) [2004] ECR I-7477................115, 142, 179, 195, 204, 339

Marks \& Spencer (C-446/03) [2005] ECR I-10837...96, 100, 105, 112, 115, 119, $161,195,231,257,279,284,290,297,302,309,316,331,355,358,375$

Martinez Sala (C-85/96) [1998] ECR I-2691....................................... 66, 217

Mattner (C-510/08) [2010] ECR I-3553 …………….......................... 83, 206

Meeusen (C-337/97) [1999] ECR I-3289 …………................................. 323

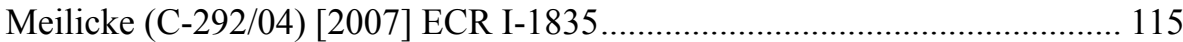

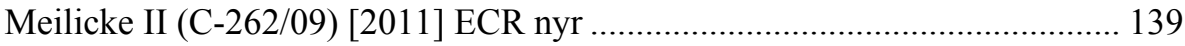

Meindl (C-329/05) [2007] ECR I-1107 ........................................ 85, 156, 162

Mertens (C-431/01) [2002] ECR I-7073 ……………................................. 85

Metallgesellschaft and Others \& Hoechst (Joined Cases C-397\&410/98) [2001] ECR I-1727 $81,139,178,282,315$

Metock (C-127/08) [2008] ECR I-6241 ........................................................ 32

Missionswerk Werner Heukelbach (C-25/10) [2011] ECR nyr......................... 84

Mobistar and Belgacom Mobile (C-544/03) [2005] ECR I-7723 .................... 104

N. (C-470/04) [2006] ECR I-7409 …................139, 224, 250, 255, 258, 298, 365

National Grid Indus (C-371/10) [2011] ECR nyr ......99, 110, 112, 161, 250, 255, 261, 277, 297, 341, 366, 378

Océ van der Grinten (C-58/01) [2003] ECR I-9809 ......................... 87, 137, 176

Omega Spielhallen (C-36/02) [2004] ECR I-9609 ……............................... 219

Orange European Smallcap Fund (C-194/06) [2008] ECR I-374770, 71, 82, 107, 108,161

Ospelt and Schlössle Weissenberg (C-452/01) [2003] ECR I-6025 ....... 219, 225

Oy AA (C-231/05) [2007] ECR I-6373 .....81, 112, 113, 161, 240, 256, 263, 281, 290, 297, 330, 362, 378

Paletta II (C-206/94) [1996] ECR I-2357

Papillon (C-418/07) [2008] ECR I-8947 ..161, 269, 281, 290, 297, 306, 346, 375

Passenheim-van Schoot \& X (Joined Cases C-155\&157/08) [2009] ECR I-5093

111,190

Pelati (C-603/10) [2012] ECR nyr . $57,88,178$

Persche (C-318/07) [2009] ECR I-359 117,159

Philips Electronics (C-18/11) [2012] ECR nyr .................................... 309, 376

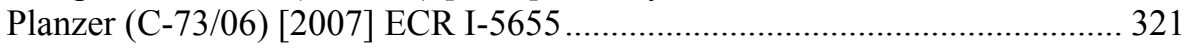

PreussenElektra (C-379/98) [2001] ECR I-2099 ............................................. 219

Prunus and Polonium (C-384/09) [2011] ECR nyr................................. 70, 74

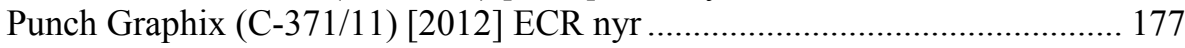

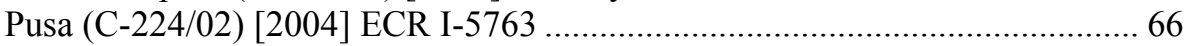


Renneberg (C-527/06) [2008] ECR I-7735 85,168

Rewe Zentralfinanz (C-347/04) [2007] ECR I-2647 .81, 161, 240, 253, 259, 262, 297, 303

Reyners (2/74) [1974] ECR 631 319

Ritter-Coulais (C-152/03) [2006] ECR I-1711 85,165

Rousseau Wilmot (295/84) [1985] ECR 3759 45

Royal Bank of Scotland (C-311/97) [1999] ECR I-2651 $58,139,175,357$

Rüffler (C-544/07) 57

Safir (C-118/96) [1998] ECR I-1897 $57,85,180$

Säger (C-76/90) [1991] ECR I-4221 $66,100,147$

Saint-Gobain (C-307/97) [1999] ECR I-6161 $81,115,161,195,285,358$

Sandoz (C-439/97) [1999] ECR I-7041 57, 62, 105, 112, 141, 142, 159, 220, 289 Schempp (C-403/03) [2005] ECR I-6421 $68,106,250$

Scheunemann (C-31/11) [2012] ECR nyr. 80

Scheuten Solar Technology (C-397/09) [2011] ECR nyr ...........89, 137, 139, 176 Schilling and Fleck-Schilling (C-209/01) [2003] ECR I-13389 ...................... 164

Schmid (C-113/99) [2001] ECR I-471 46

Schmid (C-516/99) [2002] ECR I-4573 $64,139,215$

Schulz-Delzers and Schulz (C-240/10) [2011] ECR nyr ....................... 106, 107 Schumacker (C-279/93) [1995] ECR I-225 .......85, 107, 114, 115, 146, 149, 162, $166,194,195,201,247,279,308,333$

Schwarz and Gootjes-Schwarz (C-76/05) [2007] I-6849 $67,68,136,218$

Scorpio (C-290/04) [2006] ECR I-9461 $85,107,112,173$

Secilpar - Sociedade Unipessoal (C-199/10) [2010] ECR I-154 .70, 83, 109, 161, 207,213

Segers (79/85) [1986] ECR 2375 312

Sehrer (C-302/98) [2000] ECR I-4585 $163,219,220$

SEVIC Systems (C-411/03) [2005] ECR I-10805 99

SGI (C-311/08) [2010] ECR I-487 $81,112,113,161,223,273,297,335$

SIAT (C-318/10) [2012] ECR nyr 113,336

Singh (C-370/90) [1992] ECR I-4265 162,219

Skandia and Ramstedt (C-422/01) [2003] ECR I-6817 $85,181,182$

Sotgiu (152/73) [1974] ECR 153 148,219

Stahlwerk Ergste Westig (C-415/06) [2007] ECR I-151 ............80, 101, 161, 223

Stanton v INASTI (143/87) [1988] ECR 3877 163

Stauffer (C-386/04) [2006] ECR I-8203 $83,159,189,224$

STEKO Industriemontage (C-377/07) [2009] ECR I-299 83

Svensson and Gustavsson (C-484/93) [1995] ECR I-3955

Talotta (C-383/05) [2007] ECR I-2555 $219,220,340$ Tankreederei I (C-287/10) [2010] ECR I-14233 ........85, 188, 275, 297, 328, 355

Tate \& Lyle Investments (C-384/11) [2012] ECR nyr .................................... 214 Terhoeve (C-18/95) [1999] ECR I-345 $48,85,163$

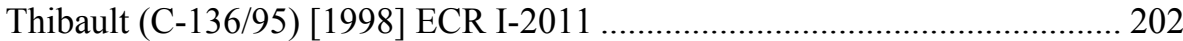
Thin Cap Group Litigation (C-524/04) [2007] ECR I-2107 ......81, 101, 113, 116, $161,205,223,262,266,310,325,331$

Trojani (C-456/02) [2004] ECR I-7573 
Truck Center (C-282/07) [2008] ECR I-10767 .....70, 75, 105, 108, 160, 224, 280 Trummer and Mayer (C-222/97) [1999] ECR I-1661 $219,220,222$

Turpeinen (C-520/04) [2006] ECR I-10685 68,218

TV10 (C-23/93) [1994] ECR I-4795 311

VALE Építési (C-378/10) [2012] ECR nyr 99

Van Binsbergen (33/74) [1974] ECR 1299 241,311

Van Hilten-van der Heijden (C-513/03) [2006] ECR I-1957 ....83, 106, 220, 249, 280

Verkooijen (C-35/98) [2000] ECR I-4071 $.64,179,184,288$

Veronica (C-148/91) [1993] ECR I-487 311

Vestergaard (C-55/98) [1999] ECR I-7641 $57,85,180$

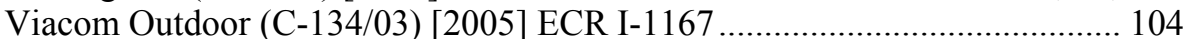

W.N. (C-420/98) [2000] ECR I-2847 89,122

Wallentin (C-169/03) [2004] ECR I-6443 $85,153,155,162$

Waypoint Aviation (C-9/11) [2011] ECR nyr ............................................ 188

Weidert and Paulus (C-242/03) [2004] ECR I-7379...................................... 186

Weigel (C-387/01) [2004] ECR I-4981 ……………............................... 289

Werner (C-112/91) [1993] ECR I-429 ..............33, 57, 69, 98, 101, 115, 141, 148

Wielockx (C-80/94) [1995] ECR I-2493 ....69, 115, 181, 194, 195, 201, 272, 340

Wünsche Handelsgesellschaft (69/85) [1986] ECR 947 .................................. 30

$\mathrm{X}(\mathrm{C}-498 / 10)$ [pending] 112

$X$ AB and Y AB (C-200/98) [1999] ECR I-8261 81,358

$\mathrm{X}$ and $\mathrm{Y}(\mathrm{C}-436 / 00)$ [2002] ECR I-10829 $\ldots 69,74,161,312,318,342,358$

X Holding (C-337/08) [2010] ECR I-1215 ......112, 161, 274, 281, 290, 298, 363, 376

Zanotti (C-56/09) [2010] ECR I-4517 $67,109,136,218$

Zurstrassen (C-87/99) [2000] ECR I-3337 $85,152,162$

Zwijnenburg (C-352/08) [2010] ECR I-4303 88,140

Court of Justice of the European Free Trade Association States

Arcade Drilling (E-15/11) [2012] EFTA Court Report nyr ................................ 99 Fokus Bank (E-1/04) [2004] EFTA Court Report 11 ...................................... 211

Seabrokers (E-7/07) [2008] EFTA Court Report 172 .................................... 183

\section{Benelux Court of Justice}

Metabouw (A 06/2), Judgment of 19 March 2007 157

International Court of Justice / Permanent Court of International Justice

S.S. Lotus (France v Turkey), 1927 P.C.I.J. (ser. A) No. 10 (Sept. 7) 250 
Her Majesty's Courts of Justice of England and Wales

Court of Appeal, Judgment of 20 February 2007, Halsey (HM Inspector of Taxes) v Marks \& Spencer Plc [2007] EWCA Civ 117 .................................. 360

\section{Courts of Germany}

Bundesfinanzhof, Decision of 28 June 2006, Case I R 84/04, BStBl. 2006 II, p. 861 300

Bundesfinanzhof, Judgment of 21 October 2009, Case I R 114/08, BStBl. 2010 II, p. 774 288

FG Münster, Judgment of 11 November 2008, Case 15 K 1114/ 99 F, EW, EFG 2009, p. 309 288 



\section{List of Figures}

Figure 1. Simple network of three cases A, B and C..................................36

Figure 2. New and completed cases by year (1983 through 2011)..............52

Figure 3. Legal basis of new cases by year (1983 through 2011).................53

Figure 4. The giant component of the case law network. ...........................123

Figure 5. A connected network of closely connected clusters.....................126

Figure 6. The Watts-Strogatz small-world network model..........................127

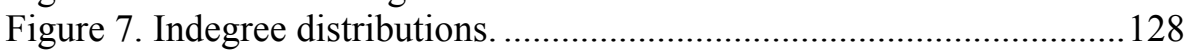

Figure 8. Log-log plot of the indegree distribution....................................130

Figure 9. Community structure in a small network. ..................................132

Figure 10. Networks of the five selected communities................................145

Figure 11. Community 1 with short case names......................................147

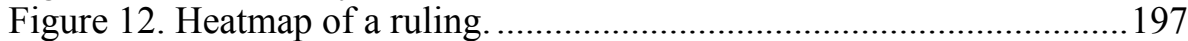

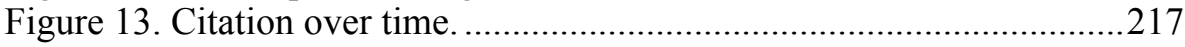

Figure 14. The Marks \& Spencer network................................................240

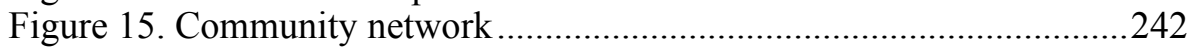

Figure 16. Example of a citing paragraph................................................253

Figure 17. Citation summary of Marks \& Spencer, paras $45 \& 46$............254

Figure 18. EUR-Lex summary of Marks \& Spencer ..................................256 



\section{List of Tables}

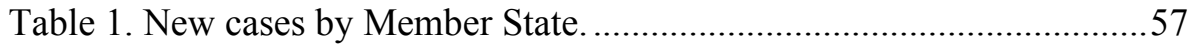

Table 2. Article 267 TFEU cases by national courts. ....................................60

Table 3. OECD classification of completed cases......................................62

Table 4. Completed cases on taxes on dividends by OECD classification...63

Table 5. Legal basis of rulings by TFEU provision.....................................65

Table 6. Cases on relations with non-member States. .................................73

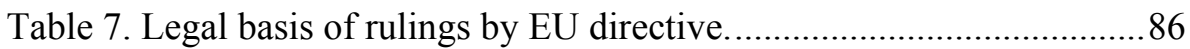

Table 8. Cases by bench hearing the action. ................................................91

Table 9. Cases by chambers of the Court.....................................................92

Table 10. Judge rapporteurs with most direct tax cases................................92

Table 11. Proportion of judgments without AG opinion. ..............................93

Table 12. Advocates General involved in 10 or more cases........................93

Table 13. Reasoned orders in the field of direct taxation. .............................95

Table 14. Most important rulings by academic notes. ................................115

Table 15. Properties of the case law network. ..........................................125

Table 16. Communities: legal basis and size ……….................................139

Table 17. Communities: subject matter ....................................................... 141

Table 18. Subcommunities by Louvain method .......................................... 144

Table 19. The most important direct tax precedents by authority score ..... 194

Table 20. Distribution of top-20 cases over communities ...........................195

Table 21. Most cited non-tax precedents by sample cases...........................219

Table 22. Communities of the Marks \& Spencer network...........................241

Table 23. Accepted and rejected justifications in selected cases .................297 

I Introduction 



\section{Chapter 1 General Introduction}

\section{$1.1 \quad$ Aim}

The aim of this book is to establish a framework of a legal doctrine on EU law in the field of direct taxes. This is a rather traditional goal of legal studies, but this book makes an attempt to pursue it in an innovative manner. Although it is hard to 'turn law into numbers' as Siems explains, ${ }^{1}$ doctrinal legal research may nonetheless benefit from more empiricism through the use of quantitative methods, $^{2}$ even though not all original legal questions can be addressed in this way. ${ }^{3}$ The research in this book is a modest contribution to this broader debate.

We will see later in this book that EU law in the field of direct taxes essentially is a subfield of EU constitutional law. The large majority of legal norms in this area are derived directly from the Treaty on the Functioning of the EU (TFEU) through judicial decision making by the Court of Justice of the European Union (CJEU). For this reason, the research aim is put in context by relating it to the seminal work of Von Bogdandy who defined a doctrine of principles on European constitutional law as a systematic exposition of its most essential legal norms. ${ }^{4}$ The aim of this book is, using Mackor's definition of legal doctrine, to offer a description and a rational reconstruction of the legal order of EU law in the field of direct taxes. ${ }^{5}$

Section 1.3 will explain the research framework after the introduction to the research question of Section 1.2. Following in this introductory Chapter is a synopsis of the book in Section 1.4. The limits of the research are mentioned in Section 1.5 and Section 1.6 gives further guidance to the reader.

When we ultimately want to arrive at a doctrine of EU law in the field of direct taxes, we need to distinguish at the least between the most important and less important legal norms. Also, we need to organise and give structure to those rules in a manner that is relevant to those rules. This exposition may be said to be systematic if the structure and organisation of the individual legal norms gives identity to them as a united whole.

Because the goal of a complete doctrine on EU law in the field of direct taxes in all its positive and normative aspects is beyond the scope of this book, the research will focus on building a framework. The book attempts to sketch the

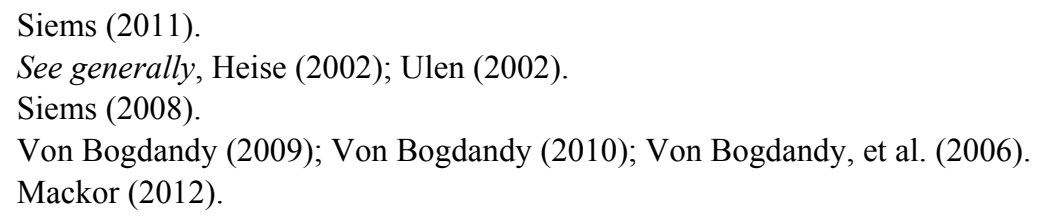


basic contours of the system of EU law in the field of direct taxes. This framework of a legal doctrine in this subject area is meaningful if it advances our rational understanding about the structure and organisation of legal sources and norms in this field of EU law. In short, this book purports to research EU law in the field of direct taxes as a system and the research aims to describe its structure and organisation. This goal can be restated in the central research question of this book.

\subsection{Research question}

The central research question of this book is: What is the structure and organisation of EU law in the field of direct taxes?

The Oxford English Dictionary defines structure as "the mutual relation of the constituent parts or elements of a whole as determining its peculiar nature or character' and defines a structure as 'an organized body or combination of mutually connected and dependent parts or elements'. Organisation is defined as 'the arrangement and coordination of parts into a systematic whole'.

This book looks at how the elements of EU law in the field of direct taxes are arranged by the relations between them and how this organisation gives identity to EU law in the field of direct taxation as a whole; as a system. This presupposes that there is, at the least, a weak form of cohesion between the individual elements of this system. Also, we believe that the whole is larger than and different from the sum of its parts. It is not sufficient to know what combination of elements exits in a system, but it is equally important to understand how these elements cohere into a larger and distinct identity.

The prevailing opinion among regulators, academics and practitioners on EU law in the field of direct taxation is that it is a complex system and produces outcomes that are unpredictable. ${ }^{6}$ Thus, while not wishing to question the validity of that presupposition, it does have some important consequences for the manner in which we research this field and, consequently, the interpretation of the research question.

The distinction between complex and complicated should be stressed at this point. A system is complicated when it is composed of many elements or 'things'. EU law in the field of direct taxes is complicated because it is composed of a multitude of legal provisions, judgments, rules, facts and opinions. It would be less complicated and easier to understand if we could reduce the number of those elements and variables for our consideration. Accordingly, the main approach in prior research on EU law in the field of direct taxes was to consider each judgment or rule first in isolation and, after we gained insight in each separate element, we compared those elements and related them in successively larger groups and slowly induced the system by further

See, Section 1.3.

Miller and Page (2007), p. 10. 
generalisation. Many publications on European and international tax law apply such a reductionist approach and review a particular judgment, an individual rule, or a specific legal provision.

However, the existence of a multitude of different elements and variables is not the key reason why EU law in the field of direct taxes is complex and produces unpredictable outcomes. The complexity of EU law in the field of direct taxes results from the linkages and interdependencies between those elements. ${ }^{8}$ In fact, they are 'irreducibly intertwined'. ${ }^{9}$ Complexity in a system cannot be reduced, but we can advance our knowledge by researching its structure and organisation.

If the system of law is reduced to a collection of individual judgments and individual rules and we assume that they are created under some form of centralised strategic planning of the Court-i.e. the Court may be held primarily accountable for the homogeneity of those elements - we gain insight into the Court's reasoning in those judgments and the requirements and effects of the rules that it governs. However, this knowledge about the various elements is not necessarily insight about how they are linked as a collective whole.

Prior research has provided negative normative evaluations of the effectiveness of the Court's strategic planning of the legal system, essentially because the elements of that system were found to be heterogeneous and the relations between them could not be rationally reconstructed into a collective whole. The normative recommendation that followed was, of course, that the Court's control should be tempered for it is evidently not competent and strategic planning of the legal system through a democratic process of legislation would be preferable. In sum, the Court encroaches too much upon the national legislator's competence and its judgments adversely affect the traditional system of international taxation.

If we accept that the system of law cannot simply be reduced to individual rules and judgments, and given that the Court is not the only agent in the negative integration process, ${ }^{10}$ we may perhaps better understand the complexity of EU law in the field of direct taxation, given that complexity exists and persists. Instead of making a rational reconstruction of the relations between the elements in the system, would research not be more effective and insightful if we observed and studied those relations directly? This is what the research question asks us to do.

The research question presupposes that EU law in the field of direct taxes is a cohesive whole that is organised and structured in a complex system. This book wants to observe, describe and give a rational reconstruction of that organisation and structure. The research question is for this reason academically relevant

Miller and Page (2007), p. 9.

9 Mitchell (2009), p. 4. According to Miller and Page (2007), p. 9: 'Complicated worlds are reducible, complex ones are not'.

10 See generally, Fligstein and Sweet (2002) on interlinking of social agents and the effects on institutionalisation of European integration. 
because the basic debate in prior research in this field is whether EU law in the field of direct taxes is a cohesive whole that is structured and organised in a legally relevant manner, or not.

\subsection{Research framework}

Prior research has approached the problem by qualitative legal analysis (methods of interpretation of the law) alone. This has resulted in an academic debate of dialectic arguments from which little agreement has emerged, and agreement has emerged only slowly. The status quo is aptly described by Farmer who spoke of a 'bewildering array of concepts':

Over the last 20 years, the Court has responded case by case to a series of Member State arguments. The result is that we now have a somewhat bewildering array of concepts in the case law such as non-comparability of situations, territoriality, fiscal coherence, tax avoidance, balanced allocation of taxing powers, and so forth. It is perhaps time for the Court—or perhaps one or more of the Court's Advocates-General - to seek to rationalize such concepts and explain the relationship between them. ${ }^{11}$

Graetz and Warren surmised the - rather pessimistic - conclusion that the Court has led itself into a 'labyrinth of impossibility'. ${ }^{12}$ Wattel argued that the case law is full of 'red herrings'. ${ }^{13}$ Vermeend equated reading the Court's decisions in the field of direct taxation with reading 'Alice in Wonderland' as early as in $1996 .{ }^{14}$ To keep up with these popular semantics, the research question may be restated as: is there order in the chaos of EU law in the field of direct taxes?

In plain English, the departure from prior research is basically this.

Prior research has inferred the structure and organisation of the system by inductive reasoning, while at the same time questioning its existence as a united whole, by researching individual judgments and rules. In other words, it reduced the system of EU law in the field of direct taxes to its sources and norms and it presumed that a more detailed and advanced knowledge of those individual elements resulted in a better understanding of the system as a whole.

This book deduces the structure and organisation of the system from the system itself by researching it as a united whole and it describes the place and role of the judgments and rules within that system. The legal doctrine that emerges in this way in this book is more a doctrine about the system as such, and less a doctrine about its individual legal sources and norms. The qualitative analysis of individual cases is, for that reason, rather concise in this book. The intention is not to approach the Court's interpretation of EU law in its direct tax

Farmer (2007), p. 44.

12

Graetz and Warren (2006); Graetz and Warren (2012).

Wattel (2004).

14 Vermeend (1996). 
case law critically, but to work towards a positive legal theory about the system that emerges from the body of case law in the field of direct taxes. For that purpose we follow a research framework of complexity science. ${ }^{15}$ Mitchell defines this research field as:

An interdisciplinary field of research that seeks to explain how large numbers of relatively simple entities organize themselves, without the benefit of any central controller, into a collective whole that creates patterns, uses information, and, in some cases, evolves and learns. ${ }^{16}$

The study of complex systems and networks has pervaded all of science. ${ }^{17}$ The emerging field of computational social sciences analyzes complex networks and leverages the current capacity to collect and analyze data on individual and group behaviour. ${ }^{18}$ A small but increasing body of literature in legal studies analyzes law as a complex system. ${ }^{19}$ The general motivation for this strand of research is that the legal system shows all of the characteristics common to complex adaptive systems such as eco-systems. ${ }^{20}$

The research framework of complexity science has theoretical implications for the way the structure and development of the law is viewed. Some important studies have approached the issues connected with the law as a complex system by researching the path dependence of legal change, ${ }^{21}$ the application of chaos theory to legal evolution, ${ }^{22}$ and self-similarity within the structure of the legal system; its fractal nature. ${ }^{23}$ In this book, we also draw from the recent advancements in networks science to study the legal system of choice in this book; EU law in the field of direct taxes.

The concept of emergence is central to complexity science. A complex system is a 'system that exhibits nontrivial emergent and self-organizing behaviors', according to Mitchell. ${ }^{24}$ The general idea is that behaviour and interactions at the micro-level of individual agents lead to macro-level properties — patterns and structures - of the system as whole. And, the central question in this field of research is consequently which processes and dynamics lead to emergent and self-organising behaviour. ${ }^{25}$ According to Miller and Page:

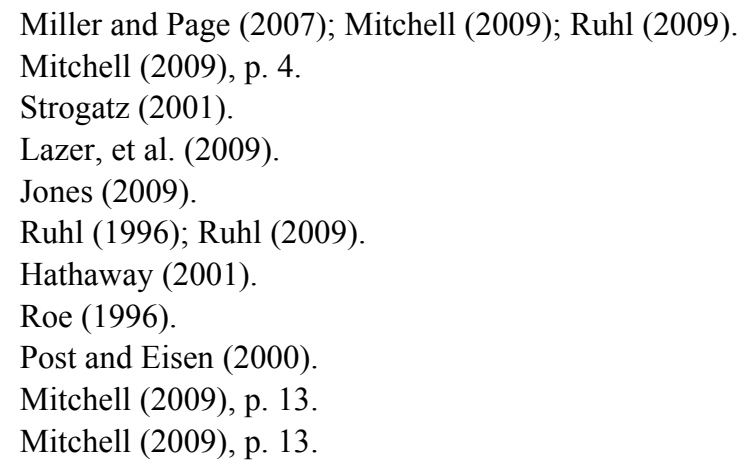


[E]mergence is that individual, localized behavior aggregates into global behaviour that is, in some sense, disconnected from its origins. Such a disconnection implies that, within limits, the details of the local behaviour do not matter for the aggregate outcome. ${ }^{26}$

Thus, the more precise reason why this book does not go into the details of the Court's grounds of judgment of the individual rulings - at least in Part II of this book - is that such details are not per definition decisive for the structure and organisation of the system of EU law in the field of direct taxation. A normative evaluation of and recommendation for the application and interpretation of EU law on a micro-level in individual cases does not have priority if the primary aim of the research is to advance the understanding of the overall system that the Court's rulings have established.

The research framework of complexity is closely related to theoretical jurisprudence of legal autopoiesis of Luhmann and Teubner. ${ }^{27}$ This jurisprudence has also been applied by Prebble in the field of taxation research. $^{28}$ The jurisprudence of legal autopoiesis also adopts a systems perspective on the law and has in common with complexity theory that the law is not reduced to a collection of individual rules and social agents, but that it treats the law as an emergent of the interactions within the system ('law is communication'). What legal autopoiesis and complexity theory also share is that they both accept the existence and significance of dynamic and selforganising processes. The systems not only exhibit emergence, but the emergent also is also an organised complexity that is due to feedback that is introduced to the system as a result of interactions. The theory of law as an autopoietic system, which was adapted from sociology, has also connected to network and graph theory for purposes of empirical analysis. ${ }^{29}$ This book continues on the perspective of complexity theory, specifically network science, and suffices with this mention of legal autopoiesis to give further context.

In short, this book contributes to the more general paradigm shift from a reductionist model of law to a complex adaptive systems model of law between order and chaos. ${ }^{30}$ The specific methodology of the research design will be explained in later chapters.

\section{$1.4 \quad$ Synopsis}

This book is divided into four parts. Part I, which is this first Chapter, gives the general introduction. Part II researches the breadth of the Court's case law in the field of direct taxes and Part III provides an in-depth rational reconstruction of

Miller and Page (2007), p. 44.

Luhmann (1989); Teubner (1993).

28 E.g. Hikaka and Prebble (2010); Prebble (2011).

29 Paterson and Teubner (1998).

30 See, Bourcier and Clergue (1999); Ruhl (1996). 
the balanced allocation of taxing powers and its relation with other justification grounds. Part IV presents the conclusions.

We will analyse how the body of CJEU case law on EU law in the field of direct taxes is structured and organised as a whole in Part II. First, Chapter 2 provides an analytical framework for this part by explaining the theoretical background to the process that we assume has driven the organisation the body of case law and we describe the method of research. Second, Chapter 3 will explore the properties of the case law by analysing aggregated meta-data on the cases. Third, Chapter 4 will analyse how the body of case law is structured and organised on various levels and scales. We will specifically examine whether there is structural cohesion in the body of case law and whether its organisation is legally relevant. The main innovation of Part II is that the research relies on a quantitative method called social network analysis to establish the structure and organisation of the system and to define which legal sources and norms are to be considered most essential to the evolution of EU law in the field of direct taxes. In that respect, this approach differs greatly from prior research that has attempted to establish legal doctrine only by constructive qualitative legal analysis. The overall product of the research of Part II is reported in Annex A which gives a structured overview of the most essential legal norm of EU law in the field of direct taxes.

We will limit our focus in Part III and research the structure and organisation of the law further by establishing the meaning of the legal norm 'a balanced allocation of the power to impose taxes between the Member States'. It is proffered in prior research that the introduction of this norm marks a critical juncture in the evolution of the system of EU law in the field of direct taxes and is important for its overall structure and organisation.

The main innovation here is that the chapters of Part III exhaustively research the legal norm of a balanced allocation of taxing powers with the result that we give a robust and well-defined meaning to it that is consistent with other legal norms that we identified in Part II. After an introduction to the analytical framework in Chapter 5, we first examine the Court's interpretation of that norm as such in Chapter 6. Then, Chapter 7 continues with an analysis of the relations with other legal norms which are functionally equivalent in legal doctrine, i.e. also perform the role of justification. Thereafter, the balancing of freedom of movement and the balanced allocation as an overriding reason of public interest is reviewed further by specifically researching elements of proportionality in the balanced allocation of taxing powers in Chapter 8. As a final step of research in this part, we revisit the reasoning and outcome in Marks \& Spencer (C-446/03), which is the original authority of this legal norm, and Chapter 9 offers a revised interpretation of that case.

The various elements of the research are tied together in Part IV in a general conclusion about the state of EU law in the field of direct taxation. The aim of the conclusion of Chapter 10 is to give a concise summary of the specific findings of this book, to revisit the overarching research aim and question more generally and to surmise what the findings of the research imply as avenues for future research. 
Parts II and III are relatively self-contained, which means that some Court cases are introduced twice in this book and a few points are repeated. This choice mainly contributes to the readability of the book.

Overall, the weight of discussion in Part II is more on personal income taxes, whereas Part III is focused on EU law in the field of corporation taxes. In line with the internal logic of the Court's case law, Part II pays closer attention to the conception and existence of a restriction, because Part III is aimed specifically at researching the content of justifications for tax restrictions on freedom of movement. This organisation of themes was not a deliberate research design choice as such, but emerged naturally as the research progressed over time. ${ }^{31}$

\section{$1.5 \quad$ Limits}

Member States of the European Union remain competent to legislate in the field of direct taxation. Although the Union has adopted only a few directives in the field of direct taxes, it nevertheless exerts extensive regulatory control over national direct tax systems. ${ }^{32}$ The process of integration from which this control results is chiefly directed by the judicial supervision of the Court of Justice of the European Union. Or, as Radaelli and Kramer put it, the single major factor of legal pressures in the field of direct taxes is the case law of the Court. ${ }^{33} \mathrm{In}$ contrast to national direct tax law which is codified in many Member States to high levels of complexity, the content of EU law in the field of direct taxation is thus almost exclusively based on case law. Consequently, EU law in the field of direct taxation evolves incrementally in a common law fashion, case by case, without superimposed codification or strategic legal planning by an EU legislator. This justifies limiting our research to case law only. The system of EU law in the field of direct taxes is a narrow conception and only represents the system embodied in the case law of the Court.

National judicial decisions are ignored in this book. The limited aim of giving outlines of a legal doctrine on EU law in a specific field neither requires, nor merits the discussion of those national decisions. Also, language is a constraint to the potential countries that we could include if we were to conceive the relevant body of case law in a much broader definition to include national decisions, despite Google Translate. ${ }^{34}$ Furthermore, data collection for the purposes of our research would be significantly more cumbersome. On balance, we believe that the limitation to the case law of the Court is justified.

The focus of the research is on EU law as interpreted by the Court, and this requires analysing the application of rules to the facts as evidently understood by

In that context, we should disclose that the first draft of the text of Part II was written when the research and draft for Part III was largely completed.

32

Genschel and Jachtenfuchs (2011).

33

34

Radaelli and Kraemer (2008).

$<$ http://translate.google.com>. 
the Court, even if the Court's take on the facts or the national legal framework may be incomplete or inaccurate. Although it is a responsibility of the academic community to draw attention to the normative merits of the ruling in view of its particular consequences for the national legislation in the various EU Member States ('the outcome'), one first needs to acquire an understanding of the rule that has been applied to determine whether a fact of national law that has been missed or misinterpreted by the Court would be material for the outcome in the first place.

The aim of this book is to arrive at a systematic understanding of the role and function of the various judicial rules that apply and belong to the legal doctrine of EU law in the field of direct taxes. Moreover, a very recent dissertation project by Douma has researched the normative merits of the outcomes of the rulings on EU law in the field of direct taxes. ${ }^{35}$ The reduction of national sovereignty that was the combined result of the outcomes of the individual rulings has been subject of Isenbaert's recent dissertation project. ${ }^{36}$ Monsenego has focused specifically on the case law concerning the taxation of foreign income. ${ }^{37}$ As stated above, this book applies a research framework that is fundamentally different from the approach in those studies. The research of this book is therefore limited to a positive legal research and we will only touch upon the merit or demerit of the Court's interpretation of the law on a tangent.

The following topics will only be touched upon briefly because they concern a normative discussion about the future direction of EU law in the field of direct taxation: most-favoured-nation treatment, ${ }^{38}$ non-discriminatory tax restrictions, ${ }^{39}$ and juridical double taxation. ${ }^{40}$ Although comparative law approaches, ${ }^{41}$ economic neutrality benchmarks, ${ }^{42}$ or other extra-legal theoretical models, ${ }^{43}$ may give much desired insight into potential normative evaluations and recommendations for these issues, all of that is not the topic of this book. We also do not wish to base our analysis on a traditional normative framework of tax policy. The important study of Lang and English on the European legal tax order based on the principle of ability to pay is a prime example of such a taxoriented principles-based approach. ${ }^{44}$ This is also not the type of research that this book aims to report.

For example, the disadvantage of juridical double non-taxation was clearly held not to be contrary to EU law according to the Court's line of authority

35

36

37

38

39

40

41

42

43

44

Douma (2012b).

Isenbaert (2010).

Monsenego (2012).

Section 4.3.5.3.3 on the ruling in D. (C-376/03).

Sections 3.6.2.2 and 4.3.5.5.2 on the Säger/Kraus formula.

Section 3.6.2.2.1.

Avi-Yonah, et al. (2007); Mason (2008).

Mason and Knoll (2012).

Roxan (2000).

Lang and Englisch (2006). 
starting with Kerckhaert and Morres (C-513/04). For that reason, any discussion about the merit or demerit of the reasoning and outcome of that judgment is normative in nature and therefore does not fall within the scope of this research which is concerned primarily with a positive theory on the structure and organisation of EU law in the field of direct taxes. The question whether and how the rule of Kerckhaert and Morres 'fits' within this structure and organisation is of course an obvious follow-up to the findings of this research.

\subsection{Guidance to the reader}

Since this book builds on prior research and because science is a collective effort, even if the research was done by a single person under supervision of another, this book uses a 'we'-narrative instead of 'I' throughout this book. Also, 'we' refers to both the reader and the author and allows for a more engaging writing style than the 'I'-narrative. All errors or omissions in this book are of course my own.

This book was written with a reader in mind who is knowledgeable about the basics of EU law and taxation. The institutional framework of EU law will not be discussed, nor will we venture into general reviews about well-known principles as supremacy, conferral of competences, subsidiarity, proportionality, and direct effect. These principles are only explained shortly when relevant and it therefore suffices to refer to the usual textbooks. ${ }^{45}$

This book makes a rather strict division between views on the object of research as analysed in prior research and the qualitative analysis of the case law. Prior research is used primarily to formulate the research questions. Prior research is therefore reviewed on the basis of the main contributions of several publications. It would be methodologically weak to use the same literature to answer those questions. All references to the literature are given in author-date short form in footnotes. The full reference is given in the list of references in the back matter of this book.

All cases of the CJEU are cited in short form and usually directly in the main text. References to a set of cases are however put in a footnote to enhance readability of the text. The case number is given when the case is mentioned for the first time in each chapter. Thereafter, only the short name is used. When a reference may be ambiguous - especially for cases pursuant to direct actionsthe case number is also mentioned to avoid confusing the reader. The full references of cases of other courts are given in footnotes. This book includes a list of cases with full references. Full references to legislation other than the Treaties are exclusively given in footnotes. All references to the Treaties are to the current Articles of the TEU and TFEU, and quotations have been adapted with the use of square brackets, unless the provision was no longer in force post-

45

E.g., Barnard (2010); Craig and De Búrca (2008); Kapteyn, et al. (2008); Tridimas (2006). 
Lisbon. References to EU directives are to the instrument in force on 1 January 2012.

Some final words on the use of the word 'Court' in this book complete this Chapter. The institution CJEU is currently composed of the Court of Justice, the General Court and the Civil Service Tribunal. The capitalised word 'Court' is, in this book, a short name for the Court of Justice of this institution. References to the other courts are made explicit by using the full name. The national court that made the reference to the Court in preliminary reference procedures is normally not identified and the wording 'national court' is used, unless the context requires identification. 

II The Structure and Organisation of the Case Law 



\section{Chapter 2 Introduction to Part II}

\section{$2.1 \quad$ Introduction}

A central overriding theme in prior research on EU law in the field of direct taxation is whether the Court acts within the limits of its judicial competence when interpreting EU law in the field of direct taxation, or oversteps its margin of appreciation (zone of judicial discretion) and infringes the principle of conferral of competences. ${ }^{46}$ The discussion in the literature is predominantly focused on the normative merits and demerits of the Court's rulings, particularly with regard to the legitimacy of the reduction of national fiscal 'sovereignty' through the (de)regulatory control exerted by the Court. ${ }^{47}$

We will see later in this book that more than 200 cases have been referred to the Court between 1983 and 2011 on the compatibility of national provisions of income and capital taxation of individuals and companies with the imperatives of the fundamental rights to non-discrimination and free movement. ${ }^{48}$ In order to acquire an understanding about the direction and nature of legal integration through judicial decision making in this specific functional field of EU law, the research starts with analysing the properties and the structure and organisation of the body of case law of the Court on the interpretation of EU law in the field of direct taxes.

The main controversy of prior research is whether the body of case law of the Court is cohesive and prior decisions are interpreted and applied consistently in subsequent case law. ${ }^{49}$ Prior (post-)doctoral studies do not necessarily take account of the structure and organisation of the body of case law as a whole, but rather focus on the normative merits and demerits of the individual judicial decision, compares individual decisions and then reveals from these analyses general conclusions about the system. ${ }^{50}$ Notwithstanding, this research is

See e.g., Douma (2012b); Vanistendael (2006a); Vanistendael (2008b) for surveys of the literature.

Douma (2012b); Graetz and Warren (2006); Isenbaert (2010); Lang (2009); Van Thiel (2008a); Wattel (2008); Weber (2006).

Chapter 3.

See e.g., Farmer (2003); Graetz and Warren (2006); Graetz and Warren (2007); Graetz and Warren (2012); Lang (2006a); Lang (2009); Terra and Wattel (2012); Van Thiel (2008a); Vanistendael (2008a); Wathelet (2008); Wattel (2007); Wattel (2008).

See e.g, Cordewener (2002); Douma (2012b); Isenbaert (2010); Kofler (2007b); Monsenego (2012); Van Thiel (2002). 
important and has given much insight into the Court's method of reasoning when it is confronted with interpreting EU law in the field of direct taxation. However, the Court's method of reasoning is something different than the structure and organisation of the law.

Prior research also reviewed how the regulatory control of the Court through its direct tax jurisprudence impacts national law and international tax relations. There are comprehensive studies on the substantive impact of the EU case law on the regulation and administration of direct tax laws in the Member States. ${ }^{51}$ The reception of the Court's rulings by national judges and the application of the acte clair doctrine has also been studied in detail. ${ }^{52}$ Similarly, the substantive impact of EU law on international tax law is well documented in prior research. $^{53}$

Despite a significant body of literature on the effects of the outcomes of the judicial decisions, very little attention has yet been paid to the dynamics of the Court's judicial decision making process and its relevance for the emergence of legal norms in this field of law. Whereas we now have a well advanced insight into the basic method of interpretation of EU law in the field of direct taxes in individual cases and knowledge about requirements of compatibility with EU law of national direct tax legislation for a wide range of topics, our understanding of this area of law as a functional subsystem of EU law is underdeveloped. A closer insight into the dynamics of judicial decision making is however necessary for the framing of normative discussions about the outcomes of the judicial decision-making process. By acquiring a better understanding of the process of judicial decision making we can thus advance our knowledge of EU law in the field of direct taxation as a system.

The focus of research on institutional processes at the Union level has yet been limited to the legislative branch, i.e. the process of positive integration. The main studies focus on the process of harmonisation of corporate taxation and the governance of tax competition within the EU. ${ }^{54}$ No comprehensive study has yet been published about the structural processes that underlie the evolution of the Court's judicial doctrine in the field of direct taxation. This marks the academic relevance of this book.

The research of Part II advances our understanding of EU law in the field of direct taxation as a functional subsystem of EU law by applying a network analytical framework-social network analysis (SNA). Network science allows us to consider the body of case law in the field of direct taxation as a whole and to infer its structure and organisation in a manner that is detached from a normative evaluation of the judicial decisions. It is not the individual decisions and the particular observations that the Court made in those decisions that are the subject of this research, but rather the collection of decisions as such.

52 Dourado and da Palma Borges (2008).

53 Graaf de (2004); Kofler (2007b); Panayi (2007); Pistone (2002).

54 Cerioni (2007); Martin Jiménez (1999); Pinto (2003); Radaelli (1997). 
The purpose of this Chapter is to provide the basic theoretical background of the process of judicial decision making and to explain the research method of SNA. The remainder of Part II is dedicated to researching the body of case law in the field of direct taxes with this methodology. The general assumption on which the research is based is that the authority of precedent may be used to systematically research the structure and organisation of EU law in the field of direct taxation as a system, because the interpretative guidance of precedent appears to play a central role in the judicial decision-making process of the Court. Before the theoretical and methodological background will be explained, the research questions that it designs to answer will be formulated first.

\section{$2.2 \quad$ Research questions}

The analysis and discussion that follows in the next Chapters is structured around the following research questions and subquestions.

Research question 1: What are the properties of the body of case law in the field of direct taxation (Chapter 3)?

Research question 2: How did the doctrine of precedent shape the structure and organisation of jurisprudence on EU law in the field of direct taxation (Chapter $4)$ ?

- Is the structure and organisation of the case law cohesive?

- Are legal grounds an adequate first order description of the organisation of the case law, if any?

- What are the most important sources and legal norms?

- And, how is EU law in the field of direct taxation connected to its environment, i.e. narrowly defined as the larger system of EU law? The research is limited to the question how developments outside the field of direct taxation have been received by the field of direct taxation.

This Chapter is structured as follows. The network analytical framework requires first an understanding about the role and function that precedent plays in judicial decision making on EU law at the Court. This is necessary because the research builds on the assumption that the main driver of the process of structuring and organising EU law in the field of direct taxation is the notion of precedent. Section 2.3 below aims to first provide this necessary theoretical framework. Section 2.4 then presents a short introduction to the method of SNA insofar as is necessary to understand the technical analysis that follows. Finally, Section 2.5 explains the criteria by which the data set, i.e. the relevant body of case law, has been defined. 


\section{3}

\section{Theoretical background}

\subsubsection{Normative background}

2.3.1.1 Choice against an attitudinal model of judicial decision making

Many lawyers would agree that prior case law acts as interpretative guidance to decide subsequent cases. Critics of that proposition however argue that precedent only acts an ex-post justification of judges' personal views and attitudes on policy and case outcomes. ${ }^{55}$ Similarly, the Court is said to follow the policy preferences of the (most powerful) Member States in reaction to the threat of override of and non-compliance with its judicial decisions. ${ }^{56}$ This begs the question how the Court exercises its judicial powers in reaching decisions on the legal disputes that are brought before it. A critical political theory that primarily focuses on the ideology of the judge and the strategic political use of its judicial powers is not exactly what Montesquieu had in mind. Rather it is 'l'état despotique' in which '...le juge est lui-même sa règle'. Thus, the preliminary choice is to reject an attitudinal model of judicial decision making as a framework for understanding the Court's case law.

\subsubsection{Montesquieu and the role of the judge}

According to Montesquieu, judgments should conform to an objective conception of the law and not the private opinions of the judges, because the people should not live in a society without knowing the obligations it lays on them. To ensure the freedom of people it should be assured that the judge is unprejudiced and is objective in measuring and applying the force and rigor that law prescribes. The ordinary courts of the nation should speak the law as if they were inanimate creatures without moderating its force or rigour:

Les juges de la nation ne sont que les bouches qui prononcent les paroles de la loi; des êtres inanimés qui n'en peuvent modérer ni la force ni la rigeur.

The relevant passage and context of this quote in De l'esprit des lois (Book XI, Chapter 6) on the constitution of England concerns three exceptions of situations in which courts composed of common people, which Montesquieu believed should be the ordinary courts of the nation and as a judicial power should be generally detached from the legislature and executive power, are not the appropriate courts to judge. Montesquieu purported to show that England, with its mixed constitution, had maintained a balance of powers that conformed to his political theory.

See, Fowler and Jeon (2008); Lindquist and Cross (2005) for a general review of the continuum of theories of precedent in the literature. 
Montesquieu's view of the role of the judge is, in short, to measure the state of the law in an objective manner. If the law is found to be determinate, the judge is obliged to follow the force and rigor prescribed by the letter of the law, irrespective of his personal views. Even when the state of law is indeterminate, the court remains institutionally bound, in Montesquieu's theory, to observe and pronounce it.

The 'observer effect' in physics however taught that a complete separation of observer and the observed in scientific experiment is contentious. ${ }^{57}$ The same applies to judicial decision making as a scientific experiment. Some observations are pure discoveries and are non-invasive on the observed, e.g. looking at the trees in a forest. ${ }^{58}$ Other observations are invasive and can only be made by creating an effect on the object that is observed. ${ }^{59}$ For example, to observe the burnability of wood one has to burn a piece of wood. ${ }^{60}$ The effect is that the piece of wood is destroyed. Conversely, observations may also be invasive acts of creation. ${ }^{61}$

For the purposes of our discussion, it is sufficient to realise that the Court does not observe the law as if it discovers trees in a forest. A judicial decision which resolves indeterminacy in the law is an invasive observation because the observation has an effect on what is being observed as the law. ${ }^{62}$ There is no objective reality of law from which the judicial power is detached; the Court (observer) is intertwined with the law (the observed) and the act of judgment necessarily has an effect on the law. The law is given a determinate content by the Court's judgment and the judgment so 'makes' law. ${ }^{63}$

What is important in Montesquieu's ideas about the role of the judge in a state in which not all law is determinate, l'état monarchique, is that judges are called upon to exercise this discretion and give content to the law autonomously. But, they should decide and determine the content of the law consistently with the spirit of the laws in order to remain objective in applying its force and rigor. ${ }^{64}$ Montesquieu did not view the judge as an actor who is or should be completely detached from the content of law. Even after the French revolution, the interpretation of the law, which was accepted as necessarily indeterminate to a degree, was within the purview of the judge. ${ }^{65}$ The room for gradual change in law over time, which Montesquieu favoured above revolution and sudden reform, ${ }^{66}$ was so maintained. Carrese proffers that the search for the spirit of the

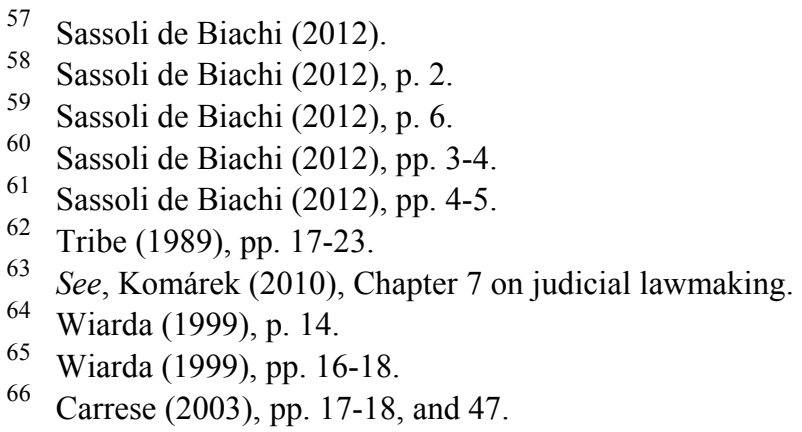


laws clearly echoes complex judging in English common law and its reasoning with prior decisions. ${ }^{67}$

When interpreting EU law, the Court and national courts are required to look into 'the spirit, the general scheme and the wording' of the provisions of EU law to determine their content, according to Van Gend \& Loos $(26 / 62) .{ }^{68}$ It follows from CILFIT (283/81), paras 18 and 19, that the different language versions should be considered when the wording of the provisions is interpreted and that the terminology and legal concepts used have an autonomous meaning in EU law. Furthermore, the context ('general scheme') and object and purpose ('spirit') of EU law are dynamic which requires, according to CILFIT, para 20, that the objectives of EU law should be interpreted with regard to the state of evolution of EU law at the date at which the provision is to be applied. ${ }^{69}$

After the court has objectively determined the state of the law, the institutional wiring of society constructs this as the true state of the law. So, when the experiment of judgment is replicated and the judge is called upon to measure the state of the law again in a subsequent case under exactly the same conditions and circumstances, the objective judge conforming to Montesquieu's description would apply the law with the same force and rigor as it did in the previous case. This makes it predictable for citizens to know the obligations that society lays on them. Citizens can plan their actions accordingly. Montesquieu believed, as explained by Carresse, that the spirit of moderation should not be that of the judges, but that of the legislator. ${ }^{70} \mathrm{~A}$ departure from precedent would imply to speak the law with moderation. A different measurement of the law than the measurement obtained in a previous case can thus only be justified either by a change in the letter or in the spirit of the law itself, or by the finding that the letter or spirit of the law was wrongly measured in the prior experiment.

In synthesis, Montesquieu's political theory requires judges to treat the content and spirit of the law in an objective manner and not to be guided by personal attitudes and ideology when exercising judicial power. Since Montesquieu's theory remains the basic normative foundation of the institutional arrangements in the EU and in its Member States which distributes the legislative, executive and judicial powers over different political agents to achieve a balanced exercise of the state's power on its citizens, the research proceeds from the assumption that the CJEU also aims to conform with the Montesquieu's normative requirements associated with judicial power. That

67

68

Carrese (2003), p. 36

See e.g. Fennelly (1996); Itzcovich (2009); Koopmans (2003); Maduro (2007). Notably, the order of methods of interpretation is the reverse of Article 31(1) of the Vienna Convenvention on the Law of Treaties which speaks first of 'terms' ('wording'), second of 'context' ('general scheme') and finally of 'object and purpose' ('spirit' in Van Gend \& Loos), all of which should be considered in 'good faith'.

69

70

See generally, Bengoetxea (1993) on the legal reasoning of the CJEU. 
model does not imply that judges cannot make law; it rather requires that indeterminacy in the law is resolved within the framework of the spirit of the laws by the judge and that, once the law is observed in a determinate state, that later observations of this state cohere with prior observations. ${ }^{71}$ Consequently, judicial power is bounded by the spirit of the laws; solutions which do not cohere with 'the spirit, the general scheme and the wording' of EU law are not legal. Before we can continue we need to ask whether Montesquieu's normative expectations are empirical fact.

\subsubsection{A view from European political science on judicial governance}

The exhaustive literature review of Stone Sweet gives three points on which there is general agreement in European political science discourse on the Court's use of judicial power and its impact on European integration. ${ }^{72}$ It suffices to list the basic implications of this field of research to indicate that it is plausible that Court treats the law seriously in its judicial decisions. It is therefore warranted to assume that a legal doctrine is inherent in the case law, which is not primarily politically motivated in terms of policy preferences of Member States, but is a legal doctrine that is a rational reconstruction of the system of the law.

The first predominant view is that the CJEU uses its judicial powers to promote integration within the Union. That means that it understands its mandate as a trusteeship of the fundamental objective inherent in the Treaties, namely to work towards an ever closer Union. ${ }^{73}$ In Montesquieu's view one could also say that integration is the spirit of EU law. Even if European integration is the Court's overriding 'political' motivation, it only establishes the general direction in which the path of law develops through judicial decision making; indeterminacy in the law will be resolved in favour of integration.

Secondly, there is also a broad consensus on the view that the CJEU values coherence in its case law, because it reinforces the strategic legitimation of the Court's judicial power over national political decisions. A coherent body of case law is difficult, if not impossible, to achieve if the Court's rulings are contradictory on the content of the law. Thus, the Court should in principle respect its own legal analysis of previous rulings in subsequent decisions, or should find a mechanism to reason using prior decisions that contradict current preferences over similar cases, while maintaining objective. The doctrine of precedent is capable of dealing with this task and a minimally robust conception is accepted to be necessary for the law to become path dependent. ${ }^{74}$ The more a legal system becomes path dependent, the more historical process rather than initial conditions determine legal outcomes. ${ }^{75}$

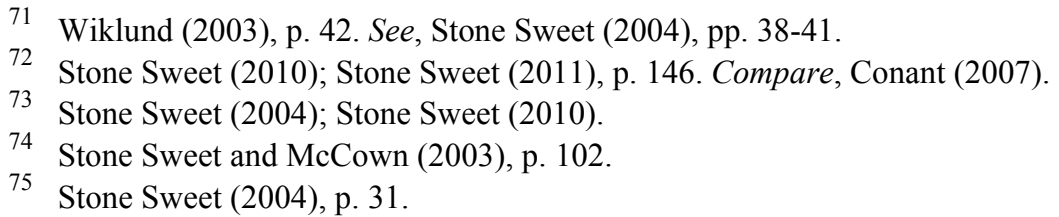


The third common ground is that the Court tries to ensure that national and Union institutions comply with its decisions. We will see below that the state liability for serious breaches of CJEU decisions, established by the Köbler (C224/01) ruling, is one technique developed by the Court to further compliance by national institutions with its case law.

These three points of accepted knowledge on the judicial politics at the CJEU conclude with a basic assumption that the Court values the legal authority of its decisions. A political science theory of neo-functionalism does not exclude that the Court uses the law strategically and is responsive to political interests by exploiting majoritarian activism, but the predominant view on the Court's use of judicial power is that, if the Court aims to pursue strategic goals, it will do so primarily by reinforcing the legal authority of its decisions, ${ }^{76}$ by a display of the objective process of judicial decision making that Montesquieu requires. ${ }^{77}$ The studies that assert that the Court would defer to the political preferences of particular Member States - the intergovernmentalist theory ${ }^{78}$ - have not found convincing empirical support in European political science discourse. ${ }^{79}$ The argument against such an attitudinal model of European judicial governance is persuasive. ${ }^{80}$ Rather, the Court is most likely to accept the legal analysis of the Commission. ${ }^{81}$

To conclude, this book rejects an attitudinal model of judicial decision making as the theoretical framework of research and the research proceeds with a model of exercise of judicial discretion that should be, and is constrained by the content and spirits of the law, which includes the content and spirits given to the law in prior judicial decisions.

\subsubsection{Positive law background}

\subsubsection{The authority of precedent in EU law}

A review of the legal literature shows that the prevailing legal doctrine is that previous judgments of the Court indeed have authority over the content of EU law. The aim of the discussion that follows is thus not to argue this proposition critically in an exhaustive manner, but rather to explain in an illustrative and maybe opportunistic way, why this is a plausible interpretation based on findings of prior research.

Burley and Mattli (1993); Maduro (1998); Mattli and Slaughter (1995); Mattli and Slaughter (1998).

77 Bengoetxea (1993), p. 135.

78 Carrubba, et al. (2008); Garrett (1992); Garrett (1995); Garrett, et al. (1998).

79 Conant (2007); Stone Sweet (2010); Stone Sweet and Brunell (2012).

80 Kelemen (2012).

81 E.g., Conant (2007), p. 53. Compare, Granger (2004); Granger (2006). 
It should be pointed out at the outset that the rulings of the CJEU are not sources of EU law, meaning they have no formal authority over the content of the law. This is an immediate consequence of the civil law origins of the Court. ${ }^{82}$ We will see that the Court's rulings however have practical authority in the sense that they are statements about what EU law is.

The process of coherent judicial decision making through time is summarised by the particularly strong legal norm of stare decisis as applied in (Anglo-American) common law or the soft civil law version of jurisprudence constante. The authority of precedent is accepted in a similar fashion in EU law, and also as it applies in the field of direct taxes. ${ }^{83}$

It is beyond the scope of this book to carry out a comparative law research on the practices of precedent in the national systems of the EU Member States. However, the practice of precedent in a comparative law perspective was the topic of the 2006 Congress of the International Academy of Comparative Law. ${ }^{84}$ The general report recognizes that the practice of precedent is well-established in the common law jurisdictions and mixed legal systems, such as Scotland, but also Israel. ${ }^{85}$ The civil law systems in Western Europe differ more than the common law systems, but the prevailing opinion that emerges from the national reports is that a soft version of precedent is applied in the Western European civil law systems. ${ }^{86}$ Although the system of precedent that existed in the ius commune period was abolished in theory during the codification period, precedent remained relevant to the practice of law. ${ }^{87}$ Furthermore, the decisions of the CJEU and the ECtHR appear to exert considerable influence on the growing importance of precedent in Western European civil law. ${ }^{88}$ The practical importance of precedent in Western European civil law systems contrasts with the low status of precedent in jurisdictions in Central and Eastern Europe. Hondius submits that the importance of case law should be stressed more in these systems - by legal doctrine, law reports, annotations, and by legal education - to make possible a movement towards a greater importance of case law and precedent to the practice of law. ${ }^{89}$ The Central and Eastern European law systems still seem to 'suffer', as Hondius puts it, 'from their socialists past'. 90

It is common ground in prior research that the CJEU is not strictly bound by its earlier rulings, but those precedents are persuasive in deciding like cases. ${ }^{91}$

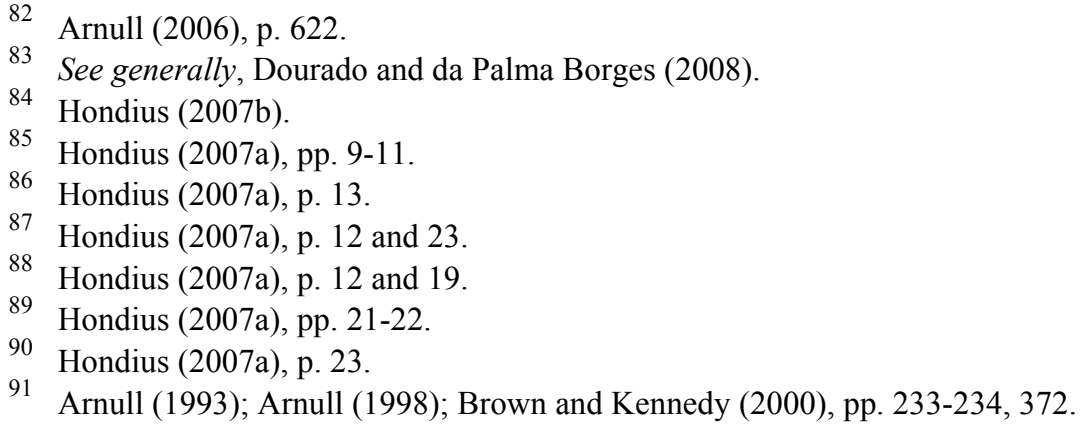


Toth referred to the Court's rulings as 'authoritative evidences' of EU law. ${ }^{92}$ Koopmans however argued that the CJEU considers its own precedents to have binding authority. ${ }^{93}$ Also Tjon Tjin Tai and Teuben find that horizontal precedent is the rule. ${ }^{94}$

The sources cited here all agree that the practical authority over the content of the law gives the Court's rulings special legal significance. This authority influences the process of judicial decision making. Because the Court is bound to interpret the law, and its rulings have practical authority over the content of the law, then prior rulings constrain the Court's freedom to interpret the same law differently in subsequent rulings. Prior decisions provide interpretative guidance to decide new cases because the indeterminacy of the law has already been resolved by those decisions.

Stone Sweet and McCown (2003) have shown that the CJEU's recourse to precedent has increased over time, and a clear majority of new rulings cite earlier rulings since 1980. Moreover, they found that the CJEU used sets of precedents to construct legal doctrine ('clusters') and has invoked these sets repeatedly; thereby codifying legal doctrine through case based judicial lawmaking. Indeed, there are several published collections of the Court's formulas in its case law on the preliminary ruling procedure, ${ }^{95}$ competition, ${ }^{96}$ state aid, ${ }^{97}$ merger control, ${ }^{98}$ and direct taxes. ${ }^{99}$ These books provide further evidence that the Court's case law is precedent oriented in that the court reasons with judicial rules and codifies those rules using citation of precedent. Notwithstanding their evident practical use, there is however no information on the method or procedure by which these formulas are defined, structured and distinguished in the directories.

One of the most exhaustive and current reviews on the Court's use of precedent is the dissertation by Komárek. He distinguishes two generic models of precedent. Komárek's conception of precedent involves the models by which the Court reasons using previous decisions to decide subsequent cases.

First there is the model of legislative precedent. Komárek finds this model 'omnipresent' in the Court's case law. ${ }^{100}$ He refers to the various formulas and tests that the Court applies with its copy-and-paste approach to reasoning using previous decisions. ${ }^{101}$ Komárek finds that this model is favoured by the preliminary reference procedure in which the Court renders judgments by

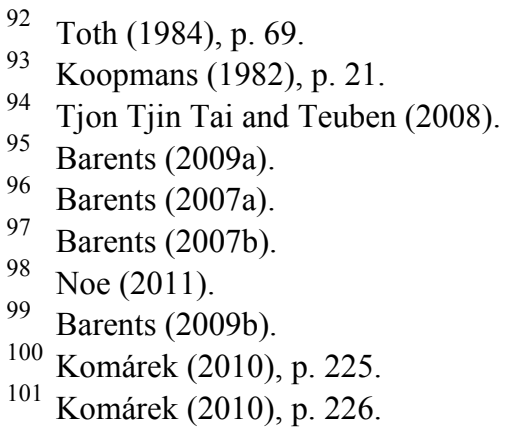


replying to the questions in a rule-like fashion. The text of the previous decision is the determinative basis of authority, in a similar fashion as the text of legislative provisions. ${ }^{102}$ This method directly opposes common law precedent because the Court's statements are interpreted 'as if they were legislated rules'. ${ }^{103}$

The second model is the case-bound model of precedent, which more resembles a common law precedent. There are two variations of this model. In the first alternative of fact-intensive case-bound precedent, the Court reasons explicitly with the facts of previous cases and considers whether the reasoning of the previous case in the context of its particular circumstances may be transposed to the specific situation of the case at hand. The second alternative is a norm-intensive case-bound model of reasoning in which the Court compares national measures of different Member States to evaluate whether the analysis and interpretation of EU law reached with respect to the national legislation of Member State A in a previous decision may be transposed to the interpretation of EU law with regard to the national legislation of Member Sate B in view of the differences and similarities of those national measures. The authority of the case-bound model is defined by the experiment of the particular previous case. ${ }^{104}$

In sum, the conclusion is that the prevailing view in the literature is that the process of judicial decision making of the CJEU is 'precedent oriented'. ${ }^{105} \mathrm{We}$ will now turn to a closer examination of the precise legal authority of precedents in EU law in order to understand the potential scope of control on the process of judicial decision making. For this purpose, we will review the doctrine of acte éclairé and acte clair

\subsubsection{Acte éclairé and acte clair}

The authority of precedent in EU law was established by the doctrine of acte éclairé and acte clair as a main standard of the larger legal framework of cooperation between national and Union courts in the preliminary reference procedure of Article 267 TFEU. Craig and de Búrca stated that the Court created a de facto system of binding precedent in EU law by introducing acte éclairé in $D a$ Costa (Joined Cases 28-30/62). ${ }^{106}$ Acte éclairé is the rule that an interpretation of EU law given in a prior CJEU ruling may be applied equally in a factual identical subsequent case before any national court without seeking additional interpretative guidance by the CJEU. The national court is consequently not obliged to refer a question for preliminary reference on that point of law to the Court, even if there is no judicial remedy possible against that national court's ruling.

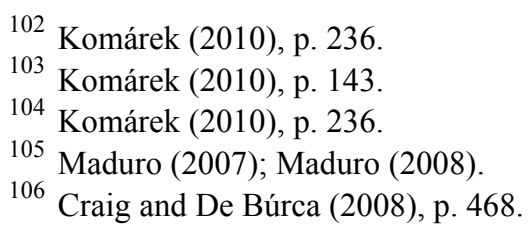


Acte éclairé questions, as per Da Costa, are thus unnecessary and are empty of substance since the indeterminacy in the law has already been resolved by precedent. If a national court decides not to refer a preliminary question to the CJEU for reason of acte éclairé, it ought to decide that identical subsequent case in the same way as the precedent. The precedent case has binding authority (enactment force) and is dispositive of the subsequent case.

Likewise, the doctrine of acte clair as developed in CILFIT (283/81) permits a national court, against whose decisions there is no judicial remedy under national law, not to refer a question concerning the interpretation of EU law for a preliminary ruling to the CJEU, if it has established that the correct application of EU law is so obvious - either based on interpretation in sufficiently similar prior cases, or because the law itself is determinate - as to leave no scope for any reasonable doubt on its correct interpretation, also not for national courts in other Member States. Whereas the rationale for acte éclairé in Da Costa was primarily the assertion of the authority of the Court's rulings in a formal sense, the rationale for acte clair in CILFIT was to establish a ground for clarity in the sense of material likeness of issues. ${ }^{107}$

To sum up, the difference between acte clair and acte éclairé is the degree of likeness between precedent and the subsequent case under review. Acte éclairé concerns the same issue in law in an identical case in fact; the question whether an authority exists. Acte clair concerns precedent cases that may be distinguished on facts, but nevertheless clearly concern the same question of law as is at issue in the subsequent case; the question whether existing authorities apply to the case at issue. The likeness of acte clair precedent is thus to be determined at a higher level of abstraction compared to acte éclairé.

National courts are accordingly left a margin of discretion in comparing cases by analogy, and are required to determine whether or not they are distinguishable from precedent.

The Da Costa-CILFIT case law requires the highest national court to evaluate whether the case at hand is distinguishable from CJEU precedent. In a case before a highest national court in which a same or sufficiently similar (indistinguishable) question was already subject to the CJEU's interpretative guidance, the Da Costa-CILFIT case law permits the highest national court to refrain from referring the case for a preliminary ruling to the CJEU. The $D a$ Costa-CILFIT line of authority leaves the possibility that CJEU precedent on the issue pre-empts the existence of a question on the interpretation of indeterminate EU law, which would be subject to referral under Article 267 TFEU but for the precedent. If the national court comes to the conclusion that the case at hand indeed cannot be distinguished from CJEU precedent, then that precedent is binding on the national court if it does not make a referral to the CJEU. That logically implies that most cases that reach the CJEU are not clearly comparable to precedents. 


\subsubsection{Member State liability for disregard of precedent}

The power of the Da Costa-CILFIT line of authority is however with the way it forces national courts to respect CJEU rulings which in their opinion were wrongly decided. This is so because manifest disregard of the CJEU's case law by a national court creates state liability for that national court's Member State according to the Köbler (C-224/01) judgment. Manifest disregard-not misinterpretation - of precedent is equated with a breach of EU law. This case law effectively makes the practical authority of precedent equally binding on the national courts as the formal sources of EU law itself.

In this regard, the rulings in Commission v Italy (C-129/00) and Commission $v$ Spain (C-154/08) should be mentioned specifically. In Commission v Italy (para 29), the Court held on basis of the precedent of Commission v Belgium (77/69) (para 15) that a Member State may be held accountable for failure to fulfil the obligations under EU law caused by the action or inaction of any state body, even if the institution is constitutionally independent. The failure of Italy in Commission v Italy was due to combined inaction of the legislator to amend national VAT law, the non-harmonious interpretation of that national law by Italian national courts, including the Corte suprema di cassazione (Supreme Court of Italy), and the application of that law in administrative practice.

However, in Commission v Spain the Court ruled that the Kingdom of Spain failed to fulfil its obligations solely because of the reason that Spanish (regional) courts adopted an interpretation of VAT law that was contrary to the interpretation of the Sixth VAT Directive (77/388/EEC) established by consistent case law of the CJEU. ${ }^{108}$ The fact that the Tribunal Supremo (Supreme Court of Spain) confirmed the wrong interpretation was material for the decision. The objective situation was indeed that the Spanish jurisprudence was contrary to CJEU precedent. However, it did not concern 'isolated or numerically insignificant judicial decisions taking a different direction' in the national case law, but the Spanish jurisprudence was 'a widely-held judicial construction which has not been disowned by the supreme court, but rather confirmed by it' (Commission v Spain, para 126). The role of the supreme court is relevant because it is under an obligation to refer questions on the interpretation of indeterminate EU law, since there is no judicial remedy available against its decisions.

It should be noted that judicial decisions may constitute a failure to fulfil obligations under EU law, even if there also exists an EU law compliant widelyheld judicial construction in parallel to the opposite view in breach of EU law (Commission v Italy, para 33). A situation of significant divergent views is evidently a minimum threshold for state liability in terms of Köbler. The

108 Sixth Council Directive 77/388/EEC of 17 May 1977 on the harmonization of the laws of the Member States relating to turnover taxes - Common system of value added tax: uniform basis of assessment, O.J. L 145, 13/06/1977, p. 1-40 ('Sixth VAT Directive', repealed). 
'insignificant judicial decisions taking a different direction' are only treated as unfortunate accidents, but a widely-held construct, particular when confirmed by the supreme court may lead to state liability of the Member State concerned.

There may be numerous situations in which a national court does not agree with the judicial doctrine of the CJEU, or at least questions in which direction the doctrine should evolve. But, instead of autonomously taking a different view than the CJEU, a national court can easily mitigate legal risk, and is best advised to take the position that a seemingly similar case under review should be distinguished on new grounds - thereby creating a new question which the national court is legally obliged to refer-or to frankly request the CJEU to reconsider its earlier position.

The res judicata of an interpretative ruling by the CJEU does not extend beyond the case in which the guidance was sought. The mere fact that a legal issue was resolved in an earlier case does therefore not bar the national court from raising that issue again in a subsequent similar case. Res judicata in the sense of issue preclusion is not part of EU law and the Da Costa-CILFIT case law expressly recognises the national court's right to refer on the same issues of law in later cases.

If the highest national court takes the view the acte clair/éclairé precedent was wrongly decided and, for whatever reason, resists applying the precedent in the case at hand, the highest national court should express its doubts by referring the case to the CJEU. As we have seen in the case of Commission v Spain, a highest national court cannot overrule an acte clair/éclairé autonomously as this would undermine the CJEU's constitutional duty to safeguard the coherence and uniformity of the interpretation of EU law, and would consequently endanger the equality in application of EU law in the different Member States. The basic standard is either to treat acte clair/éclairé precedent as correctly decided and follow its result in judging the case at hand, or to refer the issue again for a preliminary ruling in a new case to the CJEU, with or without distinguishing on new grounds.

Should a national court decide to refer a legal issue again to the CJEU for a preliminary ruling on the merits, we will see in the next Sections that the CJEU is free to stand by or overrule the precedent. The national court is however obliged to follow the interpretation of EU law stated by the CJEU in the case at hand as a matter of res judicata. The national court cannot question the validity of the merits of a preliminary ruling it requested itself in an individual case, as the Court expressly ruled by reasoned order in Wünsche Handelsgesellschaft $(69 / 85)$. This holding was derived directly from the aim of the cooperation between national and EU courts under the preliminary reference procedure, that is to ensure that EU law is applied in a unified manner throughout the Union (Wünsche Handelsgesellschaft, paras 12 and 13).

In synthesis, Article 267 TFEU and the Da Costa-CILFIT line of authority ultimately require a national court to follow CJEU precedents, even if it considers those judgments wrongly decided, and moreover when the CJEU rejects the national court's invitation to overrule such precedent. Thus, the authority to overrule CJEU precedent rests solely with the CJEU. This 
demonstrates that, ultimately in fact, CJEU precedent is strictly binding on national courts against whose decision no judicial remedy is possible. ${ }^{109}$ The compliance of national courts with this hierarchy is monitored by the CJEU with the instrument of state liability for breaches of EU law through judicial decisions.

\subsubsection{A self-imposed constraint}

The acte clair/éclairé doctrine governs the cooperation and vertical relation between national and EU courts in their joint task of interpreting EU law. The preliminary reference procedure was introduced to enable the CJEU to perform a quasi-constitutional role in ensuring the uniform application and interpretation of EU law throughout the Union. The acte clair/éclairé doctrine should also be understood in this context. As we have seen above, the acte clair/éclairé doctrine of precedent serves the uniform application and interpretation of EU law in that indeterminacies in EU law should principally be resolved by the CJEU and that final authority on the interpretation of EU law rests with the CJEU.

The introduction of the doctrine of acte clair/éclairé also served efficiency concerns in view of the growing case load. ${ }^{110}$ By allowing national courts to withhold a referral on matters of EU law if the interpretation of the law was clear, the Court limited the number of cases that it would receive. But, by the same decision it also limited the nature of the cases that it would receive. ${ }^{111}$

Since it may be expected that cases which are similar in facts to CJEU precedents and do not concern salient new issues of law are adjudged autonomously by national courts, the large majority of cases which arrive at the CJEU's docket are either likely to be relatively easily distinguishable from precedent or are implicit requests to overrule past doctrine. ${ }^{112}$ The CJEU consequently regarded its task under Article 267 TFEU not only to safeguard the uniform interpretation and application of existing EU law, but also and specifically to reserve the development and evolution of judicial doctrine under its own control. Within the dialogue on EU law between national and Union courts, the CJEU clearly is the discussion leader, even though the national courts and the Commission may set the agenda stating which issues of EU law are discussed.

By defining the division of tasks between national and Union courts on the basis of the doctrine of acte clair/éclairé, the process of judicial decision making under the preliminary reference procedure became precedent oriented. Should the CJEU not follow its own precedents, the requirement imposed on national courts to respect the same CJEU precedents, and thus their authority, would be

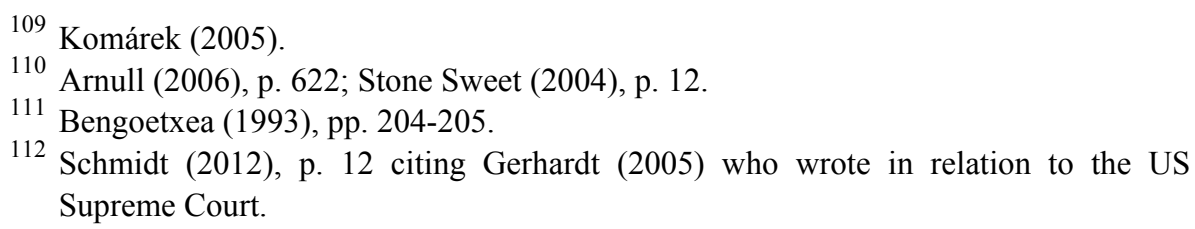


undermined. ${ }^{113}$ It is therefore reasonable to conclude that with the introduction of acte clair/éclairé the CJEU not only bound national courts to respect CJEU precedent, but the Court also in principal constrained itself to follow past rulings as a matter of EU law. It would only use its judicial discretion if it could not give evidence that the content of the law had already been determined in a precedent and, accordingly, if there was indeed no clarity in the interpretation of EU law. That is also plausible and Stone Sweet and McCown (2003) found that an increasing proportion of decisions since 1980 cited previous decisions, which is roughly the period since the moment when CILFIT was decided. ${ }^{114}$

\subsubsection{Overruling and distinguishing by the CJEU}

Prior research draws attention to the fact that the CJEU indeed has the power to overrule its own rulings but has only done so on rare occasions. ${ }^{115}$ Komárek distinguishes between explicit and justified departures (he gives the example of Keck and Mithouard (Joined Cases C-267\&268/91)), explicit and non-justified departures (e.g. Metock (C-127/08)) and tacit departures (e.g. Bergaderm (C352/98P)). ${ }^{116}$ Arnull also lists examples of overruling in similar categories. ${ }^{117}$ Over the years, Arnull remarks, the Court has grown more accustomed to explicitly indicate and justify departures from prior case law, even though this practice is not common. ${ }^{118}$

There is a difference between positioning the current case in the system of law, thus signalling legal relevance of precedent, and the nature of legal relevance of that precedent and the specific role the subsequent case will take in relation to prior case law in the body of EU law. A precedent can thus be affirmed by the CJEU by applying the rule of law contained in that prior case to the subsequent case, or the CJEU rejects the precedent and dismisses the application of the rule. The latter result requires the CJEU to use the practice of distinguishing and to elaborate on the ratio decidendi of the rule of law contained in precedent in relation to the facts and outcome of the precedent case. Prior research provided indications that the CJEU indeed approaches precedent as a common law judge, distinguishing the ratio of the rule and the application of the rule based on the individual circumstances of the case. ${ }^{119}$

In whatever way the practical authority of precedent is modified (either broadened or narrowed), the modified rule would still uphold the case outcome in the precedent but would lead to a different case outcome in the subsequent case compared to the scope of application of the rule as established in the

113 Bengoetxea (1993), p. 206.

114 Stone Sweet and McCown (2003).

115 Arnull (2006); Brown and Kennedy (2000), pp. 370-371; Szudocky (2009), p. 347.

116 Komárek (2010), p. 151.

117 Arnull (2006), pp. 629-630.

118 Arnull (2006), p. 633.

119 Koopmans (1982), p. 23; Szudocky (2009), p. 347. 
original precedent. The practice of distinguishing is defined by the result that the original precedent remains within the modified scope of application of the judicial rule. Otherwise, the ratio itself would be modified, and the precedent would be overruled and the new rule would no longer uphold the outcome in the original case.

The facts of a subsequent case can either (i) fall outside the original ratio, or scope, of the precedent rule, or (ii) the subsequent case prima facie falls within the ratio of precedent.

The effect of distinguishing in situation (i) could lead the CJEU to conclude that the rule of law should indeed not be applied because the material facts do not meet its conditions of application. A very clear example of distinguishing in the field of direct taxation is Werner (C-112/91) in which the Court distinguished this case from three other cases in great detail.

The Court extensively replied to the national court which inquired whether the case of Mr Werner was analogous to the movement which gave access to EU law in Knoors (C-115/78), Biehl I (C-175/88) or 'Avoir Fiscal' (270/83). In a very detailed account of a comparison of the facts of these three cases with the facts of Werner, the Court explained the material reasons for reaching the different outcome in Werner that EU law was not involved (Werner, paras 1017).

Alternatively to distinguishing with the purpose of resisting the application of a precedent rule, the Court could conclude that the subsequent case ought to fall within the ratio, but that the scope of application of the rule of law should be broadened to that effect and consequently its conditions should be relaxed. Brown and Kennedy provide an example with the doctrine of direct effect, which was broadened in scope in subsequent cases to include, apart from primary Treaty law, also secondary legislative acts. ${ }^{120}$ For less drastic changes, the broadening of a judicial rule is evident from the judgment because the Court cites the precedent case explicitly 'to that effect'.

In situation (ii), the CJEU does not have to perform an action of distinguishing if the precedent readily applies. However, sometimes such a result might not be preferred by the Court. Although the circumstances of the precedent are present in the case at hand, there may also be other facts and circumstances which lead the Court to conclude that the outcome should rightfully be different than precedent. The effect of distinguishing in the second situation is that a prima facie applicable precedent rule of law would be narrowed in scope.

In this regard, the practice of distinguishing effectively allows the CJEU to correct ex post for contingencies which it had not contemplated as relevant and material when deciding prior case law. As a result, inefficient lock-in effects can be eliminated from the path of law.

A classic example of a judgment that corrected for inefficient lock-in effects and narrowed the scope of a prima facia applicable judicial rule is Keck and 
Mithouard. With that ruling, the CJEU eliminated the inefficient lock-in effect of treating selling arrangements as prima facie restrictions of the free movement of goods; an effect which was, understandably, not foreseen in the precedents of Dassonville (8/74) and Cassis de Dijon (C-120/78), but only became apparent with the 'Sunday Trading' case law. This inefficiency was highlighted by the Court explicitly:

In view of the increasing tendency of traders to invoke Article 30 of the Treaty as a means of challenging any rules whose effect is to limit their commercial freedom even where such rules are not aimed at products from other Member States, the Court considers it necessary to re-examine and clarify its case-law on this matter (para 14).

The case outcomes of Dassonville and Cassis de Dijon would not have been different if the modified Keck and Mithouard rule would have been applied. However, Keck and Mithouard evidently overruled the 'Sunday Trading' case law, but the Court did not indicate explicitly which cases it had overruled, and for which it received criticism. ${ }^{121}$

To sum up, an orientation to precedent is a plausible first order description of the process of judicial decision making of the CJEU. The main question is thus how the case law in the field of direct taxes has structurally evolved under this precedent oriented process of judicial decision making. We will now explain the method of research that we adopt in Part II in an attempt to answer that question.

\section{$2.4 \quad$ Method}

\subsubsection{Preliminary remarks}

As a preliminary point to the discussion on the method of research that follows, we note that we will not primarily aim to answer the research questions of this Part from a lawyer's subjective interpretation by performing legal analysis on the content of the individual decisions. The method of network analysis that will be presented below is independent from the substantive interpretation of the law, or the substantive attributes and logic of a decision. Where legal analysis normally takes a substance over form approach (especially when done by tax lawyers), the current methodology is more aptly described as form over substance. The principal driver for the analysis in Part II is the relations between the decisions. That is, the analysis is based on the formal links between the judicial decisions in the field of direct taxation. We will only take account of the citations to precedent contained in the decisions and base our subsequent analysis primarily on the information they provide. We will evaluate whether the results obtained by this methodology have face validity with regard to the substance of the law by qualitative (legal) analysis of the cases.

${ }^{121}$ Arnull (2006), p. 532. 
Network science has proven instrumental in understanding the emergent and structural properties of complex systems. ${ }^{122}$ The fundamental assumption of social network analysis (SNA) is that structural relations between entities provide relevant information that the attributes of those entities alone cannot offer. ${ }^{123}$ The assumption is that the behaviour of entities cannot be viewed in isolation, because the individual behaviour of one entity influences the behaviour of other entities. Their structural relations create paths and mechanisms by which that behaviour is enforced. ${ }^{124}$ Consequently, these relations should be viewed as a dynamic process. The study of that dynamic process is not possible by analyzing attributes of entities alone. ${ }^{125}$

Translated to the legal context, specifically judicial decision making, these fundamentals apply directly. They imply that it is not only important to research the similarity or harmony of fact patterns and outcomes of cases (attributes), but it is equally important to understand the structural relations between those cases. Without an understanding of these relations and their dynamics it is impossible to interpret the legal system that has emerged from those cases. Because social network analysis allows for dynamic networks, due account can be taken of law as dynamic system.

A simple network constitutes nodes (or vertices) representing the individual entities, and edges (links or arcs) representing the relations between entities. ${ }^{126}$ Translated to law this means the following. The law can be seen as a web of citations, a network of legal authorities, including cases, statutes, treatises and journal articles, which are linked to each other by their citations. ${ }^{127}$ If the web is constrained such as to consist only of case law as legal authorities, which is an accurate simplification for EU law in the field of direct taxes, then these cases are the nodes of the network and the relation between these cases are edges. If case $B$ cites case $A$, then there exists an edge between the nodes $B$ and $A{ }^{128}$ We assume on that basis that case $A$ acts as precedent to case $B$ and that there is a flow of legal communication between those cases. Figure 1 gives an example for three cases $A, B$ and $C$, where each case is a node and the citations (arrows) are the edges in this simple network.

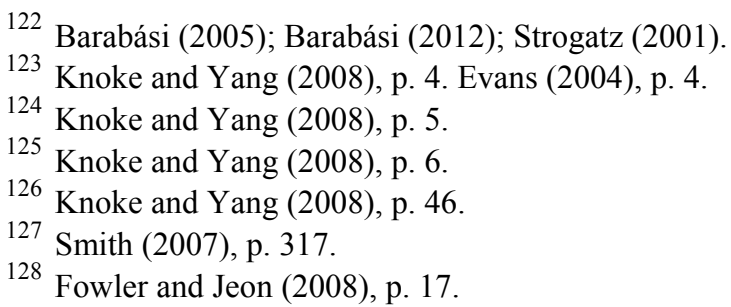




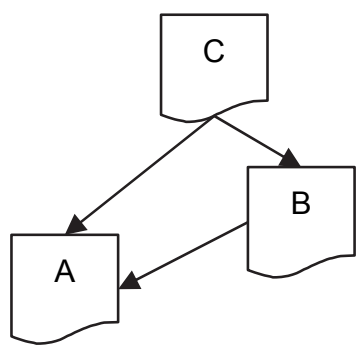

Figure 1. Simple network of three cases A, B and C.

The edges between nodes can be directed or undirected. ${ }^{129}$ Considering the chronological process of judicial decision making, the case law network is built exclusively by directed relations. If case $i$ cites case $j$, a directed relation from $i$ to $j$ exists. Case $i$ can be called the ego and all cases which it cites, for example case $j$, are its alters (or neighbours, or adjacent nodes). Undirected relations, such as a marriage or friendship relation between two persons, are not present in the case network.

In short, the interpretative guidance of precedent is the mechanism by which one case affects judicial decision making in another case and thus structural relations between judicial decisions are created by which judge-made rules are enforced. These structural relations surface as citations to precedent in the Court's rulings. The authority of precedent determines the degree by which one case constrains judicial discretion in subsequent cases.

Prior research has empirically researched the relevance of legal precedent by social network analysis to find the most authoritative and important precedents in US law. ${ }^{130}$ Even if a citation to a case is not a positive reliance on authority, the fact that the case is cited by the court provides relevant information about the role that the rule of the case plays as precedent in the case law network. ${ }^{131}$ The motivation of Fowler et al. (2007) to apply SNA was that '...each judicial citation in an opinion represents a latent judgment by the Court about which cases are most relevant for addressing a legal question. When a citing opinion references another case, it indicates that the decision has a connection to the present legal dispute and signals it continuing legal relevance'. ${ }^{132}$

To be clear, we follow Stone Sweet and McCown, ${ }^{133}$ and accordingly:

We do not, in our analysis, conflate the practice of citation with the concept of precedent, or with doctrinal structures; rather we take citation to be a highly reliable indicator of the presence of such phenomena.

129 Knoke and Yang (2008), p. 46.

130 Fowler and Jeon (2008); Fowler, et al. (2007).

131 Fowler and Jeon (2008), p. 18.

132 Fowler and Jeon (2008), p. 17; Fowler, et al. (2007), p. 328.

133 Stone Sweet and McCown (2003), p. 109. 
The Court develops and reasons with precedent-based 'argumentation frameworks' in order to organise its interpretation of the law. ${ }^{134}$ These doctrinal structures determine, on the one hand, how parties to a legal dispute frame their arguments, and, on the other hand, how the Court frames its decisions. ${ }^{135}$

Citation patterns in the Court's case law thus connect individual cases and we assume those links constitute evidence of an interpretation and application of precedent in subsequent cases. The process of judicial decision making may thus establish new legal rules through repeated application of effective analogies, but their creation is conditioned on the historical sequence of precedents and their evolution is dependent on which future cases follow. This reflects the theory that the process of judicial decision making by precedent is path-dependent. ${ }^{136}$ The structural relations in the case law can only be created and path-dependency can thus only occur when another condition is met, namely that prior decisions have positive feedback in that they create new litigation in response to the Court's previous ruling. Feedback is required for judicial decision making to develop as a path-dependent process. Precedent creates a path-dependent process insofar as judicial decisions motivate or de-motivate subsequent litigation. ${ }^{137}$

The role of precedent as providing interpretative guidance to subsequent cases, and the path-dependency of judicial decision making is also consistent with Dworkin's chain novel theory of precedent. ${ }^{138}$ Dworkin argued that judges decide hard cases, not by simply applying past legal decisions, but by constructive interpretation of past decisions and applying the unified law that follows from those interpretations to decide a subsequent case. His metaphor views judges as a group of novelists that write a single unified novel of the law in which each judicial decision resembles a chapter, and each subsequent chapter should fit as best as possible with preceding chapters. This process should consequently direct a community to act in a coherent and principled manner to all its members, according to Dworkin.

Dworkin's theory is consistent with the law as a dynamic process that incrementally develops over time. Analysis of the interpretation of precedent in a chain of subsequent cases thus provides relevant information about the unified meaning of the law. That proposition however presumes at the least that the CJEU cites precedent consistently and consequently such a unified novel, a structurally cohesive network, exists.

\footnotetext{
134 Stone Sweet (2004), pp. 32-41.

135 Stone Sweet (2004), p. 34. Compare, Richards and Kritzer (2002) on 'jurisprudential regimes' in relation to the US Supreme Court.

136 Fon, et al. (2005); Hathaway (2001); Lindquist and Cross (2005), pp. 1169-1173; Schmidt (2012).

137 Schmidt (2012); and Stone Sweet and McCown (2003).

138 Lindquist and Cross (2005).
} 


\subsubsection{Related work on courts and law}

This is not the first study to apply SNA to judicial decision making. Citation analysis is an established method for research, especially in a law and economics research framework. ${ }^{139}$ However, the applications and possibilities that network science offers for the study of law and the legal system are not yet fully developed. Accordingly, the application of SNA in a European legal context is limited.

SNA has been applied in a common law as well as in a civil law context. Siems used SNA in a comparative study on the case law of the German Federal Supreme Court and the Court of Appeals of England. ${ }^{140}$ Geist carried out an exploratory analysis on the 1985-2008 case law of the Austrian Supreme Court. ${ }^{141}$ Winkels, de Ruyter and Kroese used SNA on Dutch case law to identify the most important cases. ${ }^{142}$

Moving beyond the national level, Lupu and Voeten comprehensively analysed the citation structure of the body of case law of the ECtHR trough 2006 and found that the ECtHR in part uses precedent to provide strategic legitimation to its decisions, not by responding to national political or cultural interests, but primarily by demonstrating impartial and careful decision making. ${ }^{143}$

Other studies focused on transnational judicial communication and international norm diffusion. Voeten examined the cross-citation behaviour of the most prominent international courts, including the ECtHR and the CJEU. ${ }^{144}$ Gelter and Siems looked in two studies at how national supreme courts of ten EU Member States cited each other's decisions. ${ }^{145}$

Most relevant to this book is however the research by Malgram on link analysis on the complete body of the Court's case law. ${ }^{146}$ Also the study by Mirshahvalad, Lindholm, Derlen and Rosvall is important for the finding of legally relevant and significant communities in the body of the Court's case law. ${ }^{147}$

Outside the judicial arena, Boulet et al. have applied SNA in a legislative context in a study on citations in the French environmental code. ${ }^{148}$ Siems used

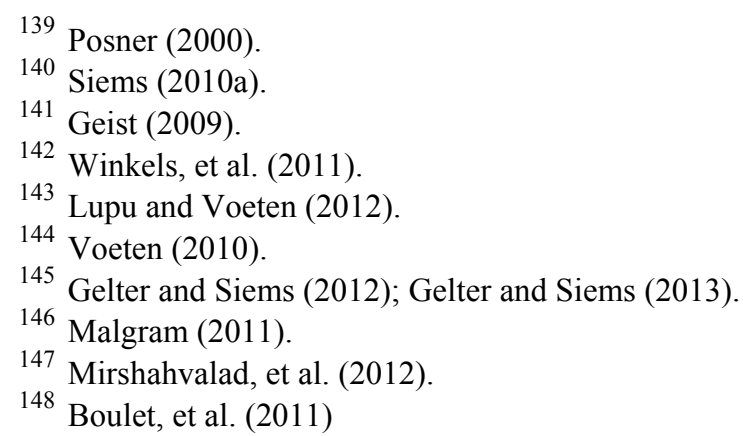


SNA for a comparative analysis of shareholder and creditor protection law in 25 countries. ${ }^{149}$

In the US context, Bommarito, Katz and Isaacs-See reviewed how the US Tax Court interpreted the US Internal Revenue Code using network analytical tools. ${ }^{150}$ Social network analysis has also been applied to examine structure in the US Code, ${ }^{151}$ to the Delaware corporate law, ${ }^{152}$ to patent citation networks, ${ }^{153}$ and to research the social structure of the federal judiciary and the law professoriate in the US. ${ }^{154}$

\subsubsection{Self-organisation of complex networks}

The above prior research suggested that the evolving process of the creation of a structure and the self-organisation of legal networks may be compared with the main variables that underlie the evolution of complex networks, and in particular that of scale-free networks. ${ }^{155}$ The limited prior research points out that judicial citation networks exhibit the defining property of every scale-free network: a power law distribution. An informal description of a scale-free distribution is a distribution of edges in a network that is characterized by a few nodes with many edges to other nodes and many nodes which edges connect it to only a few other nodes; a distribution with a long tail. We will return to this concept in Section 4.2.3 when we research the structure of the case law network. For now, it is sufficient to point out that this is a generic property of many real complex networks. Prior research identified that the case law networks of the US Supreme Court showed scale-free properties. ${ }^{156}$ Malgram reviewed the full body of the Court's case law and found that this network also had scale-free properties. ${ }^{157}$

To be clear, this book does not assert that the case law network on EU law in the field of direct taxation is in fact a scale-free network. However, we will see in Chapter 4 that it is plausible that it is. ${ }^{158}$ Therefore, a complex networks perspective on the case law network may provide a useful first-order description to place the dynamics of the process of judicial decision making and the structural self-organization of the body of rulings in the context of the authority of precedent.

Although the Court decides each case autonomously and the reasoning of each individual ruling has its own internal logic, it is nonetheless submitted that,

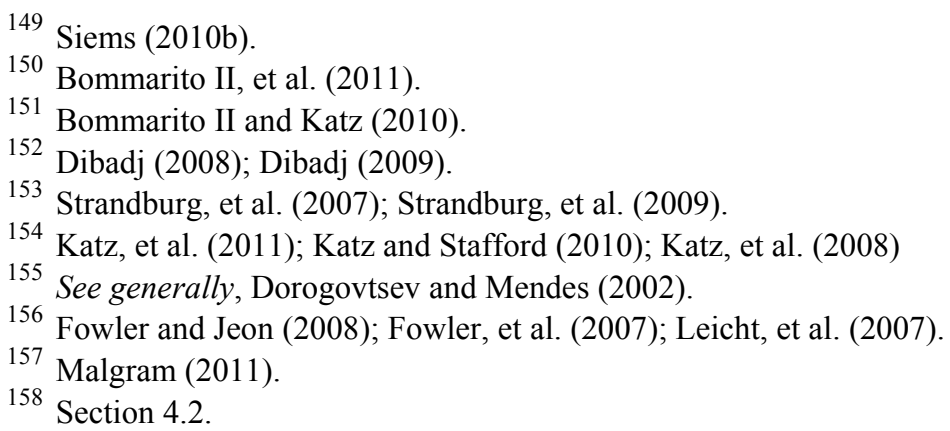


over time, a structured and organised system of EU law in the field of direct taxation emerges from a dynamic process of judicial decision making with a first order orientation to precedent.

The main variables that prior research connects to the evolution and selforganisation of complex networks, including the scale-free property of those networks are growth, preferential attachment, ageing, and competition. ${ }^{159} \mathrm{We}$ will now review how these variables may relate to the evolution of the case law network, if it is assumed that the case law network evolves by similar dynamic processes as scale-free networks. Therefore, the main variables of these dynamic processes will be translated to the legal context in the following Sections.

\subsubsection{Growth}

Every new ruling cites previous judgments, and so new nodes and edges expand the size of the case law network. This constant growth of the network over time is a general factor that determines the complex network structure. ${ }^{160}$ Even if we assume that any given case is as likely to be cited as any other case in the network at a distinct point in time-which is not the case, see below-older cases would still be cited more frequently than newer cases over time. Older cases simply have had more time to accumulate links. This variable is important for judicial decision making as a path dependent process because of the relevance it attaches to initial conditions. Although it is generally true that older cases are likely to have collected more citations than more recent ones and have a lasting impact on the evolution of the law, growth is only one variable that explains why some cases are cited more often than others.

\subsubsection{Preferential attachment}

Closely related to the growth variable is the 'rich-get-richer' effect, or preferential attachment model. ${ }^{161}$ A preferential attachment network model means that new nodes are more likely to connect to nodes that are already well connected. The likelihood with which a new node links to already existing nodes is proportional to the number of links that those already existing nodes have already acquired. Albert and Barabási explained that web pages will more likely link to web pages, which are linked to by many other web pages, and research papers are more likely to cite other well-cited papers, because those popular web pages and papers can be found at lower cost than less-known web pages and papers. ${ }^{162}$ Thus, the fundamental idea of preferential attachment for the case law network

\footnotetext{
159 Albert and Barabási (2002), pp. 76-86

${ }^{160}$ Barabási and Albert (1999); Barabási, et al. (1999).

161 Barabási and Albert (1999).

162 Albert and Barabási (2002), p. 71.
} 
is that a well-known case which was already cited more often as precedent than a lesser known case is also more likely to be cited again.

If we take the copy-paste approach of the Court to drafting the text of its rulings literally ${ }^{163}$ - which we probably should ${ }^{164}$ - then preferential attachment is likely to occur because a paragraph or passage of a judgment (including its citations) which has been copied and pasted before is very likely to be copied and pasted again. ${ }^{165}$

\subsubsection{Ageing}

Growth and preferential attachment taken together explain why a few older cases have very many links, whereas many other cases have very few links. ${ }^{166}$ Another dynamic in the self-organisation of networks is ageing. The likelihood that a node acquires new links initially increases through growth and preferential attachment but then decays as the node ages further. ${ }^{167}$ Older cases gradually lose their ability to attract new citations. This was already pointed out in the classic law and economics study of Landes and Posner on precedent. ${ }^{168}$ Fowler and Jeon showed that the authority of precedents of the US Supreme Court indeed follows a general pattern of increasing authority, followed by a period of stabilization and decreasing authority. ${ }^{169}$

By citing precedent, the Court plausibly not only desires to signal the relevance of prior case law but the Court also may have an interest in signalling that the line of authority is a current one. The reference to precedent which was decided in the same economic and social political context is less controversial then if the Court would have relied on old precedents which were decided in possibly different societal circumstances.

\subsubsection{Competition}

The last general factor that explains how the structure evolves in real complex networks is competition. ${ }^{170}$ Competition between nodes explains why some newer nodes are as well or even better connected than older nodes.

A node's inherent competitive ability to attract links is called the node's fitness. Nodes have different fitness and attract links at different speeds. The

163 Komárek (2010), p. 226.

164 Barents (2007a); Barents (2007b); Barents (2009a); Barents (2009b); Noe (2011).

165 See, Albert and Barabási (2002) on research that applied a copying meachnism to explain the structure of the WWW.

${ }^{166}$ Barabási and Albert (1999); Barabási, et al. (1999)

167 Dorogovtsev, et al. (2000); Zhu, et al. (2003).

168 Landes and Posner (1976).

169 Fowler and Jeon (2008).

${ }^{170}$ Bianconi and Barabási (2001a); Bianconi and Barabási (2001b). 
higher the node's fitness, the more links it attracts in a shorter time. Likeness of facts and intrinsic authority over the law are two plausible elements of a precedent's fitness.

The competition between cases is probably based on the likeness of facts because the Court is more or less bound to apply and cite cases that deal with a similar issue in similar circumstances. Parties to the proceedings and the Advocate General are unlikely to overlook clear precedents and will submit observations and arguments by analogy which the Court realistically cannot ignore in its ruling. Likeness of facts is a relative measure of fitness: the extent to which a precedent shares common attributes (facts, legal issues, and national context) with a new case before the Court. Put more formally, a case which logically makes a more effective argument by analogy is a fitter precedent.

The Court's zone of judicial discretion, however, becomes greater as the similarity of facts and issues between the case at hand and prior jurisprudence becomes less clear.

In law, a precedent's fitness can also be seen as the precedent's intrinsic authority over the content of the law. Normative discussions about whether the merits and internal logic of the Court's rulings are convincing are in fact perceptions on the fitness of individual rulings. If one ruling is a better reasoned interpretation of the law than another ruling, which may suffer logical defects in reasoning, then the first case can be regarded as more authoritative and consequently a fitter precedent which would more likely be cited, all other things held equal. The Court is likely to cite a precedent that is legally more convincing if it can choose between several like cases that have previously been cited the same number of times and are similar analogies to the facts.

Another aspect of intrinsic authority could be whether the precedent established a narrowly formulated rule or introduced a higher level principle of EU law. The latter type is fitter to provide persuasive guidance in a broader range of cases than the former. Landmark precedents that establish general principles that apply throughout all fields of the system of EU law are likely to be effective analogies to a potentially high proportion of subsequent cases. This implies that they quickly gather links and their authority is further reinforced under a process of preferential attachment. Consequently, the Court will prefer to connect new cases to these landmark rulings to show that it interprets the law according to the system's most important constraints.

In short, the Court can exercise judicial discretion in applying precedent. The choice of which case to cite becomes a competition between precedents.

Although it is naturally appealing to lawyers to focus exclusively on fitness in constructing dialectic arguments in legal scholarship, the structure and organisation of the law in a system may be perhaps better understood within a larger perspective on the process of judicial decision making over time that includes elements of growth, preferential attachment and ageing as elements of a larger path dependent process.

In Chapter 4 we will research if it is plausible that the case law organised itself in a scale-free structure through a first order orientation to precedent, and, if so, whether the structure and organisation we find is legally relevant. We will 
see how a network perspective can be used to reveal the precedents which are structurally central in the body of case law. A focused analysis of the most important precedents so defined would in turn provide valuable information on the most relevant legal standards and rules that have shaped the evolution of EU law in the field of direct taxation. These sources and norms may be thought of as the outlines of the judicial doctrine on EU law in the field of direct taxation as it currently stands. This goal first requires that the data by which the network of case law in the field of direct taxes is constructed be defined (Section 2.5) and that the properties of that dataset be reviewed (Chapter 3).

\section{$2.5 \quad$ Data}

\subsubsection{What are direct taxes in EU law?}

In order to build a citation network it is necessary to define the sample of cases which were the subject of Court proceedings about national legislation on direct taxes. To that end, it is necessary to first define what 'direct taxes' are in EU law?

Article 65 TFEU refers to 'tax law', 'the field of taxation' and 'tax measures' to define situations in which free movement of capital may be restricted. Part Three, Title VII, Chapter 2 on 'Tax Provisions' of the TFEU uses the term 'internal taxation' in Articles 110 and 111 TFEU to lay down a prohibition on discriminatory taxation of that kind. It is possible that internal taxation includes direct taxation, but the legal norm is difficult to apply to direct taxes, given that it requires to examine whether imported products are taxed more heavily than domestic products and it is near to impossible to prove this proposition if the price effects of the tax are intractable, which normally is the case for direct taxes. Furthermore, the other tax provisions of the same section of the Treaty explicitly apply exclusively to indirect taxes. ${ }^{171}$

The phrase 'turnover taxes, excise duties and other forms of indirect taxation' is included in Articles 112 and 113 TFEU for the purposes of inviting Union action in this field. Article 173 TFEU in Title XVII on 'Industry' refers to 'tax provisions' to preclude the provision from laying down a legal basis for Union action in that regard. Finally in Part Six of the TFEU, Article 223 on the European Parliament states that unanimity in the Council is required for measures governing the 'taxation' of its Members. The TFEU does not refer to 'direct taxation', but it follows from Articles 112 TFEU and 113 TFEU that there is a demarcation between indirect and direct taxation which is Treaty relevant. However, the Treaty itself does not even define what a 'tax' is. ${ }^{172}$

171 Opinion AG in Baxter (C-254/97), points 16 and 17.

172 See generally, Peeters (2005). 
The ordinary meaning of a direct tax may be considered to be laid down in the IBFD International Tax Glossary. ${ }^{173}$ The relevant entry reads:

There is no generally accepted distinction between a direct and an indirect tax. John Stuart Mill gave the following definition: "A direct tax is one which is demanded from the very persons who it is intended or desired should pay it. Indirect taxes are those which are demanded from one person in the expectation and intention that he shall indemnify himself at the expense of another." The distinguishing feature may therefore be said to be whether the taxpayer is or is not the person on whom the economic burden of the tax is expected to fall. In this respect, a tax may be said to be direct either in the sense of assessment or collection. Thus, income tax is generally assessed directly on the taxpayer but collection is becoming increasingly indirect (e.g. by way of withholding). An important distinguishing feature of direct taxes is sometimes said to be their capacity to take into account the circumstances of individual taxpayers. This suggests there may also be a relation between indirect taxes and "in rem" taxes, the latter not generally taking into account personal circumstances. Another approach (adopted by the United Nations in its System of National Accounts) bases the distinction on whether the tax is levied at regular intervals on sources of income such as employment or property (direct taxes), or on producers in respect of the production, sale, etc. of goods and services, which they charge to the expenses of production (indirect taxes). A commonly accepted (if not comprehensive) distinction may be made on the basis of whether the tax is a tax on income (including capital gains and net worth) (direct) or on consumption (indirect). Indirect taxes are considered to be one of the oldest sources of government revenue. Examples of taxes generally regarded as indirect include value added tax, sales tax, excise duties, stamp duty, services tax, registration duty and transaction tax. While gift tax, death duties and property tax are generally considered direct taxes, some forms of death duties may be considered as an indirect tax.

One of the sources of secondary EU legislation that mentions direct taxes is the Administrative Cooperation Directive (2011/16/EU), ${ }^{174}$ in point 2 of its preamble, but it does not define the term. However, this directive, in Article 2(2), currently excludes from its material scope the VAT, customs duties, and excises covered by Union legislation and social security contributions. Article 2(3) excludes fees and contractual dues from the definition of tax for the purposes of the directive. The Administrative Cooperation Directive replaced the Mutual

173 Rogers-Glabush (2012).

174 Council Directive 2011/16/EU of 15 February 2011 on administrative cooperation in the field of taxation and repealing Directive 77/799/EEC, O.J. L 64, 11/03/2011, p. 112 ('Administrative Cooperation Directive'). 
Assistance Directive (77/799/EEC). ${ }^{175}$ This repealed directive listed various Member States' income and capital taxes as legislation to which the directive applied and evidently equated direct taxes with taxes on income and capital. According to Article 1(2) of the Mutual Assistance Directive (77/799/EEC):

There shall be regarded as taxes on income and on capital, irrespective of the manner in which they are levied, all taxes imposed on total income, on total capital, or on elements of income or of capital, including taxes on gains from the disposal of movable or immovable property, taxes on the amounts of wages or salaries paid by enterprises, as well as taxes on capital appreciation.

A search in the 'all legislation' section of EUR-Lex with search term 'direct tax*' (full-text search) resulted in 137 additional hits. A similar search in the 'EU case law' section of EUR-Lex resulted in 407 hits. ${ }^{176}$ This means that a notion of what taxes are direct taxes is legally relevant in EU law.

However, it is consistent case law that, to determine whether a directive regulating taxation prohibits the levy of a certain tax, the (national) classification of a tax, including its characterization as a direct or indirect tax, has no decisive influence. $^{177}$ It is also irrelevant whether a levy is qualified in national legislation as a direct tax to assess its compatibility with, now, Regulation (EC) No $883 / 2004$ on the coordination of social security. ${ }^{178}$

Advocate General Stix-Hackl has proffered the following interpretation in her opinion in Banca popolare di Cremona (C-475/03). The case concerned the question whether Italy had introduced a national tax (the 'IRAP') which was incompatible with the Sixth VAT Directive (77/388/EEC) because it had to be qualified as a tax which had the essential characteristics of a VAT. The AG concluded that in the context of that examination it is irrelevant whether the tax is a direct or indirect tax. She argued that Member States may not jeopardise the harmonisation of indirect taxes by direct taxes, just as the Union may not encroach on the Member States' reserved competence in the field of direct taxes by adopting measures on the legal basis of Article 113 TFEU (paras 48-61). Therefore, EU VAT law may prohibit direct taxes if these jeopardise the harmonised system of VAT. AG Stix-Hackl seems to follow the IBFD definition in her opinion in Banca Popolare di Cremona:

175 Council Directive 77/799/EEC of 19 December 1977 concerning mutual assistance by the competent authorities of the Member States in the field of direct taxation, O.J. L 336, 27/12/1977, p. 15-20 ('Mutual Assistance Directive').

176 Searches as at 11 April 2012.

177 E.g., Bautiaa and Société française maritime (Joined Cases C-197\&252/94), para 39 on the characterization of capital duties; and Rousseau Wilmot (295/84) on the taxes, duties or charges which can be characterized as a VAT.

178 Commission v France (C-34/98), para 34; and the opinion of AG La Pergola in that case, point 19. See Regulation (EC) No 883/2004 of the European Parliament and of the Council of 29 April 2004 on the coordination of social security systems, O.J. L $166,30 / 04 / 2004$, p. $1-123$ 
53. In that connection, it should be recalled that the Treaty contains no definition of a difference between direct and indirect taxation, and it is commonly accepted that no complete, unambiguous and universally valid definition can be formulated.

54. Certainly, the essence of the distinction is clear: a direct tax is collected directly from the person who bears the economic burden; an indirect tax is included in a sum paid by that person to another, who does not bear the economic burden but who accounts for the tax.

55. Typical direct taxes include those on personal wealth, property or income; and it may be the case that only taxes levied on individuals as such are wholly direct in nature. By contrast, VAT as regulated by the Sixth Directive is an indirect tax par excellence, since it is completely neutral as regards the economic operators from whom it is collected and is in principle always passed on to the final consumer as an identifiable proportion of the price (and as a specified sum when an invoice is issued).

56. However, the situation is not always as clear-cut. Some taxes which are primarily direct may partake of the nature of indirect taxation, and vice versa. And even if a satisfactory criterion could be found for distinguishing in law between direct and indirect taxation, some of the effects of a tax such as IRAP seem capable of overlapping with those of VAT, so that interference between the two cannot be ruled out.

AG Jacobs wrote in his opinion in the same case:

34. Classification of taxes into 'direct' and 'indirect' is not always either simple or even, for many purposes, relevant. Here, the question is not whether IRAP is to be categorised as a direct or an indirect tax, but whether it has the same essential features as VAT.

35. However, a commonly accepted distinction between direct and indirect taxation is that the former burdens a (natural or legal) person's own available wealth or income, with no possibility of being passed on to any other person, whereas the latter is levied on spending or consumption and its burden may be - indeed, normally is - passed on to and borne by the ultimate consumer. In that light, it seems to me that the mechanism described by the Italian Government is that of an indirect tax, the burden of which will essentially be borne by the ultimate consumer.

In his opinion in Schmid (C-113/99), AG Mischo stated:

16. That liability to minimum tax exists even in the absence of any income is a legal consequence of the simple fact of being a capital company with unlimited tax liability. Where the tax has to be paid by a capital company with no corresponding income, it may operate, in effect, as a tax on capital. In no circumstances does it acquire the characteristics of an indirect tax. As the Commission explained, indirect taxes are usually distinguished by the 
fact that the burden is passed on to others and that they arise from a specific act, like a sale or the execution of some legal transaction.

Also the Court has conceded that the distinction between direct and indirect taxes is not always legally relevant. The case in point is Commission v Belgium (C-250/08) which concerned a registration duty on transfers of immovable property, which constitutes an indirect tax under the IBFD Glossary description, but which AG Sharpston labelled as direct. ${ }^{179}$ The Court held in para 34 of its judgment:

...the disagreement between the parties concerning the classification of the registration duties at issue as direct or indirect taxation is irrelevant since, as the Commission noted in its application, in the absence of any harmonisation measures concerning registration duties, Member States must exercise their powers in a manner consistent with European Union law. This implies that those duties must be subject to an examination similar to that carried out when examining the compatibility of direct taxes with European Union law.

\subsubsection{The sample of cases}

On the basis of the above descriptions, it is not necessary to construct and apply a strict definition of which cases concern a dispute over direct taxes. Nonetheless, we need to apply a plausible demarcation between EU law in the fields of direct and indirect taxes in order to limit the scope of our research in accordance with its overall aim. For this reason, the sample of cases is taken from the European Commission's list of cases in the field of, or in particular interest for, direct taxation. $^{180}$

This list not only includes completed cases, but also pending cases, and cases removed from the court registry in the field of direct taxes. Moreover, cases from other courts are listed too. It is fair to assume that the Commission's understanding of what taxes are direct taxes is an accurate interpretation of the Union meaning of the term, especially since the Court and AGs consistently sided with the Commission views in relevant context in the above quoted cases. Furthermore, since the Commission is notified systematically of each case before the Court, we may presume that the list is complete. ${ }^{181}$ It is not likely that the list suffers from collection errors by exclusion of relevant cases on direct taxes; i.e. the risk of undercoverage is negligible. In short, this expert list is an accurate and complete collection of relevant cases on EU law in the field of direct taxes.

The sample is defined to include all cases in which the proceedings before the Court concerned the compatibility of national direct tax provisions with EU law and a decision on the merits has been rendered by the Court or is still

179 Opinion of AG Sharpston in Commission v Belgium (C-250/08), point.

180 European Commission (2012a).

181 Article 23 Statute of the Court of Justice of the European Union. 
pending. All legislative acts in the field of direct taxes are directives and need to be transposed properly into national law. The sample therefore also includes cases in non-harmonised as well as harmonised areas in the field of direct taxes.

The sample was formally constructed by the following steps.

First we collected all cases from the tables 'Judgments in the area of direct taxation' and 'Pending cases: Court of Justice' of the Commission's list. This gives us all completed and pending Court cases in the field of direct taxes. Cases which were referred to the Court but removed from the registry without a decision on the merits are consequently not included in the sample.

Second, we deleted from the initial collection all cases which were highlighted gray. The European Commission considers these cases to be of particular interest for direct taxation, but these cases do not concern the compatibility of national provisions of direct taxes with EU law in the Commission's view. Section 4.6 of this book will evaluate the relevance of these non-tax cases.

Third and purely as an additional check for overcoverage, we reviewed all remaining cases and coded them according to the national subject matter of the proceedings. We followed the OECD classification of taxes for this purpose. ${ }^{182}$ This is an internationally accepted and clearly defined classification system which allows distinguishing between different types of taxes on the basis of the main characteristics of the levy. We subsequently removed all cases from the sample with OECD classes 2000 (social security contributions), 5000 (taxes on goods and services) and 6000 (other taxes) from the sample, since these are definitely not cases concerning direct taxes $(n$ removed $=2)$. ${ }^{183}$ Cases with OECD class 4000 (taxes on property) were kept as these also include direct taxes and in any event represent taxes which are neither coordinated nor harmonised at the Union level, and should thus be decided in close analogy with cases in the field of income taxation. Consequently, they provide meaningful information on the structure and organisation of EU law in the field of direct taxes.

As a fourth and final step, all cases which were referred to the CJEU after 31 December 2011 are removed (no cases removed). No account was taken of the joinder of cases on the ground of similarity (one case id $=$ one case registered at the Court). The final sample includes all cases in the OECD classes 1000 (taxes on income, profits and capital gains), 3000 (taxes on payroll and workforce) and 4000 (taxes on property). These classes represent cases in the field of direct taxation under a broad definition, which is consistent with the EU law meaning of the term. ${ }^{184}$

182 OECD (2011), Annex A.

183 The two cases which were removed are Terhoeve (C-18/95) (OECD class 2120) and De Coster (C-17/00) (OECD class 5126).

${ }^{184}$ Section 3.4.1 reviews the subject matter of the cases in more detail according to the classification. 
The final sample is 234 cases large. This sample of cases defines the body of completed and pending Court cases in the field of direct taxation for purposes of the research in Part II.

\subsection{Synthesis}

This Chapter explained the basic theoretical and methodological framework for the research in Chapters 3 and 4 in particular but the discussion of this Chapter is also generally relevant for Part III. Section 2.1 gave context to the research by explaining its academic relevance. Section 2.2 formulated the research questions for Part II.

Section 2.3 explained the theoretical background. First, we made the normative background of this book explicit by rejecting an attitudinal model of judicial decision making. We decided to follow a model of judicial decision making that assumes that the Court's judicial discretion is constrained by the content and spirit of the law, including the interpretative guidance of precedent. Second, we carried out a positive legal analysis of the Court's approach to precedent under the doctrine of acte clair/éclairé. In line with prior research, we concluded that the process of judicial decision making on EU law is characterised by a first-order orientation to precedent.

Section 2.4 explained the method of research. We described the basics of social network analysis as a research methodology to study structural relations in the case law. We conceive the body of case law as a network in which cases are linked to each other by citation to precedent. We assumed that citations to precedent are reliable indications for doctrinal structures. We mentioned prior research that applied this method. In addition, we described how a judicial decision making process with a first-order orientation to precedent may lead to self-organisation in the complex network of the case law. We concluded that social network analysis is a useful method to research the structure and organisation of the Court's case law in the field of direct taxes. Chapter 4 will build upon this basic framework in more depth.

Finally, we defined the sample of cases that constitutes the body of the Court's case law on EU law in the field of direct taxes for the purposes of our research in Section 2.5. Chapter 3 will carry out a survey of the properties of this sample. 



\section{Chapter 3}

\section{Properties of the Case Law}

\section{$3.1 \quad$ Introduction}

This Chapter analyses the properties of the body of case law by reviewing aggregated meta-data on the sample of cases in the field of direct taxes. The analysis thus starts by looking at the individual components of the system (the 'sum of the parts') instead of analysing the system as a whole. We research how complicated EU law in the field of direct taxes actually is.

This Chapter is structured as follows. Section 3.2 gives an overview of the general trends in activity before the Court in the field of direct taxes. Descriptive statistics for the Member States are discussed in Section 3.3. The subject matter of the case law is analysed in Section 3.4, both from a national as well as from an EU law perspective. Section 3.5 provides information about the more procedural aspects of the judicial decision making process in the field of direct taxes. Section 3.6 reviews the outcomes of the Court's rulings and Section 3.7 gives a concise overview of the reception of the case law in academic literature. This chapter concludes with a short discussion about the direction and nature of European integration in the field of direct taxes through judicial governance in Section 3.8.

\subsection{General trends in activity}

Figure 2 shows the general trend in the activity of the Court in the field of direct taxation. The Court decided a total of 192 cases in the field of direct taxes in the period between 1 January 1983 and 31 December 2011. The first case leading to a judgment of the Court in the field of direct taxes was a direct action against France for a failure to fulfil the obligations of Article 52 of the EEC Treaty (now Article 49 TFEU) in Commission v France (Avoir Fiscal) (270/83). The Court ruled that France breached the freedom of establishment by denying nonincorporated secondary establishments of foreign companies within French territory a credit on received dividends (the avoir fiscal in French), whereas that credit was accorded to French subsidiaries of foreign companies. That case was referred to court in December 1983 and was decided about two years later on 28 January 1986.

Not only was Avoir Fiscal the first ruling in the field of direct taxation on the free movement of persons, it was also the case giving a first impression on the freedom of establishment as it applies to companies in the whole body of case law of the Court. Avoir Fiscal is the oldest judgment on the EU law rights of companies in the case law directory code 4.04.02 'Freedom of Establishment' of 


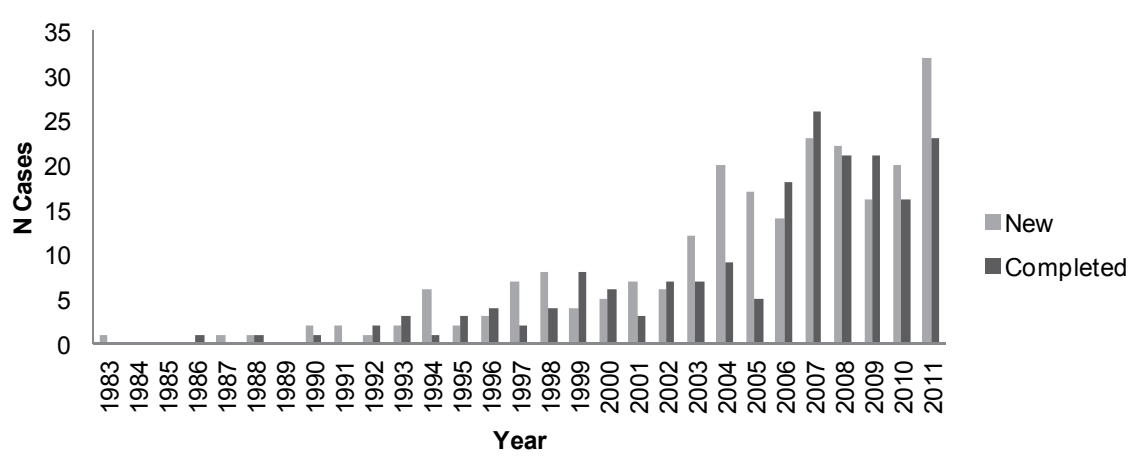

Figure 2. New and completed cases by year (1983 through 2011).

the EUR-Lex database. There are only fifteen rulings in the same directory that are older - all of which concern the rights of individuals under the freedom of establishment. ${ }^{185}$

The last completed case in the sample is the preliminary reference of Banco Bilbao Vizcaya Argentaria (C-157/10) which was ruled on 8 December 2011. The Court found that Spain was not obliged to avoid juridical double taxation on interest received from foreign companies, insofar as there was no difference in treatment in Spanish tax practice compared to interest received from companies established in Spain.

We see a general trend of a rising number of new cases brought to the Court over the years in Figure 2. The number of completed cases (judgments and reasoned orders) shows an approximately similar trend that lags about two years. This responsive lag reflects the duration of proceedings before the Court for cases in the field of direct taxation. ${ }^{186}$

The distribution of the completed cases over the years is roughly as follows. The first quartile of cases was completed in the period from 1986 through mid 2003, the next quartile of cases was completed in the period from mid 2003 through mid 2007, the third quartile between mid 2007 and mid 2009, and the last quartile was completed in the period from mid 2009 until the end of 2011. There have been more than 30 cases pending at the end of each year since 2005 , with the exception of 2009 when 29 cases were pending at the end of that year. On 31 December 2011 there were 42 cases pending before the Court, a proportion of about $6.5 \%$ of all pending cases (excluding appeals) at the Court of Justice of the CJEU.

Figure 3 shows the new cases brought to the Court per type of procedure in each year. Most cases ( $80 \%$ or 188 of 234 new cases through 2011) are referred

185 Fearon and Company $v$ Irish Land Commission (182/83) was limited on substance to the EU law rights of individuals, even though the applicant in the main proceedings 186 before the Irish court was a company.

See, Section 3.5.3. 


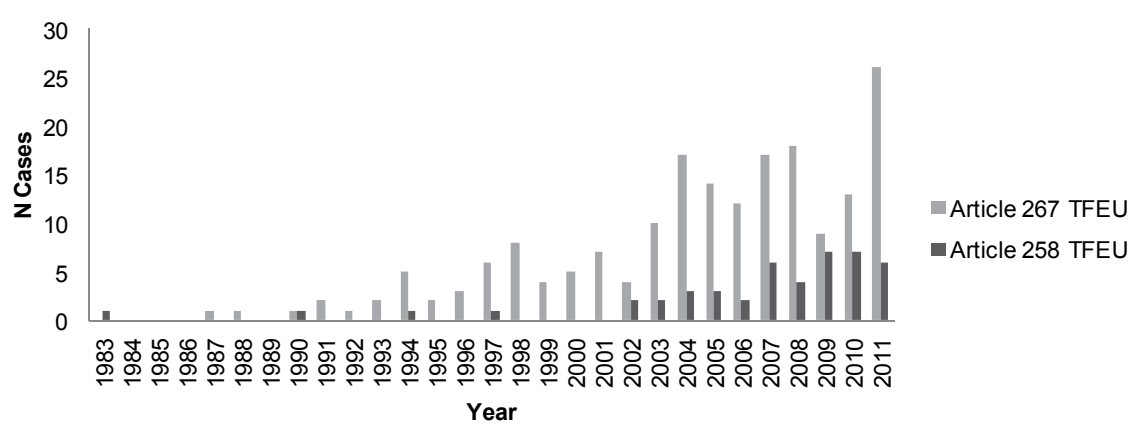

Figure 3. Legal basis of new cases by year (1983 through 2011).

to the Court by national courts as a request for a preliminary ruling on the interpretation of EU law pursuant to Article 267 TFEU. The Commission has brought a total 46 direct actions against Member States to the Court (a proportion of $20 \%$ ) for a failure to implement EU law in their national laws pursuant to Article 258 TFEU.

Although the Commission had started a few direct actions against Member States in the field of direct taxes before 2002, a clear indication that infringement proceedings were pursued as a matter of strategic policy can be derived from the steady increase of new infringement proceedings after 2002 . The Commission published a tax policy strategy that explicitly highlighted the Commission's role as guardian of the Treaties and proposed increased Commission action in 2001. ${ }^{187}$ The change from an apparent reactive to an explicit proactive Commission EU law enforcement policy in the field of direct taxes is shown in Figure 3 by the increased proportion of Article 258 TFEU proceedings of all new cases in the period 2001-2011 compared to the period before 2001.

The public announcement of greater Commission action in the judicial arena may arguably be interpreted as using the threat of court activism to overcome resistance of the Member States to Union action; a political strategy that the Commission has been known to use. ${ }^{188}$ We should bear in mind that the direct tax directives that are currently in force were all prepared as genuine instruments of policy convergence and were initiated before judicial governance emerged as the dominant arena in this field. Shortly after the Commission published its working paper 'Company Taxation in the Internal Market', ${ }^{189}$ it identified the company taxation issues discussed in that paper as 'Priorities for the years ahead', but communicated that agenda explicitly within a context of strategic use of its autonomous litigation powers. ${ }^{190}$

187 European Commission (2001c).
188 Schmidt (2000).
189 European Commission (2001a).
190 European Commission (2001c). 
The Commission again used the strategy of deference to judicial activism in 2003. Whereas the 2001 Communication only implied said strategy, the Commission now openly took a position in its follow-up Communication of 2003:

This reluctance on the part of certain Member States to co-ordinate their tax systems can only lead to more and more decisions by the Court which the Member States concerned might perceive as 'destructive'. In any event the Commission will continue to insist on the unequivocal respect of the EU Treaty in taxation and it will design its policy for launching appropriate infringement procedures in a more targeted and pro-active way. The Commission hopes, therefore, that its future initiatives to promote active discussions among Member States on important legal tax matters and to develop guidance on the broader implications of ECJ jurisprudence will be welcomed with a more constructive stance. ${ }^{191}$

Despite the evident efforts, ${ }^{192}$ the Commission has, however, not yet capitalised on the 'emerging arena of judicial tax policy' by moving Member States to coordinate national direct tax systems. ${ }^{193}$ Radaelli and Kraemer point to the 'lukewarm' reception by the Member States of the non-binding initiatives on the tax treatment of occupational pensions, dividend taxation, exit taxation and crossborder loss relief. ${ }^{194}$ Notably, these initiatives responded to precedents set by the Court. On the basis of both a quantitative and qualitative analysis, Kemmerling finds that Europeanisation has a visible impact on national tax policy, but has not accelerated policy convergence in the area of direct taxation. ${ }^{195}$ He finds that there is (strategic) divergence on corporation tax policies between the Member States and that policy convergence on individual income taxes is low, specifically when compared to strong policy convergence in the area of VAT and excises. Kemmerling submits that the deregulatory policy imposition through the Court's case law has enhanced competition between the Member States. Two studies commissioned by the European Parliament showed that Member States have responded to the Court's deregulation primarily by re-regulation of na-

191 European Commission (2003b), p. 7.

192 The Internal Market Scoreboard no. 23 of September 2011 showed that most infringement procedures are in the field of direct taxation $(13.2 \%)$ of all infringement proceedings, followed by indirect taxation (10.2\%), and topics relating to the environment, see European Commission (2011a).

193 Radaelli and Kraemer (2008). See, European Commission (2001b); European Commission (2003a); European Commission (2006a); European Commission (2006b); European Commission (2006c).

194 Radaelli and Kraemer (2008).

195 Kemmerling (2010). 
tional law 'with Luxembourg in mind' rather than actively endorsing policy convergence at the Union level. ${ }^{196}$

These findings are corroborated by Genschel et al. who conclude that corporate tax competition in the EU is greater than in the rest of the world. ${ }^{197} \mathrm{In}$ the same line, the recent review article by Genschel and Schwarz shows more generally that there is empirical evidence for tax arbitrage of taxpayers and targeted competition between states mainly in the area of corporation taxes and capital income taxation, but that there is also a fairly recent trend towards tax cooperation. ${ }^{198}$ The hopes for international cooperation as an effective method of policy convergence should however not be overstated.

Whereas the historical institutional setting of international tax governance has proven successful in maintaining stability in the core value of avoiding double taxation, Rixen explains that it has significant negative effects in that it does not enable governments to curb under-taxation and tax competition beyond small and incremental changes. ${ }^{199}$ The situation in the EU is that unanimous decisions by the Member States are necessary to adopt legislative rules in the field of direct taxation at the EU level, while enhanced cooperation under Title IV of the TEU by a limited number of Member States is explored to introduce a harmonised common (consolidated) tax base for corporation taxes. ${ }^{200}$

We will see in Section 3.4.1 that the Court has been particularly active in the realms of corporation taxes and other taxes on capital income. In the context of these recent studies, it may be proffered that the effective strategic political use by the Commission of the Court's decisions has so far been limited to enhanced compliance of national direct tax systems with the Treaties, but it has not brought about a closer Union in the field of direct taxation in the sense that direct tax policies converged as a result of judicial or legislative governance. Rather, it seems that institutional change is needed before further significant steps of convergence may be expected.

\subsection{Member States before the Court}

\subsubsection{Proceedings by Member States}

Table 1 gives an overview of the number of cases by each Member State. The Table also shows in which case each Member State made its 'debut' as litigant

196 European Parliament (2008); European Parliament (2011). Blauberger (2011) submits that Member States can respond in three basic ways to judicial deregulation: (i) non-compliance, (ii) EU-compatible re-regulation, and (iii) regulatory surrender (i.e. harmonisation).

197 Genschel, et al. (2011).

198 Genschel and Schwarz (2011).

199 Rixen (2010).

200 Bettendorf, et al. (2010). 
in a direct tax case before the Court. The debut case is defined as the first case registered at the Court's docket in the field of direct taxation for the Member State. The number of cases per Member State is given as $i / j$ where $i$ is the number of preliminary references requested by national courts of that Member State and $j$ is the number of direct actions brought before the Court against that Member State.

Of all 27 current Member States, nine Member States have not been active before the Court in direct tax matters. These Member States have all-with the exception of Ireland that acceded to the EU in 1973 - only recently joined the EU in 2004 or 2007. Of the 'new' Member States that acceded to the EU in 2004 or later, only Estonia, Hungary, Poland, and Slovenia had yet to defend a national direct tax provision before the Court. We should bear in mind that it took 25 years after the foundation of the EEC for the first direct tax case to go to court.

As could be expected, the first Member States to appear before the Court in a direct tax case were the founding Member States. They account for two-thirds of all cases in the field of direct taxes. Italy was the last founding Member State to make its debut before the Court as a result of a direct action lodged at the Court by the Commission in 2007. This fact does not fit consistently with Italy as one of the most active Member States before the Court both in preliminary reference procedures and direct actions in general. ${ }^{201}$

In contrast, the three Member States that acceded in 1995 appeared before the Court already shortly after their accession: Sweden within one year, Austria within two years, and Finland after five years of membership. The debut cases of these three Member States were all referred to the Court by national courts pursuant to a referral for a preliminary ruling.

As regards Ireland, it should be noted that Irish courts have referred only a little more than 60 cases in total to the CJEU for a preliminary ruling through 2011. ${ }^{202}$ Also, the courts of Denmark and Sweden are known to be reluctant to refer cases to the Court. It is proffered in prior research this may be due to different democratic ideals and traditions in these countries according to which the courts apply judicial restraint and focus on the settlement of concrete disputes instead of actively engaging in judicial review by calling in the interpretative guidance of the Court. ${ }^{203}$ This may also explain the data presented here, but it should be mentioned that Brokelind found that the Court's case law in direct tax matters is effectively enforced in Sweden, and that advance rulings play a major role in dispute resolution. ${ }^{204}$

\footnotetext{
201 Court of Justice of the European Union (2012).

202 Court of Justice of the European Union (2012).

203 Wind (2010).

204 Brokelind (2008).
} 


\begin{tabular}{|c|c|c|c|}
\hline Member State (accession) & NCases & Percent & Debut case \\
\hline Austria (1995) & $8 / 2$ & $4.3 \%$ & Sandoz (C-439/97) \\
\hline Belgium (1958) & $25 / 9$ & $14.5 \%$ & Bachmann (C-204/90) \\
\hline Bulgaria (2007) & 0 & $0 \%$ & - \\
\hline Cyprus (2004) & 0 & $0 \%$ & - \\
\hline Czech Republic (2004) & 0 & $0 \%$ & - \\
\hline Denmark (1973) & $3 / 2$ & $2.1 \%$ & Vestergaard (C-55/98) \\
\hline Estonia (2004) & $0 / 1$ & $0.4 \%$ & Commission v Estonia (C-39/10) \\
\hline Finland (1995) & $9 / 1$ & $4.3 \%$ & Danner (C-136/00) \\
\hline France (1958) & $21 / 2$ & $9.8 \%$ & Avoir Fiscal (270/83) \\
\hline Germany (1958) & $50 / 5$ & $23.5 \%$ & Werner (C-112/91) \\
\hline Greece (1981) & $2 / 3$ & $2.1 \%$ & Commission v Greece (C-8/97) \\
\hline Hungary (2004) & $1 / 1$ & $0.9 \%$ & CIBA (C-96/08) \\
\hline Ireland (1973) & 0 & $0 \%$ & - \\
\hline Italy (1958) & $6 / 2$ & $3.4 \%$ & Commission v Italy (C-540/07) \\
\hline Latvia (2004) & 0 & $0 \%$ & - \\
\hline Lithuania (2004) & 0 & $0 \%$ & - \\
\hline Luxembourg (1958) & $8 / 1$ & $3.8 \%$ & Biehl I (C-175/88) \\
\hline Malta (2004) & 0 & $0 \%$ & - \\
\hline Netherlands (1958) & $25 / 2$ & $11.5 \%$ & Halliburton Services (C-1/93) \\
\hline Poland (2004) & $2 / 0$ & $0.9 \%$ & Rüffler (C-544/07) \\
\hline Portugal (1986) & $4 / 6$ & $4.3 \%$ & EPSON Europe (C-375/98) \\
\hline Romania (2007) & 0 & $0 \%$ & - \\
\hline Slovakia (2004) & 0 & $0 \%$ & - \\
\hline Slovenia (2004) & $1 / 0$ & $0.4 \%$ & Pelati (C-603/10) \\
\hline Spain (1986) & $1 / 8$ & $3.8 \%$ & Commission v Spain (C-219/03) \\
\hline Sweden (1995) & $8 / 1$ & $3.8 \%$ & Safir (C-118/96) \\
\hline United Kingdom (1973) & $14 / 0$ & $6 \%$ & Daily Mail $(81 / 87)$ \\
\hline EU-6 (1958) & $135 / 21$ & $66.7 \%$ & - \\
\hline EU-10 (1958 through 1981) & $154 / 26$ & $76.9 \%$ & - \\
\hline EU-15 (1958 through 1995) & $184 / 44$ & $97.4 \%$ & - \\
\hline EU-25 (1958 through 2004) & $188 / 46$ & $100 \%$ & - \\
\hline EU-27 (1958 through 2007) & $188 / 46$ & $100 \%$ & - \\
\hline
\end{tabular}

Table 1 . New cases by Member State.

Prior research found that national courts of Member States with majoritarian democracy, e.g. Denmark, Sweden, Finland and the UK, are less likely to engage the Court by referring preliminary questions. However, that research did not find empirical evidence for the hypothesis that the level of economic integration (intra-EU trade) is significantly correlated to divergences in the extent to which national courts of different Member States refer preliminary questions. ${ }^{205}$

Most cases in the field of direct taxation that reach the Court are litigated against the EU's largest Member State by population i.e. Germany. This is

205 Wind, et al. (2009). 
consistent with the overall statistics on preliminary references according to the CJEU. ${ }^{206}$ The Benelux Member States, with a combined population far below half of Germany's population, have however litigated more cases in direct tax matters than Germany. But, the overall statistics show that the private litigators in the Benelux often base claims on EU law grounds considering the high number of references from the national courts of these Member States. Nonetheless, the Dutch Hoge Raad also sometimes fails to make a reference to the Court. ${ }^{207}$ The high number of cases from Belgium - ranked second of all Member States - is striking in this context, especially compared with equally sized countries such as Portugal and Greece.

De Sousa de Câmara submits that private litigators in Portugal often do not base their claims on EU law grounds because they find litigation on EU law grounds too costly. ${ }^{208}$ Also, the authority of EU law in the field of direct taxes is not completely accepted in Portugal, according to De Sousa de Câmara. ${ }^{209}$ Dourado describes the Portuguese situation in the 1980's and 1990's as 'a general attitude of indifference'. ${ }^{210}$ This might account for the relatively low number of references from Portuguese courts to the Court in direct tax matters.

In respect of Greece, Matsos attributes the lack of references in direct tax cases to systematic deficiencies in Greek tax law and a lack of knowledge on EU law of private litigators and judges. ${ }^{211}$ The characterisation of Greek direct tax law by Matsos as primarily focused on procedure is consistent with the nature of the two Greek preliminary references which concerned a directly discriminatory corporation tax rate and the imposition of withholding taxes on dividends that was contrary to the Parent-Subsidiary Directive (90/435/EEC). ${ }^{212}$

Although UK courts only really started to refer cases to the Court after Factortame (C-213/89), which was decided in 1990, and usually invoked acte clair opportunistically, the reluctance to refer applied to a lesser extent to cases in tax matters (including VAT) which accounted for most of the references by UK Courts in the period 1971-1998. ${ }^{213}$ This observation corresponds with the data presented here. Considering the equivalent sizes of the UK and France, the data for France does not raise further questions, also in view of the overall statistics.

Kofler notes on Austria that this Member State may be considered a 'European model student' since, as Kofler opines, Austria takes the spirit of the internal market and the case law seriously. ${ }^{214} \mathrm{He}$ submits that Austria generally

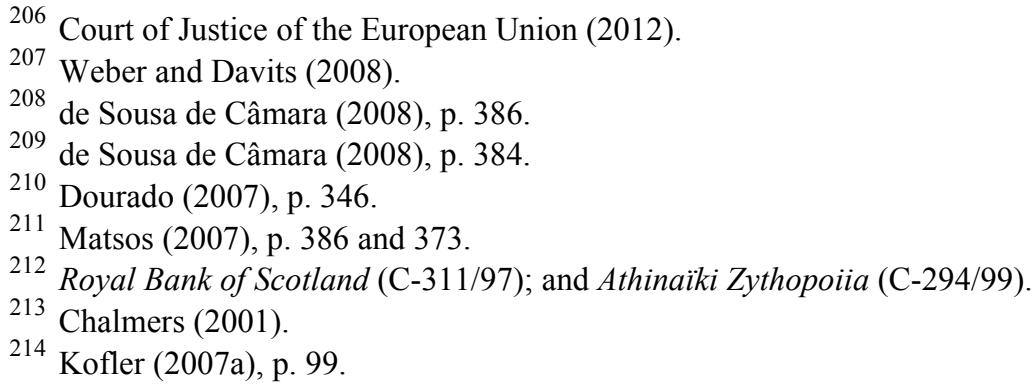


responds actively to the Court's rulings and brings its laws and administrative and judicial practice in line with EU law. ${ }^{215}$ Furthermore, Austrian courts were not hesitant to accept the Court's authorities on EU law in the field of direct taxation after the accession to the EU in $1995 .{ }^{216}$ Also, taxpayers generally enjoy a high rate of success in direct tax proceedings before Austrian courts when the claim is grounded in EU law. ${ }^{217}$ Consequently, the fact that Austrian courts have not referred many questions to the Court-when compared to the Beneluxdoes not cause one to doubt the effectiveness of EU law on Austrian direct tax law.

Table 1 also shows that most requests for a preliminary reference have been submitted by German courts $(n=50)$ and most direct actions have been brought to court against Belgium $(n=9)$. Except for Poland, Slovenia and the UK, all Member States from which the national court has referred a direct tax case to the Court had also had a direct action brought against them before the Court. ${ }^{218}$ Spanish national courts have referred over 270 cases for a preliminary ruling to the Court in history, ${ }^{219}$ but they have referred only one case in the field of direct taxation, i.e. Banco Bilbao Vizcaya Argentaria (C-157/10). The other eight direct tax cases in which Spain litigated before the Court were direct actions for its alleged failure to comply with EU law. In the five cases decided until 31 December 2011, the Court held in favour of the Commission and ruled that Spain indeed failed to fulfil its obligations under EU law. ${ }^{220}$ Garcia Prats attributes the low number of referrals to an opportunistic use of the acte clair doctrine. ${ }^{221}$ That conclusion is at the very least consistent with Spain's record in direct actions in direct tax cases as presented here.

\subsubsection{Preliminary references by national court}

We have observed that there are differences between Member States in the number of cases referred to the Court. There are also differences between the Member States with regard to the type of national court referring the preliminary questions. Table 2 shows the division by national court of the preliminary references of the EU-27 and the five Member States which referred the most cases pursuant to Article 267 TFEU to the Court.

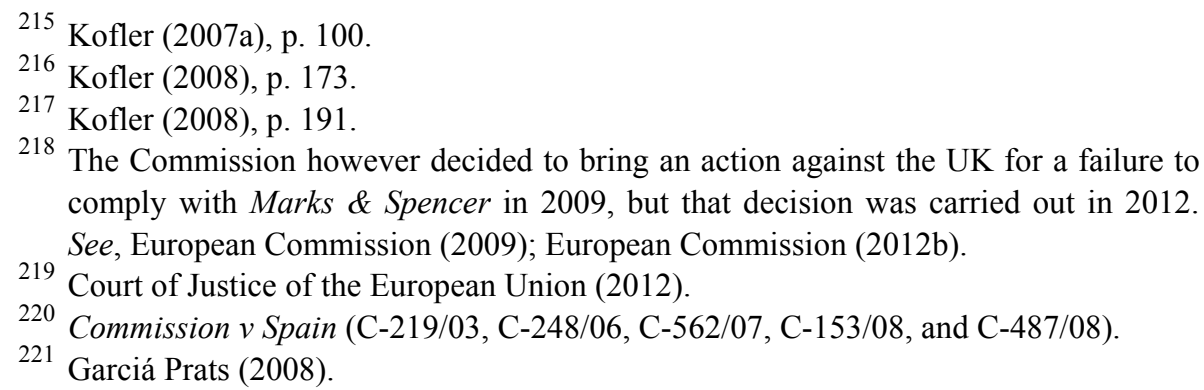




\begin{tabular}{|c|c|c|c|}
\hline \multicolumn{2}{|c|}{ Member States and their national courts } & \multirow{2}{*}{$\begin{array}{l}N \text { Cases } \\
186\end{array}$} & \multirow[t]{2}{*}{ Percent } \\
\hline EU-27 & & & \\
\hline & supreme courts & 81 & $44 \%$ \\
\hline & lower courts & 105 & $56 \%$ \\
\hline \multirow[t]{3}{*}{ Germany } & & 50 & \\
\hline & Bundesfinanzhof (supreme) & 25 & $50 \%$ \\
\hline & Finanzgerichte (lower) & 25 & $50 \%$ \\
\hline \multirow[t]{4}{*}{ Belgium } & & 25 & \\
\hline & Hof van Cassatie (supreme) & 3 & $12 \%$ \\
\hline & Hoven van Beroep (lower) & 10 & $40 \%$ \\
\hline & Rechtbanken van Eerste Aanleg (lower) & 12 & $48 \%$ \\
\hline \multirow[t]{3}{*}{ Netherlands } & & 25 & \\
\hline & Hoge Raad (supreme) & 15 & $60 \%$ \\
\hline & Gerechtshoven (lower) & 10 & $40 \%$ \\
\hline \multirow[t]{5}{*}{ UK } & & 14 & \\
\hline & House of Lords (supreme) & 1 & $7 \%$ \\
\hline & High Court of Justice (lower) & 10 & $71 \%$ \\
\hline & Special Commissioners (lower) & 2 & $14 \%$ \\
\hline & Upper Tribunal (lower) & 1 & $7 \%$ \\
\hline \multirow[t]{5}{*}{ France } & & 21 & \\
\hline & Conseil d'État (supreme) & 6 & $29 \%$ \\
\hline & Cour de Cassation (supreme) & 2 & $10 \%$ \\
\hline & Tribunaux de Grande Instance (lower) & 1 & $5 \%$ \\
\hline & Tribunaux Administratif (lower) & 12 & $57 \%$ \\
\hline
\end{tabular}

Table 2. Article 267 TFEU cases by national courts.

Of all 188 preliminary references, only two cases were declared inadmissible by the Court because the referring national body was not a court for the purposes of Article 267 TFEU. ${ }^{222}$ Only national courts which have made at least one referral in direct tax matters are listed. There are some differences between the Member States with respect to the national courts that refer the preliminary questions to the Court.

More cases are referred by lower courts compared to the proportion of cases referred to the Court by supreme courts (i.e. courts of last resort in tax matters) for the EU as a whole. Most preliminary references in the field of direct taxes came from the German Bundesfinanzhof, the supreme court in the field of taxes and customs. The distribution between references from supreme and lower courts in Germany does not deviate greatly from the aggregated data for all Member States. The distribution of preliminary references by Dutch courts is comparable. ${ }^{223}$ The UK House of Lords has referred only one case, Daily Mail

222 Corbiau (C-24/92); and Schmid (C-516/99).

223 Until 2005, the first instance was at the Gerechtshoven. But since 2005, the Rechtbanken are courts of first instance and the Gerechtshoven are courts of appeal. No Rechtbank has yet made a referral in a direct tax case to the Court. 
(81/87), and all other cases were referred by lower courts, mainly by the High Court of Justice. ${ }^{224}$ Also in Belgium lower courts account for the majority (88\%) of all preliminary references. The situation for France is distorted due to the joinder of cases. The tribunal administratif de Montreuil referred the same two preliminary questions in ten similar cases in $2011 .{ }^{225}$ If these cases are counted as one, the conclusion is that the supreme courts of France (the Cour de Cassation and the Conseil d'Etat) account for most preliminary references on the compatibility of French direct tax law with EU law.

\subsection{Subject matter of the proceedings}

The subject matter of the cases can be analysed from two perspectives. The first perspective is to analyse the subject matter of the main proceedings before the national court for preliminary references and the nature of the national legislation of the Member State at issue for direct actions (Section 3.4.1). The second perspective is to analyse the proceedings before the Court and the provisions of EU law on which the Court decided the case (Section 3.4.2). Both perspectives will be explored below for all completed cases in the period from 1983 through 2011.

\subsubsection{National subject matter}

\subsubsection{Subject matter by OECD classification}

To describe their national subject matter, all completed cases in the period from 1983 through 2011 were coded according to the OECD Classification of Taxes. ${ }^{226}$ Table 3 provides a detailed account of the number of completed cases for each OECD class. The vast majority of cases concerns income taxes $(88 \%)$ and a minority group concerns property taxes $(11 \%)$. CIBA (C-96/08) was the only case on OECD class 3000 and was about a vocational training levy. Baxter (C-254/97) was classified in OECD class 1300 and concerned a special levy on net turnover on medicinal products after deduction of R\&D expenses.

There is one case more on corporation taxes than there are cases on personal income taxes. All Member States with ten or more rulings have litigated both in individual income tax cases and corporation tax cases, except for the UK which

224 Since 1 April 2009, the appeal against tax decisions of HMRC has been transferred from the Special Commissioners to the Tax Chamber of the First-tier Tribunal, see The Transfer of Tribunal Functions and Revenue and Customs Appeals Order 2009 (no. 56).

225 FIM Santander Top 25 Euro Fi (Joined Cases C-338-347/11).

226 OECD (2011), Annex A. 
has only appeared before the Court in corporation tax cases. ${ }^{227}$ A relatively small proportion $(15 \%)$ of all completed income tax cases concern the taxation of capital gains of either individuals or companies. These capital gains taxation cases also include the 'exit tax' and taxes on gambling winnings cases. We also coded all income tax cases that concerned the taxation of dividends. A considerable proportion (28\%) of all completed income tax cases are about the taxation of dividends, but there are three times as many corporation tax cases as there are personal income tax cases on dividends as Table 4 shows. Taxes on dividends levied from companies make up almost half of all cases in OECD class 1210 .

\begin{tabular}{cr}
\hline OECD Classification & $n$ Cases \\
\hline 1000 Taxes on income, profits and capital gains & 169 \\
1100 Individual taxes & 83 \\
$1110 \ldots$... income and profits & 68 \\
$1120 \ldots$ on capital gains & 15 \\
1200 Corporation taxes & 85 \\
$1210 \ldots$...on income and profits & 75 \\
$1220 \ldots$ on capital gains & 10 \\
1300 Unallocable as between 1100 and 1200 & 1 \\
3000 Taxes on payroll and workforce & 1 \\
4000 Taxes on property & 22 \\
4100 Recurrent taxes on immovable property & 3 \\
4200 Recurrent taxes on net wealth & 3 \\
4300 Estate, inheritance and gift taxes & 10 \\
4400 Taxes on financial and capital transac- & 6 \\
tions & \\
4500 Other non-recurrent taxes on property & 0 \\
4600 Other recurrent taxes on property & 192 \\
\hline
\end{tabular}

Table 3. OECD classification of completed cases.

The taxes on property mainly concern estate, inheritance and gift taxes. Six cases which were coded in OECD class 4400 were about taxes on transactions in immovable property, ${ }^{228}$ a stamp duty tax on loan agreements, ${ }^{229}$ and taxes on the raising of capital and financial transactions. ${ }^{230}$ These last six cases may be said to concern indirect taxes rather than direct taxes. Due to the method of data col-

${ }^{227}$ These Member States with $n$ completed cases between parentheses are: Germany (50), Belgium (26), Netherlands (25), France (13) and the UK (12).

${ }^{228}$ Halliburton Services (C-1/93); Commission v Greece (C-155/09); and Commission v Belgium (C-250/08).

${ }^{229}$ Sandoz (C-439/97)

${ }^{230}$ Commission v Belgium (C-415/02); and Commission v Italy (C-197/03). 


\begin{tabular}{lc}
\hline OECD Classification & $n$ Cases on taxation of dividends \\
\hline 1000 Taxes on income, profits and capital gains & 47 \\
1110 Individual taxes on income and profits & 11 \\
1210 Corporation taxes on income and profits & 36 \\
\hline
\end{tabular}

Table 4. Completed cases on taxes on dividends by OECD classification.

lection, these cases were not excluded a priori from the sample of cases on direct taxes. $^{231}$

\subsubsection{The relevance of DTCs}

Since proceedings on EU law involve situations of cross-border activity, the interaction of the national legislative framework with the international law of double tax conventions (DTCs) is possible and likely. The TFEU and DTCs are also said to pursue corresponding goals, in that both attempt to mitigate legal barriers to cross-border economic activities. ${ }^{232}$ We reviewed and coded all completed cases for a mention of a DTC in the text of the decision ending the proceedings before the Court, so indicating its potential or actual relevance to the main proceedings, to research to what extent the law of double taxation conventions is taken into account in the proceedings before the Court.

References to the OECD Model were not coded as a reference to a double tax convention, given that the OECD Model is not an instrument of law that has binding legal effect. The Court nonetheless refers at times to the OECD Model and the Commentary in its rulings. Lehner suggested that provisions of national law and DTCs benefit from a presumption of compatibility with EU law if they are consistent with the OECD Model rules. ${ }^{233}$ Kemmeren concluded that the OECD rules have a strong influence on the Court's case law and even found that the Court 'sometimes flies too much on the OECD autopilot'. ${ }^{234}$ Dubut however points to a declining importance of the OECD Model in recent case law and concludes that the Model itself is irrelevant for the interpretation of EU lawespecially with regard to secondary EU law - and the Court may be said at the most to interpret actual DTC rules with the Commentary in mind. ${ }^{235}$ For this reason, we analyse the relevance of actual DTCs and not citations to the OECD Model or its Commentary.

The text of the decision ending the proceedings before the Court included a reference to an existing double tax convention in $37 \%$ of all completed cases. In

\footnotetext{
231 Section 2.5.

232 Kemmeren (2012).

233 Lehner (2000).

234 Kemmeren (2012).

235 Dubut (2012).
} 
a clear majority of cases $(63 \%)$ the text of the final decision did not mention an actual DTC.

These statistics run contrary to intuition, considering that the network of double tax conventions between the Member States is near to complete, and recalling that almost all DTC between Member States are modelled after the OECD Model that covers most cross-border tax situations. This justifies the expectation that double tax conventions have a legal effect in most situations that lead to proceedings before the Court, and the mere presence of such legal effects at least is of some relevance for the Court to completely understand the legal background of the issue in the main proceedings. Accordingly, we would expect a double taxation convention to be mentioned in the majority of direct tax decisions.

The findings however do not validate this hypothesis but rather point to the direction that either the national courts and the Commission for some yet unidentified reasons choose not to include the legal effect of double tax conventions in the legal background of their references to the Court, or that the legal effects of double tax conventions are simply irrelevant in most cases to assess a potential infringement of EU law through the application of national tax laws. ${ }^{236}$

\subsubsection{EU law subject matter}

The EU law subject matter was analysed on the basis of the legal provision(s) that the Court cited in the formal ruling of the decision (also referred to as the operative part, or dispositif in French) of all completed cases in the sample period 1983-2011. All cases were coded according to the TFEU provision or the directive which the Court ruled upon. In general, most direct tax proceedings $(n=160)$ concern the relation between national law and one or more of the fundamental freedoms of the TFEU. The Court interpreted a direct tax directive in 30 completed cases in the 1983-2011 period. Some cases neither cite TFEU provisions, nor a direct tax directive, but only refer to EU law in general, ${ }^{237}$ to the EEA Agreement, ${ }^{238}$ to other legal instruments, ${ }^{239}$ or do not refer to a provision of EU law at all. ${ }^{240}$

${ }^{236}$ But see, Section 4.5.2.2 on the neutralisation of discrimination through application of a DTC.

${ }^{237}$ Barbier (C-364/01).

${ }^{238}$ Krankenheim Ruhesitz am Wannsee-Seniorenheimstatt (C-157/07); Commission v Netherlands (C-521/07); and Établissements Rimbaud (C-72/09).

239 Verkooijen (C-35/98); Commission v Belgium (C-415/02); Commission v Italy (C197/03); and Hengartner and Gasser (C-70/09).

${ }^{240}$ Corbiau (C-24/92); and Schmid (C-516/99). 


\subsubsection{The interpretation of the TFEU}

Table 5 presents the statistics for a selection of TFEU provisions. Only provisions relating to freedom of movement are considered. Article 18 TFEU prohibits all discrimination of Union citizens on grounds of nationality; Article 21 TFEU protects the right of Union citizens to move and reside within the territory of the Member States; Article 45 TFEU protects the free movement of workers; Article 49 TFEU protects the freedom of establishment and Article 54 TFEU extends this freedom to companies and firms; Article 56 TFEU protects the freedom to provide services; and Article 63 TFEU protects free movement of capital, whereas Articles 64 and 65 TFEU describe the situations in which this last freedom is not guaranteed.

Gross counts of citations to the Treaty provision are given in Table 5. The number of exclusive citations is the number of cases in which the Court cited only this TFEU provision and no other TFEU provision mentioned in Table 5. The Court often relies on more than one provision of EU law. The sum of all counts therefore does not equal the sum of all completed cases in the 1983-2011 period. For this reason, a cocitation matrix is also included in Table 5. This cocitation matrix is symmetrical; the information on both sides of the diagonal is equivalent.

\begin{tabular}{llllllllllll}
\hline TFEU & \multicolumn{1}{c}{$n$ Citations } & \multicolumn{1}{c}{$n$ Cocitations TFEU Articles } \\
Provision & Total & Exclusive & 18 & 21 & 45 & 49 & 54 & 56 & 63 & 64 & 65 \\
\hline Art. 18 & 2 & 0 & - & 2 & 1 & 1 & 0 & 0 & 0 & 0 & 0 \\
Art. 21 & 13 & 2 & 2 & - & 8 & 7 & 0 & 4 & 0 & 0 & 0 \\
Art. 45 & 26 & 15 & 1 & 8 & - & 8 & 0 & 5 & 0 & 0 & 0 \\
Art. 49 & 68 & 28 & 1 & 7 & 8 & - & 24 & 5 & 11 & 2 & 3 \\
Art. 54 & 24 & 0 & 0 & 0 & 0 & 24 & - & 0 & 4 & 1 & 3 \\
Art. 56 & 31 & 17 & 0 & 4 & 5 & 5 & 0 & - & 5 & 0 & 0 \\
Art. 63 & 63 & 25 & 0 & 0 & 0 & 11 & 4 & 5 & - & 5 & 22 \\
Art. 64 & 5 & 0 & 0 & 0 & 0 & 2 & 1 & 0 & 5 & - & 2 \\
Art. 65 & 22 & 0 & 0 & 0 & 0 & 3 & 3 & 0 & 22 & 2 & - \\
\hline
\end{tabular}

Table 5. Legal basis of rulings by TFEU provision.

\subsection{The basic rights of Articles 18 and 21 TFEU}

In order to place the cases in the field of direct taxation in their right context, it is necessary to first take a brief tangent to the Court's early case law on citizenship of the Union and the interpretation and scope it gave to Article 21 TFEU. $^{241}$

The Court established in Grzelczyk (C-184/99) that Union citizenship is 'destined to be the fundamental status of nationals of Member States enabling

241 See e.g., Jacobs (2007), van der Mei (2011), and Wollenschläger (2011). 
those who find themselves in the same situation to enjoy the same treatment in law irrespective of their nationality, subject to such exceptions as are expressly provided for' (para 31). The Court already held in Bickel and Franz (C-274/96) that situations which involve the exercise of rights protected by Article 21 TFEU fall within the scope of EU law. A national of a Member State who lawfully resides in another Member State thus falls within the material scope of the TFEU provisions concerning Union citizenship, according to Martinez Sala (C85/96). According to D'Hoop (C-224/98, para 30), a Union citizen who exercised the right protected by Article 21 TFEU to move and reside in another Member State may therefore not be treated in a less advantageous manner in the Member State of which he is a national than the treatment he would enjoy if he would not have exercised his right of freedom of movement. Baumbast (C413/99) explicitly held that Article 21 TFEU had direct effect. It furthermore follows from D'Hoop (paras 34-36) and also Pusa (C-224/02, para 20) that, unless objective differences can be identified, the fundamental status of a Union citizen guarantees the same treatment in law in the exercise of the Union citizen's freedom to move.

In that interpretation of the Treaty protection afforded to nationals of Member States, which is directly attached to their complementary status as Union citizens, the Treaty provisions not only pre-empt discrimination on grounds of nationality as Article 18 TFEU prohibits, but also all other forms of discrimination against (or, restrictions on) the exercise of freedom of movement. All national measures that in terms of Säger (C-76/90) and Kraus (C-19/92) 'prohibit, impede or render less attractive' - discriminate against - the exercise of freedom of movement is thus legislation that unlawfully undermines the Union citizen's fundamental status and so breaches general principles of the Treaty.

In short, discrimination in a manner contrary to the Treaty is a wide concept and involves a disadvantageous treatment in law or in fact of a Union citizen, simply and specifically because he exercised free movement. A national measure that treats non-residents in a manner less advantageous than residents is thus not only liable to specifically affect nationals of other Member States - and for this reason breaches Article 18 TFEU-but it is also liable to specifically affect nationals of the Member State concerned who have exercised the right to move freely and now reside in another Member State. That effect is contrary to Article 21 TFEU and it has been so held by the Court, also in the field of direct taxation. $^{242}$

It is well-established case law, also in the field of direct taxation, that the general principles of non-discrimination on grounds of nationality and freedom to move and reside in the territory of the Member States of, respectively, Articles 18 and 21 TFEU have found specific expression in the other free

242 See generally, Arendonk van (2012). 
movement provisions. ${ }^{243}$ If the situation is covered by the material scope of a specific free movement provision, there is consequently no need to examine the case in the context of the general rights of Articles 18 and 21 TFEU. It already follows from a significant number of cases in the field of direct taxation that these general TFEU provisions accordingly protect Union citizens who are not economically active in another Member State, but nevertheless have made, or desire to make use of their right to move freely and reside in another Member State. ${ }^{244}$ Articles 18 and 21 TFEU therefore serve a residual function in practice.

The line between what is economic and non-economic activity can be a thin one. For example, the Court was not informed conclusively in Zanotti (C-56/09) whether the advanced LL.M in international tax law offered by the International Tax Center Leiden constituted a provision of service for remuneration for the purposes of Article 56 TFEU, or not. The LL.M constituted a service in accordance with Article 56 TFEU if it was essentially financed by private funds through e.g. tuition fees, which normally is the case for professional and specialist training (Zanotti, paras 32 and 33). Article 21 TFEU only applied if this was not the case, since university education offered through a public programme does not constitute a service normally provided for remuneration for Treaty purposes, and thus is not an economic activity (para 31). The Court left the issue for the national court to decide.

The Court interpreted the general principle of non-discrimination on the basis of nationality, which Article 18 TFEU lays down, only twice in the field of direct taxation; first in Schempp (C-403/03) and then again in Commission $v$ Greece (C-155/09). The Court found no different treatment with regard to nationality in Schempp, but held that the different treatment was based on objective criteria. Thus, Mr Schempp was not treated differently because his former spouse resided in another Member State, but because his former spouse was subject to a different system of taxation in Austria compared to Germany. Had his former spouse resided in a Member State that attributed taxable character to maintenance payments received from former spouses, like Germany or the Netherlands, Mr Schempp would have been able to claim a deduction from income tax for those payments. However, since Austria did not include the payments received by his former spouse in her basis of assessment, Germany lawfully denied Mr Schempp's deduction in the Court's view (paras 32-36).

Commission v Portugal (C-345/05), para 13; Commission v Sweden (C-104/06), para 15; Schwarz and Gootjes-Schwarz (C-76/05), para 34; Commission v Germany (C318/05), paras 32 and 35; Commission v Germany (C-152/05), para 18; Commission $v$ Germany (C-269/07), paras 98-99 and 106; Zanotti (C-56/09), para 24; Commission $v$ Greece (C-155/09), para 41 and 68; and Commission v Hungary (C-253/09), para 44.

244 Commission v Portugal (C-345/05), para 37; Commission v Sweden (C-104/06), para 30; Commission v Belgium (C-522/04), para 72; Commission v Germany (C-152/05), para 30; Commission v Germany (C-269/07), para 115; Commission v Greece (C155/09), para 60; and Commission v Hungary (C-253/09), para 87. 
Germany also required that, as a condition for the deduction, tax was actually paid in another Member State by the former spouse. However, since Austria did not consider maintenance payments as taxable income at the outset, the compatibility of that further condition with EU law became a moot issue in the case at hand as the Court so replied in an obiter to Mr Schempp's submission in that regard (paras 37-39).

The Court decided Commission v Greece (C-155/09) mainly on the basis of the freedom of persons. The action was successful because Greece reserved an exemption from transfer tax on the purchase of immovable property in Greece for residents, whereas non-residents intending to settle in Greece were required to pay the tax upon the purchase of a residence in Greece. The Court also held that the national measure breached Article 18 TFEU because nationals of Greece and persons of Greek origin could nevertheless qualify for the exemption, despite having the status of a non-resident prior to moving to Greece. Other Union citizens, who also exercised free movement in order to settle in Greece, could not apply for an exemption and were consequently directly discriminated against by reserving a tax benefit for nationals who had exercised free movement, according to the Court.

The general right to move and reside of Article 21 TFEU was cited more frequently in the case law in the field of direct taxation than Article 18 TFEU. However, this count is still significantly less than the citation counts of any of the specific free movement rights (Articles 45, 49, 56 and 63 TFEU).

The provision applied exclusively in two cases; Turpeinen (C-520/04) and Rüffler (C-544/07). The taxpayer in Turpeinen had exercised free movement to permanently reside in a Member State other than her Member State of nationality upon her retirement, after having pursued employment in the Member State of which she was a national. For that reason, the situation at issue was not covered by the freedom of workers but was nevertheless protected by Article 21 TFEU. The latter case of Rüffler concerned a similar situation of a pensioner.

Article 21 TFEU pre-empts restrictions on the exercise of free movement in a very broad manner. This is stressed because the same scope of protection applies under the specific freedoms. For example, in Commission v Germany (C318/05) and Schwarz and Gootjes-Schwarz (C-76/05) the Court held the right to free movement of children - residents of Germany-attending a school in another Member State restricted because their parents were denied a deduction from personal income tax of the school fees in Germany, whereas such a deduction was allowed had the children attended school in Germany.

In Schempp (C-403/03), the Court also applied Article 21 TFEU, even though it was his former spouse, and not Mr Schempp himself, who exercised her basic right to free movement by transferring her residency to Austria. According to the Court: 'since the exercise by Mr Schempp's former spouse of a right conferred by the [Union] legal order had an effect on his right to deduct in his Member State of residence, such a situation cannot be regarded as an internal situation with no connection with [Union] law' (Schempp, para 25). However, we have already seen that the Court attributed the cause of the tax disadvantage 
suffered by Mr Schempp to disparities between the tax systems of Germany and Austria, and accordingly dismissed Mr Schempp's claim that German law accorded him a treatment that did not comply with EU law.

\subsection{The freedom of establishment}

The Court has based its rulings in most cases in the field of direct taxes on the freedom of establishment of Article 49 TFEU. The Court's case law on Article 49 TFEU largely relates to the taxation of business income earned by companies, but also includes preliminary references on the taxation of self-employed taxpayers; a definition that includes director-shareholders of companies and partners in partnerships for the purposes of the Treaty. ${ }^{245}$

A little less than a third of those cases concerned the rights of legal persons, as can be derived from the explicit citations of Article 54 TFEU. That proportion is likely biased downward, given that 42 cases relating to a corporation tax dispute (OECD classes 1210 and 1220) were decided based on Article 49 TFEU, but only 18 of those cases cited Article 54 TFEU in the ruling. All citations to Article 54 TFEU are however in rulings in which the Court also cited Article 49 TFEU. These cases are about corporation taxes. A few exceptions are $X$ and $Y$ (C-436/00) and De Baeck (C-268/03) about capital gains taxation on the transfer of shares by individuals, CIBA (C-96/08) about a vocational levy paid by companies, Baxter (C-254/97) about a special levy on pre-tax turnover, and Halliburton Services (C-1/93) about a tax on transactions of immovable property. An extended overview of the case law on the freedom of establishment in the field of direct taxation is given by O'Shea. ${ }^{246}$

\subsection{The free movement of capital}

The second most cited TFEU provision is Article 63 TFEU on the freedom of capital and payments. ${ }^{247}$ Cases on the free movement of capital were unsurprisingly predominantly about the taxation of dividends and capital gains and other kinds of income from capital, including gifts and inheritances. Most cases on property taxes were decided on the basis of free movement of capital.

The special clause of Article 64(1) TFEU that permits restrictions on the free movement of capital to or from third countries involving direct investments was cited in five rulings. Smit proffered that this clause should be interpreted on the basis of the facts of the specific case and applies only when the actual

245 Werner (C-112/91); Wielockx (C-80/94); Asscher (C-107/94); Conijn (C-346/04); Talotta (C-383/05); Columbus Container Services (C-298/05); Filipiak (C-314/08); and Gielen (C-440/08).

246 O'Shea (2008) and the works cited therein.

${ }^{247}$ For a general review, see Snell (2011). 
investment in the case is a direct investment. ${ }^{248}$ In FII Group Litigation (C446/04) and Orange European Smallcap Fund (C-194/06), the Court established that direct investments to which Article 64(1) TFEU applies are investments of any kind undertaken by natural or legal persons and which serve to establish or maintain lasting and direct links between the persons providing the capital and the undertakings to which that capital is made available in order to carry out an economic activity. In FII Group Litigation the Court considered that holdings in a company which do not allow the shareholder to participate effectively in the management of that company or in its control cannot be regarded as direct investments, and Orange European Smallcap Fund established the mirror image that holdings which allowed effective management or control were indeed direct investments for the purposes of Article 64(1) TFEU.

The exception of Article 64(1) TFEU only applies to restrictions which already existed on 31 December 1993. The Court decided in Holböck (C157/05) and Prunus and Polonium (C-384/09) that Article 63 TFEU was without prejudice to the restrictive national tax provisions in issue because they complied with that condition. In FII Group Litigation the Court left it to the national court to decide whether the clause applied to the restriction at issue. In CFC and Dividend Group Litigation (C-201/05) the answer to the fourth question of the national court cited 'Articles 56 EC to 58 EC' (Articles 63 TFEU to 65 TFEU) and the case was therefore coded as a ruling upon Article 64 TFEU. However, the fifth preliminary question about the interpretation of Article 64(1) TFEU did not concern the fourth, but only the first, second, and third preliminary questions. The Court however found no need to reply to the fifth question in the light of its answers to questions one to three.

In a third of the Article 63 TFEU cases the Court also relied on Article 65 TFEU. This provision provides in paragraph 1 for specific derogations for the application of the freedom of capital to national tax laws. This exception is however not to be interpreted as an a priori limitation to the general nondiscrimination principle which underlies all fundamental freedom provisions in the TFEU. ${ }^{249}$

The exception of Article 65 TFEU was cited in the formal ruling in D. (C376/06) but the Court did not find any infringement of Article 63 TFEU, and therefore there was also no need to subject the exceptions of Article 65 TFEU to closer examination in this case. The same is true for Truck Center (C-282/07) and Block (C-67/08). The Court only found a breach of Article 63 TFEU in Secilpar - Sociedade Unipessoal (C-199/10) contingent on the national court's finding of fact whether the difference in treatment imposed by Portugal was neutralised pursuant to a DTC. If so, the national measures at issue in that case would not breach Article 63 TFEU at all.

The Court considered that the Article 65 TFEU exception rendered an infringement of Article 63 TFEU lawful in only a few cases. In Blanckaert (C-

248 Smit (2006).

249 O'Brien (2010); Usher (2008). 
512/03) the Court found the unequal treatment causing a prima facie infringement of Article 63 TFEU to be covered by the objective difference in situations between residents and non-residents described in Article 65(1)(a) TFEU. For the same reason the national legislation in Orange European Smallcap Fund (C-194/06) was, in some aspects, not contrary to EU law, but this notwithstanding it infringed EU law on other grounds. The restriction on the free movement of capital in $A$ (C-101/05) was justified by the need to guarantee the effectiveness of fiscal supervision, a ground recognised by the exception of Article 65(1)(b) TFEU. The national measures in CFC and Dividend Group Litigation (C-201/05) breached EU law on some points, and in other parts did not contravene the principle of free movement of capital, or were justified under Article 65(1)(b) TFEU, again by need to guarantee the effectiveness of fiscal supervision.

\subsection{The third country dimension to freedom of movement}

The free movement of capital of Article 63 TFEU is the only specific fundamental freedom provision that expressly applies in relation to non-member States. This third country dimension of Article 63 TFEU has been particularly relevant to the field of direct taxation. ${ }^{250}$ The dividing line between the free movement of capital, and especially in the field of direct taxation, the freedom of establishment was acknowledged early on as one of the most important, but also most difficult analytical topics in regards the Court's line of authority on the application of the free movement of capital in relations with non-member States. ${ }^{25}$

A broad application of Article 63 TFEU was also thought to be at variance with numerous international agreements between EU Member States and nonmember States, which in practice were generally interpreted and applied in a more favourable way to national tax rules compared to the non-discrimination principle of EU law. ${ }^{252}$

Article 49 TFEU on the freedom of establishment only applies within the EU, but national tax measures that restrict freedom of establishment are also liable to be at odds with the free movement of capital. Therefore, if a breach of Article 49 TFEU implies a breach of Article 63 TFEU, then this implied breach indirectly extends the scope freedom of establishment to third countries. The prevailing opinion in the literature is that the Court tries to keep Article 63 TFEU distinct from the other freedoms-in particular the freedom of establishment - to avoid the result that a breach of Article 49 TFEU automatically implies a breach of Article 63 TFEU and application of the national measure is unlawful in relations with non-member States. ${ }^{253}$

${ }^{250}$ O'Brien (2010); Pistone (2006); Smit (2012). See, Smit (2011) for an exhaustive research.

251 Flynn (2002).

252 Smit (2005).

253 See e.g., Barnard (2009), p. 568. 
However, several studies, including very recent research, observe ambiguity in the reasoning of the Court and find that the Court does not take a clear position on the scope of application of Article 63 TFEU in the field of direct taxation. ${ }^{254}$ While prior research disagrees on which test the Court applies with an aim to resist the application of Article 63 TFEU in relations with nonmember States, the rational and normative basis that justifies a rule of precedence of Article 49 TFEU over Article 63 TFEU is at the same time subject of critical discussion. ${ }^{255}$

Prior research finds common ground as to the two potential tests that could define the order of application between free movement of capital and freedom of establishment; a facts of the case test and a purpose of the national legislation test. But, neither test has yet acquired clear majority support in Dutch, German and English literature. National courts show a similar degree of divergence in their preferences for those two standards. ${ }^{256}$

Especially the Dutch literature takes the position that the applicable freedom should ultimately be decided on the basis of the facts of the case. ${ }^{257}$ This first view submits that Article 63 TFEU cannot be invoked, also not in relations with non-member States, if the actual situation in the case at hand is covered by the material scope of Article 49 TFEU. The material scope of the freedom of establishment is normally affected in the situations of branches and subsidiaries over which the parent company exercises decisive influence according to the Baars-formula.

Other studies concluded that the actual circumstances of the case are not decisive, but the specific application of the Treaty provisions depends primarily on the aim and purpose of the national measure under review. ${ }^{258}$ According to this second view, the protection of Article 63 TFEU may be invoked in relations with non-member States for restrictions caused by national rules which are not aimed to apply exclusively to situations covered by the material scope of Article 43 TFEU. If the national measure is not restricted to apply solely to such situations of controlling holdings, brances or agencies, this view holds that Article 63 TFEU is involved, irrespective of the actual circumstances in the case at hand. The German literature mainly takes this second view, ${ }^{259}$ although dissenting opinions that support the first view are proffered as well. ${ }^{260}$

${ }^{254}$ Cordewener (2009); Cordewener, et al. (2007b); Hemels and Rompen (2010); Hemels, et al. (2010); Hindelang (2010); O'Brien (2010).

255 See e.g., Fontana (2007); Snell (2011), pp. 571-573.

256 Den Boer (2010); Hemels and Rompen (2010); Hemels, et al. (2010).

${ }^{257}$ Kiekebeld (2009b); Nijkeuter (2006); van der Kroon (2010).

258 Cordewener, et al. (2007a); Fase (2008); Peters (2007); Smit (2007).

259 Haslehner (2008); Köhler and Tippelhofer (2007); Tippelhofer and Lohmann (2008); Völker (2009).

${ }^{260}$ Wunderlich and Blaschke (2008); Zorn (2010). 


\begin{tabular}{llcc}
\hline & & \multicolumn{2}{c}{ Legal basis of ruling } \\
Case & Short name & Article 49 TFEU & Article 63 TFEU \\
\hline C-264/96 & ICI & yes & no \\
C-307/97 & Saint-Gobain & yes & no \\
C-315/02 & Lenz & no & yes \\
C-513/03 & Van Hilten-van der Heijden & no & yes \\
C-446/04 & FII Group Litigation & yes & yes \\
C-492/04 & Lastertec & yes & no \\
C-524/04 & Thin Cap Group Litigation & yes & no \\
C-101/05 & A & no & yes \\
C-105/05 & A and B & yes & no \\
C-157/05 & Holböck & no & yes \\
C-201/05 & CFC and Dividend Group Litiga- & yes & yes \\
& tion & & \\
C-194/06 & Orange European Smallcap Fund & no & yes \\
C-415/06 & Stahlwerk Ergste Westig & yes & no \\
C-377/07 & STEKO Industriemontage & no & yes \\
C-439/07 & KBC-Bank & yes & yes \\
C-436/08 & Haribo & no & yes \\
C-437/08 & Österreichische Salinen & no & yes \\
C-384/09 & Prunus and Polonium & yes & yes \\
\hline Tab 6. Cas & &
\end{tabular}

Table 6. Cases on relations with non-member States.

The indeterminacy in the law will probably definitely be settled with the Court's Grand Chamber decision in FII Group Litigation II (C-35/11) which was still pending before the Court at the time of writing. The UK High Court of Justice requested a preliminary ruling of the Court on, inter alia, this question:

Where the national legislation in question does not apply exclusively to situations in which the parent company exercises decisive influence over the dividend paying company, can a resident company rely upon Article 63 TFEU (formerly Article $56 \mathrm{EC}$ ) in respect of dividends received from a subsidiary over which it exercises decisive influence and which is resident in a third country?

Accordingly, it is particularly interesting to look closer to see in what context the Court allows concurrent application of Article 49 and 63 TFEU. Furthermore, we coded all rulings on Articles 49 and 63 TFEU for relevance to relations with non-member States. In that regard, cases were considered a case relevant to relations with non-member States if the facts of the main proceedings (as reported in the Court's ruling) concerned a relation with a non-Member State, or the request expressly referred to relations with a non-member State. Relations covered by the EEA Agreement were not considered relations with nonmember States for this purpose, since the freedom of establishment also applies within the EFTA and between EFTA States and EU Member States. The resulting list of cases is given in Table 6 . These 18 cases will be analysed in detail below. 
Although the case law on relations between Member States cannot provide persuasive guidance for non-member State relations, that case law may also not be inconsistent with situations in which the protection of Article 63 TFEU may be invoked. Since the principle of free movement of capital applies equally within and beyond the EU, the scope of Article 63 TFEU may not be defined inconsistently with regard to EU relations compared to relations with non-member States. That is, if Article 63 TFEU cannot be invoked in certain situations in relations with non-member States, that implies a fortiori that Article 63 TFEU cannot be invoked in similar situations concerning relations between Member States. $^{261}$

The Court ruled on Articles 49 and 63 TFEU in 11 cases, as can be derived from Table 5. All cases of this subset were preliminary references, except for the direct action in Commission v Greece (C-406/07). This is the only case in which the Court additionally ruled upon Article 21 TFEU.

In $X$ and $Y$ (C-436/00), De Baeck (C-268/03), and Commission v Greece (C406/07), the Court held the national provisions liable to restrict both the right to establishment and the free movement of capital. The former freedom was in those cases restricted for holdings which gave a shareholder definite influence over the decisions of a foreign legal company and allowed him to determine its activities, but the latter only to the extent that the shareholdings did not give such control. The main proceedings before the national courts in $X$ and $Y$ and $D e$ Baeck and the action sought by the Commission in Commission $v$ Greece however only concerned intra-EU relations. It is therefore not possible to infer any conclusion on the application of Article 63 TFEU in relation to non-member States when the national legislation is contrary to Articles 49 and 63 TFEU in the relations between Member States.

The Court held in Prunus and Polonium (C-384/09) that the national provisions on the taxation of investments in immovable property in France, as they applied to relations to the British Virgin Islands - an OCT in EU law, but a non-member State for purposes of Article 63 TFEU (para 31) - were in breach of the principle of free movement of capital, but were nevertheless permissible by force of Article 64(1) TFEU because those rules already existed on 31 December 1993 (paras 25 and 37).

The national legislation at issue in ACT Group Litigation (C-374/04) applied equally to both types of holdings, and the facts of the case potentially concerned both categories, ${ }^{262}$ but the Court found these measures not in breach with Articles 49 and 63 TFEU. Also in Accor (C-310/09) the national legislation was targeted to controlling and non-controlling holdings and the measure was found

${ }^{261}$ It is assumed here that Articles 64 TFEU or 65 TFEU do not apply.

262 Potentially, because the Court found that it lacked sufficient information to exclude the possibility that the shareholdings in fact would not give definite influence over the company to the shareholders. 
to breach both freedom of establishment and free movement of capital. ${ }^{263}$ In Columbus Container Services (C-298/05) and Truck Center (C-282/07) the Court examined the cases under Article 49 TFEU because the facts of the case clearly concerned situations in which the owners of the corporate rights could exercise definite influence over the legal person. Both cases moreover only concerned intra-EU situations. The Court found no discrimination against the right of establishment in either case. That implied that the national provisions at issue were also compatible with Article 63 TFEU for the same reasons, according to the rulings. The national provisions at issue in these three cases are therefore also lawful in relation to non-member States, although the Court was not specifically requested to review this situation.

The cases discussed thus far only concerned relations between Member States. We will now turn to concurrent application of Articles 49 and 63 TFEU in cases on relations with non-Member States.

The proceedings in FII Group Litigation concerned a grand total of nine individual preliminary questions, some of which were divided into several sub questions. For a proper understanding of FII Group Litigation it is necessary to examine the structure of the ruling a bit closer. Questions 6, 7, 8 and 9 concerned the form of compensation due to breaches of EU law and will therefore not be analysed below. However, questions 1 to 5 requested an interpretation of Articles 49 and 63 TFEU. It should be noted that questions 1 to 3 were phrased by the national court to restrict the interpretation of Articles 49 and 63 TFEU to relations between Member States. This can be conclusively derived from question 1, where companies in other Member States are expressly identified in short form as 'non-resident companies'. That term is also used in questions 2 and 3. Question 4 again uses the term 'non-resident companies', but explicitly observes that this term includes 'companies resident in third countries' for the purpose of that question. Question 5 requested an interpretation of Article 64(1) TFEU. It may consequently be inferred beyond reasonable doubt, that only questions 4 and 5-and not questions 1 to 3-regard relations to nonmember States. The Court's reply should therefore be interpreted accordingly.

The explicit framing of the preliminary questions in FII Group Litigation has been overlooked or implicitly deemed irrelevant in prior research. ${ }^{264}$ Furthermore, those studies find that FII group Litigation is not a clear interpretation of EU law. ${ }^{265}$ It is therefore necessary to analyse the Court's reasoning in regard Questions 1 to 5 in detail.

Question 1 concerned the application of national rules, which applied differently (in law and fact) when it concerned a holding less than 10\% (para 6). Inasmuch as the national rules applied to holdings of $10 \%$ or more, the Court found that the freedoms of Articles 49 and 63 TFEU could both be potentially

263 The facts of this intra-EU case were also not sufficiently clear to the Court in this case.

Cordewener, et al. (2007b); Hemels, et al. (2010); O'Brien (2010).

265 Cordewener, et al. (2007b), p. 113; Hemels, et al. (2010), p. 22. 
affected by the national legislation (para 36), but that the tax treatment was not discrimination which is contrary to the principles of freedom of establishment or free movement of capital (para 57). The national rules in regard to holdings less than $10 \%$ were held to be in breach of Article 63 TFEU only (para 65). The facts of the case clearly concerned only controlling holdings (para 37), but it could not be excluded that an interpretation of Article 63 TFEU would be irrelevant to the dispute in main proceedings, considering that the reference was made for only two test cases of a group litigation (para 38). Since the set of rules applicable to holdings less than $10 \%$ were evidently not liable to affect freedom of establishment, the Court only ruled on Article 63 TFEU for these national rules.

The national rules that were the subject of question 2 were not aimed to apply exclusively in situations of an exercise of freedom of establishment (para 80), and were ruled to breach both Articles 49 and 63 TFEU for the same reasons (paras 81, 94, 95 and 98).

Question 3 was divided into two sub questions. The national rules referred to in the first sub question were capable of affecting situations which came within the scope of both Article 49 and 63 TFEU, according to the Court (para 117). The Court however held that the Treaty provisions permitted those national rules (paras 127 and 128). The national rules that were the subject of the second sub question only applied to groups of companies. For this reason, the Court only interpreted and ruled on Article 49 TFEU (para 118).

Also for the national rules in question 4, the Court observed that they were capable of affecting both the freedom of establishment and free movement of capital (para 142). As regards Article 49 TFEU, the Court further held:

143. Having regard to the facts in the main proceedings (see paragraph 37 of this judgment), the legislation at issue in those proceedings should be considered in the first place from the perspective of [Article 49 TFEU].

Since the analysis in para 37 was confined to relations between Member States, because it was delivered in the context of question 1, it is reasonable to interpret para 143 as merely stating that Article 49 TFEU can be invoked in regard to the national rules of question 4 inasmuch as they were applied to the actual situations of the two test cases that concerned an exercise of freedom of establishment within the Union. No conclusion can be drawn from that statement as regards relations with non-member States, although it is evident that the two test cases also concerned relations with non-member States (para 28). The Court's holding with regard to Article 63 TFEU in para 165 of the ruling supports this reading:

165. In so far as, according to the national court, that question also concerns companies established in non-member countries which, accordingly, do not fall within the scope of [Article 49 TFEU] on freedom of establishment, and for the reason set out in paragraph 38 of this judgment, the question arises whether national measures such as those at issue in the main proceedings also contravene [Article 63 TFEU] on the free movement of capital. 
The Court does not expressly limit the application of Article 63 TFEU to situations that do not constitute an exercise of freedom of establishment within the EU. Rather, para 165 is properly understood as meaning that Article 63 TFEU applied in FII Group Litigation to all situations concerning companies established in a non-member State, and all EU situations that do not constitute an exercise of freedom of establishment. The Court held that both freedoms were infringed by the national rules at issue, for the same reasons (paras 164, 168 and 172).

The reasoning of the Court in reply to question 5 moreover supports the above interpretation of the ruling on Question 4. The Court clarified that, in the case of FII Group Litigation, Article 64(1) TFEU applies only to the restrictive national provisions referred to in question 4 inasmuch as they apply to holdings that enabled the shareholder to participate effectively in the management or control of a company (para 185). Whether that restriction already existed on 31 December 1993 was a matter that the Court left to the national court to determine (para 194).

The point is, if controlling holdings in non-member State relations would in no case be covered by Article 63 TFEU, why would the Court find it necessary to examine whether Article 64 TFEU states an exception to Article 63 TFEU as regards, inter alia, these holdings? ${ }^{266}$

The breach of Article 63 in non-member State relations in FII Group Litigation consequently was relevant to controlling holdings. Accordingly, the reference to companies established in non-member States in para 165 relates to a general category and is not limited to non-controlling holdings. The reference to para 38 in para 165 means that Article 63 TFEU also applies to non-controlling holdings in relations between Member States which are not covered by Article 49 TFEU. $^{267}$

Insofar as CFC and Dividend Group Litigation (C-201/05) concerned the same preliminary questions about dividend tax concessions as submitted by the UK court in FII Group Litigation, the Court adjudged the reasoned order in CFC and Dividend Group Litigation on the same grounds as its judgment in FII Group Litigation. In reply to the additional question whether the same interpretation also applied in relation to non-member States, the Court confirmed its analysis only in relation to the cases which it examined in the light of Article 63 TFEU in the relations between Member States. The Court found special justification for those restrictions on free movement of capital in relation to non-member States. As regards the other preliminary question in CFC and Dividend Group Litigation about the compatibility of the UK CFC-rules with the fundamental freedoms, the Court based its reasoning on its precedent of Cadbury Schweppes (C-196/04) about those same national provisions. These measures only applied to controlling holdings and the Court accordingly found

266 Cordewener, et al. (2007a).

${ }^{267}$ Peters (2007) shares this interpretation of para 165 but he does not discuss the other preliminary questions in FII Group Litigation. 
those rules to be incompatible with Article 49 TFEU in both rulings. Therefore it found no need to examine that question in the light of Article 63 TFEU, or to hold those CFC-rules contrary to Article 63 TFEU in relation to holdings in subsidiaries of non-member States.

In summary, FII Group Litigation and CFC Dividend Group Litigation do not suggest that Article 63 TFEU cannot be applied to actual cases of controlling holdings in relations to non-member States. On the contrary, FII Group Litigation and CFC Dividend Group Litigation support the hypothesis that Article 63 TFEU may be invoked in all cases involving relations with nonmember States if the national provision at issue is liable to affect situations that do not constitute an exercise of freedom of establishment of Article 49 TFEU, whether or not the scope of the national provisions also applies to situations covered by the material scope of Article 49 TFEU. Of course, the EU law protection of Article 63 TFEU in those non-member State cases is always contingent on the application of Articles 64 and 65 TFEU and the more liberal interpretation of the effectiveness of fiscal supervision justification. However, if the national legislation only applies to situations covered by the material scope of freedom of establishment, the protection of either Article 49 TFEU or 63 TFEU cannot be invoked in relations with non-member States. The rulings in FII Group Litigation and CFC and Dividend Group Litigation accordingly only support the purpose of the national legislation rule as regards Article 63 TFEU in relations with non-member States.

Joined Cases KBC Bank and Beleggen, Risicokapitaal, Beheer (Joined Cases C-439\&499/07) predominantly revolved around the question whether Belgium had transposed the Parent-Subsidiary Directive (90/435/EEC) correctly into national law. The Court found that this was not the case for relations between Member States. The national court also asked in both cases if that finding would consequently render the application of the same national provisions to internal situations to be in breach of EU law but the Court determined that the decision on this question was an exclusive matter for the national court. The national court in KBC Bank additionally requested the Court to rule if those same national provisions - applying equivalently to internal relations, relations between Member State, and relations to non-member States-breached Article 63 TFEU in relations with non-Member States. The Court left it to the national court to determine whether Article 63 TFEU applied and to examine the merits of its question. According to the Court's judgment, the application of the free movement of capital should be determined in consideration of the purpose of the national legislation and the facts of the actual case before the national court. If the national legislation does not depend on the extent of the shareholding, then the national legislation potentially affects both the right of establishment and free movement of capital. However, if an actual holding in question has definite influence over the subsidiary to the parent company, then Article 49 TFEU applies to the actual case before the national court. Consequently, for a national provision to be potentially incompatible with the free movement of capital in relation to non-member States, the national rule should not be aimed exclusively 
at controlling holdings. The Court reasoned in paras 67-71 of its ruling as follows:

67. If, by virtue of the application of the national legislation, dividends from a company established in a non-member State are treated less favourably than dividends from a company with its seat in Belgium, it is for the national court to determine at the outset whether [Article 63 TFEU] is applicable.

68. In that regard, in order to determine whether national legislation falls within the scope of one or other of the freedoms of movement, it is clear from what is now well established case-law that the purpose of the legislation concerned must be taken into consideration (see Case C-157/05 Holböck [2007] ECR I-4051, paragraph 22, and the case-law cited).

69. The Court has held also that national legislation, the application of which does not depend on the extent of the holding which the company receiving the dividend has in the company paying it, may fall within the purview both of [Article 49 TFEU] on freedom of establishment and of [Article 63 TFEU] on the free movement of capital (see, to that effect, Test Claimants in the FII Group Litigation, paragraph 36, and Case C-284/06 Burda [2008] ECR I4571, paragraph 71).

70. However, to the extent to which the holdings in question confer on their owner a definite influence over the decisions of the companies concerned and allow it to determine their activities, it is the provisions of the Treaty relating to freedom of establishment which apply (Test Claimants in the FII Group Litigation, paragraph 81).

71. Consequently, it is for the referring court to determine, in the light of the purpose of the national legislation and the facts of the case before it, whether [Article 63 TFEU] may be invoked. If so, it is for that court to determine whether that article precludes the different treatment of dividends from subsidiaries established in a non-member State compared to dividends from subsidiaries with their seat in Belgium.

The Court only provided very general instructions to the national court, but did not decide the case itself. It seems odd however that the instruction in para 70 was based on a paragraph of the FII Group Litigation ruling that was restricted to an interpretation of Articles 49 TFEU and 63 TFEU in relations between Member States, whereas the question in KBC Bank specifically concerned the interpretation of Article 63 TFEU in relation to non-member States. The observation in FII Group Litigation, para 165, would have been a more relevant interpretation of Article 63 TFEU to apply to the question in KBC Bank. It was already observed above that FII Group Litigation provides no evidence for the application of the facts of the case rule to determine the applicability of Article 63 TFEU in non-member States relations. The instructions to the national court in $K B C$ Bank suggest the opposite, but not too much should be read into those statements. In that context, it is relevant to note that FII Group Litigation was a 
Grand Chamber judgment and $C F C$ and Dividend Group Litigation was decided by the Fourth Chamber in a panel of five judges on same grounds by reasoned order - thus signalling acte clair. Judge Lenaerts, President of the Fourth Chamber, was Judge Rapporteur in both cases. Joined Case KBC Bank and Beleggen, Risicokapitaal, Beheer were ruled by the Fifth Chamber in a panel of three judges. However, Judge Rapporteur Levits, in Joined Cases KBC Bank and Beleggen, Risicokapitaal, Beheer, did not sit on the bench in either FII Group Litigation or CFC and Dividend Group Litigation. ${ }^{268}$ Since the Court did not finally decide whether Article 63 TFEU could be invoked in the circumstances of the $K B C$ Bank case, that ruling is on balance not liable to bring about reasonable doubt about the consistency of the Court's case law. This conclusion is moreover based on the fact that the reply in regards Article 63 TFEU in KBC Bank and Beleggen, Risicokapitaal, Beheer also supports the interpretation of the purpose of the national legislation rule in relations with non-member States.

From the above follows now that the Court allows a concurrent application of Articles 49 and 63 TFEU if the national measure is liable to have effects on the free movement of capital and its material scope is not limited to apply exclusively to situations which constitute an exercise of freedom of establishment. We will now turn to cases which were ruled on based on Article 49 TFEU, but not on Article 63 TFEU, and were relevant to relations with nonmember States.

The three reasoned orders in Lasertec (C-492/04), $A$ and B (C-102/05), and Stahlwerk Ergste Westig (C-415/06) all follow the same pattern of reasoning. ${ }^{269}$ Lasertec concerned national rules which applied to controlling holdings, and $A$ and $B$ and Stahlwerk Ergste Westig concerned alleged restrictions applied to branches. The Court established first that the national rules in issue were designed to apply exclusively in situations covered by the material scope of Article 49 TFEU. Second, the Court held that if the national rules have 'restrictive effects on the free movement of capital, such effects must be seen as an unavoidable consequence of any restriction on freedom of establishment and do not justify an examination of that measure in the light of [Articles 63 TFEU and 65 TFEU]'. There was consequently no need to examine the national rules in the light of free movement of capital in any of the three cases. The national rules at issue fell 'solely' within the material scope of Article 49 TFEU. Third and last, the Court held that the territorial scope of Article 49 TFEU did not extend to situations concerning relations to non-member States and that consequently the freedom of establishment could not be relied upon in disputes in the main proceedings.

In synthesis, the Court consistently applied the purpose of the national legislation test in these three cases to limit the scope of Article 63 TFEU. They

268 Judges Ilešič and Borg Barthet were the other two Judges in KBC Bank. They also sat on the bench in the Grand Chamber panel in FII Group Litigation.

269 The same line of reasoning was followed in Scheunemann (C-31/11) which was decided in 2012. 
do not support the facts of the case test in relations with non-member States. The rulings in ICI (C-264/96) and Saint-Gobain (C-307/97) mentioned in Table 6 do not affect this conclusion.

It is true that the Court ruled multiple cases on Article 49 TFEU and resisted the application of Article 63 TFEU to those cases because the facts of the cases concerned an exercise of freedom of establishment. In the rulings in which the Court determined that Article 49 TFEU applied on basis of the facts of the case, but the national rule applied not exclusively to situations constituting an exercise of freedom of establishment, all cases concerned relations between Member States. ${ }^{270}$ It should also be noted that, if the Court established that the national rule at issue was aimed exclusively at situations covered by Article 49 TFEU, then the Court only ruled on Article 49 TFEU. ${ }^{271}$ This was also the case in Thin Cap Group Litigation (C-524/04) that is relevant to relations with non-member States. The case law on Article 49 TFEU is consistent with the case law on the concurrent application of Articles 49 and 63 TFEU.

For a final assessment of the third country dimension of the freedom of movement we will analyse the cases in which the Court interpreted only free movement of capital in relations with non-member States.

As a preliminary point, we should acknowledge that, although the national court requested the Court to answer the preliminary question in Lenz (C-315/02) for relations between EU Member States and non-member States-and is therefore analysed in this section-the Court observed in this case that the facts in the main proceedings before the national court only concerned the exercise of the free movement of capital within the EU (paras 16-17). The ruling in Lenz consequently does not provide any meaningful information on the interpretation of Article 63 TFEU in relations with non-member States.

The same national provisions as in Lenz were at issue in Holböck (C-157/05). In contrast to Lenz, the facts in the main proceedings of Holböck concerned relations with Switzerland. Affirming the precedent of Lenz, the Court held the effects of the national rules to be generally in breach with the principle of Article 63 TFEU (para 30). However, the Court ruled in the end that Article 63 TFEU did not preclude the application of those rules in the specific circumstances of the case of Mr Holböck. The Court observed that Mr Holböck made a direct investment in Switzerland because he held two thirds of the share capital in a company established in Switzerland (paras 33-38). Since the national rules applied to Mr Holböck only insofar as it concerned direct investments in

270 Baars (C-251/98); Keller Holding (C-471/04); Rewe Zentralfinanz (C-347/04); Lammers \& Van Cleeff (C-105/07); Burda (C-284/06); Aberdeen Property Fininvest Alpha (C-303/07); and SGI (C-311/08).

${ }^{271} X A B$ and $Y A B$ (C-200/98); Metallgesellschaft and Others \& Hoechst (Joined Cases C-397\&410/98); Cadbury Schweppes (C-196/04); Commission v Portugal (C345/05); Commission v Sweden (C-104/06); Commission v Denmark (C-150/04); Thin Cap Group Litigation (C-524/04); Commission v Belgium (C-522/04); Oy AA (C-231/05); Geurts and Vogten (C-464/05); and Lidl Belgium (C-414/06). 
non-member States, this restrictive effect was caught by the exception of Article 64(1) TFEU (paras 37 ('inasmuch'), and 44), because the national provisions in issue already existed on 31 December 1993 (para 43).

The reasoning in Holböck leaves no doubt as to whether Mr Holböck's situation was principally covered by Article 63 TFEU. Indeed, the substantive condition of Article 64(1) TFEU is the existence of a prima facie restriction on the free movement of capital. Any situation to which Article 64(1) TFEU applies also falls necessarily within the scope of Article 63 TFEU. Holböck merely clarifies that the nature of that restriction-whether or not on direct investment - should be determined according to the facts of the actual case, if the national legislation at issue is also liable to apply to situations that do not constitute a direct investment in terms of Article 64(1) TFEU. In sum, Mr Holböck exercised a movement of capital as covered by Articles 63 to 65 TFEU, but he could not invoke the protection normally afforded by those Treaty provisions for his situation because the Treaty provisions were without prejudice to the restrictive effects of the national rules in the specific circumstances of his case. Holböck neither suggests nor signals doubt on the part of the Court that the interpretation that Article 63 TFEU generally applies to all restrictions on capital movement posed by national rules, which are not exclusively aimed at situations constituting an exercise of freedom of establishment. This is nevertheless the case although the circumstances of a particular situation may constitute a protected exercise of the freedom of establishment if the situation would have concerned a relation with another Member State.

The ruling in $A(\mathrm{C}-101 / 05)$ followed the line of reasoning in Holböck. The national legislation at issue in $A$ was evidently not limited to apply only to situations covered by Article 49 TFEU. The preliminary reference was restricted to an interpretation of Article $63 \mathrm{TFEU}$ as applied to relations with non-member States. This reference was in accordance with the actual circumstances of the case in the main proceedings. However, the Court lacked sufficient information to ascertain positively whether the facts of the case in the main proceedings in $A$ concerned a direct investment in a non-member State. If the national court established that the case related to such a direct investment, then the restriction at issue, inasmuch as it applied to that actual case, was caught by the exception of Article 64(1) TFEU because it already existed on 31 December 1993 (para 53). If not, the Court held the restriction in $A$ was justified contingent on the national court's finding of fact that the restriction '.. was subject to conditions compliance with which can be verified by the competent authorities of that Member State only by obtaining information from the State of establishment of the distributing company' (para 67). This is the same application of the fiscal supervision justification as in CFC and Dividend Group Litigation.

The restriction on free movement of capital in Orange European Smallcap Fund $(O E S F)(\mathrm{C}-194 / 06)$ was precluded by Article 63 TFEU for relations with Member States and with non-member States (respectively, paras 97 and 108). OESF moreover confirmed that Article 64(1) TFEU covers all direct investments which it defines as 'investments of any kind undertaken by natural or legal persons and which serve to establish or maintain lasting and direct links 
between the persons providing the capital and the undertakings to which that capital is made available in order to carry out an economic activity' (para 102). This definition therefore does not include holdings in a company which do not put the holder in a position to participate effectively in the management or control of that company (paras 98 and 101). The Court did not state that the required degree of participation should at least be of decisive influence, but from Holböck it is evident that controlling holdings are also included in the Court's definition of direct investments. Accordingly, since the exception in Article 64(1) TFEU applies to controlling holdings and other direct investments, Article 63 TFEU also applies to actual controlling holdings.

The national legislation in STEKO Industriemontage (C-377/07) was evidently only liable to impose a restriction in cases where a resident company of Germany had a holding of less than $10 \%$ in a non-resident company, whether or not resident in another Member State or in a non-member State (paras 3-12). That was also the actual situation of STEKO in the fiscal year 2001, which was at issue in the main proceedings (para 13). It is therefore obvious, although the Court did not observe this expressly, that Article 49 TFEU was irrelevant in this case. As in $A$, the possibility that a relation with a non-member State was concerned could not be excluded in STEKO Industriemontage (para 13). Consequently, STEKO Industriemontage does not provide any meaningful information, other than that Article 63 TFEU was generally applicable in this case.

Similarly to STEKO Industriemontage, the outcome Van Hilten-van der Heijden (C-513/03) also applies to relations to non-member States, given the facts of the case and the explicit consideration of those situations under Article 63 TFEU, as indicated by the Court (para 37). The Court however found no difference in treatment to the disadvantage of free movement of capital to or from other Member States - and a fortiori, but admittedly not held explicitly, also not in relations to non-member States-in that case. Consequently, the Court ruled that Article 63 TFEU did not preclude the effects of the national measure in the case at issue (paras 46, and 49-50).

There are many cases in the field of direct taxation in which the Court was asked for an interpretation of Article 63 TFEU, but not for an interpretation of Article 49 TFEU. In some cases, the Court was however asked for an interpretation of Article 49 TFEU, but it only referred to Article 63 TFEU in the operative part of the ruling. In those cases in which the Court barred an examination of the case in relation to the freedom of establishment, the Court considered that the facts of those cases did not concern an exercise of the freedom of establishment, even when the national rule was not targeted exclusively at situations covered by the material scope of free movement of capital, or if sufficient information about the facts was not available to the Court. $^{272}$ Freedom of establishment also did not apply if these situations were 
not covered by the scope of the national rules, ${ }^{273}$ or the rules applied under conditions which would not normally entail an exercise of the freedom of establishment in fact or otherwise primarily targeted capital transactions as such. $^{274}$

It follows from the above that there is no evidence in the body of case law in the field of direct taxes that supports the facts of the case test to resist the application of Article 63 TFEU in relations with non-member States. The Court has only barred the application of Article 63 TFEU in relations with nonmember States if the national rules under review were exclusively aimed at applying to situations of controlling holdings or the establishment of foreign branches. Consequently, the principle of free movement of capital should be safeguarded by all national rules which concern capital movement and do not exclusively apply in situations covered by the material scope of freedom of establishment of Article 49 TFEU. We may accordingly conclude that the only relevant test in non-member State relations is the purpose of the national legislation test. However, the facts of the case are relevant for the application of Article 64(1) TFEU. This approach may be applied by national courts as a matter of acte clair and this interpretation is expected to be affirmed by FII Group Litigation II.

We already observed that national courts applied diverging standards based on the case law analysed above. Hemels et al. reported that French, UK and German courts examine the purpose of the national rule to assess the applicability of Article 63 TFEU in relation to non-member States. ${ }^{275}$ This is consistent with the approach proffered here. However, Hemels et al. also observed that the Dutch Supreme Court (Hoge Raad) decides the applicable freedom ultimately on the basis of the facts of the case, without first seeking interpretative guidance from the Court. If the case concerns a controlling holding, in fact, the Dutch Supreme Court resists the application of Article 63 TFEU in relation to non-member States, even if the national measure is not aimed at exclusively applying to situations covered by the material scope of Article 49 TFEU. Based on the findings here, we submit that the approach governed by the Dutch Supreme Court reflects an erroneous understanding of EU law as it currently stands.

\subsection{The freedom to provide services}

The case law on the freedom to provide services is rather diverse. Rulings on Article 56 TFEU include disputes relating to, inter alia, pension and savings

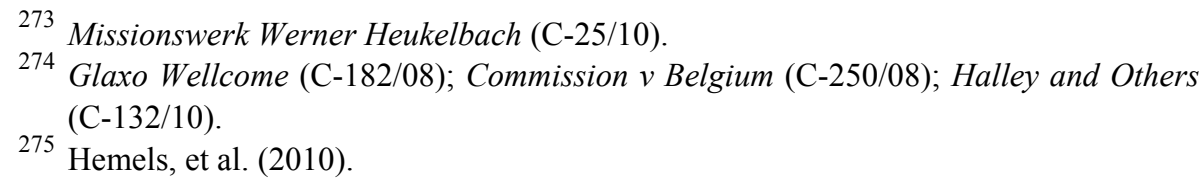


taxation, ${ }^{276}$ R\&D and investment tax incentives, ${ }^{277}$ and the deduction of business and professional expenses. ${ }^{278}$ We will touch upon these lines of authority again in the next Chapter.

Article 57 TFEU defines the concept of services to exclude the economic activities covered by the freedom of movement for goods, capital, and persons. This suggests that Article 56 TFEU on the freedom to provide services applies only if the situation at issue is not covered by any of the other fundamental freedom provisions. ${ }^{279}$ The Court however held in Fidium Finanz (C-452/04) that Article 57 TFEU '[...] does not establish any order of priority between the freedom to provide services and the other fundamental freedoms. The notion of "services" covers services which are not governed by other freedoms, in order to ensure that all economic activity falls within the scope of the fundamental freedoms' (para 32). Thus, the Court allows the concurrent application of the freedom to provide services and another fundamental freedom, which is evidenced in Table 5.

\subsection{The free movement of workers}

The Court ruled on the freedom of movement of workers of Article 45 TFEU in the least number of cases of the specific provisions concerning freedom of movement. The difference with the gross count of rulings concerning the freedom to provide services of Article 56 TFEU is however small. The counts of Article 45 and 56 TFEU cases are each still double the number of Article 21 TFEU cases.

The freedom of movement of workers cases are almost exclusively personal income taxation cases, including in particular the larger part of the Schumacker line of authority about general ability-to-pay issues, including tax benefits attached to personal and family circumstances, ${ }^{280}$ and taxation of frontier workers in general. ${ }^{281}$ Another collection of freedom of movement of workers cases concern tax benefits on the acquisition or sale of immovable property, in

276 See e.g., Bachmann (C-204/90); Commission v Belgium (C-300/90); Safir (C118/96); Danner (C-136/00); Skandia and Ramstedt (C-422/01); Commission v Denmark (C-150/04); and Commission v Belgium (C-522/04).

277 See e.g., Commission v France (C-334/02); Laboratoires Fournier (C-39/04); Commission v Spain (C-248/06); Jobra (C-330/07); and Tankreederei I (C-287/10).

278 See e.g., Vestergaard (C-55/98); Gerritse (C-234/01); Scorpio (C-290/04); and Centro Equestre da Lezíria Grande (C-345/04).

279 Barnard (2009), p. 356.

280 See e.g., Schumacker (C-279/93); Gschwind (C-391/97); Zurstrassen (C-87/99); De Groot (C-385/00); Wallentin (C-169/03); Ritter-Coulais (C-152/03); Meindl (C329/05); Lakebrink and Peters-Lakebrink (C-182/06); and Renneberg (C-527/06).

281 See e.g, Biehl I (C-175/88); Commission v Luxembourg (Biehl II) (C-151/94); Gilly (C-336/96); Terhoeve (C-18/95); Mertens (C-431/01); and Commission v Germany (C-269/07). 
particular in relation to owner occupied dwellings and the transfer of residence to or from another Member State. ${ }^{282}$ This case law will be examined in more detail in the next Chapter.

\subsubsection{The interpretation of the EU direct tax directives}

The next Sections will review to what extent the Court has interpreted the EU directives in the field of direct taxation. For that purpose we have summarised our findings in Table 7. We will see that the Court has specifically interpreted the Parent-Subsidiary Directive (90/435/EEC) and the Mergers Taxation Directive (2009/133/EC). The other EU directives have only been interpreted in one case or not at all. Table 7 also gives the cocitations to the TFEU in the operative part of the ruling in matrix form.

\begin{tabular}{lccllllllllll}
\hline & $n$ Citations & \multicolumn{10}{c}{$n$ Cocitations to TFEU provisions } \\
Directive & Total & Exclusive & 18 & 21 & 45 & 49 & 54 & 56 & 63 & 64 & 65 \\
\hline 90/435/EEC & 19 & 12 & 0 & 0 & 0 & 5 & 1 & 4 & 0 & 0 & 1 \\
2009/133/EC & 8 & 8 & 0 & 0 & 0 & 0 & 0 & 0 & 0 & 0 & 0 \\
2003/49/EC & 1 & 1 & 0 & 0 & 0 & 0 & 0 & 0 & 0 & 0 & 0 \\
$2003 / 48 / \mathrm{EC}$ & 0 & 0 & 0 & 0 & 0 & 0 & 0 & 0 & 0 & 0 & 0 \\
$2010 / 24 / \mathrm{EU}$ & 0 & 0 & 0 & 0 & 0 & 0 & 0 & 0 & 0 & 0 & 0 \\
$2011 / 16 / \mathrm{EU}$ & 1 & 1 & 0 & 0 & 0 & 0 & 0 & 0 & 0 & 0 & 0 \\
\hline
\end{tabular}

Table 7. Legal basis of rulings by EU directive.

\subsection{The Parent-Subsidiary Directive (90/435/EEC)}

The Parent-Subsidiary Directive (90/435/EEC) established a harmonised set of rules on company taxation that aims particularly to avoid the economic and juridical double taxation of distributions of profit received by a parent company of one Member State from a qualified subsidiary of another Member State. ${ }^{283}$ In short, the directive requires the first Member State effectively to exempt from corporation tax the dividends received at the level of the parent company, and

282 See e.g., Commission v Portugal (C-345/05); Commission v Sweden (C-104/06); Commission v Germany (C-152/05); and Commission v Greece (C-155/09).

283 Council Directive 90/435/EEC of 23 July 1990 on the common system of taxation applicable in the case of parent companies and subsidiaries of different Member States, O.J. L 225, 20/8/1990, p. 6-9 ('Parent-Subsidiary Directive'). In 2012 this Directive was repealed and replaced by Council Directive 2011/96/EU of 30 November 2011 on the common system of taxation applicable in the case of parent companies and subsidiaries of different Member States, O.J. L 345, 29/12/2011, p. 8 16. 
the dividend distribution may also not be charged with a withholding tax by either Member State.

The Parent-Subsidiary Directive was ruled upon in 19 decisions, but this number is still considerably less than the counts for any of the specific free movement provisions. All cases were rulings on preliminary references.

Six cases concerned the issue whether a national tax was covered by the definition of a 'withholding tax' which Member States are not allowed to charge according to Article 5 Parent-Subsidiary Directive. ${ }^{284}$

The remaining cases concern a variety of issues. Aberdeen Property Fininvest Alpha (C-303/07) and Gaz de France (C-247/08) established that companies with company forms not listed in the Annex pursuant to Article 2 Parent-Subsidiary Directive cannot invoke its benefits, unless this different treatment amounts to discrimination contrary to the Treaties. The scope of application of the directive was further explained in Denkavit International, VITIC Amsterdam \& Voormeer (Joined Cases C-283, 291\&292/94) as regards the interpretation of the minimum holding period of Article 3 of the ParentSubsidiary Directive. Les Verges du Vieux Tauves (C-48/07) explained that shares held in usufruct do not constitute a holding of shares for the purposes of that same Article. The Court ruled upon the deduction of costs in connection with a holding falling within the scope of Article 3 Parent-Subsidiary Directive in Bosal (C-168/01). The question as regards the interpretation of the concept 'profits distributed by subsidiary' of Article 4 of the Parent-Subsidiary Directive was the subject of the preliminary reference in Banque Fédérative du Crédit Mutuel (C-27/07). In Cobelfret (C-138/07) and KBC Bank and Beleggen, Risciokapitaal Beheer (Joined Cases C-439\&499/07) the Court held that the Belgian imputation system of taxing dividends was contrary to the exemption system required by Article 4 of the Parent-Subsidiary Directive. Finally, Amurta (C-379/05) cited the Parent-Subsidiary Directive in the formal ruling but the case in fact concerned the taxation of dividend payments which fell outside the material scope of the directive.

The direct tax directives and the fundamental freedom provisions both aim to eliminate restrictions on cross-border activity of corporate groups within the European Union. Secondary legislative acts of the Union also have to be compatible with the primary law of the Treaties and consequently may not be contrary to the fundamental freedom provisions of the TFEU. In 7 cases on the Parent-Subsidiary Directive, the Court also cited TFEU provisions.

In Amurta and Aberdeen Property Fininvest Alpha the Court ruled that the national provisions at issue infringed the right of establishment, respectively the free movement of capital, although the situations at issue were not covered by the Parent-Subsidiary Directive. In Burda and KBC bank and Beleggen, Risico Kapitaalbeheer the Court found contingent breaches of EU law, but interpreted

284 These cases are EPSON Europe (C-375/98); Athinaïki Zythopoiia (C-294/99); Océ van der Grinten (C-58/01); Burda (C-284/06); and Ferrero and General Beverage Europe (Joined Cases C-338\&339/08). See, Section 4.3.5.6.2. 
the Parent-Subsidiary Directive and Articles 49 and 63 TFEU rather autonomously. Only in Bosal was the Parent-Subsidiary Directive interpreted in the light of the right of establishment. The Court held that the Netherlands had not transposed the option of Article 4 of the Parent-Subsidiary Directive into national law correctly because it introduced an unjustified restriction on the establishment of subsidiaries in other Member States by parent companies of the Netherlands. The national provision at issue refused the deduction of costs in connection with a holding contingent on the subsidiary generating taxable income in the Netherlands. The Court found that such a subsidiary is likely to be established in another Member State. The Dutch legislation was therefore contrary to the aim and purpose of the Parent-Subsidiary Directive because it hindered the establishment of subsidiaries in other Member States, notwithstanding the option for Member States to introduce limits on the deduction of costs in connection with holdings pursuant to Article 4 of the Parent-Subsidiary Directive.

\subsection{The Mergers Taxation Directive (2009/133/EC)}

The Mergers Taxation Directive (2009/133/EC) provides for deferral of tax on capital gains realised at the cross-border reorganisation of companies. ${ }^{285}$ The directive exempts qualified mergers, (partial) divisions, transfers of assets and exchanges of shares of tax, so that tax charges on these companies, or their owners, do not impede the rationalisation of business operations between companies of different Member States. The Court interpreted the Mergers Taxation Directive in eight cases. ${ }^{286}$ The application conditions of the Mergers Taxation Directive to an exchange of shares were interpreted in Leur-Bloem (C-28/95), Kofoed (C-321/05), and A.T. (C-285/07). The Court also interpreted the antiabuse clause of Article 15 of the Mergers Taxation Directive in the former two cases and also in Zwijnenburg (C-352/08). Andersen og Jensen (C-43/00) requested the Court to interpret the application of the directive in the context of a transfer of assets. The only direct action in Commission v Greece (C-8/97) concerned the failure of Greece to transpose the directive into national law on time within the adoption period.

285 Council Directive 2009/133/EC of 19 October 2009 on the common system of taxation applicable to mergers, divisions, partial divisions, transfers of assets and exchanges of shares concerning companies of different Member States and to the transfer of the registered office of an SE or SCE between Member States, O.J. L 310, 25/11/2009, p. 34-46 ('Mergers Taxation Directive'). Until 2009, Council Directive 90/434/EEC of 23 July 1990 on the common system of taxation applicable to mergers, divisions, transfers of assets and exchanges of shares concerning companies of different Member States, O.J. L 225, 20/08/1990, p. 1-5 applied.

286 In 2012, the Court decided Pelati (C-603/10) with regard to national legislation under which authorisation must be obtained for the grant of a tax advantage of the Merrges Taxation Directive (2009/133/EC). 


\subsection{Other EU directives}

The Interest and Royalty Directive (2003/49/EC) abolished withholding taxes on payments of interest and royalties between qualified associated companies. ${ }^{287}$ The Interest and Royalty Directive was interpreted only once in Scheuten Solar Technology (C-397/09) and concerned the compatibility of German limitation of interest deductibility rules with the directive. The Court held in Scheuten Solar Technology that the directive was not concerned with the corporation tax treatment of the interest payment at the level of the paying agent and ruled in favour of the German national provisions and denied the alleged breach of the directive.

Also the Administrative Cooperation Directive (2011/16/EU) was interpreted only once in W.N. (C-420/98); a 'loss of tax' refers to unjustified saving of tax. ${ }^{288}$ Prior research has shown that this directive is nevertheless very relevant since the Court extensively referred to this directive to support its reasoning on various other points of law. ${ }^{289}$ The fact however that few cases have gone to the Court on this directive may be explained by the purpose of the directive to establish common rules of cross-border cooperation between tax administrations for the assessment and recovery of taxes, whereas the other directives harmonise rules of substantive tax law. Any disputes which may arise on the interpretation and application of the national rules adopted on the basis of the Administrative Cooperation Directive are therefore unlikely to be the subject of proceedings between the taxpayer and the tax administration before a national court, unless the taxpayer claims that his taxpayer rights have been infringed by the tax administration while cooperating with a tax administration of another Member State.

The Court has not yet interpreted the Savings Income Taxation Directive (2003/48/EC) that introduced reporting obligations on paying agents to tax administrations, and established a compulsory withholding tax for Austria, Belgium and Luxembourg until the end of the transition period due to their

287 Council Directive 2003/49/EC of 3 June 2003 on a common system of taxation applicable to interest and royalty payments made between associated companies of different Member States, O.J. L 157, 26/06/2003, p. 49-54 ('Interest and Royalty Directive').

288 Council Directive 2011/16/EU of 15 February 2011 on administrative cooperation in the field of taxation and repealing Directive 77/799/EEC, O.J. L 64, 13/0/2011, p. 112 ('Administrative Cooperation Directive'). The ruling in W.N. interpreted the repealed Council Directive 77/799/EEC of 19 December 1977 concerning mutual assistance by the competent authorities of the Member States in the field of direct taxation, O.J. L 336, 27/12/1977, p. 15-20 ('Mutual Assistance Directive').

${ }^{289}$ Hemels (2009); Lang (2012); Spies (2012). 
banking secrecy rules. ${ }^{290}$ Also the Mutual Assistance for the Recovery of Tax Claims Directive (2010/24/EU) was not yet interpreted by the Court. ${ }^{291}$

\subsection{Procedural properties}

\subsubsection{Bench hearing action}

The Court has distinguished between salient and less salient cases in its formation of the bench hearing the action even before the entry into force of the Treaty of Nice on 1 February 2003 (formally introducing, inter alia, the Grand Chamber). Cases which are salient or important and are therefore decided by a Grand Chamber since 2003 were usually decided by the full Court or a small plenum before 2003. These pre-2003 cases are also referred to as Grand Chamber rulings in this section for simplicity. A judgment by the full Court is now reserved for cases of exceptional importance. The Court has not ruled in a full Court formation on proceedings concerning national legislation on direct taxation since 2003. The more standard questions of EU law are ordinarily resolved in chambers of five or three judges.

We have observed above that the distribution of decided cases in the field of direct taxation is not even over the years. For this reason the counts in Table 8 are aggregated for the period 1983 through 2002 (i.e. the pre-Nice period) and for the period 2003 through 2005. The counts for the last six years, i.e. the period 2006 through 2011, are given per year because the Court delivered more than 15 cases in the field of direct taxes in each of these years and a comparison per year is thus possible.

There is a clear trend of declining importance of more recently decided cases, measured by the bench hearing the action. The proportion of Grand Chamber cases has declined almost shockingly since 2007, as Table 8 shows. In 2010 no cases were decided by a Grand Chamber and only one case was decided by the Grand Chamber in 2008, 2009 and 2011.

There is no formal 'direct tax' chamber in the Court. Table 9 shows that there is also no chamber that informally performs the role of 'direct tax' chamber if only rulings in chambers of five or three judges are considered. Notwithstanding, the $5^{\text {th }}$ Chamber delivered almost all of the first rulings in the field of direct taxation, which were not delivered by a Grand Chamber. This might have been a deliberate choice of the Court to maintain cohesion in this

${ }^{290}$ Council Directive 2003/48/EC of 3 June 2003 on taxation of savings income in the form of interest payments, O.J. L 84, 31/03/2010, p. 1-12 ('Savings Income Taxation Directive'). Belgium abolished its banking secrecy as of 1 July 2011 but already discontinued applying the transitional rules as of 1 January 2010.

291 Council Directive 2010/24/EU of 16 March 2010 concerning mutual assistance for the recovery of claims relating to taxes, duties and other measures, O.J. L 84, 31/03/2010, p. 1-12 ('Mutual Assistance for the Recovery of Tax Claims Directive'). 
very new field of EU law. Although relatively few cases in the field of direct taxation have been decided by the $6^{\text {th }}, 7^{\text {th }}$ and $8^{\text {th }}$ Chamber, there is not one single chamber that decides a clear majority of cases in the field of direct taxation.

All rulings involving a judicial determination are collegiate rulings signed by all judges on the bench in the case. The Court does not issue dissenting opinions (or concurrences) and the judges decide on the judgment by consensus or a majority of votes. The influence of individual judges on the text of the judgment and the potential influence of their individual beliefs on the law cannot be determined since individual voting records are not publicly available. However, the distribution of cases between the several judges who act as rapporteurs of the cases in Table 10 suggests that experience in EU law as it applies to direct taxation lies with a few judges in particular.

The judge rapporteur is the lead judge for a case because he or she is responsible for writing the report for the hearing that summarises the facts and the written arguments of the parties and interveners and he or she is responsible for writing the first draft of the ruling. These tasks allow the judge rapporteur to influence the direction of the interpretation of EU law in the case considerably.

Five judge rapporteurs account for nearly half $(47 \%)$ of all cases. There are eight other judges who account for another $28 \%$ of all cases and who were rapporteur in five to ten cases each: Arestis, Bonichot, Edward, Kasel, Lohmus, Ó Coaimh, Silva de Lapuerta and Von Bahr. But 26 judges, accounting for the remaining $25 \%$ of cases, only reported in one to four cases each. If only the Grand chamber cases are considered, judges Lenaerts and Wathelet were the most frequent rapporteurs.

It should be mentioned that judges Moitinho de Almeida and Edward also reported in Grand chamber judgments, respectively in four and three cases which ranks them fourth and fifth on Grand Chamber cases alone. There are 11 other judges besides those mentioned in Table 10 and Moitinho de Almeida and Edward who were rapporteur in Grand Chamber cases, but each in merely one or two judgments. In short, the expertise (as measured by experience) in EU law as it applies to direct tax matters was specifically with judges Levits, Lenaerts and Wathelet. They have been the key judges who shaped EU law in the field of direct taxes.

\begin{tabular}{lcccccccc}
\hline Bench & $\begin{array}{c}1983- \\
2002\end{array}$ & $\begin{array}{c}2003- \\
2005\end{array}$ & 2006 & 2007 & 2008 & 2009 & 2010 & 2011 \\
& 20 & 4 & 6 & 7 & 1 & 1 & 0 & 1 \\
\hline Grand Chamber & 21 & 10 & 11 & 16 & 19 & 17 & 14 & 19 \\
5 judges & 5 & 7 & 1 & 3 & 1 & 3 & 2 & 3 \\
3 judges & 46 & 21 & 18 & 26 & 21 & 21 & 16 & 23 \\
N Cases & &
\end{tabular}

Table 8 . Cases by bench hearing the action. 


\begin{tabular}{lccccc}
\hline Bench & $1983-2002$ & $2003-2005$ & $2006-2008$ & $2009-2011$ & Total \\
\hline $1^{\text {st }}$ Chamber & 2 & 4 & 11 & 21 & 38 \\
$2^{\text {nd }}$ Chamber & - & 2 & 8 & 9 & 19 \\
$3^{\text {rd }}$ Chamber & - & 1 & 13 & 15 & 29 \\
$4^{\text {th }}$ Chamber & - & - & 16 & 7 & 23 \\
$5^{\text {th }}$ Chamber & 18 & 9 & - & 4 & 31 \\
$6^{\text {th }}$ Chamber & 6 & 1 & - & - & 7 \\
$7^{\text {th }}$ Chamber & - & - & 1 & 1 & 2 \\
$8^{\text {th }}$ Chamber & - & - & 2 & 1 & 3 \\
\hline
\end{tabular}

Table 9. Cases by chambers of the Court.

\begin{tabular}{lccc}
\hline Judge rapporteur & $n$ Cases & $n$ Grand Chamber & Term of office \\
\hline Levits & 25 & 5 & 2004 - current \\
Lenaerts & 23 & 8 & 2003 - current \\
Wathelet & 19 & 6 & $1995-2003$ \\
Jann & 13 & 1 & $2002-$ current \\
Rosas & 11 & 2 & $1995-2009$ \\
\hline
\end{tabular}

Table 10. Judge rapporteurs with most direct tax cases.

Source: Own calculations and CJEU website: <www.curia.eu>.

\subsubsection{Opinions of the Advocates General}

Since the entry into force of the Treaty of Nice in 2003, the Advocates-General are no longer required to deliver an opinion in every case that reaches the Court. Where a case raises no new point of law the Court may proceed to judgment without an opinion of the AG in the case, according to Article 20 of the Statute of the Court. Reasoned orders ruled pursuant to Article 104(3) of the Rules of Procedure do not concern new points of law by definition. Although the Court may request an opinion of the AG according to the second sentence of Article 104(3) of the Rules of Procedure, an opinion is normally not delivered. We therefore ignore these reasoned orders for the purposes of the following analysis.

Consistent with the fact that the opinion of the AG is contingent on the case raising a new point of law, we observe a clear correlation between the bench hearing the action and presence of an AG opinion in the case at hand. Table 11 gives the proportion of cases delivered by judgment by a bench hearing the action over the period 2003 through 2011.

The AG delivered an opinion in all Grand Chamber cases since 2003 and three-judge Chamber cases are most likely to proceed to judgment without an opinion. It should be kept in mind when reading the table that the number of cases which are decided by a Grand Chamber or in Chambers of three judges is very low in each year, but the totals over the period 2003-2011 clearly show the differences between the benches.

We have seen that the standard situation is that a case is decided in chambers of five judges. There is a clear observable trend that the proportion of judgments 
by a chamber of five judges which are not preceded by an AG's opinion has increased since 2003. For these standard questions of interpretation, there is a $2: 1$ ratio between positive $(\mathrm{N}=69)$ and negative decisions $(\mathrm{N}=33)$ to deliver an opinion when the period 2003-2011 (column: Total) is considered.

\begin{tabular}{lcccccccc}
\hline Bench & $2003-2005$ & 2006 & 2007 & 2008 & 2009 & 2010 & 2011 & Total \\
\hline Grand Chamber & $0 \%$ & $0 \%$ & $0 \%$ & $0 \%$ & $0 \%$ & n.a. & $0 \%$ & $0 \%$ \\
5 judges & $0 \%$ & $27 \%$ & $21 \%$ & $22 \%$ & $59 \%$ & $50 \%$ & $32 \%$ & $33 \%$ \\
3 judges & $14 \%$ & $0 \%$ & $50 \%$ & $100 \%$ & $100 \%$ & $0 \%$ & $100 \%$ & $47 \%$ \\
All judgments & $5 \%$ & $17 \%$ & $17 \%$ & $25 \%$ & $60 \%$ & $47 \%$ & $39 \%$ & $29 \%$ \\
\hline
\end{tabular}

Table 11. Proportion of judgments without AG opinion.

The five Advocates General who were involved in most cases in the field of direct taxes are listed in Table 12. Since they did not deliver an opinion in each case they were assigned, the number of cases in which they did deliver an opinion is also given. Although the $A G$ as a person manages a team of referendaires who actually draft most opinions, the $A G$ as an institution is responsible for the opinion. It is indeed rare that the AG him- or herself writes an opinion from start to finish. ${ }^{292}$ We see that AGs Kokott and Léger have been especially active in the field of direct taxation.

\begin{tabular}{lcccl}
\hline Advocat General & $n$ Cases & n Opinions & $n$ Grand Chamber & Term of office \\
\hline Kokott & 24 & 17 & 3 & 2003 - current \\
Léger & 19 & 18 & 5 & $1994-2006$ \\
Mengozzi & 19 & 12 & 1 & 2006 -current \\
Sharpston & 14 & 9 & 0 & 2006 - current \\
Bot & 11 & 5 & 2 & $1995-2009$ \\
Colomer & 10 & 6 & 4 & $2006-$ current \\
\hline
\end{tabular}

Table 12. Advocates General involved in 10 or more cases.

Source: Own calculations and CJEU website $<$ www.curia.eu $>$.

Future research could explore what variables motivate an AG to deliver an opinion in a standard case. A plausible indication of increased salience of a seemingly standard case is the number of Member States submitting observations during the proceedings. The complexity of the case may be another reason why an opinion is desirable. Since these are general questions of judicial politics, which are not confined solely to the field of direct taxation, this research is best conducted on a larger sample of Court cases instead of the one discussed here. 


\subsubsection{Duration}

The distribution of the duration of proceedings follows a normal distribution. ${ }^{293}$ Proceedings before the Court took on average 21.4 months (std. dev $=6$ months) but may be completed faster if one of the procedural stages can be excluded. If the Court proceeds to judgment without an opinion of the Advocate General in the case the mean time of the proceedings is 17.5 months. The difference with the mean duration for proceedings in which there is an opinion of the Advocate General of 22.7 months is statistically significant with $p \leq 0.01$ (two-tailed $\mathrm{t}$ test). ${ }^{294}$

\subsubsection{Form of rulings}

Almost all cases in the field of direct taxation are decided by judgment. Only a few cases have been decided by reasoned order pursuant to Article 104(3) of the Rules of Procedure. These eight cases and the most relevant precedent(s) on which they directly rely are listed in Table 13.

\subsection{Outcomes of the proceedings}

\subsubsection{Taxpayer rate of success}

The outcome of a ruling can be coded into one of four possible categories. These four categories will be further explained below. Broadly speaking and although the Court does not apply EU law to the case at hand-but only interprets the law - we may think of a case as won by the taxpayer if the Court finds that EU law precludes the national measure at issue. If the Court does not find that a Member State failed to fulfil its obligations under EU law at all, we may consider it a lost case from the taxpayer's perspective.

The first category is consequently the type of ruling in which the Court found that the national measure was fully inconsistent with EU law. This is a clear 'win' for the taxpayer. Alternatively, the second category of a clear loss is the type of ruling in which the Court held that EU law did not ultimately preclude the national measure.

Sometimes, when the Court cannot determinatively decide whether there is a breach or not on the basis of the available information, it usually provides the national court with specific interpretative guidance to decide the compatibility of the national provisions with EU law. Normally in such cases, the Court writes the operative part of the ruling as a contingent breach and includes the conditions that the national court needs to review and apply to determine the ultimate outcome (breach, or no breach).

\footnotetext{
293 Statistical evidence not reproduced.

294 The Levence's test for equality of variances was not significant.
} 


\begin{tabular}{ll}
\hline Reasoned order & Precedents \\
\hline C-431/01 Mertens & C-141/99 AMID \\
C-268/03 De Baeck & C-436/00 X and Y \\
C-492/04 Lasertec & C-196/04 Cadbury Schweppes \\
& C-452/04 Fidium Finanz \\
& C-524/04 Thin Cap Group Litigation \\
C-102/05 A and B & C-196/04 Cadbury Schweppes \\
& C-452/04 Fidium Finanz \\
C-415/06 Stahlwerk Ergste Westig & C-524/04 Thin Cap Group Litigation \\
& C-196/04 Cadbury Schweppes \\
C-201/05 CFC and Dividend Group Litigation & C-452/04 Fidium Finanz \\
& C-524/04 Thin Cap Group Litigation \\
& C-374/04 ACT Group Litigation \\
C-439/07 \& C-499/07 & C-446/04 FII Group Litigation \\
KBC-bank \& Beleggen, Risicokapitaal, & C-524/04 Thin Cap Group Litigation \\
C-199/10 Secilpar - Sociedade Unipessoal & C-138/07 Cobelfret \\
& \\
& C-374/04 ACT Group Litigation \\
& C-379/05 Amurta \\
\hline
\end{tabular}

Table 13. Reasoned orders in the field of direct taxation.

A good example is Cadbury Schweppes:

[Articles 49 and 54 TFEU] must be interpreted as precluding the inclusion in the tax base of a resident company established in a Member State of profits made by a controlled foreign company in another Member State, where those profits are subject in that State to a lower level of taxation than that applicable in the first State, unless such inclusion relates only to wholly artificial arrangements intended to escape the national tax normally payable. Accordingly, such a tax measure must not be applied where it is proven, on the basis of objective factors which are ascertainable by third parties, that despite the existence of tax motives that controlled company is actually established in the host Member State and carries on genuine economic activities there. (Emphasis added).

There are also cases that decide one aspect or question of the preliminary reference in favour of the taxpayer, but the Court holds in favour of the Member State on another distinct aspect of the measure or on another preliminary question of the same referral. This was the case in Futura (C-250/95) for example:

[Article 49 TFEU] does not preclude a Member State from making the carrying forward of previous losses, requested by a taxpayer which has a branch in its territory but is not resident there, subject to the condition that the losses 
must be economically related to the income earned by the taxpayer in that State, provided that resident taxpayers do not receive more favourable treatment. On the other hand, that article does preclude the carrying forward of losses from being made subject to the condition that, in the year in which the losses were incurred, the taxpayer must have kept and held in that State accounts relating to his activities carried on there which comply with the relevant national rules. The Member State concerned may, however, require the non-resident taxpayer to demonstrate clearly and precisely that the amount of the losses which he claims to have incurred corresponds, under its domestic rules governing the calculation of income and losses which were applicable in the financial year concerned, to the amount of the losses actually incurred in that State by the taxpayer. (Emphasis added).

Another slightly different type of contingent breach is the case where the national measure is in principle consistent with EU law, but may nevertheless be disproportionately restrictive in certain situations. A relevant example is Marks \& Spencer (C-446/03):

As [EU law] now stands, [Articles 49 and 54 TFEU] do not preclude provisions of a Member State which generally prevent a resident parent company from deducting from its taxable profits losses incurred in another Member State by a subsidiary established in that Member State although they allow it to deduct losses incurred by a resident subsidiary. However, it is contrary to [Articles 49 and 54 TFEU] to prevent the resident parent company from doing so where the non-resident subsidiary has exhausted the possibilities available in its State of residence of having the losses taken into account for the accounting period concerned by the claim for relief and also for previous accounting periods and where there are no possibilities for those losses to be taken into account in its State of residence for future periods either by the subsidiary itself or by a third party, in particular where the subsidiary has been sold to that third party. (Emphasis added).

These three types of cases cannot be clearly considered as cases won by either the taxpayer or the Member State. To code these cases as wins or losses of the taxpayer would oversimplify the outcome of the ruling. Accordingly, we have included these cases in a third category, labelled 'contingent rulings'. Consequently, if the operative part of the ruling includes both positions, or the Court includes additional conditions ex officio (whether or not subject to verification of the national court), then the ruling falls into this third category. Since this book ignores national decisions, we did not review national decisions in the cases of this third category to ascertain whether the taxpayer ultimately won or lost the case before the national court.

The fourth and last category is the purely interpretative ruling. These are rulings which do not include a statement in the operative part about whether EU law does or does not preclude a national measure or whether a Member State has or has not failed to fulfil its obligations under EU law. Usually, these are cases 
on the interpretation of a directive. An example is Athinaïki Zythopoiia which defines the concept of 'withholding tax' in the Parent-Subsidiary Directive:

There is a withholding tax, within the meaning of Article 5(1) of [the ParentSubsidiary Directive], where national legislation provides that, in the event of distribution of profits by a subsidiary (a public limited company or equivalent company) to its parent company, in order to determine the taxable profits of the subsidiary its total net profits, including income which has been subject to special taxation entailing extinction of tax liability and non-taxable income, must be reincorporated into the basic taxable amount, when income falling within those two categories would not be taxable on the basis of the national legislation if they remained with the subsidiary and were not distributed to the parent company.

From 1983 through 2011, in a proportion of about 65\% of all rulings, the Member States clearly lost the case before the Court. In about $15 \%$ of all cases in the field of taxation the Court held fully in favour of the Member States and in another $13 \%$ of all rulings the Court's ruling was contingent on one or more conditions. A small proportion, $7 \%$ of all cases, is purely interpretative.

For direct actions, the success rate of the Commission is $93 \%$, whereas in $57 \%$ of preliminary references the Court definitely found the national measure to be inconsistent with EU Law. ${ }^{295}$ This is not a much higher success rate for private litigators attacking national measures, compared to areas like free movement of goods, social provisions and sex equality, and environmental protection, where a violation of EU law is found in 50 to $60 \%$ of cases. ${ }^{296}$ Before 2005, the Court only held the national measure fully consistent with EU law in five (of 57) cases: Daily Mail, Bachmann, Werner, Gilly, and Gschwind. However, if we only look at the period since 2005, we observe that the Court has ruled in favour of the taxpayer in only $49 \%$ of the preliminary references on average, and that $22 \%$ and $21 \%$ are rulings of respectively categories 2 and 3 . A closer examination of the content of those two categories may shed light on which legal developments have brought about this change. On which grounds does the Court hold against the taxpayer?

\subsubsection{Grounds held against taxpayers}

Rulings in which the Court holds against the taxpayer and in favour of the Member State are particularly interesting, because these cases concern national measures which were expressly found to comply with EU law. Since the majority of all rulings states what Member States may not do, the limited minority of cases that expressly allow national measures set relevant standards against

295 The only two direct actions in the field of direct taxation which were lost by the Commission are Commission $v$ Belgium (C-300/90) (same national measure as 296 Stone Sweet and McCown (2003), p. 95. 
which national governments will test future regulatory initiatives. The Member States' legislators will rely on these rulings to assure that national tax policy stays well within the protected margin of appreciation under their reserved competence to impose direct taxes. The availability of legal precedent allows a successful emulation of EU-compatible rules by the Member States as Blauberger explains. ${ }^{297}$ Member States can so avoid or respond to deregulation of the Court with regard to their own laws by re-regulating the national measure in an EUcompatible way through emulation of national measures of other Member States which were found to be consistent with EU law. Policy convergence may so emerge.

The next paragraphs will discuss the rulings coded in categories 2 (no breach) and 3 (contingent ruling) and the Court's motivation to hold the contested national measures in principle (or in part) to comply with EU law. The aim of the discussion that follows is merely to present a survey of the grounds that the Court applied to hold against the taxpayer. We do not intend to discuss the normative merits of these decisions critically here.

We will see that the relevant cases can be classified as variations upon three themes; (i) the taxpayer could not invoke a right in EU law; (ii) the national treatment did not amount to discrimination; and (iii) the restriction on freedom of movement was justified on the basis of an overriding reason in the public interest.

\subsubsection{EU law does not confer the invoked right}

For a national direct tax measure to be found contrary to EU law before the Court, the situation in which it applies should be covered by EU law, and the relevant provision of EU law should have direct effect in order for a Union citizen to make a successful claim grounded in EU law.

The taxpayer could not invoke protection of EU law in a small number of cases because EU law did not confer the right on which the taxpayer relied. In Daily Mail the Court ruled that the invoked right did not exist; in Gilly the Court ruled that the invoked provision had no direct effect; while some other cases fell outside the territorial scope of the Treaty provision that materially applied, and in Werner the Court resisted protection of EU law for the reason that it was invoked in a purely internal situation.

In the 1988 ruling of Daily Mail the Court held that freedom of establishment did not provide the right to transfer the place of effective management of the company from the UK to the Netherlands while retaining its status as a company incorporated under UK legislation. In this case, Daily Mail wished to move to the Netherlands to avoid UK capital gains tax on shareholdings. HM Treasury opposed the transfer and was only prepared to give consent if Daily Mail would settle its UK taxes before the migration. The Court affirmed Daily Mail and its interpretation of EU law in the mirror image case of National Grid Indus (C-

${ }^{297}$ Blauberger (2011). 
$317 / 10$ ) in 2011. The Dutch company with the same name transferred its place of effective management to the UK and so triggered taxes in the Netherlands on the accrued capital gains on its business assets.

Since in Daily Mail the consent of HM Treasury was required only for transfers if the company was not wound-up, Daily Mail is properly understood as meaning that a Member State may principally deny the transfer of the company's effective management to another Member State if the company wishes to remain governed by the legislation of the Member State of origin. This was lawfully accomplished in Daily Mail by withholding consent of HM Treasury, which in effect amounted to a preclusion of the transfer. The consent was withheld because Daily Mail refused to settle its taxes before transfer. National law may accordingly principally require the winding-up of the company upon the transfer of effective management. Obviously, such a liquidation would have triggered an equivalent tax charge as the one that Daily Mail wanted to avoid by moving to the Netherlands. Properly construed, Daily Mail does not imply that the lawful transfer of effective management to another Member State would not be an exercise of freedom of establishment.

To go on a brief tangent, the above proposed reading of Daily Mail also explains the Court's rulings in SEVIC Systems (C-411/03) and Cartesio (C210/06). The Court basically affirmed Daily Mail in these cases but also stipulated that Member States may not preclude transfers of effective management (or the registered seat) under the freedom of establishment when the transfer is required to facilitate a lawful merger with a company duly established in the host Member State, or is executed in order to lawfully convert into a legal form recognised by the legislation of the host Member State. In SEVIC Systems it was clear that the company did not wish to maintain legal personality under the legislation of the Member State of original incorporation, and the situation was on that basis rightfully distinguished from the material ground of judgment in Daily Mail. The partnership in Cartesio, however, desired to maintain its original status after transfer to another Member State and the Court held that the Member State of origin was allowed to preclude the transfer on that basis. In short, a transfer with a view to lawfully change governing company law is a protected exercise of freedom of establishment. ${ }^{298}$

In National Grid Indus, the Netherlands allowed the transfer of the company from the Netherlands to England and did so neither requiring the winding-up of the company, nor the prior consent of the tax authority. ${ }^{299}$ The Netherlands charged the company immediately with corporation taxes on unrealised capital gains as required by its law. This is in substance equivalent to the tax settlement condition that HM Treasury imposed as a condition for its consent to the transfer

See, VALE Épitési (C-378/10) which was decided in 2012. I thank Dr Mieke Olaerts for the constructive exchange of ideas on this point. All errors are mine.

299 Compare the 2012 judgment of the EFTA Court in Arcade Drilling (E-15/11) which concerned Norwegian law and a possible requirement of liquidation upon the transfer of the head office to another state. The EFTA Court followed National Grid Indus. 
in Daily Mail (and which Daily Mail refused), but the Dutch approach was admittedly executed in a more brute fashion, absent the British courtesy of negotiating consent. Since the transfer of effective management in National Grid Indus was lawfully carried out under national law, the Court ruled that the company could invoke the protection of Article 49 TFEU against the corporation tax charge upon this transfer.

It is arguable whether the line of reasoning in National Grid Indus does better justice to the dispute at issue in the main proceedings of Daily Mail. The only difference between the cases is that the exit tax in National Grid Indus was imposed on an ex-post facto basis (the transfer constituted the taxable event), whereas the UK legislation required ex-ante consent of HM Treasury, but admittedly exclusively for the purpose of securing a tax claim and certainly not for fundamental concerns on the question under what circumstances a UK company remains governed by UK company law. Both Member States did not attach consequences to the legal personality of the companies by reason of their transfer of effective management to the other Member State. However, through a rather shrewd reformulation of the first preliminary question referred by the national court in Daily Mail, the Court chose to first answer the (moot) question whether Member States may attach such company law consequences in principle, i.e. to require annulment of the company's legal personality. The answer was positive and this sufficed to adjudge Daily Mail. If Daily Mail would not comply with the conditions set by HM Treasury then the winding up of the company upon transfer of the seat was the consequence under UK law and the Court held that this requirement complied with EU law.

We may speculate whether the Court acted this way to avoid the more complex questions relating to the national tax law consequences which were relevant to the national dispute in Daily Mail. Let us be reminded that the restriction based approach to free movement of persons was only developed in Säger (C-76/90) and Kraus (C-19/92) a few years later. Recall also that the only direct tax case decided before Daily Mail in 1988 was Avoir Fiscal which basically concerned direct nationality discrimination against foreign companies. Also, Daily Mail was the first case on national company law. Furthermore, the balanced allocation of the power to impose taxes between the Member Stateson which National Grid Indus so strongly relies to justify the exit tax-was not established in EU law before the Court ruled Marks \& Spencer in $2005{ }^{300}$ These facts may put Daily Mail into the right perspective on the evolutionary stage of EU law at the time but AG Darmon nonetheless aptly predicted the outcome of National Grid Indus in his opinion in Daily Mail. Maybe the Court just did not want to be accused of judicial activism and therefore hesitated to follow the AG?

Anyway, Daily Mail established that Member States may in principle, absent Union action, freely determine the connecting factors for granting and annulling the legal personality of companies and National Grid Indus reiterated that

300 See, Chapter 6. 
Member States have the same freedom to determine the connecting factors of taxation. This is ultimately not a contradiction, as much as it may be fun to speculate about the mind of the Court.

The Court ruled in Gilly that the second indent of Article 293 TEC (repealed by the Lisbon Treaty) which required Member States to eliminate double taxation did not have direct effect. Other cases involved the scope of the fundamental freedoms in relations to non-member countries. The freedom to provide services was held inapplicable to a provider of services who was a resident of a non-member country in Scorpio. The reasoned orders in Lasertec, $A$ and $B$, and Stahlwerk Ergste Westig did not explicitly include a statement in the operative parts on the question whether EU law precluded the national measures at issue and they were therefore coded as interpretative rulings. The orders show that the national measures at issue in those cases fundamentally affected the freedom of establishment but that the Court interpreted the freedom of establishment to the effect that Article 49 TFEU could not be relied upon in those cases, simply because the cases concerned situations involving nonmember States. Similarly, in Thin Cap Group Litigation the Court held that freedom of establishment had no bearing on the UK thin capitalisation measure insofar that measure applied to UK companies which were controlled by companies established in non-member countries, but not by companies established within the EU. ${ }^{301}$

The Court ruled in Hengartner and Gasser that the Agreement on the freedom of persons between the European Community and the Swiss Confederation did not confer a right of non-discrimination in regard of a tax charge due in respect of the provision of services, ${ }^{302}$ which was in the case at hand a hunting tax due in Austria for a right to hunt on Austrian territory by two Swiss nationals.

Only in Werner could the taxpayer not invoke the freedom of workers, because the Court regarded the situation as a purely internal situation. ${ }^{303}$ The interpretation held in Werner became evidently outdated with the introduction of Union citizenship which allows invoking the protection of freedom of movement, even if there is no border crossing of economic activity but rather a Union citizen, like Mr Werner, moves to reside in another Member State for purely personal reasons. ${ }^{304}$ In any case, Werner has never been applied by the Court as precedent in a subsequent case to resist protection of freedom of movement.

301 See, Section 3.4.2.1.4.

302 Annex I to the Agreement between the European Community and its Member States, of the one part, and the Swiss Confederation, of the other, on the free movement of persons, signed in Luxembourg on 21 June 1999, O.J. 2002 L 114, p. 6.

See, Section 2.3.2.5.

See, Section 3.4.2.1.1. 


\subsubsection{The legal effects do not amount to a restriction}

Most litigation success has been enjoyed by the Member States in a second class of cases in which the Court held that the national measure at issue did not impose discriminatory or restrictive tax burdens. According to the Court's wellestablished case law, discrimination contrary to EU law is treating identical situations differently, or treating different situations the same. EU law precludes specifically national measures which are less advantageous to nationals of other Member States by e.g. imposing conditions that are more easily fulfilled by nationals such as a residence criterion. Also, any national measure which does not discriminate on grounds of nationality but, according to the well known Säger/Kraus formula, prohibits, impedes or renders less attractive the exercise of free movement breaches EU law for that reason. In short, the main question is whether the exercise of freedom of movement has less advantageous treatment than an internal situation. ${ }^{305}$ A restriction that affects the exercise of freedom of movement by nationals of other Member States in particular is also discrimination. By way of introduction, we will now proceed with a general introduction on the concept of restriction.

Whereas prior research found the concept of a tax restriction of free movement elusive, ${ }^{306}$ and noted terminological ambiguity and shifts in the Court's case law between discrimination and restriction, ${ }^{307}$ these studies do not give evidence that these developments are grounded in genuine fundamental changes in doctrine. The decision to apply the discrimination test or the restriction test may be best understood, it seems, in the context of the facts of the case.

The question that usually arises in cases of inbound movement is whether the host Member State applies the same rules and conditions to nationals of other Member States as it applies to its own nationals. In the field of direct taxation that normally requires a comparison between a non-resident taxpayer with a resident taxpayer, or a comparison between a secondary establishment of a resident company with a branch, agency, or subsidiary of a company established in another Member State. That is the classic test of indirect discrimination on grounds of nationality. But it is also possible to phrase it in terms of the Säger/Kraus-formula as a comparison between a Union citizen or a company who has exercised freedom of movement from another Member State and a Union citizen or company who has not.

In cases of outbound movement, the Court is usually asked to evaluate whether the Member State of origin applies different rules or conditions to economic activities undertaken in the territory of other Member States compared to those that apply to activities in national territory. That analysis basically requires a comparison between two resident individuals or a comparison

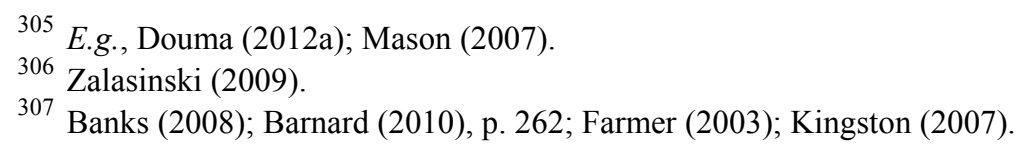


between a company with a secondary establishment in the national territory and a company with a foreign branch, agency or subsidiary. The classic test of indirect discrimination on grounds of nationality falls short here due to the lack of a non-resident person as a comparator. Thus, it is likely that the Court applies the Säger/Kraus-formula in such cases and consequently compares a Union citizen or company who has exercised freedom of movement to another Member State with a Union citizen or company who has not.

It has been suggested that the Court could be willing to interpret the fundamental freedoms to prohibit non-discriminatory tax restrictions in the future, as it did in its non-tax case law. ${ }^{308}$ What is meant is that there are national tax measures which apply equally in law to internal and free movement situations which the Treaty may notwithstanding preclude, even though there is also no indirect discrimination on grounds of nationality. But, we will see now that such measures are only contrary to the freedom of movement if they have disadvantageous effects on cross-border activity specifically.

The words 'less attractive' in the Säger/Kraus-formula imply a baseline situation against which the exercise of freedom of movement is compared. The Court operationalised and gave meaning to this implicit baseline with the idea of market access. Despite the fact that the case law is not fully consistent in using this conception of non-discriminatory restrictions, market access is undeniably a key notion in the Court's judicial doctrine when confronted with seemingly even handed regulatory measures. ${ }^{309}$

A non-discriminatory restriction on the exercise of freedom of movement is therefore best conceived as the situation in which a national measure is specifically disadvantageous to Union citizens and companies who desire to access the market of another Member State (market entrants) when compared to the measure's effects on citizens and companies who are already active on the market of that Member State (market incumbents). Thus, the regulatory measure induces imbalances in relative competitive positions between locally new and locally established undertakings. ${ }^{310}$

It should be stressed that the potential effects on market access should be plausibly caused by the national measure at issue. When the causal relation between the potential effects (however small) and the conditions imposed by the national measure is 'too uncertain and indirect' as was the case in Graf (C190/98), then the national measure cannot be said to produce effects that are contrary to EU law and, thus, is not capable of being precluded by EU law. This approach to causation in respect of non-discriminatory measures was already taken in Krantz (C-69/88) in the context of the free movement of goods. In that case, the Court held that national legislation allowing the seizure of goods by the tax collector as security for the recovery of an unpaid tax debt was not liable to

\footnotetext{
308 Douma (2012a); Farmer (2003).

309 Snell (2010).

310 Davies (2010).
} 
restrict freedom of movement as the restrictive effects on freedom of movement were also 'too uncertain and indirect' (para 11).

Some types of measures are particularly liable to affect market entrants more than market incumbents. The classic cases of non-discriminatory measures are of course the authorisation, licensing and registration requirements that may create regulatory double burdens for cross-border active economic actors. The hallmark cases in the context of workers' access to the market are obviously Gebhard (C-55/94) and also Bosman (C-415/93) to some extent.

To overcome these kinds of regulatory double burdens, the Court has imposed on Member States the principle of mutual recognition that obliges, particularly in relation to the freedom to provide services, Member States to principally recognise that, if a market participant has lawfully accessed the market of and may operate on the national territory of another Member State, that actor should, on that basis, also be awarded equal access to the national market and territory of the Member State concerned. Although Member States may impose additional formal requirements, those are subject to strict scrutiny under the principle of proportional justification before the Court.

Another type of non-discriminatory measure which specifically affects market access is national legislation that regulates marketing practices and limits effective means of market penetration. Examples are the prohibition on cold calling that was at issue in Alpine Investments (C-384/93), the prohibition on remuneration on sight accounts of CaixaBank (C-442/02), and also the obligation to contract on all local motor insurance companies of Commission $v$ Italy (C-518/06).

Income and property taxes can hardly be considered formal preconditions to access to the market - they only become due when the market has been successfully accessed. Most cases in the field of direct taxation concern national measures which formally distinguish between free movement and internal situations; the provisions apply with distinction in either law or fact.

Also, direct taxes are not similar to the regulation of marketing practices. The closest type of tax with similar regulatory effects is perhaps a tax on advertising or on communication like the ones at issue in Viacom Outdoor (C-134/03) and Mobistar and Belgacom Mobile (C-544/03). The case of Mobistar and Belgacom Mobile is briefly touched upon here to explain the point, even though the case is not included in the sample of cases in the field of direct taxation. The Court ruled in Mobistar and Belgacom Mobile that a tax on mobile telephone installations did not breach the freedom to provide services. After recalling the principle of non-discrimination and the Säger/Kraus-formula, the Court continued as follows:

31. By contrast, measures, the only effect of which is to create additional costs in respect of the service in question and which affect in the same way the provision of services between Member States and that within one Member State, do not fall within the scope of Article 59 of the Treaty.

32. As regards the question whether the levy by municipal authorities of taxes such as those in question in the main proceedings amounts to a restric- 
tion incompatible with Article 59, it is necessary to point out that such taxes apply without distinction to all owners of mobile telephone installations within the commune in question, and that foreign operators are not, either in fact or in law, more adversely affected by those measures than national operators.

33. Nor do the tax measures in question make cross-border service provision more difficult than national service provision. Admittedly, introducing a tax on pylons, masts and antennae can make tariffs for mobile telephone communications to Belgium from abroad and vice versa more expensive. However, national telephone service provision is, to the same extent, subject to the risk that the tax will have an impact on tariffs.

34. It is appropriate to add that there is nothing in the file to suggest that the cumulative effect of the local taxes compromises freedom to provide mobile telephony services between other Member States and the Kingdom of Belgium.

It thus appears that a tax restriction on the freedom of movement at least requires a difference in effect, or, put another way, disadvantageous tax consequences that are specific to free movement situations compared to internal situations, even if the law formally applies without distinction. ${ }^{311}$ This is the same conception which can be derived from Keck and Mitouard (Joined Cases C-267\&268/91).

In this landmark ruling on the free movement of goods, the Court allowed certain selling arrangements (a general prohibition on resale at a loss in the case at hand) as compatible with EU law if they affected in the same manner, in law and in fact, cross-border and internal trade of goods. There thus needs to be a distinct disadvantage to freedom of movement which is caused by the national measure in order for that measure to be incompatible with EU law.

Snell argued that the Court is hesitant in its case law in the field of direct taxes to employ the full force of its restriction concept as it does in cases on regulatory barriers. ${ }^{312}$ However, in the cases mentioned below, in which the Court held that there was no prima facie breach of the fundamental freedoms, the Court gave reasons which also may be applied to regulatory burdens. This is

311 This conception of tax restrictions is wide enough to capture cases like Deutsche Shell (C-293/06) and Sandoz (C-439/97), but sufficiently narrow to exclude the possibility that non-discriminatory taxation as such, e.g. Truck Center (C-282/07) and Columbus Container Services (C-298/05), is considered a restriction. See also, Douma (2012a). Furthermore, this conception is equivalent to the interpretation we gave to discrimination in the context of Union citizenship in Section 3.4.2.1.1. The same approach was favoured by AG Poiares Maduro in his opinion in Marks \& Spencer (C-446/03), points 28, 39 and 40.

312 Snell (2007). 
also true for the issue of juridical double taxation, which is still highly contentious even after the Court unambiguous rulings in principle. ${ }^{313}$

In some cases in the field of direct taxes, the Court ruled that the disadvantage in free movement situations could not be attributed to the national measure at issue and was rather due to lawful differences in the allocation of taxing powers between the Member States. In other cases there was an objective difference that justified the different treatment, or the alleged difference in treatment was not conclusively found to actually exist.

\subsection{Allocation of taxing powers and disparities}

The mere fact that a Member State asserts fiscal jurisdiction and imposes a tax is a real disadvantage, but it is neither discrimination, nor a restriction. In Gilly and Van Hilten-van der Heijden the Court held that the use of the criterion of nationality to assert fiscal jurisdiction by a Member State on non-resident nationals of that Member State did not amount to discrimination. In the absence of any harmonising measures, it remains within the Member States' exclusive competence to determine the criteria on which to base the allocation of taxing powers between the Member States.

Similarly, the disadvantages that result from disparities between the tax laws of the Member States are not contrary to EU law. In Gilly, the disadvantage to a taxpayer of being subjected to a higher effective tax scale in one Member State compared to that applicable in another Member State did not amount to discrimination. Also, in Schempp and Schulz-Delzers and Schulz (C-240/10) the Court held that the Treaties do not provide a guarantee of neutrality if a taxpayer chooses to reside or pursue activities in another Member State that applies different criteria of taxation than the taxpayer's Member State of origin. Also disadvantages which are due to the fact that Member States may exercise their taxing powers in parallel are not considered restrictions on the freedom of movement by the Court's standard. For this reason, the Court held in Kerckhaert and Morres (C-513/04), Block, Damseaux (C-128/08), Columbus Container Services, and Haribo Lakritzen and Österreichische Salinen (Joined Cases C$436 \& 437 / 08$ ) that juridical double taxation, i.e. the imposition of comparable taxes on the same income of the same taxpayer in the same period by two Member States, ${ }^{314}$ was not precluded by EU law. ${ }^{315}$ The Court found that the cause of the disadvantage to free movement situations was not related to the national measure at issue, but was due to a reason that EU law allowed to persist as lawful.

313 See e.g., Cerioni (2009); Eden (2010); Kofler and Mason (2008); Rust (2011).

314 OECD Model Commentary, Introduction, para 1.

315 See, the reasoned order in Levy and Sebag (C-540/11) that the Court delivered in 2012. 


\subsection{Objective differences}

The Court found in several cases that the litigating non-resident taxpayer was in an objectively different situation than a resident taxpayer. In Futura, the limitation of loss relief to losses incurred on Luxembourg territory for non-resident taxpayers in Luxembourg, whereas resident taxpayers could also deduct foreign losses from taxable income was held to be consistent with the fiscal principle of territoriality and could therefore not be considered as discrimination. What the Court found compatible with EU law was the simple distinction between taxing residents universally and taxing non-residents on income derived from activities pursued on the national territory. ${ }^{316}$ The ruling does not add to what the Court already established in Schumacker.

Especially in the field of personal income taxation, the Court has made some important decisions as regards comparability of resident and non-resident taxpayers. The Court found in Gschwind, Gerritse and D. (C-376/03)following its landmark ruling in Schumacker - that the non-resident taxpayer was not in a comparable position as a resident taxpayer as regards tax advantages relating to personal and family circumstances and the basic tax free allowance specifically. Since the non-resident taxpayer was not liable to tax on all or nearly all of his income like resident taxpayers of the Member State against which was litigated, it was accordingly lawful to deny tax advantages that aimed to take account of the taxpayer's full ability to pay. The claim of the taxpayers in Schulz-Delzers and Schulz was similarly denied because the taxpayer's ability to pay tax was not affected in a comparable way as the taxpayers to whom the law granted a special tax concession in relation to income paid to adjust for different living conditions in another Member State.

In $D$. and ACT Group Litigation the Court held incomparable the situation of a non-resident taxpayer who is covered by the personal scope of double taxation conventions between two Member States with the situation of a nonresident taxpayer of a third Member State who was not covered by that bilateral agreement. A similar reasoning applied in Orange European Smallcap Fund and the Court held - in the specific circumstances of that case- that situations in which the relations between the Member States were governed by a double tax convention could not be compared to situations in relations with Member States without such international agreement. ${ }^{317}$

It follows from Gerritse, Scorpio, and Centro Equestre da Leziria Grande that non-resident taxpayers are however comparable to resident taxpayers insofar as both classes of taxpayers are subject to tax on income accruing from economic activities undertaken on the Member State's national territory. This

316 The Court refers in para 23 to 'such a system' and describes the distinction in paras 21 and 22.

317 This case law has been recieved critically in the context of most-favoured-nation treatment in EU law, see e.g. Cordewener and Reimer (2006a); Cordewener and Reimer (2006b); Kofler (2005); Van Thiel (2007a); Van Thiel (2007b). 
implies in particular that the non-resident taxpayer may claim deductions from tax with regard to expenses that are directly connected to those activities. Unrelated tax advantages that are granted to resident taxpayers should not-as a rule - be made available to non-resident taxpayers under EU law, unless Schumacker applies.

In Blanckaert, the Court held that an objective difference could be found in the fact whether the taxpayer was rightfully insured or not under the social security system of the Member State in a claim for a tax credit in respect of national insurance. In Truck Center the situations of non-resident and resident taxpayers were not comparable because resident companies of Belgium were directly subject to fiscal supervision in that Member State, whereas Belgium requires the assistance of other Member States for the recovery of tax charged to non-resident taxpayers. This difference in situations justified that a withholding tax was charged on interest paid to a non-resident company by a company established in Belgium but that resident recipient companies of interest originating in Belgium were assessed on a different legal basis and by a different procedure, namely with corporation tax on interest received.

Although Article 49 TFEU also confers freedom of choice of appropriate legal form upon Union citizens who exercise their right of establishment, the Court holds the situations of a foreign branch and foreign subsidiary incomparable insofar as the tax treatment of domestic branches is also different from the tax treatment of domestic subsidiaries, but no difference in treatment is imposed on basis of the place of establishment of the different types of secondary establishments. This was the case in KBC Bank and Beleggen, Risicokapitaal, Beheer and Columbus Container Services (for tax transparent partnerships vis-à-vis subsidiaries).

\subsection{No disadvantage}

Especially in cases concerning the taxation of dividends, the Court could not find a less advantageous treatment in law of free movement situations compared to internal situations. In ACT Group Litigation, FII Group Litigation, CFC and Dividend Group Litigation, Burda, Orange European Smallcap Fund, and Haribo Lakritzen and Österreichische Salinen and (in part) contrary to the submissions of the taxpayers, the Court found that - under well defined circumstances - the Member States treated both situations in the same way. Even if there was a disadvantage to the taxpayer in cross-border situations in some of these cases, that effect could not be attributed to the exercise of taxing powers of the Member State against which the taxpayer litigated in those cases. The Court has consistently held, since FII Group Litigation, that an imputation system for resident companies receiving a distribution of profit from a company established in another Member State avoids economic double taxation in an equivalent manner as the concession granted to an identical resident company by means of an exemption from taxes on dividends received from a company established in the same Member State. The Member States should however not apply a higher rate to foreign dividends compared to domestic dividends and must impute for- 
eign corporation taxes to the fullest extent, up to the limit of the tax charged domestically.

The Court found a breach of EU law in Zanotti because Italy did not allow a tax deduction from gross income of fees paid for university courses offered in other Member States. However, assuming such a deduction had been allowed, there would be no disadvantage to the free moving taxpayer if the deduction would be capped at the ceiling fixed for deductions in respect of similar university courses in Italy. There is accordingly no disadvantage in generally applicable limitations to tax deductibility of expenses.

In some cases, the alleged different treatment could not be confirmed before the Court in the end. The Court could not determine conclusively in Gerritse whether the $25 \%$ rate charged to non-residents would result in a higher effective charge compared to the progressive scale applicable to residents insofar as both categories were assessed with personal income tax on the same activities. A similar instruction to compare tax burdens was given to the national court in FII Group Litigation in respect of the taxation of profit distributions. In a rather procedural ruling in the direct action of Commission v Portugal (C-105/08) the Court held that the Commission failed to substantiate its claim that Portugal imposed discriminatory tax burdens on foreign financial institutions beyond a purely hypothetical example. In Secilpar - Sociedade Unipessoal it was for the national court to establish if the restriction imposed through a discriminatory withholding tax in Portugal was neutralised by another Member State pursuant to a double tax convention with Portugal. If so, there would be no discriminatory disadvantage ultimately.

\subsubsection{The restriction is justified}

The third and last class of cases are those in which the Court held a restriction on freedom of movement nonetheless lawful because it found a proportional justification. It is consistent and well-established case law that restrictions on free movement may be justified by overriding reasons of public interest if they are appropriate in ensuring the attainment of objectives which are compatible with the TFEU and do not go beyond what is necessary to achieve those objectives (Futura). The following discussion ignores cases in which the restriction could in principle be justified, but for the fact that it definitely did not meet the proportionality requirement. Also 'justifications' that the Court consistently rejects are not discussed due to research design. The discussion below shows that the accepted justifications in the field of direct taxation are the cohesion of the tax system, the effectiveness of fiscal supervision, the need to maintain a balanced allocation of the power to impose tax between the Member States (with the prevention of international double loss relief) and the prevention of tax avoidance or evasion. This corresponds with the findings of prior research. ${ }^{318}$ The exact

318 See e.g., Cordewener, et al. (2009); Van Thiel (2008b); Van Thiel (2008c). 
meaning and role of those justifications as judicial rules will be examined closer in Part III of this book.

\subsection{Cohesion of the tax system}

In Bachmann, Commission v Belgium (C-300/90), Krankenheim Ruhesitz am Wannsee-Seniorenheimstatt, Commission v Belgium (C-250/08), and Commission $v$ Hungary (C-253/09) the cohesion of the tax system fully justified the restriction at issue. The Court also accepted this justification in National Grid Indus. Cohesion of the tax system means that the national measure is required to maintain a direct link between a tax advantage and a countervailing tax levy in view of the aims pursued by the tax system. A sufficiently direct link exists, according to the case law cited here, if the tax advantage and countervailing levy are charged on the same taxpayer with regard to the same tax.

Bachmann and Commission v Belgium (C-300/90) concerned the same Belgian tax measure on the deductibility of sickness and invalidity insurance contributions, and pension and life insurance contributions. Since Belgium neither taxed the future benefits from insurance policies with foreign insurers, nor imposed a charge to tax on those foreign insurers, it was justified to deny a deduction for contributions paid in consideration for those foreign insurances. In internal situations a deduction was granted, but the cohesion of the tax system was safeguarded by subjecting the future benefits to tax when they were made payable. The Court considered other possible means to safeguard recovery of tax in cross-border situations not less restrictive as the rule at issue in the proceedings before it.

Under the law at issue in the proceedings in Krankenheim Ruhesitz am Wannsee-Seniorenheimstatt, Germany allowed companies established in its national territory to relieve losses suffered at foreign branches against domestic tax payable in the same way as for domestic branches. However, at such a time as the foreign branch became profitable again, this tax advantage was reversed. That legal effect was however necessary to safeguard the cohesion of the tax system, according to the Court's ruling, since the national court submitted that Germany surrendered its power of taxation in respect of foreign branches by the double tax convention. The direct link between the tax advantage and the subsequent effective charge to tax in relation to losses and profits of the same foreign branch of a company thus reflected a 'logical symmetry'. The idea of logical symmetry within the system of taxation was also applied in the three other cases mentioned, which were all delivered in the last week of November 2011.

\subsection{Effectiveness of fiscal supervision}

The effectiveness of fiscal supervision was only partly accepted in Futura. In that case the Court held it however disproportional to require that proper accounts were kept according to the domestic rules of, and within national territory 
of the Member State in which a branch of a company of another Member State was established. But in Futura the Court also ruled that the Member State may require the taxpayer to submit documentary evidence to make it possible to determine 'clearly and precisely' whether the accounts drafted up under foreign law also complied with domestic rules on the calculation of income, and therefore could substantiate a claim for tax advantages, such as the relief of losses at issue in that case.

The Court validated an extended recovery period in respect of foreign assets and income in Passenheim-van Schoot \& X (Joined Cases C-155\&157/08). In terms of effective supervision, the Court acknowledged that the risk of discovery of concealed assets and income is lower in respect of foreign assets and income than in internal situations where a system of automatic exchange of information between the tax authorities and domestic financial institutions is in place. The Court distinguished the situation in which the tax authorities have no knowledge of the fact that foreign assets and income had been concealed by the taxpayer, and the situation in which that information was available to the tax authorities and they were thus able to initiate investigations for the purpose of recovering evaded taxes. In the latter situation, an extension of the recovery period is only proportionate insofar as it specifically intends to permit the tax authorities to request the mutual assistance from the other Member State(s) concerned.

In ELISA (C-451/05), the Court held that the Mutual Assistance Directive $(77 / 799 / \mathrm{EEC})^{319}$ did not preclude Member States from concluding double taxation conventions between them that exclude a certain group of taxpayers from the provisions concerning exchange of information contained therein if these provisions reflect the national law or administrative practise of the Member State concerned, which equally prevents the collection of or use of information from that group of taxpayers for internal taxation purposes. However, the difficulty of obtaining information from the taxpayer for taxation purposes does not allow Member States to systematically refuse a tax advantage to taxpayers who exercised their right to free movement of capital in the interest of preventing tax evasion. To completely prevent taxpayers from submitting documentary evidence to show that their situations do not constitute acts of tax avoidance or evasion is a disproportional measure.

Contrary to the situation that applies within the EU, the Court held in $A, C F C$ and Dividend Group Litigation and Établissements Rimbaud that Member States may lawfully refuse to extend a tax advantage to the taxpayer, in relations with non-member countries, if the tax authorities can only verify the claim by the taxpayer that he meets the satisfying requirements for that concession by obtaining information from the competence authorities of a non-member country. However, no provisions on information exchange are in force pursuant to an international agreement with the non-member country which would enable

319 This Directive has been repealed and replaced by the Administrative Cooperation Directive (2011/16/EU). 
the Member State to conduct such inquiries and legally oblige the non-member country to lend the requested assistance. ${ }^{320}$

Recalling that the case in the main proceedings concerned a material time before Directive 2001/44/EC came into force in 2001, the Court considered a system of retention at source for non-resident taxpayers a proportionate mechanism to safeguard the effective collection of tax in Scorpio, whereas personal income tax was charged on an assessment basis to resident taxpayers. ${ }^{321}$

\subsection{The balanced allocation of taxing powers}

The need to maintain a balanced allocation of the power to impose tax between the Member States justified a national measure for the first time in Marks \& Spencer. In that case, and in the subsequent authorities of Lidl Belgium and X Holding (C-337/08), the Court held that 'the preservation of the allocation of the power to impose taxes between Member States may make it necessary to apply to the economic activities of companies established in one of those States only the tax rules of that State in respect of both profits and losses'. Furthermore, in case the claims of the taxpayers in those cases had been allowed, this would have enabled a cross-border relief of losses. To give companies the free choice to determine in which Member State their losses or profits would be taken into account, the Court reasoned, would undermine the balanced allocation of taxing powers. In $O y$ AA, Glaxo Wellcome, SGI, and National Grid Indus the Court however stressed that the preservation of a balanced allocation means that it is justified for Member States to prevent 'conduct capable of jeopardising the right of a Member State to exercise its tax jurisdiction in relation to activities carried out in its territory'. Moreover, in all cases mentioned here, apart from X Holding and National Grid Indus, the Court accepted this public interest justifycation only in conjunction with the need to prevent that the same losses would be taken into account in two Member States, or the need to prevent tax avoidance. Due to the ambiguity of the Court's holdings, the precise meaning of its most recent justification ground in the field of direct taxation is still subject to debate in the literature. ${ }^{322}$

\subsection{The need to prevent tax avoidance and evasion}

The need to prevent tax avoidance and evasion is also an overriding reason of public interest that is able to justify national measures with restrictive effects on free movement. What follows from cases like Sandoz, Marks \& Spencer, Cad-

320 See, Nijkeuter (2011).

321 In its 2012 judgment in $X(\mathrm{C}-498 / 10)$ the Court affirmed this conclusion for a post2001 situation.

322 See, Part III. 
bury Schweppes, Thin Cap Group Litigation, Kofoed (C-321/05), Oy AA, ELISA, $C F C$ and Dividend Group Litigation, Glaxo Wellcome and SGI are two consistent rulings. First, the need to prevent tax avoidance and evasion cannot justify national provisions that set irrefutable presumptions of abuse or fraud which apply generally on the basis that the right to move and reside freely within the Union has been exercised. Second, the proportionality principle requires that individual situations are examined on a case-by-case basis, and that national anti-avoidance or anti-evasion measures apply only to proven wholly artificial arrangements that are set up with an aim to escape taxes normally due on income from activities undertaken in the national territory of the Member State. ${ }^{323}$ In that context, the Court requires that the taxpayer is given the opportunity to produce documentary evidence to show that his actions are bona fide commercial activities.

\subsection{Reception in the academic literature}

It is beyond the scope of this Chapter and this book to examine in detail how each case has been received in the academic literature. Prior dissertations have applied a case-by-case analysis and discuss the normative merits of each case; the interested reader is referred to those publications for academic critique that is specific to an individual case. ${ }^{324}$ That approach has many advantages, but one very important drawback is that it is difficult to get an overview of which cases have particularly dominated academic discussions. Students, practitioners and academics who are not specialised in the field may find these publications too exhaustive and not suitable as an introduction. Although there are some good general textbooks available which may serve as introductory reading, it is perhaps more helpful to phrase the information problem as follows. Suppose you are new to the field and have limited time to study only 20 cases, which cases should you read to be able follow the main themes of the academic debate? The approximate answer likely depends on which cases have been discussed most in the academic literature.

The EUR-Lex database keeps track of the academic literature that relates to the case law of the Court. Many publications on EU law in many languages are included in the database. The information so provided gives a good general idea of which cases were found to be important in European academic literature. Although completeness cannot be expected and little public information on the criteria of inclusion is available, the number of academic notes included in the database on an individual case is a readily available indication of the relevance

323 See e.g., the 2012 judgment in SIAT (C-318/10) in which the Court held that the conditions of the national measure did not the requirements of the principle of legal 324 certainty to be 'clear, precise and predictable as regards their effect'.

See e.g., Isenbaert (2010). 
of the cases in academic discussions on EU law in the field of direct taxation. ${ }^{325}$ We may even extrapolate a bit and consider that the more a case is discussed in academic publications, the more important the case has been for the evolution of this area of law.

The mean number of academic notes is 9.4 per completed case (excluding joined cases) but only about $26 \%$ of all rulings have more than 10 academic notes. Thus, the distribution of academic notes is skewed. There are some cases that have disproportionately many notes, but many cases are not discussed frequently in academic notes. This is nothing unusual if one considers the well known 'long tail of legal scholarship' according to which few articles garner a disproportionate high amount of citations and downloads. ${ }^{326}$ Table 14 reports the 20 cases with the most academic notes as per the end of 2011. These cases may be considered the most important cases as ranked by academics by lack of a better alternative.

The majority of cases which have been discussed most frequently by academics have also been deemed important by the Court; in 15 out of 20 cases the Court decided the case in Grand Chamber or the Court issued a press release on the judgment. The ruling in Marks \& Spencer on the relief of losses incurred by a foreign subsidiary to its UK parent company is clearly considered the current landmark judgment in direct taxes. The judgment has sparked a discussion whether it signalled a turning point in judicial doctrine with the introduction of the balanced allocation of the power to impose tax between the Member States as a novel justification. ${ }^{327}$

The ruling in Schumacker of 1995 was considered the most important ruling before Marks \& Spencer was decided in late 2005. The Schumacker judgment included a positive answer to the preliminary question whether the fundamental freedoms could restrict national income tax law and established a rule on the tax treatment of non-resident individual taxpayers which was contrary to customary international tax practice.

To complete the top three, De Lasteyrie du Saillant (C-9/02) was the first case in which a tax was assessed upon the transfer of residence as a taxable act. ${ }^{328}$ The compatibility of a tax charge directly connected to the exercise of free movement was one of the major questions of EU law in the field of direct taxes and its relevance to the field may be best compared to the relevance of the Bosman ruling for the evolution of the free movement of workers in general.

325 The information in the EUR-Lex database appears identical to the entries in the 'annotations of judgments' lists on the website of the CJEU, see $<$ www.curia.europa.eu> under 'case law', last visited 1 October 2012.

326 Bak (2006); Caron (2006); Smith (2007).

327 See, Part III.

328 Rather, the first case in which the Court chose to review the compatibility of such a tax charge with EU law after Daily Mail; see, Section 3.6.2.1. 


\begin{tabular}{lllll}
\hline Case & Short name & notes & Bench & Press release? \\
\hline C-446/03 & Marks \& Spencer & 91 & GC & yes \\
C-279/93 & Schumacker & 66 & GC & n.a. \\
C-9/02 & De Lasteyrie du Saillant & 52 & 3 & yes \\
C-168/01 & Bosal & 41 & 5 & yes \\
C-283/94 & Denkavit International & 36 & 5 & no \\
C-28/95 & Leur-Bloem & 36 & GC & no \\
C-196/04 & Cadbury Schweppes & 35 & GC & yes \\
C-80/94 & Wielockx & 34 & GC & n.a. \\
$81 / 87$ & Daily Mail & 33 & GC & n.a. \\
C-324/00 & Lankhorst-Hohorst & 33 & 5 & no \\
C-319/02 & Manninen & 32 & GC & no \\
C-264/96 & ICI & 31 & GC & no \\
C-376/03 & D. & 30 & GC & no \\
C-307/97 & Saint-Gobain & 29 & GC & no \\
C-107/94 & Asscher & 26 & 5 & no \\
C-292/04 & Meilicke & 25 & GC & yes \\
C-204/90 & Bachmann & 24 & GC & n.a. \\
C-234/01 & Gerritse & 21 & 5 & no \\
C-112/91 & Werner & 20 & GC & n.a. \\
C-141/99 & AMID & 19 & 3 & no \\
\hline Table 14. & M & &
\end{tabular}

Table 14. Most important rulings by academic notes.

The importance of the case was perceived differently by the Court and by academics in five cases. For which rules of EU law in the field of direct taxation does the Court seem to have 'miscalculated' the evident importance of the case according to academic literature, or alternatively, in response to which rulings have academics maybe overreacted?

The ruling in Joined Cases Denkavit International, VITIC Amsterdam \& Voormeer (Joined Cases C-283, 291\&292/94) was the first judgment on the Parent-Subsidiary Directive - also the first case on any direct tax directive - and it is plausible that the case attracted the attention of academics for this reason. The judgment established the rule that the minimum holding period of two years does not have to be completed before the benefits awarded by that directive may be enjoyed by companies. This interpretation was contrary to the interpretation of almost all Member States which had implemented the option of Article 3(2) of the Parent-Subsidiary Directive to set a minimum holding period of two years as an additional qualifying condition for the benefits of the Directive. This fact was expressly noted by the Court and Germany was consequently not liable for damages for its breach of EU law.

Lankhorst-Hohorst (C-324/00) ruled that thin capitalisation rules may not exclusively apply in situations in which freedom of establishment was exercised. This was the first case in which a rule limiting interest deductibility for the purposes of corporation tax was put to the test for compatibility with EU law and failed this test. The many comments in the academic literature reflect that tax avoidance through excessive debt financing of companies is one of the 
dominating themes of the international tax policy debate on corporation taxes during the last decade. ${ }^{329}$ The constraint of EU law set by Lankhorst-Hohorst is still significantly controlling national tax policy options on this subject and the rule was affirmed and specified in the 2007 judgment in Thin Cap Group Litigation.

The rulings in Asscher and Gerritse concerned a type of tax discrimination against non-residents which fell outside the limited set of discrimination cases established in the landmark case of Schumacker. First, the Court established a rule in Asscher that Member States may not apply higher tax rates to nonresidents compared to residents earning the same income irrespective of whether the taxpayer is insured or not under the national social security system. Second, Gerritse established that non-resident taxpayers may not be taxed with a final withholding tax on gross income, whereas resident taxpayers are taxed on net income, i.e. gross income after deduction for income related expenses. The discrimination in EU law was of the vanilla kind; an indirect discrimination on nationality. The two cases significantly constrained the margin by which Member States could differentiate between rules of income tax as they applied to resident and non-resident individuals. The principle that emerged from these cases was that the tax base should be defined in the same way and same rates should apply to those two categories of taxpayers.

The ruling in AMID (C-141/99) related to Belgian rules on loss offsetting in relation to treaty-exempt (thus foreign) income. The Belgian law at issue- the so called Velasquez doctrine-required that any domestic losses were first balanced against DTC-exempt income before they could be made available as carry forward to offset future domestic profits. The Court held this tax treatment contrary to the freedom of establishment. This ruling evidently raised broader questions on the corporation tax treatment of foreign losses. These issues would later manifest in the most annotated judgment in the field of direct taxation; Marks \& Spencer.

We have observed in Section 3.2 that rulings are not distributed equally over the years. As many cases were decided between 1983 and 2003 as between 2009 and 2011. All cases in Table 14 were decided before mid 2007, meaning they belong to the first and second quartiles of judgments. Table 14 does not include any case decided in 2008 or later. Older cases have attracted the most academic discussion.

The low ranking of very recent cases is due to the simple fact that it takes some time to write and publish a comment to a case. Looking at the cases of Table 14, about $90 \%$ of all academic notes were published within two years after the year in which the case was decided. The importance of a case to academic discussion can be estimated accurately after this period.

A ranking of academic notes per rulings also fails to take account of the normative importance of some cases. Take for example Kerckhaert and Morres (C-513/04). The overall rank of this case is 66-79 with eight academic notes. In 
that case, the Court ruled that juridical double taxation is not, as such, a restriction on the freedom of movement. Juridical double taxation is the most fundamental problem of international tax law, but the first ruling of the Court on this issue was not important? The Court delivered its decision only two months after the ruling in Cadbury Schweppes which is ranked $7^{\text {th }}$ overall.

It is fairly easy to decide for academics which cases to write about if there were only four rulings of the Court in the field of direct taxation in a given year but the decision becomes more difficult in years with on average two rulings per month. One could say that rulings decided in 2007 or later have a stronger position in the competition for research time than prior rulings. The divergences between the numbers of rulings per year may be eliminated by additionally considering the yearly rankings. Only considering the rulings of 2006 shows that Kerckhaert and Morres was ranked $10^{\text {th }}$ in that year, with Cadbury Schweppes as the most commented case of the year $(n=18)$. The low overall placement of Kerckhaert and Morres thus does not give a very distorted estimate of the relative importance of the case to academic discussion; the case is also ranked low in the yearly ranking. Academics found the topic of abusive tax avoidance and EU law apparently more interesting to write about than juridical double taxation and EU law. One cannot say that either issue is a priori more important than the other. In 2008, however, the trend turned and Block (C-67/08) (on juridical double taxation of inheritances) was ranked $2^{\text {nd }}$ in that year with 11 notes $\left(52^{\text {nd }}\right.$ overall), only superseded by the only Grand Chamber ruling of 2008 in Persche (C-318/07) on the deductibility from income tax of gifts made to foreign charities which has 16 notes and is ranked $33^{\text {rd }}$ overall. Consequently, juridical double taxation is evidently regarded as an important problem of EU law in the field of direct taxes by academics, even though the overall ranking does not show this directly. ${ }^{330}$

The overall list of Table 14 thus seems to be biased in favour of older cases but it still has indicative value of the importance of cases to academic discussion. We should however also take into account the relative ranking of the case to other decisions of the same year with an aim to rid the overall ranking from distortions caused by time. In the next Chapter we will review another method of ranking cases by importance, not by relying on academic notes, but by taking advantage of the structure of the case law as a network.

\subsection{Synthesis and discussion}

In this Chapter, we have reviewed the properties of the body of case law of the Court in the field of direct taxes from 1983 through 2011. To put this body of case law into a broader perspective, consider for example that there are now considerably more rulings on the application of EU law to direct taxes than that

330 The 2009 ruling in Damseaux (C-128/08) has 5 academic notes and was ranked $9^{\text {th }}$ of the 19 rulings in 2009. That case was a direct follow-up to Kerckhaert and Morres. 
there have been Court decisions on internal taxation which is regulated expressly in Article 110 TFEU. ${ }^{331}$ There are also more rulings on direct tax matters than on fundamental rights or on general non-discrimination and Union citizenship, to name only two other politically salient areas. ${ }^{332}$ Although these observations confirm the great extent to which EU law imposes normative constraints on national rules on direct taxation, there are still twice as many Court rulings in the (harmonised) field of value added tax. ${ }^{333}$ The regulatory control of the Union on taxation matters is thus most prominent in the sphere of indirect taxation, both from a legislative and judicial perspective. The realm of direct taxes is however quickly gaining ground.

It may be proffered that the impact of EU law on direct taxation is politically more salient than in the area of indirect taxes. The Member States committed very early in the process of European integration to harmonise indirect taxes. This was considered to be a logical consequence of the establishment of a customs union and the free movement of goods. The regulatory control exerted by the Union in the field of direct taxation-mainly through judicial supervision - is not a result of a positive political decision in that respect. EU law in the field of direct taxation has evolved incrementally; case by case. Basically, this has only been possible by what Stone Sweet has coined as a juridical coup d'état; 'a fundamental transformation in the normative foundations of a legal system through the constitutional lawmaking of a court ${ }^{334}$ In advancing European legal integration, the Court has used its Treatyinterpretation powers to construct a supra-national constitution, despite opposition from the Member States. ${ }^{335} \mathrm{EU}$ law has been able to impact the field of direct taxation through judicial supervision, only because the Court declared EU law to be higher in legal hierarchy than national law.

A wide variety of issues, touching many aspects of tax design of various systems of direct taxation have been adjudged by the Court in the period between 1983 and 2011 that was reviewed in this Chapter. The judicial doctrine seems to have arrived at a relatively stable state of maturity in the most recent years, but only the future will tell whether a burst of new questions similar to the one between 2001 and 2005 is about to happen in years to come. Since 2005 the inventory of pending cases is constant at around 30 new proceedings per annum. An increasing proportion of new cases is however made up by direct actions. This indicates that current litigation is more focused on monitoring compliance of past novelties in the law than oriented towards exploring green fields of EU

331 There are 137 judgments and 7 reasoned orders in directory 4.10 .01 (Internal taxation) of the digest of the case law in EUR-Lex as per 1 January 2012.

332 Respectively, directory codes 1.04 (Fundamental rights) and 1.09 (Nondiscrimination and citizenship of the Union) of the digest of the case law in EURLex.

333 See directory 4.10 .02 (Value added tax) of the digest of the case law in EUR-Lex.

334 Stone Sweet (2007).

335 Burley and Mattli (1993); Stein (1981); Weiler (1991). 
law in the area of direct taxation. It also appears that less preliminary references need to be decided by a Grand Chamber and more standard cases can do without an opinion of the Advocate General since 2005. Thus, a cautious conclusion seems that the relevance of new litigation for the development of EU law in the field of direct taxation is decreasing. These observations are arguably speculative in nature.

The geographical representation of proceedings is unbalanced. ${ }^{336}$ The current judicial doctrine has developed on basis of and is very much oriented towards the sophisticated and long established systems in Western Europe. Although many judicial rules apply to common features of all income tax systems, the relative lack of preliminary references from courts in the Mediterranean Member States, like Italy and Spain, is striking. It might also be just a matter of time before the direct tax laws of the 'new' Member States will be scrutinised before the Court. The Eastern European Member States have income tax systems which are designed differently and their compliance with EU law could involve different issues than precedent has resolved until now.

Exactly because of the political salience of its rulings, the Court has been the subject of strong criticism and has been accused of overstepping the limits of its mandate. It may indeed be rebutted, as Vanistendael already stated, ${ }^{337}$ that the Court carries out an ordinary mandate of judicial review that is similar to that of the ECtHR and national constitutional courts. Also, the Member States have had sufficient opportunities since the first ruling of Avoir Fiscal in 1986 to limit the influence of EU law in the field of direct taxation.

The fact that the Member States have not included specific provisions in the Treaties of Maastricht, Amsterdam, Nice and Lisbon to that effect may perhaps be taken as (silent) acquiescence to the Court's power of interpretation in the field of direct taxation. Notwithstanding this political observation, the proportion of cases in which the Court accepted a justification or otherwise ruled in favour of the Member States has risen since 2006. The increased proportion of cases won by the Member States indicates clearly that the Court has conceded that its deregulatory power of interpretation is, even in the absence of an express Treaty provision, not unlimited indeed.

The review of grounds which the Court held against taxpayers, in particular on the level of justifications, and also the high number of academic notes to the Marks \& Spencer ruling suggest that this ruling is a critical juncture and that the balanced allocation of taxing powers is an important rule of EU law in the field of direct taxation and deserves further research. Part III of this book aims to make a comprehensive contribution to that task.

Before we turn to the legal analysis of this recent standard of EU law, we continue in Chapter 4 with a closer look at the structure and organisation of the body of case law. Chapter 3 reviewed the properties of the case law in the field of direct taxes but only touched upon the deeper structural relations between

\footnotetext{
336 In that aspect, little has changed over time, see Wathelet (2004).

${ }^{337}$ Vanistendael (2007).
} 
cases opportunistically to make a qualitative judgement of the aggregated data. Chapter 4 researches these relations at length and provides fresh perspectives on the way in which this field of EU law evolved and the manner by which judicial rules emerged within the field of direct taxation as a functional subsystem of EU law. 


\section{Chapter 4 A Network Analysis of the Case Law}

\subsection{Introduction}

This Chapter views the body of case law in the field of direct taxation as a network and analyse its structure and organisation on various scales using quantitative and qualitative methods.

The Chapter proceeds as follows. Section 4.2 presents descriptive data about the topology of the network and reviews the structure and organisation on a macro-level. We subsequently analyse the meso-structure of the network in Section 4.3 by quantitatively identifying densely connected communities of cases using two common algorithms and by giving a qualitative legal analysis of those communities. We are primarily interested in the question whether a community structure of the network emerged from a complex and dynamic process of judicial decision making with a first order orientation to precedent and, if so, whether it is organised in a legally relevant manner.

We then continue with a micro-perspective on the network in Section 4.4 by researching which cases play a central role for the structure and organisation of the network as a whole. Because judicial decisions are the main sources of EU law in the field of direct taxation, this Section is aimed at finding the most important precedents by taking advantage of the network structure. We continue this line of thought in Section 4.5 and we propose and apply a method for extracting the most important legal norms from the body of case law. The joint product of Sections 4.4 and 4.5 is a systematic collection of EU law rules in the field of direct taxation, which has been determined primarily in a quantitative, objective and thus reproducible manner. These norms are the positive legal conception as the most essential outlines of judicial doctrine on EU law in the field of direct taxation as it currently stands. The findings are reported in Annex A.

Section 4.6 returns to a macro-level perspective and researches how the case law in the field of direct taxes is structured and organised within the larger body of case law of the Court. This research gives meaningful information about the reception of general EU law in the field of direct taxation over time. In particular, we analyse which non-tax cases are applied within the field of direct taxation and how they have shaped judicial doctrine in this field. This Chapter concludes with a synthesis and discussion of findings in Section 4.7. 


\subsection{Global network properties}

Since we are interested in the question how judicial decision making with a first order orientation to precedent has shaped the EU law in the field of direct taxation, we collected all outward citations of the cases in the final sample from the EUR-Lex database. ${ }^{338}$ Through this approach we find all precedents which are of interest for the field of direct taxation because it is determined in a positive manner that those rulings have provided interpretative guidance to resolve an EU law dispute on direct tax proceedings. We are however not interested in the reception of direct tax precedents in other areas of EU law; for this reason we do not collect inward citations to all cases included in the sample. In this way, we constructed a network with relations between all sample cases and between sample cases and their 'non-tax' precedents (i.e. cases not included in the final sample). This is sufficient for the purposes of our research. We do not construct relations between non-tax cases since they do not provide direct evidence on the research question how the interpretative guidance of precedent has influenced the interpretation of EU law in the field of direct taxation.

\subsubsection{Connectedness}

The complete network consists of 615 nodes (cases) in total and 2,300 edges (citations). The largest weakly connected component, i.e. the giant component, of the case law network is shown in Figure 4. ${ }^{339}$ The size of nodes (cases) in Figure 4 is proportional to the total of other cases that cite it, i.e. the number of inward edges. The giant component includes $96.9 \%$ of all nodes and $99.4 \%$ of all edges and is thus of the same order of size as the network. ${ }^{340}$

Only seven sample cases are isolated from the giant component. They form together five weakly connected components, which are very small, and are therefore not visualised. Isolated from the giant component are Corbiau (C24/92: on the meaning of 'court or tribunal' in Article 263 TFEU), Commission v Greece (C-8/97: failure to transpose Mergers Taxation Directive (2009/133/EC) within prescribed period), WN (C-420/98; on the Mutual Assistance Directive (77/799/EEC)), Commission v Belgium (C-415/02: on the Directive on indirect taxes on the raising of capital $\left.(2008 / 7 / \mathrm{EC})^{341}\right)$, Commission $v$ Spain (C-219/03: taxes on capital gains, incompatibility not disputed), Commission v Belgium (C-392/07: failure to transpose the Mergers Taxation Directive (2009/133/EC) within prescribed period), Commission v Portugal (C105/08: Commission failed on burden of proof).

\footnotetext{
$338<$ http://eur-lex.europa.eu>.

339 Force Atlas layout of Gephi (0.8beta), see Bastian, et al. (2009).

340 Boccaletti, et al. (2006), p. 181

341 Council Directive 2008/7/EC of 12 February 2008 concerning indirect taxes on the raising of capital, O.J. L 46, 21.2.2008, p. 11-22.
} 


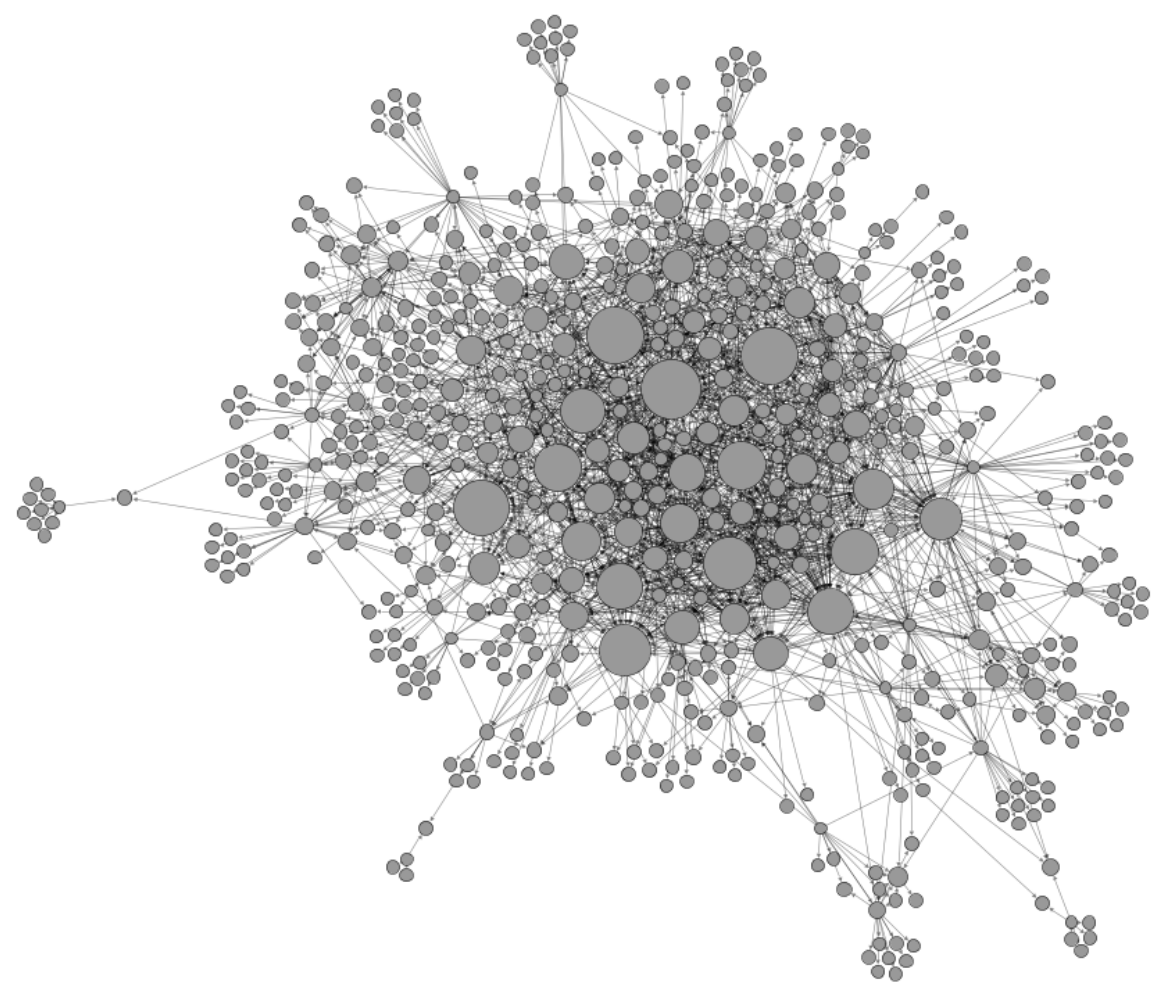

Figure 4. The giant component of the case law network.

The fact that almost all cases in the field of direct taxation are connected to each other through citation links shows that the Court consistently embeds new rulings in the existing body of case law by citing precedent. Merely two of the sample cases in the giant component do not cite any precedent: Commission $v$ France (Avoir Fiscal) (270/83) and Daily Mail (81/87). The fact that a giant component exists makes it possible that information about the law in individual cases spreads through interpretation of precedent throughout the body of case law. The presence of a giant component indicates that there is, at least, a weak form of structural cohesion in the body of case law. ${ }^{342}$

Recall that the final sample included 192 Court cases in the field of direct taxes. Therefore, there are 423 other cases in the network which do not deal with direct taxes as their subject matter but which have nonetheless evidently provided interpretative guidance to decide cases on EU law in the field of direct taxes. The global properties of the network show that the Court not only consistently embeds new cases in the field of direct taxation within the

342 Moody and White (2003), p. 106. 
collection of existing rulings on direct taxation, but also embeds its case law in the field of direct taxes within the larger body of case law. There is accordingly structural cohesion within the field of direct taxation and structural cohesion between the field of direct taxation and the larger system EU law.

Section 4.6 explores the reception of general judicial doctrine on EU law within the field of direct taxes. We will see there that the Court moved to cite precedent within the field of direct taxation more strongly over time. The relative reliance on judicial decisions on EU law outside the field of direct taxation decreased over time.

\subsubsection{The small-world effect}

We have seen above that almost all cases in the network are either directly or indirectly linked through citation to precedent. The network of case law is thus connected. For a better understanding about the system that emerged from this case law network, we need to analyse how the connections between the cases have created a network structure, if any.

A network may, at one extreme, have a highly regular structure in which nodes occupy a particular space in a closely connected neighbourhood, but are on average well distanced from each other. On the other end of the spectrum, nodes may connect to each other in a network in a completely random manner; although there may be a single connected network, this network appears chaotic without any other structure or organisation apart from its connectedness.

Random networks are graphs of which the nodes of the network have no characteristic structural position associated with them, of which the length of the paths between nodes in the network is relatively short on average, ${ }^{343}$ and of which nodes are generally not organised in closely connected clusters. ${ }^{344}$ Accordingly, a random network shows no local structure besides its global properties of connectedness. The global properties of the random network must therefore be designed to correspond to those of the real case law network in terms of connectedness for the purpose of determining whether our real network has a local structure which distinguishes it topologically from a random network. The presence of a local structure in the network indicates that the underlying process by which connections are created is also non-random, and may be self-organising.

To evaluate whether there is a local structure in the real case law network we have simulated a so called Erdős-Rényi $G(N, E)$ random graph that corresponds

343 The average shortest path length $(L)$ is, for random networks of large $N$, proportional to $\ln (N)$; Watts and Strogatz (1998). Also referred to as the minimum walk, characteristic path length or geodesic; Boccaletti, et al. (2006), pp. 182-183.

344 Evans (2004), p. 4. 


\begin{tabular}{lrrr}
\hline Network measure & Full network & Giant Component & Random Graph \\
\hline Components & 6 & 1 & 1 \\
$N$ (number of nodes) & 615 & 596 & 596 \\
$E$ (number of edges) & 2300 & 2286 & 2286 \\
$K$ (average degree) & 3.740 & 3.836 & 3.836 \\
$L$ (average path length) & 2.831 & 2.832 & 4.901 \\
Diameter & 8 & 8 & 11 \\
$D$ (density) & 0.006 & 0.006 & 0.006 \\
$C$ (av. clustering coefficient) & 0.094 & 0.097 & 0.005 \\
\hline
\end{tabular}

Table 15. Properties of the case law network.

in terms of global network properties with the real network so that they may be compared on differences in local structure, see Table $15 .^{345}$

The real network, which is reduced to the giant component, and the random graph are both directed graphs with the same number of nodes $(N=596)$ and same number of edges $(E=2286)$. From this follows that the average number of edges per node - average degree $K$ in formal terms - is the same $(K=3.836)$. Also the density $(D=0.006)$ of the networks is the same. The density $D$ of the network is a basic measure of connectedness and is calculated informally as the ratio between the number of edges that actually exist and the number of possible edges between the nodes of a network. ${ }^{346}$ A low density, such as the one measured here, means that both networks are sparsely connected. ${ }^{347}$

The seminal study by Watts and Strogatz defined a middle ground between regular networks and random networks as the 'small-world' network model. ${ }^{348}$ Very recent papers on the social network of Facebook showed that $99.91 \%$ of Facebook users were connected to each other and that it takes on average only 4.74 persons to link two other randomly chosen persons from the 721 million worldwide Facebook users to each other. ${ }^{349}$ Prior research found that many different types of real networks exhibit small-world effects. ${ }^{350}$

This idea of a small world was already exemplified by experiments in the 1960s. ${ }^{351}$ Travers and Milgram sent 269 letters to some systematically chosen and other randomly chosen residents of Nebraska and Boston, asking them to forward the letter to a target person who was a Boston stockbroker. If the first recipient of the letter did not know the target person personally, he or she had to forward the letter to a personal acquaintance that was more likely to know the

345 Erdős and Rényi (1959). $G(N, E)$ denotes a randomly chosen graph $G$ from the collection of possible graphs with $N$ nodes and $E$ edges. See also, Erdös and Rényi (1960).

346 All network measures presented in this Section were computed with Gephi (0.8beta).

347 A network is sparse if $E \ll N^{2}$; Boccaletti, et al. (2006), p. 181.

348 Watts and Strogatz (1998).

349 Backstrom, et al. (2011); Ugander, et al. (2011).

350 Watts (1999).

351 Travers and Milgram (1969). 


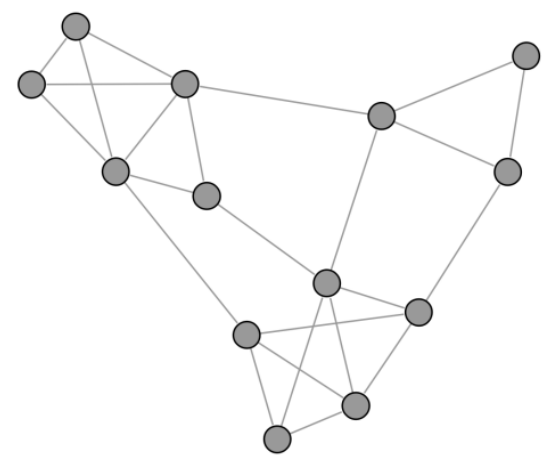

Figure 5. A connected network of closely connected clusters.

target person. Travers and Milgram found that 64 letters (of 217 letters that were forwarded at least once) reached the target person and that the mean number of other persons between a randomly chosen addressee and the target person was 5.7. The small-world effect which Travers and Milgram observed is also known in popular culture as the 'six degrees of separation'. 352

In network measures, the distance between two nodes in a network is measured as the shortest path length or minimum walk, that is the minimum number of edges one has to follow ('walk') to reach the one node $i$ from the other node $j$. A direct edge between two nodes $i, j$ is equivalent to a shortest path length of 1 between those nodes, notwithstanding that these nodes may also be indirectly linked by connections to e.g. common adjacent nodes.

The Watts-Strogatz small-world network model builds to the theory of the strength of weak ties in networks. This theory is named after Granovetter's study with the same title. ${ }^{353}$ Granovetter interviewed people about how they found their current employment, after they had recently changed jobs. He found that many interviewees had not found their current job through their close friends (their strong ties) but rather through acquaintances (weak ties). These acquaintances were likely to have strong ties to other persons with whom the jobseeker had, however, no ties. The social structure that Granovetter theorised is one in which one's close friends are likely to be close friends to each other, but one's acquaintances have close friends and other acquaintances that one does not directly know. Weak ties between social agents are thus important for the overall structure of communication and spread of information in the social network because they may act as bridges between clusters of closely tied social agents. Figure 5 illustrates this in a basic model. ${ }^{354}$

352 See e.g., Guare (1990). A fun procrastination tool is the Kevin Bacon game; e.g. Justin Bieber has a Bacon number of 3: $<$ http: \loracleofbacon.org $>$.

353 Granovetter (1973).

354 The figure is an adaption of Watts and Strogatz (1998). 


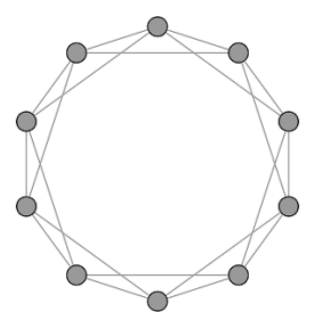

(a) regular network

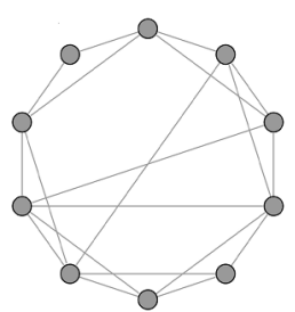

(b) small-world network

Figure 6. The Watts-Strogatz small-world network model.

It was Kleinberg who showed that agents (nodes) in a network are good at navigating these bridges, since they were able to find a shortest path to a target node even though they did not have complete information on the network but operated on basis of the information about the structure of their local neighbourhoods. ${ }^{355}$ Kleinberg's theoretical results have also been shown experimentally in a large-scale and global e-mailing experiment - a current day version of the letter experiment by Travers and Milgram. ${ }^{356}$

The Watts-Strogatz small-world network model was discovered by introducing these bridges or 'weak ties' between clusters of tightly knit nodes through randomly rewiring nodes in a network with a highly regular structure, see Figure 6. The regular network in Figure 6(a) is a ring lattice in which each node is connected to its neighbours and its neighbours' neighbours. In their research design, the average shortest path length $(L)$ between any two nodes on this ring was higher than that of the corresponding random network. Watts and Strogatz however found that the average shortest path length of the regular network significantly reduced to values that approximated those of random networks when a few bridges were created by randomly rewiring nodes. Yet, even after this random rewiring, the small-world network model largely maintained the characteristically clustered structure of the regular network; see Figure 6(b).

In short, the Watts-Strogatz small-world network model is defined as a large $N$ sparse network with an approximately same average shortest path length $(L)$ as the associated random network, but it is distinguished from a random network by a very much higher average clustering coefficient $(C) .^{357}$ The clustering coefficient measures how closely connected the neighbours of a particular node are connected to each other.

\footnotetext{
355 Kleinberg (2000).

356 Dodds, et al. (2003).

357 Watts (1999), pp. 508-509.
} 


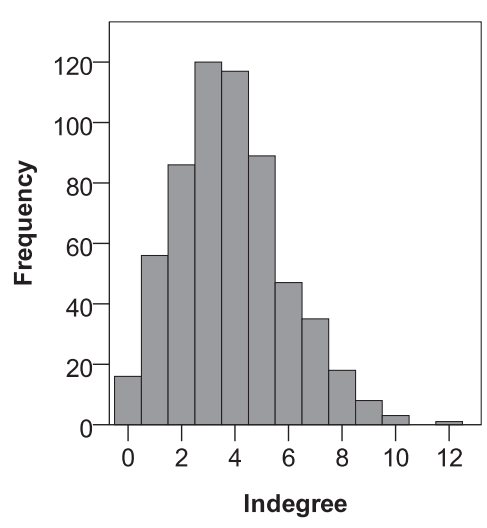

(a) random network

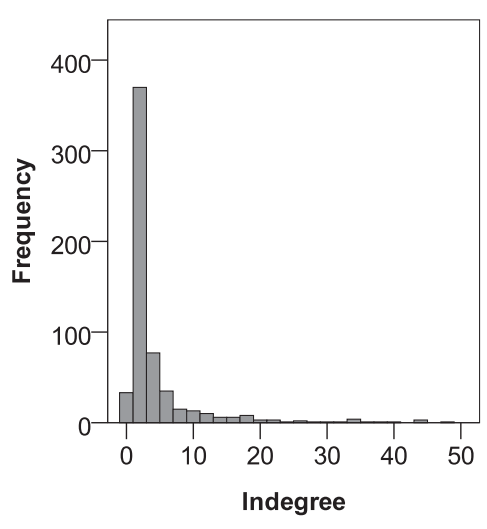

(b) case law network

Figure 7. Indegree distributions.

We can derive from the network measures in Table 15 that the giant component of the case law network exhibits the basic properties of a small-world network. First, the diameter of the real network is 8 , whereas the diameter of its associated random network is 11 . The diameter is the longest of the shortest paths between any two nodes in the network. Second, the average shortest path length $(L)$ between any two nodes in the network is also significantly shorter in the real network compared to the simulated random version $\left(L_{\text {real }}=2.832\right.$; and $L_{\text {ran }}$ $\left.d_{o m}=4.901\right)$. Consequently, the giant component of the case law network is indeed approximately similar to a random network on global properties. Third, the real case law shows the distinctive feature of small-world networks of a very high clustering coefficient $\left(C_{\text {real }}=0.097\right)$ when compared to that of the random network $\left(C_{\text {random }}=0.005\right)$. These clustering coefficients are fairly comparable to the values that Watts and Strogatz found for a power grid network, which they identified as a small-world network. ${ }^{358}$

In conclusion, the giant component of the network of cases in the field of direct taxation shows small-world effects which are consistent with the WattsStrogatz network model. The dynamical process by which it was formed is for this reason considered to be non-random, so that a meaningful self-organisation may occur.

\subsubsection{Degree distribution}

A random network is created by a process in which the probability that two nodes are linked through an edge between them is independent from the existence of edges with other nodes in the network. ${ }^{359}$ Consistent with the central

\footnotetext{
358 Watts and Strogatz (1998).

359 Boccaletti, et al. (2006), p. 291; Newman (2003), p. 180.
} 
limit theory, the distribution of edges per node will converge around a single mean value for large networks. The distribution of the total number of edges that are directed towards a node (the indegree of a node) for the Erdös-Rényi random network that we used in the previous section is presented in Figure 7(a). This indegree distribution indeed shows that the distribution is centred on a single mean value in a binomial distribution consistent with probability theory. ${ }^{360}$

Figure 7(b) presents the indegree distribution of citation links between nodes in the case law network. The indegree of a case is the total of the number of citations that a case receives from other cases (incoming citations). The indegree distribution of the real network is extremely positively skewed. This means that the Court pays a disproportionate amount of attention to a small number of rulings compared to the rest of the body of case law.

The distribution in Figure 7(b) is very similar to the distribution for the complete body of the Court's case law found by Malgram. ${ }^{361}$ Similar highly skewed distributions were found by prior research for the case law network of the US Supreme Court, ${ }^{362}$ the Austrian Supreme Court, ${ }^{363}$ and the European Court of Human Rights. ${ }^{364}$ This suggests that the underlying dynamic processes that created the network structures for these Courts are also similar. This is in turn consistent with their similar (quasi-)constitutional role of judicial review. The similarity of findings indicates in a broader context that the process of judicial review is generic and independent from the law that is subject to interpretation.

Malgram found that distributions for networks of cases which were limited to the same Treaty article (like our case law network that is limited to the subject matter of direct taxation) were similar to the distribution of the full network. ${ }^{365}$ The macro-structure of a subnetwork of cases thus looks approximately similar to the macro-structure of the complete body of case law. In other words, the network of the Court's case law shows a fractal pattern. ${ }^{366}$ A fractal is a geometric shape that is (approximately) self-similar across various scales of magnification. A classic example of a fractal shape in nature is broccoli. Each little branch of the broccoli is a reduced size copy of the complete flower head. Networks which are self-similar across various scales of magnification are scalefree networks. Malgram accordingly concluded that the Court's case law network exhibits scale-free properties.

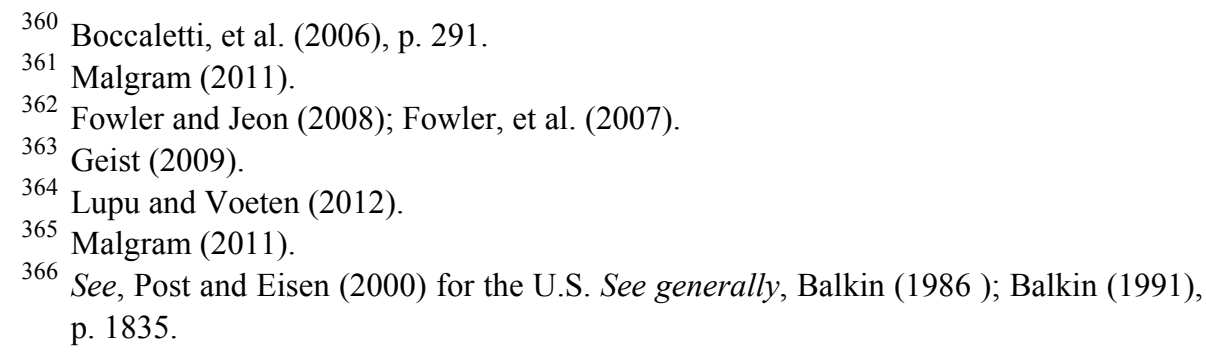




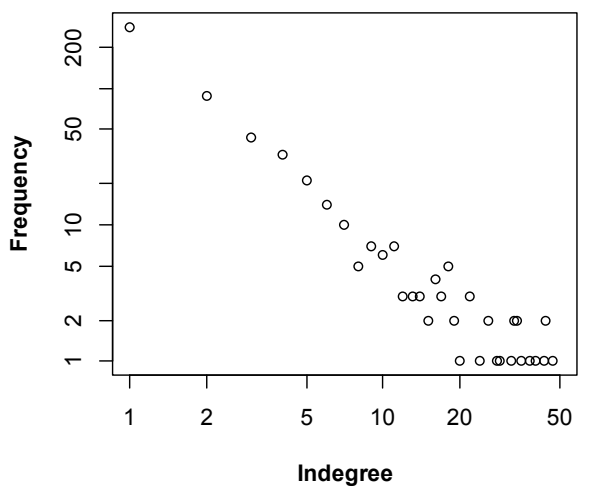

Figure 8. Log-log plot of the indegree distribution.

Scale-free networks in the strict sense show a particular type of distribution, i.e. a power law distribution. ${ }^{367}$ A good example of a scale-free network is the World Wide Web. ${ }^{368}$ The dataset used for the current research is too small to conclusively prove a power law distribution. ${ }^{369}$ A log-log plot of the indegree distribution shows the straight line that is characteristic of power laws, ${ }^{370}$ see Figure $8 .^{371}$ However, the tail is rather noisy, which makes a positive conclusion difficult. The shorter diameter and the shorter average path length $(L)$ of the case law network compared to the random network are additional indications that the case law network may be scale-free. ${ }^{372}$ The inferences we make here about the scale-free properties are to be treated with caution since we have not made a statistical assessment about the full network of the Court's case law, but only studied the subset of a sample of cases in the field of direct taxation. ${ }^{373}$

As we explained in Chapter 2, scale-free networks emerge from a dynamic and self-organising process of preferential attachment and competition between nodes. A plausible translation of this process to judicial decision making is a first order orientation to precedent. We assumed that existing rulings constrain the interpretation of law in subsequent rulings in that similar situations should be decided similarly and different situations should be distinguished. The existence of these constraints is evidenced by a citation to precedent and the nature of the constraint depends on the interpretation of the precedent in the subsequent case.

367 Clauset, et al. (2009).

368 Albert, et al. (1999). On the internet topology, see Faloutsos, et al. (1999).

369 See e.g., Katz and Stafford (2010) for a similar limitation.

370 Barabási and Albert (1999); Newman (2008).

371 A log-log plot is a plot of the distribution on a double-logarithmic scale.

372 Cohen and Havlin (2003).

373 Stumpf, et al. (2005). 
Citation and interpretation of precedent is context dependent and consistent citation to precedent does not necessarily imply that prior rulings and legal rules are also interpreted consistently and the integrity of the chain novel of case law is maintained in the Dworkian sense. To test this latter proposition requires a detailed legal interpretation of all cases of the main component. That is beyond the scope of this research. Dworkin's theory not only presumes the existence of a single novel but also that the relations between different chapters are made on basis of the relations between the facts and legal issues. We could thus review whether the meso-structure ('chapters') of the network ('chain novel') is legally relevant. This is the purpose of the next Section.

\subsection{Community structure}

\subsubsection{Community detection}

We already found the giant component of the case law network to exhibit smallworld effects and we accordingly expect the network to show some organisation of communities of densely connected nodes with the nodes of several communities being sparsely connected to each other. A community may thus be defined as a dense subnetwork within a larger network. ${ }^{374}$ Communities are likely functional units within the network, groups of nodes that share common attributes and/or nodes that perform similar roles. ${ }^{375}$ The goal of this Section is to detect the community structure of the case law network and to give a qualitative analysis of the detected communities.

Community detection is a method to find structure in a network by organising nodes in groups only on basis of their topological position in the network. ${ }^{376}$ It is thus the network itself that determines the number and size of the groups and not a predefinion of the researcher. ${ }^{377}$ The organisation of nodes in a community structure is illustrated in Figure 9 by using the same network of Figure $5 .{ }^{378}$

The quality of the detected community structure can be measured by its modularity $(Q) .{ }^{379}$ The modularity $(Q)$ of a division of a network is calculated as the fraction of edges within a community of nodes minus the expected value of that fraction if the edges between the nodes in the network would be made at random. ${ }^{380}$ It thus measures how the density of intra-community edges compares to the edges between communities.

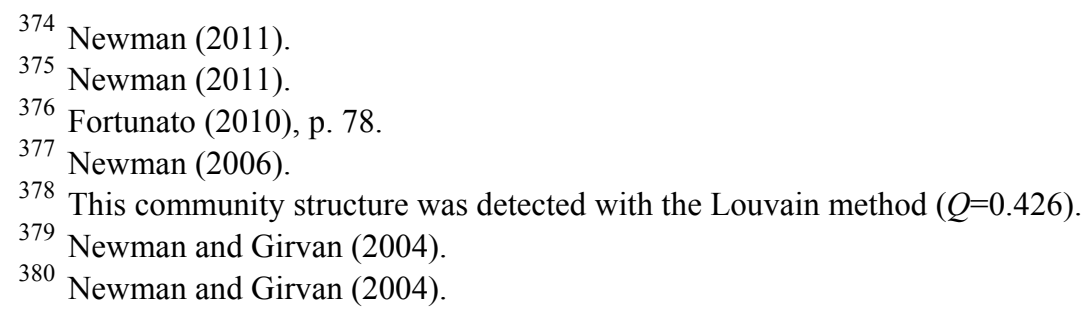




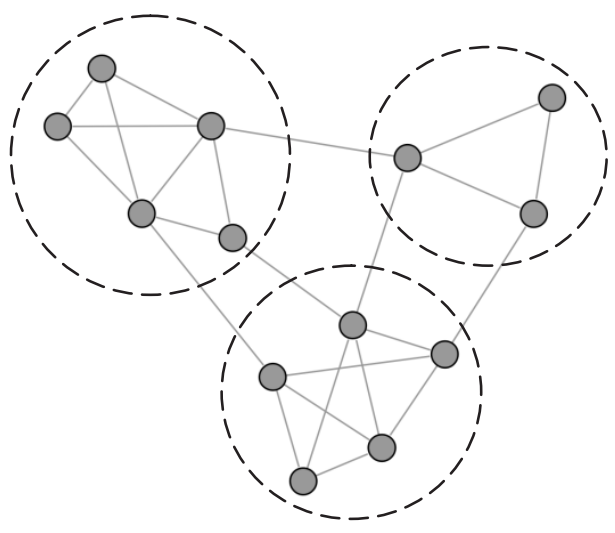

Figure 9. Community structure in a small network.

A value of $Q=0$ indicates that the detected community structure is not better than random, whereas positive values, up to the maximum positive value of $Q=1$, indicate stronger community structure of densely connected communities with sparse inter-community links. ${ }^{381}$ Most real networks return values of $Q$ between 0.3 and $0.7 .^{382}$ Accordingly, values of $Q \geq 0.3$ are considered in practice to be associated with significant community structure. ${ }^{383}$

There are many different methods to detect communities in networks, ${ }^{384}$ but we will only use two. The first method we apply is the Girvan-Newman algorithm $(\mathrm{GN}){ }^{385}$ The second community detection method is the Louvain method. ${ }^{386}$ Both methods are well accepted and proven techniques for good quality community detection. The Louvain method was found to return one of the best results. ${ }^{387}$ The basic difference is that GN is a (hierarchical) divisive algorithm and Louvain is an optimisation method. The former finds communities by deleting edges between nodes and so dividing the network and the latter combines nodes in communities in order to optimise the modularity. The two techniques are further introduced in the below sections.

Prior research used the Newman (2004) fast-greedy algorithm to find communities in case law networks. ${ }^{388}$ Newman is an optimisation method which attempts to optimise modularity by grouping nodes in communities. The

381 Newman and Girvan (2004).

382 Newman and Girvan (2004).

383 Clauset, et al. (2004).

384 Boccaletti, et al. (2006), pp. 275-287; Fortunato (2010); Lancichinetti and Fortunato (2009); Newman (2011).

385 Girvan and Newman (2002).

386 Blondel, et al. (2008).

387 Lancichinetti and Fortunato (2009).

${ }^{388}$ Lupu and Voeten (2012). 
Newman algorithm requires less computing time than GN. ${ }^{389}$ For larger networks of more than a few thousand nodes, it is therefore efficient to apply Newman instead of GN. However, the two algorithms detect communities with equivalent stabilities, and GN usually detects more, thus smaller, communities in the networks. ${ }^{390}$ Considering that we analyse a rather small network and detailed data about the attributes of the cases enable an easy analysis of smaller communities, ${ }^{391}$ we first apply GN to our network. This essentially follows the suggestion made by Newman to continue to apply GN in computationally tractable situations, such as the one here, because it generally provides better results. $^{392}$

As a robustness check, we nonetheless detected community structure with the algorithm of Clauset, Newman and Moore (CNM), which is a fast implementation of Newman and produces equivalent results. ${ }^{393}$ A run of CNM on the full case law network returned 20 communities, but a higher value of $Q=0.382$ when compared to $\mathrm{GN}$, see below. Yet, we will see that this modularity is still lower than the value returned by the Louvain method. ${ }^{394}$ For that reason we prefer the Louvain method as a basis for our conclusions. Upon qualitative analysis, we found that the results of the Louvain method differed only slightly from the community structure that CNM detected. Specifically, CNM found a strong organisation of sample cases on personal income taxes and (nonharmonised) corporation taxes in the two largest communities.

\subsubsection{Qualitative expectations}

As we have seen in Chapter 3, there are two basic perspectives to organise the case law in the field of direct taxes into different legally relevant categories. We could first make a legally relevant classification of cases along the lines of the legal basis in EU law of the decision. A community structure along this classification means that, for example, cases on freedom of workers are more densely connected to other freedom of workers cases than to cases on the free movement of capital. Second, from the national law perspective, the substance matter of the dispute may provide another reason to classify cases in the same community. This could mean, for example, that cases dealing with corporation taxes are grouped in a different community in the network than cases dealing with personal income taxes.

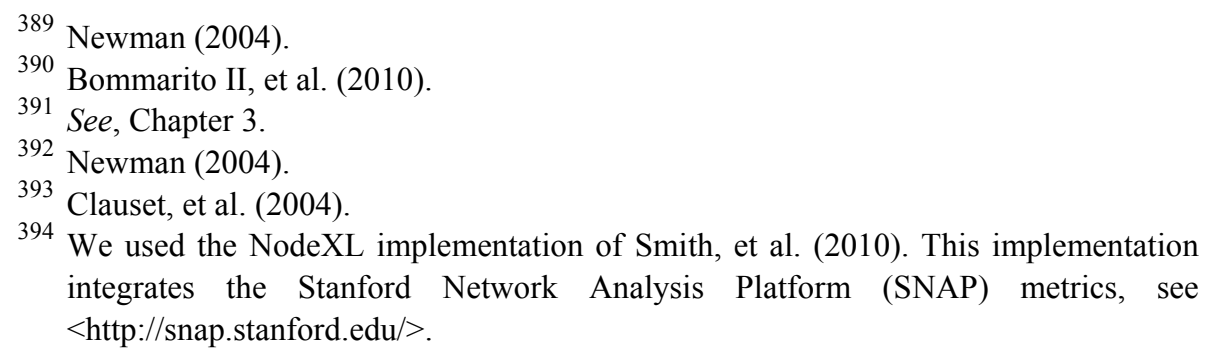


These two classifications are however correlated. For example, a corporation tax case is more likely to be decided in the context of freedom of establishment or capital, instead of the freedom of workers. Personal income tax cases on taxation of income from employment or from professional services are likely to be decided on the basis of the freedom of workers or free movement of services, but cases relating to taxation of private businesses would probably mainly fall within the scope of freedom of establishment. More relations like this are equally self-evident. The question as regards a legally relevant community structure of the case law network in the field of direct taxes is thus not a onedimensional issue, but should be approached in an attempt to achieve a plausible two-dimensional classification of communities.

The question is thus whether the EU law and national subject matter perspective jointly explain the organisation in communities and accordingly give legal relevance to the structure of the case law network, in that cases relating to the similar legal issues for similar circumstances are more densely connected through citation of precedent than cases resolving different types of disputes?

A community structure of the case law network does not necessarily only relate to substantive legal grounds. Other potential factors include differences in views between Chambers of the Court, the origin of the case (i.e. which Member State litigated), and, possibly, temporal spatiality between periods of the Court. ${ }^{395}$

However, if an observable organisation of the case law into different communities cannot be reasonably explained on plausible legal grounds, this result would conflict directly with the fundamental assumption that the choice of precedent is primarily based on the degree of substantive similarity of circumstances and legal issues between cases. Citation of precedent would in that case not evidence a constraint on judicial decision making set by the interpretation of the law according to positive legal doctrine, but we would observe a result which is contrary to the political and legal theoretical framework on the authority of precedent as presented in Section 2.3. We will see that this is not the case here.

The absence of any community structure in the case law network does not, in itself, lead to the rejection of the hypothesis that precedents are cited because of substantive similarity. ${ }^{396}$ The network of cases on EU law in the field of direct taxation is plausibly a community of the larger network of the complete body of the Court's case law.

We have seen in the previous Chapter that almost all cases in the field of direct taxation are decided on the basis of the fundamental freedom provisions in the TFEU. Then, if there are no communities within the network of direct tax cases, that could also be taken as indirect evidence for the proposition that the freedoms have converged. That proposition asserts that the legal analysis to test

395 Temporal spatiality has been observed for the US Supreme Court; Leicht, et al. (2007).

396 Recall, we assumed that citations are reliable evidence for legal analogies. 
the compatibility of national measures with a fundamental freedom provision of the Treaty is so similar for each of the freedoms that the judicial rules developed for the interpretation of the several Treaty provisions are becoming functionally equivalent. ${ }^{397}$ Accordingly, if the Court indeed aims to communicate the truth of this proposition through its decisions, it has no interest in discriminating between judicial doctrine in e.g. the sphere of freedom of workers or free movement of capital for purposes of its choice of precedent. In short, the citation links would not lead to a significant community structure along the lines of the different legal bases for the case law in the field of direct taxes. Also, because we only look at direct taxation cases which, for the most part, concern income taxes, it is also very well possible that there is no organisation of cases along the lines of national subject matter.

The evident way to test the truth of the fundamental assumption that the Court cites precedent in a legally relevant manner is then to examine the community structure of the entire body of the Court's case law. However, that question is beyond the scope of this book. That limitation is defensible because the assumption is well accepted in prior research. Furthermore, very recent research found that there is a community structure in the entire body of Court's case law which is organised in a legally relevant manner. ${ }^{398}$ Also, the results of Mirshahvalad et al. give evidence that there is indeed a certain convergence between the freedoms. ${ }^{399}$ Consequently, we zoom in on the rather homogeneous subset of cases that deal with the interpretation of EU law in the field of direct taxes particularly with the aim to find out if community detection can uncover distinct lines of authority by computational methods.

\subsubsection{Girvan-Newman method}

\subsubsection{Method}

It is appropriate to first apply GN to find communities in the network of the Court's case law in the field of direct taxes. This algorithm is a widely-used method developed for community detection in various social and biological networks. ${ }^{400}$ It is found to provide stable results for legal citation networks. ${ }^{401}$

GN detects community structures in networks by sequentially deleting edges from the network. The order of deletion is determined by the measure of betweenness of edges. The betweenness of an edge is defined as the number of shortest paths between any two nodes that run along it. The higher number of shortest paths running along an edge, the more information flows between those

\footnotetext{
397 See e.g., Tryfonidou (2010).

${ }^{398}$ Mirshahvalad, et al. (2012).

${ }^{399}$ Mirshahvalad, et al. (2012), p. 6.

400 Girvan and Newman (2002).

401 Bommarito II, et al. (2010).
} 
nodes and, recalling the small-world network model, the more likely the edge is 'between' different communities of nodes. Hence, inter-community edges are likely to have a high betweenness because they bridge communities. GN divides the network into communities by deleting edges with the highest betweenness. This process is reiterative until no edges remain and the betweenness of the edges affected by the deletion is recalculated after each deletion.

\subsubsection{Results}

GN found 36 communities $(Q=0.239)$, of which only four included 15 cases or more. ${ }^{402}$ The modularity is rather low, which indicates that the detected community structure is not significant. This is confirmed upon examination of the size of the communities.

Community 1 is in total 320 cases and the second consists of 30 cases. The third community is 20 cases and there are 15 cases in community 4. The distribution of the sample cases over these groups is as follows. In community 1 there are 136 sample cases $(=70.8 \%)$, community 2 includes four sample cases and six sample cases are in community 3 . However, there is only one sample case in community 4, so we do not expect this community to give meaningful insights. In contrast, there are seven sample cases in community 9 , which is only 11 cases large in total. Community 22 has three sample cases but is only seven cases large. The 30 other communities, of which five are the smaller disconnected components, all have only one or two sample cases.

The cases in community 1 have no particular attribute in common that distinguishes them from the cases in the other groups. There is no separation along legal basis or national subject matter of proceedings. This absence of community structure is consistent with the converging interpretation of the fundamental freedoms, but it does not imply that the network of case law lacks meaningful organisation when the following results are considered.

The sample cases of community 2 have in common that they are cases on income taxation of individuals and were decided on the legal basis of the general right to free movement of Article 21 TFEU. ${ }^{403}$ Most sample cases on Article 21 TFEU are in group 1. Nonetheless, community 2 suggests a particular relevance of Union citizenship in the Court's reliance on precedent which deserves further legal analysis. ${ }^{404}$

The six sample cases of community 3 concern only the interpretation of the Mergers Taxation Directive (2009/133/EEC). Considering that the Court decided eight cases in total on this directive, this community suggests that there is a structural division between judicial doctrine in harmonised areas of EU law in the field of direct taxes and non-harmonised law.

\footnotetext{
${ }^{402}$ We used the NodeXL implementation of Smith, et al. (2010).

403 Commission v Germany (C-318/05); Schwarz and Gootjes-Schwarz (C-76/05); Rüffler (C-544/07); Zanotti (C-56/09).

404 See, Section 3.4.2.1.1.
} 
Community 9 is organised of cases on the Parent-Subsidiary Directive (90/435/EC) and includes the only case on the Interest \& Royalties Directive $(2003 / 49 / \mathrm{EC}){ }^{405}$ All of these sample cases did not cite to a TFEU provision in the operative part of the ruling (dispositif), in contrast to the sample cases on the Parent-Subsidiary Directive which also interpreted the TFEU and are grouped in community 1.406

A structural divide between harmonised and non-harmonised EU law in the field of direct taxation follows furthermore from the very few inter-community edges between communities 1 and 3 . There are three edges running from community 1 to community 3, and also three edges in the opposite direction. Community 3 has 20 nodes and 27 intra-community edges.

Also, community 1 cases on the Parent-Subsidiary Directive cite community 9 cases, which is evidenced by 13 edges in that direction. However, only four edges are directed from community 9 to community 1 . Community 9 has 11 nodes and 14 intra-community edges.

In contrast, there is a relatively strong reciprocal tie between groups 1 and 2 . The number of inter-community edges from community 1 to community 2 is 23 and there are 18 edges directed from community 2 to community 1 . To put these numbers into context, recall that there are 30 vertices (cases) in community 2 and note that there are 60 intra-community edges in group 2.

The exchange of legal ideas or flow of information between the two groups we interpret from the inter-community edges between communities 1 and 2 in both directions does not suggest that the principle of non-discrimination and freedom to move and reside are interpreted significantly different depending on whether the general or the specific provisions apply. We have already seen in the previous Chapter that the case law on Articles 18 and 21 TFEU is very clear on the point that the rights contained in these provisions have found specific expression in the specific fundamental freedoms and the consequential point that Articles 18 and 21 TFEU serve a residual function in that they apply only when the situation of the case at hand is not covered by the material scope of the specific freedoms. The legal interpretation of the formal structural relations between provisions of the TFEU is therefore consistent with community structure in the network of case law in the field of direct taxes.

Denkavit International, VITIC Amsterdam \& Voormeer (Joined Cases C-283, 291\&292/94); EPSON Europe (C-375/98); Athinaïki Zythopoiia (C-294/99); Banque Fédérative du Crédit Mutuel (C-27/07); and Scheuten Solar Technology (C-397/09).

406 Furthermore, the sample cases of Community 22 are also exclusively about the Parent-Subsidiary Directive, Océ van der Grinten (C-58/01); and Ferrero and General Beverage Europe (Joined Cases C-338 \& 339/08). 


\subsubsection{Louvain method}

\subsubsection{Method}

The multi-level modularity optimisation method as developed in Blondel et al., ${ }^{407}$ commonly referred to as the 'Louvain method', is a relatively recent algorithm which compares favourably to other algorithms in terms of computing time and accuracy of detected communities. ${ }^{408}$ The Louvain method accurately detected scientific specialities in author cocitation networks. ${ }^{409}$ It has also been applied to a citation network of more than six million research papers and the community structure corresponded well to the various research fields. ${ }^{410}$

The Louvain method optimizes $Q$ in one or more passes consisting of two phases. ${ }^{41}$ This procedure can be described informally as follows. In the first phase, each node is considered to constitute a community on its own. Then, pairs of neighbouring nodes are aggregated into the same community by taking one node from its own community and moving it to the community of one of its neighbouring nodes. A node $i$ is aggregated with the community of a specific neighbour $j$ if the $i, j$ grouping achieves the maximum positive gain in $Q$ compared to the other possible groupings with different neighbours of $i$. This process is repeated sequentially until no positive gains in modularity can be achieved by moving individual nodes into a neighbouring community.

In the second phase, the communities of nodes of the first phase are regarded as individual nodes in a new network. The steps of the first phase are repeated to this redefined network, meaning that neighbouring communities found in the first phase are merged in order to achieve maximal positive gains in modularity. These two phases are iterated until $Q$ is maximal for the network, i.e. until no positive gains in modularity can be achieved by another pass.

\subsubsection{Results}

The Louvain method found ten communities in the main component and the modularity of $Q=0.406$ indicates significant, but not very strong community structure. ${ }^{412}$ Table 16 provides an overview of the size of each community by total cases (including the non-sample cases in the network) and by sample cases. In that respect, it should be noted that communities 2 and 6 are too small to provide meaningful information on the organisation of the body of case law and

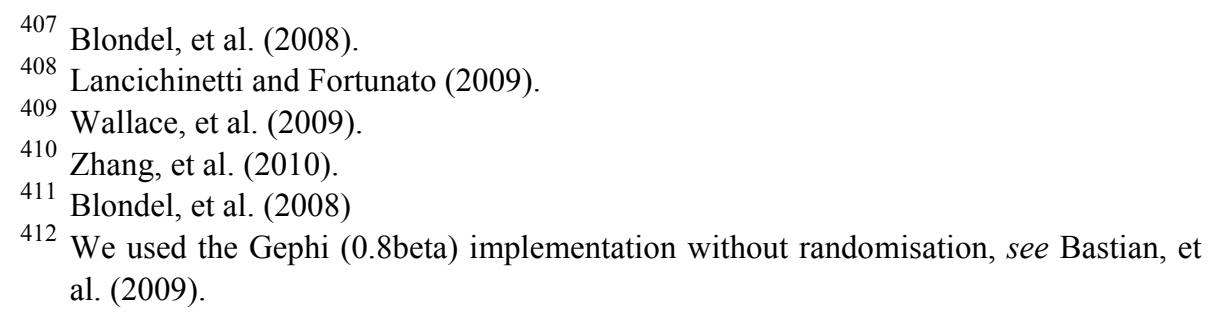




\begin{tabular}{|c|c|c|c|c|c|c|}
\hline \multirow{2}{*}{ Community } & \multicolumn{4}{|c|}{$n$ Cases } & \multirow{2}{*}{$\begin{array}{c}\% \text { Sample } \\
\text { of total }\end{array}$} & \multirow{2}{*}{$\begin{array}{c}\% \text { Total } \\
\text { of Giant } \\
\text { Componen }\end{array}$} \\
\hline & Directive & TFEU & Sample & Total & & \\
\hline 1 & 0 & 20 & 21 & 52 & 40 & 8.46 \\
\hline 2 & 0 & 1 & 2 & 12 & 17 & 1.95 \\
\hline 3 & 3 & 47 & 48 & 93 & 52 & 15.12 \\
\hline 4 & 2 & 27 & 29 & 74 & 39 & 12.03 \\
\hline 5 & 0 & 13 & 14 & 76 & 18 & 12.36 \\
\hline 6 & 1 & 3 & 4 & 36 & 11 & 5.85 \\
\hline 7 & 0 & 10 & 10 & 58 & 17 & 9.43 \\
\hline 8 & 13 & 9 & 22 & 96 & 23 & 15.61 \\
\hline 9 & 6 & 0 & 6 & 22 & 27 & 3.58 \\
\hline 10 & 1 & 28 & 29 & 77 & 38 & 12.52 \\
\hline
\end{tabular}

Table 16. Communities: legal basis and size

will not be evaluated below. Since the Court's institutional function is to interpret EU law we will primarily distinguish the communities in terms of EU law subject matter. The national subject matter is treated as a secondary distinguishing feature.

Also note the following. The reason why there is one case less on the TFEU than that there are sample case in community 1 is that Commission $v$ Netherlands (C-521/07) relied exclusively on Article 40 of the EEA Agreement in the ruling. The preliminary reference in Schmid (C-516/99) of community 2 was held inadmissible by the Court and did not cite any of the Treaty provisions for which the cases were coded. Hengartner and Gasser (C-70/09) of community 5 was ruled on the Agreement on the free movement of persons between the EC and its Member States, and Switzerland.

Table 16 shows that communities 8 and 9 are about the interpretation of the directives. Community 8 includes cases on the Parent-Subsidiary Directive. Also, the only case on the Interest and Royalties Directive is grouped in this community. ${ }^{413}$ In terms of national subject matter, community 8 includes two cases on personal income taxes, ${ }^{414}$ and two cases on taxes on financial and capital transactions (OECD class 4400). ${ }^{415}$ All other cases are about corporation taxes (OECD class 1200). There are five cases (four rulings due to joinder of cases) on corporation taxes which do not cite a directive. ${ }^{416}$ Only one of those two cases is not about the taxation of dividends. ${ }^{417}$

\footnotetext{
413 Scheuten Solar Technology (C-397/09).

${ }^{414}$ N. (C-470/04) (OECD class 1120); and Meilicke II (C-262/09) (OECD class 1110).

415 Halliburton Services (C-1/93); and Commission v Italy (C-197/03).

416 FII Group Litigation (C-446/04); Metallgesellschaft and Others \& Hoechst (Joined Cases C-397\&410/98); Royal Bank of Scotland (C-311/97); and Accor (C-310/09).

417 Royal Bank of Scotland.
} 
The cases on the Mergers Taxation Directive are all grouped together in community $9,^{418}$ except for the two cases which were isolated from the giant component. ${ }^{419}$ It should be recalled that these two cases were not about the interpretation of the directive but concerned the failure of the Member States concerned to transpose the directive within the prescribed period. ${ }^{420}$ The results of the Louvain method correspond to GN in regards these cases.

The seven cases on the interpretation of directives which were grouped in communities 3, 4, 6, and 10 all concerned the Parent-Subsidiary Directive. However, these cases concerned either fully or partly situations which ultimately fell outside the scope of application of that directive. ${ }^{421}$ The Court therefore had to resolve the material issues in those cases by interpretation of the TFEU. In contrast, only one case in community 8, Burda (C-284/06), cited both the Parent-Subsidiary Directive and the TFEU, specifically Article 49 TFEU. The distinguishing feature of that case is that the situation of that case was indeed covered by the material scope of the Parent-Subsidiary Directive, but that directive did not preclude the national measure in issue.

In the following paragraphs we will focus on the remaining communities. For that purpose, Table 17 provides an overview of the EU law subject matter of the sample cases in the selected communities by the provision of the TFEU that the Court cited in the ruling. Because the Court did not rely frequently on Articles 18 TFEU and 64 TFEU, these provisions are ignored below. The national subject matter is presented by a consolidation of OECD classes. All personal income tax cases are consolidated as OECD class 1100 and the same is true for the corporation tax cases which are presented as OECD class 1200. Since there was only one case in OECD class 1300 and only one case in OECD class 3000 , we also ignore these classes in the following discussion. Any distinctions on the basis of the fact whether the case concerned the taxation of capital gains or dividends will be explained in the text only.

The most cited TFEU provision by the sample cases in community 1 is Article 45 on the free movement of workers. Although Articles 49 and 63 TFEU are also cited in this community in six sample cases, most cases on the freedom of establishment and free movement of capital are grouped in communities 3 and 4.

The sample cases in community 1 are almost exclusively about personal income taxes. There is only one case in community 1 about corporation taxes. ${ }^{422}$

418 Leur-Bloem (C-28/95); Andersen og Jensen (C-43/00); Kofoed (C-321/05); A.T. (C285/07); Zwijnenburg (C-352/08); and FOGGIA-SGPS (C-126/10).

419 Commission v Greece (C-8/97); and Commission v Belgium (C-392/07).

${ }^{420}$ Section 4.2.

421 Amurta (C-379/05); Aberdeen Property Fininvest Alpha (C-303/07); KBC Bank and Beleggen, Risicokapitaalbeheer (Joined Cases 439 \& 499/07); Les Vergers du Vieux Tauves (C-48/07); and Commission v Germany (C-284/09).

${ }^{422}$ Commission $v$ Netherlands (C-521/07). This case is not shown in Table 17 because the case was ruled on Article 40 of the EEA Agreement. 


\begin{tabular}{cccccccccc}
\hline Community & OECD Class & \multicolumn{1}{c}{ Sample cases on } & TFE Article & n Sample cases \\
& & 21 & 45 & 49 & 54 & 56 & 63 & 65 & Totals \\
\hline 1 & 1100 & 1 & 8 & 6 & 0 & 1 & 3 & 0 & 17 \\
& 1200 & 0 & 0 & 0 & 0 & 0 & 0 & 0 & 1 \\
3 & 4000 & 0 & 0 & 0 & 0 & 0 & 3 & 2 & 3 \\
& 1100 & 0 & 0 & 3 & 1 & 0 & 6 & 1 & 7 \\
4 & 1200 & 0 & 0 & 28 & 14 & 0 & 10 & 4 & 37 \\
& 4000 & 0 & 0 & 3 & 1 & 0 & 0 & 0 & 3 \\
& 1100 & 0 & 0 & 1 & 1 & 0 & 10 & 4 & 10 \\
5 & 1200 & 0 & 0 & 4 & 2 & 0 & 7 & 1 & 8 \\
& 4000 & 0 & 0 & 0 & 0 & 0 & 9 & 5 & 11 \\
7 & 1100 & 4 & 9 & 3 & 0 & 1 & 0 & 0 & 11 \\
& 1200 & 0 & 0 & 0 & 0 & 2 & 0 & 0 & 2 \\
& 4000 & 1 & 1 & 1 & 0 & 0 & 0 & 0 & 1 \\
& 1100 & 6 & 2 & 2 & 0 & 5 & 0 & 0 & 9 \\
10 & 1200 & 0 & 0 & 0 & 0 & 1 & 0 & 0 & 1 \\
& 4000 & 0 & 0 & 0 & 0 & 0 & 0 & 0 & 0 \\
& 1100 & 1 & 4 & 3 & 0 & 14 & 7 & 2 & 20 \\
& 1200 & 0 & 0 & 2 & 0 & 5 & 1 & 1 & 7 \\
\hline
\end{tabular}

Table 17. Communities: subject matter

Three cases are about property taxes in this community. ${ }^{423}$ All cases which concerned Article 45 TFEU were, logically, about personal income taxes. If we consider only the cases of this community that cited Article 49 TFEU in the ruling we find that all six cases were also about personal income taxes. Five of these cases were preliminary references and the facts of these cases further substantiate the claim that community 1 is, broadly speaking, about the application of free movement of persons to personal income taxes on workers or selfemployed persons. ${ }^{424}$

The taxpayer in Asscher was director of the company of which he was the sole shareholder. The Court therefore considered that he exercised freedom of movement as a self-employed person, since he was not in a relation of subordination which is a material condition for the definition of worker for purposes of Article 45 TFEU. ${ }^{425}$ Consequently, freedom of workers did not apply to him, even though he was considered a worker for the purposes of the national legislation in issue in Asscher. Also the taxpayers in Talotta, Conijn and Gielen exercised freedom of movement in their capacity as self-employed persons by running a business through an undertaking in another Member State than their Member State of residence. Although the taxpayer in Werner ran a

\footnotetext{
423 Sandoz (C-439/97); D. (C-376/03); and Commission v Belgium (C-250/08).

424 The only direct action that was ruled on Article 49 TFEU in Community 1 was

${ }^{425}$ Asscher, paras 25-27.
} 
dental practice in his Member State of residence, and the Court finally ruled that the situation was purely internal, he was also a self-employed person.

Community 3 is clearly about the freedom of establishment as applied to corporation taxes; 37 of 48 sample cases are about corporation taxes. Of all 24 sample cases on Article 54 TFEU a total of 17 cases are grouped in community 3. 16 cases in this community cite Treaty provisions on free movement of capital. A clear majority $(n=11)$ of these cases were about the taxation of dividends. Although there are seven Article 63 TFEU cases on the taxation of dividends in community $4,{ }^{426}$ the majority of cases on free movement of capital in community 4 do not concern the taxation of dividends. Of the remaining five cases, only one concerned personal income taxes. The relevant ruling in Columbus Container Services (C-298/05) was about the taxation of income earned by partners in a partnership which was considered tax transparent in the Member State of residence of the partners.

Community 4 particularly includes cases on the free movement of capital. As stated above, cases on the taxation of dividends account for a minority of case in this community. Also, there are only a few cases on corporation taxes in this community. The evident distinguishing national subject matter of community 4 is property taxes and this is the main distinguishing feature from the other communities. Specifically, nine of ten cases in the sample on estate, inheritance and gift taxes (OECD class 4300) are in community $4 .{ }^{427}$ Furthermore, two of three cases on recurrent taxes on immovable property on other taxpayers than households (OECD class 4120) are in community 4. In contrast, no cases on recurrent taxes on net wealth are in this community, but these are grouped in community $1,{ }^{428}$ or in community $3{ }^{429}$ There are also no cases on taxes on financial and capital transactions (OECD class 4400) in community 4, but these can be found in community $1,{ }^{430}$ community $5,{ }^{431}$ and community $8 .{ }^{432}$

Community 5 shares basic characteristics with community 1 in that both communities concern cases on the application of the free movement of persons to personal income taxes. The two communities may however be distinguished on Article 21 TFEU. Whereas community 1 includes only one case on the freedom to move and reside protected by Article 21, there are five cases on Article 21 TFEU in community 5. Further distinguishing features will be reviewed with the analysis of subcommunities below.

Community 7 is similar to community 5 , since community 7 includes six sample cases on Article $21 \mathrm{TFEU}$, which is one more than in community 5. The

426 The number of rulings is five due to joinder of cases. Manninen (C-319/02); $A$ (C101/05); CFC and Dividend Group Litigation (C-201/05).

427 Geurts and Vogten (C-464/05) is in Community 3.

428 D. (C-376/03).

429 Baars (C-251/98); and Heinrich Bauer Verlag (C-360/06).

430 Sandoz (C-439/97); and Commission v Belgium (C-250/08).

431 Commission v Greece (C-155/09).

432 Halliburton Services (C-1/93); and Commission v Italy (C-197/03). 
distinguishing feature between communities 5 and 7 is that the most cited specific free movement provision in the former is Article 45 TFEU, whereas the sample cases of the latter community particularly rely on the freedom to provide services of Article 56 TFEU.

The distinguishing feature of community 10 is that this community includes the absolute majority of sample cases on Article 56 TFEU and particularly in respect of its application to personal income taxes. Only six of 29 sample cases in community 10 are about corporation taxes, and four of these cite freedom to provide services as legal basis, while in two cases the Court interpreted freedom of establishment.

In synthesis, we have established now that the two community detection algorithms found a legally relevant community structure in the case law network. Both methods found an organisation of, on the one hand, cases which interpreted the direct tax directives and, on the other hand, cases interpreting the TFEU. Also, both methods found a structural division within the collection of cases on the TFEU in that cases dealing with Article 21 TFEU were grouped in distinct communities. The meso-structure of the network that was established with the Louvain method was more detailed than the community structure that GN identified; the Louvain method found more communities which provided meaningful information.

\subsubsection{Subcommunities}

\subsubsection{Introduction}

The results of the previous section provide persuasive evidence for the claim that the case law in the field of direct taxes is organised in a legally relevant manner. The community structure is however still rather rough. Notwithstanding the interesting results that subcollections of similar cases may be found quantitatively by computation instead of qualitative analysis through legal review, we could analyse the structural organisation further and at a larger magnification. In other words, is there also a nested structural organisation within the communities? For example, does the Court distinguish in its judicial doctrine between specific issues concerning personal income taxes? If so, we would hope to find distinct subcommunities within communities 1 and 5 that represent distinct line of authority.

For the purpose of this research question, we followed the suggestion in Blondel et al. to consider each community as a separate network, thereby ignoring inter-community links at the highest hierarchical level. ${ }^{433}$ The Louvain method was reapplied to the communities that are larger than 50 cases to unfold their lower-level hierarchical structure. This implies that, besides communities 2

433 Blondel, et al. (2008). 


\begin{tabular}{cccl}
\hline Community & $n$ Subcomm. & Modularity $(Q)$ & \multicolumn{1}{c}{ Subject matter } \\
\hline 1 & 5 & 0.502 & personal income taxes / employment \\
2 & n.a. & n.a. & n.a. \\
3 & 4 & 0.254 & corporation taxes / dividends \\
4 & 7 & 0.421 & property taxes \\
5 & 6 & 0.594 & Article 21 TFEU / Article 45 TFEU \\
6 & n.a. & n.a. & n.a. \\
7 & 5 & 0.436 & Article 21 TFEU / Article 56 TFEU \\
8 & 8 & 0.517 & Parent-Subsidiary Directive \\
9 & n.a. & n.a. & Mergers Taxation Directive \\
10 & 6 & 0.412 & personal income taxes / services \\
\hline
\end{tabular}

Table 18. Subcommunities by Louvain method

and 6 which were already left unconsidered above, community 9 is also not analysed further below.

\subsubsection{Results}

Table 18 provides the results of the Louvain method for the seven communities which were larger than 50 cases. The networks of the seven remaining communities are shown in Figure 10. ${ }^{434}$ The number of subcommunities varies between four and eight, with a mean value of 5.86 and a median of six subcommunities.

Especially communities 1,5 and 8 show a relatively strong community structure of groups of densely connected cases which are only sparsely connected to the other subcommunities, which is reflected by their relatively high modularity $Q$. This suggests that distinct lines of authority may be identified through a qualitative analysis. In contrast, community 3 has a low modularity and also no significant community structure is evident from Figure $10(b)$.

The sections which follow carry out a qualitative analysis of selected communities. For the purpose of assessing whether the quantitative analysis has face validity in terms of a legally relevant organisation of the case law it is not necessary to examine all communities.

We have chosen not to subject community 4 to a further analysis, since we established that this community is clearly distinct from the other communities in that it includes the bulk of the case law on property taxes. We also found that property taxes are least prevalent in the Court's case law, so that a qualitative analysis of the subcommunities in this regard is likely not to be of major relevance to the overall organisation and structure of the body of case law. ${ }^{435}$ For those reasons, it is warranted to leave the analysis of this community for future research.

\footnotetext{
${ }^{434}$ Visualisations were made with Gephi (0.8beta) using the Force Atlas layout.

${ }^{435}$ For reviews, see e.g. Liberatore (2010); Navez (2012); Peeters (2012).
} 


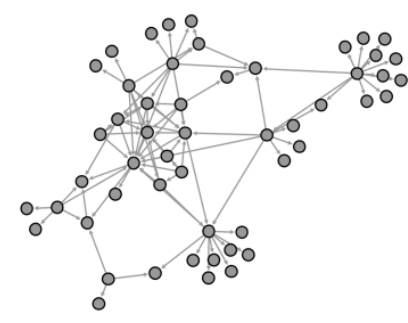

(a) Community 1

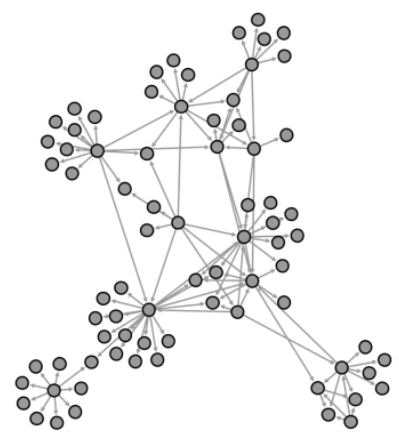

(c) Community 5

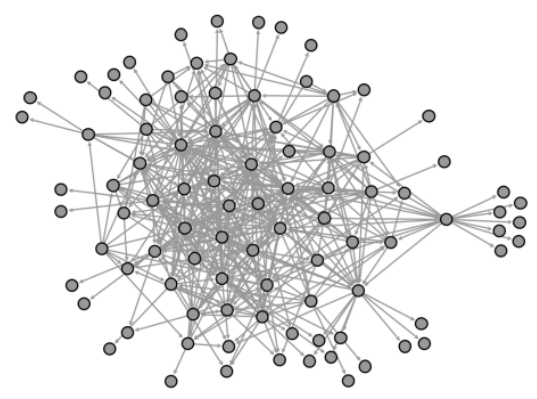

(b) Community 3

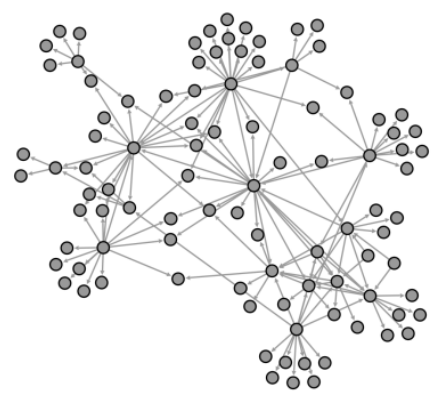

(d) Community 8

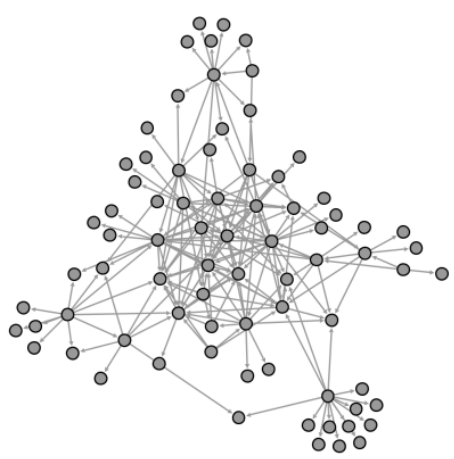

(e) Community 10

Figure 10. Networks of the five selected communities.

Also community 7 will be left out in favour of community 5 , which we found was approximately similar in terms of subject matter, because community 5 has a higher modularity value and the highest of all communities and we therefore expect a pronounced community structure also by qualitative analysis. Communities 5 and 7 are comparable in total size and the proportion and of sample cases of the total cases in the communities. Although their subject matter may be different considering the TFEU subject matter, this alone does not justify a full qualitative analysis. 
To sum up, we will carry out a qualitative analysis of the two communities with the highest modularity (communities 5 and 8), the lowest modularity (communities 3 and 10) and community 1, since this is the main community on personal income taxes and it is similar in terms of subject matter to community 5 , but has a lower modularity. We believe that this selection gives an accurate qualitative overview of the body of case law in the field of direct taxes

\subsubsection{Qualitative analysis of community 1}

\subsection{Preliminary remarks}

The main subcommunity in community 1 is a line of authority that started in direct taxation with Schumacker (C-279/93) and concerns in short the degree to which EU law requires Member States to grant tax advantages attached to personal and family circumstances to non-resident taxpayers for consideration of their overall ability to pay tax. Figure 11 shows the network of this community in a larger version, including the short names of the cases that will be discussed in the next subsections. This is to give a visual example that illustrates in more detail how the qualitative analysis in this and the following sections was guided by the network analysis. The node size and the label size are proportional to the indegree of the node.

Since we will not revisit the cases of this community subsequently in this book, we have included a rather extensive review of this line of authority. The main purpose of that review is to highlight the development of judicial doctrine by analysing the relations between and the role of the several cases that establish the distinct argumentative framework on EU law in the context of personal income taxes and cross-border workers.

Schumacker is not the first case that reached the Court on the different treatment of resident and non-resident taxpayers. Three prior cases, which may be considered to be the prelude to Schumacker, were grouped in the same subcommunity and are also reviewed below.

The Asscher (C-107/94) case was grouped in a separate subcommunity. This case is somewhat different from the other Schumacker-type cases in that Asscher concerned the general ability to pay with reference to the applicable progressive tax rate, whereas the Schumacker line of authority concerned specific tax advantages attached to personal and family circumstances. The Asscher case may be better compared to the case law following De Groot (C-385/00) that is discussed in relation to community 5 in Section 4.3.5.5. That line of authority concerned to a greater extent general issues of tax rate progressivity and ability to pay with reference to aggregate income. Furthermore, the De Groot line of authority is also specific in that it includes cases of Union citizens against the Member State of which they are nationals, and the Court was thus forced to go beyond the narrative of indirect discrimination on grounds of nationality and to 


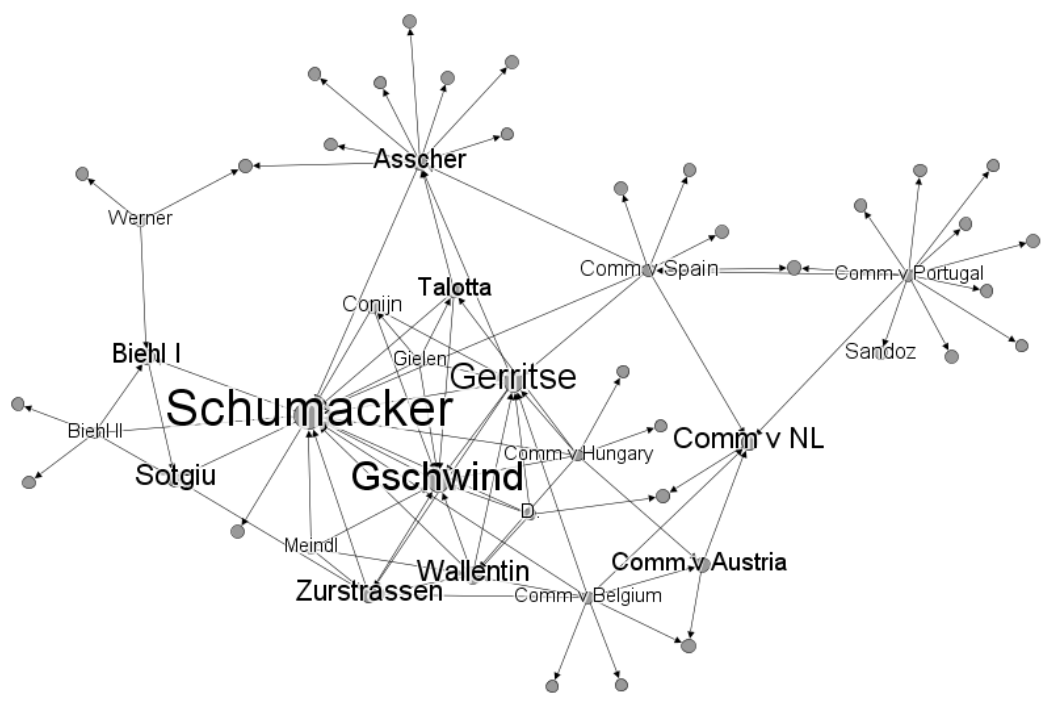

Figure 11. Community 1 with short case names.

adopt the restriction based language developed in Säger and Kraus. In contrast, Asscher stays well within the framework of indirect nationality discrimination as applied in Schumacker.

The main issue in Asscher was whether a Member State could apply a higher statutory rate of personal income taxation to the income earned by a nonresident from activities pursued on the national territory of the Member State concerned than the rate that applied to residents who were taxable on the same amount of income. The Court ruled that this constituted indirect discrimination on nationality that could not be justified. The Member State concerned (the Netherlands) argued that the higher rate assured that non-residents did not escape progressive taxation, but the Court recalled from Schumacker that this was primarily a matter for the Member State of residence of $\mathrm{Mr}$ Asscher according to international tax practice and that he was not at risk to escape progressivity in his Member State of residence due to application of the DTC (para 51). The fact that Mr Asscher was not properly insured in the Netherlands for social security could also not render the difference in treatment lawful, according to the Court.

Although the focus of this section will be on the Schumacker line of authority, we will also review two subcommunities which concern capital movement. The substantive overlap which explains their grouping in community 1 is the application of the Schumacker rules to capital movement in some of these cases. These cases furthermore concern related subject matter in that some of them are also about relations with EFTA States. Although the coherence between these cases is not as evident as the very strong coherence that we find in the subcommunity concerning the Schumacker line of authority, the 
organisation of the cases within these other subcommunities and their structural relations with the other subcommunities is still legally relevant and distinguishes these cases from cases in other communities.

\subsection{Prelude to Schumacker}

The Werner (C-112/91) case is a somewhat useless authority nowadays because the introduction of Union citizenship in the TFEU has changed the law insofar a transfer of residence for personal reasons, as was at issue in Werner, is currently afforded the same protection as an exercise of free movement for economic reasons. ${ }^{436}$ Nonetheless, the case concerned the same question as Schumacker, namely to what extent Member States may impose heavier tax burdens on nonresident taxpayers than on resident taxpayers, if the non-resident earns all or almost all of his income in the Member State concerned and that Member State refuses to grant tax relief associated with personal and family circumstances.

The proceedings in Biehl I (C-175/88) and Commission v Luxembourg (Biehl II) (C-151/94) concerned the same national measure of Luxembourg which precluded a repayment of overpaid wage tax, which was withheld and remitted to the Revenue by employers, to taxpayers who resided in Luxembourg for only part of the year, whereas taxpayers who were residents of Luxembourg during the full year could request a repayment of those taxes. The case of Biehl I laid the grounds for the landmark ruling in Schumacker because the Court applied its precedent of Sotgiu (152/73), which in its turn is itself a landmark ruling on free movement of persons and also the most cited non-sample case in this subcommunity, for the first time in the field of personal income taxes to establish that a different treatment based on residence potentially amounts to indirect discrimination on grounds of nationality. ${ }^{437}$ Although Biehl I and Biehl II concerned different treatment between full and partial residents, the Court again applied the rule of Sotgiu in Schumacker and held that different tax treatment between residents and non-residents could also amount to indirect discrimination on grounds of nationality.

436 Section 3.4.2.1.1.

437 The Court held in Sotgiu, para 11: 'The rules regarding equality of treatment, both in the Treaty and in article 7 of Regulation No 1612/68, forbid not only over discrimination by reason of nationality but also all covert forms of discrimination which, by the application of other criteria of differentiation, lead in fact to the same result. [...] It may therefore be that criteria such as place of origin or residence of a worker may, according to the circumstances, be tantamount, as regads their practical effect, to discrimination on the grounds of nationality, such as is prohibited by the Treaty and the Regulation.' 


\subsection{The Sotgiu/Schumacker line of authority}

The Schumacker (C-279/93) judgment is an important ruling not because it again affirmed and applied the rule of Sotgiu in the field of direct taxation, but rather because it qualified its conditions for application in this area of law. In that regard, the Schumacker ruling first introduced a general limitation to the Sotgiu rule for the field of direct taxation (the Schumacker-rule), and secondly established a specific exception to this first limitation (the Schumackerexception).

In Schumacker the Court first held, applying Sotgiu, that '...tax benefits granted only to residents of a Member State may constitute indirect discrimination by reason of nationality' (para 29). Non-residents are likely to be non-nationals of course. The crucial qualification in Schumacker was that the Court found that '[i]n relation to direct taxes, the situations of residents and of non-residents are not, as a rule, comparable' (para 31) and that therefore '...the fact that a Member State does not grant to a non-resident certain tax benefits which it grants to a resident is not, as a rule, discriminatory since those two categories of taxpayer are not in a comparable situation' (para 34). In paras 32 and 33 the Court explained that residents are taxed on the basis of the internationally recognised principle of overall taxation (the ability to pay principle), which is determined by reference to the taxpayer's aggregate income and his or her personal and family circumstances, and that non-residents are taxed on only the part of income earned in the host Member State. The Court reasoned that the major part of the income of taxpayers is normally concentrated in the Member State of residence, i.e. where the taxpayer has his usual abode, and that the situation of non-residents was consequently objectively different from the situation of residents. The Court also considered that it is more easy to assess the taxpayer's overall ability to pay by the Member State of residence, since this is the Member State in which the financial and personal interests of the taxpayer are centred, and which has generally available all the necessary information to assess the taxpayer's overall ability to pay. The first point of Schumacker is accordingly that it is in principle lawful to leave the assessment of the taxpayer's overall ability to pay an exclusive matter of the Member State in which the taxpayer resides.

This first point is actually not all that new if we recall that the Court already considered in Sotgiu that discrimination between residents and non-residents may be permitted if their different treatment corresponds to objective differences between their situations. The main point of Sotgiu was that in each case that revolves around a criterion of residence as a qualifying condition for a benefit, it is necessary to examine whether such a criterion is arbitrary or can be rationally explained in view of the aims of the national measure. In Sotgiu it concerned a separation allowance which was granted to workers in public service if they had to work in a different place than their place of residence. The Court reasoned in Sotgiu that it could be objectively justified to distinguish between workers who resided in a different place, but in the Member State in which they worked and workers who lived in another Member State altogether. The Court's analysis in 
Schumacker that taxpayers normally earn the major part of their income in the Member State of residence is intuitive and is a plausible representation of reality for the great majority of taxpayers. Accordingly, it is indeed fair to say that - as far as income taxes are concerned-residents and non-residents are not, as a rule, comparable. This is the Schumacker-rule.

The Schumacker-rule has suffered from criticism in prior research. One main argument submits that the rule is contrary to the Court's own recognition that the TFEU precludes any-it is stressed-discrimination on nationality. The argument essentially goes that the general limitation that Schumacker introduced is contrary to this basic principle. ${ }^{438}$ As explained in the immediately preceding paragraph, there is no tension between the non-tax case law (represented by Sotgiu here) and Schumacker; the recognition of objective differences is an intrinsic part of the fundamental freedoms as equality clauses. In income tax, there is an internationally recognised distinction between the scope of taxation of resident (universal taxation) and non-resident taxpayers (source taxation) which was (and is) customary practice within the Union. It is consistent with this distinction to deny benefits relating to personal and family circumstances to non-resident taxpayers, since those benefits systematically relate to taxation on basis of overall ability to pay, which is formally only imposed on resident taxpayers. The objective difference from the perspective of taxation by the Member State of employment is thus the fact that the overall ability to pay of persons who are non-resident taxpayers in that Member State is taken into account in another Member State.

A closely related point of criticism is that the Court's statement that taxpayers earn the major part of their income in their Member State of residence, is not true in regards the group of workers which EU law affords legal protection through the fundamental freedoms. ${ }^{439}$ Actually, the Court affirmed this point as valid in Schumacker and this is reflected in the second doctrinal 'innovation' of Schumacker which will be addressed below. According to the Court:

36. The position is different, however, in a case such as this one where the non-resident receives no significant income in the State of his residence and obtains the major part of his taxable income from an activity performed in the State of employment, with the result that the State of his residence is not in a position to grant him the benefits resulting from the taking into account of his personal and family circumstances.

37. There is no objective difference between the situations of such a nonresident and a resident engaged in comparable employment, such as to justify different treatment as regards the taking into account for taxation purposes of the taxpayer's personal and family circumstances.

438 Wattel (2004).

439 Wattel (2004). 
38 In the case of a non-resident who receives the major part of his income and almost all his family income in a Member State other than that of his residence, discrimination arises from the fact that his personal and family circumstances are taken into account neither in the State of residence nor in the State of employment.

The Court evidently was of the opinion that the exercise of freedom of movement could not render the ability to pay principle inapplicable. But, by ruling in Schumacker that this obligation only comes into effect if the Member State of residence cannot grant these tax benefits relating to overall ability to pay, the Court also assured that the taxpayer would not obtain a 'double' advantage merely be exercising freedom of movement. The Schumacker-exception thus comes into effect when the Member State of residence is not in a position to take account of overall ability to pay, because the taxpayer earns the major part of his income in another Member State so that there is insufficient tax liability in the Member State of residence to provide relief for personal and family circumstances. The Court's intermediate conclusion in para 41 makes this very clear:
41. [...] In a situation such as that in the main proceedings, the State of resi- dence cannot take account of the taxpayer' s personal and family circum- stances because the tax payable there is insufficient to enable it to do so. Where that is the case, the Community principle of equal treatment requires that, in the State of employment, the personal and family circumstances of a foreign non-resident be taken into account in the same way as those of resi- dent nationals and that the same tax benefits should be granted to him.

In this holding of para 41, the Court does not require an examination of the exact proportion of income that is taxable in the Member State of employment. We will see that the Court's approach to finding discrimination between residents and non-residents has consistently been reasoned with the position of the Member State of residence and less with the exact proportion of income that makes a non-resident comparable to a resident taxpayer in the Member State of employment. In the cases in which the Court found that the Member State of employment did not discriminate, this finding was reasoned with the argument that the Member State of residence was indeed in the position to consider the ability to pay as it could be assumed to be according to customary international tax practice as recognised by the Schumacker-rule. Only the ruling in $D$. evaluates the comparability closer which can be explained by the particular circumstance in that case that the Member State of residence did not impose any capital taxes on Mr D. and only a minor part of his capital was situated in the Member State in which he claimed the personal allowance.

The Court reiterated its position of Schumacker in Gschwind (C-391/97) and held that non-residents and residents were not generally comparable with regard to the objective differences between those categories of taxpayers '... both from the point of view of the source of their income and their personal ability to pay tax or their personal and family circumstances' (Gschwind, para 34). The Court also affirmed the exception to this general limitation, but explicitly distinguished 
the situation of Mr Gschwind from Mr Schumacker's situation, in that nearly $42 \%$ of the family income of the Gschwind couple was earned in their Member State of residence, so that this Member State was in a position to take account of their overall ability to pay (paras 28-30). The German national measure at issue, which only provided for national treatment of non-resident taxpayers based on them earning at least $90 \%$ of the family income in Germany or, if the proportion was less, applied only if their foreign income did not exceed an absolute fixed ceiling, was therefore not contrary to EU law in the sense that the situation of Mr Gschwind was improperly excluded from the scope of application of that rule.

Member States and authors of prior research have interpreted Gschwind to hold that the Member State of employment is not obliged to grant tax advantages attached to personal and family circumstance when the material scope of tax liability of the non-resident is less than effective overall taxation (the $90 \%$-criterion). This interpretation is however not fully accurate.

The Court's line of authority essentially revolves around the question whether it is justified in the individual case to apply a different treatment, even when the Member State of employment is best placed to consider the overall ability to pay of the taxpayer, because the Member State of residence, which normally may be assumed to be in this position, is actually not capable of doing so, simply and specifically because the taxpayer exercised freedom of movement. The Court answered this question in the negative in Schumacker.

The answer to the question of which Member State is best placed to consider the taxpayer's overall ability to pay cannot be solely determined with regard to the proportional distribution of taxable income between the Member States, but also, it is for an important part contingent on the absolute amount of income. That is so because tax advantages attached to personal and family circumstances, and the basic tax allowance particularly (whether it is an income exemption or a tax credit), essentially serve to keep a minimum subsistence amount of income free from tax. Even a non-resident tax liability on a proportion of $30 \%$ of aggregate income in the Member State of employment may result in manifest overtaxation of the taxpayer when aggregate income is very low. Such manifest overtaxation is evidently an infringement of the ability to pay principle and thus a discrimination against non-resident taxpayers. ${ }^{440}$

Zurstrassen (C-87/99) concerned the discriminatory tax treatment of $\mathrm{Mr}$ Zurstrassen, a resident taxpayer of Luxembourg who was subject to less advantageous treatment than other residents by treating him as a single taxpayer instead of allowing him a joint assessment as a married couple because his spouse and children resided in Belgium. Luxembourgish personal income tax law only allowed joint assessment if both spouses resided in national territory and it was not in dispute that the other qualifying conditions for joint assessment were met. The Court found that this different treatment purely based on

See, Commission v Estonia (C-39/10) which was decided in 2012 and therefore was excluded from the sample. 
residence without any underlying objective difference was not covered by the general limitation of Schumacker and consequently amounted to indirect discrimination on grounds of nationality according to Sotgiu, since family members of non-national residents (the Zurstrassens had Belgian nationality) are more likely to live in another Member State (paras 18-23).

The Court clarified the material scope of the general limitation of Schumacker by holding that this limitation only applied to tax benefits which are not 'directly linked to the activity that generated the taxable income' (para 27) in Gerritse (C-234/01). A deduction for business expenses was, however, a tax benefit which was directly linked to the activity that generated the taxable income. It consequently amounted to indirect discrimination on grounds of nationality if that deduction was not granted to non-resident taxpayers who carried on economic activity in national territory. ${ }^{441}$ In contrast to business deductions, the Court held that a tax-free allowance relates to the overall ability to pay because it has a social purpose as it allows 'the taxpayer to be granted an essential minimum exempt from all income tax', and accordingly falls within the scope of the Schumacker-rule (para 48). Notwithstanding, it was clear to the Court that the situation of Mr Gerritse was not covered by the Schumackerexception since the Court established that there was sufficient tax liability in the Member State of residence that absorbed the personal tax allowances (para 49 and 50). However, it would be contrary to the rule established in Sotgiu if a nonresident was taxed at a higher rate than the rate that actually applies to a resident taxpayer who is taxed on the same amount of income, after eliminating the tax benefit of the tax-free allowance (paras 52-54). ${ }^{42}$ In that context, Gerritse resembles Asscher.

The Court applied the Gerritse ruling with regard to the tax-free allowance to the case of Wallentin (C-169/03) since it could not distinguish the Swedish law that applied in this case from German law in terms of the social aim of this basic exemption. Mr Wallentin was a student and resided in Germany but he was taxable as a non-resident in Sweden due to a short-term summer job with the Church of Sweden. The denial of personal tax benefits in Sweden resulted in manifest overtaxation of Mr Wallentin. The Court considered in para 18 of its ruling that his Member State of residence did not attach taxable character to the income that $\mathrm{Mr}$ Wallentin received in that Member State-maintenance

441 See, Section 4.3.5.5.6.

442 The Court's exact wording in Gerritse, para 54 was: 'In order to compare comparable situations, it is necessary in that respect, as the Commission has rightly pointed out, to add to the net income received by the [non-resident] person concerned in Germany an amount corresponding to the tax-free allowance.' So, if the tax-free allowance for resident taxpayers is $€ 10,000$ and the non-resident earns a taxable income of $€ 15,000$ (after deduction of business expenses), the correct comparison is to compare the actual effective tax rate for the non-resident taxpayer with the hypothetical effective tax rate for a resident taxpayer who is taxed on a taxable income of $€ 25,000$ (before application of the tax-free allowance). 
payments from his parents and a study grant from the German state-and also that there was no tax liability in Germany on grounds of which Germany could take into account Mr Wallentin's ability to pay (para 21). This reasoning as regards the capacity of the Member State of residence to take into account the overall ability to pay of the taxpayer was explicitly clarified in Wallentin as assurance against an 'unjustified fiscal benefit':

23. Furthermore, the grant in the present case of the same tax allowance as that laid down for persons resident in Sweden throughout the tax year would not give Mr Wallentin an unjustified fiscal benefit since he has no taxable income in his Member State of residence which could confer entitlement to a similar allowance in that State.

The D. (C-376/03) case concerned an individual taxpayer who resided in Germany and owned immovable property in the Netherlands. The Netherlands charged Mr D. with capital tax on that property. Whereas resident taxpayers were granted a basic tax allowance by national law, Mr D. was denied the same exemption due to his status as non-resident taxpayer in the Netherlands. Mr D. claimed that he should nonetheless be granted the tax concession since residents of Belgium could claim the basic tax allowance pursuant to the DTC between the Netherlands and Belgium of 1970 if they were assessed with capital tax in the Netherlands. The Netherlands also extended the basic exemption for capital taxation to residents of Belgium by force of Article 25(3) of the BelgiumNetherlands DTC 1970. Mr D. submitted that he was discriminated against compared to residents of Belgium, because he was not accorded the same benefits as residents of Belgium were accorded by the DTC. Mr D. grounded his claim in EU law since he was neither a resident of the Netherlands nor of Belgium, and therefore was not covered by the personal scope of the BelgiumNetherlands DTC $1970 .{ }^{443}$

The Court held, however, in favour of the Dutch Revenue which submitted that the tax treatment of Mr D. was not precluded by the free movement of capital. In $D$. the Court considered the benefit of Article 25(3) of the BelgiumNetherlands DTC 1970 not separable from the remainder of the Convention, but an integral part thereof and so contributing to its overall balance. Mr D.'s submission was accordingly dismissed.

It should be noted that in $D$. the Court also examined the case first within the traditional framework of national treatment. The Court found no discrimination of non-resident taxpayers compared to resident taxpayers in the Netherlands. $\mathrm{Mr}$ D. was taxed in the Netherlands on only $10 \%$ of his assets, but the remainder of his property which was situated in his Member State of residence Germany was not taxed, since Germany had abolished its capital tax. Neither was the major part of Mr D.'s property situated outside his Member State of residence, nor was

443 Neither the Court's ruling nor the AG's opinion explain why Mr D. had not relied on Article 24(1) of the Germany-Netherlands DTC 1956 which is textually equivalent to Article 25(3) of the Belgium-Netherlands DTC 1970. 
there a risk that $\mathrm{Mr} \mathrm{D}$. would suffer overtaxation on his aggregate capital because the Netherlands did not grant the personal tax allowance.

The Court distinguished the case of Mr D. from the judgment in Wallentin, because the Court found that the sums that $\mathrm{Mr}$ Wallentin received in his Member State of residence were not considered taxable income by their nature, whereas the property of Mr D. in his Member State of residence could not be qualified as such, despite the absence of liability to tax on it in his Member State of residence (D., paras 41 and 42). In Mr Wallentin's case the absence of tax liability in his Member State of residence resulted in an overtaxation of $\mathrm{Mr}$ Wallentin's aggregate income in terms of his personal ability to pay. Since Sweden did not consider Mr Wallentin's personal situation, simply because he exercised freedom of movement, and Germany as his Member State of residence was - in view of its national legislation - not in a position to consider his personal situation as it exempted all taxable income from Sweden, the Court was consistent in holding Sweden accountable for the overtaxation that Mr Wallentin suffered on his income earned in Sweden compared to resident taxpayers of Sweden.

Since the Court thus found no infringement of the national treatment standard in the first place in $D$., the judgment in $D$. is consistent in that the Court also dismissed a secondary discrimination between two groups of non-residents, which the taxpayer submitted was inherent in the fact that the concessional tax policy was regulated in a DTC.

The case of a most-favoured-nation obligation beyond national treatment, which was in abstract the issue in $D$., is arguable and the $D$. ruling accordingly has been criticised. ${ }^{44}$ But, the purpose that such a MFN obligation would serve seems to us to fit poorly in the system of the Treaties that primarily aim to eliminate restrictions on the exercise of free movement.

The judgment in $D$. may, in that context, be interpreted as follows. If a tax concession that is typically reserved for residents is extended by way of a DTC to taxpayers who are resident in another Member State, voluntarily and as an inseparable part of the reciprocal rights and obligations contained in that DTC, but not as the result of a national treatment obligation, then there can also be no legal obligation resulting from the principle of non-discrimination to extend that tax concession to non-residents of other Member States which are not covered by the scope of the DTC that contains the tax concession. That is of course subject to the caveat that those other non-residents are otherwise not in comparable positions as resident taxpayers. Granting benefits selectively to situations in which free movement has been exercised by concluding DTCs with individual Member States is not contrary to EU law if that policy amounts to positive discrimination, i.e. if it results in some non-residents being treated more favourably than the national treatment obligation ensuing from EU law. ${ }^{445}$

\footnotetext{
444 Cordewener and Reimer (2006a); Cordewener and Reimer (2006b); Kofler (2005); Van Thiel (2007a); Van Thiel (2007b); Weber and Spierts (2004).

445 Ghosh (2007), pp. 69-74.
} 
Consider the following example as a further clarification on this point. Suppose that it has been established that Member State A has lawfully not extended national treatment to residents of Member State B-due to objective differences or overriding reasons of public interest like in $D$. - then the primary conclusion is that there is, strictly speaking, no restriction on freedom of movement imposed by Member State A in relation to Member State B. An extension of concessions normally (and lawfully) reserved for residents of Member State A to residents of Member State B, by way of a DTC, must consequently be considered a positive action unrequired by EU law. If the situation of residents of Member State $\mathrm{C}$ is generally comparable to those of Member State B, then we could on the same basis assume that Member State A also does not restrict the exercise of free movement by residents of Member State C, irrespective of whether Member State A has concluded a DTC with Member State C, or not.

However, we must also note that free movement in relation to Member State $\mathrm{B}$ is more free than free movement in relation to Member State $\mathrm{C}$ due to a joint action by Member States A and B in which EU law did not require the Member States to engage. Thus, to argue that there is an autonomous role for a MFN obligation beyond national treatment is equivalent to arguing that relative differences of free movement between Member States are restrictions on free movement. We believe that this claim has no basis in Treaty law as it is wellestablished case law that the Treaties offer no guarantee of neutrality as regards taxation in the exercise of freedom of movement in the absence of any discrimination against or restriction on the exercise of freedom of movement. ${ }^{446}$

The case of Conijn (C-346/04) concerned a resident individual of the Netherlands who was also liable to tax as a non-resident in Germany by reason of his shareholding in a German limited partnership. Mr Conijn could not deduct costs involved in obtaining tax advice from his taxable income in Germany. The issue was whether the deduction of this personal expense (according to German law) was covered by the material scope of the Schumacker-rule. The Court found that this was not the case and applied Gerritse. In the Court's view, Mr Conijn's duty to file a tax return in Germany resulted from the fact that he received income in Germany (para 22). The expenses for obtaining tax advice in relation to that return were thus directly linked to that income in terms of Gerritse and the denial of deduction consequently amounted to indirect discrimination on grounds of nationality.

Meindl (C-329/05) was about the issue whether it was contrary to EU law to deny joint assessment to a resident taxpayer of Germany due to the fact that his spouse resided in Austria and derived income from sources in that Member State in excess of a fixed amount. Austria did not attach taxable character to Mrs Meindl's income. The Court applied Zurstrassen by analogy and ruled that the German tax measure amounted to indirect discrimination on grounds of nationality.

${ }^{446}$ See e.g., Schempp (C-403/03), para 45. 
The Court ruled in Talotta (C-383/05) that a Member State may not apply a minimum basis of assessment for non-resident taxpayers if the Revenue lacks evidence to determine the correct amount of taxable income, whereas the Revenue estimates the income of residents in similar situations by a different procedure. The two categories of taxpayers were held comparable by the Court because the Revenue faces the same difficulties in assessing the income of taxpayers who perform the same activities in the national territory of the Member State concerned (para 28). Thus, there were no objective differences in terms of Sotgiu and Schumacker. ${ }^{447}$

In Gielen (C-440/08) the Court made a similar refinement on comparability as in Talotta. The Dutch national measure at issue in Gielen granted a deduction to taxpayers who earned income as self-employed entrepreneurs. The problem was not that this deduction was refused to non-resident taxpayers like Mr Gielen in the case at hand but rather that the qualifying conditions were applied differently to non-resident and resident taxpayers. To qualify for the deduction the taxpayer had to work a minimum amount of 1225 hours in relation to his business. Whereas residents could include hours worked on establishments both in Dutch and foreign territory, non-resident taxpayers could only take into account the hours worked in relation to establishments in the Dutch national territory. The Court reasoned that the aim of the national measure was to grant a deduction to persons whose main activity was running their business. In that context, the Court adjudged that the distinction between residents and nonresidents was arbitrary in view of the aim of the deduction and ruled that the different treatment amounted to indirect discrimination on grounds of nationality since less advantageous conditions were applied to non-residents. Furthermore, that discrimination could not be rendered lawful by the availability of an option for non-residents to be treated as resident taxpayers on their request, since the obligations of EU law on Member States are unconditional.

The last sample case in this subcommunity is Commission v Hungary (C253/09). This case clearly shows the limits of the Schumacker line of authority and the scope of different treatment of non-residents that the Court is willing to accept. At issue was national legislation that provided for an allowance for the value against which a previous private residence was sold against the basis of an assessment in regards property tax charged upon the purchase of new private residence in Hungary within a certain period. That allowance was however only granted if the previous residence was also situated in Hungary.

The Court then recalled the Schumacker-rule that resident and non-resident taxpayers are not, as a rule, comparable as far as direct taxation is concerned (para 55-56). But, the Court distinguished Commission $v$ Hungary from Schumacker on the ground that the latter was decided in the context of personal income taxes but the former basically concerned a tax on a property transaction and was not based on a conception of ability to pay that took into account the

Compare, the Benelux Court of Justice judgment in Metabouw (A 06/2) with regard to a minimum basis of assessment for companies. 
personal circumstances of the taxpayer (para 57). Consequently, it could not be assumed that the different treatment of resident and non-resident persons was legitimate at the outset, since both categories were required to pay the same tax that was determined solely by the price of the purchased property (para 58). According to the Court in para 59:

In such circumstances, acceptance of the proposition that a Member State may freely apply a different treatment solely by reason of the fact that an EU citizen's first principal residence is situated in another Member State would deprive the rules relating to the freedom of movement for persons of all meaning (see, to that effect, Case 270/83 Commission v France, paragraph 18, Joined Cases C-397/98 and C-410/98 Metallgesellschaft and Others [2001] ECR I-1727, paragraph 42; and Case C-418/07 Papillon [2008] ECR I-8947, paragraph 26).

In contrast to Schumacker, the Court concluded in Commission v Hungary that residents and non-residents should be assumed to be in comparable situations (para 60). The Court then established that the disputed difference was not consistent with the aim of the national legislation. Since the principal aim of the national legislation was effectively to exempt from property tax the capital of the private residence that was sold and reinvested in the newly purchased private residence (para 62), the Court held that the difference in treatment was, in view of this aim, not consistent with the objective situations of non-residents (para 63-64). Evidently, Union citizens who previously resided in another Member State and who intended to settle in Hungary were likely to reinvest the proceeds from the sale of their previous residence in that other Member State in the new private residence that they purchased in Hungary and upon which property tax was due in the same way as residents of Hungary were assumed to act by the law. Although the Court nonetheless found a justification for this discrimination in the cohesion of the tax system, ${ }^{448}$ the important point to make here is that the original authority of Sotgiu - requiring that lawful differences in treatment are at the least consistent with objective differences in situations that are relevant in view of the aim of the national measure - still governs an important part of the judicial doctrine on EU law in the field of direct taxation, even when the narrative of nationality discrimination has been exchanged for the narrative of freedom of movement for Union citizens, like in Commission v Hungary, and notwithstanding the well-established line of authority following Schumacker.

\subsection{Capital movement and the EEA Agreement}

Commission v Netherlands (C-521/07) applied Amurta (C-379/05) to relations with EFTA States. Both cases concerned the same discriminatory tax treatment of dividends distributed to foreign recipients that was laid down in the national legislation of the Netherlands. The Court held in Commission v Netherlands that 
free movement of capital was to be interpreted uniformly in the context of relations between Member States and in the context of relations with EFTA States in order to ensure the 'fullest possible realisation of free movement within the EEA' (para 32). The rule on free movement of capital in Article 40 of the EEA Agreement was found to be identical in substance to the rule of Article 63 TFEU (para 33). We will see in Section 4.6.2.5 that the Court continued here on a line of authority that was established outside the field of direct taxation.

If only the national subject matter is considered, it should be conceded that Commission v Austria (C-10/10) is most similar to the cases on charities and lotteries that we will discuss in Section 4.3.5.7.5. The case concerned national legislation which precluded a deduction from personal income tax of gifts made to research and educational organisations established outside Austria, whereas such tax relief was granted when a charitable contribution was made to a national institute. On the basis of the precedents of Stauffer (C-386/04) and Persche (C-318/07) the Court ruled that this difference in treatment based on the place of establishment of the institute was contrary to free movement of capital. However, these precedents did not concern the question whether the measure was contrary to the prohibition on restrictions on free movement of capital laid down in Article 40 of the EEA Agreement. ${ }^{449}$ On this matter, the case of Commission $v$ Austria was decided in accordance with Commission $v$ Netherlands.

Also Commission $v$ Belgium $(\mathrm{C}-250 / 08)$ that is grouped in this subcommunity also relied on Commission $v$ Netherlands to ensure free movement of capital in relations with EEA States. On the national subject matter, the case of Commission $v$ Belgium was equivalent to Commission $v$ Hungary (C-253/09) that was discussed above. The judgments are on material points of reasoning verbatim copies. This is the qualitative clarification of why the case is grouped with the Schumacker cases in broader context.

\subsection{Preferential tax rates and capital transactions}

The Louvain method found a subcommunity of three sample cases which define to what extent a Member State may apply preferential tax rates to capital transactions by individuals. Also here the EEA Agreement was relevant and the relation on EU law grounds with the cases of the preceding Section is evident.

The Court ruled in Sandoz (C-439/97) that Austria complied with free movement of capital by imposing a stamp duty at the same rate to loan agreements which were taken out domestically and loan agreements which were contracted in other Member States by resident taxpayers. This finding was however established at the justification level; the legislation was necessary to prevent tax evasion in Austria and did not impose arbitrary discrimination (paras 24-26). The Court first found that the measure potentially restricted free movement of capital since it made it less attractive to take out a loan in another

449 See, the 2012 ruling in Commission v Belgium (C-370/11). 
Member State because it cancelled out absence of taxation on that loan agreement in the other Member State (para 19). We will see that the Court has also ruled that compensatory taxation may constitute a breach of EU law when it is applied specifically in cross-border situations and internal situations are left unaffected by the rules, unlike in Sandoz. ${ }^{450}$

Commission v Spain (C-562/07) concerned a difference in treatment between residents and non-residents in relation to the (flat) tax rates that applied to capital gains accruing on the disposal of assets owned for more than one year, which were taxable in Spain. Residents were charged with personal income tax at a rate of $15 \%$ and a rate of $35 \%$ was imposed on similar capital gains earned by non-resident taxpayers in Spain. The Court applied Schumacker, Asscher and Gerritse to this case and held that non-residents and residents were in an objectively comparable position since Spanish income tax was charged on both categories in respect of similar capital gains located in Spain (paras 49 and 50, and para 54). Furthermore, the difference in rates and the resulting more favourable treatment of residents did not pursue a 'social purpose' in terms of Gerritse, para 48 (Commission v Spain, para 52). In conclusion, the preferential tax treatment granted to residents was contrary to free movement of capital and also breached Article 40 of the EEA Agreement. As regards the latter provision, the Court cited Commission v Netherlands (C-521/07) again.

The preferential tax treatment of public debt securities issued by Portugal as compared to the higher tax rate that applied to income from public debt securities issued by other Member States was contrary to free movement of capital as was ruled in Commission v Portugal (C-20/09). Applying, inter alia, Sandoz, the Court held that the Portugese legislation made it less attractive to make an investment in another Member State (para 54). The Court applied Commission $v$ Spain to argue that the difference in treatment also constituted a breach of Article 40 of the EEA Agreement since the scope of that provision is equivalent to Article 63 TFEU.

\subsubsection{Qualitative analysis of community 3}

There are two subcommunities that are difficult to distinguish on a particular feature. One subcommunity includes mostly older sample cases. ${ }^{451}$ The other subcommunity includes more recent sample cases. However, both subcommunities cannot be easily distinguished on legal grounds. Since this is consistent with the relative low modularity of community 3 (the lowest of all analysed Communities) and also because the other two subcommunities can be distinguished specifically, we will accept that the first two subcommunities of community 3 concern fairly homogeneous case law primarily on corporation taxes in general.

${ }^{450}$ See Section 4.3.5.5.6 and Section 6.5.3 on Eurowings (C-294/97).

451 Commission v France (Avoir Fiscal) (270/83); Daily Mail (81/87); Commerzbank (C-330/91); ICI (C-264/96); Gilly (C-336/96); AMID (C-141/99). The exception is Truck Center (C-282/07). 
It appears that the Court applies the same judicial rules in those cases to resolve the indeterminacy of EU law. We will not review this judicial doctrine on substance here, since many of the cases will be analysed in Part III. ${ }^{452}$

One subcommunity of 13 sample cases evidently revolves around the issue of whether freedom of establishment or free movement of capital applies. All cases in this subcommunity, except Saint-Gobain, consider the question whether freedom of establishment or free movement of capital is affected by the national legislation at issue. ${ }^{453}$ This is corroborated by three facts. First, this subcommunity includes the reasoned orders which were exclusively about this issue. ${ }^{454}$ Also, the relevant precedents of those reasoned orders are grouped in this subcommunity. ${ }^{455}$ Second, this subcommunity includes five of six cases which were identified in Table 6 on page 73 as relevant to relations with nonmember States. As we have already established there, the distinction between the two freedoms is particularly relevant for these types of cases. Other cases which were relevant to relations with non-member States can be found in community 4. Third, Baars (C-251/98) is the original precedent which established the 'decisive influence' formula to determine whether freedom of establishment or free movement of capital is primarily affected and this case is included in this subcommunity. The judicial doctrine of this subcommunity was already discussed in more detail in Section 3.4.2.1.4 of Chapter 3.

The last subcommunity of twelve sample cases includes ten sample cases on the taxation of dividends. ${ }^{456}$ The two other cases are Marks \& Spencer $(\mathrm{C}$ 446/03) and De Lasteyrie du Saillant (C-9/02). There are also five other cases on the taxation of dividends in other subcommunities of community 3 . $^{457}$ Nonetheless, it appears that taxation of dividends is an accurate distinguishing

452 See generally, Terra and Wattel (2012), pp. 1001-1016.

${ }^{453} X$ and $Y$ (C-436/00); Keller Holding (C-471/04); Rewe Zentralfinanz (C-347/04); Oy AA (C-231/05); Columbus Container Services (C-298/05); Deutsche Shell (C293/06); Heinrich Bauer Verlag (C-360/06); Lidl Belgium (C-414/06); Papillon (C418/07); Krankenheim Ruhesitz am Wannsee-Seniorenheimstatt (C-157/07); Aberdeen Property Fininvest Alpha (C-303/07); CIBA (C-96/08); SGI (C-311/08); X Holding (C-337/08); Commission v Portugal (C-493/09); National Grid Indus (C371/10).

454 Lasertec (C-492/04); $A$ and B (C-102/05); and Stahlwerk Ergste Westig (C-415/06).

455 Cadbury Schweppes (C-196/04); Thin Cap Group Litigation (C-524/04); and Fidium Finanz (C-452/04).

456 ACT Group Litigation (C-374/04); Amurta (C-379/05); Denkavit Internationaal and Denkavit France (C-170/05); Orange European Smallcap Fund (C-194/06); Commission v Italy (C-540/07); Damseaux (C-128/08); Commission v Spain (C487/08); Dijkman and Dijkman-Lavaleije (C-233/09); Commission v Germany (C284/09); and Secilpar - Sociedade Unipessoal (C-199/10).

457 Commission v France (Avoir Fiscal) (270/83); Saint-Gobain (C-307/97); Holböck (C-157/05); Commission v Greece (C-406/07); and Aberdeen Property Fininvest Alpha (C-303/07). 
feature of this subcommunity. The case law regarding dividend taxation has been reviewed rather exhaustively in prior research and a closer examination to establish the main lines of authority is therefore not necessary in view of the purpose of the current research. ${ }^{458}$ We will see in Section 4.5 that the relevant judicial rules may be considered acte clair, see Section 3 of Annex A. In Section 4.5.2.2 we will therefore focus specifically on the most contentious issue on dividend taxation, i.e. the issue of DTC neutralisation of restrictive withholding taxes on dividends.

\subsubsection{Qualitative analysis of community 5}

\subsection{Preliminary remarks}

Community 5 , like community 1 , is about personal income taxes. One distinguishing factor that we already highlighted was that community 5 includes cases on Article 21 TFEU. The relevant cases are about tax benefits associated with private residences and are grouped in a separate subcommunity. ${ }^{459}$ Also, community 5 is generally about the tax regulation of private residences and immovable property. Furthermore, a common denominator of these cases is that they were resolved by an interpretation of free movement law that moves beyond the Sotgiu/Schumacker-framework of indirect nationality discrimination. The case law that will be discussed below mostly used the narrative of restrictions in terms of the Säger/Kraus-formula. It should be mentioned that one case, Hengartner and Gasser (C-70/09), which is grouped in a subcommunity of its own will not be discussed below.

\subsection{The Singh/De Groot line of authority}

The Sotgiu/Schumacker line of authority as discussed above either concerned securing national treatment of non-residents in the host Member State, ${ }^{460}$ or revolved generally around a different tax treatment based on the place of residence of the taxpayer, ${ }^{461}$ or his or her family. ${ }^{462}$ The cases which are grouped together in the subcommunity of this subsection concern the application of the rule of Singh (C-370/90):

16. [...] the provisions of the Treaty relating to the free movement of persons are intended to facilitate the pursuit by Community citizens of occupational

458 Denys (2007); Englisch (2010); Gammie (2010); Graetz and Warren (2007); Hellerstein, et al. (2009); Lang (2008); Tenore (2010); Terra and Wattel (2012), pp. 1045-1063; Vanistendael (2010).

459 Section 4.3.5.5.4.

460 Schumacker; Gschwind; Gerritse; Wallentin; D.; Conijn; Talotta; and Gielen.

461 Biehl I and II.

462 Zurstrassen; and Meindl. 
activities of all kinds throughout the Community, and preclude measures which might place Community citizens at a disadvantage when they wish to pursue an economic activity in the territory of another Member State. ${ }^{463}$

The common denominator of the cases discussed below is that they are about the question to what degree the Member State of origin may introduce tax rules which potentially prohibit, impede or make it less attractive for its own nationals to pursue economic activities, specifically employment, in another Member State. The restriction language of the Court in these cases consistent with the observation we made in Section 3.6.2.2 on the natural preference for the Säger/Kraus-formula in outbound cases. ${ }^{464}$ Contrast this with the consistent use of discrimination language of the Sotgiu/Schumacker line of authority which concerned inbound cases.

The case of Singh is the most cited non-sample case in this subcommunity. In that context it should be noted that the sample cases also cite, on the same point, Terhoeve (C-18/95), ${ }^{465}$ Graf (C-190/98) and Sehrer (C-302/98). In Terhoeve the Court ruled in reply to the first preliminary question of the national court that a Union citizen may rely on freedom of movement for workers against the Member State of which (s)he has nationality if that Member State places the citizen at a disadvantage because (s)he worked in another Member State. The rulings of Sehrer and Graf rely, on the same point, on the authority of Terhoeve. $^{466}$ The most cited sample case in community 5 is De Groot (C$385 / 00$ ) and we will therefore refer to the judicial doctrine of this subcommunity as the Singh/De Groot line of authority.

In De Groot the Court was asked to decide whether it was contrary to EU law if a resident national individual of the Netherlands, who had worked in other Member States, could not enjoy the full benefit of the tax advantages relating to ability to pay because those benefits - the tax free allowance and a deduction for maintenance payments to a former spouse-were proportionately attributed to the income that Mr De Groot earned through his foreign employment and which the Netherlands exempted from tax as relief for double taxation. After establishing on the basis of e.g. Terhoeve that Mr De Groot could rely on the protection of EU law against his Member State of origin, the Court found that the tax treatment by the Netherlands constituted a restriction on the free

463 The Court cited to Stanton v INASTI (143/87), para 16.

464 The Court used the terms 'obstacle' in De Groot, para 95; and 'barrier' in Schilling and Fleck-Schilling, para 37. Also in Ritter-Coulais, para 37, which is a case of another subcommunity of community 5 , the Court used restriction language by holding the treatment 'less favourable'. The Court only used explicit discrimination language in Lakebrink and Peters-Lakebrink, but that case concerned inbound movement.

465 This case was only removed from the sample in the last step, see fn 183.

${ }^{466}$ In Graf the Court also refers in that context to Bosman (C-415/93), which in turn relies on Singh. 
movement of workers. The Court argued that Mr De Groot 'derived...a lesser tax advantage than he would have received had he received his entire income...in the Netherlands' (para 83). In para 91 of its judgment, the Court made the same point again in other words by holding that 'as a consequence of his exercise of his right to freedom of movement, he forfeited part of the tax allowances provided for by Netherlands law to which he was entitled as a resident of the Netherlands.'

The Court also held that there was no obligation for the host Member States to grant $\mathrm{Mr}$ De Groot similar tax benefits in relation to his personal and family circumstances and reiterated its position in Schumacker and Gschwind that those Member States could only be so obliged by exception under EU law, namely if the Member State of residence was not in a position to take these benefits into account. That was not the case in De Groot. In any event, the Court established that the Netherlands had neither assured that the host Member States took into account Mr De Groot's ability to pay, nor had those Member States compensated Mr De Groot by their own motion for the loss of benefits in the Netherlands (paras 98-102). The position of the Court in De Groot therefore remained that the Netherlands as the Member State of residence could not be released by EU law from its obligation to ascertain that, irrespective of any relief for the avoidance of double taxation, Mr De Groot enjoyed the full benefit of all tax benefits relating to his family and personal circumstances and was assessed on the basis of his overall ability to pay, specifically because he exercised free movement. ${ }^{467}$

The Court ruled in Schilling and Fleck-Schilling (C-209/01) on the application of Terhoeve and De Groot to German nationals who had moved their residence from their Member State of origin to Luxembourg in order to accept employment as Union officials in Luxembourg. The Court stated that $\mathrm{Mr}$ Schilling and Mrs Fleck-Schilling had exercised freedom of movement and could rely on the protection that the Treaty affords to migrant workers against their Member State of origin. Pursuant to Article 13 of the Protocol on the privileges and immunities of the European Union the couple was considered to have maintained their fiscal domicile in Germany. The issue in the case was whether Germany could lawfully deny a deduction for expenses that $\mathrm{Mr}$ and Mrs Schilling incurred in relation to household assistance in Luxembourg against the additional income from letting of property and self-employment that $\mathrm{Mr}$ Schilling earned in Germany. German income tax law allowed such deductions for ordinary resident taxpayers only if payments were made to the German national pension insurance scheme for the household assistant. The household assistant who worked for $\mathrm{Mr}$ and Mrs Schilling in Luxembourg was insured under the Luxembourgish pension scheme and the German Revenue denied the deduction on this basis. The Court decided that such tax treatment was liable to

${ }^{467}$ The case of Beker and Beker (C-168/11), which was pending before the Court at time of writing, is basically about the same issue as De Groot, with the difference that Beker and Beker concerns German law. 
deter nationals of Member States from transferring their residence to another Member State in order to accept and pursue employment, as officials of the Union, in that other Member State.

\subsection{Negative income and progressivity of tax rates}

Ritter-Coulais (C-152/03) and Lakebrink and Peters-Lakebrink (C-182/06) were grouped in the same subcommunity and are indeed very similar cases. Both concerned the tax treatment by the host Member State of negative income arising from immovable property in the Member State of residence. In both cases the Revenue of the host Member States refused to take that negative income into account in determining the progressive tax rate to be applied on the income earned by the taxpayers in that Member State. Consequently, the taxpayers suffered a higher effective tax burden than the one which would have been imposed if their immovable property was situated in the host Member States. The national courts raised the question with the Court if this tax treatment was contrary to freedom of workers. The Court answered that question in the positive.

Ritter-Coulais is the earlier of the two cases and concerned the protection EU law afforded to taxpayers against the Member State of which they have nationality. This makes the case a closer analogy from the outset to De Groot and Schilling and Fleck-Schilling than to Schumacker.

Whereas the Court interpreted the free movement of workers in Schumacker as an equality clause that precluded indirect discrimination against non-nationals by application of the criterion of residence, the right to free movement of workers was paraphrased in Ritter-Coulais as precluding any different treatment against Union citizens who have exercised freedom of movement and who, irrespective of their nationality and place of residence, are put at a disadvantage because they work in a different Member State than their Member State of residence. ${ }^{468}$ That restatement is closer to a formulation in terms of the Säger/Kraus-formula than to the language used in the Sotgiu/Schumacker line of authority. We have observed in Section 3.6.2.2 that it is indeed possible to formulate an indirect discrimination on grounds of nationality in terms of the Säger/Kraus formula in this way.

Also, it should be noted that it was not necessary to examine the Schumacker-rule and its exception in Ritter-Coulais. The facts of Ritter-Coulais revolved around a couple with German nationality-Mrs Ritter-Coulais was also a national of France - who resided in France, but worked in Germany. Mr and Mrs Ritter-Coulais were assessed with income tax as resident taxpayers in Germany because they had chosen be treated as such according to the express option provided for in German tax law as as result of the implementation of Schumacker. The issue whether Mr and Mrs Ritter-Coulais were comparable as actual non-residents to true residents of Germany therefore did not arise in the case since the couple was in principle assessed with tax on the total of income. 
Also, the national measure in Ritter-Coulais applied equally to true resident taxpayers, whereas the measures at issue in the Sotgiu/Schumacker case law clearly applied with distinction. The Court reasoned in Ritter-Coulais that nonresident workers were more likely to own a house in another Member State than their Member State of employment and the national measure thus treated nonresidents less favourably, in fact, because negative income from immovable property in Germany was not subject to the limitation which applied to foreign property. Ritter-Coulais is, in this respect, very much comparable to Schilling and Fleck-Schilling.

However, the Court needed to apply Schumacker in Lakebrink and PetersLakebrink because the taxpayers were assessed as non-resident taxpayers in Luxembourg which was consistent with their actual situation as residents of Germany. In the relevant grounds of judgments (paras 26 and following) the Court used discrimination language consistent with the other cases in the Sotgiu/Schumacker line of authority. Moreover, in contrast to Ritter-Coulais, the taxpayers were nationals of Germany and had not left their Member State of origin in order to accept employment in Luxembourg. The facts of the case were roughly similar to Schumacker. The Court followed Schumacker because $\mathrm{Mr}$ Lakebrink and Mrs Peters-Lakebrink earned the total of their income in Luxembourg, and were thus comparable with resident taxpayers in terms of Schumacker, and their Member State of residence did not provide any relief for the negative income. The Court explained Schumacker again to clarify that the case concerned all tax relevant factors of a person which affect his or her overall ability to pay, and not just specific benefits relating to personal and family circumstances:

34. Secondly, the ground $[. .$.$] on the basis of which the Court made its find-$ ing of discrimination in Schumacker concerns [...] all the tax advantages connected with the non-resident's ability to pay tax which are not taken into account either in the State of residence or in the State of employment (see also the Opinion of Advocate General Léger in Ritter-Coulais, points 97 to 99), since the ability to pay tax may indeed be regarded as forming part of the personal situation of the non-resident within the meaning of the judgment in Schumacker .

It should be recalled that the Court already stated in Schumacker, para 32 that ability to pay of a taxpayer is determined ' $[\ldots]$ by reference to his aggregate income and his personal and family circumstances [...]' (emphasis added). The above quoted holding in Lakebrink and Peters-Lakebrink is therefore a clarification, and certainly not an extension of Schumacker. ${ }^{469}$ Considering that the Lakebrink and Peters-Lakebrink concerned the appropriate progressive tax rate with reference to overall income, and not personal and family deductions or allowances, the grouping in community 5 can be explained on that basis. As far as

The Lakebrink and Peters-Lakebrink ruling has been misconceived in prior research in this respect, see e.g. Kemmeren (2008). 
national subject matter is concerned, Lakebrink and Peters-Lakebrink is a closer analogy to the other cases in community 5 than to the cases of community 1 .

\subsection{Tax benefits for private residences}

The sample cases of the subcommunity that is discussed here all concerned tax benefits in respect of owner occupied dwellings. The cases discussed below are close analogies with Ritter-Coulais and Lakebrink and Peters-Lakebrink in the sense that they also were about tax reliefs in respect of immovable property which was situated in another Member State than the Member State against which the action was made.

Commission v Portugal (C-345/05) and Commission v Sweden (C-104/06) were about similar national legislation that exempted from personal income tax the capital gain made upon the sale of a private residence, subject to the condition that this gain was reinvested in a new dwelling on national territory of the Member State concerned. The Court held that it was contrary to EU law to withhold this tax benefit from persons who had acquired a new residence in another Member State. This treatment was likely to 'deter' the person concerned from enjoying the right to move freely and transfer his residence to another Member State as protected by Article 21 TFEU and the other specific provisions concerning freedom of movement of persons (Commission v Portugal, para 22; and Commission $v$ Sweden, para 23). The restriction narrative was used throughout the judgments with reference to, inter alia, De Groot and Schilling and Fleck-Schilling in point.

The case of Commission v Greece (C-155/09) concerned an exemption from transfer tax of the first purchase of a private residence in Greece. However, that exemption was reserved for residents or nationals of Greece and we have seen in Section 3.4.2.1.1 that the Court found this national legislation to infringe the right to free movement. Whereas Portugal and Sweden deterred persons from leaving those Member States, the Greek government hindered persons from moving to Greece through tax regulation as regards private residences.

A tax subsidy for the construction or purchase of a private residence was at issue in Commission v Germany (C-152/05). The Commission submitted that, since the subsidy was only available for owner occupied dwellings situated on national territory of Germany, the national legislation discriminated against certain resident taxpayers who intended to construct or purchase a private dwelling outside Germany. The direct action was limited by the Commission to the situations to which the Schumacker-exception applies; actual non-residents who were effectively subjected to the same material scope of taxation as resident taxpayers in the host Member State due to the exercise of an option to be properly treated as such or due to a fiction (in case of civil servants with German nationality). The Court found that the limitation to properties situated on national territory specifically put this category of taxpayers at a disadvantage compared to ordinary resident taxpayers and accordingly restricted the Union citizen's freedom to move freely and leave Germany in order to reside in another Member State. Although the direct action was effectively limited to 
Schumacker-situations, the Court reasoned with the restriction narrative and referred particularly to its case law on tax benefits attached to private residences that was discussed in the preceding paragraphs. The same national legislation would be the subject of the direct action in Commission v Germany (C-269/07) that we review in the next Section.

\subsection{Renneberg and Commission v Germany (C-269/07)}

The subcommunity of this Section includes, of the sample cases, only Renneberg (C-527/06) and Commission v Germany (C-269/07). Both cases relate to income tax rules in respect of private residences.

Before we turn to the tax issue in Renneberg, we note that the Court applied Schumacker in this case but introduced its analysis with paraphrases of the freedom of workers in terms of De Groot in para 43. Mr Renneberg was a national of the defendant Member State, the Netherlands. Also, the Court held in its final analysis that there was a 'discriminatory' (para 79) difference in treatment which amounted to an 'obstacle' (para 80) to freedom of workers. This is a relaxed use of legal language, which - as stated before- does not necessarily imply doctrinal shifts. What matters is that arbitrary distinctions on the basis of a residence criterion are contrary to EU law, even if the Member State applies those national measures to the disadvantage of its own nationals who have exercised freedom of movement.

The facts of the case concerned a national of the Netherlands who was employed as a civil servant in Maastricht in the Netherlands, but who had transferred his residence across the border to Belgium for personal reasons. The freedom of workers was therefore in point in Renneberg. The situation of the taxpayer in this case is virtually identical to that of the taxpayer in Werner. The primary reason that EU law might be involved in both cases was that the taxpayer moved to another Member State for purely personal reasons. In Werner the Court concluded that EU law was not involved. In Renneberg however, the Court held in that regard:

36. In that regard, it should also be noted that any Community national who, irrespective of his place of residence and his nationality, works in a Member State other than that of his residence falls within the scope of [Article 45 TFEU] (see to that effect, inter alia, Case C-152/03 Ritter-Coulais [2006] ECR I-1711, paragraph 31; Case C-212/05 Hartmann [2007] ECR I-6303, paragraph 17; Case C-182/06 Lakebrink and Peters-Lakebrink [2007] ECR I-6705, paragraph 15; Case C-287/05 Hendrix [2007] ECR I-6909, paragraph 46; and Case C-152/05 Commission v Germany [2008] ECR I-0000, paragraph 20).

37. It follows that the situation of a Community national such as Mr Renneberg who, following the transfer of his residence from one Member State to another State, works in a Member State other than that of his residence falls, after that transfer, within the scope of [Article 45 TFEU]. 
The authorities which the Court cites in Renneberg, para 36, are all cases of community 5. The legal framework shaped by the Singh/De Groot line of authority and the introduction of Union citizenship to freedom of movement with Article 21 TFEU has clearly moved the Court to depart from the position it held in Werner. The Court laid down the new position in Ritter-Coulais (C-152/03), Hartmann (C-212/05) and Hendrix (C-287/05).

The preliminary reference in Renneberg raised the question whether the Netherlands should allow a deduction of negative income arising from the owner occupied dwelling in Belgium (mortgage interest deduction), which is the taxpayer's actual Member State of residence, against taxable employment income earned in the Netherlands. Whereas Ritter-Coulais and Lakebrink and Peters-Lakebrink also concerned negative income from immovable property situated in another Member State than the Member State of employment, those cases were limited to the question whether the Member State of employment should take that income into account to determine the applicable progressive rate of taxation. The Court explicitly refused to rule on the exact question of Renneberg in Ritter-Coulais, because the determination of the basis of assessment was not at issue in the main proceedings before the national court, even though the question was referred by the national court. In Renneberg the Court gave a positive answer by applying the Sotgiu/Schumacker line of authority.

The Renneberg ruling has been heavily criticised in the (Dutch) literature. ${ }^{470}$ The criticism firstly revolves around the interpretation of the allocation of taxing powers in respect of immovable property under a DTC. The argument goes essentially that the Court failed to understand that the allocation of taxing powers had, pursuant to judicial doctrine on the interpretation of DTCs of the Dutch Supreme Court, different legal effects, from the perspective of the Netherlands, contingent on the taxpayer being an actual (i.e. treaty) resident of the Netherlands or not. In the case of an actual non-resident taxpayer such as Renneberg, it is submitted, the DTC leaves the Netherlands no possibility to take into account the positive or negative income from immovable property situated in the other contracting state; it is fully excluded from the Netherlands' fiscal jurisdiction. In respect of treaty resident taxpayers, and as noted accurately by the Court in Renneberg, paras 52-57, the Netherlands shares fiscal jurisdiction with the contracting state in which the immovable property is situated and, accordingly, may take the positive and negative income that arises from that property into account. The Court however evidently operated on the assumption that the disputed disadvantage in Renneberg resulted from a unilateral choice of the Netherlands not to consider the negative income of Mr Renneberg, whereas this refusal was really the direct legal effect of the allocation of taxing powers under the DTC. In short, the holding of Renneberg, para 57 is, according to prior research, a too broad and, therefore, wrong interpretation of the Netherlands' margin of discretion under the DTC:

${ }^{470}$ Kavelaars (2008); Kemmeren (2009); Meussen (2009b); Schaper (2009). 
57. Since that Convention does not preclude the taking into account of negative income received from immovable property in Belgium for the calculation of income tax payable by a resident taxpayer, it is therefore evident, contrary to the submissions of the Netherlands Government, that the refusal by the Netherlands tax authorities to allow a taxpayer such as Mr Renneberg to make a deduction is not the result of the choice made in the Convention to allocate the power to tax income from immovable property of taxpayers falling within the scope of the Convention to the Member State in whose territory that property is located.

Unrelated to the first point of criticism on the interpretation of the DTC, there is a second reservation of prior research with the Renneberg ruling. This other point of criticism regards the interpretation of the second condition of the Schumacker-exception - the Member State of residence is not in a position to take into account the taxpayer's overall ability to pay.

It is clear from the facts of the case that Mr Renneberg was in a comparable situation as a resident taxpayer in the Netherlands because the total of his (positive) income from employment as a civil servant was subject to tax in the Netherlands.

The dispute before the Court was therefore limited to the issue whether there was, notwithstanding evident comparability with a resident taxpayer, any discrimination in the case of Mr Renneberg. The Dutch government submitted that this was not the case since Belgium, as the Member State of residence, in any event did not allow a deduction of negative income from employment income according to national law. On that basis, it is difficult to see how discrimination could arise in Renneberg in terms of Schumacker, para 38, which literally states that ' $[\ldots]$ discrimination arises from the fact that his personal and family circumstances are taken into account neither in the State of residence nor in the State of employment' (emphasis added). Thus, the fact that Belgium exempted all of Mr Renneberg's positive income from tax pursuant to the DTC as a method of double taxation relief had no real consequences in the sense that Mr Renneberg was subject to less advantageous treatment in his Member State of residence due to his employment in another Member State.

The Court replied to this submission:

75. In that regard, it must be noted that the difference in treatment at issue in the main proceedings does not arise, contrary to the assertions of the Netherlands Government, simply from the disparity between the national tax rules concerned. Assuming the Belgian income tax system to be as it is presented by the Netherlands Government, even if the Kingdom of Belgium allowed losses such as those at issue in the main proceedings to be taken into account for determination of the basis of assessment of income tax of its residents, a taxpayer in a situation such as that of Mr Renneberg, who receives all or almost all of his income in the Netherlands, would be unable, in any event, to take advantage thereof. 
Renneberg clarified that the second condition of the Schumacker-exception works to excuse the host Member State from affording national treatment to a non-resident taxpayer who is in a comparable position as a resident taxpayer when the Member State of residence is in a position to grant the tax benefits the taxpayer claims in the host Member State. In other words, a Member State should take into account all tax relevant factors which relate to the taxpayer's personal ability to pay, i.e. aggregate income and personal and family circumstances, and grant him the same preferential tax treatment that it affords to resident taxpayers, unless the Member State of residence has already taken those factors into account consistent with its best placed capacity in customary international tax practice.

In the event that a non-resident taxpayer is actually taxed on the basis of his aggregate worldwide income and the corresponding tax liability amounts to overtaxation when compared to the treatment afforded to residents, a proper reading of Renneberg, para 75, implies that this disadvantage is justified only if the Member State of residence is in a position to restore the taxpayer's ability to pay.

We argued in a prior publication (in Dutch) that this is not an authentic interpretation of the Schumacker doctrine, or at the least required additional reasoning. ${ }^{471}$ It is true that the Court has always textualised the Schumackerexception as the 'position' of the resident Member State, ${ }^{472}$ but we argued that we should look to the actual capacity of the resident Member State in the specific case or, in other words, the position in fact.

The different treatment in Renneberg indeed arose because non-residents were not granted the tax benefits associated with owner occupied dwellings in the Netherlands but residents could benefit. The Court was right, in that context, in its first sentence of para 75 in Renneberg. Still, from that point, it does not necessarily follow that $\mathrm{Mr}$ Renneberg had suffered a disadvantage in his Member State of residence Belgium, in that he could not cash a tax benefit associated to his personal ability to pay. Since Mr Renneberg did not lose a tax benefit in Belgium, his personal ability to pay was taken into account in Belgium in effect. On that basis, it is difficult to see how discrimination could arise in Renneberg in terms of Schumacker, para 38, which literally states that '[...] discrimination arises from the fact that his personal and family circumstances are taken into account neither in the State of residence nor in the State of employment' (emphasis added). That is however not the only possible interpretation of Renneberg and Schumacker.

The alternative reading of Renneberg implies that discrimination 'arises', not because neither Member State actually takes into account the taxpayer's ability to pay, but only because the host Member State treats differently a non-resident taxpayer, who is in a comparable position as a resident taxpayer, and the Member State of residence is not in a position to grant the benefits claimed in

${ }^{471}$ Schaper (2009).

${ }^{472}$ See e.g., Schumacker, para 36. 
the host Member State. This is nonetheless consistent with the Court's judicial doctrine, as recognised in Renneberg, para 75, that disadvantages which are caused by disparities do not amount to discrimination. Consequently, the effects of disparities should be eliminated from analysis which is achieved by only considering the national legislation of the host Member State. In that interpretation, Renneberg is good law because there was manifest overtaxation of Mr Renneberg when his situation was compared to resident taxpayers.

Commission v Germany (C-269/07) was about tax incentives attached to savings-pensions schemes. The Commission complained successfully about three issues before the Court. All three issues related to the tax benefits being conditioned upon the beneficiary of the savings-pension scheme being a resident taxpayer of Germany. Beneficiaries which were resident taxpayers could (i) deduct from personal income tax their contributions to the savings-pension scheme and could also claim a tax deductible savings-pensions bonus, (ii) use part of the built-up capital under that scheme for the construction or purchase of a private residence on national territory, but (iii) they were required to repay the savings-pensions bonus and the tax benefits (i) upon termination of their status as resident taxpayers. The Court ruled that the residency requirement and the territorial requirement (ii) discriminated against cross-border workers, i.e. nonresident taxpayers who were employed in Germany.

The Court considered that the savings-pension bonus constituted a social advantage pursuant to Regulation No 1612/68 and should thus be extended to all workers in Germany, including non-resident taxpayers who were employed in Germany as a result of the exercise of freedom movement. Since the subsidised capital may not be used for a private residence that was situated outside Germany, the national legislation in that regard also discriminated against crossborder workers since they were more likely to live outside Germany (paras 7980). Also, the repayment obligation deterred migrant workers - generally nonnationals - to leave Germany to reside in another Member State and therefore amounted to a restriction that was prohibited by Article 45 TFEU. The reasoning of the Court was very similar to the line of argumentation that it used in the case law that was reviewed in the preceding Section. Also considering the subject matter of tax benefits associated with private residences that continues throughout the case law of community 5, it may be concluded that the grouping of Renneberg and Commission v Germany (C-269/07) in this community is coherent with the legal issues in these cases.

\subsection{Business deductions}

We have seen in Section 4.3.5.3.3 that the Court distinguished in Gerritse (C234/01) certain tax deductions from the personal tax concessions to which Schumacker applies. The Schumacker-rule of general incomparability of residents and non-residents does not apply when it concerns tax advantages that are 'directly linked to the activity that generated the taxable income' (Gerritse, para 27). Non-resident taxpayers may claim an EU law right of deduction in the host Member State insofar as the expenses directly link to the income on which they 
are taxed in that Member State and the deduction of those expenses is allowed for resident taxpayers. This rule was later applied in Scorpio (C-290/04) and Centro Equestre da Leziria Grande (C-345/04) which are grouped together in the same subcommunity. Also grouped in this subcommunity is Eurowings (C294/97) which also concerned a limitation to the deductibility of business expenses as was in abstract also the case in Scorpio and Centro Equestre da Leziria Grande. All three cases were decided in the context of the freedom to provide services. This subcommunity is accordingly the continuation of Gerritse in regards deductions from income tax which are not covered by the Schumacker line of authority. The Court paraphrased its judgment in Gerritse as follows in Scorpio:

42. The Court has already had occasion to rule on whether [Articles 56 and 57 TFEU] preclude national tax legislation which as a general rule takes into account gross income when taxing non-residents, without deducting business expenses, whereas residents are taxed on their net income, after deduction of those expenses (Gerritse, paragraph 55).

43. In Gerritse the Court first found that the business expenses in question in that case were directly linked to the activity that had generated the taxable income, so that residents and non-residents were placed in a comparable situation in that respect. It then answered in the affirmative the question referred to it for a preliminary ruling, holding that a national provision which, in matters of taxation, refuses to allow non-residents to deduct business expenses, whereas residents are allowed to do so, constitutes indirect discrimination on grounds of nationality, contrary in principle to [Articles 56 and 57 TFEU]. It did not, however, rule on the question of the stage of the taxation procedure at which the business expenses incurred by a provider of services must be deducted, in a case where several different stages are possible.

The Court ruled in Scorpio that a deduction for business expenses should also be allowed if the tax is retained at source, when the provider of the service has reported the deductible items to the recipient who is obliged to withhold the tax from his payment to the service provider and to remit the charge to the Revenue. Furthermore, the Court reiterated its position that Gerritse only applies to costs or expenses that are directly linked to the activity that had generated the taxable income (paras 50-52). It is for national courts to consider whether the requirement of a direct link is fulfilled when considering individual claims for deduction (para 26). This is in particular the case for operating expenses as follows from Centro Equestre da Leziria Grande. The Court ruled in that case that the obligation to grant a deduction is absolute and cannot be made conditional on the expenses exceeding half of the amount of income, if that threshold does not apply in internal situations (para 37). Moreover, it follows explicitly from Centro Equestre da Lezíria Grande that EU law does not oblige-and also does not preclude-Member States to allow deductions for items that are not directly linked to the activities, unlike operating expenses: 
24. Thus, where powers of taxation are exercised by a State in the territory in which activity has generated taxable income, it must be possible for the costs directly connected to that activity to be taken into account in the taxation of non-residents. In that connection, Community law does not preclude a Member State from going further, by allowing costs that do not have such a connection to be taken into account (see, to that effect, FKP Scorpio Konzertproduktionen, paragraphs 50 to 52).

25. Operating expenses directly connected to the income received in the Member State in which the activity is pursued must be understood as being expenses which have a direct economic connection to the provision of services which gave rise to taxation in that State and which are therefore inextricably linked to those services, such as travel and accommodation costs. In that context, the place and time at which the costs were incurred are immaterial.

The limitation of deduction of business expenses that was at issue in Eurowings was slightly different from the type in Gerritse, Scorpio and Centro Equestre da Lezíria Grande. The deduction of business expenses (lease payments on fixed business assets in case) was not completely denied in Eurowings but the tax advantage was nonetheless partially reversed since the company had to add-back half of the deduction to taxable income for purposes of the local trade tax in Germany, essentially because the lessor was established in another Member State and was therefore not charged with German trade tax on the lease payments received from Eurowings. The Court held that this disadvantageous treatment in fact of cross-border leasing, which is considered a provision of service for consideration for Treaty purposes, amounted to a restriction that was prohibited by Article 56 TFEU. In that view the restriction in Eurowings is a close analogy to Scorpio which was also decided on the basis that the national legislation on the deduction of business expenses made it less advantageous to enjoy a service from a provider established in another Member State.

\subsubsection{Qualitative analysis of community 8}

\subsection{Preliminary remarks}

Community 8 has a fairly high modularity $(Q=0.517)$, but many subcommunities. There are five subcommunities in community 8 which include only one sample case. ${ }^{473}$ These subcommunities are not expected to provide meaningful information. It should however be noted that all but one case (i.e. N. (C-470/04)) concern the taxation of distributed profits, which is the same subject matter as 
governed by the Parent-Subsidiary Directive (90/435/EEC) that is the main subcommunity of community 8 .

Furthermore, one subcommunity only includes the two sample cases of Royal Bank of Scotland (C-311/97) and Halliburton Services (C-1/93). Royal Bank of Scotland cites Halliburton Services on only one point of law, namely that Article 18 TFEU applies independently to situations in regard to which the Treaty lays down no specific non-discrimination rules. ${ }^{474}$ Both cases concerned situations which were covered by freedom of establishment.

Despite the fact that these six subcommunities provide little qualitative information, the other two larger subcommunities represent two distinct lines of authority. The largest subcommunity interprets legal concepts of the ParentSubsidiary Directive (90/435/EEC) and one subcommunity also concerns the taxation of dividends, but provides particular interpretative guidance on the remedies for breaches of EU law.

\subsection{Concepts of the Parent-Subsidiary Directive}

The main subcommunity of community 8 is the case law that is discussed here about the interpretation of legal concepts of the Parent-Subsidiary Directive (90/435/EEC). The primary topic of judicial interpretation was the concept of 'withholding tax'. The directive precludes Member States from levying a withholding tax on profits distributed by a subsidiary to its parent company.

The concept of 'withholding tax' for the purposes of the Parent-Subsidiary Directive has been textualised rather consistently by the Court. The Court has consistently held that any tax on income received in the State in which dividends are distributed is a withholding tax on distributed profits for the purposes of Article 5(1) of the directive where (i) the chargeable event for the tax is the payment of dividends or of any other income from shares, (ii) the taxable amount is the income from those shares and (iii) the taxable person is the holder of the shares. ${ }^{475}$ Only in Athinaïki Zythopoiia (C-294/99), paras 28 and 29, did the Court fail to mention the third condition.

In Burda, the Court found that the third condition was lacking and the national measure therefore did not constitute a withholding tax within the meaning of the Parent-Subsidiary Directive (para 63). The taxpayer, Burda $\mathrm{GmbH}$, and the European Commission submitted that Athinaïki Zythopoiia implied that the third condition could not be given decisive importance and proposed, in the Court's words, 'economic considerations inherent in the withholding tax mechanism' (para 62). The Court replied in that regard in para 61 of its judgment that it had included the third condition as a material criterion in its case law that followed Athinaïki Zythopoiia. That reply is a true statement;

474 See, Section 3.4.2.1.1.

475 EPSON Europe (C-375/98), para 23; Athinaïki Zythopoiia (C-294/99), paras 28 and 29; Océ van der Grinten (C-58/01), para 47; Burda (C-284/06), 52; and Ferrero and General Beverage Europe (Joined Cases C-338 \& 339/08), para 26. 
Océ van der Grinten, i.e. the first case on the issue following Athinaïki Zythopoiia, textualised the judicial interpretation in its initial restatement of EPSON Europe, para 23, including a citation to Athinaïki Zythopoiia, paras 28 and 29.

It is true that the Court did not explicitly apply the third condition in Athinaïki Zythopoiia and it is furthermore plausible that, if the Court had indeed done so, it would have found that the taxable person who was formally liable to tax was not the holder of the shares, but the company that distributed the dividends. Moreover, although the Court cited EPSON Europe, para 22 in Athinaïki Zythopoiia, para 26 to recall that the wording of the directive did not limit the concept of withholding tax to any specific national taxes, the Court did not apply para 23 of that precedent in which it had interpreted the term withholding tax for the first time, including all three conditions which it would reiterate in subsequent case law. This is all the more interesting for three reasons. First, Advocate General Alber listed all three conditions in point 28 of his opinion. Second, he opined that application of the directive would formally fail on the third condition, but that this should not be given decisive importance-since the economic effect of the national measure was notwithstanding the same-and the directive therefore precluded the measure. The Court did not reason on this point, however. It simply ignored it. This is, third, remarkable, because four of five judges (Wathelet, Edward, Jann, and Sevón) sat on the bench in both cases. ${ }^{476}$

The above point of possible judicial inconsistency on the interpretation of the concept of a 'withholding tax' in Athinaiki Zythopoiia should however not be exaggerated. The material reason why the recipient of the dividend may be considered the taxable person for a dividend withholding tax is simply because the tax is assessed and charged on exclusively the fraction of profits that have been distributed to that recipient. The other material feature is of course that a withholding tax is calculated, retained and remitted to the Revenue by the company distributing the profits. Accordingly, to say that ' $[\mathrm{t}]$ he taxation relates to income which is taxed only in the event of a distribution of dividends and up to the limit of the dividends paid.' (Athinaiki Zythopoiia, para 29) is to say that the taxable person is the person receiving the dividends, i.e. the holder of the shares. To conclude, we believe that Athinaiki Zythopoiia is not an exception to the line of authority on the definition of a 'withholding tax'.

The concept of 'withholding tax' was also subject of interpretation in Scheuten Solar Technology (C-397/09), but for purposes of the Interest \& Royalties Directive $(2003 / 49 / E C)$. The Court however found that there was 'nothing' in its case law on the Parent-Subsidiary Directive that 'could be of assistance in the interpretation of Article 1(1) of Directive 2003/49 in relation to national legislation such as that at issue in the main proceedings' (para 35). The Court held that the denial of the deduction of interest did not constitute a withholding tax for the purposes of the Interest \& Royalties Directive.

${ }^{476}$ None of the judges of Athinaïki Zythopoiia sat on the bench in Burda. 
Two other cases in this subcommunity on the Parent-Subsidiary Directive concerned other concepts. ${ }^{477}$ Banque Fédérative du Crédit Mutuel (C-27/07) concerned the concept of profits distributed by the subsidiary for the purposes of Article 4(2) and Gaz de France (C-247/08) established that the directive only applies to companies of the Member States which take a form that is included in the list of companies of the Annex to the directive. The Court ruled that this list is exhaustive.

\subsection{Dividends and liability for damages}

The subcommunity of this Section concerns three cases on the taxation of dividends and in particular the liability of Member States for breaches of EU law. The issue of remedies for tax charges which were improperly levied due to a breach of EU law was first brought up in the joined proceedings of Denkavit International, VITIC Amsterdam \& Voormeer (Joined Cases C-283, 291\&292/94). ${ }^{478}$

The proceedings in Denkavit International, VITIC Amsterdam \& Voormeer concerned the question whether the minimum holding period of three years, which Member States may impose according to Article 3(2) of the ParentSubsidiary Directive (90/435/EEC), has to be completed before the companies to which the directive applies may claim its benefits. If so, distributions of profits should be postponed for three periods, which obviously requires the parent company to incur an interest loss during that time. Germany as the Member State against which the companies litigated submitted that it did have this right. The Court ruled that Member States may not refuse the benefits of the Parent-Subsidiary Directive merely because the minimum holding period has not yet passed, but the Member States may ascertain in an objective manner that this requirement will be observed by the companies. Germany thus breached EU law.

The Court found that the breach of EU law in Denkavit International, VITIC Amsterdam \& Voormeer was not sufficiently serious in terms of Brasserie $d u$ Pêcheur and Factortame (Joined Cases C-46\&48/93) since the view taken by Germany was not manifestly and gravely in disregard of the directive. As we have seen in Section 3.7, the Court noted in finding so that Germany's perspective was common ground among almost all Member States and that the rule which was at issue was a measure expressly aimed at preventing abuse (Denkavit International, VITIC Amsterdam \& Voormeer, para 51). Furthermore, the Court acknowledged that there was no precedent on this matter (Denkavit International, VITIC Amsterdam \& Voormeer, para 52). The rule that Germany breached was evidently not so clear and precise that mere infringement thereof

477 In 2012, the Court decided in Punch Graphix (C-371/11) that the concept of 'liquidation' under the Parent-Subsidiary Directive cannot be interpreted as covering 478 the dissolution of a company upon a merger by acquisition.

See generally, Wattel (2008). 
constituted a sufficiently serious breach leading to State liability for loss and damages in EU law.

Metallgesellschaft and Others \& Hoechst (C-397\&410/98) was about UK legislation on Advance Corporation Tax (ACT). In Metallgesellschaft and Others \& Hoechst the question was whether it was contrary to freedom of establishment if resident companies were required to pay ACT on profit distributions distributed to their non-resident parent companies, whereas ACT was not due if the dividend was paid to a parent company that was established on UK national territory and a group income election was made. That group income election was not available in relation to non-resident parent companies. The difference in treatment, which the Court found to restrict freedom of establishment, only amounted to a loss of interest as the subsidiary would in any case be subject to a final corporation tax on its profits against which previous ACT payments could be offset.

The national court inquired with the Court if and how this breach should be remedied when the claim for a remedy is made in an action for restitution of undue charges, and, alternatively, when the claim is made in an action for compensation for damage for a breach of EU law.

The reply of the Court stated that the legal classification was a matter of national procedural autonomy (para 81). Nonetheless, Member States are required to repay tax charges levied in breach of EU law, since the right to repayment is 'a consequence and complement' of the EU law rights (para 84). Because restitution of the interest loss was the objective of the claim of the taxpayers in Metallgesellschaft and Others \& Hoechst, EU law obliges Member States to principally allow such a claim in accordance with national procedure (para 88).

Also, the interest loss may be claimed as repair for damages; as a loss of profit (para 91). In Metallgesellschaft and Others \& Hoechst the Court did not further elaborate on the conditions of Brasserie du Pêcheur and Factortame like it did in Denkavit International, VITIC Amsterdam \& Voormeer, and it did not establish whether the claim for damages had to be allowed in the case at hand. The Court merely found that compensation of the interest loss was essential in view of the restriction at issue when such a claim was allowed (para 95). The Court held, however, that a claim for damages may not be dismissed on the sole ground that the taxpayer did not claim a benefit which national law in any case denied (para 107). To require otherwise would conflict with the principle of effectiveness that has to be assured in EU law (para 106). ${ }^{479}$

The broad lines on the application of Brasserie du Pêcheur and Factortame in the field of direct taxation were later affirmed and explained in more detail in FII Group Litigation to provide the national court with interpretative guidance on resolving the issue of remedies for breaches of EU law by direct tax measures. The Court recalled in that context in para 215:

479 The principle of effectiveness was also at issue in Pelati (C-603/10) which was decided by the Court in 2012. 


\begin{abstract}
...the national court must take into account the fact that, in a field such as direct taxation, the consequences arising from the freedoms of movement guaranteed by the Treaty have been only gradually made clear, in particular by the principles identified by the Court since delivering judgment in Case 270/83 Commission v France. Moreover, as regards the taxation of dividends received by resident companies from non-resident companies, it was only in Verkooijen, Lenz and Manninen that the Court had the opportunity to clarify the requirements arising from the freedoms of movement, in particular as regards the free movement of capital.
\end{abstract}

This implies that, according to the Court, the breach of EU law in FII Group Litigation was clearly sufficiently serious in terms of Brasserie du Pêcheur and Factortame only when the UK had persisted in infringing EU law as regards the avoidance of economic double taxation of distributed profits which were not regulated by the Parent-Subsidiary Directive, after the issues in FII Group Litigation had become settled case law with the judgments in Verkooijen, Lenz and Manninen (para 216).

For infringements committed before that time, the national court was called upon to apply the conditions of Brasserie du Pêcheur and Factortame, para 56 that require the national court to assess all factors of the situation that determine the seriousness of a breach of EU law; clarity and precision of the rule infringed, whether the infringement and damage caused were intentional or involuntary, whether any error of law was excusable or inexcusable, the contribution of Union institutions towards the adoption of maintenance of national measures or practices contrary to EU law (FII Group Litigation, paras 213 and 217).

\title{
4.3.5.7 Qualitative analysis of community 10
}

\subsection{Preliminary remarks}

Community 10 is organised in six subcommunities. There is one sample case that is grouped in a separate subcommunity in community 10 . The Court ruled in Commission v Belgium (C-433/04) that Belgium had breached EU law by imposing national legislation that provided that contracting parties which were not registered in Belgium, but active in the Belgian construction sector, were jointly and severally liable for their tax debts and in addition imposed a withholding tax of $15 \%$ on payments to these non-resident contracting parties. The Court found that freedom to provide services was restricted and that more proportional measures than the ones at issue were available to the Belgian legislator in order to prevent tax fraud in the construction sector.

The remainder of the case law that is organised in community 10 is divided over five other subcommunities. We will see that the organisation of cases in subcommunities is legally relevant as the different subcommunities return different lines of authority. One subcommunity concerns case law on pension taxation specifically, whereas another subcommunity more generally revolves around disadvantageous treatment of foreign investment and the development of 
the cohesion of the tax system as a justification. A third subcommunity is a close analogy to the second in that it represents a line of authority on national legislation that made the availability of tax benefits conditional on the use of assets or the performance of activities on national territory. A fourth subcommunity also concerns case law in which tax benefits were reserved for internal situations, but may be distinguished on the ground that the context is morally salient. This subcommunity is on the taxation of lotteries and charities. The fifth and last subcommunity is also a collection of cases that deal with investment income, but it particularly clarifies the justification of effectiveness of fiscal supervision. We will now concisely review each subcommunity.

\subsection{Taxation of pensions and annuities}

The first subcommunity concerns mostly cases on the tax treatment of life insurance and pension policies. In contrast, the national legislation in Vestergaard (C-55/98) put a higher burden of proof on the taxpayer if he wanted to claim a deduction for expenses made in relation to a professional training course that he took in another Member State. The Court ruled that freedom to provide services was restricted since the national measure made it more difficult to deduct expenses made in relation to training offered by a foreign provider. On a higher level of abstraction, this type of legislation is not different from a national measure that denies a deduction of pension contributions paid from taxable income if the provider of the pension policy is established in another Member State, as discussed below. In both cases, there is a different, less advantageous treatment in relation to a tax deduction if a foreign service provider is involved. ${ }^{480}$

The type of national legislation that was at issue in the other proceedings before the Court was savings in the form of a life insurance or a pension that were taxed more heavily when the policy was taken out with an institution that was not established in the Member State in which the taxpayer concerned was a resident.

In Safir (C-118/96) the savings of a capital life insurance policy that was taken out with a foreign institution were subjected to an additional tax. The administrative requirements associated with foreign policies also put an additional burden on taxpayers who enjoyed the services of a provider that was established in another Member State. The Court found that the cumulative additional burden that was put on taxpayers who exercised freedom of movement could not be justified under EU law, despite the fact that certain elements of the Swedish national legislation at issue purported to ease that burden; inter alia by allowing offsetting comparable foreign taxes against the additional tax due in Sweden.

The main line of authority of this subcommunity is a collection of cases that dealt with national legislation that limited the deductibility of contributions made to pension insurance policies that were taken out with a foreign insurance

${ }^{480}$ See, Section 4.3.5.5.6 on business deductions. 
institution, whereas contributions made in respect of policies taken out with national pension insurers were deductible. In Danner (C-136/00), Skandia and Ramstedt (C-422/01), Commission v Denmark (C-150/04) and Commission v Belgium (C-522/04) the Court held that the denial of this tax advantage infringed the freedom to provide services. The Court reasoned that such national measures constituted a dual restriction in that they dissuaded individuals from receiving services, i.e. pension insurance policies, from providers established in other Member States and on the same basis dissuaded those foreign service providers from offering their pension insurance policies in the Member States concerned. ${ }^{481}$ The Court consistently recalled in those cases:

In the perspective of a single market and in order to permit the achievement of its objectives, [Article $56 \mathrm{TFEU}$ ] precludes the application of any national rules which have the effect of making the provision of services between Member States more difficult than the provision of services purely within one Member State. ${ }^{482}$

The first cases of this kind are Bachmann, Commission v Belgium (C-300/90) and Wielockx. The Court also found in those cases that a limitation of the tax deductibility of pension contributions paid to foreign pension institutions was contrary to the freedom to provide services. These cases are also organised in community 10, which makes sense also from a legal point of view. However, in Bachmann and Commission v Belgium the Court held that this restriction was justified by reason of the cohesion of the tax system, see next Section. This justification was then significantly limited in Wielockx for situations in which cohesion was shifted to the level of the reciprocity of rules agreed by the contracting states to a DTC as the Court phrased it (para 24). In that situation could a restriction on freedom of movement no longer be justified with reference to the cohesion of the national tax system of the Member State concerned. Furthermore, the cohesion of the tax system was tested in various other cases dealing with preclusion of tax benefits for different types of foreign investment. Hence, Bachmann, Commission $v$ Belgium and Wielockx have a broader legal relevance than the field of pension's taxation to which the relevance of the cases of the subcommunity that is discussed here is confined.

In the cases of Danner, Skandia and Ramstedt, Commission v Denmark, and Commission v Belgium (C-522/04) the Court held that the restrictions in those cases, though very much comparable to the ones at issue in Bachmann and Commission $v$ Belgium, were not justified by reason of the cohesion of the tax system.

In Danner, the Court found that there was no direct link between the deductibility of contributions and the taxation of pension benefits as was the case in Bachmann and Commission v Belgium. The Finnish legislation in Danner subjected pension benefits to tax irrespective of whether the

481

482 See e.g., Danner, para 31.
See e.g., Danner, para 29. 
contribution payments were previously deducted from tax or not (paras 36-39). This distinguished the Finnish tax system from the Belgian legislation that the Court reviewed in Bachmann and Commission v Belgium and which only taxed pension benefits when paid by national institutions but exempted foreign pension policies from tax, as the Court reasoned in those cases. Furthermore, the Court applied Wielockx in Danner and held that Finland in any case had forfeited its right to tax pension benefit payments paid by the German institution in the case at hand by way of the DTC (paras 13, and 40-43).

The Swedish legislation at issue in Skandia and Ramstedt also did not establish a direct link between the deductibility of contributions and the taxation of benefits in terms of Bachmann and Commission v Belgium. The national measure in Skandia and Ramstedt limited the deduction of pension contributions paid by the employer to foreign institutions in that such a deduction was only allowed at a time when the benefits from the pension policy were paid to the employee, whereas the employer could deduct contributions paid in consideration for national pension insurance policies when they were paid to the institution. In both situations the employee was liable to tax on the benefits he received, so the Court reasoned that the difference in treatment as regards the timing of deductions for the employer was not directly correlated with an offsetting difference in treatment when pension benefits were paid and the restriction did thus not contribute to the cohesion of the tax system (paras 3037).

The national legislation that was put to the test for compatibility with EU law in Commission v Denmark (C-150/04) was on material points indistinguishable from the legislation in issue in Bachmann and Commission v Belgium. The Danish tax system made deductibility of contributions paid for in consideration of pension insurance policies contingent on the benefits accruing from those policies being taxed, as the Danish government explained in its submissions (paras 61, 63 and 64). The Court however dismissed the Danish government's defence. In contrast to its judgments in Danner, Skandia and Ramstedt, and also Wielockx, the Court did not hold in favour of the taxpayer by reasoning that there was no direct link, but the Court pointed to a new ground which rendered the Danish tax system inconsistent and therefore required the rejection of cohesion of the tax system as a justification for the restriction on freedom of movement.

The new ground advanced by the Court's Grand Chamber in Commission $v$ Denmark was that Denmark failed to reverse previously granted deductions paid in consideration of national pension insurance policies when the taxpayer transferred his residence to another Member State and so caused Denmark to lose the competence to tax the pension benefits, even when they were paid by institutions established in its national territory (paras 71 and 72). The Court also held that nothing prevented Denmark from taxing pension benefits paid by foreign institutions to resident beneficiaries (para 73). The Court so determined that the material factor that was liable to adversely affect cohesion between the deduction of contributions and the taxation of benefits was not the place of establishment of the pension insurance policy-as it held previously in 
Bachmann and Commission $v$ Belgium-but the place of residence of the beneficiary of the pension insurance policy, i.e. the taxpayer (para 73). The difference in treatment on the basis of the place of establishment of the pension insurance institution could thus not be justified.

While the Court's technical understanding of the tax legislation at issue in Commission v Denmark cannot, as such, be faulted, it is evident that this case clarifies the important point that it is not only necessary that there is a direct correlation between a tax advantage and an offsetting tax levy for a national measure to be justified in terms of cohesion, but also that the tax system consistently and systematically maintains this direct link in all relevant aspects of its design. ${ }^{483}$

The last case of this subcommunity on taxation of pensions is Commission $v$ Belgium (C-522/04). This direct action concerned various tax regulations relating to taxation of pensions which withheld tax benefits when a foreign pension insurance institution was involved. The Court ruled that Belgium had failed to fulfil its EU obligation with regard to all claims made by the Commission by applying less favourable tax rules to situations in which a foreign pension insurance institution was involved compared to the treatment accorded to situations which involved institutions established in Belgium. Commission $v$ Belgium affirms the line of authority of the cases discussed above, albeit in the context of different technical rules. For this reason it is not necessary to discuss this case further, given that the national and EU law subject matter is the same as the other cases and it is now evident that this subcommunity is clearly organised in a legally relevant manner.

The subcommunity of cases on taxation of pensions that was discussed above represents a consistent line of authority on the cross-border provision of pension insurance policies. We have seen that in this context the cohesion of the tax system has been material to understand the outcome of these cases in relation to the judgments in Bachmann and Commission v Belgium. We will now turn to the subcommunity in which these two cases are organised.

\subsection{Cross-border investment and fiscal cohesion}

The cases of the subcommunity that is analysed in this Section concerned national measures that withheld certain tax benefits when investments were made in other Member States. ${ }^{484}$ In this context the Court has been called upon to clarify the application of the cohesion of the tax systems as a justification ground to other types of national legislation than the area of taxation of pensions in which this overriding reason of public interest was first accepted. We will not revisit Bachmann, Commission v Belgium and Wielockx at this point and we will immediately proceed with the other cases of this subcommunity.

${ }^{484}$ Compare, the EFTA Court judgment in Seabrokers (E-7/07). 
The proceedings in Verkooijen (C-35/98), Bosal (C-168/01), Lenz (C$315 / 02$ ), and Weidert and Paulus (C-242/03) all concerned the question to what extent EU law required tax benefits associated with investments in holdings of shares also to be conferred on holdings in companies established in another Member State than the Member State concerned.

The issue in Verkooijen was whether the Netherlands properly denied a resident taxpayer a (partial) dividend exemption to which he would otherwise have been entitled, but for the fact that the dividend was received from a company established in another Member State. The Netherlands tried to give reason to the national legislation by maintaining that the difference of treatment was justified by reason of the cohesion of the tax system, since the company which distributed its profits was not subject to tax in the Netherlands and the dividends would thus escape taxation in the Netherlands if the exemption were to be granted. The Court however recalled from Bachmann and Commission v Belgium that this justification can only be accepted if there is a direct link between the tax advantage - the dividend exemption in case - and an offsetting tax levy, which would have been a tax charge on the profits (distributed or not) of the company. According to the Court:

58. No such direct link exists in this case between the grant to shareholders residing in the Netherlands of income tax exemption in respect of dividends received and taxation of the profits of companies with their seat in another Member State. They are two separate taxes levied on different taxpayers.

This approach to cohesion disproves the existence of a direct link by stating that the advantage and levy concern different taxable persons and different taxes. After Verkooijen, a direct link may thus only be assumed to exist if the advantage and levy relate to the same tax liability, in that they are applied to the same person for the same tax as was the case in Bachmann and Commission v Belgium. This understanding of the cohesion of the tax system laid the grounds for the Court's ruling in Bosal. ${ }^{485}$

Bosal concerned a company that was established in the Netherlands and which was denied a deduction of costs associated with its shareholding in a subsidiary which was in turn established in another Member State. Those costs would only have been tax deductible had the subsidiary derived taxable profits from activities undertaken in Dutch national territory, which it had not. The Court reasoned that the requirement of deriving taxable profits from activities in Dutch national territory hindered freedom of establishment, since a foreign subsidiary normally does not derive profits in the Netherlands and the parent company might so be dissuaded from establishing a subsidiary in another Member State instead of in the Netherlands (para 27). The Dutch government however argued that the national legislation was justified on grounds of cohesion of the tax system, since the tax advantage granted to a parent company 
of a deduction of costs associated with holdings in its subsidiary was contingent on there being a tax levy on that subsidiary.

The Court's reasons to find in favour of the taxpayer were twofold and strongly reinforced the position it took in Verkooijen. First, the Court started by establishing that the parent company and its subsidiary were '...distinct legal persons, each being subject to a tax liability of its own [...]' (para 32). Because the tax advantage of a deduction of costs was applied at the level of the parent company and the tax levy intended by the legislator to offset that advantage was applied at the level of the subsidiary (para 31), there was accordingly no direct link 'in the context of the same liability to tax' (para 32). The Court thus concluded that the limitation of the deduction of costs associated with holdings in subsidiaries was not balanced by a corresponding tax advantage and that it in effect resulted in an unjustified overtaxation of companies which held shares in foreign companies (paras 33 and 34).

Then, secondly, the Court moved beyond Verkooijen and held that it could not establish on any other basis a legal correlation between the deduction of costs for the parent company and the amount of, or even existence of taxable profits of the subsidiary in the Netherlands (para 35). Furthermore, it pointed to other inconsistencies in the tax system in additional support of the point that there was no consistent and systematic legal correlation between the treatment of costs connected to shareholdings and tax liability in the Netherlands:

36. Moreover, as the referring court and the Commission have pointed out, one is entitled to question the coherence of a system of taxation based on the existence of a link between costs incurred in relation to holdings and the existence of profits taxable in the Netherlands within the same group of companies, while subsidiaries of parent companies established in other Member States cannot deduct from their profits taxable in the Netherlands the costs in relation to holdings of those parent companies.

It is true that the Bosal judgment has been received critically in the literature on the application of the justification of cohesion of the tax system. ${ }^{486}$ Notwithstanding that one could question the application of the rule on the facts of an individual case and the outcome of a particular ruling, the fact nonetheless remains that the Court's line of authority is consistent and requires a direct link between a tax advantage and an offsetting tax levy, in that the underlying aims ('cohesion') of the tax system are legally configured in a consistent and systematic manner. ${ }^{487}$ When the advantage and levy are applied in relation to the same tax liability, i.e. as regards the same tax and the same taxpayer, an explicit legal configuration is evident. Nonetheless, inconsistencies or systematic deviations from national legislation pursuant to a DTC (Wielockx) adversely affect the cohesion of the tax system so that it cannot be relied upon to justify a denial of tax advantages to situations in which freedom of movement has been exercised.

486

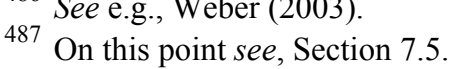


The judgments in Lenz and Weidert and Paulus fully continue this line of authority. Lenz concerned national legislation which subjected dividends received by individuals to a half rate of personal income tax, but only if they were distributed by companies established in the Member State concerned (Austria). The Austrian government argued that the half rate of personal income tax was directly linked to the level of corporation tax on the companies which distributed those dividends. Since non-resident companies were not subjected to Austrian corporation tax, it followed that profits distributed by those companies were not required to receive the same preferential treatment in the hands of their shareholders. The Court applied Verkooijen and Bosal:

36. In this case, apart from the fact that tax on the income of physical persons and corporation tax are two distinct taxes which affect different taxpayers (Case C-251/98 Baars [2000] ECR I-2787, paragraph 40; Verkooijen, paragraphs 57 and 58; Case C-168/01 Bosal [2003] ECR I-0000, paragraph 30), it should be noted that the Austrian tax legislation does not make the obtaining of the tax advantages at issue enjoyed by Austrian residents on their domestic revenue from capital dependent upon the taxation of the companies' profits by way of corporation tax.

It again follows from this holding that the Court understands a tax system to be cohesive (or, coherent) only if it is deliberately configured to achieve the intended aims through express dependencies between the rules of the national legislation. ${ }^{488}$ It is for this reason, that the Court recalled in Lenz that 'the need to preserve the coherence of a tax system must be verified having regard to the aim pursued by the tax legislation in question' (para 37). The Court then evaluated whether the aim of the national legislation at issue in Lenz would be adversely affected if the restriction against shareholdings in foreign companies was to be lifted and the same tax advantage was extended to foreign-sourced dividends and established that this was not the case (para 38-39). The Court accordingly ruled that the Austrian legislation restricted free movement of capital as it dissuaded resident taxpayers from making investments in foreign companies and made it more difficult for those companies to raise capital in Austria (paras 20 and 21).

The judgment in Weidert and Paulus is just another variation on the same theme. The national legislation of Luxembourg offered a special personal income tax relief for cash acquisitions of shares, but limited this benefit to acquisitions of shares in companies established in Luxembourg. Although the Court obviously found this difference in treatment to constitute a breach of free movement of capital, because it made investments in foreign companies less attractive, the government of Luxembourg argued that the restriction was justified by the cohesion of the tax system. This time it was the fact that dividends received from companies established in other Member States (Belgium in case) would be subjected to a lower level of taxation in 
Luxembourg, because of the DTC that allocated the other Member States in part the right to subject those dividends to tax that adversely affected the cohesion according to the national government. The Court was not able to validate that the alleged link between the tax relief and the taxation of dividends was indeed laid down in national legislation (paras 20-23). It also pointed to its authority of Wielockx that stipulated that cohesion of the tax system cannot be claimed successfully if the Member State had knowingly created the inconsistency and deviated from its intended national cohesion by agreeing to surrender its taxing powers (partially) to another Member State pursuant to a DTC (paras 24-26).

The case of Kerckhaert and Morres (C-513/04) concerned juridical double taxation of dividends received by resident individuals of Belgium, but the Court explicitly distinguished the case from Verkooijen and Lenz to hold that Belgium did not restrict free movement of capital in the case at hand by imposing different treatment on similar situations:

16. In Verkooijen, Lenz and Manninen, the Court found that the laws of the Member States at issue did not treat in the same way dividend income from companies established in the Member State in which the taxpayer concerned was resident and dividend income from companies established in another Member State, thereby denying recipients of the latter dividends the tax benefits granted to the others. Having concluded that the situation of taxpayers receiving dividends from companies established in another Member State is not objectively different to that of taxpayers receiving dividends from companies established in the Member State in which they are resident, the Court held that the laws at issue amounted to restrictions of the fundamental freedoms guaranteed by the Treaty.

17. Contrary to the arguments submitted by Mr and Mrs Kerckhaert-Morres, the case in the main proceedings differs from those which gave rise to the judgments cited above inasmuch as the Belgian tax legislation does not make any distinction between dividends from companies established in Belgium and dividends from companies established in another Member State. Under Belgian law both are taxed at an identical rate of $25 \%$ by way of income tax.

The remainder of the judgment concerned the reverse side question of the discrimination medal whether Belgium improperly treated different situations the same. The Court found that this was not the case (paras 18 and 19), and held in para 20 that the disadvantage of juridical double taxation had to be attributed to the parallel exercise of taxing powers by the Member States.

The judgment of Laboratoires Fournier (C-39/04) concerned a French tax credit for research which was only afforded to taxpayers if they had incurred expenditures for research activities which were carried out by the commissioned 
research institutes in the national territory of France. The Court likened this restriction to the one of Vestergaard: $:^{489}$

15. Moreover, the legislation of a Member State, such as that at issue in the main proceedings, by restricting the benefit of a tax credit for research only to research carried out in that Member State, makes the provision of services constituted by the research activity subject to different tax arrangements depending on whether it is carried out in other Member States or in the Member State concerned (see, to that effect, Case C-55/98 Vestergaard [1999] ECR I-7641, paragraph 21).

16. Such legislation differentiates according to the place where the services are provided, contrary to Article 49 EC.

The national court also asked if the restriction could be justified by the cohesion of the tax system. The French government submitted on this point that the difference of treatment corresponded to the principle of fiscal territoriality, since France did not levy corporation taxes on the service provider when the activities were performed outside France. The Court disagreed by holding in paras 17 and 18 that the French government had misconceived the Court's judgment in $\mathrm{Fu}$ tura (C-250/95). Also, there was no direct link in terms of the cohesion case law between the general corporation tax (on the research activities performed by the service provider) and the tax credit that the recipient of those services could claim in relation to expenditures made in consideration for the research services (para 21).

\subsection{Tax benefits solely for activities on national territory}

There is a third subcommunity that includes four sample cases about similar national measures as reviewed in Laboratoires Fournier, i.e. national legislation that makes a tax advantage conditional on the carrying out of economic activities in national territory. The national legislation at issue in Commission v Spain (C-248/06) provided for a less advantageous tax deduction in respect of research and development expenditures if, in effect, the research and development activities were carried out in another Member State. The national measures at issue in Jobra (C-330/07), Tankreederei I (C-287/10), and Waypoint Aviation (C-9/11) also conferred tax subsidies for the investment in or use of certain business assets (respectively, vehicles, navigation vessels, and aircrafts), but that tax advantage was also refused if the assets were not actually used in national territory. The Court could not find justification for this difference in treatment and held that it restricted freedom to provide services. The main idea of the line of authority of this subcommunity is clearly that a national measure that awards tax

Vestergaard is also organised in Community 1, but in the subcommunity on taxation of pensions; Section 4.3.5.7.2. 
advantages conditioned upon economic activity to be carried out in national territory is contrary to EU law.

\subsection{Lotteries and charities}

The fourth subcommunity concerns three sample cases on, on the one hand, the taxation of charities, ${ }^{490}$ and on the other hand the taxation of winnings from games of chance. ${ }^{41}$ Both subject matters are examples of morally salient issues. Lotteries are generally considered socially undesirable activities and charities are generally socially desirable activities. In relation to both ends of this spectrum the Court applied an equivalent approach.

In relation to the taxation of winnings from games of chance, the Court has held that it may be lawful to discourage the participation in these activities in general, but is contrary to EU law to discourage the participation in lotteries organised in other Member States specifically by increased taxation compared to domestic games of chance. ${ }^{492}$

Similarly, the Court has held that each Member State may set the criteria under which charities are granted preferential tax treatment and are accordingly not obliged to mutually recognise foundations that qualify as a charity under the laws of another Member State. However, a Member State concerned may not deny preferential tax treatment to foundations established in another Member State if these foundations pursue the same charitable goals and also otherwise fulfil the conditions that are required to receive the same preferential tax treatment as granted to charities that are established in the Member State concerned. $^{493}$

To conclude, the mere fact that a charity is established in another Member State, or the mere fact that a lottery is organised by a body that is established in another Member State cannot lawfully have a less advantageous tax treatment as a consequence. Such different treatment amounts to discrimination and thus a breach of EU law.

\subsection{Effective fiscal supervision and cross-border investments}

Four rulings which are grouped together in a subcommunity illustrate the Court's approach to the effectiveness of fiscal supervision as justification for restrictions on cross-border investments. Commission v France (C-334/02) concerned national legislation which allowed taxpayers the option to elect to have income from certain investments in debt instruments subjected to a fixed levy, which was generally lower than the marginal rate of personal income taxation.

${ }^{490}$ Stauffer (C-386/04).
491 Lindman (C-42/02); and Commission v Spain (C-153/08).
${ }^{492}$ Lindman, para 21; and Commission v Spain, para 34.
${ }^{493}$ Stauffer, paras 37-40; and see Commission v Spain, paras 30-32. 
However, if the debtor was resident in another Member State the taxpayer could not opt for the fixed levy. The Court held that this different treatment was contrary to freedom to provide services because it dissuaded French taxpayers from making cross-border investments and also restricted free movement of capital since it dissuaded foreign companies from raising debt capital in France (paras 22-25). The Court's analysis as regards the existence of a restriction was equivalent to the one it had adopted in its case law that we reviewed in Section 4.3.5.7.3.

The problem in terms of justification was that the fixed levy was deducted at source by the debtor or its paying agent. The French government therefore submitted in its defence that the restriction was justified by the need to ensure effective fiscal supervision, given that enforcement would be more difficult when the debtor was established in a Member State other than France. The Court dismissed this argument and held that administrative difficulties could not be justified under this heading because even the French government had admitted that these were not insurmountable in practice.

The other cases in this subcommunity also deal with various "practical problems' relating to the collection and recovery of tax on cross-border investment income. Since the Mutual Assistance Directive (77/799/EEC) aimed to enable administrative cooperation between tax authorities to overcome those problems, the Court's standards for allowing a restriction to be justified by the need to ensure effective fiscal supervision are high. ${ }^{494}$ This is shown by the case law of this subcommunity.

In ELISA (C-451/05) the Court even applied strict scrutiny in situations in which the directive did not oblige Member States' tax authorities to cooperate. Even in those situations it was not proportional to categorically refuse tax advantages with regard to cross-border investments, according to the Court.

The judgment in Commission v Portugal (C-267/09) only left room to require the appointment of a fiscal representative of a non-resident taxpayer in Portugal when the taxpayer resided in a non-member State, since those situations fell outside the scope of the Mutual Assistance Directive (77/799/EEC), and Portugal and the other state had not entered into 'any undertaking of mutual assistance' (para 55). In view of the ruling in Passenheim van Schoot \& $X$ such an undertaking of mutual assistance could be agreed by way of e.g. a DTC, but in the direct action against Portugal the Court held that the Commission submitted insufficient proof that an undertaking of that kind was in place in those situations (Commission v Portugal, para 56).

The issue in Passenheim van Schoot \& X (Joined Cases C-155 \& 157/08) was whether the Netherlands was allowed to maintain a longer recovery period in force for situations in which the taxpayer concealed income from the tax authorities and the improperly unpaid tax related to assets held in other Member States. The Court first established that an extended period of twelve years compared to the recovery period of five years that ordinarily applied in internal

${ }^{494}$ See, Hemels (2009). 
situations did not, as such, correspond to the additional time that may be afforded to enable an exchange of information with other Member States pursuant to (now) the Administrative Cooperation Directive (2011/16/EU) or an international agreement, e.g. a DTC (para 60).

The Court continued its judgment nonetheless by holding in favour of the tax authorities that an extended recovery period was however justified and proportional in situations in which the tax authorities have no evidence of the existence of the foreign assets which would enable the tax authorities to initiate an investigation and to request the administrative cooperation of tax authorities of other Member States (paras 66-70).

\subsection{The most important precedents}

\subsubsection{Method}

We have seen in the preceding Sections how the precedent-oriented process of judicial decision making has established a self-organised community structure in the network of case law with legally distinguishable lines of authority. In that context, recall that the overarching aim of this research is to establish outlines of a doctrine on EU law in the field of direct taxation. This requires making a systematic exposition of the most essential legal norms in the legal order so defined. The previous Sections have shown that it is possible to achieve a legally relevant organisation of the case law without legal interpretation, but through a social network analysis of the body of case law. Although a qualitative legal analysis was necessary to expose the lines of authorities of the different (sub)communities that the Court adhered to, the organisation of the case law was achieved by computation and not through (subjective) qualitative analysis. We have so resolved the most important step of legal doctrine (achieving a structured organisation of sources of law) in an objective, transparent and reproducible manner.

The second challenge is how to distinguish between important and less important legal norms. As EU law in the field of direct taxes evolves incrementally and new legal norms are consequently established initially as grounds of judgment in one individual ruling, it is first necessary to distinguish between important and less important judicial decisions. We accordingly expect to find the most essential legal norms in the most important precedents. Also for this task it is possible to rely on computation through social network analysis instead of on a lawyer's personal opinion.

Prior research established that deliberately deleting a small percentage of the most connected nodes in a scale-free network significantly affects the structure of those networks, whereas such networks are resilient to change if nodes are deleted randomly. ${ }^{495} \mathrm{~A}$ targeted removal of no more than $3 \%$ of the most 
connected nodes normally results in the disconnection of the network. ${ }^{496}$ It has also been found that these highly connected nodes are crucial to understand epidemics of biological or computer viruses, communication and spreading phenomena in networks. ${ }^{497}$ For that reason, we believe that, as a rule of thumb, the top- $3 \%$ of cases were most important for the spreading of legal norms in judicial doctrine.

In terms of the case law network, these highly connected nodes are cases which - given their key position in the network structure - are important for the integrity of the chain novel of EU law on direct taxation. These cases lie at the heart of, and maintain the cohesion in the Court's judicial doctrine. Consequently, we believe that a collection of the 20 most important cases is a sufficient collection of sources on the basis of which the main outlines of judicial doctrine on EU law in the field of direct taxation can be defined in a representative manner. ${ }^{498}$

The importance of a case can be determined on the basis of its centrality in the network. A case that is connected to many other cases takes up a more central place in the network than a case that is connected to only a few other cases. Simple calculations of the number of times a case cites other cases, or is cited by other cases, are raw and imprecise measures of centrality, and they do not take full advantage of all of the information in the network structure.

In line with the prevailing approach in prior research we compute the importance of a case as the $h u b$ and authority score of that case. ${ }^{499}$ This method of link analysis - the HITS-algorithm - as developed by Kleinberg not only allows to distinguish between inward and outward citations, but also considers the quantity as well as the quality of citations. ${ }^{500}$

The network theory of hubs and authorities can be transposed to legal networks as follows. A case that is cited by many other important cases functions as an authority to those other cases. A case that cites many other important cases functions as a $h u b$ for those other cases. Most cases function both as an authority to some later cases, and as a hub for other prior cases. The degree to which cases fulfil these roles is mutually reinforcing; a good hub cites many good authorities, and a good authority is cited by many good hubs. ${ }^{501}$

The hub and authority scores of cases are context dependent. This means that the hub and authority scores of the cases in the network change as new cases and citations are added to the network. This is consistent with the legal network as a dynamic network and the well accepted view that the judicial interpretation of

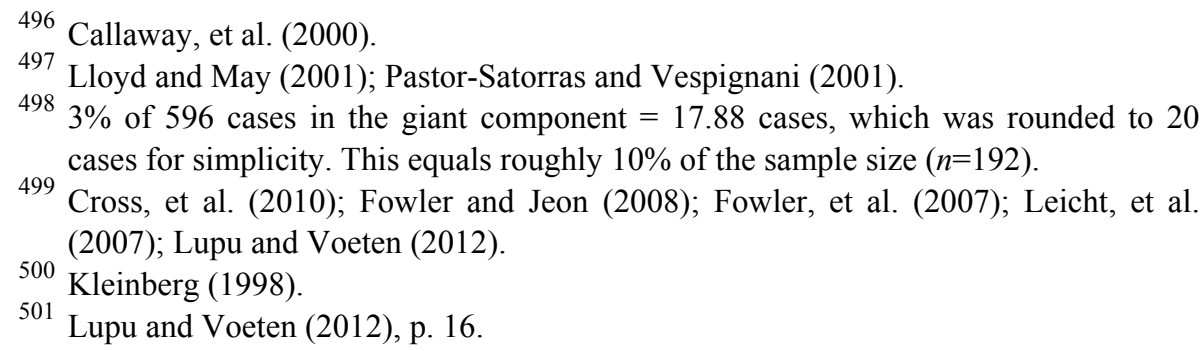


the law develops over time with changing circumstances of society. So, the relative importance of cases in the network is also a dynamic characteristic of cases. Since our primary interest is with the law as it currently stands, we do not analyse the development of importance scores of cases over time.

The extent to which a particular case performs the connector roles of hub and authority can be determined by ranking the computed hub and authority scores of all cases. Ranking of authority scores identifies the cases that have provided the strongest persuasive guidance to other cases, i.e. have been most influential to the development of judicial doctrine. Ranking of hub scores identifies the cases that are more strongly grounded in precedent. Accordingly, cases with high hub scores do not necessarily establish new rules, whereas cases with high authority scores evidently resolved indeterminacy in the law and thus created relevant new judicial rules which induced positive feedback effects and became relevant to adjudge later cases. Hub cases can be thought of as cases that tie together various lines of established authority and thus signal what is settled and well-established case law.

We will define the most important precedents by a ranking of authority scores. The authority score enables cases to be ranked by the degree of interpretative guidance provided to decide later cases. The most authoritative precedents are consequently expected to have been most influential for the evolution of EU law in the field of direct taxes.

\subsubsection{Results}

The 20 most important cases by authority score in the network of case law in the field of direct taxation are presented in Table 19. The table should be read as follows. Indegree is the number of inward citations for the case with the ranking based on indegree of the case between parentheses. Since we collected outward citations only for cases in the initial sample, this count is the number of other sample cases that cite the precedent. Bench is the bench hearing the action of the case; $G C$ stands for the Grand Chamber and 5 indicates that the case was heard by a panel of five judges. ${ }^{502} P R$ indicates whether the Court released a press release on its judgment or not $(\mathrm{Y} / \mathrm{N})$. There is no public data available on press releases for judgments decided before 1996 (n.a.).

This top-20 shows a mix of older and more recent cases. In that context it should be noted that the 'oldest case' in the complete sample is Avoir Fiscal $(270 / 83)$. All cases in the top-20 are sample cases.

502 Consistent with Chapter 3, all panels composed of more than five judges is considered a Grand Chamber for this purpose. 


\begin{tabular}{llllll}
\hline Rank & Case & Short name & Indegree (rank) & Bench & PR? \\
\hline 1. & C-319/02 & Manninen & $44(2)$ & GC & N \\
2. & C-35/98 & Verkooijen & $47(1)$ & GC & Y \\
3. & C-204/90 & Bachmann & $44(2)$ & GC & n.a \\
4. & C-307/97 & Saint-Gobain & $40(5)$ & GC & N \\
5. & C-446/03 & Marks \& Spencer & $35(7)$ & GC & Y \\
6. & C-264/96 & ICI & $38(6)$ & GC & N \\
7. & C-196/04 & Cadbury Schweppes & $33(10)$ & GC & Y \\
8. & C-374/04 & ACT Group Litigation & $34(8)$ & GC & Y \\
9. & C-300/90 & Commission v Belgium & $32(12)$ & GC & Y \\
10. & $270 / 83$ & Commission v France & $33(10)$ & GC & n.a. \\
11. & C-446/04 & FII Group Litigation & $29(13)$ & GC & Y \\
12. & C-524/04 & Thin Cap Group Litigation & $28(14)$ & GC & Y \\
13. & C-251/98 & Baars & $26(15)$ & 5 & N \\
14. & C-397/98 & Metallgesellschaft & $22(18)$ & 5 & N \\
15. & C-80/94 & Wielockx & $34(8)$ & GC & n.a. \\
16. & C-471/04 & Keller Holding & $19(22)$ & 5 & N \\
17. & C-279/93 & Schumacker & $43(4)$ & GC & n.a. \\
18. & C-336/96 & Gilly & $22(18)$ & GC & Y \\
19. & C-311/97 & Royal Bank of Scotland & $26(15)$ & 5 & Y \\
20. & C-250/95 & Futura & $24(17)$ & GC & N \\
\hline
\end{tabular}

Table 19. The most important direct tax precedents by authority score

The legal weight of cases appears to be correlated to the number of inward citations, because 19 of the top- 20 cases by authority score are also ranked in the top-20 cases by indegree. ${ }^{503}$ Because the relative ranking is different, the authority score seems to include additional information about the legal importance of cases which is attributable to the structural role that the case performs in the total network. For example, Schumacker is the $4^{\text {th }}$ most cited case in the complete network, yet it is ranked at 17 by authority score. A similar, but less pronounced difference holds for Wielockx.

The authority score also appears to correspond closely with the Court's measure of importance. 17 out of the top- 20 cases were heard by a Grand Chamber or were given public attention through a press release. The top-12 cases were all decided by a Grand Chamber. No cases which were decided in Chambers of three judges are in the top-20 list.

${ }^{503}$ The difference is due to Keller Holding which is included in the authority top-20, but is ranked $22^{\text {nd }}$ on indegree. Commission $v$ France $(\mathrm{C}-334 / 02)$ is ranked $20^{\text {th }}$ on indegree, but $21^{\text {st }}$ on authority score. 


\begin{tabular}{clr}
\hline Community & Subject matter (Section 4.3.4.2) & $n$ Cases \\
\hline 1 & personal income taxes / employment & 1 \\
2 & n.a. & 0 \\
3 & corporation taxes / dividends & 10 \\
4 & property taxes & 1 \\
5 & Article 21 TFEU / Article 45 TFEU & 0 \\
6 & n.a. & 0 \\
7 & Article 21 TFEU / Article 56 TFEU & 0 \\
8 & Parent-Subsidiary Directive & 4 \\
9 & Merger Taxation Directive & 0 \\
10 & personal income taxes / services & 4 \\
\hline
\end{tabular}

Table 20. Distribution of top-20 cases over communities

\subsubsection{Evaluation}

The distribution of the top-20 cases over the communities (Louvain method) is shown in Table 20. Most cases relate either to corporation taxes or the taxation of dividends (communities 3 and 8). A minority group concerns personal income taxes (communities 1 and 10), but we have seen in the previous sections that the bulk of cases in community 1 concerns a variation upon Schumacker, which is included in the top-20. However, cases on Union citizenship (communities 5 and 7) are not represented. In view of the distribution of cases over the different subject matter classifications that we established in Chapter 3, the selection of cases produced by the top- 20 is rather balanced and does not give rise to serious doubts as to whether the selection of cases is a sufficiently accurate representation of all sample cases.

When compared to the top-20 of most cited cases by academics in Table 14 in Chapter 3, the ranking by link analysis performs better if measured against the Court's internal measures. The top-20 includes more Grand Chamber cases (16 versus 13) and also more cases with a press release (9 versus 5).

The degree of correspondence between the two rankings is $25 \%$, meaning that of the 32 different cases included in the two rankings eight cases are included in both lists. The following cases are included in both rankings: Manninen; Bachmann; Saint-Gobain; Marks \& Spencer; ICI; Cadbury Schweppes; Wielockx; and Schumacker.

It is difficult to say which ranking is a better approximation of reality. One advantage of the ranking based on the Court's citations is that we can be relatively sure, within the limits of the sample definition, that all relevant cases in the field of direct taxation have been included in the computation of the ranking. However, we lack information on the inclusion criteria for the data from which we computed the academic ranking. Future research might compare the network ranking with a citation ranking based on specialist tax journals which are read throughout Europe, e.g. British Tax Review, Bulletin for 
International Taxation, EC Tax Journal, EC Tax Review, European Taxation, and INTERTAX.

However, a closer look at cases which are included in both rankings reveals that all common cases belong to the collection of the ten most cited cases by the Court, see the indegree-column in Table 19. Also, all common cases were Grand Chamber cases. In synthesis, we may conclude that, in general, the Court and academics do not have widely divergent views on which cases were the most important for the evolution of EU law in the field of direct taxes. The method of links analysis has arguably found the most important cases.

The most important judicial rules

\subsubsection{Method}

This Section will analyse the context dependent information contained in the inward citations to each case in Table 19 and aims to determine the most important judicial rules of the Court's doctrine on EU law in the field of direct taxation. We assume that the most important judicial rules of the Court's doctrine were established by the most important cases. By reviewing which parts of the Court's grounds of these rulings were cited most frequently in subsequent decisions, we can determine which particular judicial rules the ruling established or validated. The main contribution of this Section is to establish a method to discover the core of the judicial doctrine of EU law in the field of direct taxation in a systematic and reproducible manner. The relevant procedure may be summarised in six steps:

1. Collect all inward citations to the top-20 cases from EUR-Lex;

2. Construct an extraction summary of each top-20 case;

3. Construct a citation network between the extracted paragraphs;

4. Find components and communities;

5. Paraphrase the paragraphs as representative judicial rules;

6. Organise the rules in a legally relevant manner.

First, we collected all inward citations to the top-20 cases from all CJEU rulings (judgments and orders) from the EUR-Lex database. ${ }^{504}$ Thereby, we examined how the 20 most important precedents were received in subsequent case law. Thus, we consider each citation of a different paragraph of the precedent, or in an evident different context. Multiple citations in the same ruling of the same paragraph of a prior ruling, or in the same context, are only counted once.

${ }^{504}$ We only collected rulings decided by the Court of Justice. Decisions by the General Court or the Civil Service Tribunal of the CJEU were not reviewed. If the full text of the ruling was not available in EUR-Lex we consulted the CJEU's database, available at $<\mathrm{http}$ ://curia.europa.eu $>$. 


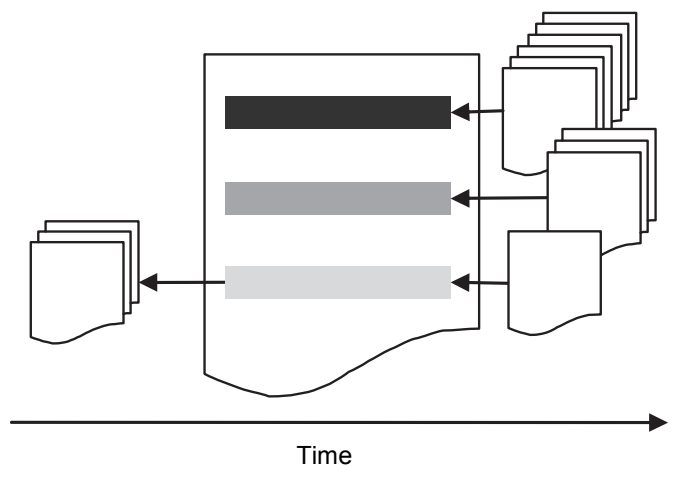

Figure 12. Heatmap of a ruling.

Second, by investigating which particular parts of a precedent are most frequently cited in subsequent case law, we can construct a 'heat map' of each ruling. Parts of a ruling that have not been cited have evidently not contributed to the development of the Court's doctrine. It is possible that the Court cites a case several times in a ruling and in various contexts. A precedent may be important for more than one reason; there is no persuasive legal theoretical argument to proceed from the assumption that individual rulings establish only one new or apply only one already existing judicial rule.

The frequency of citation of each paragraph (the indegree) is for this purpose a reasonable standard. The paragraphs and passages of a ruling that attract the most citations are accordingly assumed to be the most important sections of the ruling. ${ }^{505}$ A legal analysis of the 'hottest' section(s) of each of the top-20 rulings is then an effective method to expose the most influential legal norms by which EU law in the field of direct taxation evolved. The basic idea is visualised in Figure 12. Darker coloured regions represent paragraphs of the ruling which have received proportionately more citations from subsequent rulings. In terms of efficiency, this method compares favourably to human reading of all

505 Only citations to Bachmann and Commission v Belgium (C-300/90) were often not to a specific paragraph of those rulings. However, when this was the case, subsequent rulings cited those precedents either in the context of establishing cohesion of the tax system as a valid justification ground, or in the context that cohesion was only accepted in those cases because the Court established a direct link between the tax advantage and a subsequent tax levy in those cases. We have interpreted the first context (cohesion as valid justification) as citations to Bachmann, para 28 or Commission v Belgium, para 21. The second context (the direct link criterion) was interpreted as referring to Bachmann, paras 21-23 or Commission v Belgium, paras 14-16. Since Bachman cites Commission v Belgium (though both rulings were handed down on the same day), we have also treated Bachmann, paras 21-23 as citing Commission v Belgium, paras 14-16 respectively. 
judgments and extracting the most important paragraphs by qualitative legal analysis.

The method of analysis proposed in this step is analogous to what is known as an extraction summary in the field of computational linguistics. An extraction summary is a set of sentences from a text that provides a focused overview of the information contained in that text. ${ }^{506}$ Transposed to the context of a Court ruling this means that an extraction summary of the most cited paragraphs provides a focused overview of the holdings which established the ruling's precedential significance and have emerged as judicial rules through repeated application in subsequent rulings. In other words, we so quantitatively approximate a ruling's ratio decidendi; it's proven contribution to judicial doctrine.

The extraction summary is based on the indegree of a paragraph. We consider only paragraphs which have an indegree equal or above the average indegree of the ruling. Note that this threshold is a relative measure; it is calculated for each ruling separately.

Third, after we have collected all paragraphs of the precedents we construct a citation network between these paragraphs. Only relations between the extracted paragraphs are considered relevant for this purpose. These relations are good proxies for substantive similarity between the paragraphs, without having to analyse the content of all extracted paragraphs qualitatively.

Fourth, we apply the Louvain algorithm to find communities of paragraphs. We assume that each weakly connected component of the network and each community within a larger weakly connected component of the network represent a distinct judicial rule. Indications for the existence of relations between judicial rules are provided by inter-community links within components. This step was only included to facilitate the qualitative analysis of the next step. ${ }^{507}$

Fifth, we perform a qualitative legal analysis of these components and communities and paraphrased the Court's judicial rules in representative sentences. Accordingly, we want to summarise our findings by giving representative rules which cover the content of paragraphs with evident substantive overlap. Indications for such overlap are found in the communities which we established by the previous step. This aim also requires a qualitative analysis of semantic similarity of the extracted sentences. In drafting the representative sentences we stayed as close as possible to the original text of the Court's judgments. Where the Court used clear catchphrases or standard formulas, the Court's original text is used. To make the results of this research of value to current practice, we have maintained a style that refers to the European Union (not European Community), to the TFEU (not the Treaty or the EC Treaty) and that uses the language of Union citizenship. Also, cross-

506 Elkiss, et al. (2008).

507 This step was not particularly helpful, therefore the results are omitted. 
references between the rules are included when this relation is evident from the sources.

Finally, we evaluated and organised the judicial rules in legally relevant categories. As a final note, recall that the purpose of this book is to increase our understanding of EU law in the field of direct taxes as a system and that the specific aim of this section is to uncover the role and function of the cases which we have found to be of structural importance to the system. This also means that we are not primarily interested in the meaning or application of these rules at this point, but we simply want to know what parts of text (rules) of the most important rulings are responsible for the structure of the network as a whole. These parts of text are our understanding of what may be considered as the most essential legal norms of the system.

\subsubsection{Results}

\subsubsection{General}

Annex A presents the full results of our analysis. Our method has uncovered many distinct conceptualisations of EU law in the field of direct taxes which we have labelled rules. They are so called 'legal memes'; ideas, concepts, formulas and catchphrases which have become part of the deep structure of judicial doctrine- the genes of EU law in the field of direct taxation. ${ }^{508}$ These units of information have replicated through repeated application in the Court's rulings and together form the outlines of legal doctrine on EU law in the field of direct taxation. We believe that these rules are dominant in legal doctrine in this subfield of EU law and may be considered acte clair.

If we count all units of information about the interpretation of EU law that we extracted from the rulings, we find that the core of the judicial doctrine on EU law in the field of direct taxation is composed of 74 distinct units of law. We organised these units as paragraphs of 23 rules, which we again combined in five Sections. We have distinguished between rules which reflect general principles of EU law (Section 1), rules which restated the rights protected by the fundamental freedoms (Section 2), rules which were narrowly formulated to apply in a specific functional context, i.e. the taxation of dividends (Section 3), rules on valid and invalid justification of restrictions (Section 4) and finally, rules which are about the remedies for of a breach of EU law by tax legislation (Section 5). ${ }^{509}$

It goes too far to make a qualitative analysis of or write a detailed legal commentary on every rule of Annex A. Nonetheless, in order to illustrate how these rules have been established, we continue with a detailed account of one of

${ }^{508}$ See, Deakin (2002); Fried (1999); Goodenough (2005); Katz, et al. (2011).

509 In regards the Europeanisation of tax procedure, see e.g. van Dam and van Eijsden (2010a); van Dam and van Eijsden (2010b); Wattel (2008). 
the most contentious rules on the DTC neutralisation of restrictive dividend withholding taxes. Therefore a discussion of the emergence and reproduction of Rule 3:3 and specifically Paragraph 4 suffices. We explain the origins of the rule and how it has been adopted in the field of direct taxation. Furthermore, the following Section gives insight into how subsequent application in various cases determined the content and specified further conditions that are not evident from the rule itself as it is laid down in Annex A.

\subsubsection{DTC neutralisation of restrictive dividend withholding taxes}

\subsection{Introduction}

This Section serves as an example of how a legal norm emerges and evolves through repeated application and interpretation. The relevant rule of Annex A is reproduced here (footnotes omitted) for convenience:

\section{Rule 3:3 - Outbound dividends}

(1) In order for shareholders which are nationals of other Member States or companies which have their corporate seat in another Member State receiving dividends (foreign shareholders) not to be subject to a restriction on freedom of establishment, the Member State in which the company making the distribution has its corporate seat, is obliged to ensure that, under the procedures laid down by its national law in order to prevent or mitigate a series of liabilities to tax, foreign shareholders are subject to the same treatment as shareholders which are nationals or companies of the Member State concerned (national shareholders), if the Member State concerned is in the same position, as regards the prevention or mitigation of a series of charges to tax and of economic double taxation, with regard to foreign and national shareholders.

(2) The Member State concerned is not in the same position as regards the prevention or mitigation of a series of charges to tax and of economic double taxation, with regards to foreign and national shareholders for purposes of Paragraph 1, unless the Member State concerned, unilaterally or by a convention, imposes a charge to income tax not only on national shareholders but also on foreign shareholders in respect of nationallysourced dividends.

(3) To require a Member State, to which Paragraph 2 applies, to ensure that nationally-sourced dividends distributed to foreign shareholders are not liable to a series of charges to tax or to economic double taxation, either by exempting those profits from tax at the level of the company making the distribution or by granting the shareholder a tax advantage equal to the tax paid on those profits by the company making the distribution, would mean in point of fact that the Member State concerned would be obliged to abandon its right to tax a profit generated through an economic activity undertaken on its territory. 
(4) It is for the national court to determine, in each case, whether the obligation of Paragraph 1 has been complied with, taking account, where necessary, of the provisions of the DTC that the Member State concerned has concluded with the State of the foreign shareholder.

The context of interpretation of Rule 3:3 is as follows. First, it follows from Rule 3:3(1) that foreign shareholders are 'shareholders who are nationals of other Member States or companies which have their corporate seat in another Member State'.

Second, Rule 3:3(1) should be read in the context of the principle of nondiscrimination of Rule 1:3 and therefore the reference to "nationals of other Member States' is to be interpreted inclusive of other criteria of differentiation which in fact lead to the same result as discrimination against non-nationals, e.g. a residence criterion. The comparability of residents and non-residents is to be assessed in principle in terms of Schumacker as operationalised in Rule 1:4 as regards individuals and in terms of Rule 2:1(7) as regards companies, which also defines the term corporate seat as the registered office, central administration or principal place of business. 510

Third, the Court has given specific content to those two standards in the context of situations to which Rule 3:3 applies - the taxation of the distribution of dividends-by formulating Rule 3:3(3) that requires the imposition of an income tax on the foreign shareholder as the taxable person of that charge.

Rule 3:3 is not only fairly recent - it was found in ACT Group Litigation by the method of Section 4.5.1 - but it also has been received very critically in prior research. It therefore is a good example in view of academic innovation.

Rule 3:3(4) may perhaps be regarded to contradict Rule 4:3 (Cohesion of the tax system) and Rule 4:6 which excludes all other tax advantages as justification for restrictions on free movement. Specifically, the Court's language does not require as a material condition for Rule 3:3(4) that there is a direct link between the tax advantage and a corresponding tax levy.

Furthermore, the Court has consistently held since Wielockx that discrimination arising from the legislation of one Member State cannot be rendered lawful by application of the justification of cohesion of the tax system if cohesion has been 'elevated' to the higher legal hierarchical level of a DTC, meaning that the right to collect the corresponding tax levy has been allocated the other contracting Member State.

This is in stark contrast with the requirements of Rule 3:3(4) that allow a compensation of specific disadvantages to the exercise of freedom of movement that arise from the national legislation of one Member State to be rendered lawful, particularly if the disadvantage is neutralised pursuant to a DTC obligation by another Member State which has been allocated to right to tax by that same DTC. On these grounds, Rule 3:3(4) may be considered to fit poorly within the larger system of EU law in the field of direct taxation.

510 The same language as used in Article 54 TFEU. 
As will be explored below, Rule 3:3(4) has developed as an argument of procedural nature about the jurisdiction of the Court, and the cooperation and division of tasks between the national courts and the Court in the preliminary reference procedure. The Court has in this context explicitly proceduralised the issue of discrimination. In contrast, the rules on cohesion of the tax system and other tax advantages do not attach to a procedural rule of the Court's judicial decision making process.

Cohesion and other advantages substantively reinforce the principles of the fundamental freedoms as norms of strict equity and that discrimination is to be assessed against the background and the evident aims that the national legislation pursues. Their main purpose is to underline that subsidiary redistributions to the specific disadvantage of situations of freedom of movement are unlawful, and that this may only be different if they are neither arbitrary nor inconsistent with the larger goals of government that the national legislation pursues. In other words, they give concrete content to the open principle of freedom of movement by setting substantive norms.

\subsection{Origins}

The first case in which Rule 3:3(4) was formulated was ACT Group Litigation (C-374/04). In that case, the Court only mentioned that the effects of DTCs should be taken into account when assessing whether a Member State complied with the requirement not to impose a restriction on free movement. The real relevance would however only become clear with Amurta (C-379/05). For this reason Rule 3:3(4) will be referred to as the Amurta-rule below.

In Amurta, paras 75-80, the Court allowed Member States to ensure compliance with EU law by concluding a double tax convention with another Member State. In effect, Member States are allowed to introduce prima facie restrictive provisions unilaterally, under the condition that another Member State fully compensates for this disadvantage and provided that the obligation to compensate is included in an international agreement between the Member States. Non-compliance with that agreement on part of the other Member State will uphold the breach of EU law on the part of the first Member State, because the prima facie restrictive provision ultimately remains uncompensated pursuant to the legal framework of that first Member State.

The legal origins of the Amurta rule outside the field of direct taxation are Dietz (C-435/93) and Thibault (C-136/95). The Court derived from that case law the general rule that it is not for the Court to interpret national law and assess its effects within the framework of the procedure of Article 267 TFEU (Dietz, para 39). In accordance with the division of functions between the national courts and the Court, it is for the national court to establish the facts giving rise to the dispute, to interpret national law and to rule upon its application to the case in the main proceedings (Thibault, para 21).

These rules of judicial procedure were introduced to the field of direct taxation by the Third Chamber judgment in case Bouanich (C-265/04), in particular as regards their application to the interpretation of double tax 
conventions. The Court held that the France-Sweden DTC formed part of the legal background to the main proceedings in Bouanich. Since the national court had presented the double tax convention as such, the Court had to consider the convention in order to give an interpretation of EU law that is relevant for the Swedish national court. The Court however noted that it was for the national court to interpret and apply the double tax convention to the facts of the case in the main proceedings (Bouanich, para 51).

The above division of tasks between the courts also implies that the Court can neither interpret nor apply a double tax convention at its own motion, because a double tax convention does not have its legal basis in EU law. If the national court does not include the legal effects of a double tax convention which are relevant to the case in the reference for a preliminary ruling, these effects cannot be taken into account by the Court in order to give an interpretation of EU law. Indeed in Bouanich, para 54, the Court held that the finding and assessment of facts is a matter for the national court, citing consistent non-tax case law. Consequently, if the national court does not fully communicate the relevant facts and national provisions, including the legal effects of double tax conventions in national law, the Court cannot interpret EU law in the context of the specific circumstances of the case, but it has to suffice with conditional statements about the interpretation of EU law. This was exactly the case in Bouanich where the Court left it to the national court-due to a lack of information about the historical acquisition price and nominal value of the shares - to establish whether there was, in the actual case at hand, a restriction against free movement and whether Sweden in fact complied with EU law, or not (Bouanich, para 55).

The Court's Grand Chamber, citing the precedent of Bouanich, in ACT Group Litigation, para 71, left it to the national court to determine whether comparable situations were taxed differently in fact, explicitly instructing the national court to take into account, where necessary, the effects of double tax conventions on the taxation of the free movement situation. In the particular circumstances of ACT Group Litigation it concerned specifically the question if, and if so, to what extent, the UK imposed economic double taxation on dividends distributed by UK companies to non-resident shareholders, compared to domestic shareholders. Given that the France-Sweden DTC limited the Swedish withholding tax on dividends distributed by Swedish companies to French shareholders in Bouanich, it is not surprising that the Court in $A C T$ Group Litigation considered the effects of a DTC relevant in order for the national court to assess to what extent the UK imposed unrelieved economic double taxation by levying a corporate tax on undistributed profits at the level of the company and a potential subsequent (limited) withholding tax on those dividends at distribution.

It was only two days after the Grand Chamber's ruling in ACT Group Litigation that the First Chamber in Denkavit Internationaal and Denkavit France (C-170/05) ruled that the France-Netherlands DTC did not neutralise the restriction imposed by French law. That conclusion was based on the premise, as it derived from prior precedent, that a double tax convention forms part of the 
legal framework of the contracting Member States and its effects should be taken into account by the Court when it interprets EU law in the context of the particular circumstances of the case (Denkavit Internationaal and Denkavit France, para 45). It should be noted that the Court not only derived this rule from the case law of Bouanich and ACT Group Litigation as reviewed above, but also cited Manninen (C-319/02), para 21, to that effect.

Manninen was decided in 2004, but the Court neither cited the case as precedent in Bouanich nor in ACT Group Litigation, although both judgments were delivered in 2006. For this reason, a closer examination of the facts is necessary to clarify the relation between these cases.

The Court was faced with discriminatory taxation of dividends in both Manninen and Denkavit Internationaal and Denkavit France. The Member States in those cases, Finland and France respectively, chose to relieve economic double taxation for purely internal situations, but unilaterally imposed unrelieved economic double taxation on comparable cross-border dividends. The inbound dividends in Manninen and the outbound dividends in Denkavit Internationaal and Denkavit France were in fact treated less favourably than respectively dividends received from domestic companies, and dividends distributed to domestic shareholders. In Manninen it concerned the Finnish refusal to impute Swedish corporate tax on dividends against Mr Manninen's Finnish individual income tax, and in Denkavit Internationaal and Denkavit France imposed a withholding tax on outbound dividends, but effectively exempted those dividends in the hands of domestic recipients. In Manninen, para 21 the Court's Grand Chamber stated that:

[i]t is undisputed that the tax convention concluded between the States of the Nordic Council for the prevention of double taxation is not capable of eliminating that unfavourable treatment. That convention does not provide for any system for setting off corporation tax against income tax due on revenue from capital. It merely seeks to attenuate the effects of double taxation in the hands of the shareholder in relation to that latter tax.

Indeed the ordinary tax credit provided for in the multilateral tax convention allows a set-off of withholding tax, but not of corporation tax levied by the state in which the dividends arise. Since the particular economic double taxation in Manninen was not partially caused by a restrictive withholding tax, a credit for this withholding tax could not even potentially neutralise the restriction imposed by Finland. The credit provided for in the Nordic convention was thus not suitable to relieve the economic double taxation at issue.

However, in Denkavit Internationaal and Denkavit France the FranceNetherlands convention provided for an ordinary credit of the limited, but still prima facie discriminatory French withholding tax against Dutch corporation tax. Nonetheless, the dividends received by Dutch company shareholders were exempt from corporation tax, thus effectively limiting the ordinary credit to zero. The restrictive economic double taxation imposed by France remained unrelieved by any provision pursuant to any instrument within the legislative framework of France, and the Court adjudged that France ultimately did not 
comply with its Union fidelity obligation to duly protect the fundamental freedoms through French law (Denkavit Internationaal and Denkavit France, paras 46-49, and 54-55).

The relation between Manninen and Denkavit Internationaal and Denkavit France concerns the different degree to which the double tax conventions in those cases were suitable to relieve a tax discrimination imposed by one contracting Member State. In Manninen, the credit was fully unsuitable because it credited the wrong tax. The credit in Denkavit Internationaal and Denkavit France credited the withholding tax that gave rise to discrimination, but the credit was not designed properly to effectively take away the discrimination completely in a systematic and consistent manner. That the ordinary credit mechanism in general is ill suited in design to compensate for discriminatory withholding taxes would be confirmed and explained in subsequent case law, see below.

It only took another three months until the Grand Chamber confirmed the Court's approach to the relation between double tax conventions and EU law for the second time after Manninen. The Court cited all precedents in the field of direct taxation mentioned above in this section and reiterated in case Thin Cap Group Litigation (C-524/04), para 54:

...since the tax regime resulting from a DTC forms part of the legal framework applying in the main proceedings and has been presented as such by the national court the [Court] must take it into account in order to provide an interpretation of [EU law] that is relevant to the national court.

In the particular circumstances of the case in Thin Cap Group Litigation the Court declared that there was insufficient evidence to conclude that pursuant to UK law, and in consideration of the effects of the relevant double tax conventions applicable in the main proceedings, a requalification of interest into a distribution of profit under UK law would in fact be compensated by a corresponding adjustment or compensatory tax advantage in the Member State in which the recipient of the payment resided (paras 55 and 56). Although the compensatory effect pursuant to the double tax convention was unproven, it does not become clear from Thin Cap Group Litigation what standard of evidence the Court actually applies in these types of situations. In Amurta, Commission v Italy (C-540/07) and Commission v Spain (C-487/08), however, the Court subsequently clarified the required scope and effects of the tax advantage provided by the one Member State pursuant to a double tax convention to be suitable to compensate for a prima facie restrictive tax disadvantage in another Member State.

\subsection{The criterion of regulatory control}

In Amurta, paras 75-80, the Court for the first time related the compensatory advantages rule under double tax conventions to the compensatory advantages justification defence it consistently rejected in prior case law. According to that interpretation, the Court recalled in Amurta that it is settled case law that a re- 
striction against free movement cannot be justified by other advantages, citing Verkooijen, para 61. A Member State that imposes a restrictive tax disadvantage under its national law cannot rely on the existence of an advantage unilaterally granted by another Member State under that other Member State's national law (Amurta, para 78 without citation to precedent).

In subsequent case law of Eckelkamp (C-11/07), para 69 and Arens-Sikken (C-43/07), para 66 concerning succession duties the Court confirmed this rule, citing Amurta as only precedent. These arguments were considered in the context of the justification analysis in combination with the unacceptable compensatory advantages defence. The Court specifically considered that the national law of one Member State and the tax advantages contained in that law fall beyond the regulatory control of another Member State (Eckelkamp, para 66; and Arens-Sikken, para 68).

The distinguishing factor of absence of regulatory control by the discriminating Member State on the availability of a compensatory advantage in another Member State was again applied in Mattner (C-510/08), paras 41-43, to dismiss Germany's defence, citing Eckelkamp and Arens-Sikken. In Mattner the issue was the exclusion of a tax free allowance in the German system of gift taxation of gifts between non-resident donors and donees. Germany argued that Mrs Mattner would be able to benefit from multiple advantages if Germany would be obliged to extend the tax free allowance to non-residents, because Mrs Mattner could also make use of the tax free allowance in her Member State of residence (Mattner, para 40).

The formal criterion of regulatory control could have sufficed in Mattner to dismiss the compensatory tax advantages defence by Germany. But the Court also continued to state that the defence would also fail if the compensatory advantage in the other Member State would not fully compensate for the disadvantage incurred in Germany (para 44), or the law would in its technical application not take account of a potential difference between the compensatory advantage and the discriminatory disadvantage (para 45). These obiter remarks resemble the conditions which were construed five months earlier in Commission v Italy (C-540/07), see below. That case was however not cited in this context by the Court in Mattner.

The Amurta-rule can thus be explained by recalling that, in the absence of harmonising or unifying measures at the Union level, it is the duty of the Member States - as a matter of Union fidelity - to ensure compliance with EU law by safeguarding the Union citizen's fundamental free movement rights in their national laws.

The national law of one Member State does not form part of the legal framework of another Member State through which that other Member State should safeguard the Union citizen's rights. Consequently, any advantage granted autonomously by that other Member State cannot justify in law the infringement of Union fidelity by the first Member State. The advantages granted by the other Member State neither reflect a decision on fairness nor represent any tax equity norm in the laws of the first Member State whose provisions are under EU law scrutiny. This holds true notwithstanding the 
possibility that the Union citizen, on balance, does not face a burden as a result of the parallel exercise of the Member States' taxing competences. This is the general rule on the irrelevance of compensatory advantages.

The law is different if the legal provision that is suitable to neutralise the discrimination imposed by the other legal provision is within the scope of regulatory control of the Member State that allegedly restricts freedom of movement. That is the case if the national legal systems of two Member States are legally linked through a formal agreement between the Member States. In that situation the Member States have a possibility to partially control the tax advantages granted by the laws of other Member States by including state obligations in a double tax convention. An international agreement between the Member States, such as a double tax convention, forms part of the legal framework of both Member States (Amurta, para 80), according to their national constitutional systems. Since the rights contained in that agreement form part of the legal framework of both Member States, they are suitable to compensate in law the prima facie infringement of free movement rights under national law of either Member State. Where both Member States duly observe their obligations under the international agreement, the rights contained in that agreement can ensure compliance with the Union fidelity obligations of both Member States (Amurta, para 79). As long as the Union citizen can, in law and in fact, rely on those rights, be it directly or indirectly through their correct and full implementation in national law, the citizen's fundamental rights under EU law can also be effectively safeguarded by the Member States jointly through such agreements. Should the restriction not be compensated fully in the end by the other Member State, the Member State which imposed the restriction has the duty to relieve the discriminatory tax burden, for that Member State is accountable for the restriction in the first place. Non-performance of the obligation to relieve a restriction under the DTC thus remains a risk of the Member State that poses the restriction. The precise conditions of effective neutralisation will be reviewed below.

\subsection{Conditions of effective neutralisation}

The Court's Second Chamber elaborated in Commission v Italy (C-540/07) under which conditions a tax advantage granted by another Member State under a double tax convention is suitable to effectively compensate for a restriction caused by the national laws of a Member State. The Second Chamber's analysis was subsequently confirmed by the First Chamber in Commission v Spain (C487/08) and the Fifth Chamber's reasoned order in Secilpar - Sociedade Unipessoal (C-199/10).

The possibility of compensation was treated as a matter of acte clair by citing ACT Group Litigation, para 71 and Amurta, para 79 as the relevant precedents (Commission v Italy, para 36; Commission v Spain, para 58; and Secilpar Sociedade Unipessoal, para 39). The direct actions in Commission v Italy and Commission v Spain concerned economic double taxation of outbound dividends under a discriminatory withholding tax. In Secilpar - Sociedade Unipessoal the 
same problem was adjudged as a result of a preliminary reference by a national court of Portugal. The Court declared that additional withholding tax on outbound dividends compared to internal distributions is compensated if the additional taxation 'totally disappear[s]' and the withholding tax can be credited in the other Member State in the full amount of the difference in treatment arising under the national legislation' (Commission v Italy, para 37; and Commission v Spain, para 59; as affirmed in Secilpar - Sociedade Unipessoal, para 40). These conditions require a full credit of the part of the withholding tax that is discriminatory. The Court spelled this out as follows in Commission $v$ Spain:

In order to attain the objective of neutralisation, the application of the method of deduction relied on by the Kingdom of Spain should therefore enable the tax on dividends levied by that Member State to be deducted in its entirety from the tax due in the Member State of residence of the recipient company, so that if the dividends received by that company were ultimately taxed more heavily than the dividends paid to companies resident in Spain, that heavier tax burden could no longer be attributed to the Kingdom of Spain, but to the State of residence of the company receiving dividends which exercised its power to impose taxes. (para 60)

An example may further illustrate this clarification by the Court. Suppose undistributed profits earned by resident companies are taxed in Member State A with corporation tax. Upon distribution of those profits, Member State A levies a general $15 \%$ withholding tax on the gross dividend. Thus, the dividend bears economic double taxation that is fully attributable to the tax system of Member State A. Further, assume that the withholding tax is however reduced to $5 \%$ if the dividend is distributed to resident shareholders. Consequently, shareholders who are residents of other Member States bear an additional 10\% (15\%-5\%) tax on gross dividends received. This difference in treatment is principally precluded by EU law as it discriminates against foreign owners of corporate rights. In either case, economic double taxation of 5\% remains. That fraction is however not precluded by EU law, because equal situations are so far treated equally.

Nonetheless, the difference in treatment between resident and non-resident shareholders is a potential restriction against both the freedom of establishment and the free movement of capital. In the example, residents and non-residents find themselves in a comparable position as regards taxation principles in Member State A. Both are principally liable to tax on dividends received from resident companies. Consequently, any disadvantageous treatment of nonresident beneficiaries compared to resident beneficiaries constitutes a facial discrimination against free movement.

However, if a double tax convention with another Member State provides for a fully redeemable credit for the amount of additional and thus discriminatory withholding tax of $10 \%$, the restriction is fully neutralised and Member State A has complied with EU law. It is not necessary that the 5\% withholding tax that is imposed in all cases is creditable. Since that part of the tax was not liable to 
constitute a restriction in the first place, it also is not in need of compensation in order for Member State A to fully observe its duties under EU law. Withholding tax as such is not a restriction on the freedom of movement.

A full credit as it is commonly understood in international practice, i.e. a fully redeemable credit for the complete withholding tax levied by the other state, is therefore not necessary, though it is a suitable measure given that also meets the Court's standard of full compensation. In excess of the additional withholding tax, a full credit would systematically and consistently neutralise the 5\% withholding tax that Member State A may lawfully levy under EU law. To require a full credit would therefore impose more stringent obligations than EU law actually compels.

The credit cannot be made subject upon the actual level of taxation of the dividend in the other Member State (Commission v Italy, para 38; and Commission v Spain, para 62). A tax credit granted by another Member State pursuant to a double tax convention is not a suitable measure of consistent and systemic compensation if the amount of compensation is either limited to the fraction of domestic tax due in the state of residence of the recipient which is attributable to the foreign income, or the credit is limited to the total amount of domestic tax due in that Member State. Hence, the ordinary credit of Article $23 \mathrm{~B}$ of the OECD Model Convention, the standard credit method in international tax practice, is not a suitable measure. This was explicitly confirmed in Commission $v$ Spain in which the Court considered that the majority of Spanish double tax conventions included the ordinary credit method for the avoidance of double taxation on dividends (Commission v Spain, para 61). The judgment in Commission v Germany (C-284/09) reaffirmed this point (paras 61-70). ${ }^{511}$

The actual taxation level in the other Member State does not cause the restriction. That circumstance is therefore irrelevant in the analysis and cannot be taken into account for the protection of the Union citizen's fundamental rights to free movement. In Commission v Italy, para 38, the Court referred in that regard to the Advocate General's opinion, paras 58 and 59. The Advocate General noted in para 59 that the actual taxation in the hands of the shareholder 'is beyond the influence of the Italian Republic, however, and can also be unilaterally changed by the other Member State at any time without a double taxation convention preventing it'. A credit rule that limits the application of the fundamental rights on the basis of the unilateral tax treatment in another Member State is therefore not suitable to systematically and consistently ensure compliance with EU law by the restricting Member State. If the level of taxation in the other Member State would be included as a constituent element of the credit rule, such a condition would introduce an element of unjustifiable arbitrary differentiation. This was however precisely the situation in

511 The Court took the same position in its reasoned order in Amorim Energia (C-38/11), which it handed down in 2012, see in particular paras 61-63 of that ruling. 
Commission v Italy (paras 39) and Commission v Spain (para 64) and the Court lectured Italy and Spain that:

The choice as to whether to tax income from Italy/Spain in the other Member State or the level at which it is to be taxed, depends not on the Italian Republic/ Kingdom of Spain but on the tax rules laid down by the other Member State.

Because Italy and Spain had no regulatory control over the tax rules of the other Member State, they consequently failed to convince the Court that they genuinely ensured that the discrimination imposed on non-resident taxpayers through their withholding taxes was compensated in full. In Secilpar - Sociedade Unipessoal the matter was left for the Portuguese national court to adjudge.

Commission v Spain also confirmed again that the tax treatment in the other Member State is irrelevant to determine the existence or justifiability of a tax restriction arising under Spanish law, likewise if Spain did not conclude a double tax convention with that Member State, i.e. Cyprus (paras 66-67, citing Amurta, para 78). In Commission v Italy, para 41, the Court noted-by Italy's own submission - that Italy had not concluded a double tax convention with Slovenia and therefore Italy in any event discriminated against taxpayers residing in Slovenia. This conclusion is consistent with the case law concerning rejected compensatory advantages available under the laws of another Member State.

The above analysis in Commissiom v Italy, Commission v Spain, Commission $v$ Germany and Secilpar - Sociedade Unipessoal was conducted by the Court fully in the context of finding a restriction against free movement. Taking into account national and international instruments within the national legal frameworks, in the final analysis such a restriction was held to exist. The restriction was attributable exclusively to Italy and Spain respectively, and it needed to be proportionately justified (quod non) for those Member States to have observed their duties under EU law.

The analytical position as part of the initial tax discrimination analysis of the Amurta rule is theoretically correct. The relevant frame of reference for the discrimination analysis remains the tax policy choice made by the national legislator, as do the aims of the national legislation pursued by one Member State. ${ }^{512}$ The technical legal rules that serve as a basis to decide on potential discrimination should all form part of the legal framework of that Member State. The Member States can only control tax policy within the legal framework of their regulatory competence. In that context it should be recalled that Member States have remained competent to conclude DTCs with each other. Those DTCs are international laws of their legal framework. The DTC is then only taken into account to assess whether the tax policy choice is enacted equally for internal and free movement situations in a consistent and systemic manner throughout the detailed rules of the relevant legal framework. If so, there should

512 Murphy and Nagel (2002), pp. 165-166. 
not be a differential tax burden between internal and free movement situations, neither in law nor in effect. There can also be no question of discrimination then, since the tax policy decision does not suffer a subsidiary redistribution between different categories of taxpayer.

\subsection{The EFTA Court judgment in Fokus Bank}

In relation to the above discussion, the EFTA Court's judgment in Fokus Bank (E-1/04) should be pointed out. The issue in the main proceedings in Fokus Bank was whether Norway was obliged to grant an imputation credit to nonresident shareholders. In contrast to the taxation of resident shareholders who had to report received dividends as general income, a withholding tax on dividends was levied upon distribution to non-resident shareholders. Resident shareholders of Norway were granted an imputation credit against the income tax assessed on dividends received from resident companies in Norway. In effect, the final effective tax burden on dividends received by resident taxpayers was the underlying corporation tax on the undistributed earnings. In this way, Norway avoided that company earnings would be subject to economic double taxation. Non-residents however faced a cumulative taxation of corporation and dividend withholding tax on distributed corporate profits of companies established in Norway.

The EFTA Court in Fokus Bank found a discrimination against free movement of capital of Article 40 of the EEA Agreement in reasoning in a way consistent with the Court's case law. It also held that the availability of a tax credit to offset the Norwegian withholding tax in the resident state of the taxpayer was of no relevance, referring the Court's case law on other tax advantages (Fokus Bank, para 37). The national Norwegian court however also specifically inquired with the EFTA Court whether a tax credit pursuant to a double tax convention between Norway and the resident state of the taxpayer could possibly excuse Norway from a breach of the EEA Agreement. The EFTA Court in Fokus Bank however dismissed this possibility as follows from paras 37 and 38 of its judgment:

37. [...] A Contracting Party cannot shift its obligation to comply with the EEA Agreement to another Contracting Party by relying on the latter to make good for discrimination and disadvantages caused by the former's legislation. Likewise, the principle of legal certainty would require that the granting, or not, of an imputation tax credit to a non-resident shareholder, may not depend on whether a tax credit is granted in his or her state of residence in respect of dividend payments.

38. Accordingly, the Court holds that Article 40 EEA precludes legislation whereby shareholders resident in a specific Contracting Party are granted a tax credit on dividends paid by a company resident in that Contracting Party, whereas non-resident shareholders are not granted such a tax credit. Whether the taxpayer is resident in another Contracting Party which, in a 
tax agreement with the Contracting Party upon the territory of which the dividend is distributed, has undertaken to grant credit for withholding tax, or whether the taxpayer in the specific case actually is granted, or will be granted, credit for the withholding tax, is of no legal significance.

Considering that Fokus Bank was ruled in November 2004, a mere two months after the Court ruled in Manninen, the EFTA Court can be forgiven for not predicting the evolution of the Court's refined approach to compensatory tax advantages pursuant to a double tax convention in its Amurta ruling. The judgment in Amurta was handed down by the Court in November 2007, three full years after the Fokus Bank judgment.

Notwithstanding the application of a 'wrong rule' in Fokus Bank-a tax credit pursuant to a double tax convention is legally relevant to assess discrimination - the outcome in that case would not have been altered if the EFTA Court would have been able to anticipate the Court's stance. The relevant conventions for the taxpayers in Fokus Bank, the Norway-UK and NorwayGermany DTCs, provided for ordinary tax credits of withholding taxes on dividends. As is clear from the line of authority analysed above, such credits are not suitable to relieve the restriction imposed by Norwegian law, because they make the right to credit in part subject to the resident state's tax system and level of taxation. These aspects fall outside Norway's span of regulatory control, thus outside its legal framework against which potential discrimination is assessed, and an ordinary tax credit would indeed-from this angle-not meet the minimum standard of legal certainty on which a taxpayer may rely in EU law.

The EFTA Court's judgment in Fokus Bank and the Court's Amurta line of authority are consequently not irreconcilably incompatible. In both cases it is the legal framework of one State only against which a potential breach of the principle of freedom of movement is assessed.

The Amurta-rule confirms the overall tenor of the general rule on irrelevance of other tax advantages, namely that the frame of reference against which the Court assesses discrimination is ultimately defined by the express legal design of the tax system. The Amurta-rule makes explicit that the boundaries of that system are set by the limits of the Member States' span of regulatory control. This span of control encompasses DTCs concluded by the Member States. Private rights contained in those agreements are part of the legislative framework of one Member State, even if the right is in practice enjoyed in the other Contracting State.

\subsection{Comparison with prior research}

Prior research discussed if the ordinary credit method is a suitable measure to compensate the disadvantages of discriminatory withholding taxes. The argument in support of this hypothesis is that the application of the ordinary credit 
method can also in effect leave the taxpayer with no burden on balance, provided that any credit limitations do not have effect. ${ }^{513}$ Others however argued that only a full credit would comply with the Court's conditions, because an ordinary credit still leaves potential for discrimination. ${ }^{514}$ Douma rejected the case law from which Rule 3:3 emerged as 'unfortunate' and that the option of DTC neutralisation 'has no basis whatsoever' in the objectives of the national legislation in issue in that case law. ${ }^{515} \mathrm{He}$ does not give a final conclusion on whether an ordinary credit might be a suitable measure given the particular circumstances of an individual case. ${ }^{516}$

Kofler's remark that a more 'natural understanding' of the case law allows direct actions and preliminary rulings to be evaluated differently because the Court interprets EU law outside the context of a factual situation in the former, has no basis in EU law. ${ }^{517}$ In both types of proceedings the Court interprets EU law, and if the Court interprets EU law in direct actions to hold ordinary credits not suitable for consistent and systematic neutralisation, as it does, this interpretation also applies to preliminary reference proceedings. It is the same EU law that is interpreted and therefore should be applied equally at the national level to guarantee the fundamental freedoms for Union citizens and companies, irrespective of the procedure through which the national measure was held incompatible with EU law.

Kofler specifically refers to Amurta and Secilpar - Sociedade Unipessoal to support his view on factual neutralisation. In Amurta and in Secilpar-Sociedade Unipessoal the national courts were indeed delegated by the Court to find whether a DTC, if any, enabled neutralisation. In that context, Secilpar Sociedade Unipessoal was a reasoned order that stated the conditions of neutralisation, which the national court was ordered to apply, in para 40 with reference to the direct actions of Commission $v$ Italy (C-540/07) and Commission v Spain (C-487/08). The Court rejected in those precedents that an ordinary credit was a suitable measure of neutralisation. Neither Amurta nor Secilpar - Sociedade Unipessoal may therefore be interpreted as a positive statement by the Court that an ordinary credit could be a suitable measure. They certainly do not 'clearly indicate', as Kofler states, that neutralisation depends on the circumstances of the actual case at hand. ${ }^{518}$ Even if Kofler's distinction between the types of proceedings before the Court should be accepted-which we should not - the preliminary rulings in Amurta and Secilpar - Sociedade Unipessoal in any case do not support his view.

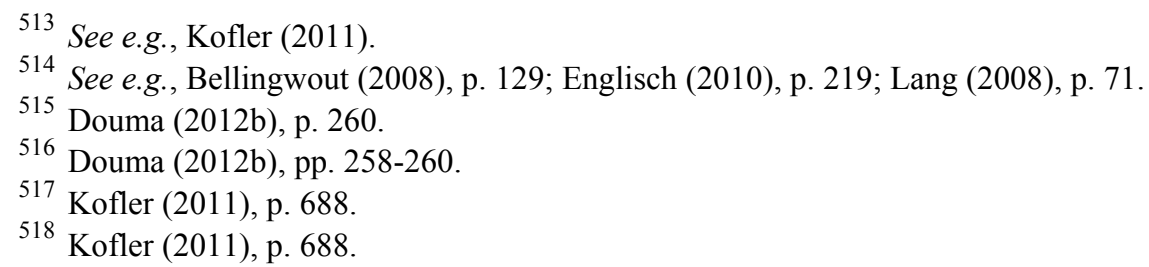




\subsection{Synthesis}

The above analysis has shown that the case law of the Court is clear. We found that Rule 3:3(4) is to be interpreted to require a fully redeemable credit for the discriminatory fraction of the withholding tax as the compensatory measure that meets the Court's standard of 'neutralisation'. ${ }^{519}$ The initial proceduralisation of the question whether the principle of freedom of movement has been complied with through deference to a DTC has evolved through subsequent litigation into a distinct substantive rule with defined content and concrete conditions. ${ }^{520}$

\subsubsection{Evaluation}

We now return to a general evaluation of the rules of Annex A and leave the specific issue of DTC neutralisation behind. The judicial rules which we have quantitatively identified by network analysis are best considered acte clair rules. Indeed, our quantitative method assured that the rules so identified have been applied repeatedly in various subsequent cases after the judgment which first established the rule. In that regard, our method significantly differs from a qualitative method to evaluate the existence and degree of acte clair, e.g. the ranking system developed by Pistone. ${ }^{521}$

It is not that the rules of Annex A are the only acte clair rules in the field of direct taxes, but we believe that our research design warrants the claim that these rules lie at the heart of legal doctrine; they have been material in resolving the most important cases on the interpretation of EU law in the field of direct taxes. A concise evaluation of the rules of Annex A gives some further insights into the nature of legal doctrine on EU law in the field of direct taxation.

The rules of Annex A can be divided in three broad types of judicial rules. First, Type I rules are restatements of the rights conferred by Union legislation. The Court interpreted directly the text of the TFEU. The restatements of the freedom of establishment and the free movement of capital in Section 2 are examples of Type I rules. Also, the general principles of Rule 1:1 (on the principle of conferral) and of Rule 1:3 (on non-discrimination) may be considered Type I rules.

Second, the Court has adopted judicial rules which it developed outside the context of direct taxes and also adapted some to take specific account of the context of direct taxes. Section 4.6 examines these Type II rules in a more systematic manner. The Rules of Section 5 on Remedies are of this type.

519 'Fully redeemable' should also be understood as opposing the idea that a carryforward of any excess credit on the withholding tax is sufficient relief for discrimination inherent in the withholding tax. See e.g., Bellingwout (2008).

520 The procedural aspects are again explicit in Tate \& Lyle Investments (C-384/11) which also applied Rule 3:3(4), but was decided as a reasoned order in 2012.

521 Pistone (2008). 
Type III rules have been created specifically for the context of direct taxes. It is striking that most of the rules of this third and last Type limit the deregulatory effects of EU law on national direct tax laws. This is for example the case with the specific tax justifications (Section 4 of Annex A) and the rule on incomparability of residents and non-resident taxpayers as established in Schumacker (Rule 1:5).

The dividing line between these three types is not a rigid one; they are best considered as three areas of a spectrum. The best illustration for this is the rules on dividend taxation of Section 3. These rules are so specific and narrowly tailored to the issue of economic double taxation of dividends that they are best regarded as Type III rules, even though they are applications and adaptations of the non-discrimination principle which is not specific to direct taxation. Our example of choice of Rule 3:3(4) on DTC neutralisation of restrictive dividend withholding taxes was found initially to be an adaptation of basic judicial rules about the division of tasks between the national court and the Court in the context of the preliminary reference procedure under Article 267 TFEU as regards the interpretation of DTCs in EU law proceedings concerning tax claims. However, subsequent litigation invited the Court to elaborate on the normative content of that rule and ultimately forced it to create new conditions to determine its meaning in the specific context of the taxation of outbound profit distributions.

If we take Annex A as the outlines of legal doctrine in this subfield of EU law, we may conclude that the regulatory control of the Court in the field of direct taxes seems not to go significantly beyond what was already implied in judicial doctrine outside the field of direct taxes. ${ }^{522}$ To the contrary, the regulatory control of the Court is specifically limited in the field of direct taxes through the creation of specific rules (Type III rules).

\subsection{The reception of rules of general EU law}

\subsubsection{Quantitative analysis}

\subsubsection{Structural openness but organisational closure}

Only two of the sample cases do not rely on precedent: Commission v France (Avoir Fiscal) (270/83) and Daily Mail (81/87). 11 other sample cases only refer to precedents outside the sample, but these are actually only nine rulings due to joinder of cases. ${ }^{523}$ We could interpret the degree to which cases in the field of

523 Biehl I (C-175/88); Commission v Belgium (C-300/90); Denkavit International, VITIC Amsterdam \& Voormeer (Joined Cases C-283, 291\&292/94); Leur-Bloem (C28/95); Sandoz (C-439/97); Schmid (C-516/99); Commission v Italy (C-197/03); Hengartner and Gasser (C-70/09); and Commission v Austria (C-387/10). 
direct taxes cite precedents decided outside this field as the extent to which general rules of EU law were received by and transposed to the field of direct taxation. By analysing the Court's behaviour in this regard over time, we can also infer to what extent EU law in the field of direct taxes has emerged as a functional subsystem of EU law over time. Greater reliance over time on cases in the field of direct taxation, rather than reliance on cases outside this field, indicates that a functional subsystem is emerging.

Figure 13 shows, measured in intervals of three years after 1990, that the average outdegree of sample cases increased as the network grew over time (solid line, right $\mathrm{Y}$-axis), but also that the average proportion of non-tax cases of all cases cited by sample cases in the network decreased as more sample cases entered the network (dashed line, left Y-axis). That means on the one hand that the Court increasingly relied on the interpretative guidance of precedent, ${ }^{524}$ but also increasingly relied on precedents that also concerned a dispute in the field of direct taxes, instead to seek interpretative guidance from other precedents which were not decided in relation to national legislation on direct taxation. Consequently, the system of EU law in the field of direct taxes evolved over time to a stronger demarcation between EU law as interpreted inside and outside this field.

We defined the size of the network as the number of sample cases decided until the end of the respective year. When there are few tax precedents, the Court has little discretion in citing tax precedents (sample cases), and is bound to find analogies outside the field of direct taxation (non-sample cases). When more precedents in the field of direct taxation become available through subsequent litigation over time as a result of positive feedback effects, the likelihood that a prior tax case makes a more effective analogy than a nonsample case increases and we would thus expect to find that the Court would cite proportionately more tax precedents in time under the assumption that the Court values cohesion. The results presented here are consistent with this hypothesis.

As the average number of precedents cited in the sample cases increased to two cases in the first years of adjudication in the field of direct taxes (until end of 1995), the proportional reliance on non-tax precedent in the body of case law ruled through 2000 remained above or around 50\% (1996-2000). ${ }^{525}$ Particularly in this period were general rules of EU law transposed to the field of direct taxation in cases of original impression. After 2000, the percentage steadily decreased over the years and ultimately fell below $40 \%$ in 2007 . This implies that, at the end of the year 2000 , the collection of decided cases in the field of

524 This densification process appears as a common feature of the evolution of real networks, see Leskovec, et al. (2005). For the US Supreme Court case law network, see e.g. Cross, et al. (2008), pp. 1240-1246

525 The inventory of decided cases in the field of direct taxes was 12 at the end of 1995 and 36 at the end of 2000 . 


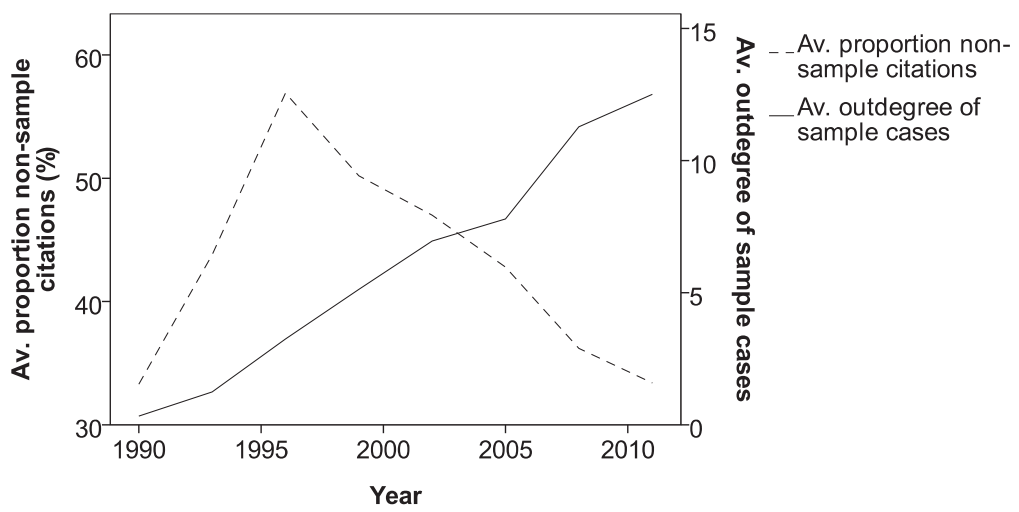

Figure 13. Citation over time.

direct taxes had acquired the critical mass that made the emergence of functional judicial doctrine in the field of direct taxation possible.

We will see that this does not mean that the system is no longer susceptible to noise from the general system of EU law, which consists, inter alia, of legal innovations in other functional fields of the larger system of EU law we assume exist. Rather, the subsystem in the field of direct taxation became robust to those perturbations from outside.

Although the Court still relied heavily or completely on non-sample precedents in sample cases decided after 2000, the evolutionary trend clearly moved from the reception of rules from outside the field in the early years to a reproduction of those rules within the field of direct taxation. Until the end of 2011 , the average percentage of citations to non-tax cases within the body of case law in the field of direct taxation decreased further to about $33 \%$.

The relative decline of the relevance of non-tax cases for the interpretation of EU law in the field of direct taxes does not imply, in itself, that no new rules have been received in the field of direct taxation after 2007 and legal evolution stood still, as it were. EU law in the field of direct taxation is sensitive to developments in the larger system of EU law in the sense that innovations outside the field resonate inside the field and the system of law in this field so adapts to them. EU law in the field of direct taxation embeds these innovations in its existing structure and organisation, and the structure and organisation is so adapted, but this happens without changing the functional identity of the system.

For example, one very clear and fundamental advancement of EU law, which was also received within the field of direct taxation in the period 2007-2011, was the interpretation of the Union citizen's general right to move and reside of Article 21 TFEU. The potential deregulatory ramifications of that provision, which was introduced by the Maastricht Treaty, became clear only some years later with the (non-tax) rulings in e.g. Martinez Sala (C-85/96), Grzelczyk (C184/99), and Baumbast (C-413/99). The Court gave meaning to Article 21 TFEU as a directly effective fundamental right of EU law that was directly attached to having citizenship of a Member State and that afforded Treaty 
protection to situations which were not protected (by the Treaty) before $1993 .{ }^{526}$ Those rulings sparked positive feedback with the result that proceedings on the interpretation of Article 21 TFEU in the context of direct taxation quite rapidly found their way to the Court, either through preliminary questions submitted by national courts or through direct actions which the Commission initiated against Member States.

For the purpose of determining the interpretation of Article 21 TFEU in the field of direct taxation, the Court relied more on non-tax precedents than on precedents which were decided in field of direct taxation. ${ }^{527}$ This is also evident from the low proportion of sample cases in communities 5 and 7 in Table 16, respectively $18 \%$ and $17 \%$ of all cases in these communities. As a comparison, note that $40 \%$ of all cases in community 1 are sample cases. We have already seen in Section 4.3 that (some of) these cases are organised in separate communities within the body of case law on EU law in the field of direct taxation, but these communities are still part of the larger network of cases in the field of direct taxation. New law was explicitly embedded in the system of existing law. Again, this indicates the evident value that the Court attaches to cohesion within the system of EU law.

Stone Sweet and McCown found that the system of EU (case) law is developing 'an internal coherence that is organised, in a self-referential manner, through precedent. ${ }^{528}$ The results presented here warrant the claim that EU law in the field of direct taxation has closed to a true functional subsystem of EU law; it communicates with other elements of the system of EU law, but it referentially distinguishes itself. ${ }^{529}$ In other words: EU law in the field of direct taxes is structurally open to the larger system of EU law, but it has organisationally closed to a smaller and coherent functional subsystem of its own over time. ${ }^{530}$

\subsubsection{The most important non-tax precedents}

It should be recalled that we did not include links between cases that were not included in the sample of cases in the field of direct taxes as elements of our network. It should also be noted that these non-sample cases have no outward citations as a result of the research design and, thus, do not link to each other. The inward links to these non-sample cases were, however, collected and provide meaningful information.

526 Section 3.4.2.1.1.

527 See e.g., Turpeinen (C-520/04); Commission v Germany (C-318/05); Commission v Germany (C-152/05); Schwarz and Gootjes-Schwarz (C-76/05); Commission v Germany (C-269/07); Zanotti (C-56/09); Rüffler (C-544/07); and Commission v Greece (C-155/09).

528 Stone Sweet and McCown (2003), p. 113.

529 We adopted the language of autopoiesis here; Mingers (2002), p. 292.

530 See, Mingers (2002), p. 280. 


\begin{tabular}{lll}
\hline Case & Short name & n Citations \\
\hline C-484/93 & Svensson and Gustavsson & 17 \\
C-478/98 & Commission v Belgium & 16 \\
C-452/04 & Fidium Finanz & 15 \\
C-55/94 & Gebhard & 11 \\
C-452/01 & Ospelt and Schlössle Weissenberg & 10 \\
C-370/05 & Festeren & 9 \\
C-222/97 & Trummer and Mayer & 8 \\
C-112/05 & Commission v Germany (Volkswagen) & 7 \\
$152 / 73$ & Sotgiu & 6 \\
$263 / 86$ & Humbel and Edel & 6 \\
C-46/93 and C-48/93 & Brasserie du Pêcheur and Factortame & 6 \\
C-379/98 & PreussenElektra & 6 \\
C-157/99 & Geraets-Smits and Peerbooms & 6 \\
$244 / 80$ & Foglia & 5 \\
$286 / 82$ and 26/83 & Luisi and Carbone & 5 \\
$205 / 84$ & Commission v Germany & 5 \\
$305 / 87$ & Commission v Greece & 5 \\
C-370/90 & Singh & 5 \\
C-381/93 & Commission v France & 5 \\
C-212/97 & Centros & 5 \\
C-302/98 & Sehrer & 5 \\
C-184/99 & Grzelczyk & 5 \\
C-36/02 & Omega Spielhallen & 5 \\
C-464/02 $-406 / 04$ & Commission v Denmark & 5 \\
\hline Table 21. & De Cuyper & 5 \\
\hline
\end{tabular}

Table 21. Most cited non-tax precedents by sample cases

If we examine the non-sample rulings, which did not concern a direct tax dispute, we find 25 rulings with five or more inward citations; $;{ }^{531}$ see Table 21. These inward citations came from sample cases and thus are a reliable indicator of the degree to which individual non-sample cases have provided interpretative guidance to resolve indeterminacy in EU law as it applies to the field of direct taxation.

It should also be recalled that the sample of cases in the field of direct taxation was drawn from the list of cases maintained by the European Commission. As already noted, that list also includes cases which do not necessarily involve the interpretation of $\mathrm{EU}$ law in relation to national legislation on direct taxes, but which the Commission nevertheless considers relevant to the field of direct taxation. The question thus arises to what degree

531 There are also 22 rulings with four citations, 34 rulings with three citations and 69 rulings with two citations. The remaining 268 non-tax cases have received only one citation each. 
the cases of Table 21 are listed as cases 'of particular interest for' direct taxation in the Commission's list?

The results are quite surprising. The Commission identified only seven of the most cited non-tax cases as 'of particular interest for' the field of direct taxation. These are the five most cited cases and also Centros (C-212/97) and Sehrer (C302/98). None of the other 18 cases of Table 21 are listed. This does not imply that the other cases (over 60 in total) which the Commission included in its list are not interesting or relevant for the field of direct taxation. It is however a stretch to maintain that cases which have provided direct and significant interpretative guidance to resolve indeterminacy of EU law in the field of direct taxation are not 'of particular interest for' the field of direct taxation.

To advance our understanding on how non-tax precedents have played an evident structural role in the functional subsystem of EU law in the field of direct taxation, we will carry out a qualitative analysis of the five most cited non-sample cases in the next section. For that purpose, we collected and reviewed the sample cases that cited these non-sample cases and we analysed the context in which they were cited.

\subsubsection{Qualitative analysis}

\subsubsection{Svensson and Gustavsson}

The case of Svensson and Gustavsson (C-484/93) did not concern a direct tax dispute. At issue was whether Luxembourg could make an interest rate subsidy on loans taken out for the financing of construction, acquisition, or improvement of housing subject to the requirement that the loan was taken out with a credit institution approved by Luxembourg law. The Full Court obviously ruled that this authorisation requirement breached EU law.

The second most cited holding is Svensson and Gustavsson, para 10, in which the Court held this requirement to restrict freedom of capital. In the three direct tax cases that cite this holding, the Court would paraphrase this holding to the effect that:

It should be recalled that measures imposed by a Member State which are likely to deter its residents from contracting loans or making investments in other Member States constitute restrictions on the free movement of capital, within the meaning of [Article $63 \mathrm{TFEU}]{ }^{532}$

In the two most recent of those cases, the Court also cited to Trummer and Mayer (C-222/97), para 26, which is ranked seventh, and Sandoz (C-439/97), para 19. The latter case, also cites to Svensson and Gustavsson, para 10, but the

532 Commission v Portugal (C-20/09), para 54. See, Sandoz (C-439/97), para 19; and Van Hilten-van der Heijden (C-513/03), para 44. 
former relies on two cases which were decided before Svensson and Gustavsson. ${ }^{533}$

The case of Svensson and Gustavsson is cited most frequently by the sample cases in the context of the cohesion of the tax system justification. The Court rejected the application of that justification as first developed in Bachmann and Commission $v$ Belgium (C-300/90) in Svensson and Gustavsson by distinguishing the two former cases from the latter as follows in para 18:

In those cases there was a direct link between the deductibility of the contributions and the tax on the sums payable by the insurers under death and oldage insurance policies, a link which had to be preserved in order to preserve the integrity of the relevant fiscal regime, whereas there is no direct link whatsoever in this case between the grant of the interest rate subsidy to borrowers on the one hand and its financing by means of the profit tax on financial establishments on the other.

Consequently, the ruling in Svensson and Gustavsson is important for the development of EU law in the field of direct taxation, because it is the first case after Bachmann and Commission v Belgium (C-300/90) in which the Court explicitly required this direct link as a material condition of the cohesion of the tax system justification. The content of a judicial rule which has been developed inside the field of direct taxation was so specified outside the field and this specification was then adopted by legal doctrine on EU law in the field of direct taxation again.

\subsubsection{Commission v Belgium (C-478/98)}

Commission v Belgium (C-478/98), para 18 was cited a few times in subsequent case law. The context of those references is the same as Svensson and Gustavsson, para 10, and concerns the point that a Member State may not make it more difficult for its own residents to make an investment or obtain a loan in another Member State. We will see below that Fidium Finanz is also cited as authority in that context.

The Commission initiated a direct action against Belgium because Belgium prohibited its resident individuals from subscribing to Belgian public securities on the Eurobond market in Frankfurt. The Belgian government argued that this measure aimed to pre-empt its residents from evading Belgian withholding tax on the interest payments, but the Full Court found that the measure breached EU law. In that context, subsequent case law in the field of direct taxation cited Commission $v$ Belgium mainly because of its statements on combating tax avoidance as a justification. In para 39 the Court held that the 'fight against tax evasion and the effectiveness of fiscal supervision' are justification grounds that Article 65(1)(b) TFEU recognises. But, the judgment of Commission v Belgium

Luisi and Carbone (Joined Cases 286/82 \& 26/83), para 28; and Lambert (308/86), para 16. 
is mainly an authority to the field of direct taxation because of para 45 that states:

As appears from [Leur-Bloem (C-28/95), para 44], a general presumption of tax evasion or tax fraud cannot justify a fiscal measure which compromises the objectives of a directive. That applies all the more in the present case, where the contested measure consists in an outright prohibition on the exercise of a fundamental freedom guaranteed by [Article 63 TFEU].

The case of Commission v Belgium thus provided an authentic interpretation of a case that concerned direct taxation. ${ }^{534}$

\subsubsection{Fidium Finanz}

Germany resisted granting a banking authorisation to the Swiss-based company Fidium Finanz to enable it to grant credit on a commercial basis to clients that were established in Germany. The national court submitted preliminary questions to the Court that essentially asked whether these activities were covered by the freedom to provide services - in which case no protection should be afforded since Switzerland is not a Member State of the EU-or whether the effects of the national legislation should be assessed against free movement of capital that also extends to relations between Member States and non-member States, and, if so, if the authorisation requirement amounted to a restriction that was prohibited by Article 63 TFEU. The Court ruled that Article 56 TFEU applied to the case and consequently, no Treaty protection could be claimed by Fidium Finanz.

The case of Fidium Finanz provided interpretative guidance on two issues. The most important one will be reviewed below and concerns the central issue of the case on the distinction between the freedoms. The only other context in which Fidium Finanz is cited is its holding of para 41 that movement of capital should be interpreted in terms of the nomenclature annexed to Directive 88/361. Three cases in the field of direct taxes cite Fidium Finanz in this respect. ${ }^{535}$ The respective rule of Fidium Finanz, para 41, actually belongs to the core of legal doctrine in the field of direct taxation and it is laid down as Rule 2:2(5) of Annex A. This point of law was originally established in Trummer and Mayer, para 21. ${ }^{536}$

With regard to the most important contribution of Fidium Finanz to the field of direct taxation, we see an interesting citation practice of the Court. Instead of citing individual paragraphs of this ruling, the Court cites the passage of paras 34 and 44-49 in five cases. When the Court cited Fidium Finanz in this context, it used the following formula, or a close variation thereof:

534 Section 7.4.

535 Jäger (C-256/06), para 24; Eckelkamp and Others (C-11/07), para 38; and ArensSikken (C-43/07), para 29.

536 Only two of the eight sample cases that cite Trummer and Mayer do not cite the case for this reason. 
As regards the question whether national legislation falls within the scope of one or other of the freedoms of movement, it is clear from what is now well established case-law that the purpose of the legislation concerned must be taken into consideration. ${ }^{537}$

The Court cited individual paragraphs of Fidium Finanz in seven cases. Also in five cases, the Court cited the passage of paras 48 and 49. In that context, the following catchphrase was consistently used:

If $[\ldots]$ that national measure has restrictive effects on the free movement of capital, such effects must be seen as an unavoidable consequence of any restriction on freedom of establishment and do not justify an examination of that measure in the light of [Articles 63 to 65 TFEU]. ${ }^{538}$

It is now evident that Fidium Finanz is the original authority of Rule 2:3 of Annex $A$ and that the distinction between freedom of establishment and free movement of capital (and freedom to provide services) is to be approached along similar lines as the distinction between freedom to provide services and free movement of capital; it is the purpose of the national legislation that is material for deciding which freedom provision of the TFEU applies.

\subsubsection{Gebhard}

Gebhard (C-55/94), a Full Court judgment, is a hallmark case of EU law and hardly needs an introduction. As a reminder, the central issue was to which degree Member States may subject the cross-border provision of legal services to national rules regulating the profession of lawyers. Mr Gebhard was a German lawyer who was authorised to practice law in Germany as Rechtsanwalt, but resided in Italy and wanted to open permanent chambers in Milan under the Italian title of avvocato. The Milan Bar Council however opposed the pursuit of his activities and his registration on the roll. The Court ultimately ruled that Member States should protect freedom of establishment by proceeding from the equivalence (mutual recognition) of diplomas and that additional professional requirements should be applied by a comparison with the knowledge and qualifications of the person concerned.

Gebhard is cited in three different contexts and the Court either cites para 25 or para 37. All citations to Gebhard, para 25, are accompanied by the same catchphrase: (C-415/06), para 13; SGI (C-311/08), para 25; and Haribo Lakritzen and Österreichische Salinen (Joined Cases C-436 \& 437/08), para 34.

Thin Cap Group Litigation (C-524/04), para 34; A and B (C-102/05), para 27; CFC and Dividend Group Litigation (C-201/05), para 106; Lidl Belgium (C-414/06), para 16; Stahlwerk Ergste Westig (C-415/06), para 16. 
In accordance to settled case-law, the concept of establishment within the meaning of the Treaty is a very broad one, allowing a [Union citizen] to participate, on a stable and continuous basis, in the economic life of a Member State other than his State of origin and to profit therefrom. ${ }^{539}$

When the Court cites Gebhard, para 37, it does so for two reasons. The first reason is to recall the Säger/Kraus formula of a restriction on freedom of establishment in terms of Article 49 TFEU: ${ }^{540}$

[i]t is settled case law that all measures which prohibit, impede or render less attractive the exercise of freedom of establishment must be regarded as constituting such restrictions.

The second reason why the Court cites Gebhard, para 37, is to apply the rule of reason (Rule 4:1 of Annex A). The Court reiterates in two cases with reference to Gebhard that a national measure which restricts freedom of movement can only be justified if it is appropriate to achieve an overriding reason in the public interest and does not go beyond what is necessary to obtain that purpose. ${ }^{541}$ In Commission v Spain (C-248/06), para 32, the Court even listed all four requirements of the rule of reason of Gebhard, para 37, verbatim:

It follows, however, from the Court' s case-law that national measures liable to hinder or make less attractive the exercise of fundamental freedoms guaranteed by the Treaty must fulfil four conditions: they must be applied in a non-discriminatory manner; they must be justified by imperative requirements in the general interest; they must be suitable for securing the attainment of the objective which they pursue; and they must not go beyond what is necessary in order to attain it (see Case C-19/92 Kraus v Land BadenWuerttemberg [1993] ECR I-1663, paragraph 32).

Only in Commission v Spain (C-153/08), para 37, did the Court specifically point out that, according to the first condition of the rule of reason, overriding reasons cannot be relied upon if the national measure is a discriminatory restriction. Spain was brought before the Court by the Commission for a national measure that exempted winnings from games of chance, but only if the body that organised the lottery was established in Spain and was recognised as pursuing a social purpose under Spanish law. According to the Court, that difference in treatment according to the seat of the lottery amounted to a discrimination against bodies which were established in other Member States and pursued the same social and charitable objectives as those bodies to which Spanish law accorded preferential tax treatment, and were consequently comparable to those

Cadbury Schweppes (C-196/04), para 53; Stauffer (C-386/04), para 18; N. (C470/04), para 26; and Filipiak (C-314/08), para 52.

540 Columbus Container Services (C-298/05), para 34; Deutsche Shell (C-293/06), para 28; and Truck Center (C-282/07), para 33. For a discussion, see Section 3.6.2.2.

541 Futura (C-250/95), para 26; and Lindman (C-42/02), para 25. 
Spanish bodies (para 34). ${ }^{542}$ It should be recalled that, according to Rule 2:1(8) and (9) of Annex A, a different treatment of undertakings based on the place of their corporate seat amounts to a direct discrimination on grounds of nationality. From Gebhard followed that this type of restriction on freedom of establishment could only be justified by the derogations in the interest of public policy, public health, and public security which are expressly recognised in Article 52(1) TFEU (para 37). The Court found that this was not the case here.

\subsubsection{Ospelt and Schlössle Weissenberg}

The case of Ospelt and Schlössle Weissenberg (C-452/01), which was decided by a Full Court formation of the Court, was about the transfer of a plot of land in Austria, owned by a national of Liechtenstein, to a foundation established in Liechtenstein. The Austrian administration refused the transfer on the ground that the authorisation requirements for land acquisition by foreigners were not fulfilled. The Court was ultimately called upon to determine whether those requirements constituted a breach of free movement of capital between Austria and Liechtenstein.

Ospelt and Schlössle Weissenberg is relevant to the evolution of EU law in the field of direct taxation because the Court recognised in this case the need to ensure that the rules of the EEA Agreement should be interpreted uniformly with the rules of the TFEU, insofar they are they are identical in substance. ${ }^{543}$ The Court found that Article 40 of the EEA Agreement and Article 63 TFEU were identical and should therefore be given a uniform interpretation (paras 2729). That means, as the Court held in Ospelt and Schlössle Weissenberg (para 32) and also e.g. Etablissements Rimbaud (C-72/09, para 22) that those provisions have the same legal scope. Particularly in direct actions, the Court has ruled that a breach of Article 63 TFEU also implies a breach of Article 40 EEA and a separate examination is thus not necessary. ${ }^{544}$ The Netherlands, for example, has been brought to, and condemned by, the Court in Commission $v$ Netherlands (C-521/07) for a failure to apply the case law of Amurta (C-379/05) on free movement of capital in regards its national measures also to relations with EFTA States. ${ }^{545}$

The Court does not cite precedent in Ospelt and Schlössle Weissenberg. The grounds of judgment build upon Opinion 1/92 [1992] ECR I-2821. In that Opinion the Court found that it been granted jurisdiction to interpret the

542 Section 4.3.5.7.5.

543 Keller Holding (C-471/04), para 48; Krankenheim Ruhesitz am WannseeSeniorenheimstatt (C-157/07), para 24; Commission v Netherlands (C-521/07), para 32; Commission v Italy (C-540/07), para 65; Établissements Rimbaud (C-72/09), paras 19-21; Commission v Portugal (C-267/09), para 50; and Commission $v$

544 Section 4.3.5.3.4. Germany (C-284/09), para 95.

545 Section 4.3.5.3.4. 
identical provisions of the EEA Agreement and that the Joint Committee should observe the binding nature of those rulings on the EEA Agreement in resolving the disputes brought before it. The reason why the Court was granted this authority was precisely to assure that a most homogeneous interpretation of the EEA Agreement and the TFEU would be achieved by the Joint Committee and that freedom of movement, as incorporated in the provisions of the EEA Agreement, would thus be equally protected between Member States and in the relation between Member States and EFTA States.

According to the Court: ${ }^{546}$

One of the principal aims of the EEA Agreement is to provide for the fullest possible realisation of the free movement of goods, persons, services and capital within the whole European Economic Area, so that the internal market established within the European Union is extended to the EFTA States.

While this may be a nice quote to end the analysis of Ospelt and Schlössle Weissenberg with, the case also gives a little technical insight to the EUR-Lex database which reminds us that quantitative analysis and qualitative analysis are complementing research methods. Although the EUR-Lex bibliographical notice lists Ospelt and Schlössle Weissenberg as one of the cases that Commission v Belgium (C-522/04) cites in para 44, the actual text of the judgment does not show any reference to this case. The coding of the EUR-Lex database is plainly wrong here. However, Commission v Belgium, para 44 cites, inter alia, Keller Holding (C-471/04), para 48 'and the case law cited'. Crawling through the web of case law by following the structural links that it gives us, we find that it is indeed true that Keller Holding, para 48 cites Ospelt and Schlössle Weissenberg, para 29. A coding error is thus not necessarily a mistake.

\subsection{Synthesis and Discussion}

This Chapter explored the use of Social Network Analysis for the study of EU law in the field of direct taxation. The original research in this Chapter reviewed the way the authority of precedent has shaped EU law in the field of direct taxation and how it emerged as a functional subsystem of EU law in six steps.

First, we found that a large majority of cases are connected to each other through citation links. We have seen that the network of rulings in the field of direct taxation includes a giant component. This is the first indication that the Court aims to achieve a coherent judicial doctrine, since later judgments are explicitly embedded within the body of existing precedents.

Second, we have observed that the Court cites precedent selectively. A few precedents are cited very often, and many cases are only cited once or twice. We have compared the global properties of the case law network to a corresponding random network and we have examined its small-world and scale-free 
properties. Our findings indicate that the dynamics of judicial decision making amount to a self-organising process.

In the third step, we analysed the community structure in the case law network using the Girvan-Newman and the Louvain method. We found a legally relevant organisation on the basis of the subject matter of the case law in the field of direct taxation upon qualitative analysis of the main communities and selected subcommunities. Our findings indicate that Court chooses and cites precedent primarily on basis of the similarity of facts and legal issues between cases.

The first three results of this Chapter all support the claim that the Court aims to construct a cohesive judicial doctrine through a process of judicial decision making which is based on the interpretative guidance of precedent. This is consistent with the Court's mandate to safeguard the uniform interpretation and application of EU law as stated in the Treaty.

We then continued with an analysis of the role and function of individual cases and legal norms in the case law network.

As a fourth step in the research, we focused on finding the most important cases, because we believed these to be the sources of the most important legal norms. Consistent with prior research, we have applied Kleinberg's HITS algorithm to compute an authority ranking of precedents in the field of direct taxation. We have compiled a top-20 of rulings in this field which we believe are important for the structural stability of the case law network. Our findings corresponded with the Court's internal measures of importance and we compared the list with the academic ranking of Chapter 3.

Fifth, we examined how the top-20 rulings (ranked by authority) have been cited in subsequent case law by analysing which passages of the rulings have been cited in order to find the most important judicial rules of EU law in the field of direct taxation. We proposed an innovative quantitative method to determine which paragraphs or passages of a judgment's grounds were most relevant for legal doctrine. This procedure resulted in an outline of a judicial doctrine of EU law in the field of direct taxation as presented in Annex A. That outline is first and foremost a legal doctrine that was computed. It was not found through a lawyer's subjective interpretation of the case law as a primary method of analysis, but in an objective and reproducible manner by looking with different scales of magnification at the overall structure of the network of case law in the field of direct taxes. The method that we applied is moreover generic; the same protocol may be applied to other fields of judicial EU law.

The sixth and last step of research was to examine the reception of rules of general EU law in the field of direct taxation. We found that the Court relied less on cases outside the field of direct taxation over time. We also researched how the Court treated these non-tax cases in its direct tax case law. Our findings on the basis of a qualitative analysis of five case studies show that the Court treats these non-tax cases consistently and applies the distinct innovations of EU law in those cases to the field of direct taxation. Furthermore, the longitudinal trend is that EU law in the field of direct taxation is increasingly interpreted with the guidance from prior rulings in this field. This implies that EU law in the field of 
direct taxation is incrementally, but clearly, becoming less indeterminate over time. Notwithstanding, general innovations in EU law, such as the introduction of Union citizenship, are received within the field of direct taxation and spark new issues of EU law in the field of direct taxation in proceedings before the Court.

Overall, our findings in this Chapter show that the Court values cohesion in its case law. The connectedness of the network of case law, its community structure and the way in which general EU law is adopted in the field of direct taxation indicate on balance that the Court attempts to embed new judicial decisions in a consistent and legally relevant manner into the existing body of rulings so that a coherent legal doctrine of EU law in the field of direct taxation may emerge over time. The outlines of this legal doctrine may be found in the restatement of Annex A.

This Chapter departed strongly from prior research in that we based our findings mainly on the information that the relations between the individual cases provided and our research was less concerned with the legal reasoning of the Court in the individual decisions. We neither attempted to identify or explain alleged inconsistencies between the interpretation of EU law in the various cases, nor did we try to surmise the relevance of relations between cases which are absent from the real case law network. Our research design did not take these normative aspects about 'what ought have been in the rulings' into account. Nonetheless, we believe that the research design of this Part adequately deals, and does so systematically, with the complexity that is inherent in the functional subsystem of EU law in the field of direct taxation. 
III The Balanced Allocation of Taxing Powers 



\section{Chapter $5 \quad$ Introduction to Part III}

\section{$5.1 \quad$ Introduction}

For the first time in the field of direct taxation, the Court accepted in Marks \& Spencer (C-446/03) the need to preserve a balanced allocation of the power to impose tax between the Member States as an overriding reason of public interest. This larger aim of government was to be able to justify the denial of crossborder loss relief under UK law. Whereas resident subsidiaries could surrender losses to their UK parents - thereby reducing the parent company's tax claimthis relief was not extended in relation to foreign subsidiaries of UK parent companies. The Court held that this different treatment based on the subsidiary's corporate seat was in principle contrary to the freedom of establishment, but that this restriction was justified by the need to preserve a balanced allocation of the power to impose tax between the Member States (paras 45 and 46). This justification, however, was only recognised and 'taken together' (para 51) with the risk of tax avoidance (paras 49 and 50), and the risk that losses might be used twice (paras 47 and 48). Conversely, the restriction in the main proceedings was not justified if the foreign losses were final and could not be used in the other Member States (paras 55 and 56). These five main elements of the justification analysis in Marks \& Spencer have puzzled legal scholars greatly as we will see in Section 5.2.

The purpose of Part III is to research the meaning of the balanced allocation of the power to impose tax between the Member States; the balanced allocation of taxing powers, or BAOTP in short. The contribution to the literature of this Part is not only a new comprehensive interpretation of the balanced allocation of taxing powers as a standard of EU law; this research also contributes to legal scholarship by applying the method of social network analysis as a framework methodology for qualitative legal analysis.

In the Chapters that follow in this Part, we will find that the balanced allocation of taxing powers is an important standard of EU law. This standard defines the limits of negative European integration in the field of direct taxation. Our understanding about the limits of protection afforded by the fundamental freedoms is further advanced by an interpretation of the risk of a double use of losses as a rule to pre-empt the non-discrimination clause on freedom of movement to function as an obligation to impose reverse discrimination. Furthermore, we will see that the protection afforded by the fundamental freedom provisions in the TFEU does not extend to abusive or fraudulent conduct by wholly artificial arrangements. However, when we evaluate this rule on abuse of law on a higher level of abstraction, we find that - within the field 
of direct taxes - this rule is indistinguishable from the standard of a balanced allocation of taxing powers on the larger aims of government pursued by those rules. Both rules pre-empt that EU law affects the existence of legitimate tax claims imposed by the Member States. In contrast to prior research, we find that the 'justification' of the cohesion of the tax system is actually not an equivalent overriding reason of public interest that may restrict freedom of movement. It is best interpreted as a methodological tool of the Court to use in assessing whether legitimate tax policy goals, including a balanced allocation of taxing powers, are pursued by national measures in a consistent and systematic manner. In that regard, it relates to the judicial principle of proportionality.

The remainder of Part III is structured as follows. This Chapter proceeds with a concise review of prior research to formulate the research questions and then continues with the analytical framework by which those questions will be answered. We will also make some preliminary inferences on the research question. Following, Chapter 6 analyses the a balanced allocation of taxing powers as standard of EU law and Chapter 7 researches how it relates to other recognised justifications. Next, Chapter 8 establishes the conditions of proportionality in relation to the BAOTP standard. Finally, Chapter 9 revisits Marks \& Spencer and offers an alternative approach to resolve the issues in similar cases.

\subsection{Survey of prior research}

Prior research does not provide a consistent interpretation of the balanced allocation of tax powers as a rule of EU law. Conflicting interpretations are defended, and little overall agreement can be distilled from the literature. Moreover, some comprehensive discussions on the concept have been published, but they do not point in the same direction. ${ }^{547}$ We will see that there is no prevailing opinion in academic doctrine.

The leading question in prior research is whether Marks \& Spencer was a critical juncture in the Court's case law and has so affected the structure and organisation of the judicial doctrine with the introduction of the balanced allocation of taxing powers as an element in a composite justification analysis. Subsequent case law, as positive feedback to Marks \& Spencer, locked-in the standard in the Court's legal doctrine on EU law in the field of direct taxation. Now, it appears to be the dominating judicial rule to resolve disputes on the interpretation of EU law in the field of direct taxation and to balance the Member States' freedom to impose direct taxes with the Union citizen's right to move freely within the EU.

547 Cordewener, et al. (2009); Englisch (2007); Poulson (2012); Van Thiel (2008c); Wattel (2007). 
Wattel concluded that Marks \& Spencer is incompatible with many prior Court judgments. ${ }^{548}$ Lang submitted that Marks \& Spencer signalled that the Court possibly moved towards a new direction. ${ }^{549}$ Vanistendael however stated that Marks \& Spencer confirmed most of the principles of prior case law in the field of direct taxation, but provided new insights on the justification grounds and the argumentation style of the judgment, which he regarded more nuanced compared to previous judgments. ${ }^{550}$

In a similar line, Wathelet found that the Court's case law prior to Marks \& Spencer has been largely confirmed by Marks \& Spencer and subsequent case law, but for two issues. ${ }^{551}$ First, Wathelet concluded that Marks \& Spencer introduced the balanced allocation of tax powers as an autonomous justification ground that opens wide possibilities for Member States to lawfully discriminate. ${ }^{552}$ He suggested it is perhaps another way of speaking of protection of tax revenues. ${ }^{553}$ Second, he defended the hypothesis that the balanced allocation of tax powers 'does not play any other role than to fight against tax avoidance,. ${ }^{554}$ The Court signalled in Marks \& Spencer a turn from its prior case law on the conditions of national legislation permitted to combat tax avoidance and fraud. Combined with the balanced allocation of tax powers, the new use of the tax avoidance argument allows Member States wide discretion as they would no longer be required to demonstrate even the possibility of an artificial arrangement since Marks \& Spencer, according to Wathelet. ${ }^{555}$ With regard to the risk of losses being used twice, Wathelet found that this was not really a justification, but this argument should have been discussed in the analytical prior question on the existence of a restriction. ${ }^{556}$ Since losses could not be used twice in internal situations, cross-border situations would not be treated less favourably.

Staringer argued that the use of the balanced allocation of tax powers argument in Marks \& Spencer was based on the incorrect assumption that such a principle existed in international tax law. ${ }^{557}$ He agreed with Wathelet that Marks \& Spencer added considerable confusion to the leeway that the Court is willing to give to the Member States in combating tax avoidance; can only wholly artificial arrangements be countered, or can lower substantive thresholds be applied if tax avoidance is liable to undermine the Member States' tax system?

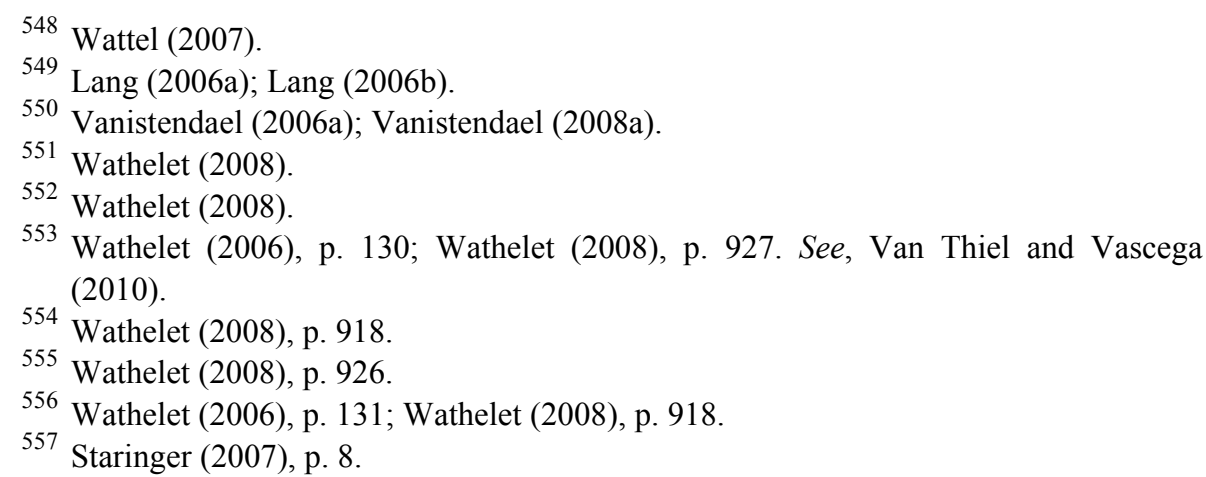


Schön submitted that the balanced allocation of taxing powers 'has been established in order to make sure, that the sovereignty of a given Member State is not overridden and legally or factually eroded by legislation of another Member State'. ${ }^{558} \mathrm{He}$ argued that the balanced allocation of taxing powers should not be interpreted as allowing a compartmentalisation of the internal market. ${ }^{559}$ That opinion was not shared by Meussen who rebutted that Schön expressed a wish to harmonise income taxes at the EU level. ${ }^{560}$

A different critique of prior research on Marks \& Spencer concerns the relation between the balanced allocation of taxing powers and other justification grounds that the Court has recognised in its case law. Defending the opposite opinion of Schön, Wattel found that the balanced allocation of tax powers, the principle of territoriality, and the concept of cohesion of the tax system represent the same idea of jurisdictional competence and the need for jurisdictional consistency or fiscal territorial cohesion. ${ }^{561}$ That territorial cohesion reflects the need to safeguard symmetrical treatment of positive and corresponding negative items of income within the nationally defined scope of taxation in a single concept of tax base integrity which also encloses the need to prevent abusive practice. ${ }^{562}$ Similarly, Farmer argued that fiscal coherence, non-comparability, territoriality, and balanced allocation of tax powers are all mainly concerned with the notion of symmetry between taxation and reliefs. ${ }^{563}$ Isenbaert and Valjemark also stated that the balanced allocation of taxing powers in Marks \& Spencer is the same as the argument of the cohesion of the tax system. ${ }^{564}$

The acceptance of this hypothesis lead Wattel to conclude that persons that are subject a different to tax situation are allowed to be treated differently because of dislocations of the tax base, thus expressly allowing for a compartmentalisation of the internal market. ${ }^{565}$ Weber defended the corresponding, but slightly different, hypothesis that the Court in, inter alia, Marks \& Spencer has not drawn the logical conclusion of the sovereignty of the Member States to determine the criteria for taxation and the limits of their tax jurisdiction. ${ }^{566}$ Cordewener, Kofler, and Van Thiel however disagreed and found that cohesion and balanced allocation of taxing powers do not share common ground. ${ }^{567}$ In their view, cohesion is concerned with a systemic direct link between a tax advantage and a subsequent charge within the tax system of one Member State, whereas the balanced allocation of taxing powers and the fiscal

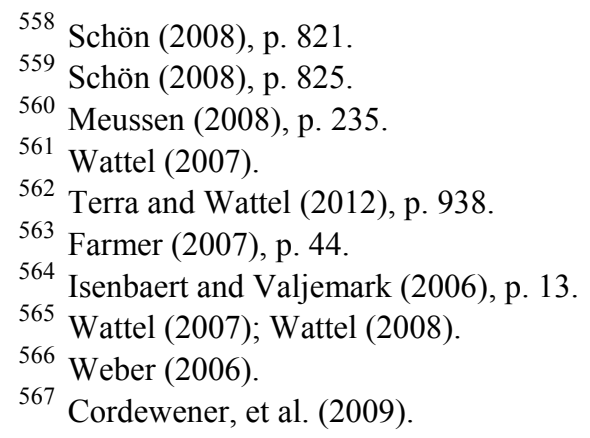


principle of territoriality concern the systemic coherence between the tax systems of two Member States. ${ }^{568}$ Lang identified tensions and contradictions in the Court's case law concerning the balanced allocation and symmetrical application of national tax rules, and only pointed to a potential indirect relation between the two concepts. ${ }^{569}$

In contrast to the above critique, prior research also suggested that, even though arguments relating to jurisdictional competence and inter-nations equity are important, considerations of inter-personal equity are pivotal. ${ }^{570}$ Vanistendael indeed labelled Marks \& Spencer the 'hallmark case of territoriality and the symmetric application of the laws of a national jurisdiction'. ${ }^{571}$ But, he also added that the fiscal sovereignty of Member States to divide tax jurisdiction, as expressed by these principles, is neither absolute, nor exclusive. ${ }^{572}$ Likewise, Douma concluded that Marks \& Spencer reflected a balanced interpretation and application of the principle of equality as required by EU law. ${ }^{573}$ The Court's case law showed no need for an individual concept of dislocations or compartmentalisation of the internal market as an independent source of lawful tax restrictions. ${ }^{574}$ Moreover, the content of the concept of dislocations is unclear according to Douma. ${ }^{575}$

Prior research also argued that the meaning of the concept of balanced allocation of taxing powers is heterogeneous and dependent on the context and individual circumstances of the case in which the Court applied it. ${ }^{576}$ Englisch distinguished four types of cases. ${ }^{577}$ These cases involved (i) the avoidance of double non-taxation, (ii) the symmetrical treatment of profits and losses, (iii) the risk of loss of the right to tax, and (iv) combatting tax avoidance. Englisch concluded that the balanced allocation of taxing powers cannot be understood as an independent justification ground, but rather facilitates a balancing of the aims of inter-personal and inter-jurisdictional equity, as the Court did in consistent prior case law. ${ }^{578}$ This finding is generally in line with Douma. ${ }^{579}$ According to Van Thiel the balanced allocation of taxing powers only justifies restrictive national measures if "the possibility to exercise the power to tax with regard to domestic-source income is jeopardized by private sector possibilities to claim

${ }^{568}$ Cordewener, et al. (2009), p. 1974.

569 Lang (2009), pp. 107-110.

570 Cordewener, et al. (2009); Douma (2006); Englisch (2007); Van Thiel (2008a);

Vanistendael (2006a); Vanistendael (2008a); Vanistendael (2008b).

571 Vanistendael (2008b), p. 93.

572 Vanistendael (2008a); Vanistendael (2008b).

573 Douma (2006), p. 530.

574 Douma (2006), p. 532.

575 Douma (2006), p. 533.

576 Cordewener, et al. (2009); Englisch (2007); Van Thiel (2008a).

577 Englisch (2007).

578 Englisch (2007), p. 407.

579 Douma (2006). 
deductions twice or to avoid tax trough artificial constructions' ${ }^{580}$ Van Thiel also submitted that the balanced allocation of taxing rights may justify the continued application of a prima facie discriminatory national tax provision because the agreed allocation between the Member States in the double tax convention may neutralise the unilaterally imposed disadvantageous effect in reality. ${ }^{581} \mathrm{He}$ distinguished, first, the case in which the balanced allocation is agreed explicitly in a double tax convention, and second, the case in which that balance follows from the general and shared autonomous understanding of the allocation of taxing powers between Member States. ${ }^{52}$ In this context, Van Thiel concluded that the Court will in the future continue to accept the traditional (i.e. OECD international tax practice) allocation of taxing powers between the Member States to shape inter-jurisdictional equity, as long as this allocation does not affect inter-personal equity to the disadvantage of crossborder active taxpayers. ${ }^{583}$ This conclusion is consistent with the findings in other studies. ${ }^{584}$

\subsection{Research questions}

As follows from the above review, the observed inconsistencies in the academic doctrine and the alleged open texture of the language used by the Court have led to indeterminacy in the law regarding the balanced allocation of taxing powers, and more generally the definition of overriding reasons in the public interest that are fit to justify tax restrictions on free movement. The concept of a balanced allocation of taxing powers is therefore a relevant subject of academic legal research.

The main goal of the next Chapters is to attempt to establish a comprehensive and rational interpretation of the concept of the balanced allocation of taxing powers as it was first used in Marks \& Spencer and as it evolved in subsequent case law. In this context, the survey of prior research leads to the following research questions and subquestions.

Research question 1: What is the Court's interpretation (ratio decidendi), as evidenced by consistent case law, of the balanced allocation of taxing powers (Chapter 6)?

- Does the ratio decidendi of the balanced allocation of taxing powers concern the balance of allocation of taxing powers agreed between the Member States (hypothesis 1.a),

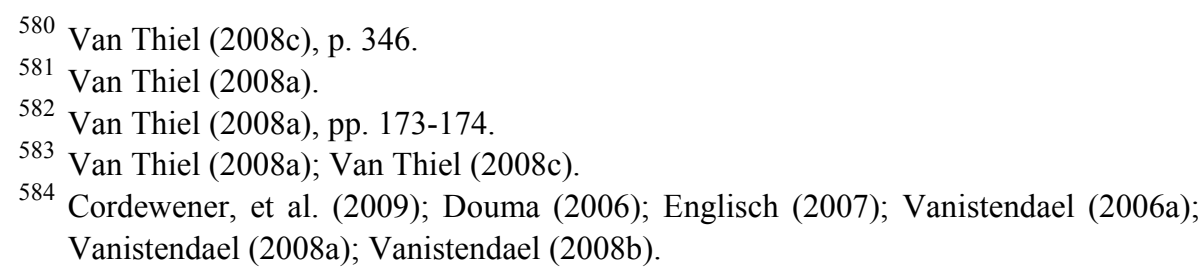


- or does it concern the taxing powers allocated to one Member State without concern for the taxing powers allocated to another Member State (jurisdictional competence, hypothesis 1.b),

- or does the Court interpret the concept differently, and to what concept or principle in international tax practice can this different interpretation be best compared (hypothesis 1.c)?

Research question 2: What is (are) the relation(s), if any, between the balanced allocation of taxing powers and other Member State justification grounds accepted by the Court in the field of direct taxes (Chapter 7)?

Research question 3: Does the Court accept the balanced allocation of taxing powers as an independent justification ground in its case law, or is it only accepted as one element within a composite justification analysis (Chapter 7)?

Research question 4: What are the proportionality conditions of restrictions which can be justified by a need to preserve a balanced allocation of taxing powers, and how can they be justified by the ratio of the concept and its relations with other defences (Chapter 8)?

\subsection{Methodology and data}

The framework methodology of research of this Part is again social network analysis (SNA). SNA serves a dual function in this Part. First, SNA defines the data sample of the research; the Court rulings that are the main object of research. Second, SNA defines the relations between the individual cases. This second function not only guides the legal interpretation de lege lata of the arguments and concepts in the selected case law, but also restricts legal interpretation. The restriction imposed by SNA is that only observable links between cases may be interpreted. Possible relations between concepts, arguments and judgments which have been discussed in prior research, but which are however absent from the results obtained by SNA are in principle not included in the research results and consequently are not considered in legal interpretation de lege lata as a matter of research design. However, it will be clearly indicated when this limitation is relaxed as we make those observations on a tangent.

The method of SNA applied to case law again builds on the role that precedent plays in the process of judicial decision making. In context of the discussion in the literature, as reviewed above, this is appropriate, because prior research questions the fit of Marks \& Spencer to prior case law, and also the fit of subsequent case law to Marks \& Spencer.

The sample of relevant rulings for the legal analysis of the standard 'a balanced allocation of taxing powers between Member States' is defined as all cases that are directly or indirectly connected to the relevant passages of Marks \& Spencer. We thus use a snowballing technique for sample selection. This link should be a sufficiently close connection in order to maintain the focus on the 
research questions-we don't want to analyse all cases, we want to analyse the relevant cases. Cases with a distance of two to Marks \& Spencer will in any case be considered as closely linked cases. ${ }^{585}$ These are the cases that are most likely to interpret the same rules that the Court applied in Marks \& Spencer, including the balanced allocation of taxing powers and are therefore relevant cases. Since Marks \& Spencer is a relatively recent ruling - it was decided late 2005-it is safe to assume that any relevant subsequent case is not more than two citation links away from Marks \& Spencer. If the Court does not directly cite Marks \& Spencer, then at least we may assume that the Court cites a ruling that in turn cites Marks \& Spencer. That means, if case $i$ cites Marks \& Spencer on relevant points then case $i$ is included in the sample for analysis. If case $j$ in turn cites the relevant paragraph(s) of case $i$ then case $j$ is also included in the sample. What the relevant points of law are will be explained below.

As we have seen by the survey of prior research, the origins of the balanced allocation of taxing powers standard are unclear. It is commonly assumed that the balanced allocation of taxing powers is a new concept that Marks \& Spencer established, because the Court did not cite precedent in paragraphs 45 and 46. It is also possible, and prior research suggests this too, that it is an old rule that goes by a new name. If the latter interpretation is true, we expect that the Court would cite precedents ruled before Marks \& Spencer in the direct context of later case law when interpreting Marks \& Spencer. The Court would do this in order to embed Marks \& Spencer better in prior case law. This behaviour is plausible under the accepted political theory that the Court values cohesion in the body of case law. To check for this alternative interpretation, for all cases $i$ and $j$ in the sample, we also collect outward citations with maximum distance of 2 and also include the cases thus found in the final sample.

The complete sample selection procedure can be formally defined in four steps. In step one, the initial sample is defined as the relevant passages of Marks $\&$ Spencer and the passages of all cases that explicitly cite the relevant passages of Marks \& Spencer. There are four passages of Marks \& Spencer which are central to the research questions and are included in the initial sample as the relevant points of law:

- paras 45 and 46 on the balanced allocation of taxing powers;

- paras 47 and 48 on double use of losses;

- paras 49 and 50 on the prevention of tax avoidance; and

- para 51 on 'taken together'.

Paragraphs 45 and 46 are directly relevant for research question 1 . Paragraphs 47 to 50 are directly relevant for research question 2. Research question 3 relates to paragraph 51 of Marks \& Spencer. The relevant cases for research question 4 are identified by legal analysis, since we first need to find the rulings in which the balanced allocation of taxing powers was accepted.

585 This maximum threshold was justified by the average path length of the giant component, which was 2.832 , see Section 4.2 . It is therefore plausible that all relevant cases are separated from Marks \& Spencer by less than three degrees. 
We collected all relevant cases and identified the relevant citing paragraph or citing passage of the ruling that includes a citation of one of the four above passages of Marks \& Spencer using the EUR-Lex database. A relevant citing passage is defined as the citing paragraph including its context paragraphs. A citing passage is a small subset of paragraphs of the ruling which together form a cohesive argument in law of the Court, but an absolute maximum was set at ten paragraphs.

Step two repeats step one and identifies indirect citations to Marks \& Spencer to account for the possibility that the Court interprets the concepts of Marks \& Spencer, but does not cite Marks \& Spencer as precedent. We again used EUR-Lex to search cases that cited the relevant paragraphs of the cases included in the initial sample after step one. Any new cases and new passages were then added to the sample.

Step three collects the outward citations for all relevant passages of the cases included in the initial sample after step two and any new cases or new passages thus found were added to the sample.

Step four repeats step three and constructs the network by collecting all outward citations of the passages thus far included in the sample and by adding any new cases and relevant passages to the initial sample after step three.

We presume that relations between the justification grounds will become visible as citation links between citing passages. When the Court cites a passage of one ruling $A$ that concerns justification $X$ in the context of the analysis of justification $Y$ in another ruling $B$, that citation link is evidence of a conceptual relation between justifications $X$ and $Y$. A qualitative legal analysis of the relevant passages of rulings $A$ and $B$ will show the nature of that relation. In other words, we look at whether the Court applies similar rules in different contexts under different names. If that is the case, we will see the relations between justifications in a connected network structure. If not, we are most likely to find four isolated components; one for each relevant citing passage of Marks \& Spencer. In that case, we should carry out a qualitative analysis of each component to establish the meaning of the several passages of Marks \& Spencer, but it will be difficult to assert that the justification grounds that they represent are overlapping or even indistinguishable legal norms.

\section{5}

Descriptive results

\section{5 .1}

\section{Properties of the network}

The Marks \& Spencer network is 136 nodes (citing passages) and 281 edges large. These citing passages were found in 82 rulings. Figure 14 shows this network. We indicated the position of citing passages of the Marks \& Spencer $(\mathrm{M} \& \mathrm{~S})$ ruling. We observe that also other paragraphs of Marks \& Spencer (i.e. paras 29, 35, 43 and 57) have been detected by our method besides the paragraphs which we considered a priori relevant. These paragraphs are indicated as well. 


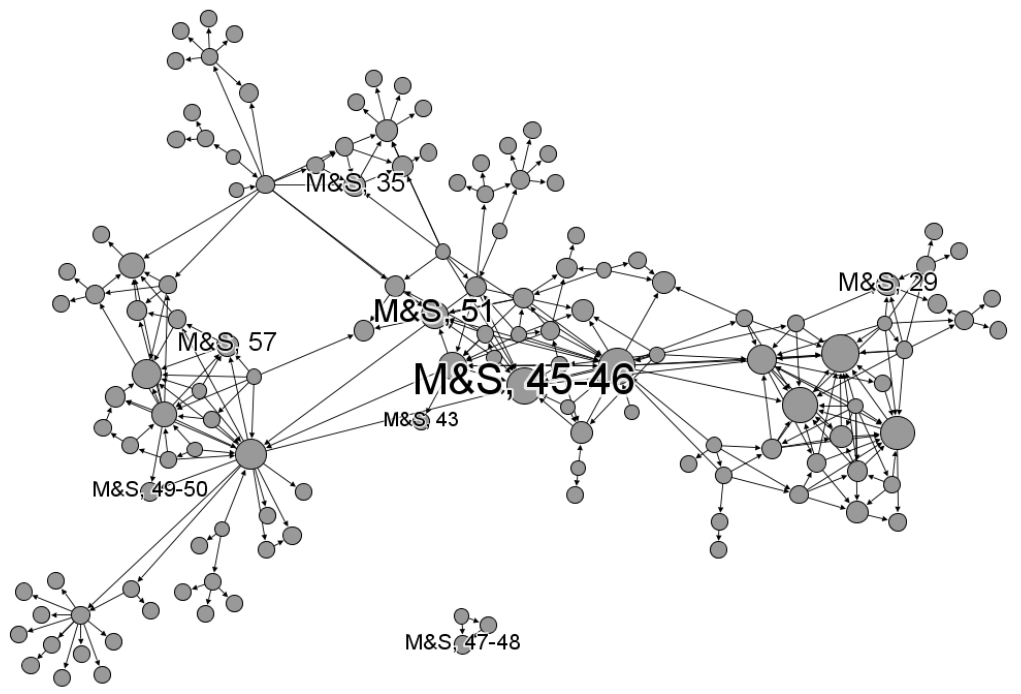

Figure 14. The Marks \& Spencer network.

The Mark \& Spencer network is split into two components. The structure of the network is clearly one of sparsely connected clusters of densely connected nodes. We will analyse this evident community structure in the next Section.

Figure 14 shows that passages of Marks \& Spencer which are concerned with the same legal issue also occupy similar topological positions in the network. For example, the proportionality analysis of Marks \& Spencer, para 57, on wholly artificial arrangements is close to the passage of Marks \& Spencer, paras 49 and 50, that recognises tax avoidance as a justification ground. Marks \& Spencer, para 35, on the requirements of the rule of reason (i.e. Rule 4:1 of Annex A) takes up a topological position in a cluster of citing passages of other cases that connects, on the one hand to the cluster of citing passages on the BAOTP justification (represented by Marks \& Spencer, paras 43, 45 and 46, and 51 ) and, on the other hand to the cluster of citing passages concerned with tax avoidance as justification. The passage of Marks \& Spencer, paras 47 and 48, on double use of losses is in an isolated component of the network, which could mean that it is conceptually distinct from other justifications.

The size of the node is proportional to its indegree. The network shows that there are some citing passages which have also been cited frequently, notwithstanding that our research design specifically looked for citations to Marks \& Spencer. In the context of the balanced allocation of taxing powers of Marks \& Spencer, paras 45-46 (12 citations) and para 51 (7 citations), the Court also frequently refers to $O y A A(\mathrm{C}-231 / 05)$, paras 50-56 (11 citations) and Rewe Zentralfinanz (C-347/04), paras 39-44 (7 citations). The judgments in Cadbury Schweppes (C-196/04), paras 51-56 (9 citations) and ICI (C-264/96), paras 26 and 27, are central in the context of tax avoidance of Marks \& Spencer, paras 49 and 50 (2 citations) and para 57 (4 citations). 


\subsubsection{Community structure}

In keeping with Chapter 4 we have applied the Louvain method to analyse the community structure of the Marks \& Spencer network. The Louvain method identified eight communities $(Q=0.684)$, see Table 22 . This is more than we expected, because we identified only four relevant passages in Marks \& Spencer. We have identified the subject matter of the communities with reference to the paragraph of the Marks \& Spencer ruling that it includes and the Rule of Annex A that it represents, if any.

\begin{tabular}{cccc}
\hline Community & Marks \& Spencer & Annex A rule & Chapter/Section \\
\hline 1 & paras 49-50,57 & $4: 5$ & $7.4 .3 \& 7.4 .5$ \\
2 & - & - & 7.4 .2 \\
3 & para 35 & $4: 1,4: 2(1), \& 4: 3$ & $7.5 \& 8$ \\
4 & - & $4: 7$ & 6.4 \\
5 & paras 47-48 & - & 7.3 \\
6 & para 29 & $1: 1 \& 1: 2$ & $6.2 \& 6.5$ \\
7 & - & - & 7.4 .4 \\
8 & paras 43, 45-46, 51 & $4: 4$ & $6.4 \& 7.2$ \\
\hline
\end{tabular}

Table 22. Communities of the Marks \& Spencer network

The last column of Table 22 indicates in which Chapter or Section of this book the lines of authority of the various communities will be analysed in detail. We organised our qualitative analysis of the case law in accordance with the organisation suggested by the computed community structure.

Since we were unable to identify communities 2 and 7 with reference to Marks \& Spencer and Annex A we give a short description here. Community 2 is a collection of passages of cases in which the Court held that EU law cannot be relied on for abusive or fraudulent ends. ${ }^{586}$ Community 7 is about the standard of proof that applies for finding an abusive practice ${ }^{587}$ Note also that community 4 is about reduction in tax revenue as a justification and community 5 is about the risk that losses might be used twice. This last justification rule is not included in Annex A since it was only applied in two other cases after Marks \& Spencer. ${ }^{588}$

As a robustness check, we also applied the Girvan-Newman algorithm to the Marks \& Spencer network. This community detection method returned ten

586 Notably, Van Binsbergen (33/74), para 13; and Centros (C-212/97), paras 24 and 24, and 27.

587 Emsland-Stärke (C-110/99), paras 52 and 53; Halifax (C-255/02), paras 75 and 75; Cadbury Schweppes (C-196/04), paras 67-71, and 72-75; Eurofood IFSC (C-341/04), paras 34 and 35; and CFC and Dividend Group Litigation (C-201/05), paras 76-81.

Marks \& Spencer, paras 47 and 48; Rewe Zentralfinanz (C-347/04), paras 46-49; and Lidl Belgium (C-414/06), paras 35 and 36. 


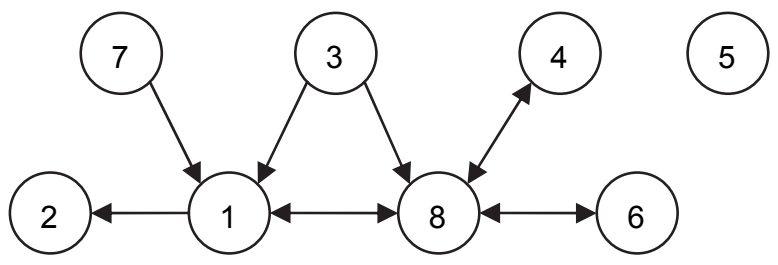

Figure 15. Community network

communities $(Q=0.670)$. The difference is due to a split of community 3 into three separate communities, each of which concerns one of the Rules of Annex A that is listed in Table 22 for community 3 . Most citing passages in community 3 are concerned with the rule of reason (Rule 4:1 of Annex A) and in particular the principle of proportionality of Rule 4:1(2) of Annex A. The detected citing passages that concern Rules 4:2 or 4:3 of Annex A mostly state that cohesion of the tax system, effective fiscal supervision and the prevention of illegal activities are recognised justifications in EU law.

Figure 15 shows the Marks \& Spencer network as a network of communities. This simplified version of the Marks \& Spencer network provides the first valuable information on the relations between the different lines of authority. On the basis of the community network we can already make five preliminary inferences about the Court's doctrine.

First, as we have already seen above, the risk that losses might be used twice (community 5) is isolated from the main component of the network. All other communities are directly or indirectly connected. This could be an indication for substantive decoherence of this justification from the other lines of authorities represented by the other communities of the network.

Second, it seems that the case law of community 1 concerning abusive practices through wholly artificial arrangements (Rule 4:5 of Annex A) applies the more general line of authority of community 2 that states that EU law cannot be relied on for fraudulent or abusive ends. More specifically, when the standard of proof of community 7 is met and an abusive practice is found to exist on the basis of the circumstances of a particular case, then it is justified, according to community 1 , to withhold the benefits of EU law as community 2 explicitly allows. However, Rule 4:1 in community 3 requires a full examination of the objective circumstances of the case by force of the principle of proportionality.

Third, communities 1 and 8 (the BAOTP rule of Rule 4:4 of Annex A) are closely connected. That perhaps is an indication that both justifications are positively related and may even be the same or should be 'taken together'. The directed edge from community 3 to community 8 plausibly indicates that the principle of proportionality should be observed when applying the BAOTP rule. The relation between communities 3 and 8 could also be evidence of a relation between the cohesion of the tax system and the BAOTP rule. However, this link could not be confirmed on the basis of the community structure suggested by the Girvan-Newman method, which separates Rule 4:3 of Annex A on cohesion of the tax system from community 3 and does not connect it to community 8 . 
Fourth, there is an edge between community 8 and community 4 (Rule 4:7 of Annex A on reduction in tax revenue). But, given that the judgment in Marks \& Spencer already indicates that the two justifications are different and that preservation of the balanced allocation of taxing powers is a recognised justification, and reduction in tax revenue is not considered an overriding reason in the public interest, our hypothesis is that the link between communities 8 and 4 has a negative sign. In that context, we observe that there is no connection between communities 3 and 4 . Accordingly, community 3 may be thought of as a rule of recognition.

The fifth and last preliminary finding is that the BAOTP rule directly attaches to the basic framework of EU law in the field of direct taxes as reflected in Rules 1:1 and 1:2 of Annex $\mathrm{A}$ on the distinction between the reserved competence to define the criteria for the allocation of taxing powers and the general requirement that those powers should be exercised consistently with EU law. This relation follows from the edge between communities 6 and 8 .

\section{$5.6 \quad$ Synthesis}

This Chapter gave the introduction to the research in Part III of this book. Our aim in the following Chapters will be to give content and meaning to the balanced allocation of taxing powers as a legal norm in EU law. We have seen in Section 5.2 that prior research does not offer a prevailing interpretation. The relations with other justification grounds and the application of the principle of proportionality are unclear. We formulated the relevant research questions in Section 5.3. Following, we explained the framework of research by describing the method by which we collected and organised the relevant case law in Section 5.4. We described our preliminary findings in Section 5.5. The main conclusion of these descriptive results is that there may be some truth in the suggestions of prior research that the balanced allocation of taxing powers is conceptually linked to other justifications, and in particular to the prevention of wholly artificial arrangements and other abusive tax practices. 



\section{Chapter $6 \quad$ The BAOTP Standard as Such}

\subsection{Introduction}

The aim of this Chapter is to draft a working hypothesis of the balanced allocation of the power to impose tax between the Member States (balanced allocation of taxing powers or BAOTP in short hereinafter) as a standard in EU law. This aim requires to give content and meaning to this standard as such and to place the legal norm within the larger basic framework of EU law in the field of direct taxation.

Before we can reason on how the BAOTP standard fits within the larger system of EU law in the field of direct taxes, it is necessary to define this basic framework of the law. Section 6.2 will present this basic framework. For this purpose we will also build on the findings of Part II of this book, i.e. the acte clair rules of Annex A. We will review the power to impose tax as a reserved competence of the Member States under the Treaties and we will distinguish the legitimate existence from the constrained exercise of that power under the law of the EU Treaties.

We will establish the content of and give meaning to the BAOTP standard in Sections 6.3 and 6.4. First, in Section 6.3, we will draw from computational linguistics and we will make a citation summary of Marks \& Spencer (C446/03), paras 45 and 46. In doing so, we can determine the wording that the Court used to interpret this passage in subsequent case law. The Court's language in subsequent judgments is used to give an authentic restatement of the relevant passage of Marks \& Spencer. Section 6.4 will carry out a legal analysis of the standard to establish its context, aims and evolution. We will distinguish between a period of emergence and a period of reproduction in the case law.

Section 6.5 relates the intermediate findings to the basic framework of the law; how does the standard fit within the general system of EU law in the field of direct taxes? We will pay specific attention to the legal relevance of the aims of the national legislation for the question why the BAOTP standard is properly conceived as a justification ground, despite the fact that we find it to apply in a rather absolute manner. Our preliminary understanding of the balanced allocation of taxing powers, which we present as the conclusion of this Chapter in Section 6.6, is that the BAOTP standard is a legal norm that pre-empts EU law from constraining the exercise of the power to impose tax beyond the point upon which the application of EU law would in effect attack the existence of that power and would, thus, force the Member State concerned to surrender a legitimate tax claim on activities that were carried out in its national territory. 


\subsection{The basic framework of the law}

\subsubsection{The principle of conferral as point of departure}

The Court recognises foremost that the field of direct taxation is a reserved competence of the Member States under the principle of conferral of competences of Article 5 TEU. ${ }^{589}$ The competence to legislate in the field of taxation has not been conferred upon the Union by the Treaties. Subject to the principles of subsidiarity and proportionality and by force of Article 115 TFEU, the Union may only act in the field of direct taxation if the Member States unanimously decide that Union action is necessary and proportionate in the interest of achieving the objectives of the Treaties, and in particular benefits the functioning of the internal market. ${ }^{590}$ Article 4 TFEU states indeed that the Union shares competence with the Member States in the area of the internal market. Also, Article 352 TFEU may be invoked as a legal basis for Union action in the field of direct taxation, if Article 115 TFEU would not apply according to the circumstances and object and purpose of the proposed legislative initiative.

Although Article 113 TFEU promotes the harmonisation of indirect taxes and explicitly invites Union action in this field, ${ }^{591}$ no similar Treaty provision applies to direct taxation. The system of Treaty law consequently suggests that positive integration in the field of direct taxation cannot be assumed at the outset to be necessary to achieve the objective of an internal market. The Treaties do not presume that harmonisation of direct taxes is necessary to establish a well functioning internal market. This implies that the principles of proportionality and subsidiarity of Article 5 TEU should be strictly observed when considering Union action in the field of direct taxes.

Existing legislative acts of the Union in the field of direct taxation have almost exclusively been motivated by the need to eliminate double taxation and the need to prevent non-compliance. The allocation of the power to tax, i.e. the division of fiscal jurisdiction between the Member States, was consequently subject of the historical process of positive integration in specific areas. No general harmonisation measures have been adopted on issues of fundamental tax design, such as the definition of the tax unit, the basis of assessment, the timing of income recognition, the setting of tax rates, and the modes of collection, administration and procedure.

The Parent-Subsidiary Directive (90/435/EEC), the Interest and Royalties Directive (2003/49/EC), and the Mergers Taxation Directive (2009/133/EC) have been adopted with a view to eliminate double taxation of companies. The

589 Rule 1:1 of Annex A.

590 See, Weber (2010) on the various legal and political basis of Union action in the field of direct taxation.

591 See, Council Directive 2006/112/EC on the Common System of Value Added Tax, O.J. L 347, 11.12.2006, p. 1-118. 
same is true for the Arbitration Convention (90/436/EEC) that aims to avoid economic double taxation by coordination of transfer pricing adjustments between the Member States through a dispute resolution mechanism of mutual agreement and arbitration. ${ }^{592}$ The Convention does not impose substantive rules on taxation.

As regards the taxation of personal income, the Savings Income Taxation Directive (2003/48/EC) aims to ensure the effective taxation of interest income from savings. The need to ensure effective supervision and recovery of taxation on cross-border activities also justified the adoption of the Administrative Cooperation Directive (2011/16/EU) and the Mutual Assistance for the Recovery of Taxes Directive (2010/24/EU). ${ }^{593}$

In short, double taxation and non-taxation are types of distortions to the functioning of the internal market for which a targeted Union-wide solution was deemed necessary by the Member States. The positive integration to date is thus characterised by a lack of 'hard' EU law in the field of direct taxation. Although some proposals aimed to harmonise national legislation on issues of fundamental tax design in the past - e.g. the proposals of the Neumark, Van Den Tempel and Ruding reports - all of those broad based efforts have failed so far. It is furthermore doubtful, at the time of writing, whether the grand project of a Common Consolidated Corporate Tax Base will be adopted by the Member States, because the proposal was still pending before the Council. ${ }^{594}$ Adoption of this proposal would mean a turning point in positive European tax integration.

Some 'soft' law measures do exist that aim to approximate substantive tax rules between the Member States. ${ }^{595}$ As with the directives, the soft law measures mainly apply to business taxation and corporation taxes in particular. The main soft law measure is notably the Code of Conduct for Business Taxation of $1997 .{ }^{596}$ Also the SME Taxation Recommendation of 1994 could be mentioned. ${ }^{597}$ As regards personal income taxes, the Commission proposed to coordinate the taxation of non-resident taxpayers with the Non-resident Workers Taxation Recommendation, ${ }^{598}$ even before the Court decided the issue in Schumacker (C-279/93) in 1995. Also, a number of Commission Communications on direct taxation policy exist which were primarily drafted

592 Convention on the elimination of double taxation in connection with the adjustment of profits of associated enterprises (90/436/EEC) ('Arbitration Convention'), O.J. L 225, 20/08/1990, p. 10-24.

593 See, Commission Implementing Regulation (EU) No 1189/2011 of 18 November 2011 laying down detailed rules in relation to certain provisions of Council Directive 2010/24/EU concerning mutual assistance for the recovery of claims relating to taxes, duties and other measures, O.J. L 302, 19/11/2011, p. 16-27.

${ }_{595}$ European Commission (2011b).

595 See generally, Gribnau (2007); Gribnau (2008).

596 ECOFIN Council (1997).

597 European Commission (1994).

598 European Commission (1993). 
and published in response to case law of the Court. ${ }^{599}$ We already observed in Chapter 3 that the Commission pursues a proactive strategy of monitoring compliance of the Member States with the case law of the Court by initiating infringement proceedings since 2001. Most Communications since 2001 should be understood in the context of this primary policy strategy.

The targeted measures to achieve a partial positive integration in the field of direct taxation contrast with the wide scope of application of the fundamental freedom provisions of the Treaty. The fundamental freedoms should be observed by Member States in the exercise of all of their actions. This does not mean that the freedoms impose an unrestricted obligation on the Member States to achieve further European integration in the interest of eliminating all distortions to the functioning of the internal market caused by their national legislation.

\subsubsection{The legitimate existence of the power to impose tax}

The Court's early authority of Schumacker drew a distinction between the existence and the exercise of the Member States' power (or competence) to impose direct taxes. The Schumacker ruling established that the scope of the Court's regulatory control on direct taxation only extends to the exercise of the power to impose tax, but leaves the existence of the power to impose direct taxes in principle unaffected.

The Court consistently held since Schumacker that, in the absence of unifying or harmonisation measures at the Union level, the Member States retain competence for determining the criteria for taxation on income and wealth with a view to eliminating double taxation. ${ }^{600}$ Although Schumacker is the case of first impression in the field of direct taxation, it is however not an original interpretation of EU law. The Court relied in Schumacker on the non-tax case of Commission $v$ UK (C-246/89), para 12. The Court thus followed a wellestablished general line of authority that can be traced back directly to case law as early as Commission v France (Joined Cases 6/69 \& 11/69) in which the Court held that 'the exercise of reserved powers cannot ... permit the unilateral adoption of measures prohibited by the Treaty' (para 17). The exercise of powers on direct taxation must also be consistent with EU law. ${ }^{601}$ EU law as it applies in the field of direct taxation is thus not special.

The Court frequently notes - first in Gilly (C-336/96) - that some targeted measures have been adopted by the Union, but also holds consistently that no unifying or harmonisation measure for the abolition of double taxation has been adopted. This means that the legitimacy of the Member States' power to impose

\footnotetext{
599 See e.g., European Commission (2003a); European Commission (2006a); European Commission (2006b); European Commission (2006c); European Commission (2007).

${ }^{600}$ Rule 1:1(2) of Annex A.

${ }^{601}$ Rule 1:2 of Annex A.
} 
direct taxes and their freedom to shape the fundamental organisation of their direct tax systems is not, as such, in question. ${ }^{602}$ This basic point of context for the legal analysis, i.e. the 'mantra' of Rules 1:1 and 1:2 of Annex A, which we read in virtually every Court ruling in the field of taxation has direct implications on which claims are justiciable before the Court.

Gilly established that, in the absence of Union measures, the Member States are thus required to allocate fiscal jurisdiction between them. The Court recognises that fiscal jurisdiction may be allocated unilaterally or by means of international agreements such as double taxation conventions (DTCs). For this purpose, the Member States remain at liberty to determine the relevant connecting factors, according to settled case law. ${ }^{603}$ The Court consistently held that it is not unreasonable for the Member States to base their agreements on international tax practice and the Model Convention drawn up by the OECD.

One of the internationally accepted connecting factors to allocate (fiscal) jurisdiction is nationality. The Court held in Gilly that a distinction in fiscal jurisdiction of a Member State between Union citizens of different nationality does not constitute discrimination. ${ }^{604}$ Nationality was used here for the purpose of allocating the power to tax, more specifically in order to define the personal scope of the law; which persons are caught by the general system of the law? The DTC provision at issue in Gilly allocated - in certain circumstances - taxing power to the contracting state of which the person was a national. As was the case in Gilly, also in the case of Van Hilten-van der Heijden (C-513/03), nationality was used as a secondary criterion to residence as the primary connecting factor. The criterion of nationality allowed the Member State concerned to assert fiscal jurisdiction on its non-resident nationals. In Gilly and Van Hilten-van der Heijden the specific application of nationality as a connecting factor was, as the Court explicitly considered in those rulings, not only generally accepted in customary international tax practice as recommended by the OECD, but it also did not result in a wider scope of application of one Member State's direct tax law on nationals of other Member States compared to the fiscal jurisdiction that the Member State asserted on its own nationals. The distinction also did not treat a national who exercised their right to move and reside freely within the Union less advantageous than nationals who stayed at home. The application of a nationality criterion corresponded fully to the nationality principle in international public law which reserves states the possibility to exercise jurisdiction on acts of its nationals carried out outside its national borders. ${ }^{605}$

602 See, Opinion of AG Poiares Maduro in Marks \& Spencer, point 23.

${ }^{603}$ Rule 1:1(2) of Annex A.

604 Rule 1:4(1) of Annex A.

605 See generally, Douma (2006); Harris and Oliver (2010), Chapter 2; Martha (1989); Monsenego (2012), Chapter 2 for reviews on connecting factors of fiscal jurisdiction in public international law. 
Similarly, distinctions in the scope of fiscal jurisdiction based on the place of residence of a person (the standard territorial proxy for nationality besides domicile in international law) are not suspect under EU law. ${ }^{606}$ It follows directly from Futura (C-250/95) that a direct tax system which distinguishes between universal fiscal jurisdiction on resident persons and asserts territorial jurisdiction in relation to non-residents does not, in itself, amount to a breach of EU law. ${ }^{607}$ More generally, an allocation of fiscal jurisdiction on the basis of the application of the principle of territoriality linked to a temporal component was held legitimate in N. (C-470/04) and National Grid Indus (C-371/10). This corresponds to the general principle of international law as established in the authority of the International Court of Justice in S.S. Lotus that an exercise of state power is legitimate with regard to acts that are performed or otherwise have an effect on the state's territory. ${ }^{608}$

The competence of each Member State to choose the connecting factors for fiscal jurisdiction and the criteria for direct taxation also implies, as the Court consistently held since Deutsche Shell (C-293/06), that a Member State is not required to draw up its tax rules on the basis of those in force in another Member State in order to ensure, in all circumstances, taxation which removes any disparities arising from national tax rules. Disparities may arise because the Member States choose different connecting factors and apply different criteria. The typical questions of fiscal jurisdiction and fundamental tax design on who is taxed for what, how much, when and by which branch of government may, in principle, be resolved by the Member States alone and each Member State is free to answer these questions differently. Consequently, there is an inherent protection in the Treaties for the diversity of choices in fundamental tax design between the Member States and the heterogeneity of underlying policy preferences.

Disparities between the laws of the Member States may result in different tax consequences for a citizen conditioned upon in which Member State that citizen resides or carries out economic activity. In this regard, the Court has consistently held, for example in Lindfors (C-365/02) and Schempp (C-403/03), that the TFEU offers no guarantee to a Union citizen that transferring his or her place of residence or economic activities to another Member State will be neutral as regards taxation. Such a transfer may be to the citizen's advantage or not, according to the circumstances. Thus, a transfer to another Member State which is disadvantageous to the citizen is in principle not contrary to the citizen's right of Article 21 TFEU to move freely and reside in another Member State, provided that the legislation of the other Member State does not place that citizen at a disadvantage as compared with those already subject to the same tax system, see Lindfors.

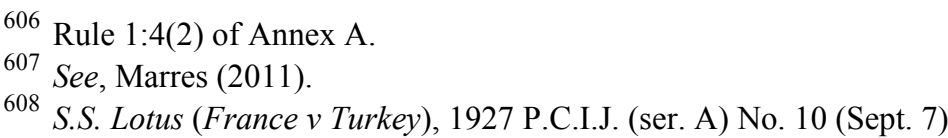


In short, the Member States are free to determine the connecting factors and basic criteria for direct taxation. Any disadvantages which are directly and exclusively caused by differences in the chosen connecting factors and criteria between the Member States ('disparities') are not contrary to the Union citizen's fundamental free movement rights. ${ }^{609}$ On balance, the basic framework of the TFEU as applied to direct taxation not only respects the choices of fundamental tax design made by an individual Member States, but affords equal constitutional protection to the diversity of policy choices between the different Member States.

\subsubsection{The constrained exercise of the power to impose tax}

We have seen that settled case law holds that the legitimate existence of the power to impose tax is not justiciable before the Court. However, as far as the exercise of the power of taxation so allocated, the Member States must exercise their direct taxation powers consistently with EU law. This means in particular, according to settled case law, that the Member States must avoid any discrimination on grounds of nationality according to Article 18 TFEU and not pose any restriction on the general right of Article 21 TFEU to move and reside freely between the Member States. ${ }^{610}$ The Member States must respect the principle of national treatment of nationals of other Member States and of their own nationals who exercise the freedoms guaranteed by the TFEU. The survey of the literature in Chapter 5 essentially suggests that balanced allocation of taxing powers seems to act as a rather absolute limit to this constraint. Thus, we will now attempt at establishing its meaning and context in the next Sections.

\subsection{A citation summary}

\subsubsection{Method}

The Court's Grand Chamber did not give meaning in Marks \& Spencer to the concept of a balanced allocation of taxing powers between the Member States. Since the Court did not cite any precedent in paras 45 and 46, the preliminary assumption is that Marks \& Spencer is a case of first impression on the balanced allocation of taxing powers as a point of law in a justification analysis. As a basis for the legal analysis of Section 6.4, we nevertheless need to define a preliminary meaning of the balanced allocation of taxing powers that is independent from the interpretations suggested in prior research.

609 The question whether a tax advantage is caused by a disparity or is harmful tax competition or constitutes state aid may be a tricky one: Szudocky and Van de Streek (2010).

${ }^{610}$ Rules 1:3 and 1:5 of Annex A. 
We will define the preliminary meaning of Marks \& Spencer, paras 45 and 46 , by a technique of citation summarisation, which is a method borrowed from recent work in computational linguistics. The method of citation summarisation is used to automatically generate summaries of research articles through computational analysis. The citation summary of a research article $(A)$ are the citing sentences of $A$, which is defined as the set of sentences of other research articles that contain explicit references to $A{ }^{611}$ The concept is further explained below.

The method advanced in Elkiss et al. (2008) and Qazvinian and Radev (2008) can be easily transposed from research articles citation networks to case law citation networks, given that both are information networks and citations in research articles serve very similar purposes as the citations found in case law. A restatement of a legal rule based on several rulings through a citation summary is likely to be more informative than the wording of that rule in a single case.

Citation summaries may prove an efficient method to quickly and accurately determine the Court's view on rules developed by its process of case based judicial decision making. It may be suggested that citation summaries are even better suited for case law networks than for research paper networks. Legal citations have a higher level of granularity then the citations of the research articles studies in prior research on citation summarisation. The Court usually refers to a particular paragraph or passage when it cites precedent. Citations in research papers normally only refer to the paper as such, but not to a specific page. By using the granular data contained in legal citations, different aspects of a ruling can easily be distinguished. Accordingly, cohesion between the citing sentences contained in case law which refer to the same part of the cited ruling is plausibly higher than for citations in research articles. Therefore, it is reasonable to assume that citation summaries of rulings are of high quality if the granular information of legal citations is used. This hypothesis will not be tested below, but it may provide an interesting avenue for future research on computational linguistics in the field of law. The current research conducts a single experiment of citation summarisation on Marks \& Spencer. The limited nature of a single experiment justifies not applying automation and rather performing the experiment by hand.

We define the citation summary of Marks \& Spencer, paras 45 and 46, as the citing paragraphs of Marks \& Spencer, paras 45 and 46. A citing paragraph is the particular paragraph of a Court's ruling that contains the citing sentence. We have identified the relevant citing paragraphs through Step one of the sample selection procedure explained above. We use citing paragraphs instead of citing sentences to control for non-explicit citing sentences (context sentences) which are about Marks \& Spencer, paras 45 and 46, but do not cite those paragraphs. Qazvinian and Radev suggested that a survey generated using context sentences along with citing sentences has higher quality than a survey built without such

611 Elkiss, et al. (2008); Qazvinian and Radev (2008). 
42. It must be acknowledged in that regard that there are courses of action which are capable of jeopardising the right of the Member States to exercise their taxing powers in relation to activities carried on in their territory and thus of undermining a balanced allocation of the power to impose taxes between the Member States (see Marks \& Spencer, paragraph 46) and which may justify a restriction on freedom of establishment (see Cadbury Schweppes and Cadbury Schweppes Overseas, paragraphs 55 and 56). The Court has thus held that the fact of giving companies the right to elect to have their losses taken into account in the Member State in which they are established or in another Member State would seriously undermine a balanced allocation of the power to impose taxes between the Member States, since the tax base would be increased in the first State, and reduced in the second, by the amount of the losses surrendered.

Figure 16. Example of a citing paragraph

context information. $^{612}$ The most informative context sentences are likely to be joined by the Court with the citing sentence in the same paragraph of the ruling.

Figure 16 gives an example of the citing paragraph of Marks \& Spencer, paras 45 and 46, in Rewe Zentralfinanz (C-347/04). The first sentence explicitly cites Marks \& Spencer and is the citing sentence. The second sentence is a context sentence, because it is joined with a citing sentence in the same paragraph, but does not explicitly cite Marks \& Spencer.

\subsubsection{Results}

The raw citation summary of Marks \& Spencer, paras 45 and 46, contained 16 citing paragraphs in 12 different rulings. We found a total of 24 individual sentences of which 16 were citing sentences and eight were context sentences. The citation summary of Figure 17 is a representative subset of the citing and context sentences of Marks \& Spencer, paras 45 and 46.

The summary shows four distinct, but closely related sentences. The inclusion threshold was set at two, which means that only sentences which were found twice or more times are represented by the citation summary. The number of occurrences of each representative sentence is given between brackets. A paragraph may include multiple sentences. Sentences are ordered by descending order of occurrence, but S1 is given first because of its general nature. We will see that this sequence is also logical.

How does this citation summary relate to Marks \& Spencer?

612 Qazvinian and Radev (2010). 
S1: The Court has acknowledged that the balanced allocation of the power to impose taxes between the Member States is a legitimate requirement. [5]

S2: Conduct which is capable of undermining the Member States' right to exercise their tax jurisdiction in relation to the activities carried out in their territory jeopardises a balanced allocation of the power to impose taxes between the Member States. [6]

S3: To give companies the right to elect to have their losses taken into account in the Member State in which they are established or in another Member State would seriously undermine a balanced allocation of the power to impose taxes between the Member States, since the tax base would be increased in the first State, and reduced in the second, by the amount of the losses surrendered. [4]

S4: The preservation of the allocation of the power to impose taxes between Member States may make it necessary to apply to the economic activities of companies established in one of those States only the tax rules of that State in respect of both profits and losses. [2]

Figure 17. Citation summary of Marks \& Spencer, paras $45 \& 46$

Comparing the text of the Marks \& Spencer ruling with the citation summary of Figure 17 shows that Marks \& Spencer, para 45, corresponds to S4 and Marks \& Spencer, para 46, corresponds to S3. Through a simple citation summary we have learned that the preservation of the balanced allocation of taxing powers is a legitimate public interest of Member States (S1) and that it refers to the Member States' right to exercise tax jurisdiction within their territory which may not be undermined (S2). Although S1 is implied in the outcome of Marks \& Spencer, S2 cannot be directly deduced from the ruling itself. Nonetheless, it is the most used sentence in the context of this justification ground and it seems to define the justification's central idea. It is best understood as an authentic ex post rationalisation of this justification ground; its ratio decidendi.

The discovery of S2 as an authentic restatement of the BAOTP standard relates to Marks \& Spencer as follows. It appears that S3 on loss transfers captures specific conduct which undermines the right referred to in S2. ${ }^{613}$ This type of conduct was at issue in Marks \& Spencer, but S2 is effect oriented and therefore does not exclude the possibility that other types of conduct may also jeopardise a balanced allocation. If the right referred to in S2 is undermined by like conduct, then S4 states how that right can be safeguarded.

The preservation of the BAOTP may be safeguarded by only applying the tax rules of the Member State in which territory the economic activities are carried out. This was achieved in Marks \& Spencer by not applying the tax rules of the United Kingdom to economic activities carried out in other Member States by

613 This follows explicitly from Cadbury Schweppes (C-196/04), para 56. 
the foreign subsidiaries of Marks \& Spencer. It is this preliminary interpretation which will be the basis of the legal analysis in the following section.

Further context of the BAOTP standard, which we found in citing paragraphs but did not include in Figure 14, is that the Court connects the BAOTP standard to Article 293 EC (repealed by the Lisbon Treaty) which obliges Member States to negotiate DTCs with each other to avoid double taxation of their nationals within the EU. ${ }^{614}$ Also, the Court gives context by recalling Rule 1:1(2) of Annex A on the freedom to organise the national tax system. ${ }^{615}$ This implied that 'in accordance with the principle of fiscal territoriality linked to a temporal component, namely the taxpayer's residence for tax purposes within national territory during the period in which the capital gains arise, a Member State is entitled to charge tax on those gains at the time when the taxpayer leaves the country'. ${ }^{616}$ It is therefore plausible that the BAOTP standard follows directly from the basic framework of the law and attaches to the distinction between the existence and exercise of taxing powers.

Furthermore, the Court has held that a reduction in tax revenue is not a justification, ${ }^{617}$ unlike the need to maintain a balanced allocation of the power to impose tax between the Member States. ${ }^{618}$ The two justifications thus identify different larger aims of government, while only BAOTP has been recognised as a valid overriding reason of public interest in EU law. This context was already given in Marks \& Spencer, para 44. Finally, the BAOTP standard applies also in relations with non-member States. ${ }^{619}$

As in related work in computational linguistics, the citation summary can also be compared with the abstract of the work that was summarised. The difference between an abstract and a citation summary is mainly that an abstract conveys an author's individual perspective of the central ideas of the work, whereas a citation summary is a collaborative and retrospective summary that shows what in fact are the main contributions of the cited work. ${ }^{620}$ Elkiss et al. showed that citation summaries overlap to some extent with abstracts, but also focus on different aspects of a research paper than the abstract. ${ }^{621}$

In the case of Marks \& Spencer, however, the summary prepared by the Research and Documentation Directorate of the CJEU-which may be considered the abstract of the judgment for this purpose-merely copies the operative part of the ruling and does not mention the balanced allocation of taxing powers at all, see Figure 18.

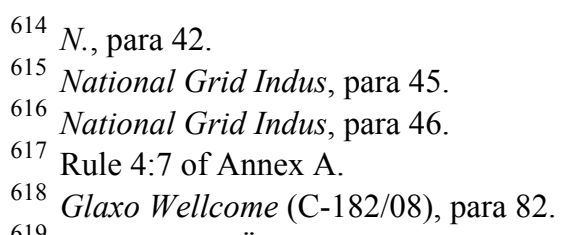


As Community law now stands, Articles 43 EC and 48 EC do not preclude provisions of a Member State which generally prevent a resident parent company from deducting from its taxable profits losses incurred in another Member State by a subsidiary established in that Member State although they allow it to deduct losses incurred by a resident subsidiary.

However, it is contrary to Articles $43 \mathrm{EC}$ and $48 \mathrm{EC}$ to prevent the resident parent company from doing so where the non-resident subsidiary has exhausted the possibilities available in its State of residence of having the losses taken into account for the accounting period concerned by the claim for relief and also for previous accounting periods and where there are no possibilities for those losses to be taken into account in its State of residence for future periods either by the subsidiary itself or by a third party, in particular where the subsidiary has been sold to that third party.

(see para. 59, operative part)

Figure 18. EUR-Lex summary of Marks \& Spencer

\subsection{Legal analysis}

\subsubsection{Two periods of legal evolution}

The Court's ruling in Marks \& Spencer is the original precedent or legal parent of the balanced allocation of taxing powers as a justification ground. It thus constituted the birth event of a legal idea that would later evolve into a dominating standard of EU law in the field of direct taxes. The legal evolution of the BAOTP standard can be divided into two stages or periods of evolution. First, there is first a period of emergence which marks the stabilisation of the concept to a robust standard. Secondly, this is followed by a period of reproduction in which the standard shows resistance and resilience to change. The standard became resistant to change because new cases did not impose great changes to its meaning. The standard also became resilient to change, because the standard's basic properties would not change if any of the subsequent cases would not have come to court. Deleting one or more of the rulings handed down in the period of emergence would however likely result in a significant loss of information. In short, the moment at which the period of emergence ends and the period of reproduction begins marks the point from which it was warranted to assert that the interpretation of the balanced allocation of taxing powers had become an acte clair.

The period of emergence in which the basic outlines of the standard were established lasts until $O y A A(\mathrm{C}-231 / 05)$ inclusive, i.e. it covers the year 2006 and the first half of 2007 . That period is a rather informally defined and it is certainly open to interpretation. Notwithstanding, $O y A A$ is a plausible cut-off point because it is the first ruling which acknowledges that $A C T$ Group 
Litigation (C-374/04) constituted a second birth event of the balanced allocation of taxing powers. The balanced allocation of taxing powers emerged again in ACT Group Litigation, but the Court did not refer to any of the previous cases in which it was already applied. A second 'original' precedent or legal parent with the same legal information content was consequently created. This justifies naming the subsequent stage in evolution a period of reproduction. All cases that followed $O y A A$ reproduced the balanced allocation of taxing powers standard by repeated application, but no major innovations took place in that period.

\subsubsection{Emergence}

The need to maintain a balanced allocation justified in Marks \& Spencer that to the economic activities of companies established in a Member State only the tax rules of that State in respect of both profits and losses applied (para 45). In Marks \& Spencer the balanced allocation of taxing powers excused the United Kingdom from 'unconditionally extending' (para 41) its group relief rules to foreign subsidiaries, because otherwise Marks \& Spencer could opt for the Member State in which its losses would be taken into account. In the Court's view, such an option creates an opportunity to transfer losses from the subsidiaries' Member States' tax bases and in turn deduct them from the UK tax basis (para 46). This loss trafficking jeopardises a balanced allocation of taxing powers between the Member States (para 46). As a result, the need to maintain a balanced allocation of taxing powers between the Member States made it necessary that, in principle, only the subsidiaries' Member States' tax rules applied to the losses incurred by those subsidiaries to the exclusion of the UK restrictive group relief rules, according to the ruling. The Court thus accepted the UK government's argument that 'in tax matters profits and losses are two sides of the same coin and must be treated symmetrically in the same tax system' (para 43), but from the perspective of the Member States in which the subsidiaries were established. Obviously, the UK government meant that argument to apply to the UK, not the Member States of the subsidiaries. One may conclude that the Court evidently disagreed.

In that context, we observe that the national measure at issue in Marks \& Spencer was asymmetrical from the outset; it allowed subsidiaries to surrender losses to their parent company, but not profits. How the safeguarding of symmetry between taxing profits and losses would then be, from the UK perspective, a material argument to deny the surrender of losses by foreign subsidiaries to their UK parent seems difficult to comprehend. ${ }^{622}$

It can be conceded, however, that the grant of loss relief in relation to foreign subsidiaries would endanger the right of the UK to charge tax on income earned by the parent companies resident on its territory. A relief of losses is a final reduction of the tax claim on the parent company. By allowing loss relief, the

See, Section 6.5 .4 on the relevance of the aim of national legislation for finding a restriction on freedom of movement. 
UK would in fact finally surrender its right to tax income earned by the parent company. We will withhold an opinion about the correctness of the Court's view in regard of loss trafficking on this place. That discussion is reserved for Chapter 9 in which we will elaborate on this thought.

The aim here is to understand the reasoning of the Court. That analysis would be distorted if it would start from different assumptions than those accepted by the Court. We should interpret the meaning of EU law concepts on the basis of the facts established by the Court, even if those facts are inaccurate or incomplete. The Court assumed in Marks \& Spencer that a loss surrendered by a subsidiary of another Member State could, in principle, no longer be taken into account for tax purposes in that Member State, in the same way as UK subsidiaries could no longer enjoy relief for losses that they had surrendered to their UK parent company. That factual basis guided the Court's interpretation of Marks \& Spencer as set out in the previous paragraphs.

The next case that was decided by the Court is $N$. (C-470/04) and concerned national legislation that imposed a charge to tax upon the transfer of residence of a resident individual to another Member State (exit tax) and it was levied on accrued but not realised capital gains on closely held shares. ${ }^{623}$ The Court cited Marks \& Spencer in $N$. as precedent in relation to the balanced allocation of taxing powers for the first time.

The Court held in $N$. that the BAOTP justification ground was a valid defence (para 42), even if it was not taken together with the risk of tax avoidance and/or the risk that losses would be used twice. That validation was supported in paras $43-45$ by citations to other precedents which all confirmed the exclusive competence of Member States to determine the factors of allocation of taxing powers in the absence of harmonisation. In this context, the Court continued:

46. Thus, gains realised on the disposal of assets are taxed, in accordance with Article 13(5) of the OECD Model Tax Convention on Income and on Capital, and in particular in accordance with its 2005 version, in the contracting State of which the person making the disposal is a resident. As the Advocate General has observed in paragraphs 96 and 97 of her Opinion, it is in accordance with that principle of fiscal territoriality, connected with a temporal component, namely residence within the territory during the period in which the taxable profit arises, that the national provisions in question provide for the charging of tax on increases in value recorded in the Netherlands, the amount of which has been determined at the time the taxpayer

${ }^{623}$ Technically, realisation was assumed by fiction to have occurred on the moment immediately prior to the transfer of residence. This was to recognise the accrued capital gain as taxable income that fell within the scope of tax liability of the migrant taxpayer in the Netherlands. Payment of tax was however deferred until the gain was realised in fact. 
concerned emigrated and payment of which has been suspended until the actual disposal of the securities.

47. It follows, first, that the measure at issue in the main proceedings pursues an objective in the public interest, and, secondly, that it is appropriate for ensuring the attainment of that objective.

In the passage quoted here the Court's Second Chamber connects the principle of territoriality to the balanced allocation of tax powers. However, the Court does not cite any precedent to support that relation, but refers to the opinion of the Advocate General in $N$., points 96 and 97. In that context, the AG's opinion, point 92, in turn cites Marks \& Spencer, para 39 and Futura (C-250/95), para 22, in addition to a citation to Marks \& Spencer, para 45. Considering that the Court subsumed the AG's conclusions in points 96 and 97 drawn on the basis of the principles laid down in para 92 of the opinion, the Court implicitly confirmed, in para 46 of the judgment, the relation between the balanced allocation of taxing powers and the fiscal principle of territoriality as used in Futura.

It should be observed that the Court in Marks \& Spencer, para 39 indeed cited Futura, but also held in para 40 that 'the fact that [the UK] does not tax the profits of the non-resident subsidiaries of a parent company established on its territory does not in itself justify restricting group relief to losses incurred by resident companies'. The Court then went on to the balanced allocation of taxing powers justifications. We will see that the Court held in subsequent case law that the balanced allocation of taxing powers does not justify a Member State to systematically deny tax benefits to cross-border economic activities by reason that this Member State cannot exercise its taxing powers in another Member State to or from which the right of free movement was exercised.

Furthermore, we observe on a tangent that the Court's approach in Marks \& Spencer has been clarified in Busley and Cibrian Fernandez (C-35/08). This case did not show in the results of our analysis, but we mention it for its holding in para 30 in which the Court explained its ruling in Futura in relation to foreign losses that the resident taxpayer in Rewe Zentralfinanz claimed:
30. However, that principle [of territoriality], the purpose of which is to es- tablish, in the application of [Union] law, the need to take into account the limits on the Member States' powers of taxation, does not preclude the tak- ing into account by a person liable to unlimited taxation in a Member State of negative income from an immovable property situated in another State (see, by way of analogy, Rewe Zentralfinanz, paragraph 69). Consequently, that provision - by virtue of which the applicants in the main proceedings, who are liable to unlimited taxation in Germany, are unable to take into ac- count losses from their house in Spain - cannot be considered as an imple- mentation of the principle of territoriality.

We believe that this holding of Busley and Cibrian Fernandez is important, because of its citation to Rewe Zentralfinanz (C-347/04), a ruling which we will discuss in more detail below. The cited paragraph of Rewe Zentralfinanz connects - as the only case in the body of case law decided through 2011 - to the 
passage of Marks \& Spencer, paras 39 and 40 and explains the territoriality principle of Futura:

69. It is true that, in accordance with that principle [of territoriality], the Member State in which a parent company is established may tax resident companies on the whole of their worldwide profits but may tax non-resident subsidiaries solely on the profits from their activities in that State (see, to that effect, Marks \& Spencer, paragraph 39). However, such a principle does not in itself justify the Member State of residence of the parent company refusing to grant an advantage to that company on the ground that it does not tax the profits of its non-resident subsidiaries (see, to that effect, Marks \& Spencer, paragraph 40). As the Advocate General stated at point 49 of his Opinion, the purpose of that principle is to establish, in the application of [Union] law, the need to take into account the limits on the Member States' powers of taxation. As regards the main proceedings, were the advantage claimed by Rewe to be granted, that would not result in a competing tax jurisdiction becoming involved. It concerns German-resident parent companies which are subject, in that respect, to unlimited liability to tax in that State. Accordingly, the legislation at issue in the main proceedings cannot be considered as an implementation of the principle of territoriality.

The principle of territoriality as established in Futura should thus be interpreted narrowly as the distinction between universal fiscal jurisdiction on resident taxpayers and source jurisdiction of non-resident taxpayers. If we recall the claim for relief of foreign losses that the non-resident taxpayer made in Futura, then it becomes clear that a competing jurisdiction would only become 'involved' in terms of Rewe Zentralfinanz when a Member State concerned would be forced to consider the foreign income of non-resident taxpayers. ${ }^{624}$

The Court ruled in Futura that it is not discrimination if a Member State does not consider the foreign losses of a non-resident taxpayer. ${ }^{625}$ However, when the claim is made by a resident taxpayer, as in Marks \& Spencer, Rewe Zentralfinanz, and Busley and Cibrian Fernandez, the universality principle of taxation that applies here does not justify at the outset that foreign losses are ignored. The denial of a claim of loss relief needs special justification in this case. That is what the Court evidently meant to say in Marks \& Spencer, paras 39 and 40, if we understand the subsequent case law of Busley and Cibrian Fernandez and Rewe Zentralfinanz correctly. This special justification is the BAOTP standard. Yet, we are still unclear about its content and conditions. For this, we need to continue with our qualitative analysis of the case law.

The Dutch exit tax rules at issue in $N$. allocated tax powers to the Netherlands on the basis of residence of the taxpayer within the territory of the Netherlands and taxed the capital gain that had accrued within the period of

${ }^{624}$ See, Opinion of AG Poiares Maduro in Marks \& Spencer, points 58-64 and also his 625

Opinion in Rewe Zentralfinanz, point 49.

Rule 1:4(2) of Annex A. 
residency. Our analysis showed that the Court only referred to territoriality in $N$. in the context of confirming the Netherlands' taxing rights on the accrued capital gains of $\mathrm{Mr} \mathrm{N}$. The Court did not equate territoriality with a balanced allocation of taxing powers between the Member States. Rather, by recognising accrued capital gains as taxable income and assessing the tax upon transfer of residence, the Netherlands preserved the right to tax income earned on Dutch territory which fell within its fiscal jurisdiction on the basis of the principle of territoriality as understood in public international law. The allocation of taxing powers was consistent with Futura and there was also no manifest conflict with customary (i.e. OECD) international tax practice (N., paras 45 and 46 ). In those circumstances, the Court was right to hold the taxing power of the Netherlands legitimate, absent instructions from the national court to the contrary. As can be clearly derived from the facts in $N$., as reported in the Court's judgment, the Netherlands would not have been able to tax the accrued income of the taxpayer earned without the contested rule. The Court apparently held the rule for this reason justified by force of the BAOTP standard.

The Court thus found that the Netherlands' power to tax income on the basis of a connecting factor based on a personal and temporal connection to the Dutch territory was legitimate and, since 'preserving the allocation of the power to tax between the Member States' was a legitimate overriding reason of public interest ( $N$., para 42), the restriction at issue was found justified. Considering the exact same wording in Marks \& Spencer, para 45, ${ }^{626}$ the semantic difference with 'balanced allocation of the power to impose taxes between Member States' in Marks \& Spencer, par. 46 should be considered immaterial. ${ }^{627}$ The word 'balanced' is best interpreted to indicate that the power to impose tax might be 'jeopardised' or not preserved, if the justification would not be allowed.

On the basis of the first subsequent application and interpretation in $N$. the following working hypothesis can be posed: a national rule can be theoretically justified by the balanced allocation of taxing powers if the rule is necessary to protect a Member State's legitimate right to tax income earned in that Member State's territory. A right to tax may be considered legitimate if a competing fiscal jurisdiction is not involved as per Futura. This interpretation of the balanced allocation of taxing powers is indeed confirmed in subsequent case law, though these cases do not cite the Court's judgment in $N$., save National Grid Indus.

Five days after the Court's Second Chamber rendered its judgment in $N$. , the Grand Chamber decided Cadbury Schweppes (C-196/04). This case was about the UK's CFC legislation and required resident parent companies of the UK to include the income of low-taxed foreign subsidiaries in their basis of assessment. The Court interpreted the freedom of establishment in Cadbury

${ }^{626}$ Both judgments read in French: 'la préservation de la répartition du pouvoir d'imposition entre les États members' in point.

${ }^{627}$ In French: une répartition équilibrée du pouvoir d'imposition entre les États members. 
Schweppes to allow Member States to prevent 'abusive practices...conduct involving the creation of wholly artificial arrangements which do not reflect economic reality, with a view to escaping the tax normally due on the profits generated by activities carried out on national territory' (para 55), but could not decide conclusively whether the UK's legislation was focused solely on these abusive practices. The relevant point in the context of this Chapter is that those abusive practices were in para 56 of the judgment in Cadbury Schweppes equated with the particular loss transfers that also entailed a risk of tax avoidance if allowed in Marks \& Spencer (citing Marks \& Spencer, para 49). The Court argued in para 56 that both practices would give room to 'conduct ... such as to undermine the right of the Member States to exercise their tax jurisdiction in relation to the activities carried out in their territory and thus to jeopardise a balanced allocation between Member States of the power to impose taxes' (citing Marks \& Spencer, para 46).

It is evident that the Grand Chamber considered a balanced allocation of taxing powers jeopardised in Cadbury Schweppes if holding the national restriction not justified would undermine a Member State's right to exercise their tax jurisdiction in relation to the activities carried out in their territory, and consequently, companies would escape tax normally due on the profits generated by these activities by abusive practices. This approach is consistent with $N$. and recognises a protected competence to impose tax in EU law.

We will not venture into a discussion about the similarities and differences in application of this anti-avoidance rule to the specific situations in Marks \& Spencer and Cadbury Schweppes at this point. For the same reason, a discussion on the same point made in Thin Cap Group Litigation, para 75 is reserved for later. Also in that case the Court discussed aspects of balanced allocation of taxing powers in a clear context of tax avoidance. We will carry out this analysis of the relation between the prevention of tax avoidance and the balanced allocation of taxing powers in Chapter $7 .^{628}$ The remainder of this Section is concerned with the legal evolution of the concept as such, outside the context of other justification grounds recognised in prior research.

Rewe Zentralfinanz (C-347/04) explicitly defined the scope of the balanced allocation of taxing powers as justification (para 41). The main proceedings concerned a claim of a resident parent company of Germany for a relief of losses stemming from partial write-downs of the book value of its shareholdings in subsidiaries of other Member States. Whereas such a loss relief is in principle allowed as a deduction of operating expenses from taxable income as regards domestic subsidiaries, the national legislation allowed deduction in cross-border relations under strict conditions, which did not apply in internal situations, and which restricted the claim in the case of Rewe Zentralfinanz.

Rewe Zentralfinanz can be seen as a first attempt of the Court to consolidate the different aspects of the principle of balanced allocation of taxing powers brought up in previous cases. The analysis in Rewe Zentralfinanz, para 42

${ }^{628}$ Section 7.4. 
started with the scope and ratio as could be derived from precedent and corresponds to the working hypothesis just defined; the BAOTP standard protects the power to impose tax in relation to activities carried on in the national territory of the Member State concerned. The Court's Second Chamber cited Marks \& Spencer, para 46 and Cadbury Schweppes, paras 55 and 56. Again, the Court clarified that allowing the request for the particular loss transfer practices in Marks \& Spencer would 'seriously' undermine a balanced allocation.

The Court further promoted in Rewe Zentralfinanz that the balanced allocation of taxing powers 'cannot in itself justify a Member State systematically refusing to grant a tax advantage to a resident parent company, on the ground that that company has developed a cross-border economic activity which does not have the immediate result of generating tax revenues for that State' (para 43). The Court did not cite precedent in this context. What may be deduced from this reasoning is that the balanced allocation of taxing powers cannot be used as an excuse for the inability to assert fiscal jurisdiction on extraterritorial economic activities, including those carried on by a subsidiary that is established in the territory of another Member State. This is consistent with the Court's statement in Marks \& Spencer, para 40 that 'the fact that [the UK] does not tax the profits of the non-resident subsidiaries of a parent company established on its territory does not in itself justify restricting group relief to losses incurred by resident companies.'

The resulting scope of the balanced allocation of taxing powers as it derives from Marks \& Spencer, N., Cadbury Schweppes and Rewe Zentralfinanz thus appears to be limited to the ability to exercise internal tax jurisdiction with respect to income generated by activities undertaken within the national territory of the Member State. It is this scope of the Member States' taxing power that EU law principally - but as will be explored below, not unconditionallyprotects.

The clarifications of the Second Chamber in Rewe Zentralfinanz were in turn validated by the Court's Grand Chamber judgment in $O y A A$ (C-231/05), paras 53-55. The Finnish national legislation in $O y A A$ allowed for a transfer of profits between group companies, but the subsidiary of Finland in this case was precluded from transferring its profits to its parent company in the UK. The claim was denied in accordance with the condition in national legislation that stipulated that the transferee company should be established in Finland. The Court found this condition to be a restriction of freedom of establishment because it imposed a different treatment on the basis of the parent company's seat. $^{629}$

As the Second Chamber did in $N$., the Grand Chamber in $O y A A$ directly connected the balanced allocation of taxing powers with the Member States' exclusive competence 'to define, by treaty or unilaterally, the criteria for

Rule 2:1(7) and (8) of Annex A on freedom of establishment. See, Sections 6.5.2 and 6.5.4. 
allocating their powers of taxation' (para 52). Certainly, the statement of para 52 was not a decisive argument in the judgment, since the Court introduced this principle with '[i]t should also be remembered that...' Nonetheless, it may be taken as implicit validation of $N$. The Court might have excluded a citation to $N$. because the Second Chamber in $N$. also included the principle of territoriality in the same context. Such a relation was however not ruled out in $O y A A$, because the Court did not explicitly reject that relation put forward by the observations made by the Finnish Government, supported by the Swedish and United Kingdom Governments (see para 47), when it discussed the competence of the Member States in para 52. But the Court also did not confirm it explicitly.

It might be relevant in this context that the territoriality principle was put forward in $O y A A$ as an autonomous justification ground, and the argument was in this regard not similar to the argument put forward by the national court in $N$. The application of territoriality in $N$. was only intended to legitimise the tax claim on capital gains. That legitimate tax claim was the reason for the Court to accept the balanced allocation of taxing powers as a justification. The Court decided to leave the issue of territoriality unanswered in $O y A A$ for reasons of procedural economy (para 66), since an autonomous interpretation of the balanced allocation of taxing powers sufficed to dispose of the case. That interpretation is nonetheless consistent with $N$.

The Court affirmed the above defined scope of the balanced allocation of taxing powers in $O y A A$, para 56. It stated that allowing full national treatment in $O y A A$ would jeopardise the balanced allocation of taxing powers of Finland, because, '.. according to the choice made by the group of companies, [Finland as] the Member State of the subsidiary would be forced to renounce its right, in its capacity as the State of residence of that subsidiary, to tax the profits of that subsidiary in favour, possibly, of the Member State in which the parent company has its establishment'. In short, the unconditional application of the principle of national treatment would affect that Finland would be obliged to waive its competence to tax income earned by activities undertaken in its territory. Or, the ability to exercise internal tax jurisdiction would be put at the mercy of the taxpayer. This latter contingency is understandably not a desirable dynamic in any tax system governed by the rule of law. The Court cited its Grand Chamber judgment in ACT Group Litigation, para 59 to indicate that it provided interpretative guidance to that effect. ${ }^{630}$ Indeed, in ACT Group Litigation the Court held in para 59:

... that to require the Member State in which the company making the distribution is resident to ensure that profits distributed to a non-resident shareholder are not liable to a series of charges to tax or to economic double taxation, either by exempting those profits from tax at the level of the company making the distribution or by granting the shareholder a tax advantage equal to the tax paid on those profits by the company making the distribu- 
tion, would mean in point of fact that that State would be obliged to abandon its right to tax a profit generated through an economic activity undertaken on its territory.

On the one hand, the Finnish legislation at issue in $O y A A$ did not concern national rules for the avoidance of economic double taxation of multiple entities in different Member States like those at issue in ACT Group Litigation. The legislation in $O y A A$ rather built on the assumption that those entities constituted an economic group that should be treated as one for tax purposes ( $O y A A$, para 22). On the other hand, the effect of unconditionally extending the scope of the tax advantage at issue in $O y A A$ to include non-resident group companies would indeed have the same effect as unconditionally extending the scope of the allegedly restrictive provisions at issue in ACT Group Litigation. A legitimate tax claim would be lost-i.e. rendered unlawful, thus not enforceable and therefore unrecoverable - in both cases if the Court had decided otherwise. Consequently, it seems particularly relevant that the Court's recourse to a precedent that did not cite Marks \& Spencer in point, explicitly confirmed that the interpretation in $A C T$ Group Litigation and $O y A A$ was guided by the same standard. That underlying standard or ratio decidendi in both cases was clearly the recognition of a legitimate right in EU law of Member States to tax income generated by economic activities undertaken in their territory.

The Court's judgment in ACT Group Litigation did not refer to this principle as 'the balanced allocation of taxing powers'. It did not even label the argument, though the ruling in ACT Group Litigation was handed down after the judgments in Marks \& Spencer, N., and Cadbury Schweppes, but prior to Rewe Zentralfinanz. One reason could be that the Court applied the standard at the level of comparability in the analytical prior question if the UK legislation in issue in ACT Group Litigation constituted a restriction of the freedom of establishment, whereas the standard was applied in $O y A A$ to answer the justification question.

In $O y A A$, the Court explicitly considered the inability to exercise extraterritorial tax jurisdiction not a material factor to hold the situations of resident and non-resident companies incomparable, bearing in mind the general aim of the system concerned (paras 35-38). But the general aim of the financial transfer legislation at issue in $O y A A$ (group treatment) was different from the main purpose of the tax credit rules at issue in ACT Group Litigation (avoidance of economic double taxation). This difference in aims may also account for the different routes of analysis, even though the standard that guided the interpretation is the same. ${ }^{63}$

While the Court cited ACT Group Litigation, para 59 in subsequent case law, these citations were mostly made in a general context of comparability conditions and did not specifically concern the Member States' right to tax

${ }^{631}$ We will revisit this point in Section 6.5.2. 
income generated by economic activities undertaken in their territory. ${ }^{632}$ Thus, this line of authority does not appear to have contributed to the legal development of the BAOTP standard.

In contrast, the Court applied the precedent of ACT Group Litigation in the context of the balanced allocation of taxing powers as a justification ground in Glaxo Wellcome, para 83 and National Grid Indus, para 46 which we will review in the next Section. It can already be concluded, however, that Glaxo Wellcome and National Grid Indus explicitly affirm through their citation links that $O y A A$ and ACT Group Litigation were decided on the basis of the same standard, usually referred to by the Court as the balanced allocation of the power to impose tax between the Member States, which is ordinarily applied as a justification ground.

\subsubsection{Reproduction}

Following the judgment in $O y A A$, the balanced allocation of taxing powers has been applied and developed in the following subsequent rulings that are, in order of date of decision: Amurta (C-379/05), Lidl Belgium (C-414/06), Papillon (C418/07), Jobra (C-330/07), Aberdeen Property Fininvest Alpha (C-303/07), Glaxo Welcome (C-182/08), SGI (C-311/08); X Holding (C-337/08); Tankreederei I (C-287/10); Haribo and Österreichische Salinen (Joined Cases C-436 \& C-437/08); Commission v Germany (C-284/09), and National Grid Indus (C371/10). These cases are reproductions of a relatively robust BAOTP standard which had emerged from the set of important rulings which we read in Section 6.4.2. As is the case for reproductions of natural creatures, the general properties which are distinctive of the species do no change very much with each generation. The gradual variations we will discover below are rather small variations and adaptations that are favourable in helping the species survive in changing conditions.

In Amurta, the Court clarified the scope of the BAOTP standard. The case was about the taxation of outbound dividends and concerned Dutch national legislation which exempted, in certain cases, the distribution of profits to companies established in national territory, but charged a dividend withholding tax on dividends distributed to companies with a corporate seat in another Member State. The Court's judgment applies Rules 3:1 and 3:3 of Annex A (taxation of outbound dividends) to hold this different treatment contrary to free movement of capital.

In its grounds of judgment in relation to a justification for the restriction posed by the Dutch legislation, the Court first reiterated the basic standard that the balanced allocation may be justified, in particular, 'where the system in question is designed to prevent conduct capable of jeopardising the right of the Member States to exercise their taxing powers in relation to activities carried on

632 See, Denkavit Internationaal and Denkavit France (C-170/05), para 34; Thin Cap Group Litigation (C-524/04), para 89; and Amurta (C-379/05), para 37. 
in their territory' (para 58), citing Rewe Zentralfinanz, para 42, and $O y A A$, para 54.

Secondly, Amurta added a further refinement to the balanced allocation of taxing powers. As the Court's Second Chamber did in Rewe Zentralfinanz, the First Chamber in Amurta distinguished that case from precedent and narrowed the scope of the balanced allocation of taxing power to reject its application in situations:

59. [...] where a Member State has chosen not to tax recipient companies established in its territory in respect of this type of income, ... [and relies] on the argument that there is a need to safeguard the balanced allocation between the Member States of the power to tax in order to justify the taxation of recipient companies established in another Member State (para 59).

Accordingly, the Member State that seeks to rely on the balanced allocation of taxing powers bears the burden of proof that its rules are genuinely aimed at preserving the power to tax income generated by activities undertaken in its territory in a systematic and consistent manner, i.e. irrespective of the fact whether these activities are performed by citizens or companies that are resident in its territory, or by non-resident taxpayers.

In Amurta, the Dutch national provisions at issue did not seek to impose economic double taxation of dividends in a consistent and systematic manner. It would have been necessary for that requirement to be fulfilled for the Netherlands to be allowed to charge a withholding tax on dividends distributed by resident companies to a specific group of non-resident companies. On the contrary, the genuine aim of the Dutch law was not to generally impose, but to generally avoid economic double taxation for that specific group of recipients of dividends distributed by Dutch resident companies (nationally-sourced dividends). Those provisions failed to be designed consistently so that nonresident recipients of nationally-sourced dividends would also enjoy the tax advantages awarded to resident recipients of similar domestic dividends. As a result, the argument based on the balanced allocation of taxing powers submitted by the UK government in its observations was rejected.

The Fourth Chamber's judgment in Lidl Belgium is the first case following Marks \& Spencer to deal directly with the issue of foreign loss relief again. In Lidl Belgium a company established in Germany claimed relief for losses incurred by its permanent establishment in Luxembourg. This claim was denied, since Germany applied a full exemption to income that was attributable to foreign permanent establishments according to the applicable DTC. The Court followed its judgment in Marks \& Spencer by analogy and held that the different treatment of domestic and foreign branches was a restriction on freedom of establishment.

After reproducing Marks \& Spencer, paras 45 and 46 verbatim, accompanied with citations to $O y$ AA, paras 55-56 in paras 31-32 of Lidl Belgium, the Court reasons with respect to the BAOTP standard as justification that: 
33. [...] in the light of the facts in the main proceedings, it should be pointed out that the Member State in which the registered office of the company to which the permanent establishment belongs is situated would, in the absence of a double taxation convention, have the right to tax the profits generated by such an entity. Consequently, the objective of preserving the allocation of the power to impose taxes between the two Member States concerned, which is reflected in the provisions of the Convention, is capable of justifying the tax regime at issue in the main proceedings, since it safeguards symmetry between the right to tax profits and the right to deduct losses.

34. In circumstances such as those of the main proceedings, to accept that the losses of a non-resident permanent establishment might be deducted from the taxable income of the principal company would result in allowing that company to choose freely the Member State in which those losses could be deducted (see, to that effect, $O y A A$, paragraph 56).

From paragraph 33 follows clearly that the Court believes that the DTC between Germany and Luxembourg safeguards symmetry between the right to tax profits and losses. It is this result that, according to the Court, achieves a balanced allocation of taxing powers. Considering the introductory phrase of paragraph 33 , it is plausible that the Court would not have accepted this justification for a denial of loss relief in the absence of the DTC. In that alternative case, Germany would have had the right to tax the permanent establishment profits and it would appear, a fortiori, similarly symmetrical to allow a relief of the permanent establishment losses.

The Court's analysis in paras 33 and 34 is however clarified in para 52. In Lidl Belgium, para 52 the Court again cites $O y A A$, para 55 and sheds further light on its position on the balanced allocation of taxing powers:

52. It must be added that the Court has recognised the legitimate interest which the Member States have in preventing conduct which is liable to undermine the right to exercise the powers of taxation which are vested in them. In this connection, where a double taxation convention has given the Member State in which the permanent establishment is situated the power to tax the profits of that establishment, to give the principal company the right to elect to have the losses of that permanent establishment taken into account in the Member State in which it has its seat or in another Member State would seriously undermine a balanced allocation of the power to impose taxes between the Member States concerned (see, to that effect, $O y A A$, paragraph 55).

The Court takes the view that the DTC has given Luxembourg the right to tax the profits of that establishment, and a contrario has taken this right away from Germany, moreover when para 52 is read together with para 33. This reading is in turn supported by para 28 in which the Court notes the submission by the referring Bundesfinanzhof that income earned by a permanent establishment is not taxed in Germany in accordance with the provisions of the DTC. Now that Luxembourg may subject those profits to its tax rules, the legal framework required 
that the losses of the permanent establishment must also in principle be subjected to Luxembourg's rules only (para 32). This appears to constitute the necessary element of symmetry to which the Court refers in para 33 of the ruling.

According to the Court, Germany is excused from providing relief, since otherwise the balanced allocation of taxing rights might be jeopardised and those losses might 'leak' away from Luxembourg to Germany depending on the taxpayer's preference (para 32). Since Germany may not recoup any losses by taxing future profits of the foreign establishment, a relief of losses would constitute a final reduction of the tax claim on income earned by activities in German territory. This result is similar to Marks \& Spencer.

The Fourth Chamber in Papillon, paras 35-40, dismissed the balanced allocation of taxing powers as justification by reason that the preliminary question only concerned the issue whether the consolidation of losses and profits recorded by residents of the same Member State should be allowed. Papillon was about the French system of tax consolidation of group companies. The taxpayer, a resident company of France, requested to form a tax consolidated group with its subsubsidiary, which was also established in France. That request was denied because this French subsubsidiary was held through a subsidiary that was established in another Member State. The Court reasoned that this difference on the basis of the corporate seat of the intermediary subsidiary constituted a restriction on freedom of establishment in line with Rule 2:1(7) and (10) of Annex A.

The question in Papillon differed from Marks \& Spencer and Lidl Belgium in that it was not at issue whether France was obliged or not to take income of foreign establishments into account. There was simply no risk that group profits earned in France would escape the taxing competence of France-whether to the benefit of another Member State, or not-if the group taxation regime would be extended to French subsubsidiaries owned by subsidiaries resident in other Member States. Evidently, the Court excluded for that reason a prima facie risk of tax avoidance (para 40). This will be further explored below in Chapter 7 on tax avoidance.

The Third Chamber's grounds in Jobra fit perfectly with precedent. We have discussed this case already in Section 4.3.5.7.4 on the line of authority that concerned national legislation which reserved tax benefits for economic activities that were carried out in national territory of the Member State concerned. With regard to the BAOTP standard as a justification, the Court cited Marks \& Spencer, para 46 and Rewe Zentralfinanz, para 42. According to the Court, it sufficed:

33. [...] to note that, in the present case, the rental income generated by hiring out the tangible assets for which Jubra [sic] claims the investment premium is taxable in Austria. Therefore, it cannot be claimed that, without the legislation at issue in the main proceedings, the right of the Republic of Austria to exercise its taxing powers in relation to activities carried on in its territory would be jeopardised. 
The quoted paragraph in fact concerns the necessity criterion of the rule of reason, see further Chapter 8. If a restrictive national provision is not necessary to safeguard the Member State's power to exercise taxing power in relation to activities carried on in its territory, the BAOTP justification fails. This implies, in terms of proportionality, that the Member State has the burden of proof to show that there are no other national measures already in force which would equally protect the taxing power as the restrictive measure under review before the Court. If it fails to deliver this proof, the Member State's balanced allocation of taxing powers defence also fails.

The First Chamber's judgment in Aberdeen Property Fininvest Alpha added another refinement to the scope of the BAOTP standard. This case was an application of Rules 3:1 and 3:3 of Annex $A$ on outbound dividends under Finnish law in relation to distributions to an open-ended investment company governed by Luxembourg law (société d'investissement à capital variable, SICAV). It specifically concerned the comparability of foreign and national investment companies, which is a contentious issue in corporation tax policy. ${ }^{633}$

After confirming in paras 66 and 67 the Member State's right to protect its internal tax competence, if designed consistently, the Court elaborated on that latter precondition in paras $68-70$ :

68. In this respect, the fact that the Tax Convention reserves to the Republic of Finland the right to exercise its tax jurisdiction over dividends paid by companies resident in Finland to recipients resident in Luxembourg is of no relevance.

69. A Member State cannot rely on a double taxation convention in order to avoid its obligations imposed under the Treaty (see Denkavit Internationaal and Denkavit France, paragraph 53, and Amurta, paragraph 55).

70. Moreover, in so far as dividends distributed by resident companies are taxed in the hands of the distributing companies as profits realised, the exemption from withholding tax on those dividends does not deprive the Republic of Finland of all right to tax the income relating to activities carried out on its territory.

The clarification in para 69 and the cases it cites can be traced back through link analysis to their original source in Commission v France (Avoir Fiscal) (270/83). This line of authority stipulates that the legality of a national provision under the laws of double tax conventions cannot be allowed as persuasive argument to adjudge an alleged failure to comply with EU law by a Member State.

The French government argued part of its defence in Avoir Fiscal by submitting that unilateral extension of the shareholders' tax credit on received dividends from resident companies (the avoir fiscal) to French branches of non-

633 See, the Court's 2012 judgments in FIM Santander and Others (Joined Cases C-338347/11) on undertakings for collective investments in transferable securities (UCITS) and in Commission v Belgium (C-387/11). 
resident companies would disturb the balance of the DTCs that France had concluded. Unilateral extension by force of EU law was regarded an inappropriate means to achieve non-discrimination, and the French government argued that DTCs could however give a balanced solution, given that they shared this same objective. Those DTCs also established the principle of nondiscrimination, but, admittedly, no DTC dealt with the extension of the 'avoir fiscal' to branches in France of non-resident companies. The DTCs thus allowed the discrimination at issue. The Court dismissed this submission and held the French government in breach of its obligations under EU law. The respect for these obligations was unconditional and could not be made subject to the contents of DTCs, according to the Court's judgment (para 26).

It is consequently irrelevant in the Court's view that a DTC awards a Member State power to tax certain income. The French government in Denkavit Internationaal and Denkavit France similarly argued that the economic double taxation imposed by French law - which was found to breach EU law-had to be relieved by the Member State in which the recipient of the dividend resided, since this was the system envisaged by international tax law in general and the double tax convention with the Netherlands in the case at hand (para 52). Denkavit Internationaal and Denkavit France also concerned Rule 3:3 of Annex A.

The Court however held that France could not rely on a DTC to avoid its EU law obligations (para 53), and in any case, the combined application of that convention and French tax law did not neutralise the restriction at issue (para 54). ${ }^{634}$ Also in Amurta, para 55 this same argument was used to reject the UK government's position that a balanced allocation of taxing powers would be jeopardised because the Netherlands could no longer charge dividend tax on dividends distributed to non-resident recipients if EU law opposed the disadvantage imposed by the Dutch national provisions, although the DTC with the UK allowed the Netherlands to withhold dividend taxes at source.

The mirror image of Avoir Fiscal, Denkavit Internationaal and Denkavit France, Amurta and Aberdeen Property Fininvest Alpha was presented in Damseaux. This last case concerned the question whether Belgium failed to comply with EU law by allowing juridical double taxation on received dividends to persist under the DTC with France.

In this case, the Court held that, even though Member States cannot rely on a double taxation convention to avoid their EU law obligations, ${ }^{635}$ this did not imply that juridical double taxation which persisted under a double taxation convention between two Member States was contrary to EU law (para 34). The

${ }^{634}$ See, Section 4.5.2.2 on DTC neutralisation of restrictive withholding taxes under Rule 3:3(4) of Annex A.

635 The English text of paragraph 34 of the Damseaux judgment is ambiguous due the use of the word 'if' where 'though' would have been a better translation of the original French ' $s i$ '. This meaning was determined using the German ('auch wenn') and Dutch ('ook al') translations. 
Court held that such a disadvantage did not amount to discrimination, since it arose from the parallel exercise of taxing powers by two Member States (para 27). Furthermore, because EU law does not lay down any general criteria for the attribution of areas of competence between the Member States in relation to the elimination of double taxation within the Community, unrelieved juridical double taxation is not in breach of EU law in the absence (or, irrespective of the existence) of a double taxation convention (paras 33-35). The Grand Chamber in Kerckhaert and Morres already took this view in 2006 and moreover stated that it was for the Member States to relieve juridical double taxation by concluding DTCs. The Damseaux ruling in 2009 established in turn that a DTC that does not fully relieve juridical double taxation is a fortior $i$ not precluded by the free movement provisions of the Treaty (para 33 and 35). It follows a contrario that, where EU law has set criteria that attribute taxing powers between the Member States, the EU law obligations thus imposed should be respected irrespective of any other allocation of taxing powers set by double taxation conventions.

Relevant in the justification analysis for the balanced allocation of taxing powers is thus only the question whether the restriction is objectively necessary to safeguard the internal competence to tax in a legally consistent manner. Accordingly, the potential loss of power to exercise jurisdiction which was granted to a Member State under a DTC does not in itself imply that the balanced allocation of taxing powers between the Member States would be jeopardised. The allocation of jurisdiction by a DTC to a Member State is rather a premise for that Member State to be able to exercise its taxing power effectively. This is however a general point of international tax law, not an issue of EU law. In the converse case, where a Member State has forfeited its power to tax in favour of another Member State pursuant to a DTC, the Court's authority of Wielockx (C-80/94) teaches that a Member State cannot invoke EU law to preserve a tax claim which it voluntarily surrendered to another Member State.

Consequently, the Avoir Fiscal line of authority is a strong indication that the balanced allocation of taxing powers does not concern the allocation of taxing rights as agreed between the Member States in DTCs (hypothesis 1.a of Chapter 5), but relates to the individual Member State's competence to exercise taxing powers in relation to activities that are carried out within the national territory (hypothesis 1.b of Chapter 5).

The judgment of the Court's Second Chamber in Glaxo Wellcome, paras 82 and 83, again reaffirmed the interpretation that the BAOTP standard justifies measures that restrict citizens' conduct that undermines the Member States' right to exercise their tax jurisdiction in relation to the activities carried out in their territory. The case concerned the German rules against dividend stripping arrangements.

Furthermore, in line with the original context in Marks \& Spencer, the Court in Glaxo Wellcome delineated the BAOTP standard from the case law in which the reduction of tax revenue was dismissed as justification of direct tax restrictions, referring to the precedent of Manninen, para 49. In Glaxo Wellcome, para 87 the Court put it as follows: 
87. Such consequences [the indirect transfer of an imputation tax credit to a non-resident shareholder equal to the corporation tax paid by a resident company in which that shareholder held shares, but alienated that holding to another resident company through dividend stripping arrangements, see paras 84-86] would not just reduce the Federal Republic of Germany's tax revenues but would mean that, by granting the non-resident a financial advantage equal to the tax credit for the tax charged on the profits of a resident company, the profits [the imputation tax credit constituted taxable income for the recipient of dividends under German tax law, see para 4] normally taxable in that company's Member State of residence would be transferred to a Member State with jurisdiction to tax the profits made by the non-resident, thus jeopardising a balanced allocation of the power to impose taxes between the Member States.

The ratio of balanced allocation of taxing powers is therefore aimed at preserving the existence of the competence to tax domestic income as such, as opposed to preserving the tax revenues generated by an exercise of that tax competence. The justification preserves the legal claim to tax, but not the status quo of revenue actually collected from that claim.

The Court's Third Chamber in the transfer pricing case $S G I$, para 60 again recalled that the BAOTP standard safeguarded the right of a Member State to exercise its tax jurisdiction in relation to activities carried out in its territory. At issue in $S G I$ was the question whether the Belgian transfer pricing rules on unusual or gratuitous advantages that reserved an income adjustment at atarm's-length standards only for international transactions was contrary to EU law. In the application of the BAOTP standard in SGI, the Court held in paras 63 and 64:

63. In the present case, it must be held that to permit resident companies to transfer their profits in the form of unusual or gratuitous advantages to companies with which they have a relationship of interdependence that are established in other Member States may well undermine the balanced allocation of the power to impose taxes between the Member States. It would be liable to undermine the very system of the allocation of the power to impose taxes between Member States because, according to the choice made by companies having relationships of interdependence, the Member State of the company granting unusual or gratuitous advantages would be forced to renounce its right, in its capacity as the State of residence of that company, to tax its income in favour, possibly, of the Member State in which the recipient company has its establishment (see, to that effect, $O y A A$, paragraph 56).

64. By providing that the resident company is to be taxed in respect of an unusual or gratuitous advantage which it has granted to a company established in another Member State, the legislation at issue in the main proceedings permits the Belgian State to exercise its tax jurisdiction in relation to activities carried out in its territory. 
The result at which the Court arrived in $S G I$ echoes the answer to the issue in $O y$ $A A$. In both cases the Court allowed the restriction because resident companies could otherwise transfer profits to affiliated entities in other Member States at their own discretion, thereby escaping a tax claim on those profits in Belgium and Finland respectively.

Only one month after the ruling in $S G I$, the Court's Second Chamber delivered its judgment in $X$ Holding. The case concerned the question whether EU law required the Netherlands to allow a resident company of the Netherlands to consolidate its assets and activities with those of its non-resident subsidiary established in Belgium, given that the national rules on a single tax entity a priori excluded non-resident subsidiaries from consolidation. The Court found the national rule to restrict freedom of establishment and first reproduced Marks \& Spencer, paras 45 and 46 verbatim in paras 28 and 29 of the X Holding ruling. Since the formation of a single tax entity and the ensuing consolidation of assets and activities of a parent company and its subsidiary necessarily and in particular entails the advantage of loss relief (see para 18 of the judgment), the Court continued:

30. The same applies with regard to a tax integration scheme such as that at issue in the main proceedings.

31. Since the parent company is at liberty to decide to form a tax entity with its subsidiary and, with equal liberty, to dissolve such an entity from one year to the next, the possibility of including a non-resident subsidiary in the single tax entity would be tantamount to granting the parent company the freedom to choose the tax scheme applicable to the losses of that subsidiary and the place where those losses are taken into account.

32. Since the dimensions of the tax entity can therefore be altered, acceptance of the possibility of including a non-resident subsidiary in such an entity would have the consequence of allowing the parent company to choose freely the Member State in which the losses of that subsidiary are to be taken into account (see, to that effect, $O y$ AA, para 56, and Lidl Belgium, para 34).

33. A tax scheme such as that at issue in the main proceedings is, for that reason, justified in view of the need to safeguard the allocation of the power to impose taxes between the Member States.

The above quoted passage was evidently considered adequate by the Court's standards to uphold the restriction at issue in X Holding in principle. Considering the precedents of Marks \& Spencer and $O y A A$ which also concerned a form of group relief and the case of Lidl Belgium in which the Court equally denied cross-border loss relief, the Court's acte clair approach to its reasoning can easily be justified by the fact that in all four cases the Court clearly identified a danger that the taxpayer could shift income between Member States at will, if the benefits of the national tax provisions at issue were to be extended unconditionally in regard of foreign establishments. This main theme did not need further elaboration in the first analytical step of justification, even though we will 
see in Chapter 9 that its factual basis is wrong. Notwithstanding the evident noise in (or, lack of) communication between the national courts, the parties to the proceedings and other actors which submitted observations in those cases, that unfortunately moved the Court to adopt its 'loss trafficking' view, it is this erroneous understanding of international tax law that shaped EU law in the field of direct taxation. Therefore, we reiterate, it is the only basis by which the Court's doctrine should be interpreted.

In Tankreederei I the Court's Third Chamber considered the interpretation of a balanced allocation of taxing powers to be a justification ground so unambiguous that it analysed and rejected its application by its own motion. The case was about a blatantly discriminatory Luxembourg tax provision that reserved a tax deduction on investments for domestic investment only. ${ }^{636}$ The Court considered that Tankreederei's business activities undertaken in the ports of Antwerp and Amsterdam were taxable exclusively in Luxembourg and that the failure to allow a deduction on investment of assets used for those foreign activities in 'no way' jeopardised Luxembourg's right to exercise its taxing powers in relation to income from those activities (para 22). The Court relied in that context on Jobra, paras 32-33. Indeed, the Court already held in Jobra that a tax advantage which discriminates against investments in other Member States could not be justified for the same reason.

The judgment in Haribo and Österreichische Salinen was also decided by the Court's Third Chamber. This judgment made it unmistakably clear that the BAOTP standard only preserves the internal tax competence of a Member State and is not concerned with tax claims on foreign income. This point was discussed with regard to the Austrian rules on relief of economic double taxation on dividends received. The Court was asked to clarify whether the same tax advantages as on dividends received from companies established in Austria were due on dividends received from companies of a third state, or that freedom of capital was not restricted if the tax advantage was denied. The Court found that freedom of capital was restricted under Rule 3:1 of Annex A and furthermore held that:

123. Treatment of portfolio dividends received by a resident company in the same way whether they come from another resident company or from a company established in a non-member State other than a State party to the EEA Agreement would not result in income normally taxable in the Member State where the recipient company is resident being transferred to the nonmember State concerned (see, to this effect, Glaxo Wellcome, paragraph 87). As the Advocate General states in point 120 of her Opinion, the main proceedings concern not the power to impose taxes in respect of economic activities carried on in national territory, but taxation of foreign income. [emphasis added] 
124. That being so, the difference in treatment between portfolio dividends according to whether they are nationally-sourced or foreign-sourced cannot be justified in light of the need to safeguard the allocation of the power to impose taxes between Member States and non-member States other than States party to the EEA Agreement.

125. It is true that exemption of portfolio dividends distributed by companies established in a non-member State other than a State party to the EEA Agreement, or granting a credit for the tax paid in that State, would result for the Republic of Austria in a reduction in its own revenue from corporation tax.

126. However, it has been consistently held that a reduction in tax revenue cannot be regarded as an overriding reason in the public interest which may be relied on to justify a measure which is, in principle, contrary to a fundamental freedom (see, inter alia, Manninen, paragraph 49, and Case C-386/04 Centro di Musicologia Walter Stauffer [2006] ECR I-8203, paragraph 59).

The Court referred in para 123 of its ruling explicitly to the opinion of AG Kokott and her same conclusion in point 120 was argued as follows:

116. The Austrian and the Finnish Governments argue that the need to safeguard the balanced allocation of the power to impose taxes between the Member States and non-member States can constitute an overriding reason in the public interest which justifies distinguishing, for tax purposes, between dividends from non-member States and national dividends.

117. It should be stated in this regard that the Court has recognised the need to safeguard the balanced allocation of the power to impose taxes as an overriding reason in the public interest in relations between Member States, initially only in conjunction with other grounds of justification, but recently also by itself. However, the scope attached hitherto to this ground of justification in case-law is narrower than the term might suggest. [emphasis added]

118. Thus, the need to safeguard the balanced allocation of the power to impose taxes may justify a restriction in particular where the restrictive measure in question is designed to prevent conduct capable of jeopardising the right of a Member State to exercise its tax jurisdiction in relation to activities carried out in its territory. In this way, the Court has essentially accorded the Member States the right to prevent a taxpayer from freely transferring profits or losses, without regard to the place where they were made, from one Member State to another Member State, thereby undermining the allocation of the power to impose taxes.

119. It should be stated, at the outset, that this ground of justification, in the form outlined hitherto, could not justify the conferral of no possibility of credit for non-member-state portfolio dividends. 
120. First, the case concerns not the power to impose taxes in respect of economic activities carried on in Austria, but taxation of foreign income, and, second, Austria's power to impose taxes would not be jeopardised as such if, in the case of non-member-state portfolio dividends, it permitted the corporation tax levied in the non-member State on the profits used for that purpose to be credited. If and in so far as the foreign tax previously paid does not reach the level of the corporation tax paid on national dividends, national corporation tax must still be paid under the imputation method [footnotes in original text omitted].

The Court's ruling and the Advocate General's opinion in Haribo and Österreichische Salinen provide an apt synthesis of the EU law standard of a balanced allocation of taxing powers, but neither introduces further conceptual elements to the principle. The two last cases of Commission $v$ Germany (C284/09) and National Grid Indus do not add anything else to the meaning of the BAOTP standard.

Commission $v$ Germany is again an application of Rule 3:3 of Annex A and clarifies in para 80 that Rule $3: 3(3)$ is indeed a specific interpretation of the BAOTP standard in relation to the taxation of outbound dividends. However, the Court found that the extension of the disputed rules to cross-border relations would not jeopardise the balanced allocation of taxing powers of Germany (Commission v Germany, para 81). The Court thus ruled that the restriction could not be justified by the BAOTP standard and also not on other grounds recognised in the case law.

National Grid Indus affirms our interpretation of $N$. which we gave above in Section 6.4.2. The case of National Grid Indus was also about national legislation of the Netherlands concerning exit taxes in the situation of a company established in the Netherlands which had transferred its place of effective management to the UK. ${ }^{637}$ In contrast to $N$., which concerned the measures applicable to capital gains of shareholdings of individuals, the rules at issue in National Grid Indus related to the taxation of accrued, but not yet realised, capital gains on business assets. The Court held with reference to $N$., para 46 that these rules also preserved the power to tax income 'in accordance with the principle of fiscal territoriality linked to a temporal component, namely the taxpayer's residence for tax purposes within national territory during the period in which the capital gains [arose] [...]' (National Grid Indus, para 46). The assertion of a tax claim on those gains upon the transfer of residence of a company to another Member State was therefore legitimate, according to the Court. Also consistent with the approach in $N$., the Court found that the tax claim asserted by the Netherlands was in line with DTC obligations as per the instructions of the national court in the order for reference and the observations of the governments of the Member States which they had submitted in the proceedings before the Court: 
47. According to the order for reference, National Grid Indus was, in accordance with Article 7(1) of the Convention, regarded after the transfer of its place of effective management to the United Kingdom as a company resident in the United Kingdom. Since, by reason of that transfer, National Grid Indus ceased to make profits taxable in the Netherlands, a final settlement was drawn up, in accordance with Article 16 of the Wet IB, with respect to the capital gains relating to the company's assets in the Netherlands at the time of the transfer of its place of management to the United Kingdom. Capital gains realised after the transfer are taxed in the United Kingdom, in accordance with Article 13(4) of the Convention.

48. Having regard to those factors, legislation such as that at issue in the main proceedings is appropriate for ensuring the preservation of the allocation of powers of taxation between the Member States concerned. The final settlement tax levied at the time of the transfer of a company's place of effective management is intended to subject to the Member State of origin's tax on profits the unrealised capital gains which arose within the ambit of that State's power of taxation before the transfer of the place of management. Unrealised capital gains relating to an economic asset are thus taxed in the Member State in which they arose. Capital gains realised after the transfer of the company's place of management are taxed exclusively in the host Member State in which they have arisen, thus avoiding double taxation.

49. The argument put forward by National Grid Indus that the tax at issue in the main proceedings cannot be justified because it is charged on an unrealised capital gain, not a realised capital gain, must be rejected. As the governments which have submitted observations to the Court observe, a Member State is entitled to tax the economic value generated by an unrealised capital gain in its territory even if the gain has not yet actually been realised.

We will return to National Grid Indus in more depth in Chapter 8 on proportionality.

The analysis of Section 6.4 has provided a well-defined meaning of the BAOTP standard as a justification ground that preserves the power of a Member State to tax income in relation to activities undertaken in the national territory of the Member State concerned, provided that this claim is asserted in a consistent and systematic manner. Indeed, our legal analysis has confirmed that S2 of the citation summary of Figure 17 is the authentic rationalisation of the BAOTP standard as laid down in Rule 4:4 of Annex A. We have now gathered sufficient information to relate the BAOTP standard to the basic framework of EU law in the field of direct taxation as explained in Section 6.2. 


\subsection{Fit within the basic framework of the law}

\subsubsection{The general case}

Ghosh summarised the basic framework as reviewed in Section 6.2 of this chapter by concluding that it is not the existence, but only the exercise of fiscal jurisdiction which is subject of the application of the fundamental freedoms. He argued that the fundamental freedoms cannot be converted into positive integrationist tools. That is, in Gosh's words, 'to attack the existence of fiscal jurisdiction in a manner which the freedoms were not designed to do and which the Court has no mandate to implement ${ }^{6}{ }^{638}$ Douma stated, albeit within the context whether the Court could move to deregulate non-discriminatory tax restrictions, that 'the principle of free movement cannot be interpreted in a way by which a regulation as such would ultimately be prohibited' (emphasis in original). ${ }^{639}$

We have seen above that the Court has created a standard which in effect acts as a rather absolute limit to the application of the fundamental freedoms by introducing the need to preserve a balanced allocation of the power to impose tax between the Member States as a justification in Marks \& Spencer. According to our reading of the case law, the BAOTP standard means that the obligations imposed by the Treaties on the Member State cannot be ultimately interpreted as requiring the Member States to surrender their legitimate power to impose tax within national borders. Consequently, the BAOTP standard may be invoked to defy an 'attack' of the fundamental freedoms on the existence of a Member State's fiscal jurisdiction. It consequently attaches directly to the distinction between the existence and the exercise of taxing powers as established in Schumacker.

However, Ghosh concluded that the Court's approach in Marks \& Spencer was wrong and that the Court should have held that the absence of UK taxation on the foreign subsidiaries of UK parent companies rendered their situation incomparable to the situation of UK subsidiaries of UK parent companies. On that basis, the TFEU freedom provisions could not be applied to force the UK to assert jurisdiction over losses of those foreign subsidiaries. ${ }^{640}$ According to Ghosh:

The Court should have held, as a matter of principle, that there was no breach by the UK in Marks \& Spencer. The "allocation of the power to impose tax" should have provided a ground to find no breach occurred at all, not a ground of justification. ${ }^{641}$

\footnotetext{
${ }^{638}$ Ghosh (2007), p. 83.

639 Douma (2012a), p. 77.

${ }^{640}$ Ghosh (2007), pp. 82-92

${ }^{641}$ Ghosh (2007), p. 92.
} 
Wattel also found that two persons are only comparable insofar as they are subjected to the same scope of taxation by the same Member State ${ }^{642} \mathrm{He}$ submitted that the BAOTP standard was misconceived as a justification in Marks \& Spencer and that the issue in reality was about the standard of comparability. ${ }^{643}$

This restatement of the law seems a too broad interpretation of the Court's authorities. Although it is true that the Court has held, e.g. in Schumacker, ACT Group Litigation, and Truck Center, that a difference between the scope of fiscal jurisdiction that a Member State asserts on resident and non-resident persons may be consistent with objective differences between the ordinary situations of those two categories of taxpayers, ${ }^{644}$ the Court has equally maintained the position that one should analyse whether the differentiation imposed by a criterion of residence is consistent with the aim of the national measure, and, if not, it is thus likely to be an arbitrary, and therefore discriminatory, redistribution to the specific disadvantage of situations in which freedom of movement has been exercised. This can only be different if the distinction between residents and non-residents pursues a legitimate larger aim of government in itself and does so in a proportionate manner. Thus, the mere fact that persons are subjected to a different scope of taxation does not imply, as a rule without exception, that they cannot be compared. Consequently, it does not follow a fortiori, that the situation of a person who is subjected to tax is per definition incomparable with a person who is not subjected to tax, contrary to the position maintained by Ghosh and Wattel. This may be the situation in some cases, e.g. ACT Group Litigation, but it should not be carved in stone as an overriding legal norm. Such an approach extrapolates the case law in a manner that is inconsistent with the object and purpose of the Court's doctrine.

The problem of EU law with the national provisions which ultimately were held to be justified by the need to preserve a balanced allocation of taxing powers, is their legal design. Instead of clearly establishing rules on fiscal jurisdiction within the fundamental framework of the law like the provisions at issue in Gilly, Van Hilten-van der Heijden, and also Futura, these national provisions normally function as exceptions to other provisions that define the technical rules dictating how the tax is imposed, i.e. the provisions act as additional safeguards and back-stops to a prior defined scope of fiscal jurisdiction. Their design transforms those provisions from rules that merely assert fiscal jurisdiction to rules governing primarily the exercise of that jurisdiction. This creates the presumption of discrimination; the law clearly imposes a different treatment resulting in the denial of a tax advantage to free movers which - at first glance - does not follow directly from the allocation of the power to tax as laid down in the basic framework of the national legislation of the Member State concerned.

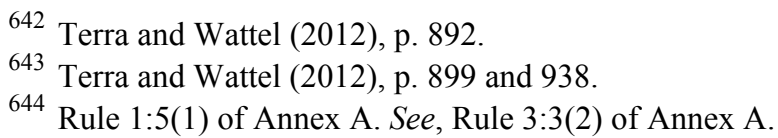


To analyse this point further, we look into a selection of cases in which the Court has considered the aim of the national measure in the context of establishing the existence of a restriction on freedom of movement in the next Section.

\subsubsection{Aims of the measure and the existence of a restriction}

In Papillon, para 27 and X Holding, para 22 the Court held that the comparability of a free movement situation with a purely internal situation must be examined having regard to the aim pursued by the national legislation.

In both cases the Court relied on $O y A A$, para 38. The aim of the Finnish group contribution regime in issue was 'to remove tax disadvantages inherent in the structure of a group of companies by allowing a balancing out within a group that comprises both profit-making and loss-making companies', $O y A A$, para 22. In view of that aim, the Court considered that the position of domestic subsidiaries with foreign parent companies could not be differentiated from the position of subsidiaries with domestic parent companies, merely because those foreign parent companies are not subject to tax in the Member State in which its subsidiaries are established.

The Court reasoned that the aim pursued by the Finnish system could be achieved in a cross-border situation by making the deductibility of the group contribution at the level of the subsidiary subject to conditions concerning the tax treatment of that contribution at the level of the parent company in the other Member State. That is true, even though the Member State in which the subsidiary is established cannot guarantee that the group contribution is taxed in the hands of the foreign parent company since the Member State of the subsidiary cannot exercise fiscal jurisdiction with regard to that parent company due to its establishment in another Member State (Oy AA, paras 36 and 37).

In $X$ Holding, the Court reasoned as follows. First, in $X$ Holding, para 18 the Court describes the aim of the Dutch system of tax integration of corporate groups. The Dutch system of a single tax unity allows that assets and activities of a group of companies are attributed to the parent company of that group. The main advantage is that this by definition results in a consolidation of profits and losses of the companies constituting the single tax entity at the level of the parent company. In addition, transactions between those companies remain neutral for tax purposes. The Court's holding was that a domestic parent company wishing to from such a single tax entity with its foreign subsidiary was objectively comparable with a purely internal situation 'in so far as each seeks to benefit from the advantages of that scheme' $X$ Holding, para 24). The Member States which submitted observations in this case however argued that these two situations were not comparable because foreign subsidiaries are not subject to the fiscal jurisdiction of the Netherlands (para 21).

In Papillon, it concerned the French tax integration system. A French parent company sought to consolidate its income with the income of its French subsubsidiary that was held through an intermediate subsidiary established in the Netherlands. This was however not allowed because the Dutch subsidiary was 
not established in France. The aim of the French legislation was described by the Court as 'to treat, as far as possible, a group constituted by a parent company with its subsidiaries and its subsubsidiaries in the same way as an undertaking with a number of permanent establishments, by allowing the results of each company to be consolidated.'(Papillon, para 28). The Court considered that the requested consolidation between parent and subsubsidiary could be attained in view of that aim and that it was irrelevant whether the intermediate subsidiary was subject to tax in France or not (para 29). The judgment of Papillon, para 27, relied in point on the precedent of Metallgesellschaft and Others \& Hoechst (Joined Cases C-397 \& C-410/98), para 60 in which the Court held with regard to the UK group income election between UK subsidiaries of foreign parent companies in respect of ACT:

60. Consequently, as the Advocate General has pointed out in paragraph 25 of his Opinion, the difference in the tax treatment of parent companies depending on whether or not they are resident cannot justify denial of a tax advantage to subsidiaries, resident in the United Kingdom, of parent companies having their seat in another Member State where that advantage is available to subsidiaries, resident in the United Kingdom, of parent companies also resident in the United Kingdom, since all those subsidiaries are liable to $\mathrm{MCT}$ on their profits irrespective of the place of residence of their parent companies.

The AG opined in that case:

25. These submissions effectively amount to a contention that the difference in treatment of subsidiaries of non-resident companies is justified by the fact that they are not subject to United Kingdom CT liability on their profits. This difference in the respective fiscal situations of the parents does not provide a justification, in my view, for denying to the subsidiaries duly established in the United Kingdom, who are so subject, a tax advantage available to comparable subsidiaries of United Kingdom parents.

The situation of Papillon indeed was a close analogy. Similar to the claim of the UK companies in Metallgesellschaft and Others \& Hoechst, the claim of the French companies in Papillon concerned the application of a grouping rule to two companies which were resident in France. Since the incidence of the tax disadvantage imposed by the different treatment in the national legislation on basis of the corporate seat of the parent company of the subsidiary in Metallgesellschaft and Others \& Hoechst and the foreign seat of the parent company of the subsubsidiary in Papillon was with the companies that were subjected to the (unlimited) fiscal jurisdiction of the UK and France respectively, those Member States could not argue that the absence of taxing powers on those parent companies justified thatthe tax disadvantage on the subsidiaries was not mitigated, because that disadvantage was due to an exercise of their taxing powers. 
The Court's only other authority in the field of direct taxation that cited Metallgesellschaft and Others \& Hoechst, para 60 is Bosal (C-168/01), para 40 in the context of the territoriality principle of Futura: ${ }^{645}$

37. An argument based on the principle of territoriality, as recognised by the Court of Justice in Case C-250/95 Futura Participations and Singer [1997] ECR I-2471, paragraph 22, has also been relied upon by the Netherlands Government in order to justify the difference in tax treatment under the 1969 Law. According to the government, the costs in connection with activities abroad, including financing costs and costs in relation to holdings, should be set off against the profits generated by those activities and the deduction of those costs is linked solely to the making or non-making of profits outside the Netherlands. According to the Netherlands Government, there is therefore no discrimination, the subsidiaries which do make profits taxable in the Netherlands and those which do not being in a situation which is not comparable.

38. In that respect, it should be noted that the application of the territoriality principle in Futura Participations and Singer concerned the taxation of a single company which carried on business in the Member State where it had its principal establishment and in other Member States from secondary establishments.

39. Having regard to the facts of the main dispute, and as the Advocate General has stated in points 50 and 51 of his Opinion, the argument that the differentiated tax treatment of parent companies is justified by the fact that subsidiaries which make profits taxable in the Netherlands and those which do not are not in comparable situations is irrelevant. The difference in tax treatment in question concerns parent companies according to whether or not they have subsidiaries making profits taxable in the Netherlands, even though those parent companies are all established in that Member State. As regards the tax situation of the latter in relation to the profits of their subsidiaries, however, it must be noted that those profits are not taxable in the hands of those companies, whether the profits come from subsidiaries taxable in the Netherlands or from other subsidiaries.

40. Moreover, in a case concerning the tax treatment of a subsidiary which varied in relation to the seat of the parent company, the Court has held that the difference in the tax treatment of parent companies depending on whether or not they are resident cannot justify denial of a tax advantage to subsidiaries, resident in the United Kingdom, of parent companies having their seat in another Member State where that advantage is available to subsidiaries, resident in the United Kingdom, of parent companies also resident in the United Kingdom, since all those subsidiaries are liable to mainstream corporation

See, Section 4.3.5.7.3 for a discussion of the main issue in Bosal in the context of cohesion of the tax system. 
tax on their profits irrespective of the place of residence of their parent companies (Joined Cases C-397/98 and C-410/98 Metallgesellschaft and Others [2001] ECR I-1727, paragraph 60).

We understand this passage of Bosal to affirm our interpretation of the territoriality principle as applied in Marks \& Spencer that we addressed in Section 6.4.2. Although the case law reviewed thus far concerns only corporation tax rules in respect of corporate groups, we observe that the Court has recently signalled that its approach in Papillon can be applied generally by applying it outside the context of corporation taxes in Commission v Hungary (C-253/09), paras 61-64, and Commission v Belgium (C-250/08), paras 61-66, with regard to similar tax legislation in relation to private dwellings.

It is now possible to make a final analogy with Marks \& Spencer on the point of the Court's finding of a restriction on freedom of establishment. It should be recalled that the incidence of the tax disadvantage that resulted from the UK legislation was with the UK parent company that made the claim that ultimately resulted in the preliminary reference. Since that parent company was subject to UK corporation tax as a resident taxpayer, there could be no question that the UK was in a position to remove the disputed tax disadvantage, despite the fact that the other group companies in respect of which the grouping rules were to be applied were not subject to tax in the UK. As a result, the Court's finding of a restriction on freedom of establishment in Marks \& Spencer is consistent with prior and subsequent case law as discussed in this Section.

\subsubsection{Compensation by other tax advantages}

The above Section discussed the case law that explicitly shows that the aim of the national measure, i.e. the underlying tax policy choice, is relevant to assess the existence of a restriction on freedom of movement. This finding is in line with tax discrimination theory, ${ }^{646}$ and it is corroborated by an older line of authority on compensation of discrimination by other tax advantages, which we will explore below.

The line of authority with which this Section is concerned is laid down as Rule 4:6 of Annex A. It states that an infringement of the fundamental freedoms due to disadvantageous tax treatment of situations in which free movement has been exercised cannot be balanced by other tax advantages. Whereas the case law in the above Section first defined the underlying tax policy choice and then evaluated whether the disadvantage is consistent with these aims, the case law on compensation by other tax advantages first establishes that there is a disadvantage to freedom of movement and the Court articulates the tax policy choice against which it tests the consistency of the national measure with regard to free movement only at a later analytical step as a justification ground when 
dealing with the argument of the Member States that compensating advantages should render the potential restriction lawful.

Two general variations of the category of compensatory tax advantages have been decided by the Court. The first general variation regards the Member States' arguments about the availability of compensatory tax advantages under its own laws to the discriminated taxpayer. The second general variation argues the availability of compensatory tax advantages under the laws of another Member State.

The classic example of the first variation is Commission v France (Avoir Fiscal). The Court reasoned that the failure to grant a shareholders' tax credit (avoir fiscal) to branches of companies not resident in France could not be offset by any advantages which branches and agencies in France may enjoy vis-à-vis companies resident of France (para 21). Although resident companies of another Member State could have carried on business in France though a subsidiary, instead of a branch, they cannot be obliged to choose a specific legal form in order to receive the shareholders' tax credit. The freedom of establishment also leaves free the Union citizen's choice of the appropriate legal form. According to the Court in Avoir Fiscal, para 22 that freedom of choice was held to be unjustifiably limited by the discrimination of non-resident against resident companies of France because the shareholders' tax credit benefit was not available to secondary establishments set up as a branch or agency, although the dividends attributable to those secondary establishments were taxed with French corporate tax irrespective of their legal form (Avoir Fiscal, paras 6, and 19 and 20).

This reasoning was repeated as precedent to decide Saint-Gobain (C-307/97). At issue in that case was a similar discrimination against the availability of shareholder tax relief of received dividends (Saint-Gobain, para 54). Again, in Saint-Gobain the Court held the differentiation between subsidiaries and branches to be unjustifiably discriminatory.

The two judgments of Avoir Fiscal and Saint-Gobain may be summarised as follows. If one policy choice in the fundamental design of the tax system is to tax all secondary establishments - and irrespective of their legal form-in France and Germany with corporation tax on received dividends then the nonavailability of tax credits directly related, legally and economically, to the taxation of dividends of secondary establishments to non-incorporated secondary establishments of non-resident enterprises distorts that choice. It effects a subsidiary redistribution of tax burdens from companies to branches, which is clearly precluded by the freedom of legal form in Article 54 TFEU.

Asscher (C-107/94) is a special case because here national law was held to be discriminatory because it distorted a policy choice of secondary EU law. In Asscher, para 53 the Court adjudged the Netherlands' provisions that applied different tax scales to comparable taxpayers depending on whether they paid social security contributions in the Netherlands or another Member State to be contrary to freedom of movement. Mr Asscher did not pay social security contributions in the Netherlands and for this reason was taxed heavier than a 
contributing taxpayer with the same amount of pre-tax income, all other things held equal, due to the application of the special 'foreign' scale of tax rates.

Differential taxation becomes discriminatory when it creates arbitrary inconsistencies as regards the tax policy that is pursued by the national measures. The Dutch government in Asscher, para 51 however argued that the differential taxation of non-contributing non-resident taxpayers was in fact a tax policy choice and therefore legitimate. ${ }^{647}$

Nonetheless, the Court ruled that penalising taxpayers for not paying social security in the Netherlands distorted the policy choice by Regulation (EEC) $1408 / 71$ that regulated in which Member State a citizen is insured for social security. ${ }^{648}$ According to the Court in Asscher, para 54:

In any event, the alternative is this: either Mr Asscher is properly insured [in Belgium] alone and there can be no question of penalizing him by means of a tax differential for not paying social security contributions in the Netherlands; or he should be insured either exclusively or additionally with the Netherlands social security scheme, which would enable the Netherlands to claim social security contributions from him and would thus take him out of the "foreign" scale of tax rates... Consequently, whether he is insured or not with one or the other national social security scheme is not a factor which can justify, in either of the two situations envisaged, the application of a higher rate of tax to a non-resident.

In short, because the policy was stipulated by EU law, the conflicting Dutch interpretation of 'equitable' taxation of non-contributing taxpayers by imposing differential tax rates was contrary to EU law because it distorted the EU's policy choice.

The second general variation of the other tax advantages rule is a block of cases in which the Member States argued that the tax restriction imposed by their laws was justified because it offset a lower (effective) level of taxation enjoyed in another Member State. The defence of the Member States in the second variation of cases is essentially that tax discrimination is justified because it offsets an unfair policy choice in another Member State

The initial response of the Court in Eurowings (C-294/97), paras 44 and 45, was to reject this position with the argument that 'such compensatory tax arrangements prejudice the very foundations of the single market'. This has not changed in subsequent case law.

In Eurowings the German company with that name leased an aircraft from an Irish company. Since the Irish company was not subject to German trade tax

${ }^{647}$ The argument was in substance the judgment of the Amsterdam Court of Appeal (Gerechtshof) against which Mr Asscher appealed in cassation before the Dutch Supreme Court (Hoge Raad) that in turn referred the case for a preliminary ruling to 648 the Court, see Asscher, paras 19-21.

The coordination of social security systems is now regulated in Regulation (EC) $883 / 2004$. 
(Gewerbesteuer), the German tax inspector increased the assessment basis of Eurowings to compensate for the trade tax foregone on lease payments received by the Irish company. That correction would not have been due if Eurowings would have leased the aircraft from a German company. The German government reasoned that the additional levy would compensate the competitive advantage that Irish companies enjoyed thanks to the absence of German trade tax on leasing income, in fact adjusting for the price differential between German and Irish lessors. The correction at Eurowings would accordingly only level the playing field of German and Irish leasing companies. The Court was however not convinced by this reasoning and held that the differential treatment was precluded by the freedom to provide services.

The importance of the definition of the tax policy choice follows clearly from Columbus Container Services (C-298/05). The Court distinguished that case explicitly from Eurowings. At issue in Columbus Container Services was the question whether it is contrary to the freedom of establishment to switch from an exemption method to the ordinary credit method for the avoidance of international juridical double taxation if the activities of the establishment and low level of taxation in the other state would make the establishment subject to the provisions on controlled foreign corporations of Germany. It was clear to the Court that the taxpayers - the German partners of the Belgian partnership that was treated as a transparent entity for German tax purposes-would not be subject to different tax rules or rates depending on the place of establishment of the partnership, be it either in Belgium or Germany (Columbus Container Services, para 39).

Although it is tempting to argue that the low level of taxation triggers differential treatment in that the taxpayers face a higher total effective tax burden than if the partnership was not established in a low taxation Member State (Columbus Container Services, para 37 and 38), the Court chose a different route of analysis.

The Court denied that the partners in the Belgian partnership would suffer higher taxes in Germany compared to a German partnership, merely because the partnership was subjected to low taxation in the Member State in which it was established, i.e. Belgium. Therefore, the principal tax policy choice to tax resident partners in domestic partnerships in Germany, and resident partners in partnerships of other Member State with the same amount of German taxes on the income from the partnership attributable to them, was not distorted by a difference in treatment against partnerships which were established in Member States with a low level of taxation. The Court held that partners in low taxation partnerships were not subjected to less advantageous treatment compared to partners in German partnerships. In this respect, the German CFC-legislation at issue in Columbus Container Services had different tax effects on German partners in foreign partnerships than the tax effects on UK parent companies with foreign subsidiaries pursuant to the UK CFC-legislation reviewed in Cadbury Schweppes. In the latter case, application of the UK law resulted in UK parent companies with foreign subsidiaries to be taxed at a potentially higher 
amount of income compared to parent companies with domestic UK subsidiaries. ${ }^{649}$

In Verkooijen (C-35/98) the Court held that the Netherlands discriminated by only granting a partial base exemption on dividends distributed by resident companies of the Netherlands, but not to dividends sourced in other Member States. In its defence, the Netherlands argued that other Member States might grant tax advantages to dividends distributed by its resident companies to shareholders in the Netherlands, whereas these foreign tax advantages would not be available in an internal situation in the Netherlands. To oblige the Netherlands to extend the tax advantage to foreign dividends would enable its shareholders to potentially secure a double advantage (para 54). The Court dismissed this argument by citing the diverse cases of Avoir Fiscal, Asscher, Saint-Gobain and Eurowings and stating that it is clear from settled case-law that unfavourable tax treatment contrary to a fundamental freedom cannot be justified by the existence of other tax advantages, even supposing that such advantages exist' (para 61).

In De Groot (C-385/00) the Netherlands argued that the tax discrimination against Mr De Groot (a resident of the Netherlands) in relation to the method of calculating double tax relief was justified because he enjoyed a progressivity advantage on the income earned in Germany, which was exempted in the Netherlands pursuant to the DTC between the Netherlands and Germany. In that context it should be noted that the progressivity advantage enjoyed by $\mathrm{Mr} \mathrm{De}$ Groot was a result of the policy choice in Germany to calculate the appropriate income tax rate of non-resident taxpayers only on basis of income earned in Germany. Resident taxpayers in Germany were taxed on basis of worldwide income. The Court dismissed the Netherlands' argument in De Groot, para 97 and considered that the German advantage was, irrespective of its actual existence, in any case irrelevant to adjudge the discriminatory Dutch provisions on double tax relief, relying on the clear precedents of Avoir Fiscal, SaintGobain, Eurowings, Verkooijen, and Asscher.

In Lenz (C-315/02) the Austrian legislation for individual resident taxpayers at issue allowed for a reduced (half) rate of personal income taxation on dividends received from domestic companies to partly mitigate the

649 The Bundesfinanzhof in its Judgment of 21 October 2009, Case I R 114/08, BStBl. 2010 II, p. 774, in Columbus Container Services nonetheless ruled on appeal against the decision of the Finance Court Münster, which made the referral to the Court and also found in favour of the tax administration, see Judgment of 11 November 2008, Case 15 K 1114/ 99 F, EW, EFG 2009, p. 309, that German tax law infringed EU law. It relied on the precedent of Cadbury Schweppes. That decision misinterprets Cadbury Schweppes. The attribution of the partnership's income to the German partners of Columbus Container Services already followed from the general system of taxation, and was not caused by the contested CFC-provision, unlike the UK provisions in issue in Cadbury Schweppes. The Bundesfinanzhof should have distinguished Columbus Container Services on that point from Cadbury Schweppes. 
disadvantageous effects of economic double taxation. That reduction was however not granted to resident individuals insofar as the dividends were received from a company established in another Member State. The Court rejected Austria's claim that the different level of taxation of the undistributed profits of Austrian vis-à-vis foreign companies was a relevant factor to adjudge the fairness of this differentiation, particularly insofar as that argument should be interpreted as a justification to counter possible advantages that may accrue to recipients of foreign dividends since the profits distributed by companies resident of other Member States might have been subject to lower levels of taxation compared to dividends from Austrian companies (para 43).

The Court found that the level of taxation of undistributed profits at the company level was not a formal legal condition in the application of the reduced rate provision for dividends from Austrian companies (para 42). Therefore, that potential factor was excluded from the tax policy choice as evidenced by the actual operation of the detailed rules in the Austrian legislation, which was to serve as a frame of reference to adjudge the alleged distortion of that choice to the disadvantage of taxpayers who received foreign dividends (para 42).

In effect, the Court separated two distinct tax policy choices by the legislator. The first policy choice was to tax distributed profits from domestic and foreign sources with personal income tax and at the same time attenuate the effects of economic double taxation by a lump sum tax advantage. The second tax policy choice was the choice of the applicable corporate tax rate to undistributed profits earned by resident companies of Austria. Since these two choices were evidently unrelated in law, the actual corporate tax burden on the distributed profit that resulted from the second choice constituted an external factor that could not be used as a criterion to assess the justice of the alleged tax discrimination with regards to the first equity choice. It was consequently simply irrelevant whether the corporate tax rates of other Member States were lower (or higher) than the corporate tax rate imposed by Austrian law.

As final thought, an analogy with case law in the field of indirect taxation can be made. Recalling the Eurowings case, the Court did not clarify why compensatory tax arrangements are contrary to the foundations of the internal market. In this context, reference can be made to a consistent body of case law in which the Court ruled that internal taxation that effectively eliminates competitive advantages of foreign goods due to their lower price levels is manifestly contrary to Article 110 TFEU, see e.g. Weigel (C-387/01, para 87). The German law under review in Eurowings was also aimed at eliminating a competitive advantage by effecting price corrections through taxation. ${ }^{650}$ In that regard, the case law in the fields of direct and indirect taxation are perfectly

650

See, Sandoz (C-439/97). In that case, the national legislation imposed rules that were specific to situations in which freedom of movement was exercised (thereby creating the assumption of a restriction), but the stamp duty was not, as such, specifically levied to compensate for a lower level of taxation enjoyed in another Member State, contrary to what was the situation in Eurowings. 
consistent in that they both preclude taxes as indirect corrective price mechanisms able to distort competition between Member States.

By arguing that other tax advantages are available to a free moving citizen against whom a Member State discriminates, the Member States purport to broaden the legal and tax policy framework against which potential discrimination is assessed. Thereby they aim to prove that there is no distortion, because the alleged discriminatory disadvantage is balanced by another tax advantage and citizens in the end are treated at par. This claim based on the citizen's individual tax position is not an argument that asserts the legitimacy of a specific public policy interest of the Member States. The Court disapproves of this loosening of standards and assesses discrimination against the actual tax policy choices of one Member State as defined with reference to the national legislator's reasoned intent, and as evidenced by the actual design of the legal framework of taxation of the Member State concerned. If there is no evident, direct link between a tax advantage and an offsetting tax levy by the standard of cohesion of the tax system of Rule 4:3 of Annex A, the Court rejects the idea of compensation by other tax advantages under Rule 4:6 of Annex A.

\subsubsection{The specific case of grouping rules}

We have seen that the Court consistently considers the precise aim of the national legislation to establish whether there is ultimately a restriction on the freedom of movement. The most explicit statements are found in the case law on tax grouping rules. For that reason, we return to this case law and rationalise it a bit further.

When we compare the Court's approach in Marks \& Spencer, Oy $A A$, Papillon, and $X$ Holding, the material point is that the Court acknowledges the interest of corporate groups to seek the advantages that tax grouping rules explicitly purport to confer, irrespective of the place of establishment of the individual companies. The Member States' defence is not particularly strengthened by the fact that grouping rules, like the ones at issue in those cases, are already a deviation from the general system that corporation tax is, in principle, assessed and charged on each company individually.

The general system of corporation taxation starts from the legal fiction created by company law that pieces of paper can assume civil rights and obligations. They are considered separate entities from the private individuals who ultimately own and control the companies. The main justification for the corporation tax is that this approach enhances tax compliance; it is generally administratively easier to use the corporation as a withholding device than to impose personal income taxes on its shareholders, specifically foreign shareholders, notwithstanding that a corporation tax may be deemed desirable and necessary on other grounds. ${ }^{651}$

${ }^{651}$ See e.g., Bird (2002). 
This basic system from which the law operates does not correspond to the economic reality of modern business in which an enterprise is managed on the basis of a coherent business strategy as a group of several cooperating companies. The tax rules applicable to corporate groups aim to deal somewhat adequately with this economic reality, but this requires a conflict with the law's basic logic. $^{652}$

The conflict is the following. All corporation tax grouping rules effectively superimpose some form of a secondary rule on income attribution between individual companies on the general system of taxation. The evident objective is to achieve an equitable treatment of corporate groups compared to single company businesses; a group of companies should not be taxed heavier as a single company with the same balance of income. In other words, the corporate law structure of a business is not considered a relevant policy criterion for a redistribution of tax burdens on similar economic activity. On top of this second legal layer the legislator usually stacks another rule that denies the application of grouping provisions in relation to foreign companies. It does so, not with a discriminatory or protectionist view of effecting a subsidiary redistribution from international to domestic businesses - corporation taxes are generally used as a policy instrument to attract international business - but to attain the different and legitimate objective of safeguarding fiscal jurisdiction on economic activities undertaken in its national territory.

The different rules necessary for this intricate type of three-dimensional tax design may cause undesired interaction effects that could amount to disguised discrimination and protectionism. This risk of a breach of the fundamental right of free movement is rightly scrutinised by the Court with close interest. The exception for foreign companies may well be fully consistent with the general system of the corporation tax in the end. That conclusion however requires an analysis of all the different aspects of this tax design. Such a review cannot be approached merely as a preliminary matter in the Court's judgment in the blackand-white version proposed by Ghosh and Wattel.

The Court is right to assess first whether the denial of the grouping tax benefit to foreign companies follows logically from the aim of the grouping regime. That conclusion cannot be derived from the legislator's reasoned intent in relation to grouping regimes which basically value equal treatment beyond corporate structure. The refusal to apply the superimposed secondary rule on income attribution is then correctly labelled as a suspect secondary redistribution of tax burdens to the disadvantage of free movers. The exception for foreign companies is rightly treated as a potential restriction on freedom of movement. But, if the interaction effects of the different rules of the three layers indeed are purely limited to safeguard internal fiscal jurisdiction, we have seen that the Court will allow the balanced allocation of taxing powers justification to deny any extension of the tax grouping benefits to free movers. A Member State may lawfully prevent that, due to the application of grouping rules, taxable income

${ }^{652}$ See generally, Masui (2004). 
earned in its territory would be attributed to a company which is not liable to tax in the Member State concerned.

\subsection{Synthesis and discussion}

The research of this Chapter results in the following working hypothesis of the balanced allocation of taxing powers between the Member States as a standard in EU law as it currently stands. The Court interprets the BAOTP standard ordinarily as a justification and consistently defines its aims as safeguarding the Member States' legitimate competence to tax income generated by economic activities undertaken in their territory, provided that the Member States assert that tax claim in a systematic and consistent manner from all taxpayers, whether they are resident or non-resident. The BAOTP standard attaches directly to the distinction between the existence and the exercise of the power to impose tax and gives content and meaning to the basic framework of the judicial doctrine on EU law in the field of direct taxes.

This proposed working hypothesis is consistent with the interpretation of Terra and Wattel that the BAOTP standard is 'something like the source country entitlement principle'. ${ }^{63} \mathrm{We}$ also find, similar to Terra and Wattel, that the fiscal principle of territoriality in terms of Futura is closely connected to the BAOTP standard. ${ }^{654}$ But, we do not believe that they are expressions of the same overall concept. Rather, we believe that the fiscal principle of territoriality is best interpreted in the context of the BAOTP standard as rendering a tax claim legitimate and thus in need of protection under the BAOTP standard, provided that a competing taxing competence of another Member State does not become 'involved', i.e. the BAOTP standard may not be invoked to preserve a tax claim on foreign income of a non-resident taxpayer.

However, the Court's doctrine does not demand in principle that Member States surrender their competence to tax resident taxpayers on income generated by extra-territorial economic activities. We observe on a tangent that this is consistent with the line of authority following Kerckhaert and Morres. On the basis of the judicial doctrine that is reviewed in this Chapter, we find that the Court actually is indifferent as to the effects of EU law on the Member States' competence to tax foreign income. No case has yet been decided in which the Court held the competence to tax foreign income jeopardised and in need of the protection of EU law by reason of the need to preserve the balanced allocation of taxing powers. To the contrary, the BAOTP standard has not shown to protect that tax claim. The Court has stated explicitly that the BAOTP standard cannot be invoked to protect a tax claim on foreign income.

653 Terra and Wattel (2012), p. 936. Notably, this 2012 interpretation deviates from the conclusion in Terra and Wattel (2008), p. 833 that the Court 'adheres and gives ${ }_{654}$ priority to source country entitlement' (emphasis added).

Terra and Wattel (2012), pp. 933-937. 
For those reasons, the Court has not decided a priority between the tax competences of Member States by introducing the BAOTP standard.

Furthermore, the BAOTP standard does not protect a Member State from suffering a reduction of tax revenue, or a limitation of the scope of taxing powers allocated to it by a DTC, if this result is necessary to ensure that the Member State concerned complies with EU law by treating comparable taxpayers at par and not impose a tax restriction on free movement.

On balance, our preliminary conclusion is that the BAOTP standard functions as a limit to the Court's mandate and defines the deregulatory reach of the TFEU's fundamental freedoms in relation to national legislation on direct taxes. It prevents that national measures, which are objectively necessary to regulate the allocation of taxing powers between the Member States, are struck down by a judicial decision merely because they impose additional conditions on the tax treatment of situations in which the freedom of movement has been exercised. The BAOTP standard prevents EU law from nullifying a legitimate tax claim by applying the fundamental freedom provisions in the TFEU. A reduction in revenue has never been, nor did it become a justification after Marks \& Spencer, but the loss of the competence to assert taxing powers within a national territory is a dominating argument to allow a national measure which seemingly restricts the exercise of free movement.

In the next Chapter we will see that we disagree with Terra and Wattel on the point that the BAOTP serves coherence of the tax system. We hold the two legal norms to be different in nature. ${ }^{655}$ Accordingly, we already take the opportunity to submit here that there is not one single concept of tax base integrity in the way that Terra and Wattel define it. ${ }^{656}$ Notwithstanding and as will be argued in Chapter 7, we agree with Terra and Wattel that the prevention of abusive practices, i.e. tax avoidance, is indistinguishable on a higher level of abstraction from the BAOTP standard. ${ }^{657}$

\footnotetext{
${ }^{655}$ Section 7.5.

656 Terra and Wattel (2012), pp. 938-939.

${ }^{657}$ Section 7.4.
} 



\section{Chapter $7 \quad$ Relations with Other Justifications}

\subsection{Introduction}

The relation between the balanced allocation of taxing powers (BAOTP) and other justifications is a central element of the discussion in the literature. The literature review of Section 5.2 provided several suggestions of similarities and differences between the several justifications. However, prior research is not conclusive as to which justifications are interrelated and, on balance, are grounded on similar or equivalent points of law. Accordingly, the null hypothesis that follows from prior research is that there is no relation between the justifications.

Before examining the relations between the BAOTP standard and other justification grounds, we will first analyse the general interplay between the justifications from three perspectives in Section 7.2. The first approach is exclusively based on outcomes and analyses congruency of results to determine likeness of justifications on an abstract level. The second approach focuses on the Court's use of language and the third approach performs links analysis on and interprets paragraph 51 ('taken together') of the Court's Marks \& Spencer ruling.

For the sake of clarity, the preliminary review of Section 7.2 only serves as a basis to further develop hypotheses on the research questions formulated in Chapter 5. These will be tested against the legal analysis in the sections that follow thereafter. First, Section 7.3 will evaluate the relation between the balanced allocation of taxing powers and the risk of a double use of losses. Second, Section 7.4 concerns the potential overlap with the prevention of tax avoidance. And third, we will see in Section 7.5 whether the cohesion of the tax system really means the same thing as the balanced allocation of taxing powers. Section 7.6 gives a summary and discussion of the findings on the relations between recognised justifications for tax restrictions on freedom of movement.

\subsection{Preliminary review}

\subsubsection{Inductive generalisation}

The first preliminary approach in this section is to review the application of the individual defences in the cases that developed the standard by inductive generalisation. Since we have identified the relevant body of case law already through 
SNA in Chapter 5, we will only use the cases of Section 6.4 which corresponds to Community 8 of the Marks \& Spencer network.

In this subsection we will discover general indications that the null hypothesis perhaps should be rejected because a positive relation, i.e. a degree of equivalence or similarity on points of law, between individual justifications exists. We will ignore the question whether the justification went beyond what was necessary and we will thus focus only on the question whether a justification was recognised as pursuing a legitimate aim in the public interest that could justify the prima facie infringement of EU law in the cases of the sample. By focussing on the congruency of outcomes on the level of justification we can investigate whether the public interest pursued by the several justifications is equivalent and represents indistinguishable points of law on a higher level of abstraction. Prior research namely argued this is the case. ${ }^{658}$

The premise for the analysis is that consistent congruent results are caused by indistinguishable grounds of justification. Although it is true that correlation does not necessarily imply causation, we actually want to analyse the existence of identity relationships between the justification grounds. In that context, it is fair to state that same outcomes suggest that the justifications are rhetorical tautologies.

If both justifications relate to the same legitimate larger aim of government, then the grounds of both justifications could be equivalent and the Court will arrive at the same result upon analysis as a general rule. That is, justification $\mathrm{A}$ is consistently congruent in result with justification B if both justifications have been accepted as a justification in at least two cases, and neither justification has been dismissed while the other justification justified the restriction in any other case included in the review. The form of inductive generalisation is thus simple enumeration; one single negative instance disproves a positive relation. A legal analysis is necessary to show whether negative instances are rather exceptions to the general rule or historical accidents, instead of disconfirming the general rule

A positive relation between two justifications may be assumed even though both justifications are not analysed and accepted by the Court in all cases investigated. The situation that one justification is analysed and accepted, but a second justification is not relied upon by the Member State(s) and/or not analysed by the Court is in itself not an indication against a positive relation between the two justifications. In any event, we do not know how the Court would have decided in that case if it had analysed another justification. Consequently, this situation can neither support a positive relation between the justifications, nor does this situation provide indications in favour of a negative relation between the cases.

Table 23 reports the results of the preliminary review and shows which justifications were accepted (A) and rejected (R) in 18 judgments of the Court. The results lead to the following observations. 
First, the balanced allocation of taxing powers justification (BAOTP in Table 23 ) is congruous with the tax avoidance justification, but for one exception. In five cases (Marks \& Spencer (C-446/03), Cadbury Schweppes (C-196/04), Oy $A A$ (C-231/05), Glaxo Wellcome (C-182/08), and SGI (C-311/08)) the Court accepted both justifications. In five other cases, both justifications were not accepted (Rewe Zentralfinanz (C-347/04), Papillon (C-418/07), Aberdeen Property Fininvest Alpha (C-303/07), Jobra (C-330/07), Tankreederei I (C287/10)). However, in National Grid Indus (C-371/10) the Court accepted the balanced allocation of taxing powers but rejected the need to prevent tax avoidance.

Second, the Court analysed the risk that losses might be used twice in three cases (Marks \& Spencer, Oy AA, and Lidl Belgium (C-414/06)) in which the Court also accepted the balanced allocation of taxing powers. The preservation of the BAOTP and the prevention risk that losses might be used twice were both rejected in Rewe Zentralfinanz and Papillon. However, in $O y A A$ the Court dismissed the risk that losses might be used twice as a justification, but accepted the BAOTP justification. Accordingly, $O y A A$ provides an indication against the hypothesis that the balanced allocation of taxing powers may only be accepted if the risk of double use of losses is also recognised as a justification in the case at hand.

Third, the balanced allocation of taxing powers is consistently incongruent with the loss of tax revenue argument in Marks \& Spencer, Cadbury Schweppes, and Glaxo Wellcome. The justifications evidently relate to different aims.

\begin{tabular}{|c|c|c|c|c|c|}
\hline Case & BAOTP & $\begin{array}{c}\text { Double use } \\
\text { of losses }\end{array}$ & $\begin{array}{l}\text { Prevention of } \\
\text { tax avoidance }\end{array}$ & $\begin{array}{c}\text { Tax system } \\
\text { cohesion }\end{array}$ & $\begin{array}{c}\text { Reduction in } \\
\text { revenue }\end{array}$ \\
\hline C-446/03 & A & A & A & - & $\mathrm{R}$ \\
\hline C-196/04 & A & - & A & - & $\mathrm{R}$ \\
\hline C-347/04 & $\mathrm{R}$ & $\mathrm{R}$ & $\mathrm{R}$ & $\mathrm{R}$ & - \\
\hline C-374/04 & A & - & - & - & - \\
\hline C-470/04 & A & - & - & - & - \\
\hline C-231/05 & A & $\mathrm{R}$ & A & - & - \\
\hline C-379/05 & $\mathrm{R}$ & - & - & $\mathrm{R}$ & - \\
\hline C-414/06 & A & A & - & - & - \\
\hline C-418/07 & $\mathrm{R}$ & $\mathrm{R}$ & $\mathrm{R}$ & A & - \\
\hline C-303/07 & $\mathrm{R}$ & - & $\mathrm{R}$ & $\mathrm{R}$ & - \\
\hline C-330/07 & $\mathrm{R}$ & - & $\mathrm{R}$ & $\mathrm{R}$ & - \\
\hline C-182/08 & A & - & A & $\mathrm{R}$ & $\mathrm{R}$ \\
\hline C-311/08 & A & - & A & - & - \\
\hline C-337/08 & A & - & - & - & - \\
\hline C-436/08 & $\mathrm{R}$ & - & - & - & $\mathrm{R}$ \\
\hline C-284/09 & $\mathrm{R}$ & - & - & $\mathrm{R}$ & $\mathrm{R}$ \\
\hline C-287/10 & $\mathrm{R}$ & - & $\mathrm{R}$ & $\mathrm{R}$ & $\mathrm{R}$ \\
\hline C-371/10 & A & - & $\mathrm{R}$ & A & - \\
\hline
\end{tabular}

Table 23. Accepted and rejected justifications in selected cases 
Fourth, the Court accepted cohesion and rejected BAOTP in Papillon. However, cohesion was rejected but BAOTP was accepted in Glaxo Wellcome. Furthermore, the Court accepted both justifications in National Grid Indus. The case law is thus inconsistent as regards the outcome.

Fifth and last, the Court accepted the BAOTP standard in the three cases of N. (C-470/04), ACT Group Litigation (C-374/04) and X Holding (C-337/08) without additionally relying on other justifications. These cases indicate that the balanced allocation of taxing powers may be a valid justification in itself and pursues a distinct larger aim of government. It thus does not have to be 'taken together' with another justification to succeed before the Court. This would in turn imply that, if the tax avoidance justification indeed cannot be distinguished from the BAOTP standard, also the tax avoidance justification can be relied upon autonomously. In that alternative interpretation, the risk of double use of losses may be relied upon only in conjunction with an accepted need to preserve a balanced allocation of taxing powers between the Member States. This hypothesis is not refuted by the preliminary results; the risk of double use of losses was only accepted taken together with the balanced allocation of taxing powers.

\subsubsection{Textual analysis}

The following additional observations about the autonomous application of balanced allocation of taxing powers can further be derived from the language used in the Court's judgments. Table 23 shows that there are in total seven casesincluding Marks \& Spencer-in which the Court accepted the balanced allocation of taxing powers and also a second or third justification of the tax restriction at hand.

The Court followed the Opinion of AG Kokott in National Grid Indus and held that the requirements of the cohesion of the tax system and the balanced allocation of taxing powers 'coincide' (para 80). Does this mean in point of fact that the two justifications are the same? A positive conclusion would nevertheless remain inconsistent with Papillon and Glaxo Wellcome.

In three cases, the Court explicitly considered the justifications 'taken together' (Marks \& Spencer, para 51; and SGI, para 69), or justified the tax restriction having regard to 'the combination of those two factors' (Oy AA, para 60). This choice of words implies that the conjunct application of justifications persuaded the Court to rule in favour of the government. These three rulings leave the impression that the individual justifications could not each justify the national restrictions under scrutiny.

In Glaxo Wellcome and Lidl Belgium the Court did not explicitly argue that the several overriding reasons can justify the restriction only when considered jointly. In Glaxo Wellcome, para 92 the exact phrasing of the Court to hold the restriction justified was '...the objective of maintaining a balanced allocation of the power to impose taxes between the Member States and of preventing wholly artificial arrangements which do not reflect economic reality and whose only purpose is to obtain a tax advantage' (italics added). Likewise, in Lidl Belgium, 
para 42 the Court held even more ambiguously that the restriction could be justified '...in the light of two of the factors referred to in paragraph 51 of the judgment in Marks \& Spencer, namely the need to safeguard the allocation of the power to tax between the Member States and the need to prevent the danger that the same losses will be taken into account twice' (italics added).

Finally, there was not a clear structural partition in the Court's analysis between the balanced allocation of taxing power and the tax avoidance justification in Cadbury Schweppes. This inclusive method of reasoning suggests that it was not necessary for the Court to explicitly state that the two justifications were in fact analysed jointly. The results based on the language used by the Court are mixed, but do not rule out the possibility that the balanced allocation of taxing powers is a discrete standard of EU law.

\subsubsection{Interpretation of 'taken together'}

Considering that the above observations do not provide a conclusive answer to the question if the balanced allocation of taxing powers can be invoked autonomously-as N., ACT Group Litigation and X Holding would suggest-we additionally perform link analysis on Marks \& Spencer, para 51 to discover any clarifications by the Court in subsequent case law about the interpretation of the phrase 'taken together'. The results of that third method of preliminary review are as follows.

In Rewe Zentralfinanz, para 41 the Court emphasised that in Marks \& Spencer, para 51 the balanced allocation of taxing powers was only accepted in conjunction with two other grounds. This statement was made in the context of defining the scope of the balanced allocation of taxing powers. In that regard, the Court cited the AG's opinion, point 32 that read that it was necessary to define the scope of the balanced allocation of taxing powers narrower than the interpretation sought by the German government in Rewe Zentralfinanz. AG Poiares Maduro interpreted the scope of the balanced allocation of taxing powers in his opinion in Rewe Zentralfinanz such that it '...cannot be separated from two other justifications relating, first, to the risk of losses being taken into account twice and, secondly, to the risk of tax avoidance.' (point 36). According to the AG, all three justifications should thus be accepted in order to be invoked successfully by the Member States. From Table 23 it can be derived that the Court arrived at a different result in more than one case. The Court's judgment in Rewe Zentralfinanz did not confirm the opinion of the AG, and the judges merely held against Germany on all three justifications.

In $O y A A$, para 51 the Court again affirmed the 'taken together' approach of Marks \& Spencer, para 51, referring to Rewe Zentralfinanz, para 41 in support. No additional clarifications were made by the Court about the implications of the 'taken together' wording, but it suffices to recall that the risk that losses would be used twice was held inapplicable in $O y A A$, para 57. Therefore, two out of three is sufficient.

The Court recalled the joint application of grounds in Marks \& Spencer, para 51 as a starting point in Amurta, para 56, but rejected the balanced allocation of 
taxing powers as a justification in the final analysis. The Court stated that the risk that losses might be used twice or the risk of tax avoidance was not relied upon by the governments who submitted observations (Amurta, para 57), but the Court went on to analyse balanced allocation of taxing powers more or less autonomously and held it inapplicable (paras 59 and 60). This second step is unnecessary if the positive application of either or both of the two other grounds is a crucial condition for the positive application of the balanced allocation of taxing powers.

The national court in Lidl Belgium referred a preliminary question to the Court on the interpretation of Marks \& Spencer, para 51. It asked whether the justifications of Marks \& Spencer must be met cumulatively, or can be relied upon alternatively (Lidl Belgium, para 38). ${ }^{659}$ Before answering this question, the Court had already held with regard to the balanced allocation of taxing powers and the risk that losses might be used twice that:

... the two justifications put forward must each be considered as being capable of justifying a restriction on the freedom of establishment arising from the tax treatment by the Member State in which the seat of a company is located of losses incurred by a permanent establishment belonging to that company and situated in another Member State. (Lidl Belgium, para 37; italics added)

From the above quotation it might be derived that the justifications are alternatives and each could justify the tax restriction autonomously. Yet, in answer to the explicit question of the national court the Court stated:

39. It must be pointed out in that regard that, in paragraph 51 of the judgment in Marks \& Spencer, the Court held that the three justifications taken together, which underlay the legislation at issue in the main proceedings, pursued legitimate objectives compatible with the Treaty and thus constituted overriding reasons in the public interest

40. However, bearing in mind the wide variety of situations in which a Member State may put forward such reasons, it cannot be necessary for all the justifications referred to in paragraph 51 of the Marks \& Spencer judgment to be present in order for national tax rules which restrict the freedom

${ }^{659}$ The ruling of the Bundesfinanzhof only stated the compatibility question as the single question formally referred to the Court for a preliminary ruling. This might explain why the Court's dispotif does not refer to the issue of 'taken together'. However, in point III.3 of the grounds of its ruling the Bundesfinanzhof (Federal Finance Court) specifically considered that it had reasonable doubt in terms of CILFIT on the question whether the Marks \& Spencer grounds should be met cumulatively or are alternatives, see Decision of 28 June 2006, Case I R 84/04, BStBl. 2006 II, p. 861. The Court was therefore bound to address this issue in the grounds of its ruling; it was necessary to relieve the doubts on the interpretation of EU law on side of the Bundesfinanzhof. 
of establishment laid down in Article 43 EC to be capable, in principle, of being justified.

41. Thus, in the judgment in $O y A A$, the Court acknowledged in particular that the national tax legislation at issue could, in principle, be justified on the basis of two of the three justifications referred to in paragraph 51 of the judgment in Marks \& Spencer, namely the need to safeguard the allocation of the power to tax between the Member States and the need to prevent tax avoidance, taken together (see $O y A A$, paragraph 60).

42. Likewise, the tax regime at issue in the main proceedings can, in principle, be justified in the light of two of the factors referred to in paragraph 51 of the judgment in Marks \& Spencer, namely the need to safeguard the allocation of the power to tax between the Member States and the need to prevent the danger that the same losses will be taken into account twice.

From the clarifications given in Lidl Belgium it can be conclusively derived that not all three Marks \& Spencer justifications should be present in a particular case. However, the Court did not explicitly hold that the balanced allocation can be invoked autonomously, without additionally relying on either the risks that losses might be used twice, or the need to prevent tax avoidance. This interpretation is moreover in line with Rewe Zentralfinanz.

The judgment in Jobra is in this context interesting because the Court held it sufficient to generally dismiss the balanced allocation of taxing powers without a need to analyse all conditions (para 33), although it first stated that it was accepted in prior case law in conjunction with other grounds (para 32), and the Austrian government had explicitly relied on the need to prevent tax avoidance in that context (para 29). Also the tax avoidance justification was dismissed by the Court.

From Jobra and also Amurta it can consequently be inferred that there is a central element in the balanced allocation of taxing powers that needs to be met at all times for it to be accepted as a justification by the Court, irrespective of the presence of any other justification and notwithstanding the possibility that the law requires the presence of another justification ground. In Chapter 6 we concluded that this central element is the lawful need to maintain the legitimate right of Member States to impose taxes in relation to economic activities undertaken in their territory.

\subsubsection{Hypotheses}

The analysis of the case law on Marks \& Spencer, para 51 provides indications that the balanced allocation of taxing powers standard is positively related with the risk that losses might be used twice (see Section 7.3) and the risk of tax avoidance (see Section 7.4). However, there is sufficient evidence to conclude that not all three justifications mentioned here need to be upheld to adjudge a tax restriction to be lawful under EU law. It is sufficient that either the risk of tax avoidance or the risk of double loss relief is accepted next to the balanced allo- 
cation of taxing powers. Whether there is any substantive overlap in meaning with the cohesion of the tax system cannot be indicated yet (see Section 7.5).

It furthermore seems, on the basis of the above preliminary findings, that the balanced allocation of taxing powers might even be a discrete standard of EU law. But the above analysis does not conclusively prove whether it functions independently in law, or needs a little help from a friend to succeed before the Court. On the other hand, it cannot be ruled out that the balanced allocation of taxing powers is an autonomous and discrete standard of EU law, but that the risk of double use of losses can only be accepted when taken together with the balanced allocation of taxing powers. This latter interpretation is supported by the outcome of ACT Group Litigation and X Holding and it is consistent with the Court's approach in all other cases in which it analysed both the balanced allocation of taxing powers and the risk of double loss relief. This alternative reading of 'taken together' will be explored in Section 7.3 which follows now.

\subsection{Relation with the risk of double use of losses}

\subsubsection{Analysis of the case law}

The Court upheld the risk of double use of losses as a justification for the restriction against foreign subsidiaries in Marks \& Spencer, paras 47-48. ${ }^{660}$ It sufficed to note that such a possibility existed if the restriction in Marks \& Spencer was not imposed and the UK was obliged to extend group relief to foreign subsidiaries. Therefore, the restriction was lawful, according to the Court. Nothing in the ruling indicates why the risk would exist, what the precise nature of that risk would be, and why preventing such a risk would be a legitimate larger aim of governments that EU law should recognise. Merely the opinion of AG Poiares Maduro demonstrates that this reasoning is potentially based on the finding that a double use of losses would be incompatible with the aim of the system as it applied internally:

74. In that regard it is plain that if the losses of foreign subsidiaries are capable of being transferred or carried forward in the State of establishment, to accord group relief in the United Kingdom risks jeopardising the aim of the group system. A transfer or carry forward of those losses in the State of establishment is in fact capable of giving an equivalent benefit to the whole of the group. The consequent benefit may be a twofold taking into account of the losses in favour of the group. Yet such advantage is contrary to the neutrality sought by that regime. Thus, in such a case the prohibition of the transfer of foreign losses to the results of the parent company appears to me to be justified. 
The Court interpreted Marks \& Spencer on this point for the first time in Rewe Zentralfinanz and dismissed its application:

45. In the second place, the German Government contends that the legislation at issue in the main proceedings is necessary in order to prevent parent companies from being able to benefit from multiple tax advantages in the form of losses incurred abroad being taken into account twice.

46. Such an argument is irrelevant in the circumstances of the main proceedings.

47. While it must be accepted that the Member States must be able to prevent the danger of tax losses being used twice (see Marks \& Spencer, paragraph 47), it must be pointed out that the losses at issue in the main proceedings are not, as the Advocate General stated at points 37 and 38 of his Opinion, comparable to losses incurred by subsidiaries abroad which the resident parent company requires them to surrender to it in order to reduce its taxable profits, which was the position in Marks \& Spencer.

48. The losses at issue in the main proceedings are incurred by the parent company because of the reduction in the book value of its shareholdings in foreign subsidiaries. Those losses related to the writing down of the book value of the shareholdings are taken into account only as regards the parent company and are subject, for tax purposes, to a different treatment from that which applies to losses incurred by the subsidiaries themselves. Such a separate treatment of, first, the losses suffered by the subsidiaries themselves and, secondly, the losses incurred by the parent company cannot, on any basis, amount to using the same losses twice.

49. Furthermore, it must be pointed out that, as the Commission of the European [Union], in particular, argued at the hearing, a parent company which is established in Germany and has subsidiaries in that State is permitted to deduct write-downs to the book value of its shareholdings in its resident subsidiaries from its taxable income, without those subsidiaries being prevented from using their own losses when they are taxed in Germany.

AG Poiares Maduro stated in point 37 of his opinion in Rewe Zentralfinanz that the losses to be relieved at the parent company level in Marks \& Spencer were the losses that the subsidiary had incurred. This is because, as pointed out by the Court in para 47 of the ruling, the UK system required a transfer of losses for tax purposes in internal situations. The subsidiary surrendered losses it had suffered to its parent company so that these losses could be relieved against the parent company's profits as if they were the parent company's own losses. The losses for which Marks \& Spencer sought relief were the same losses in law as the losses suffered by the subsidiary in fact.

In point 38 of his opinion, the $\mathrm{AG}$ dismissed the German government's submission that the write-off losses incurred by Rewe Zentralfinanz were an economic result of the fact that the subsidiaries had incurred losses, and that therefore those losses were the same losses in law and fact. As the Court argued 
in para 48 of its ruling, the losses could not on 'any basis' - the prior reference to point 38 of the AG's opinion implying also not on the basis of an economic link-be considered of the same nature as the losses in Marks \& Spencer. Neither the Court, nor the AG denied that the claimed economic link existedthe Court explicitly confirmed the causality in the first sentence of para 48 of the ruling - but both found that this link did not suffice to make these losses the same in terms of Marks \& Spencer.

The Court's final argument in para 49 of Rewe Zentralfinanz was that if Germany allowed what it considered to be a double use of the same losses in internal situations, there was moreover no reason why there would be a legitimate need to prevent this from occurring in cross-border situations. In that regard, the German government's submission was artificial and arbitrary, and consequently rightly rejected by the Court. The balanced allocation of taxing powers was not protected in a consistent and systematic manner.

The Rewe Zentralfinanz ruling sheds light on the Court's understanding of 'sameness' as a strictly legal concept. As it did in Marks \& Spencer, the Court also failed in Rewe Zentralfinanz at elaborating why it would be possible that same losses would be used twice in the first place, and secondly, why that result would be considered a dangerous risk that legitimises a restriction in EU law.

The Court evidently misunderstood the risk that losses might be used twice in Lidl Belgium. It explains in Lidl Belgium, paras 35-36, why there would be a risk that losses of a permanent establishment (PE) could be used twice by the same taxpayer, once in the Member State of the secondary (i.e. permanent) establishment and once in the Member State of the primary establishment:
35. As regards the second justification put forward in the observations sub- mitted to the Court, which is based on the danger that losses might be taken into account twice, the Court has accepted that the Member States must be able to prevent such a danger (see Marks \& Spencer, paragraph 47, and Case C-347/04 Rewe Zentralfinanz [2007] ECR I-2647, paragraph 47).

\begin{abstract}
36. In this connection, it must be pointed out that, in circumstances such as those which underlie the main proceedings, there is clearly a danger that the same losses will be used twice (see Marks \& Spencer, paragraph 48). It is possible that a company might deduct, in the Member State in which its seat is situated, losses incurred by a permanent establishment belonging to it and situated in another Member State and that, despite such offsetting, the same losses might be taken into account subsequently in the Member State in which the permanent establishment is situated, when that establishment generates profits, thereby preventing the Member State in which the principal company has its seat from taxing that profit (emphasis added).
\end{abstract}

In addition to the explicit propositions in the quoted passage, the Court based its argument in Lidl Belgium, para 36 first on the general tacit premise of its justification analysis that the Member State of the principal company should relieve the losses of the foreign establishment because it otherwise restricts the freedom of establishment. The Court then asserts as a second premise in para 36 that the 
Member State in which the company is established is prevented from recapturing a previous tax year loss relief against the PE's current tax year profits, if the previous tax year loss suffered by the PE is also set off against the PE's current tax year profits for tax purposes of the Member State of the PE. As a third premise, the Court holds however that it could not be ruled out that the Member State of the PE relieves a previous tax year loss on a carry-over basis, despite that this loss has been already relieved in the Member State in which the company is established. These premises are indeed sufficient to infer the conclusion of a risk that same losses are used twice. The Court's argument in Lidl Belgium is insofar not without grounds. It does seem however, that the second and third premises are a bit contradictory.

The second premise in Lidl Belgium, para 36 is actually false if read literally and should then be rejected as an error of fact. Loss relief systems of two Member States operate independently and carry-over relief in the Member State of the permanent establishment does not necessarily pre-empt recapture of previously granted loss relief in the Member State in which the company is established. The Court's argument however, and specifically the use of the word 'thereby', appears to force the opposite conclusion by strict necessity. If para 36 of Lidl Belgium indeed should be read this way, the Court clearly failed to understand a basic point of international tax law. We will see in Chapter 9 that the same misconception of international tax law misguided the Court's judgment in Marks \& Spencer.

The AG wrote at point 14 of her opinion in Lidl Belgium that '...if the losses could be used in the Member State where the company was resident there is a risk that they would be claimed again in the Member State of the permanent establishment once the permanent establishment became profitable, without the Member State where the company was resident being able to recoup the benefit obtained.' The AG may be understood as only stating that recapture is impossible for Germany in the circumstances of the case at hand. More precisely, she apparently aimed to argue that recapture was legally prevented by reason that Germany was bound by the DTC (and national law) to fully exempt these profits. That interpretation does not imply that carry-over relief in the Member State as such necessarily prevents recapture in the Member State in which the company is established. It is confirmed by para 36 of the AG's opinion where she proposes that Germany (re)adopts a recapture system-by including i.e. not exempting, the subsequent profits in the tax base in the Member State in which the company is principally established-as a more proportional alternative to an outright refusal of any cross-border loss relief. The Court however did not follow this advice.

The Court's statement in para 36 of the judgment in Lidl Belgium may nevertheless be read to correspond with the AG's interpretation, if the argumentative weight is put on the first sentence and specifically the passage '...in circumstances such as those which underlie the main proceedings...'. The German law as it stood and applied to the years in dispute did not allow Germany to tax profits attributable to a foreign permanent establishment. Whether Germany would be obliged to allow a relief of foreign losses against 
domestic income pursuant to EU law is a separate question which has to be assessed against the background that Germany's decision to not tax (i.e. exempt) foreign profits is to be respected. Therefore, there would be risk of double loss relief - and the restriction in issue was suited to pre-empt that risk-unless Germany would change its national law and the interpretation of the DTC to allow it to recapture a previously granted loss relief by assuming effective fiscal jurisdiction on foreign profits. The Lidl Belgium ruling simply established that Germany could not be so obliged by EU law. This amicable reading seems to be the best interpretation of Lidl Belgium.

Finally, although the Court cited Marks \& Spencer in Papillon, the Court rejected that there was a risk that losses would be used twice in the latter case, because Papillon was not concerned with the relief of foreign losses (paras 3839). Papillon thus clarifies that there is only a legitimate larger concern of government if the same losses are at risk and taken into account twice and that two different Member States would take into those same losses. It is however not necessary that the losses are used twice by the same company. Sameness of losses thus implies a single source, i.e. losses which legally belong to one and the same establishment which are however potentially relieved in two Member States. This interpretation is consistent with the Court's approach in Marks \& Spencer, Rewe Zentralfinanz and Lidl Belgium.

\subsubsection{Synthesis and discussion}

Notwithstanding that the scope of the double loss relief rule is quite clear after Papillon, its theoretical foundation as a justification ground in EU law remains obscure. Even if Lidl Belgium is read amicably, the case law does not explain why double use of losses is a 'bad thing' in EU law. What is the reason for this rule of reason?

Obviously, the danger identified by the Court is not that one Member State would take into account the same losses twice. As Papillon clarifies, this risk is a matter of cohesion of the tax system. The Court also did not aim to make a point that the UK in Marks \& Spencer and Germany in Lidl Belgium could never be obliged to take into account the losses of the foreign secondary establishment. To the contrary, the rule of Marks \& Spencer and Lidl Belgium is that EU law can oblige Member States to relieve foreign losses. What remains from the double use of losses as a relevant point in law is therefore not the position of the Member States, but only the position of the corporate taxpayer, or the tax relevant group of companies.

The analysis of the case law showed that the double use of losses justification is specifically geared towards national provisions concerning relief of operating losses of businesses. The scope of application of the rule appears to be too limited to make analogous application possible to other types of restrictions different from those at issue in Marks \& Spencer and Lidl Belgium.

If a general theoretical argument should however be proffered, the most plausible interpretation is that EU law does not oblige Member States to extend their national laws in a way that would result in free moving citizens in fact to 
be treated more favourably than domestic citizens. ${ }^{661}$ The rule of reason is then that the free movement rights as non-discrimination clauses do not purport to bestow additional benefits on Union citizens, but only function to take away comparative disadvantages. It is then perhaps more helpful to consider this rule as a limit to the scope and definition of the private right to free movement, instead of a public interest justification for an infringement of that right, particularly so given the Court's failure to identify a discrete public interest in the first place.

It is however difficult to apply this interpretation in cases in which no legitimate larger aim of government justifies the disadvantage posed by the restriction at issue. If there is no other justification, the risk of double use of losses would justify a discrimination against free movement because not applying national conditions or provisions that pose blanket restrictions would result in reverse discrimination. The proportionality of this outcome is not selfevident. Why would negative discrimination of free movers be preferable over positive discrimination of free movers in EU law? The Court indeed addressed the issue of proportionality in Marks \& Spencer and Lidl Belgium by the rule of 'final losses' - see Chapter 8 below for analysis - but there is no agreement in prior research on the correctness of the Court's approach. Furthermore, Chapter 9 asserts that the Court erred on this point. Particularly the critics of the Marks \& Spencer ruling draw attention to the argument that, although a double use of losses should be prevented, the Court's judgment adjudged a significant cashflow inequality between domestic and foreign groups of companies as lawful. ${ }^{662}$

Advocate General Sharpston also explicitly criticised the Court in her opinion in Lidl Belgium on this point, but the Court declined the invitation to overrule Marks \& Spencer in this regard as we have seen above.

The problem of potential reverse discrimination by lifting the restriction could explain why the Court chose the unusual 'taken together' justification approach in Marks \& Spencer and Lidl Belgium. The line of reasoning on justification is then that the comparative disadvantage of the refusal of a relief of losses as such is justified by safeguarding a balanced allocation of taxing powers between the Member States. The risk of a double use of losses in turn legitimises the categorical denial of benefits instead of requiring a case-by-case analysis by the Member States.

The principle of proportionality is then interpreted as follows. Despite the fact that a blanket restriction may be principally lawful, there should however be room for an exception to the rule on the basis of the facts of the case. A situation in which an exception should be granted is when relief of a disadvantage in law is not liable to turn into an undue advantage in fact, i.e. there is no real risk of double loss relief. The rulings in Marks \& Spencer and Lidl Belgium award the Member States the benefit of the doubt and the taxpayer has the burden of proof that there is no risk of reverse discrimination in the specific case by showing that 
the losses for which he seeks relief are 'final' as defined in Marks \& Spencer, para 55.

Only the absence of a risk of double losses in the actual case at hand gives legal room of manoeuvre to review the proportionality of the cash-flow disadvantage itself. That approach pre-empts that comparative advantages would generally follow from the application of EU law if the cash-flow inequality was found to be disproportionate - which it is on basis of Marks \& Spencer, para 55. The proportionality of this disadvantage has to be adjudged against the need to maintain a balanced allocation of taxing powers, since this was the justification for that restriction. The Court's approach to proportionality will be discussed in Chapter 8 below. It is consistent with the interpretation given here.

The above line of reasoning would place the double use of losses justification conceptually very far from the balanced allocation of taxing powers between the Member States because each serves a different interest. The latter standard without a doubt protects a public interest of Member States and considers only the consequences of relief on the government's ability to levy tax in assessing the lawfulness of a tax restriction under EU law. In contrast, the former rule only takes into account the effects of relief on the taxpayer's position.

Because this line of reasoning provides a plausible theoretical foundation to the case law and is consistent with the results of that jurisprudence, we shall accept it as true.

To take a brief tangent to personal income taxation might clarify the preceding discussion a bit further. In Schumacker the Court held the situation of resident private individuals to be generally incomparable with the situation of non-resident taxpayers. We have see in Chapter 4 that it is disproportionate to withhold benefits relating to general ability to pay to non-resident taxpayers who could not have their ability to pay, and/or family and personal circumstances taken into account in their Member State of residence. ${ }^{663}$

Schumacker is to be read as follows in this context. First, there is clearly a potential of discrimination against non-nationals if a Member State does not grant personal and family benefits to non-resident taxpayers, or otherwise fails to consider their ability to pay. Second, because the removal of this possibility of discrimination entails the risk that the Union citizen enjoys an undue advantage (the risk that ability to pay might be taken into account twice) due to his exercise of freedom of movement, the Member States are only obliged to act against discrimination that arises in fact, so to ensure that the free moving taxpayer will not enjoy an advantage vis-à-vis internal situations. Discrimination only 'arises' in the end when neither the resident Member State, nor the host Member State takes account of the taxpayer's ability to pay (Schumacker, para 38 ), so when an undue advantage is positively excluded.

The Schumacker case essentially follows the same line of argumentation as Marks \& Spencer. Both judgments can be broken into two basic steps of reasoning. In the first step, blanket discrimination in national legislation against 
the exercise of freedom of movement is justified. In Marks \& Spencer this justification was essentially the BAOTP standard and in Schumacker the situations were not found objectively comparable at the outset. The second step relates to the circumstances of the individual taxpayer who makes the claim and ultimately only establishes a finding of discrimination when the free moving citizen in the case at hand cannot enjoy an undue advantage in comparison to internal situations. In Marks \& Spencer that is when losses cannot be used in the Member State of the secondary establishment and in Schumacker that is when the principle of ability to pay would not be considered by the taxpayer's Member State of residence due to insufficient tax liability.

The conclusion on the relation between the balanced allocation of taxing powers and the risk of double use of losses is consequently the following. The risk of double use of losses is an argument that considers the position of the taxpayer, not the effects to government. The aim is to withhold undue advantages which free moving citizens might enjoy by successfully relying on EU law in comparison with internal situations. The Court's doctrine pre-empts that relief of discrimination against the exercise of freedom of movement turns into a subsidy on free movement. Therefore, it can only counteract the unlawfulness of a blanket restriction on free movement if the disadvantage posed by that restriction is also justified independently by a genuine overriding reason in the public interest. ${ }^{664}$ The Court recognised the preservation of a balanced allocation of taxing powers between the Member States as a legitimate larger aim of government in this context in Marks \& Spencer and Lidl Belgium. This reading does not rule out that other justification grounds may be recognised in similar circumstances in place of the BAOTP standard, but the case law which we reviewed does not provide direct evidence for an alternative justification.

\subsection{Relation with the prevention of tax avoidance}

\subsubsection{Introduction}

The need to preserve the balanced allocation of taxing powers between the Member States and the need to prevent the risk that losses might be used twice were considered as justifications by the Court in conjunction with the UK's submission that allowing the restriction in issue in Marks \& Spencer would entail a risk of tax avoidance if losses would not be taken into account in the

664 The Court held in its 2012 judgment in Philips Electronics (C-18/11), para 33: 'The host Member State, in whose territory the permanent establishment is situated, therefore cannot, in order to justify its legislation in a situation such as that in the main proceedings and in any event, plead as an independent justification the risk of the double use of losses.' (emphasis added). 
Member States of the subsidiaries. The Court allowed the UK's defence and held:

49. As regards, last, the third justification, relating to the risk of tax avoidance, it must be accepted that the possibility of transferring the losses incurred by a non-resident company to a resident company entails the risk that within a group of companies losses will be transferred to companies established in the Member States which apply the highest rates of taxation and in which the tax value of the losses is therefore the highest.

50. To exclude group relief for losses incurred by non-resident subsidiaries prevents such practices, which may be inspired by the realisation that the rates of taxation applied in the various Member States vary significantly.

The Court did not identify in this passage which Member State's tax was avoided. It merely highlighted that significant tax rate disparities provide an incentive to relieve losses against the highest tax value. The Court cited this passage, particularly para 49 of Marks \& Spencer, in three subsequent judgments. In Lidl Belgium the Court paraphrased the national court's preliminary question whether the justification analysis of Marks \& Spencer, paras 44-50, was a cumulative enumeration, and the 'taken together' conclusion of Marks \& Spencer, para 51 should be understood as such, or-alternatively - each of the three grounds could hypothetically justify the restriction severally. This aspect of Marks \& Spencer was already discussed in Section 7.2.3 above. Lidl Belgium however does not interpret Marks \& Spencer, paras 49 and 50 specifically.

There are two judgments in which the Court specifically interpreted para 49 of Marks \& Spencer, and they did so by analogy. These are the rulings in Cadbury Schweppes and Thin Cap Group Litigation (C-524/04). Both cases clarify that the Court's understanding of tax avoidance behaviour is that such private conduct, if not prevented, undermines the right of the Member States to levy taxes normally due on income from activities in the Member States' territory. This coheres with Rule 4:5 of Annex A. Thus, the result of successful tax avoidance seems that the balanced allocation of taxing powers between the Member States is jeopardised. Consequently, the need to combat tax avoidance and the need to safeguard a balanced allocation of taxing powers between the Member States might relate to the same larger aim of government; the same overriding reason in the public interest. Both justifications might therefore be indistinguishable on a higher level of abstraction. This is the central hypothesis that will be analysed in this Section.

Assuming a significant overlap between the two justification grounds, it would not be legally inconsistent if the Court relied on tax avoidance precedent to argue the balanced allocation of taxing powers justification, and vice versa. The network analysis however shows that both classes of cases belong to separate communities of the Marks \& Spencer network of Chapter 5. This indicates that the Court cites precedent selectively and thus distinguishes between the grounds on application to the cases at hand. This finding suggests that the prevention of tax avoidance is a specific rule with specific conditions, 
notwithstanding the possibility that it relates to the balanced allocation of taxing powers at a higher level of abstraction.

Table 23 in Section 7.2.1 already showed that the potential difference did not result in different outcomes for both justification grounds, except in National Grid Indus. This begs the question, if the public interest protected really is the same, what is the legally relevant difference between tax avoidance and the balanced allocation of taxing powers justifications, and how can this difference be explained?

A legal analysis of the tax avoidance cluster of cases in community 1 that contains Marks \& Spencer, paras 49, 50 and 57, is necessary to determine what conditions the Court needs to see fulfilled before it allows a restriction against the freedom of movement by reason of the need to prevent tax avoidance. This also requires looking at communities 2, 3 and 7, because these are directly connected to community 1 .

\subsubsection{EU law cannot be relied upon for abusive or fraudulent ends}

The case law of community 2 established that EU law cannot be relied upon for abusive or fraudulent ends. This means, according to the wording of Centros (C212/97), para 24, that Member States are entitled to 'take measures designed to prevent certain of its nationals from attempting, under the cover of the rights created by the Treaty, improperly to circumvent their national legislation or to prevent individuals from improperly or fraudulently taking advantage of provisions of Community law'. This line of authority descending from the Van Binsbergen (33/74) ruling of 1974 as a case of first impression has since been applied consistently in various fields of law. Whether the Court spoke of 'avoiding...rules' in Van Binsbergen, para 13 and Veronica (C-148/91), para 12, of 'attempting wrongly to evade' in Knoors (115/78), para 25, of 'circumvent legislation' in Leclerc (229/83), para 27), of 'abuses' in Lair (39/86), para 43, of 'attempting to evade' in Bouchoucha (C-61/89), para 14), of 'not realised as bona fide commercial transactions but only in order wrongfully to benefit' in General Milk Products (C-8/92), para 21, of 'wrongfully to avoid' in TV10 (C23/93), para 21, or simply of 'abuse' as it did in Paletta II (C-206/94, para 24) all of these qualifications were in later case law referred to jointly as 'abuse or fraudulent conduct'. This occurred first in Paletta II, para 25 and was shortly thereafter confirmed in Kefalas (C-367/96), para 20 and then again Centros, para 25 . The extensive citations of the above mentioned precedents, which were decided in various fields of law, in these latter three cases is clear evidence of an intentional judicial codification effort that culminated in Centros.

What we see is that the Court consolidated a seemingly heterogeneous case law collection into a coherent standard of EU law. The simple idea of Van Binsbergen that U-turn arrangements which improperly escape the ambit of national rules that are imposed for the general good must be prevented has emerged, through repeated application by analogy in subsequent cases, as a broad standard of EU law that acknowledges the Member States' general interests in combating abuse or fraud. 
The effect of this standard is that EU law is involved in relation to national rules that regulate situations of abuse or fraud if the formal requirements of application of EU law are observed by, for example, lawfully incorporating a company under foreign law (Centros, para 18), but that the benefits of the EU law provisions which a person claims may be denied on a case-by-case basis if abuse or fraud has been established on the basis of objective evidence and assessed in the light of the objectives pursued by those provisions in the case at issue (Centros, para 25). For these reasons this standard is best conceived as a justification; in service of the general good that national law is observed by all persons to whom it is intended to apply, the protection normally afforded by the Treaty provisions on freedom of movement may be withheld after all objective circumstances and interests have been considered and have been weighed.

What the Van Binsbergen-Centros line of authority did not do was to provide us with a general definition of abuse. The Court only remarked in Centros that the establishment of a company in a Member State could not, in itself, constitute abuse if that company did not pursue economic activities in that Member State, but only did (or intended to do) so by a branch established in another Member State (paras 26-29, citing Segers (79/85), para 16).

This remark was recalled again in $X$ and $Y(\mathrm{C}-436 / 00)$. The restriction at issue in this case was that the national provisions denied a deferral of tax for a transfer of shares only in situations in which the freedom of establishment was clearly exercised. The Swedish government argued that its national provisions restricting free movement were justified because of reasons of effective fiscal supervision, cohesion of the tax system and because they combated tax avoidance (paras 24, 25, and 40). ${ }^{665}$ Tax avoidance was relied on first, because the freedom of establishment would be abused in this case since the intention to obtain a deferral of tax on capital gains upon a transfer of shares was, according to the Swedish tax authority, the only reason for that transfer. Second, the Swedish government submitted that the risk of tax avoidance inherent to the

It should be noted that only para 25 reads 'tax avoidance' in English. Evidently, the terms 'tax avoidance' and 'tax evasion' were used interchangeably by the Court. Moreover it is common knowledge that the legally confusing interchangeable use of the terms (lawful) 'tax avoidance' versus (unlawful) 'tax evasion' (and also 'tax fraud') in the English translations of the rulings is probably due to fact that tax avoidance is correctly translated into French as 'évasion fiscale' and tax evasion is translated as 'fraude fiscale'. The French text of $X$ and $Y$, paras 25, 40, 60 and 62 consistently refers to 'évasion fiscale', implying abuse but not illegal conduct. Since the defence of the Swedish government was based on the Van Binsbergen-Centros line of authority, this semantic ambiguity is excusable since it effectively is irrelevant as regards the standard set by that case law. The standard applies irrespective of whether the person's conduct only wrongfully violates the legislator's intentions, but stays within the black letter boundaries of the law (abuse), or falls beyond those outer limits and amounts to illegal conduct (fraud). 
situations to which the national rules applied could justify the restriction at issue (para 40).

In response to the first part of that submission, the Court held that the denial of a tax deferral on capital gains upon a transfer of shares solely on grounds that this transfer related to a situation in which the freedom of establishment was exercised could not be justified on the ground of abuse of freedom of establishment (paras 44 and 45). In response to the second argument, the Court held:

60. Next, as regards the justification cited by the Riksskatteverket based on the risk of tax [avoidance] and that relating to effectiveness of fiscal supervision, it is to be noted, at the outset, that, in the light of the objective pursued by the national provision at issue here, those justifications overlap. In fact, the provision in question seeks to ensure both the effective taxation of the gains concerned and the effectiveness of the supervision of such taxation.

61. The provision at issue here is not specifically designed to exclude from a tax advantage purely artificial schemes designed to circumvent Swedish tax law, but concerns, generally, any situation in which, for whatever reason, the transfer at undervalue is to a company established under the legislation of another Member State or a branch set up in the Kingdom of Sweden by such a company.

62. However, tax [avoidance] or tax fraud cannot be inferred generally from the fact that the transferee company or its parent company is established in another Member State and cannot justify a fiscal measure which compromises the exercise of a fundamental freedom guaranteed by the Treaty (see, to that effect, Case C-478/98 Commission v Belgium [2000] ECR I-7587, paragraph 45).

63. In any event, the measure implemented by the Kingdom of Sweden is not capable of achieving the objective it is supposed to pursue, that is to say, ensuring that the transferor is actually taxed in Sweden on gains made on shares transferred, particularly if the transfer is made prior to his definitive move abroad. [...].

The Court used the same argument here as it did to reject the first part of the tax avoidance argument in paras 42-45; abuse or fraudulent conduct cannot be assumed only on the basis that the right to free movement was exercised. It is clear that the benefits of EU law may only be denied if the situation amounts to a wholly artificial arrangement.

It is noted that the Louvain grouped $X$ and $Y$, paras 42-45, in community 2 of the Van Binsbergen-Centros line of authority and placed paras 60-63 of that judgment in community 1 on tax avoidance in which paras 49, 50 and 57 of Marks \& Spencer are also grouped. We will see that the Court would tie together these grounds in Cadbury Schweppes when it would refer to Centros in the context of wholly artificial arrangements and the prevention of tax avoidance 
as a justification. The concept of wholly artificial arrangements was introduced a few years earlier.

\subsubsection{Wholly artificial arrangements}

The 1997 ruling in Leur-Bloem (C-28/95) and the 1998 judgment in ICI (C264/96) are the origins of the community 1 concept of wholly artificial arrangements in the context of the prevention of tax avoidance. The rules of these cases are strongly related, but the Court waited for De Lasteyrie du Saillant to finally merge these lines of authority.

Leur-Bloem, para 44 established that Member States may not apply a general rule on the basis of predetermined criteria which automatically denies certain types of situations from the benefits granted by EU law, irrespective of whether there is tax avoidance or evasion in fact. In the case at hand it concerned a denial of a deferral of tax upon reorganisation by an exchange of shares as provided for in the Mergers Taxation Directive (2009/133/EC). The Court would later rephrase the rule as follows in Commission v Belgium (C-478/98), para 45:

45. As appears from [Leur-Bloem, para 44], a general presumption of tax [avoidance] $^{666}$ or tax fraud cannot justify a fiscal measure which compromises the objectives of a directive. That applies all the more in the present case, where the contested measure consists in an outright prohibition on the exercise of a fundamental freedom guaranteed by [Article 63 TFEU].

The issue in Commission v Belgium was that Belgium prohibited resident private investors from acquiring securities in a loan issued abroad on the Eurobond market. The Belgian government waived withholding tax on this Eurobond loan. The prohibition at issue safeguarded, according to the Belgian government, that resident private investors could not escape withholding taxes normally due on interest received on bonds by acquiring securities in the Eurobond loan. The Court however noted that '... nothing prevents Belgian residents wishing to invest from acquiring loan securities issued on the Eurobond market by issuers other than the Kingdom of Belgium which are also not subject to Belgian withholding tax'(para 46). Therefore, the Court held in Commission v Belgium that a general and ill-founded presumption of tax avoidance or evasion which resulted in an outright prohibition on the free movement of capital by Belgian residents could not be justified. Accordingly, the Leur-Bloem precedent is limited to the rule that a general presumption of tax avoidance (or tax evasion) cannot justify restrictions on free movement.

In $I C I$, paras 26 and 27 the Court held:

26. As regards the justification based on the risk of tax avoidance, suffice it to note that the legislation at issue in the main proceedings does not have the

666 Again, the English translation reads 'evasion' where 'avoidance' would be the correct translation of the French text. 
specific purpose of preventing wholly artificial arrangements, set up to circumvent United Kingdom tax legislation, from attracting tax benefits, but applies generally to all situations in which the majority of a group's subsidiaries are established, for whatever reason, outside the United Kingdom. However, the establishment of a company outside the United Kingdom does not, of itself, necessarily entail tax avoidance, since that company will in any event be subject to the tax legislation of the State of establishment.

27. Furthermore, the risk of charges being transferred, which the legislation at issue is designed to prevent, is entirely independent of whether or not the majority of subsidiaries are resident in the United Kingdom. The existence of only one non-resident subsidiary is enough to create the risk invoked by the United Kingdom Government.

The Court established the concept of 'wholly artificial arrangements' in ICI. This ruling implies that considerations of tax avoidance and evasion may only justify restrictions which specifically target wholly artificial arrangements. The establishment of a company in another Member State was held insufficient in itself to establish such an arrangement. Therefore, the restrictions in UK law which applied generally in any situation in which a UK parent company established a subsidiary in another Member State could not be accepted, according to the Court's view. We have seen that a virtually identical reasoning would be applied a short year later in the Centros ruling in 1999. The ICI ruling would be cited as precedent in this context first in Metallgesellschaft and Others \& Hoechst (Joined Cases C-394 \& C-410/98), para 57, reproducing the Court's holding of $I C I$, para 26 verbatim. The lack of a proven wholly artificial arrangement in the actual case in the main proceedings, but the application of a general restriction aimed to combat tax avoidance were material reasons why Germany failed to fulfil its obligations in Lankhorst-Hohorst (C-324/00) by only applying its thin capitalisation rules to situations in which the freedom of establishment was exercised (paras 37 and 38). Accordingly, the ICI precedent established the rule that restrictions which are limited to wholly artificial arrangements may be justified on grounds of tax avoidance (or evasion), but general presumptions are disproportional.

As we have seen above, the Court employed the same reasoning in $X$ and $Y$ and even noted that the restriction at issue in that case was not specifically designed to exclude 'purely artificial schemes' (para 61) from tax advantages, but rather amounted to a general presumption of tax evasion in free movement situations. It is observed however, that the Court did not cite the ICI line of authority, but based its judgment on Commission $v$ Belgium which in turn relied on Leur-Bloem in this regard. ${ }^{667}$

667 The difference in wording between the 'purely artificial schemes' of $X$ and $Y$ and the 'wholly artificial arrangements' of ICI can be attributed to an inconsistent translation from French. The French versions of both rulings read 'les montages purement 
The evident substantive overlap between Leur-Bloem and ICI also became clear to the Court in 2004 when it merged the rules established in those precedents in the judgment of De Lasteyrie du Saillant (C-9/02). That case concerned an exit tax upon a transfer of residence from France to another Member State, motivated by the French legislator solely on grounds of prevention of tax avoidance and evasion. The Court ruled that a general presumption of tax avoidance or evasion based on the exercise of the right to free movement 'for any reason whatever' could not justify the exit tax, since it was not specifically designed to apply only to wholly artificial situations (paras 50 and 51).

The rule was repeated in Marks \& Spencer, para 57 as matter of proportionality:

57. It is also important, in that context, to make clear that Member States are free to adopt or to maintain in force rules having the specific purpose of precluding from a tax benefit wholly artificial arrangements whose purpose is to circumvent or escape national tax law (see, to that effect, ICI, paragraph 26, and De Lasteyrie du Saillant, paragraph 50).

The legal situation that existed directly after Marks \& Spencer was now the following. First, the Court recognised the broad-spectrum Van Binsbergen-Centros line of authority, meaning that benefits of EU law may be denied in situations of proven abuse or fraudulent conduct (community 2). Second, in the field of direct taxation, the case law evolved the Leur-Bloem-ICI line of authority in parallel, meaning that disadvantageous tax treatment of free movement situations may be justified if the national measure specifically targets wholly artificial arrangements, but not if the exercise of the right to free movement is used as a general presumption of tax avoidance or evasion (community 1). We have also seen that the reasoning of the Court in those two lines of authority is identical.

The ambiguity that Marks \& Spencer introduced was that the need to combat tax avoidance was 'taken together' with the need to preserve a balanced allocation of the power to impose tax between the Member States in the justification analysis. As we have seen in the review of prior research in Chapter 5 , it is particularly questioned why a general rule which denied tax benefits only on the basis of an exercise of free movement, like the one at issue in Marks \& Spencer, could be justified by the need to prevent tax avoidance. The national provisions at issue in Marks \& Spencer, so it was argued, rather amounted to a general presumption of tax avoidance, instead of being specifically designed to apply only to wholly artificial arrangements. Moreover, there is no clear positive statement of the Court in Marks \& Spencer that the denial of group relief in cross-border situations actually targeted abuse or fraudulent conduct only. In any case, paras 49 and 50, cannot be interpreted to this effect, even on the most harmonious reading of the Court's reasoning. There seems to be an internal

artificiels'. This French formula was also translated into English as 'purely artificial contrivances' in Commission v Italy (C-540/07), para 58. 
contradiction between para 57 (requiring a wholly artificial arrangement) and paras 49 and 50 (describing merely a tax planning incentive) of Marks \& Spencer. Consequently, it seemed that the conjunct application with the balanced allocation of taxing powers purported to fill this gap in the Court's reasoning.

The Court's judgment in Cadbury Schweppes, however, and the rulings that followed, provided clarity on three important issues. As we will see below, Cadbury Schweppes would explicitly link the Van Binsbergen-Centros line of authority with the Leur-Bloem-ICI case law. In other words, a wholly artificial arrangement amounts to abusive or fraudulent conduct and may therefore be denied the benefits of EU law. With Cadbury Schweppes, the Court openly embedded a seemingly distinct branch of judicial doctrine in the field of direct taxes within the larger body of judicial EU law.

Second, Cadbury Schweppes would establish that the defining nature of such conduct is to jeopardise the balanced allocation of the power to impose taxes between the Member States.

Third, Cadbury Schweppes determined what standard of proof EU law requires to successfully invoke the justification of the prevention of abusive arrangements with reference to a line of authority starting with Emsland-Stärke (community 7).

Cadbury Schweppes concerned the application of the UK CFC legislation to a UK parent company of a subsidiary established in Ireland. Due to a lower level of taxation and the activities of that subsidiary in Ireland, the parent company was attributed the profits earned by its Irish subsidiary and the parent company was assessed and charged with UK corporation tax on those profits. Since UK parent companies of UK subsidiaries did not fall within the scope of application of the CFC rules - and UK parent companies were thus not charged with corporation tax on the income of their UK subsidiaries - the Court found that freedom of establishment was restricted by those rules (paras 44-46).

Before finding that restriction, the Court first generally noted, referring to the Van Binsbergen-Centros line of authority, that the fact that a company has established a subsidiary in another Member State solely for the purpose of benefitting from the more favourable tax regime of that other Member State did not, in itself, constitute an abuse of freedom of establishment or prevent a Union citizen from relying on the right to free movement. The legal act of establishing a subsidiary under Irish company law was sufficient for the UK parent company to have complied with the formal conditions of Article 49 TFEU (paras 34-38).

After finding a restriction of the right guaranteed by Article 49 TFEU, the Court started its tax avoidance justification analysis in Cadbury Schweppes by referring to the Leur-Bloem-ICI line of authority and held:

50. It is also apparent from case-law that the mere fact that a resident company establishes a secondary establishment, such as a subsidiary, in another Member State cannot set up a general presumption of tax evasion and justify a measure which compromises the exercise of a fundamental freedom guaranteed by the Treaty [citations omitted]. 
51. On the other hand, a national measure restricting freedom of establishment may be justified where it specifically relates to wholly artificial arrangements aimed at circumventing the application of the legislation of the Member State concerned [citations omitted].

We see a similar pattern of reasoning in Cadbury Schweppes as in $X$ and $Y$. First the Court recalls the Van Binsbergen-Centros rule, then secondly examines the existence of a prima facie restriction, and thirdly analyzes whether the prevention of tax avoidance may justify that restriction. The arguments that the Court applies in the first and third step are however indistinguishable.

This became unmistakably clear in Cadbury Schweppes when the Court continued its justification analysis. It held:

52. It is necessary, in assessing the conduct of the taxable person, to take particular account of the objective pursued by the freedom of establishment (see, to that effect, Centros, paragraph 25, and $X$ and $Y$, paragraph 42).

Paragraph 42 of $X$ and $Y$ cited by the Court was part of the first step of the Court's analysis as set out in the previous paragraph on the scope of the freedom of establishment. In other words, the legal examination to be performed by the national courts is essentially the same for finding an abuse of the right of free movement and for testing the tax avoidance justification. There is thus only one question in substance: may the protection of EU law be denied in the specific circumstance of a case due to abusive or fraudulent conduct on part of the taxpayer? In Centros, para 25 and $X$ and $Y$, para 42 the Court instructed the national courts as follows:

In that regard, the national courts may, case by case, take account - on the basis of objective evidence - of abuse or fraudulent conduct on the part of the persons concerned in order, where appropriate, to deny them the benefit of the provisions of [EU law] on which they seek to rely, but they must nevertheless assess such conduct in the light of the objectives pursued by those provisions.

Cadbury Schweppes accordingly established that wholly artificial arrangements amount to abuse or fraudulent conduct. In paragraph 55 of the Cadbury Schweppes judgment, the Court would indeed refer to a wholly artificial arrangement as an abusive practice.

Until the judgment in Cadbury Schweppes the above instruction from Centros was usually the point at which the Court apparently decided to have provided sufficient interpretative guidance to the national court on EU law. In previous direct tax case law, the national provisions at issue would evidently not provide the possibility of an individual examination of the case at hand and all were consequently disproportional since they were categorical, or blanket restrictions on free movement. However, the Court continued in Cadbury Schweppes with relating the right of Member States to combat tax avoidance to the objective of freedom of establishment. 
In that regard, the Court relied on its landmark precedents of Reyners (2/74), Gebhard (C-55/94), Factortame II (C-221/89), and Commission v UK (C246/89) to define that purpose. According to Cadbury Schweppes, paras 53 and 54, those precedents established that the rights granted by freedom of establishment (i) aim to assist economic and social interpenetration within the Union and to that end, (ii) allow a Union citizen to participate, on a stable and continuous basis, in the economic life of another Member State other than his Member State of origin and to profit there from, and therefore (iii) the Treaty concept of establishment presupposes actual establishment of the company concerned in the host Member State and the pursuit of genuine economic activity there.

The Court's conclusion in Cadbury Schweppes was consequently that:

55. [...] in order for a restriction on the freedom of establishment to be justified on the ground of prevention of abusive practices, the specific objective of such a restriction must be to prevent conduct involving the creation of wholly artificial arrangements which do not reflect economic reality, with a view to escaping the tax normally due on the profits generated by activities carried out on national territory.

A wholly artificial arrangement is not an actual establishment in another Member State because no economic activity is pursued in that host Member State. A restriction of free movement may be justified on the ground of prevention of abusive practises if the national provisions are specifically designed to prevent that an arrangement is set up with a view to circumvent the tax laws of the Member State concerned.

The paragraph 55 definition of an abusive practice in Cadbury Schweppes has however a threefold implication. It first implies that real economic activity is carried out on the national territory of the Member State concerned. Second, it implies that this activity is attributed in law to a company which is established in another Member State. And third, the definition assumes that the establishment in this other Member State served no other purpose than to circumvent taxation of that activity in the Member State concerned. It is important to realise that the Court's overall tacit premise is that the undertaking in fact conducts an economic activity. If no economic activity is carried out at all, there can also be no profits and consequently no taxes which are allegedly avoided. The point is that a subsidiary is (ab)used to bring profits from economic activities outside the taxing jurisdiction of a Member State, whereas these activities would be subject to that Member State's taxing jurisdiction if they would be attributed to the parent company. The Court's description of a wholly artificial arrangement in Cadbury Schweppes is reminiscent of the U-turn arrangement in Van Binsbergen. The Court introduced the abuse of law standard in EU law in Van Binsbergen, para 13 as follows:

13. Likewise, a Member State cannot be denied the right to take measures to prevent the exercise by a person providing services whose activity is entirely or principally directed towards its territory of the freedom guaranteed by 
[Article 56 TFEU] for the purpose of avoiding the professional rules of conduct ['justified by the general good', see para 12] which would be applicable to him [and 'are binding on any person established in the state in which the service is provided', see para 12] if he were established within that state [...].

With the benefit of hindsight, the essence of the Grand Chamber's 2006 judgment in Cadbury Schweppes was already implied in the ruling delivered 32 years earlier in Van Binsbergen. The evolution that the Van Binsbergen rule has undergone during this period gave content and specified its requirements of application to emerge as a general standard of EU law which also applies in the field of direct taxation.

We have seen that the 'general good' protected by the BAOTP standard was the legitimate right of Member States to tax economic activities undertaken in their national territory. If this taxing competence of the Member States and the taxation obligations they imposed by exercising that competence would be circumvented by a person through setting up a wholly artificial arrangement, we have seen that the Court held in Cadbury Schweppes that this person may not retain the benefits of EU law.

The Court thus defined a wholly artificial arrangement in Cadbury Schweppes as an abuse of the right to free movement if it is set up to jeopardise the balanced allocation of the power to impose taxes between the Member States. Only against this conduct may Member States justifiably take specifically designed countervailing measures. The Court would also instruct the national court in Cadbury Schweppes as to which standard of proof is sufficient for a finding of abuse.

\subsubsection{The Emsland-Stärke standard of proof}

The standard of proof on abuse of law as developed in Cadbury Schweppes, paras 64-71, borrows its authority from the community 7 case law of EmslandStärke and Halifax (C-255/02). This case law laid down a two-step test that must be carried out to find an abuse. First, a combination of objective circumstances must show that the purpose of the provisions of EU law has not been achieved, despite formal observance of their conditions (Emsland-Stärke, para 52; and Halifax; para 74). Second, the existence of a subjective element must be shown - again on the basis of objective factors which are ascertainable by third parties - consisting of the intention to obtain a (tax) advantage (Emsland-Stärke, para 53; and Halifax, para 75).

Although the Court presents the standard as consisting of two distinct elements, it is also evident from the case law that each individual situation as a whole should be adjudged. In Emsland-Stärke, para 53, the Court suggested that the subjective element would amount to artificially creating the conditions of the provisions which confer the advantage. Collusion between exporter and importer was suggested as an objective indication of the subjective element by the Court (Emsland-Stärke, para 53). Artificial creation of conditions is simply a restatement of the finding that the conditions of the law have been formally 
observed, but have not been observed in fact. That implies that the legal transaction was not realised as a bona fide commercial transaction and, consequently, the purpose of the law has not been achieved (see, EmslandStärke, para 51). The Court thus suggested looking for a commercial basis to the agreement between exporter and importer.

In Halifax the Court stated that an abuse could only be found if the 'essential aim' of the transactions was the accrual of the tax advantage provided by EU law, but that transactions which may be explained by other reasons are not abuses (Halifax, para 75). Again, if there is a valid commercial justification for the transaction, then it is difficult to argue that formal observance of the law has been achieved artificially and the conferral of the advantage is against the law's purpose.

In short, the Court's standard seems a bit circular at first sight. But, circularity does not depreciate the rule's persuasive force. The two elements rather reinforce and clarify each other. Both express the Court's central concern that a finding of abuse requires an individual analysis of each case and of the specific circumstances in each individual case. This paraphrases the Court's Centros, para 25, holding that national courts should do case-by-case examinations, on the basis of objective evidence, of abuse or fraudulent conduct.

We see this central concern clearly in Cadbury Schweppes. In this case, the Court was not so much concerned with the taxpayer's subjective intentions. Yes, the Court repeated that a finding of abuse requires that a tax motive must be shown (Cadbury Schweppes, para 64), but focused its interpretation of EU law fully on the first element of the test; the question in which circumstances is there a wholly artificial arrangement.

A wholly artificial arrangement is the situation when incorporation in another Member State does not correspond with an actual establishment intended to carry on genuine economic activity in the host Member State (Cadbury Schweppes, para 65). Such a 'fictitious establishment' is a wholly artificial arrangement (Cadbury Schweppes, para 68). In this regard, the Court particularly referred in Cadbury Schweppes, para 68, to 'letterbox' or 'front' subsidiaries as defined in the Grand Chamber precedent of Eurofood IFSC (C$341 / 04)^{668}$

According to the ruling in Eurofood IFSC, paras 34 and 35, there is a presumption in EU law - in the context of EU level conflict of laws rules for insolvency proceedings - that the centre of main interests of a company is the place where it has its registered office. A 'letterbox' company however, does not carry out any business in the territory of the Member State in which its registered office is situated (Eurofood IFSC, para 35). In that case, the

Since Eurofood IFSC only refers to a 'letterbox' company, the word 'front' should be interpreted as a synonym for 'letterbox' and not as a distinct situation. A search in EUR-Lex for citations to Eurofood IFSC in the collection of judgments delivered by the Court of Justice also provided 'brass plate' company as additional synonym, see Planzer (C-73/06), para 62 on the interpretation of the place of business in VAT law. 
presumption in favour of the registered office can be rebutted if it is shown by objective circumstances to be ascertainable by third parties that the centre of main interests in actually in another Member State.

The VAT case law of the Court might be applied in analogy to the field of direct taxation. In order to establish a place of business for VAT purposes, the Court held in Planzer, with reference to Cadbury Schweppes, that this concept did not include the Eurofood IFSC type of 'fictitious presence' (para 62). For VAT purposes, one needs to ask primarily whether the place of the company's registered office coincides with the place of its central administration, the place where its directors meet and the place where the general policy of that company is determined. If so, the Planzer judgment implies that the place of business is in the Member State in which the company has its registered office. Another set of secondary indicators may also be used, such as the place of residence of the main directors, the place where general meetings are held, the place where administrative and accounting documents are kept, and the place where the company's financial, and particularly banking, transactions mainly take place (para 61). Thus, according to Planzer a place of business exists in a Member State if the essential general management decisions and functions of central administration are carried out on its territory (para 60). The company's (operational) business activities (e.g. trading of goods or provision of services) may be carried out from a secondary establishment in another Member State (para 59).

In Cadbury Schweppes the Court added two clarifications in this regard. First, for the purposes of deciding whether activities are actually carried out in the territory of the Member State of a subsidiary, it is however irrelevant whether the activities could 'just as well' have been carried out by the parent company established in another Member State (Cadbury Schweppes, para 69). Nor is the mere fact that the economic choices of the subsidiary are or can be controlled by a parent company in another Member State, in itself, sufficient to regard the subsidiary a 'letterbox' company (Eurofood IFSC, para 36). Particularly, the extent to which the company physically exists in terms of premises, staff, and equipment is, however, an objective factor which is ascertainable by third parties and on which a finding may be based on the question whether there is an actual establishment and genuine economic activity or not (Cadbury Schweppes, para 67).

In this regard, the Court broadly followed the UK's and the Commission's submissions, but did not refer to the Opinion of AG Léger in Cadbury Schweppes, points 111-114. All of the above actors before the Court in the Cadbury Schweppes proceedings agreed that physical presence is a relevant objective factor. However, the UK and the Commission submitted two other factors, one broadly based on the at-arm's-length standard, and one based on the degree of effective management and control of the subsidiary by its parent company. The Court's holding of Cadbury Schweppes, para 67, is best interpreted as accepting the 'objective factors test' as submitted by the UK and the Commission in general, and accepting physical presence specifically, but not conceding to the two other factors. 
According to AG Léger, the UK government and the Commission were right to submit that a payment from the parent company to the subsidiary in consideration of a genuine activity would not constitute a transfer of profits, whereas payments in consideration of 'activities' lacking economic substance would amount to a transfer of profits due to a wholly artificial arrangement (Opinion in Cadbury Schweppes, point 114). Although the Court did not accept this factor particularly, this argument relates to the general at-arm's-length standard which we will see the Court would later accept in Thin Cap Group Litigation and SGI as a proportional standard. AG Léger also considered the UK's and Commission's argument of the subsidiary as a 'tool of execution' was a sufficient basis to conclude that the subsidiary's activities are not genuine and are wholly artificial arrangements (point 113). This second argument does not cohere with Eurofood IFSC, para 36. The Court's holding in Cadbury Schweppes, para 67, is therefore interpreted as an implicit rejection of this third suggested objective factor.

The second clarification provided by the Court in Cadbury Schweppes on the standard of proof is that the parent company of a Member State must be given an opportunity to produce evidence that the subsidiary it has established in another Member State is an actual establishment (as opposed to a 'fictitious establishment, a 'letterbox company', or a 'wholly artificial arrangement') and that its activities are genuine (Cadbury Schweppes, para 70). Moreover, this evidence may be verified by the authorities of the Member State of the parent company with a request for administrative cooperation under the Administrative Cooperation Directive (2011/16/EU) or pursuant to a DTC (Cadbury Schweppes, para 71). ${ }^{669}$

In short, if the parent company provides objective evidence that positively shows that its subsidiary (i) in fact carries out (ii) genuine activity in the Member State in which its subsidiary has its registered office, then the subsidiary is actually established in that Member State for the purposes of the freedom of establishment and the Member States should respect the rights guaranteed by Article 49 TFEU to the companies. ${ }^{670}$ If there is genuine

669 See, Section 4.3.5.7.6.

${ }^{670}$ Compare the substantively equivalent case law under the free movement of workers. A person qualifies as worker under Article 45 TFEU if he performs 'for a certain period of a time [...] services for and under the direction of another person in return for which he receives remunaration', Lawrie-Blum (66/85), paras 16 and 17. That status should be found on the basis of objective criteria. Any person whose activities which are 'real and genuine, to the exclusion of activities on such a small scale as to be regarded as purely marginal and ancillary', must be regarded as a worker, see Meeusen (C-337/97), para 13; Collins (C-138/02), para 26; and Trojani (C-456/02), para 15. This latter requirement followed directly from the system of Treaty law 'as a whole' that the rules relating to the fundamental freedoms only guarantee the free movement of persons who 'pursue or are desirious of pursuing an economic activity', 
economic activity in the Member State in which the company has its registered office, there can be no wholly artificial arrangement in this situation which justifies a national provision that denies a tax advantage to, or imposes an additional tax charge on the parent company like CFC legislation.

Given that the concept of a 'letterbox' company is used by the Court in the fields of insolvency law (Eurofood IFSC), VAT law (Planzer), and free movement law in the area of direct taxation (Cadbury Schweppes) it is best interpreted as a general concept of EU law which should be interpreted consistently across the various fields of EU law. Therefore, a place of business as defined for VAT purposes cannot be considered a wholly artificial arrangement for the purposes of direct taxation.

Consequently, an analogous application of Planzer to the field of direct taxation reasonably requires regarding the general management and central administration functions of the company as a genuine activity for the purposes of the Cadbury Schweppes rule. Moreover, it also follows directly from Centros, para 29 , that a company is not required to carry out any operational activities in the Member State of its registered office, if it carries on business through a secondary establishment, i.e. a branch or agency, in another Member State. This right is 'inherent', as the Court qualified it, in the exercise of freedom of establishment. The Court already made that point in the precedent of Segers, para 16, on which the Court relied in Centros. The Planzer ruling affirms this view in the field of VAT inasmuch as it distinguishes between the place of business and a fixed establishment as two distinct legal concepts under the VAT Directive (2006/112/EC).

It should be recalled that the mere incorporation of a company under the laws of another Member State formally observes the conditions laid down by Article 49 TFEU. The existence of a fictitious establishment is in itself not sufficient to deny the protection of freedom of establishment. That protection may only be denied if a fake presence is set up with the evident objective to obtain an undue tax advantage. In this context, it should be pointed out that the national practice at issue in Centros neither targeted 'letterbox' companies specifically, nor applied only in cases of objectively proven abuse or fraudulent conduct. The practice at issue in Centros was a blanket restriction on the registration in Denmark of a company incorporated under the laws of another Member State that did not meet the minimal capital requirements under Danish law. In that context, it did not matter so much whether the parties in the main proceedings in Centros had actually acted with the sole aim of circumventing Danish company law now that the national practice did not allow for a case-by-case examination.

To conclude, the application of the Emsland-Stärke standard of proof on abuse of law to the case of Cadbury Schweppes was as follows. The Court held in Cadbury Schweppes that the freedom of establishment would preclude the UK CFC legislation at issue if the national provisions would apply as an

see Levin (53/81), para 17. With the introduction of Union citizenship, Article 21 TFEU now guarantees the right to free movement also for non-economic activities. 
irrefutable presumption in all cases in which tax avoidance was central to the reasons for incorporating a foreign subsidiary. Freedom of establishment would only allow CFC legislation if each individual case was put to examination and the countervailing measure would only apply if there was objective evidence indicating an abuse (Cadbury Schweppes, para 72), but would in no case apply if it was proven that the case at hand concerned a bona fide incorporation, despite the existence of tax motives (Cadbury Schweppes, para 75). This standard of proof as developed in Cadbury Schweppes was affirmed as acte clair in the reasoned order in the case of CFC Group Litigation, paras 76-81.

We now have observed that the Court's interpretation of EU law in the Centros ruling is consistent with Cadbury Schweppes, although the outcomes are a bit different. ${ }^{671}$ We emphasise that an incorporation of a company under foreign law is insufficient to establish, in itself, a wholly artificial arrangement or an abuse of law. In the context of direct tax law, the central question is whether such an incorporation is used to pursue genuine economic activity in another Member State in fact, or whether the company is used as 'letterbox' company and thus only functions to artificially bring economic activities conducted on the territory of the Member State concerned outside its taxing competence in order to avoid a tax claim on the income generated by those activities. The mere fact that the company does not pursue operational business activities in its Member State of incorporation does not automatically force the conclusion that the company is a legal lie and should be disregarded for the purposes of EU law.

\subsubsection{Prevention of tax avoidance after Cadbury Schweppes}

The Court held in Thin Cap Group Litigation that the at-arm's-length principle was compatible with the legal requirement that countervailing tax measures only apply to proven wholly artificial arrangements. The wholly artificial arrangements in Thin Cap Group Litigation did not concern the juridical act of incorporating a company, but the juridical act of a loan agreement. It was argued by the UK in this case that the national legislation prevented tax avoidance by imposing countervailing taxation on loan agreements which did not correspond to economic reality.

The at-arm's-length principle means in international tax practice that dealings between associated enterprises, or between a head office and branches or agencies ('permanent establishments') of a company, are recognised for tax purposes in the same way as similar transactions between separate and

${ }^{671}$ Exclusively for the sake of completeness: in Daily Mail the Court ruled that the formal conditions of Article 49 TFEU had not been observed because the right invoked by Daily Dail did not exist under the freedom of establishment. Consequently, the question whether, despite formal observance of Article 49 TFEU, Daily Mail acted contrary to the purpose of freedom of establishment through abuse or fraudulent conduct became a moot question. 
independent enterprises. ${ }^{672}$ The application of this principle may make it necessary for the purpose of attributing profits between associated enterprises or between several establishments of the same company, to adjust conditions of transactions between those tax entities. This is to make sure that each state in which a company or a corporate group carries out economic activities on a permanent basis may exercise its legitimate taxing right on the profits generated by the activities undertaken in its territory.

If the conditions of the transactions under scrutiny correspond to those of similar dealings between separate and independent enterprises, then the transactions are assumed to be realised at-arm's-length, meaning that they evidently amount to bona fide commercial transactions and should be recognised as such for tax purposes. To the extent that deviating conditions may be rationally explained by functional and factual business reasons, there would be no profit adjustments or countervailing taxation under the international consensus. However, inasmuch as different conditions do not cohere with a functional and factual analysis of the business, they are presumed to be essentially tax motivated and their tax consequences should be adjusted to reflect those of transactions based on normal commercial terms.

The Grand Chamber judgment in Thin Cap Group Litigation ruled that thincapitalisation legislation may be allowed under EU law if due regard is made to the individual conditions of loan agreements between associated companies with reference to the at-arm's-length principle. The Court first affirmed Cadbury Schweppes, paras 55 and 56, holding that wholly artificial arrangements are abusive practices if they jeopardise the balanced allocation of the power to impose tax between the Member States, similar to the loss transfers at issue in Marks \& Spencer (Thin Cap Group Litigation, paras 74 and 75). In this regard, the Court made the UK Government's argument its own and held:

76. [...] the legislation at issue in the main proceedings is targeted at the practice of thin capitalisation, under which a group of companies will seek to reduce the taxation of profits made by one of its subsidiaries by electing to fund that subsidiary by way of loan capital, rather than equity capital, thereby allowing that subsidiary to transfer profits to a parent company in the form of interest which is deductible in the calculation of its taxable profits, and not in the form of non-deductible dividends. Where the parent company is resident in a State in which the rate of tax is lower than that which applies in the State in which its subsidiary is resident, the tax liability may thus be transferred to a State which has a lower tax rate

Just like the loss transfers in Marks \& Spencer, the hidden profit transfers of Thin Cap Group Litigation would jeopardise a balanced allocation of taxing powers and may thus be targeted by countervailing tax measures. The Court found thin capitalisation legislation a suitable measure in that regard: 
77. By providing that that interest is to be treated as a distribution, such legislation is able to prevent practices the sole purpose of which is to avoid the tax that would normally be payable on profits generated by activities undertaken in the national territory. It follows that such legislation is an appropriate means of attaining the objective underlying its adoption.

However, the Court recalled that the German thin-capitalisation legislation at issue in Lankhorst-Hohorst was not justified because it did not target wholly artificial arrangements specifically and applied to any situation in which the freedom of establishment was exercised (Thin Cap Litigation, paras 72 and 79). Since the Court lacked necessary information to decide the proportionality of the UK measures in Thin Cap Group Litigation by its own motion, it provided the national court with the following interpretative guidance.

The Court held that countervailing tax measures such as the UK thincapitalisation legislation may only be proportionally justified if and insofar it adjusts conditions on transactions within a group of companies to normal commercial terms, or, in the words of the Court; 'the re-characterisation of interest paid as a distribution is limited to the proportion of that interest which exceeds what would have been agreed had the relationship between the parties or between those parties and a third party been one at arm's length' (Thin Cap Group Litigation, paras 80 and 83).

The first (objective) element of the Emsland-Stärke standard of proof was interpreted to allow an assumption of a wholly artificial arrangement in case an individual analysis of the case at hand showed that the loan agreement was not at-arm's-length:

81. The fact that a resident company has been granted a loan by a nonresident company on terms which do not correspond to those which would have been agreed upon at arm's length constitutes, for the Member State in which the borrowing company is resident, an objective element which can be independently verified in order to determine whether the transaction in question represents, in whole or in part, a purely artificial arrangement, the essential purpose of which is to circumvent the tax legislation of that Member State. In that regard, the question is whether, had there been an arm's-length relationship between the companies concerned, the loan would not have been granted or would have been granted for a different amount or at a different rate of interest.

The Court moreover implicitly recalled the Cadbury Schweppes, para 70, clarification of the taxpayer's right to rebut any assumption of abuse based on objective and verifiable factors:

82. [...] on each occasion on which the existence of such an arrangement cannot be ruled out, the taxpayer is given an opportunity, without being subject to undue administrative constraints, to provide evidence of any commercial justification that there may have been for that arrangement. 
It is evident that the Court regarded these conditions as minimum safeguards that rule out the possibility that the legislation would be applied to any transactions other than wholly artificial arrangements 'without any underlying commercial justification' (Thin Cap Group Litigation, para 83).

The Member States failed to convince the Court that their tax laws could be proportionately justified on the grounds relating to prevention of tax avoidance in several community 1 cases which were decided after Cadbury Schweppes. The safeguards articulated in Cadbury Schweppes and Thin Cap Group Litigation were in any case not present in the Belgian legislation on limits to interest deductibility which led to the preliminary ruling in Lammers \& Van Cleeff (C-105/07). Like the German rules at issue in Lankhorst-Hohorst, the contested provisions of Belgian law went beyond what is necessary to prevent the creation of wholly artificial arrangements. Also the Finnish corporate dividend taxation provisions at issue in Aberdeen Property Fininvest Alpha were not exclusively aimed at individual situations of abusive conduct and could not be justified by reason of prevention of tax avoidance (paras 63-65). The German investment premium rules at issue in Jobra denied eligibility in all cases of cross-border hiring out of assets and thus set an arbitrary and general presumption of tax avoidance that could not be justified by the need to prevent abusive practises (paras 35-39). ${ }^{673}$ The Italian law which generally imposed higher taxation on dividends distributed to non-resident companies than on domestic dividends also operated on the basis of a general and disproportional presumption of abuse, see Commission v Italy (C-540/07), paras 58 and 59.

A more relevant observation is however that both in Lammers \& Van Cleeff, para 27, and Aberdeen Property Fininvest Alpha, para 28, the Court used the Thin Cap Group Litigation, para 74, and Cadbury Schweppes, para 55, language to define abusive practises as 'the creation of wholly artificial arrangements which do not reflect economic reality, with a view to escaping the tax normally due on the profits generated by activities carried out on national territory'.

We have seen that the Court paid great attention in Cadbury Schweppes to clarify the concept and nature of a wholly artificial arrangement. The second part of this Cadbury Schweppes definition was not elaborated on extensively above, other than the hypothesis that the Court allows the prevention of wholly artificial arrangements if they jeopardise the balanced allocation of taxing powers.

It was also suggested above that the Emsland-Stärke conditions seem circular. But, when we compare the definition of Cadbury Schweppes to the Emsland-Stärke standard of proof we see that the objective and subjective elements are not distinctions without differences. These two elements can be restated and clarified with the Cadbury Schweppes definition of abuse.

First, the objective element in terms of Emsland-Stärke requires the finding of an arrangement without any verifiable underlying commercial justification,

For the same reasons, similar Luxembourg investment tax credit legislation was held to go beyond what is necessary in Tankreederei I, paras 28 and 29. 
i.e. a wholly artificial arrangement which does not reflect economic reality. This was the central point that the Court made in Cadbury Schweppes. We have seen that national provisions may not lay down irrefutable presumptions in this regard. Rebuttable presumptions may also not be too general, applying effectively in any situation in which freedom of establishment has been exercised. Member States are however allowed to lay down a rebuttable presumption that transfers the burden of proof to the taxpayer to show commercial justification, as long as the presumption is based on specific objective and verifiable factors (such as physical presence or the at-arm's-length principle). The taxpayer should be allowed to produce evidence that shows that the transaction was realised as a bona fide commercial dealing, without being subject to undue administrative constraints.

Second, the subjective element of a tax motive does not appear to relay subjective intent (the mind of the taxpayer), but is best interpreted as a requirement to establish objective intent. Consequently, the Emsland-Stärke standard does not require proof that it was actually in the mind of the taxpayer to attempt to wrongfully benefit from a tax advantage, or to wrongfully avoid a tax claim. Objective intent is established by the finding - on the basis of objective and verifiable factors - that the taxpayer's (intended) actions may create or have created a situation that jeopardises the balanced allocation of the power to impose tax between the Member States. Consequently, if a national court finds that this situation is artificially created by a legal arrangement without commercial justification, then it may justifiably hold that the taxpayer's conduct amounts to an abuse through tax avoidance.

The focus on the question whether the balanced allocation of taxing powers is jeopardised by the taxpayer's actions is consistent with the prevention of tax avoidance as a justification ground. By requiring objective intent instead of proof on the taxpayer's subjective intentions, the government's interests are more clearly brought to the forefront. This interest is the competence of the Member States to exercise their taxing powers on national territory. Only when this public interest is put at stake by the private actions, the right to free movement and the protection principally afforded by EU law to the disputed actions may be limited. This brings us back full circle to Van Binsbergen.

The generalisation from the taxpayer's mind to the balanced allocation of taxing powers has implications on the specific issue of the role of the tax advantage requirement in the larger picture of abusive tax avoidance. The creation of a wholly artificial arrangement to the jeopardy of the balanced allocation of taxing powers ordinarily means that an undue tax advantage accrues to the taxpayer. The taxpayer escapes tax normally due in the Member State of origin and transfers his liability to another Member State by artificially shifting income or assets to maximise the after-tax value of his economic activities. For profits this implies an artificial transfer from a high tax Member State to a lower tax (or non-tax) Member State, and for losses the taxpayer will seek to realise an artificial transfer in the opposite direction. The finding of such relevant significant disparities in levels of taxation in an individual situation is accordingly an objective and verifiable factor that shows that the disruption of 
the balanced allocation of taxing powers in fact confers a tax advantage on the taxpayer.

The law as it stood after Thin Cap Group Litigation is now rather clear. The broad standard of EU law on abuse and fraudulent practises, as articulated in the Van Binsbergen-Centros line of authority, came together with the Leur-BloemICI concept of wholly artificial arrangements and, mixed with the EmslandStärke standard of proof, the Court produced a well developed view on prevention of tax avoidance in Cadbury Schweppes and Thin Cap Group Litigation as a justification ground for countervailing taxation in individual cases of abuse. First, one needs to look into the economic substances of the transactions giving rise to the disputed tax consequences, and second, the nature of those consequences; the question whether the result is that the Member State loses the competence to exercise taxing power to some extent in favour of the taxpayer. An abuse of law may be established when that result is achieved by an arrangement lacking commercial justification.

Although we have seen that the competence to exercise taxing powers on economic activities carried out on national territory is the public interest that both the tax avoidance and the balanced allocation of taxing powers justification protect if viewed on a higher level of abstraction, we are still left with the open issue of Marks \& Spencer why the tax avoidance justification was able to justify the UK national provisions at issue in that case, even though they were not specifically designed to apply exclusively to proven wholly artificial arrangements. Given the Court's consistent reluctance, before and after Cadbury Schweppes, to accept general presumptions of tax avoidance which are effectively conditioned solely on the exercise of freedom of movement, the ruling in Marks \& Spencer unquestionably stands apart. It was however not the last time that the Court would reason this way.

In $O y A A$ and $S G I$ the Court held explicitly that the legislation at issue in the main proceedings of those cases was not designed specifically for preventing wholly artificial arrangements-applying the Cadbury Schweppes definitionbut could nevertheless be justified by the need to prevent tax avoidance and also did not go beyond what was necessary to achieve that aim. We have seen that the national provisions were in both cases also justified by the need to preserve a balanced allocation of taxing powers.

The ruling in $O y A A$ is most illustrative of the Court's approach to blanket restrictions which are nevertheless justified. The Finnish legislation at issue in $O y A A$ concerned a group contribution regime that allowed companies of the same corporate group to surrender operating profits to each other. The surrendered income was not taxed at the level of the transferor but included in the basis of assessment of the transferee. It thus was the mirror image of the loss relief system at issue in Marks \& Spencer. Like in Marks \& Spencer, a transfer of profits was however not allowed in relation to foreign companies under the national provisions at issue in $O y A A$. That was the prima facie restriction on freedom of establishment in that case.

We have seen above that allowing a transfer of profits in free movement situations in $O y A A$ would effectively result in requiring Finland to surrender its 
right to tax these profits earned by companies established on its territory. Consequently, the Court held the balanced allocation of taxing powers to be jeopardised if the group contribution regime were to be unconditionally extended to free movement situations.

In regard to the prevention of tax avoidance, the Court held in $O y A A$, paras 58 and 59, that 'the finding of significant disparities between the bases of assessment or rates of tax applied in the various Member States'(para 59) might carry the risk that companies are encouraged, if allowed, to organise profit transfers 'by means of purely artificial arrangements... within a group of companies towards companies established in Member States applying the lowest rates of taxation or in Member States in which such income is not taxed' (para 58). The Court did not specify what situation it would consider a wholly artificial arrangement in this context. But that, as we will observe below, is actually an irrelevant detail.

The irrelevance of finding a wholly artificial arrangement in $O y A A$ was introduced by the Court with the following holding in para 62 :

62. It should be noted at the outset that the objectives of safeguarding the balanced allocation of the power to impose taxes between Member States and the prevention of tax avoidance are linked. Conduct involving the creation of wholly artificial arrangements which do not reflect economic reality, with a view to escaping the tax normally due on the profits generated by activities carried out on national territory is such as to undermine the right of the Member States to exercise their tax jurisdiction in relation to those activities and jeopardise a balanced allocation between Member States of the power to impose taxes (Cadbury Schweppes and Cadbury Schweppes Overseas, paragraphs 55 and 56, and Test Claimants in the Thin Cap Group Litigation, paragraphs 74 and 75 ).

In this holding the Court explicitly confirmed that the two justifications protect the same larger aim of government. In other words, abuse or fraudulent conduct is only one way in which the balanced allocation of taxing powers might be jeopardised. The concept of a wholly artificial arrangement then merely performs a classification function; a specific method by which the balanced allocation of taxing powers might be jeopardised. Therefore, this approach does not a priori exclude the possibility that restrictions might be justifiable, even if the national provisions at issue do not target wholly artificial arrangements specifically.

How should the tax avoidance justification in Marks \& Spencer and $O y A A$ then be understood? In other words; what are, in this context, the common attributes of Marks \& Spencer and $O y A A$ on the one hand, and Cadbury Schweppes and Thin Cap Group Litigation on the other hand?

We can identify two elements which the Court in all four cases considered relevant in the context of preventing tax avoidance. First, the Court was evidently aware that the disputed actions in each case created the possibility to transfer income to another Member State without any underlying transfer of economic activities. And second, the Court consistently articulated an incentive 
to arrange these income transfers in favour of the taxpayer's economic position by reason of significant disparities in levels of taxation between the Member States.

As regards the first observation, the possibility of transferring income between Member States without an underlying shift in economic activities was at the heart of the group taxation regimes at issue in Marks \& Spencer and $O y$ $A A$. The rules operated on a basis of inherent artificiality. Companies could in principle freely surrender losses and profits to each other by a paper transaction. Since the income remained caught by the taxing competence of the Member States in which territory the economic activities in relation to that income were carried out, such income transfers in internal situations would not jeopardise the balanced allocation of taxing powers at all, even though the economic position of the individual companies as reflected on paper, no longer corresponded with the underlying economic (accounting) reality of those individual companies.

However, as soon as transfers are allowed between companies in different Member States, this carries a risk that income would be transferred from the Member State in which territory the underlying economic activities are carried out to another Member State. In short, the risk that the balanced allocation of taxing powers between Member States might be jeopardised exists by its very nature only in situations which concern at a minimum a formal exercise of freedom of movement. Therefore, the exercise of free movement was in the cases of Marks \& Spencer and $O y A A$ a necessary cause of that risk.

The risk of tax avoidance could only be prevented if this cause was eliminated completely. Consequently, exclusively a complete restriction on free movement like the one at issue in $O y A A$ was a suitable, necessary, and proportional means to achieve this result.

The Court's reasoning in $O y A A$ to hold the restriction proportionate corresponds to this line of argumentation:

64. In a situation in which the advantage in question consists in the possibility of making a transfer of income, thereby excluding such income from the taxable income of the transferor and including it in the taxable income of the transferee, any extension of that advantage to cross-border situations would, as indicated in paragraph 56 of this judgment, have the effect of allowing groups of companies to choose freely the Member State in which their profits will be taxed, to the detriment of the right of the Member State of the subsidiary to tax profits generated by activities carried out on its territory.

65. That detriment cannot be prevented by imposing conditions concerning the treatment of the income arising from the intra-group financial transfer in the Member State of the transferee, or concerning the existence of losses made by the transferee. [This] [...] would nevertheless mean that, in the final analysis, the choice of the Member State of taxation would be a matter for the group of companies, which would have a wide discretion in that regard.

As for the second observation regarding the Court's finding that significant disparities between the taxation levels of Member States provides a tax planning 
incentive, the following reasoning may clarify the Court's argument. An act of tax avoidance logically presupposes an incentive to engage in tax planning; an opportunity of arbitrage. In free movement situations, the opportunity of arbitrage is created by disparities in tax levels between the Member States. If a taxpayer acts upon this incentive, either by creating a wholly artificial arrangement, or alternatively by making use of the artificiality inherent in the tax regime then the taxpayer may realise a tax advantage without restructuring his economic activities.

Thus, if tax avoidance is viewed more generally as the realisation of a tax advantage by any tax planning action which does not reflect economic reality and at the same time jeopardises the balanced allocation of taxing powers, then the intended actions of a surrender of losses and a contribution of profits in Marks \& Spencer and $O y A A$ respectively may indeed be considered actions of tax avoidance. On this basis, there is no material difference with the wholly artificial arrangements of Cadbury Schweppes and Thin Cap Group Litigation. A wholly artificial arrangement is not the only way in which taxes may be avoided.

The combination of the fact that the national provisions at issue in Marks \& Spencer and $O y A A$ operated on the basis of inherent artificiality and thus allowed income to be transferred without an underlying transfer of economic activity, the fact that the balanced allocation of taxing powers would therefore necessarily be jeopardised in any free movement situation, and the fact that significant disparities favoured cross-border tax planning by the taxpayer thus adequately explain 'taken together' why the Court justified blanket restrictions on free movement in Marks \& Spencer and $O y$ AA. Consequently, by a method of exclusion, the only reason why a taxpayer would want to enjoy group relief or make a group contribution in cross-border situations is the possibility to obtain an undue tax advantage. On this basis, there is no difference between this type of tax avoidance and the abusive private conduct of wholly artificial arrangements. The tax avoidance justification in Marks \& Spencer and $O y A A$ is best understood with this interpretation.

The interpretation proffered here also distinguishes tax avoidance from legitimate tax planning. In Cadbury Schweppes (para 49) the Court pointed out that the genuine establishment of a subsidiary in another Member State does not amount to tax avoidance, even if the choice of the particular Member State was based exclusively on tax reasons. The fact that one Member State's tax revenues reduce if a company decides to establish a subsidiary in another Member State and to pursue genuine economic activity in that other Member State's national territory instead of carrying out that business in the first Member State is no justification for restricting the exercise of freedom of establishment (Cadbury Schweppes, para 49). In that situation, the other Member State ordinarily has the competence to exercise its taxing powers as regards the income earned by the economic activities undertaken in its national territory. This basic rule is also recognised by the Court.

In Schumacker (para 32), Lidl Belgium (para 33) and CIBA (C-96/08, para 37) the Court held that the resident Member State enjoys, in the absence of 
double tax conventions, the right to tax a taxpayer overall. For companies this is the Member State in which the registered office, or corporate seat, is located, according to the Court. Customary (OECD) international tax law posits a corollary rule that a State has no taxing jurisdiction at all on income of a company established in another State, unless the company carries out economic activities within the first State's territory ${ }^{674}$ This State has therefore no power to impose a tax which might be jeopardised or justified in EU law. Consequently, legitimate tax planning by incorporating a subsidiary in another Member State does not constitute tax avoidance against which Member States are allowed to act with countervailing tax measures.

Similarly, actual migration by individuals cannot in itself constitute an act of tax avoidance, see De Lasteyrie du Saillant. It may however jeopardise the balanced allocation of taxing powers between the Member States because the Member State from which the taxpayer transfers his residence can no longer tax income which accrued during the time he was a resident in that State. If the national legislation genuinely aims to preserve the general competence to exercise taxing powers on that income, the genus justification may be invoked autonomously, as the Court ruled in the cases of $N$. and National Grid Indus. In De Lasteyrie du Saillant however, the French government limited the objective of the French exit tax rules explicitly to prevent situations of tax avoidance and thus argued with the species justification. The argument was essentially that an exit tax prevented 'artificial' migrations. It can be debated whether the Court should verify on its own motion whether the genus justification might nevertheless justify the national provisions in such cases but it is generally accepted, and apparent from consistent case law, that it is the Member States' responsibility (and also a right of the national courts) to bring forward justification grounds and explain the underlying motives for the restrictions with reference to the national legislator's reasoned intent.

In the specific case of De Lasteyrie du Saillant, the French government's submission and the referring court's question were specifically directed towards the prevention of tax avoidance. For this reason, the Court understandably held that the national provision at issue 'does not therefore appear to be aimed at ensuring generally that increases in value are to be taxed, in the case where a taxpayer transfers his tax residence outside France, in so far as the increases in value in question are acquired during the latter's stay on French territory' (para $65)$. It was also noted that the national legislation in any case did not achieve such a general aim in a consistent and systematic manner (para 66). Accordingly, those findings were understood by the Court as contradicting the Danish, German, and Netherlands governments' submissions which were indeed roughly based on the BAOTP standard (paras 31-33, 59 and 60, and 67 and 68). The right to tax of France was not as such denied by the Court. Now, we can conclude that the genus justification was rightfully not accepted in De Lasteyrie $d u$ Saillant. Since a general exit tax is obviously a disproportional measure to 
combat abuses, the prevention of tax avoidance was also not accepted in $D e$ Lasteyrie du Saillant as we have seen above.

We have seen above that the at-arm's-length standard is accepted in EU law as a proportional method to prevent tax avoidance. The Court's judgment in $S G I$ can be regarded as a confirmation of that view. The grounds of judgment in SGI are in this context a bit ambiguous, however.

The Court's reasoning in paras 65-69 of the judgment in SGI implies that the Belgian provisions at issue were not targeted specifically at wholly artificial arrangements, but were of a general nature. The citation of $O y A A$ as the only precedent in paras 66-69 is a strong indication for that conclusion. However, the description of the national legal background in para 4 of the judgment explicitly refers to the national definition of unusual or gratuitous advantages as considerations on transactions between associated undertakings, which -in short-do not correspond to normal commercial terms between unrelated parties. This is equivalent to finding that such transactions (in part or in full) lack economic reality and should (in part or in full) be considered a wholly artificial arrangement. Para 67 of the SGI ruling indeed refers to the qualification of 'artificial arrangements' for unusual or gratuitous advantages. On the whole, this passage of the ruling however signals mixed messages.

The indeterminacy of the judgment's grounds was not necessary. The issue in SGI and Thin Cap Group Litigation was basically the same. Both cases concerned countervailing taxes on transactions between related companies which potentially did not correspond fully (or not at all) to normal business conditions. The Court held the UK provisions in Thin Cap Group Litigation to be solely justified by the need to prevent tax avoidance through wholly artificial arrangements. The Belgian provisions in $S G I$ could however only be justified 'taken together' with the balanced allocation of taxing powers. That seems a slip of the pen when the proportionality analysis in SGI is considered.

The proportionality analysis in $S G I$ clarifies that the Court indeed noticed the similarities between the national legislations in the two cases. This is so because the Court applied the conditions of proportionality developed in Thin Cap Group Litigation directly to the legislation at issue in SGI. It invited the national court to verify the submission of the Belgian government that (i) the taxpayer indeed has an opportunity to provide evidence in support of a commercial justification for the transactions without being subject to undue administrative constraints, and that (ii) the corrective taxation on the gratuitous or unusual advantage is limited to an adjustment that corrects the conditions of the transaction to correspond to normal commercial terms between unrelated contracting parties ( $S G I$, paras 71-75). If these requirements were met under Belgian law, the at-arm's-length tax corrections imposed by the Belgian provisions at issue in $S G I$ would be proportionately justified. Consequently, $S G I$ may be interpreted as confirming that the application of the at-arm's-length standard is a suitable measure to prevent tax avoidance and does not go beyond what is necessary to achieve that objective. The structure of the $S G I$ judgment is furthermore consistent with the view that the prevention of tax avoidance should be considered a species justification of the genus type of the balanced allocation 
of taxing powers. Despite a bit of fuzziness, the judgment does not adversely affect the cohesion of the Court's case law.

In another recent ruling in the case of Glaxo Wellcome, the Court found that the provisions were necessary to maintain a balanced allocation of taxing powers and followed its line of authority of Cadbury Schweppes. Accordingly, the Court required that the legislation provides for a case-by-case examination, on the basis of objective factors, of each individual situation and of the nature of the justifications for the transactions which were caught by the national provisions, for the legislation to be proportional with its intended objective of preventing tax avoidance through wholly artificial arrangements. Like in Thin Cap Group Litigation and SGI, the corrective taxation could not be in excess of the tax advantage that improperly accrued to the taxpayer who set up a wholly artificial arrangement. The countervailing measure should thus have only neutralising effects, but may not impose a hidden fine through increased taxation compared with the tax treatment of bona fide commercial transactions.

\subsubsection{Synthesis and discussion}

The research of this Section showed that there is a conception of abuse of law in the field of direct taxation. The need to prevent abusive practices (i.e. tax avoidance) as a justification is laid down as Rule 4:5 of Annex A. We find that the prevention of tax avoidance and the balanced allocation of taxing powers as justifications for restrictions on free movement are indistinguishable on a higher level of abstraction. The BAOTP standard may be considered the genus of the justification ground and the prevention of tax avoidance is the species of that justification when the cause of jeopardy relates to artificial transactions. Tax avoidance transactions may be artificial by law (Marks \& Spencer and $O y A A$ ) or may be empty legal arrangements entered into by the taxpayer ('wholly artificial arrangements').

A wholly artificial arrangement is an arrangement lacking economic reality and commercial justification. This may be a 'letterbox' company, or conditions of legal arrangements which are not at-arm's-length between associated parties. When those arrangements are used to avoid taxes by artificially arranging income transfers between Member States, the jeopardy to the balanced allocation of taxing powers justifies applying a countervailing national measure. These measures should be designed to take account of specific and objective factors indicating an abuse. ${ }^{675}$ This may be the lack of physical presence to indicate a 'letterbox company', or a comparison with third party transactions to establish normal commercial terms. Also, there should be a possibility for the taxpayer to produce evidence to refute a presumption of abuse based on those factors without being subject to undue administrative constraints. The Member

${ }^{675}$ The principle of legal certainty requires the conditions with regard to those factors to be 'clear, precise and predictable as regards their effects', see the 2012 judgment in SIAT (C-318/10), para 58. 
States may cooperate with each other to determine whether there has been an abuse in the end. Should an abuse be established, the countervailing tax measure may not go beyond what is necessary to correct and neutralise the abuse; a hidden fine by overcompensating the tax loss due to the abuse is precluded.

Prior research questioned whether there is an overall concept of abuse ${ }^{676}$ ? We found that the case law in the field of direct taxation derives its authority and content from precedents which were established outside this field. The Court's approach in handling abusive practices in the field of direct taxation must therefore be interpreted homogeneously with the case law that was decided outside this field. There is indeed a very broad judicial standard allowing the prohibition of abuse of law which applies generally to the various fields of EU law. ${ }^{677}$ Karimeri aptly concluded that his judicial standard 'has a specific manifestation in the case law on tax avoidance, ${ }^{678}$ We do not find the case law confusing or vague in that regard. ${ }^{679}$ For an exhaustive overview of the case law before Cadbury Schweppes we refer to Weber (2005).

We concur with Weber that the judicial standard allowing the prohibition of abuse of law is not a general principle of EU law in that it requires Member States to combat circumventions or abuses of their national direct tax legislation when a taxpayer claims its benefit by improperly relying on the protection of the Treaties. ${ }^{600}$ Member States may apply countervailing measures to combat fraud or abuse of national law in situations in which EU law may be seemingly involved. The judicial doctrine does not prescribe that Member States must deny benefits provided by national law to situations in which freedom of movement has not been exercised in the end, but the conditions of application have been artificially created and EU law is not ultimately involved.

However, the benefits granted by directives and regulations cannot be extended to cover fraud and abusive actions, according to the well established case law of Foggia (C-126/10), para 50; Kofoed (C-110/99), para 38; and Halifax, paras 68 and $69 .{ }^{681}$ Since directives require transposition into national law and if the directive concerned gives Member States an express option to introduce provisions combating abusive conduct, the prohibition of abusive conduct may be allowed in situations in which the directive is properly transposed in national law and the formal conditions for the granting of its benefits are only met if the national law contains such provisions or the national system recognises a principle that allows countervailing measures. ${ }^{682}$ In contrast,

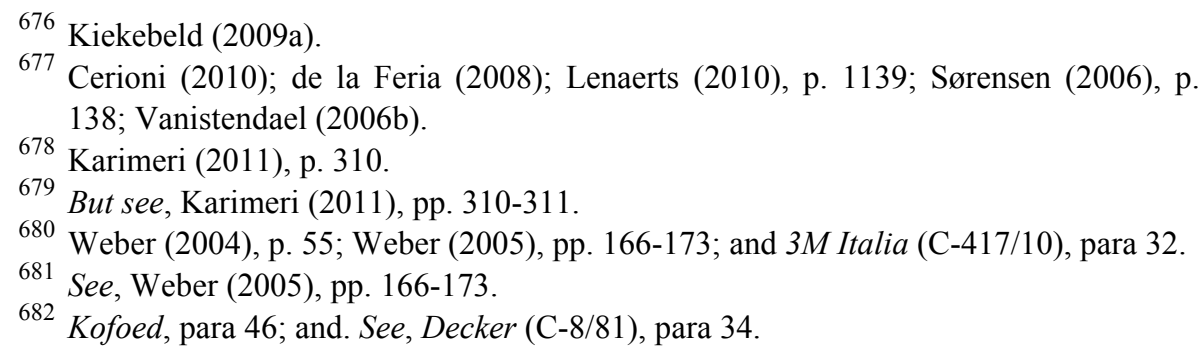


regulations do not require transposition and consequently cannot be interpreted to confer rights or benefits to Union citizens in cases of abusive conduct. ${ }^{683}$

In line with prior research we find that the concept of a wholly artificial arrangement is central to the definition of an abusive practice. ${ }^{684}$ Whether the protection of EU law should be afforded in an individual case depends on the finding whether or not the conditions of application of the EU provisions have not only been complied with formally, but that the right which the taxpayer claimed has also been exercised in substance in a manner that is consistent with its object and purpose. ${ }^{65}$

In contrast with prior research, we do not find that subjective intent or motive is a material criterion for finding an abusive practice. ${ }^{686}$ Although prior research already acknowledged that the intention of abuse should be based on objective circumstances, ${ }^{67}$ or speculated that it may have no relevance beyond supportive evidence, ${ }^{688}$ we find that an objective verification of a subjective intention of abuse is not material at all. It is the effect of the taxpayer's actions and the manner in which he acted that matter; legal arrangements corresponding to wholly artificial arrangements that jeopardise the balanced allocation of taxing powers amount to tax avoidance by abusive conduct.

To sum up, the finding of abusive conduct requires a double effect test. Although a legal arrangement is artificial if it does not produce real economic effects for the taxpayer other than a savings of tax (this should be read to include arrangements in the national legislation which operates on the basis of inherent artificiality, e.g. Marks \& Spencer, Oy AA, X Holding), that finding is, in itself, insufficient to label the arrangement as an abusive arrangement. It is also necessary that the legal arrangement has adverse effects on the competence of Member States to impose taxes in relation to economic activities carried out in their national territory. In conclusion, our findings are generally in concert with prior research insofar as we accept a two-fold test in relation to abuse, which should be carried out on a case-by-case basis and must be assessed on the basis of objective evidence. This test already includes the principle of proportionality as prior research already indicated. ${ }^{689}$ Our definition of this test as a double effect test that directly attaches to the BAOTP standard is however a significant deviation from prior research.

In that context, we observe that it is the first step of this test which distinguishes the prevention of abusive practices from the balanced allocation of taxing powers as a justification in practical application, even though we find that

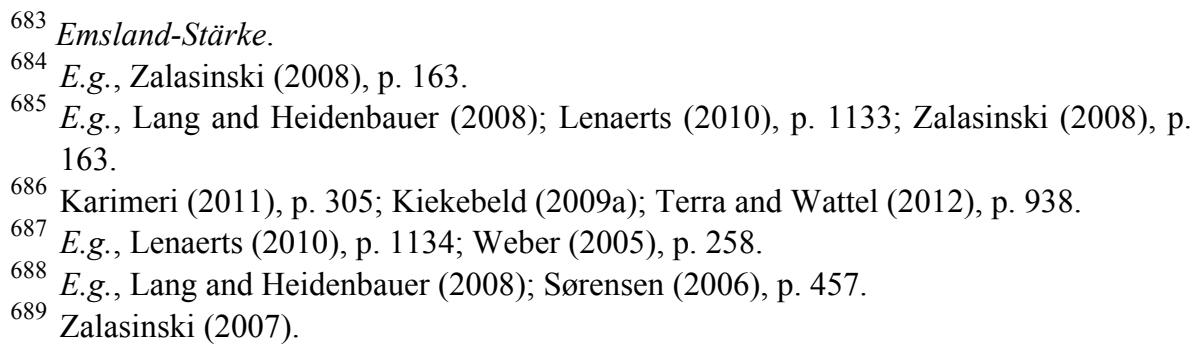


they protect the same overriding reason of public interest. Whereas the prevention of tax avoidance can only justify denying protection of EU law in relation to proven wholly artificial arrangements, we find that the BAOTP standard may also be invoked if the genuine exercise of freedom of movement jeopardises the competence to impose tax, and even when the tax advantage sought by the taxpayer does not derive from national legislation which operates on basis of an inherent artificiality. The clear evidence is provided in N., ACT Group Litigation and National Grid Indus.

The proportionality requirements of restrictions which are autonomously justified by the BAOTP standard have not been reviewed yet. This will be done in Chapter 8. However, we will first continue with an assessment of the justification of cohesion of the tax system in relation to the BAOTP standard.

\subsection{Relation with the cohesion of the tax system}

\subsubsection{Introduction}

The results obtained by the method network analysis do not point to any borrowing of grounds or arguments between the justification grounds of cohesion of the tax system and the balanced allocation of taxing powers as we stated in Chapter 5. We have also seen that the cohesion of the tax system was accepted in Papillon, but the Court rejected the balanced allocation of taxing powers as a justification in that case. In Glaxo Wellcome the Court decided the opposite and rejected cohesion, whilst accepting the balanced allocation of taxing powers. The third relevant case is National Grid Indus and the Court accepted both grounds in that case. More importantly, the Court held in National Grid Indus that 'the requirements of coherence of the tax system and the balanced allocation of powers of taxation coincide' (para 80). The preliminary conclusion therefore was that the judicial doctrine is ambiguous.

The review of Chapter 3 showed that the cohesion of the tax system also justified the restrictions at issue in Bachmann, Commission v Belgium (C300/90), Krankenheim Ruhesitz am Wannsee-Seniorenheimstatt, Commission v Belgium (C-250/08), and Commission v Hungary (C-253/09). The cohesion of the tax system also persuaded the Court to hold the national measures at issue in Manninen suitable to achieve the aims set by those rules. But, the Court also ruled in Manninen that those measures went beyond what was necessary to preserve cohesion. These cases have been specifically important in the development of the cohesion of the tax system as a justification in EU law.

The interpretation that forms the comparison first requires the requirements of cohesion to be reviewed. The requirements of the balanced allocation of taxing powers have already been reviewed in Chapter 6. Second, we will analyse if these requirements coincide and how the statement in National Grid Indus should be interpreted. Does the statement only apply to the particular case of National Grid Indus, or did the Court mean to establish generally that both justification grounds are indistinguishable on a higher level of abstraction? 
Third, we will review the function that cohesion of the tax system performed in the cases that are mentioned above and in which the Court held it appropriate as justification. That analysis is specifically aimed at establishing to what extent the balanced allocation of taxing powers was implicitly relevant to those cases.

\subsubsection{The requirements of the cohesion of the tax system}

The requirements of the cohesion of the tax system are widely reported in prior research. ${ }^{690}$ Moreover, we have already established in Chapter 4 that the rule of cohesion belongs to the core of judicial doctrine in the field of direct taxation, see Rule 4:3 of Annex A. It is common ground in the literature and wellestablished case law that the justification ground requires a direct link between a particular tax advantage and an offsetting tax levy (Svensson and Gustavsson, para 18; and Manninen, para 42). The direct nature of that link is to be examined in the light of the aims and purpose of the national measure (De Lasteyrie du Saillant, para 67; and Manninen, para 43). ${ }^{691}$ In the more abstract definition of Krankenheim Ruhesitz am Wannsee-Seniorenheimstatt, the Court requires a 'logical symmetry' between the tax advantage and the offsetting tax levy.

It follows from Bachmann, Commission v Belgium (C-300/90), Krankenheim Ruhesitz am Wannsee-Seniorenheimstatt and, most recently, from Commission $v$ Belgium (C-250/08) and Commission v Hungary (C-253/09) that a direct link may be established if the tax advantage and levy are imposed on the same taxpayer in relation to the same tax. Notwithstanding that the finding of a personal and material link is sufficient to establish a direct link according to this case law, the judgment in Manninen may be interpreted as leaving the possibility to establish a direct link between two different taxes charged to two different persons, but only if the national system is legally configured to that effect. The Court however found that the legal configuration of the tax measures at issue in the specific case of Manninen went beyond what was necessary in view of the aims pursued by those measures. Cohesion was consequently rejected as a justification in Manninen. The wide recognition of these requirements in the literature and case law merits that, for the purpose of the current research, they are accepted as true without further discussion.

It is also commonly accepted that —on the basis of a line of authority that started with Wielockx - the cohesion of the tax system cannot be invoked successfully if a Member State is prevented from imposing a countervailing levy because it has forfeited its right to tax by a double taxation convention to another Member State. In that situation, the first Member State is required to confer on taxpayers who have exercised their right to free movement the same tax advantages as granted in internal situations. A refusal to extend tax benefits to free movers amounts to discrimination, even though (internal) cohesion of the tax system of the first Member State has so been jeopardised. The Court held in

${ }^{690}$ See e.g., Vanistendael (2005); Verdoner (2009).

691 See, Section 4.3.5.7.3. 
Wielockx, paras 24 and 25, that under those circumstances cohesion is '...shifted to another level, that of the reciprocity of the rules applicable in the Contracting States', and is thus 'secured' by the double tax convention. This has been called the rule of macro-cohesion in English or Makrokohährenz in German. ${ }^{62}$

\subsubsection{Comparison with the balanced allocation of taxing powers}

The need to maintain a balanced allocation of the power to impose tax between the Member States aims to secure the Member States' competence to tax income accruing from activities undertaken in their territory, provided that the tax claim is assessed in a consistent and systematic manner. This justified the assessment of a tax claim upon the transfer to another Member State of the place of residence of an individual in $N$. and of a company's place of management in $\mathrm{Na}$ tional Grid Indus. The determination of the amount of tax owed at the time of transfer was also held to be justified and not going beyond what was necessary in National Grid Indus by the cohesion of the tax system, because:

82. Deferred recovery of the tax would not call into question the link existing in the Netherlands legislation between, on the one hand, the tax advantage represented by the exemption allowed to unrealised capital gains relating to assets as long as a company obtains profits taxable in the Netherlands and, on the other, the offsetting of that advantage by a charge to tax determined at the time when that company ceases to obtain such profits.

The Court shared and referred to the opinion of Advocate General Kokott who proffered:

99. If the Netherlands, because of the transfer, were no longer able to tax the unrealised capital gains accrued during the period of residence of National Grid Indus in its territory, coherence of the tax system would not be possible. To that extent, the objective of coherence of the tax system and the balanced allocation of the power to impose tax coincide. ${ }^{693}$

In view of her opinion in $N$., point 106, the Advocate General used the word 'coincide' with the meaning that the two justifications lead to the same result. It can be safely assumed that this is also the context of the Court's holding on the issue, since the Court made the reasoning of the Advocate General its own. Con-

692 Cordewener (2002); Kofler (2007b), p. 712; Wattel (1996).

693 Footnote 61 in the original text reads: 'See my Opinion in $N$, cited in footnote 6 , paragraph 106'. In her opinion in $N$., point 106 she submitted: 'It is true that in the present circumstances a coherent tax system would not be guaranteed if emigration made it impossible to levy tax on the profits on the shares which arose during the period of residence in the home State. To that extent cohesion of the tax system and the allocation of tax according to the principle of territoriality point in the same direction in the present case.' 
sequently, the judgment in National Grid Indus does not imply that the cohesion of the tax system and the balanced allocation of taxing powers are identical in substance, but merely that the application of both justifications led to the same result in National Grid Indus.

In De Lasteyrie du Saillant the Netherlands government also tried to defend the French exit tax with recourse to the cohesion of the tax system. We have already seen that this argument, framed by the need to prevent tax avoidance, was equivalent to a justification based on the balanced allocation of taxing powers. In a reasoning which was analogous to the Wielockx-rule, the Court held that the French national measures were not coherent because France exempted capital gains from tax subject to the condition that the new Member State of residence had actually taxed those gains (paras 65-66). In contrast, the national measure in National Grid Indus systematically and consistently aimed to tax capital gains which accrued during the period (the temporal component) that the company was a resident of the Member State concerned (the application of the principle of fiscal territoriality). The application of cohesion in National Grid Indus performed the specific function of testing whether the larger aim of maintaining a balanced allocation of the power to impose tax between the Member States was enacted coherently in the tax system in the Member State concerned. In other words, cohesion tested whether the restriction was suitable to safeguard the tax claim.

Another reasonably similar case to De Lasteyrie du Saillant, N., National Grid Indus is $X$ and $Y$. That case is similar insofar as the national measures at issue in $X$ and $Y$ were written to account for the risk that Sweden would lose a tax claim due to the transfer of the taxpayer to another Member State. To that end, Sweden refused to recognise a transfer of shares in a Swedish company by two resident individual taxpayers to another Swedish company which was a subsidiary of a Belgian company, at less than market value for tax purposes, irrespective of the actual transfer price agreed between the transferor and transferee. In internal situations, taxpayers would effectively be granted a deferral of tax on the capital gain by allowing a transfer at book value, or undervalue, also to be recognised for tax purposes. As explained in the context of the need to prevent tax avoidance, the case concerned the denial of a tax deferral on the capital gain realised by the transfer in all cases which concerned an exercise of freedom of movement because a foreign company was directly or, as in the case of $X$ and $Y$, indirectly involved in the transfer of shares. It was also stated above that the Swedish government attempted to justify the national measures by the need to maintain the cohesion of the tax system, but we have not reviewed the Court's reply in this regard.

The Court recognised that the relevant DTC with Belgium for the dispute at issue in $X$ and $Y$ allocated the right to tax capital gains made upon the transfer of shares to the contracting state in which the transferor is resident (paras 53-54). If a resident moves and subsequently transfers its shares abroad, the Member State of origin loses its taxing right in respect of capital gains made upon the transfer of shares by a former resident only after five years after the change of residency to the other contracting state to the DTC (paras 55-57). The Court thus 
recognised that Sweden principally was allowed to tax the capital gain that was in dispute in the main proceedings. Since the transferee in the case in the main proceedings was also a resident company of Sweden, this implied logically that Sweden could still exercise its tax claim on the capital gain even if a deferral was granted to the transferor. The Court did not mean to argue that the DTC applied to and precluded the disputed charge to tax as suggested in prior research. ${ }^{694}$ Exactly because the DTC did not (yet) limit Sweden's power to impose a tax on the capital gain upon the transfer of shares, the Court held that the refusal of the deferral of tax was not appropriate to prevent this gain from evading taxation in Sweden (para 57). The material reason supporting this conclusion was that:

58. Any problem relating to the coherence of the tax system at issue here would have a fundamentally different origin from that at issue in Bachmann and Commission $v$ Belgium, cited above. In those cases, payments were likely to evade taxation by the Member State which granted the tax advantage because they were made by third parties outside that Member State, that is to say in the country where those third parties were established. However, in a case such as the present, the risk relates to the fact that the tax base is liable to disappear at a subsequent stage following a definitive move abroad by the taxpayer.

59. In such a situation, in contrast to that giving rise to the judgments cited above in Bachmann and Commission v Belgium (see Bachmann, paragraph 28, and Commission v Belgium, paragraph 20), the coherence of the tax system can be safeguarded by measures which are less restrictive or less prejudicial to freedom of establishment, relating specifically to the risk of a definitive departure of the taxpayer, in respect of all types of share transfers entailing the same objective risk.

If we compare $X$ and $Y$ to $N$. and National Grid Indus it is obvious that the charge to tax in the two latter cases related specifically to an actual definitive departure of the taxpayer. The ruling in National Grid Indus is accordingly fully consistent with $X$ and $Y$ on points of EU law. The national measures at issue in $X$ and $Y$ were not designed in a consistent and systematic manner with an aim to safeguard the right to impose tax on capital gains upon the transfer of residence of the taxpayer to another Member State. In the case of $X$ and $Y$ the application of the cohesion of the tax system thus fulfilled the role of testing the suitability of the restriction in view of the reasoned intent of the national legislator on the purpose of the restriction.

The interpretation of the national measures at issue in Bachmann and Commission $v$ Belgium in subsequent case law as measures which were written to prevent the loss of a legitimate tax claim supports the view that the balanced allocation of taxing powers was already implied in those cases as the underlying 
overriding reason of public interest. The material reason for justifying the restrictions in Bachmann and Commission v Belgium was that the insurer (the 'third party' mentioned in $X$ and $Y$, para 58, as quoted above) was established in another Member State, and that therefore the subsequent payments could not be taxed. The argument was that Belgium could not effectively oblige a foreign institution to retain tax at source on pensions paid, or such an enforcement would not be less disproportional then the simple denial of a deduction as at issue, according to the Court. The Court stated it as follows in Commission $v$ Belgium (C-300/90), paras 16-20, and the following quotations from Bachmann:

23. The cohesion of such a tax system, the formulation of which is a matter for the Belgian State, presupposes, therefore, that in the event of that State being obliged to allow the deduction of life assurance contributions paid in another Member State, it should be able to tax sums payable by insurers.

24. An undertaking by an insurer to pay such tax cannot constitute an adequate safeguard. If the undertaking were not honoured, it would be necessary to enforce it in the Member State in which the insurer is established, and quite apart from the problems encountered by a State in discovering the existence and amount of the payments made by insurers established in another State, there remains the possibility that the recovery of the tax might then be prevented on the grounds of public policy.

25. It would certainly be possible in principle for such an undertaking to be accompanied by the deposit by the insurer of a guarantee, but this would involve the insurer in additional expense which would have to be passed on in the insurance premiums, with the result that the insured, who may moreover be subjected to double taxation on the sums payable under the contracts, would cease to have any interest in maintaining them.

26. It is true that bilateral conventions exist between certain Member States, allowing the deduction for tax purposes of contributions paid in a contracting State other than that in which the advantage is granted, and recognizing the power of a single State to tax sums payable by insurers under the contracts concluded with them. However, such a solution is possible only by means of such conventions or by the adoption by the Council of the necessary coordination or harmonization measures.

27. It follows that, as Community law stands at present, it is not possible to ensure the cohesion of such a tax system by means of measures which are less restrictive than those provided for by the rules in question, and that the consequences of any other measure ensuring the recovery by the Belgian State of the tax due under its legislation on sums payable by insurers pursuant to the contracts concluded with them would ultimately be similar to those resulting from the non-deductibility of contributions.

The alternative to a deduction of tax at source on pension payments by the financial institutions was also discussed by AG Mischo in points 23-29 of his opinion in Bachmann. He assessed the proportionality of a denial of a deduction 
against the deduction at source within a context of the need to prevent tax evasion. His conclusion was that deduction at source was less disadvantageous to freedom of movement since Belgium apparently had made such arrangements in the double taxation conventions to which the Court also referred in para 26 of the ruling. Also, the AG was supported in this regard by the legislation in force in the Netherlands which provided for deduction of tax at source but which allowed a deduction of contributions like the one in dispute in Bachmann. The Court evidently disagreed with the AG because it held essentially that Belgium could not unilaterally impose a deduction of tax at source for pension payments made by foreign institutions.

Both the Court and the AG did not refer to the possibility that the pension payment made by a foreign institution may be included as a taxable item of income of the beneficiary and taxes are imposed on an assessment basis instead of a deduction at source by the institution. Prior research points out however that Belgium regarded pension payments in principle as gross income which may, or may not, be exempted. ${ }^{695}$ Perhaps it was neither mentioned in any of the written memoranda, nor contemplated as an alternative by the Court's own motion. The text of the ruling and of the AG's opinion does not mention any discussion before the Court on the matter. The rather messy understanding of national law and the effects of double tax conventions in the dispute of Bachmann has been criticised in the literature - that discussion will not be repeated here. ${ }^{696}$ More importantly however, the Court fixed the gap in reasoning in subsequent rulings. The possibility to levy tax from the beneficiary of the pension or life insurance payment was the precise ground that the Court invoked for distinguishing Commission v Denmark (C-150/04) from Commission v Belgium (C-300/90) and Bachmann. ${ }^{697}$

The case of Commission v Denmark essentially concerned the same problem as Bachmann - a deduction of contributions from tax was denied when they were made to foreign insurers, but subsequent payments were exempted from tax. Conversely, contributions made to domestic institutions in Denmark could be deducted from income tax, and the pension payment was included as taxable income of the beneficiary. The Court found a restriction on free movement in Commission v Denmark on the same grounds as in Bachmann. The analysis of the cohesion of the tax system as a justification was however different in Commission v Denmark:

71. In that regard, the factor liable adversely to affect the cohesion of the Danish tax system is to be found in the fact that the transfer of the residence of the person concerned occurs between the time of payment of contributions to a pension scheme and that of payment of the corresponding benefits, and less in the fact that the pension institution is in another Member State.

${ }^{695}$ Isenbaert (2010), p. 678.
${ }^{696}$ Hinnekens and Schelpe (1992).
${ }^{697}$ Section 4.3.5.7.2. 
72. When a Danish resident, having become a member of a pension scheme with an institution established in Denmark, receives tax advantages on the contributions paid into that scheme, then, before benefits fall to be paid, transfers his residence to another Member State, the Kingdom of Denmark is deprived of the power to tax the benefits corresponding to the contributions deducted or exempted, at least where it has concluded with the Member State to which the person concerned has transferred his residence a double taxation convention based on the OECD Convention. However, in such a case, that result is not due to the fact that the pension institution is established abroad.

73. Conversely, there is nothing to prevent the Kingdom of Denmark from exercising its power of taxation over the benefits paid by a pension institution established in another Member State to a taxpayer still resident in Denmark when that payment is made, as a counterbalance to the contributions which it allowed to be deducted or exempted. It is only in the case where, before benefits fall to be paid, that taxpayer transferred his residence to a Member State other than the Kingdom of Denmark that it might encounter difficulties in taxing the benefits paid and where, therefore, the cohesion of the Danish tax system with regard to the taxation of private pensions would be adversely affected.

74. It follows that, by refusing in general to grant a tax advantage in respect of contributions paid to a pension institution established in another Member State, the contested legislation cannot be justified by the need to guarantee the cohesion of the tax system.

The statement in Commission v Denmark, para 73, that cohesion of the tax system would be jeopardised if Denmark could not collect its legitimate tax claim from the taxpayer after he had moved to another Member State is consistent with the analysis in $X$ and $Y$ and in National Grid Indus. This in turn begs the question what function the cohesion of the tax system performed in Papillon since we established that there was no jeopardy to the balanced allocation of taxing powers in that case. And conversely, why the balanced allocation of taxing powers was accepted in Glaxo Wellcome, despite the fact that the restriction in that case could not be justified by the cohesion of the tax system.

In contrast to Bachmann the cohesion of the tax system was not applied in Papillon as a disguised argument relating to the balanced allocation of taxing powers. The cohesion of the tax system was only accepted in Papillon to hold the restriction suitable to achieve the aim of tax neutrality of group transactions. That neutrality would be jeopardised if losses incurred by a subsubsidiary (held through a foreign subsidiary) would be taken into account twice within a tax consolidated group; once as operating losses of the subsubsidiary, and also as a cost of the parent company relating to a depreciation of its holding in the foreign subsidiary which was ultimately due to the loss suffered at the level of the subsubsidiary. The French regime at issue did not provide for the depreciation to be added back to the income of the tax consolidated group so that the subsubsidiary's loss was only accounted for once in consolidated income. To 
exclude the subsubsidiary from consolidation-because it was held through a subsidiary established in another Member State - was thus a suitable measure to prevent this result (paras 43-51). The Court however ruled that an obligation for the parent company to produce the necessary documentary evidence that allows the tax authorities - if necessary assisted by administrative cooperation with the authorities of the other Member State-to ascertain, clearly and precisely, whether there is a risk that losses are accounted for twice in the consolidated income is more proportional then a prohibition to include a domestic subsubsidiary held through a foreign subsidiary in the tax integration regime with the parent company (Papillon, paras 52-61). The restriction at issue thus went beyond what was necessary to safeguard the cohesion of the tax system.

Glaxo Wellcome on the other hand failed at the test of cohesion of the tax system. The Court in that case could not identify any tax advantage which might have offset the restriction at issue (para 79). It concluded that the required direct link was lacking (para 80). However, the restriction at issue was held suitable to maintain a balanced allocation of taxing powers by preventing the risk of tax avoidance. Failing the cohesion test therefore does not preclude a national measure from finding another justification in EU law. Recalling the justification for the prevention of abusive practices of Rule 4:5 of Annex A, this is not surprising, given that the this rule has incorporated the requirements of proportionality. ${ }^{698}$

The case of Krankenheim Ruhesitz am Wannsee-Seniorenheimstatt may be interpreted as the application of the cohesion of the tax system to safeguard the aim of preserving a balanced allocation of taxing powers. If a Member State is not obliged per se to allow a relief for losses suffered by a branch that is established in another Member State, according to Lidl Belgium, then it is equally consistent with the aim of preserving a balanced allocation of taxing powers if a Member State allows a temporary relief for those losses, but recaptures that tax advantage when the foreign secondary establishment becomes profitable again. The test of cohesion in Krankenheim Ruhesitz am Wannsee-Seniorenheimstatt essentially performed the function of assessing the suitability of the national measure to preserve the balanced allocation of taxing powers by imposing the disputed restriction on freedom of movement.

But how should cases Commission v Belgium (C-250/08) and Commission v Hungary (C-253/09) be understood? Cohesion of the tax system was the only justification that was explicitly recognised by the Court in these judgments.

The proceedings against Hungary were on national measures that effectively precluded deducting the value of the purchaser's previous residence from the basis of assessment of a tax charged upon the purchase of a house to be used as principal residence if that previous residence was in the territory of another Member State. In internal situations such an allowance would normally be granted so that the tax was calculated on the positive difference, if any, between the market value of the house that was bought and the house that was sold. The 
proceedings against Belgium concerned measures that applied only in the Flemish region and which reached the same effect by allowing a deduction of registration tax paid in relation to the previous residence from the registration tax paid on a new residence in Flanders, but only if that previous residence was also situated in Flanders. There was a restriction on freedom of movement in both cases, because the national laws imposed higher tax burdens on persons who transferred their place of residence from another Member State compared to persons who had previously owned a residence in Hungary and Belgium respectively. The justification analysis based on the cohesion of the tax system essentially follows similar lines of reasoning in both cases. For the purposes of clarity, only the judgment in Commission v Hungary is used to illustrate the Court's approach.

The Court found that the aim of the Hungarian measures was that registration taxes were levied only on a previously untaxed part of the new residence's value, i.e. the difference between the transfer price of the previous property and the acquisition price of the new property (para 73). To that end, the tax advantage granted with the purchase of a new residence offset the balance of registration taxes which had been levied on previous acquisitions by the same taxpayer. The Court held:

74. By contrast, when the property sold is situated in a Member State other than Hungary, the Republic of Hungary has no power to tax the transaction entered into in that other Member State by the person deciding to purchase a property in Hungary for his principal residence. In those circumstances, by providing that only those who have already paid the tax at issue on the purchase of such property in Hungary may benefit from the tax advantage in question when purchasing property of the same nature, the configuration of the tax advantage in question reflects a logic of symmetry within the meaning of the case-law (see, to that effect, Krankenheim Ruhesitz am WannseeSeniorenheimstatt, paragraph 42).

75. If taxpayers not having paid the tax at issue previously were able, under the tax regime at issue, to benefit from the tax advantage concerned, they would take unfair advantage of taxation that was not applicable to their previous purchase outside Hungary.

76. It follows that, under the tax regime in question, there is a direct link between the tax advantage granted and the initial levy. First, that advantage and the tax levy are applied to one and the same person and, second, they both relate to the same tax.

77. In that context, it should be noted that the two requirements that the levy be identical and applied to one and the same person have been found to be sufficient to establish the existence of such a link (see, inter alia, Case C35/98 Verkooijen [2000] ECR I-4071, paragraph 58; Case C-168/01 Bosal [2003] ECR I-9409, paragraphs 29 and 30; and Krankenheim Ruhesitz am Wannsee-Seniorenheimstatt, paragraph 42). In addition, it must be noted that 
the Commission has not expressly disputed that the tax advantage in question is granted to the same taxpayer in relation to the same tax.

By allowing the tax advantage to be reserved for transfers of residence within Hungary, the Court effectively recognised a legitimate right to impose a tax on property which is situated in the national territory of the Member State. In para 74 of the judgment in Commission v Hungary the Court holds that no such right exists in relation to property situated in another Member State. The underlying objective of the cohesion of the tax system as applied in Commission v Hungary and Commission $v$ Belgium is similar to the balanced allocation of taxing powers; the Court ultimately did not oblige the Member States to surrender their legitimate tax claim on immovable property situated in their territory. Cohesion of the tax system was used in those cases as a tool that tested whether that underlying policy objective was pursued in a consistent and systematic manner by imposing a restriction on free movement. This becomes very clear when the Court holds the restriction suitable to obtain the justified objective, by reason that and only because - the national measures passed the test of cohesion:

\begin{abstract}
80. In that respect, it should be noted that, in the light of the Court's caselaw, the restriction in question is appropriate to achieve such an objective, in that it operates in a symmetrical manner, since only the difference in value between the property sold which is situated in Hungary and the value of the property purchased may be taken into account in the tax system at issue (see, to that effect, Krankenheim Ruhesitz am Wannsee-Seniorenheimstatt, paragraph 44).
\end{abstract}

\title{
7.5.4 Synthesis and discussion
}

We conclude that the cohesion of the tax system is not a justification in itself. It is best conceived as a methodological tool to assess the suitability of a restriction on free movement to achieve legitimate aims of tax policy. There is cohesion in the tax measure if it pursues the legitimate aim in a consistent and systematic manner. Consistent means that a tax advantage will be offset, as a rule of logical symmetry, by a subsequent levy, or vice versa. Systematic means that this rule of neutralisation occurs by express legal design and not by chance, thus requiring the link between the advantage and the levy to constitute a specific correlation, i.e. a direct link. We will see in Chapter 8 that these are general requirements of the principle of proportionality.

It may indeed be conceded that an express systematic legal design is difficult to find when the advantage and offsetting levy concern different taxpayers and/or different taxes, unless, like it was the case in Manninen, the national provisions expressly impose such a direct link in the text of the laws. Cohesion in the tax system means that the underlying legitimate tax policy aim is pursued 
by the restriction in a coherent manner as a matter of express legal configuration. Mathisen submits: ${ }^{699}$

A measure must thus be coherent in order to be necessary, because it must be coherent in order to be suitable and suitable in order to be necessary.

The avowed aim of imposing a tax claim is not pursued in a consistent manner if the Member State has allocated the primary power to impose tax to another Member State pursuant to a DTC. Surrendering the power to impose a tax by a DTC runs counter to the objective to maintain a tax claim through national law. The Wielockx-rule identifies this type of inconsistency in the legal framework of the Member States.

The fact that a national measure does not pass the test of fiscal cohesion does not necessarily imply that the national measure is ill-suited to achieve the legitimate aims of tax policy it may pursue. Cohesion is one legal tool in the Court's cabinet to assess the suitability of a restriction. To pass the cohesion test means that the legitimate tax policy aim is pursued in a consistent and systematic manner. If the test of cohesion fails, however, and it can nonetheless be established that a national measure achieves its legitimate aims in a consistent and systematic manner, there is nothing to prevent the Court from holding the measure as being suitable to attain its aims. This explains the judgment in Glaxo Wellcome.

Because the cohesion of the tax system is only a methodological tool to assess the suitability of a restriction to achieve legitimate aims of tax policy, this implies that even coherent restrictions may go further than necessary to achieve their set aims. Consequently, a restriction passing the cohesion of the tax system test is not necessarily proportional if the same result may be achieved by means which impose a lesser restriction on free movement. This was precisely the case in Manninen and Papillon. We will therefore turn in the next chapter to the principle of proportionality as applied to the balanced allocation of taxing powers.

\subsection{Synthesis and discussion}

In Chapter 5 we formulated two research questions which were dealt with in this Chapter.

In research question 2 we asked what the relations between the BAOTP standard and other justifications were. Our findings are the following.

As regards the risk that losses might be used twice, we found in section 7.3 that this justification is not a justification in the true meaning because we could not identify an overriding public interest - a larger aim of government - to which it relates. Rather, this argument pre-empts that the freedom provisions of the TFEU are interpreted to impose reverse discrimination. The Union citizen's 
right to move and reside freely within the EU without being subject to discrimination on grounds of nationality cannot be interpreted to the effect that a free mover is treated more favourably than in an internal situation. The only requirement is that the free mover is accorded a treatment that is not less advantageous than the treatment that the Member State concerned affords in purely domestic situations. Consequently, the prohibition on restrictions on free movement should not be interpreted to afford undue (tax) advantages to free movers. This limit to the Union citizen's right is thus inherent in the free movement provisions.

As for the relation between tax avoidance and the BAOTP standard, we found in Section 7.4 that these justifications are indistinguishable on a higher level of abstraction. The BAOTP standard is the genus justification and the need to prevent abusive practices, i.e. tax avoidance by wholly artificial arrangements, is a species of the BAOTP standard. The overriding reason of public interest that both justifications protect is the same, namely to preserve the power of the Member State concerned to impose taxes in relation to economic activities carried out in the national territory. Contrary to prior research, we did not find that motive or subjective intent is a material condition for the justification on grounds of the need to prevent abusive practices. It is the existence of a wholly artificial arrangement and the jeopardy to the balanced allocation of taxing powers that together establish, on basis of the objective circumstances in the actual case at hand, a finding of an abusive of law. The burden of proof may be put on the taxpayer to show commercial justification for his legal arrangements without undue administrative burdens.

If the taxpayer claims a tax advantage that is afforded by a legal fiction in national legislation - the law operates on basis of an inherent artificiality - the finding of significant disparities between the Member States concerned and the jeopardy to the balanced allocation of taxing powers are, taken together, sufficient evidence to justify the conclusion that the taxpayer claims the tax advantage improperly when EU law is involved. We consider this line of authority to be consistent with the case law dealing with wholly artificial arrangements; there is no contradiction between e.g. Marks \& Spencer on the one hand and e.g. ICI and Cadbury Schweppes on the other hand.

Section 7.5 argued that the cohesion of the tax system is best interpreted as a methodological tool to assess whether a tax restriction pursues a legitimate goal of tax policy, e.g. preserving the balanced allocation of the power to impose tax or achieving tax neutrality in relation to corporate groups, in a consistent and systematic manner. A coherent tax measure that complies with the requirements of Rule 4:3 of Annex $A$ is a suitable measure for the protection of an overriding reason of public interest. Whether the restriction goes further than necessary is another matter of proportionality, which Chapter 8 will address.

This Chapter also sought an answer to research question 3 of Chapter 5 on the status of the BAOTP standard as an autonomous justification ground. We should recall that Chapter 6 already established that the Court considers the imposition of a tax claim as legitimate if the tax claim corresponds to the fiscal principle of territoriality and does not involve another Member State as per 
Futura. Compliance with the fiscal principle of territoriality is thus a precondition to allow a tax restriction of freedom of movement being justified on grounds of the need to preserve a balanced allocation of taxing powers.

Because we concluded that the risk that losses might be used twice only comes into play in relation to justifiable tax restrictions on freedom of movement, this argument is properly 'taken together' with e.g. the balanced allocation of taxing powers. The converse is not true. The BAOTP standard may be invoked autonomously and does not need to be 'taken together' with a risk that the Union citizen seeks an undue tax advantage.

The need to prevent abusive practices and the BAOTP standard both pursue the same recognised public interest. It is consequently irrelevant whether they are 'taken together' or not. The need to prevent tax avoidance by abusive practices implies by definition the justification of the need to preserve a balanced allocation of taxing powers. The BAOTP standard may however be invoked autonomously in cases in which a genuine exercise of freedom of movement by a Union citizen might jeopardise a legitimate tax claim of the Member State concerned on economic activities carried out in the Member State's territory. It is, however, not possible to argue a case of tax avoidance through abusive practices when a Union citizen has exercised the right to free movement properly in form as well as in substance. In other words, the BAOTP standard applies in relation to wholly artificial arrangements and also in relation to genuine exercises of freedom of movement. 


\section{Chapter $8 \quad$ Proportionality}

\section{$8.1 \quad$ Introduction}

The aim of this Chapter is to analyse the proportionality requirements that apply to direct tax restrictions on freedom of movement which are justified by the need to preserve a balanced allocation of taxing powers. In Chapter 7 we concluded that the need to prevent abusive practices was indistinguishable on a higher level of abstraction from the BAOTP standard. The research of Chapter 7 has also shown that the proportionality of direct tax restrictions which aim to prevent abusive practices needs to be assessed in light of the object and purpose of the TFEU provisions and in particular with reference to the concept of wholly artificial arrangements. We will therefore not revisit the Court's judgments in Cadbury Schweppes (C-196/04), Thin Cap Group Litigation (C-524/04), Glaxo Wellcome (C-182/08), and SGI (C-311/08) in this Chapter. The BAOTP standard was applied in those cases to prevent abusive practices through wholly artificial arrangements.

This Chapter focuses on the proportionality requirements of the BAOTP standard as such. We give a short introduction to the principle of proportionality as a judicial principle and its reception into the field of direct taxation in Section 8.2. We then return to the case law of Chapter 6 and we analyse the Court's statements on proportionality in those judgments. Section 8.3 presents this analysis and Section 8.4 gives a summary of findings of this Chapter.

\subsection{The principle of proportionality}

\subsubsection{A general and judicial principle of EU law}

Next to the requirement that restrictions may only be justified by 'overriding reasons in the public interest', i.e. the public policy or larger aims pursued must be legitimate justification grounds as such, the Court's doctrine will only allow proportionate restrictions as justified. The principle of proportionality is a general and judicial principle of EU law and is exhaustively commented on in Tridimas. ${ }^{700} \mathrm{He}$ considers it 'the most important judicial tool for drawing the distinction between lawful and unlawful impediments to free movement. ${ }^{, 701}$

\footnotetext{
700 Tridimas (2006), Chapter 5.

701 Tridimas (2006), p. 207.
} 
Consequently, the manner in which the principle of proportionality ultimately constrains deference to the need to preserve a balanced allocation of taxing powers as a justification for restrictions on freedom of movement gives meaningful insight into the nature and force of that justification.

Barnard explained the Court's approach to proportionality as a two-stage analysis of the suitability and the necessity of the restriction to achieve a balance between the protection it purports to afford to overriding reasons of public interest and the adverse consequences it has on freedom of movement. ${ }^{702}$

First, the national measure must pass a test of suitability. The Member States are required to show a genuine connection between the overriding interest pursued and the restriction imposed by the national measure. This is a factual or empirical assessment to a certain extent in that the burden of proof is on the Member State to show that that national measure is capable to pre-empt adverse consequences to the overriding reason of public interest that is at stake. ${ }^{703}$ This means, according to the Court's most recent case law, that the national measure pursues the public policy interest 'in a consistent and systematic manner'. ${ }^{704}$ Consistency means an absence of contradictions in the design of the national measure and the requirement of a systematic manner is best conceived as coherence in the sense that the connection of the restriction with the protected aims is a matter of positive connections or effects. ${ }^{705} \mathrm{~A}$ national measure will not be considered suitable if the Court finds evident inconsistencies and incoherence in the national legislation at issue that undermine the attainment of the protection of the public interest concerned, despite the submissions of the Member State to the contrary. ${ }^{706}$ Coherence is roughly similar to the degree of fit in Douma's interpretation of the necessity test to which we will turn now. ${ }^{707}$ We do not follow Douma, but perceive coherence as a proper element of the suitability test.

Next to the test of suitability, the national measure should pass a test of necessity; the adverse consequences to freedom of movement should be necessary to provide a level of protection to the public policy aims which the national measure pursues and those consequences also may not be excessive in relation to those aims and the level of protection that is actually pursued. A measure is excessive or disproportionate if the recognised public policy goal may be achieved effectively at a similar level of protection by lesser means and the adverse consequences to freedom of movement may so be mitigated in part or in full. The Court only allows the least restrictive alternative as justified. ${ }^{70}$

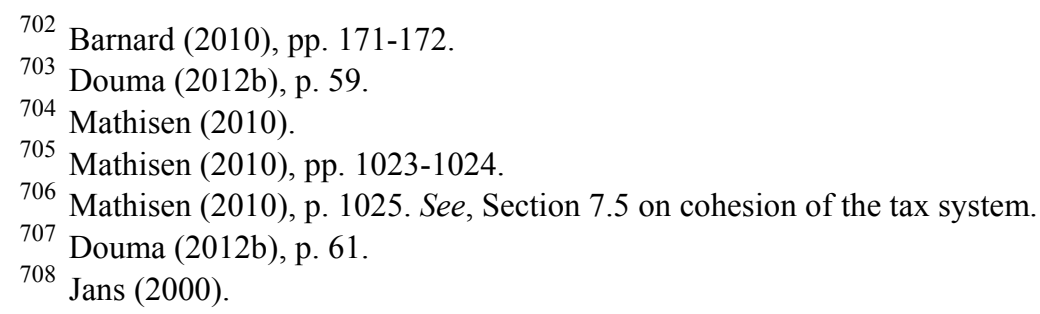


Mathisen explains that necessity is a requirement of proportionality that relates to the degree of fit between the restriction and EU law objectives. The reason for favouring an alternative measure over the restriction at issue is that the alternative measure better coheres with freedom of movement than the other, provided that the alternative measure maintains equivalent coherence with the national public policy objectives. ${ }^{709}$ Douma calls this 'subsidiarity' when speaking of necessity. ${ }^{710}$ As Tridimas explains in more detail, the existence of other, less restrictive, measures in other Member States is not a sufficient reason in itself to question the necessity of the restriction in the Member State concerned. $^{711}$

The application of the proportionality principle and the intensity of the Court's judicial review depend in part on the degree of harmonisation with respect to the public policies and competences at issue. ${ }^{712}$ A national measure is more likely to fail the proportionality tests in harmonised areas of EU law that state minimum levels of protection in relation to the recognised public policy interest concerned. In contrast, when national policies are not coordinated, the Court tends to leave the Member States a margin of discretion in setting the required level of protection. The Court made this point in e.g. Marks \& Spencer (C-446/03):

58. Furthermore, in so far as it may be possible to identify other, less restrictive measures, such measures in any event require harmonisation rules adopted by the Community legislature.

The margin of appreciation that Member States enjoy in the absence of harmonisation is particularly apparent when the public interest relates to politically sensitive areas of e.g. social and tax policies. ${ }^{713}$ In that context we quote the following passage from Tankreederei I (C-287/10), in which the Court made this point explicitly:

30. Lastly, as regards the considerations voiced by the French Government on the discretion which Member States have to make the grant of a tax advantage which seeks to meet the specific needs of its entire or of part of its population subject to the requirement of a certain degree of connection between the recipient of the advantage and the society of the Member State concerned, it must be acknowledged that it is true that the choice of interests of the general public which a Member State wishes to promote by granting tax advantages is a matter for its own discretion (see, to that effect, Case C-386/04 Centro di Musicologia Walter Stauffer [2006] ECR I-8203, paragraph 39).

709 Mathisen (2010), p. 1043.

710 Douma (2012b), pp. 62-63.

711 Tridimas (2006), pp. 214-218. See, Jans (2000), pp. 249-252.

712 Jans (2000), pp. 253-255.

713 See, Section 4.3.5.7.5 on lotteries and charities. 
31. Furthermore, as regards the need for a connection between the recipient of a benefit and the society of the Member State concerned, the Court has already held that, with regard to benefits that are not covered by European Union law, Member States enjoy a wide margin of appreciation in deciding which criteria are to be used when assessing the degree of connection to society (see, to that effect, Case C-103/08 Gottwald [2009] ECR I-9117, paragraphs 32 and 34).

32. However, in circumstances such as those of the case in the main proceedings, where a national provision consistently refuses the benefit of a tax advantage when the investment is not used in national territory, notwithstanding the fact that the investment in question is unconnected with any social objective, such a refusal cannot be justified by such considerations.

Even in the absence of alternative measures and harmonisation, a national measure may be manifestly excessive and too burdensome on freedom of movement, despite the suitability and necessity of the restriction to protect an overriding reason of public interest - the measure is disproportional in the narrow sense. Should the Court arrive at this point of law in a judgment in relation to freedom of persons, it will approach the matter in a cautious manner, because the examination of proportionality in the narrow sense requires a very delicate balancing of the interests of the Member States, of the Union citizen, and the interests of the Union as a whole. ${ }^{714}$ We agree with Mathisen that proportionality in the narrow sense does not concern inconsistencies or incoherence in the design of the national measure in relation to its aims. ${ }^{715}$

As we see it, the Court weighs two constitutional values inherent in the Treaties. On the one hand there is the fundamental constitutional protection afforded to free moving Union citizens and, on the other hand, there is the constitutional protection inherent in the Treaties to the diversity of moral values and heterogeneity of historical, social and cultural policies between the Member States, for the EU is ultimately 'united in diversity'. This importance of proportionality in the narrow sense for the interpretation of the system of EU law that inheres in the Treaties justifies in principle a mandate of the Court to substitute its own interpretation in favour of that of the national legislator. We agree with Jans that the Court will be reluctant to do so in practice in view of the sensitive nature of the division of powers between the EU judiciary (the Court), the national judiciary and the national and EU legislator. ${ }^{716}$ For that reason, the Court has a choice of options under Article 267 TFEU which ranges from deciding that the national measure complies with or breaches the principle of proportionality, to give detailed guidance as to the proportionality conditions

714 Jans (2000), pp. 248-249; Mathisen (2010), p. 1046. See, Douma (2012b), pp. 63-66 on balancing competing principles as optimisation requirement.

715 Mathisen (2010), p. 1047.

716 Jans (2000), p. 264. See, Tridimas (2006), p. 207. 
that the national court should apply, to the possibility or to leave the proportionality of the restriction for the national court to decide, according to the circumstances of the specific case at hand. ${ }^{717}$

\subsubsection{Reception in the field of direct taxation}

The principle of proportionality was formally introduced in the field of direct taxation by Futura (C-250/95) and has become part of the core judicial rules in this field as Rule 4:1 of Annex A. It may be conceded that Bachmann already included an effective proportionality analysis in paras 24-27. Understanding Bachmann in this way only reaffirms our understanding of cohesion of the tax system as a methodological tool to assess the suitability of justifiable restrictions. However, the Court did not present it as such in Bachmann.

Since Futura, the Court consistently formulated that the application of justifiable restrictions should be 'appropriate to ensuring the attainment of the objective thus pursued and [should] not go beyond what is necessary to attain it' in e.g. Marks \& Spencer, para 35. The text of Futura, para 26 is representative of the wording of community 3 and is the basis of Rule 4:1(2) of Annex A. This is the same two-stage test of suitability ('appropriateness') and necessity as discussed in the previous Section.

The principle of proportionality is a general (judicial) principle of EU law and the ruling in Futura relies in this regard in para 26 on the precedents of Kraus (C-19/92), Gebhard (C-55/94), and Bosman (C-415/93). ${ }^{718}$ All three decisions are hallmark cases on the free movement of persons. That is a strong signal that the principle of proportionality is not to be interpreted differently in the field of direct taxation compared to other areas in which EU law applies.

The Court held in Gebhard, para 37, that imperative grounds in the public interest which are not listed in the Treaty may justify national measures liable to hinder or make less attractive the exercise of free movement rights only if those measures are applied in a non-discriminatory manner. That non-discrimination condition should be understood with reference to Kraus. The Court cited Kraus, para 32, in Gebhard, para 37. The precedent of Kraus clarifies that 'nondiscriminatory' in Gebhard means 'without discrimination on grounds of nationality' as this is the phrase used in Kraus, para 32. This implies that indirectly discriminatory measures on grounds of e.g. a criterion of residence may be justified by the rule of reason if they are proportional. ${ }^{719}$ If the national law makes a distinction directly on the basis of nationality or, in the case of companies, on the basis of the company's seat, this type of discrimination may only be justified by the grounds listed exhaustively in the Treaty. ${ }^{720}$ This is why the Court held in Avoir Fiscal, Royal Bank of Scotland, para 32, and Saint-

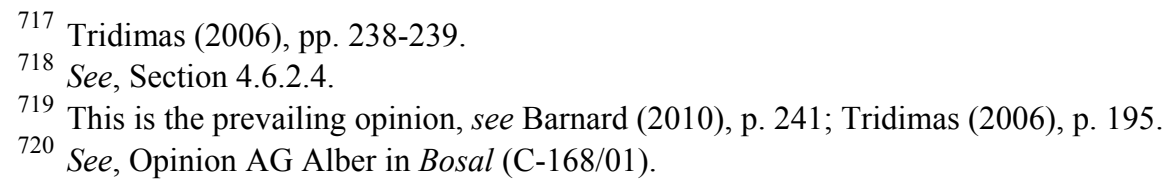


Gobain, para 45, that the discriminations at issue in those cases could only be justified by the express derogations provided in the Treaty. ${ }^{721}$ Those cases do not, contrary to the positions defended by Wattel, ${ }^{722}$ or by Van Thiel, ${ }^{723}$ give reason to believe that the non-discrimination condition of Gebhard was relaxed in later case law in the field of direct taxation. Particularly the text of the judgment in $X$ and $Y$ (C-436/00) does not indicate, contrary to the opinion of Wattel, that the Court considered the restriction a direct discrimination. The case at issue concerned the application of different rules to companies established in Sweden which were formed pursuant to an exercise of freedom of establishment compared to similar Swedish companies which had no connection to an exercise of freedom of establishment. The case did not concern a direct nationality discrimination; the question whether Sweden imposed a different tax rules on foreign companies than on companies established in Sweden.

Nonetheless, the Court regards compliance with the proportionality principle especially important where the national rule at issue excludes free movement situations from a tax advantage altogether as it held in e.g. Commission v France (C-334/02), para 28. Again, it should be recalled that the Court has held in Rewe Zentralfinanz (para 43) for a resident parent company that had exercised its right to free movement by establishing a foreign subsidiary and in $O y A A$ (para 53) for a resident subsidiary established by a parent company of another Member State, that the balanced allocation of taxing powers cannot justify a Member State systematically refusing to grant a tax advantage to a company established in its territory on grounds that this Member State cannot exercise its taxing powers in another Member State to or from which the right to free movement has been exercised. We will now turn to the application of the proportionality principle to the need to safeguard a balanced allocation of the power to impose tax between the Member States.

\subsection{Proportionality in action}

The different treatment at issue in Marks \& Spencer was an indirect discrimination against parent companies of the UK who exercised their freedom of establishment and set up subsidiaries in other Member States. Since the case was not about direct nationality discrimination, the restriction was justifiable under the rule of reason. The Court evaluated the suitability of the three justification grounds in paras $45-52$ by asking what the consequences would be if the group relief would be extended unconditionally in free movement situations (para 41). The necessity test of the Marks \& Spencer proportionality analysis was assessed as follows:

\footnotetext{
721 Compare, $X A B$ and $Y A B(\mathrm{C}-200 / 98)$.

722 Wattel (2004), p. 83.

${ }^{723}$ Van Thiel (2008a), p. 169
} 
53. $[\ldots][\mathrm{T}]$ he Court must ascertain whether the restrictive measure goes beyond what is necessary to attain the objectives pursued.

54. Marks \& Spencer and the Commission contended that measures less restrictive than a general exclusion from group relief might be envisaged. By way of example, they referred to the possibility of making relief conditional upon the foreign subsidiary's having taken full advantage of the possibilities available in its Member State of residence of having the losses taken into account. They also referred to the possibility that group relief might be made conditional on the subsequent profits of the non-resident subsidiary being incorporated in the taxable profits of the company which benefited from group relief up to an amount equal to the losses previously set off.

55. In that regard, the Court considers that the restrictive measure at issue in the main proceedings goes beyond what is necessary to attain the essential part of the objectives pursued where:

- the non-resident subsidiary has exhausted the possibilities available in its State of residence of having the losses taken into account for the accounting period concerned by the claim for relief and also for previous accounting periods, if necessary by transferring those losses to a third party or by offsetting the losses against the profits made by the subsidiary in previous periods, and

- there is no possibility for the foreign subsidiary's losses to be taken into account in its State of residence for future periods either by the subsidiary itself or by a third party, in particular where the subsidiary has been sold to that third party.

56. Where, in one Member State, the resident parent company demonstrates to the tax authorities that those conditions are fulfilled, it is contrary to Articles $43 \mathrm{EC}$ and $48 \mathrm{EC}$ to preclude the possibility for the parent company to deduct from its taxable profits in that Member State the losses incurred by its non-resident subsidiary.

57. It is also important, in that context, to make clear that Member States are free to adopt or to maintain in force rules having the specific purpose of precluding from a tax benefit wholly artificial arrangements whose purpose is to circumvent or escape national tax law (see, to that effect, ICI, paragraph 26, and De Lasteyrie du Saillant, paragraph 50).

58. Furthermore, in so far as it may be possible to identify other, less restrictive measures, such measures in any event require harmonisation rules adopted by the Community legislature.

The Court's considerations of proportionality in Marks \& Spencer explain that if losses of a secondary establishment in another Member State cannot be taken into account in that other Member State, because all legal opportunities for relief against current tax year profits or carry-back relief are fully exhausted (first indent of para 55), and because carry-forward relief for those losses is not, or no longer, possible (second indent of para 55), then the Member State in which the 
principal company is established should relieve those losses under the same conditions as for internal situations. The interpretation of para 55 as recognised possibilities by law of carry-over relief to the taxpayer, or to a (third party) transferee, is supported by the Court's consistent use of the term 'accounting period' with respect to both conditions in Lidl Belgium, para 47, and also the opinion of the Advocate General in Marks \& Spencer (points 74, 79 and 80). The burden of proof that the paragraph 55 conditions are both met is in principle with the taxpayer making the claim for loss relief (Marks \& Spencer, para 56).

The Court's description of a disproportionate restriction is the situation in which the Member State of the secondary establishment has decided to break with tax symmetry between profits and losses. The paragraph 55 conditions of proportionality hence describe the moment at which the Member State surrenders its legitimate right to attach tax consequences to specific losses suffered by a secondary establishment. That is what the Court most probably means with the 'essential part of the objectives pursued' in Marks \& Spencer, para 55, given that it held in para 44 that the preservation of the balanced allocation of taxing powers makes it necessary to apply only the tax rules of the state of establishment to the company's profits and losses.

The Member State of the principal company in these circumstances is no longer excused from giving full effect to EU free movement law, since the balanced allocation of taxing rights of the Member State of the secondary establishment is in fact not jeopardised in regard to those losses. For the same reason, if the Member State of the secondary establishment no longer takes into account the losses of that establishment for tax purposes, the risk that the losses would be taken into account by both Member States disappears completely. ${ }^{724}$

As we see it, the Court did not approach these matters as issues of proportionality in the narrow sense in Marks \& Spencer. ${ }^{725}$ Paragraph 55 states that the restriction goes beyond what is necessary to obtain the overriding

724 See, Halsey (HM Inspector of Taxes) v Marks \& Spencer Plc [2007] EWCA Civ 117 (20 February 2007), para 35: 'It is not difficult to see why the Court of Justice took the view that, in circumstances which fall within the paragraph 55 conditions, the restriction goes beyond what is necessary. If (i) the (non-resident) surrendering company has exhausted the possibilities, available in its state of residence, of having the losses taken into account for the surrender period and for previous accounting periods and (ii) there is no possibility for the surrendering company's losses being taken into account in its state of residence for future accounting periods, then: (1) full effect has been given to the power of the state of residence of the surrendering company to impose taxes on its own resident and there is no need to "protect a balanced allocation of the power to impose taxes" between that state and the state of residence of the claimant company; (2) there is no possibility that the losses of the surrendering company will be taken into account twice; and (3) there is no potential for tax avoidance - the surrendering company has been required to use its losses in its own state of residence so far as it can.'

Douma (2007) argues the contrary. See, Douma (2012b), pp. 282-285. 
reasons of public interest that it pursued; it does not state that the restriction was disproportional due to its effects on freedom of movement. We observe that the Court merely pointed to situations in which the restriction was in fact overinclusive of situations in which the public interest did not require protection. In these clearly defined circumstances a restriction on freedom of establishment was not necessary, and the national measure was therefore disproportionate insofar as it applied in those situations.

It follows from Lidl Belgium that the Court's statements in Marks \& Spencer, paras 55 and 56, were mainly concerned with the balanced allocation of taxing powers and the risk of double loss relief. In Lidl Belgium the need to combat tax avoidance was not invoked as a justification and the proportionality analysis of the Court focused entirely on the two other grounds. The restriction of loss relief in Lidl Belgium was ultimately proportional because Lidl Belgium failed to demonstrate that its losses were finally suffered with no possibility of relief in Luxembourg. Lidl Belgium's losses were in fact relieved in Luxembourg through carry-forward relief. The Court's holding in that regard in Lidl Belgium, paras 44-51, is self-explanatory and is therefore quoted in full:

44. [...] [I]t remains necessary to examine whether the tax regime at issue in the main proceedings goes beyond what is necessary to attain the objectives pursued (see Marks \& Spencer, paragraph 53, and $O y A A$, paragraph 61).

45. Lidl Belgium and the Commission of the European Communities have referred in particular to the possibility that the right of a principal company to deduct the losses incurred by a permanent establishment belonging to it could be made subject to the condition that the company incorporate in its future profits the subsequent profits of the permanent establishment, to the extent of the losses previously offset. In that context, they refer to the system which operated in the Federal Republic of Germany prior to 1999.

46. It should be pointed out that reference was made in paragraph 54 of the judgment in Marks \& Spencer to the possibility of making the benefit of the tax advantage at issue subject to such a condition, together with the possibility of making the benefit of that advantage conditional upon the subsidiary established in a Member State other than that in which the principal company has its seat having taken full advantage of the possibilities available in its Member State of residence of having the losses taken into account.

47. In that regard, the Court held in paragraph 55 of the judgment in Marks \& Spencer that a measure which restricts the freedom of establishment goes beyond what is necessary to attain the objectives pursued where a nonresident subsidiary has exhausted the possibilities for having the losses incurred in the Member State where it is situated taken into account for the accounting period concerned and also for previous accounting periods and where there is no possibility for that subsidiary's losses to be taken into account in that State for future periods. 
48. In paragraph 56 of that judgment, the Court also stated that where, in one Member State, the resident parent company demonstrates to the national tax authorities that those conditions are fulfilled, it is contrary to Article 43 EC to preclude the possibility for the parent company to deduct from its taxable profits in that Member State the losses incurred by its non-resident subsidiary.

49. As regards the main proceedings, it must be pointed out that Luxembourg tax legislation provides for the possibility of deducting a taxpayer's losses in future tax years for the purposes of calculating the tax base.

50. As was confirmed at the hearing before the Court, Lidl Belgium has in fact benefited from such an offsetting of the losses incurred by its permanent establishment in 1999 in a subsequent tax year, namely 2003, in which that entity generated profits.

51. Accordingly, Lidl Belgium has not shown that the conditions laid down in paragraph 55 of the judgment in Marks \& Spencer, for establishing the situation in which a measure constituting a restriction on the freedom of establishment for the purposes of Article $43 \mathrm{EC}$ goes beyond what is necessary to attain legitimate objectives recognised by Community law, were satisfied.

The Court's ruling in Lidl Belgium consequently forces the conclusion that Marks \& Spencer, para 57, that regards as proportional all measures which combat wholly artificial arrangements, is chiefly concerned with the need to combat abusive tax avoidance as a justification, and in any case is not a proportionality standard of national measures aimed at preventing double loss relief. As we have seen above, the UK group relief system at issue in Marks \& Spencer operated on the basis of inherent artificiality in the law. The transfer of losses between taxpayers under the UK group relief system is not the legal result of a corresponding transfer of genuine economic activity and its tax consequences are therefore wholly artificial by definition. The same applied to the group contribution regime in issue in $O y A A$ allowing the transfer of profits between group companies. Also the Dutch regime at issue in $X$ Holding was a legal fiction.

The Court first held in $O y A A$ that the Finnish group contributions concerned a right to transfer profits between taxpayers and not losses like in Marks \& Spencer. The need to prevent double loss relief could therefore not justify the restriction ( $O y A A$, para 57).

In $O y A A$ the Court thereafter considered the restriction proportionate to the objectives of maintaining a balanced allocation and the need to combat abusive tax avoidance but explicitly considered that proportionality was adjudged to those two objectives 'as a whole' ( $O y A A$, para 63). Given that these two objectives are not merely 'linked to each other' - as $O y A A$, para 62 explicitly admitted-but are actually indistinguishable in the larger aim pursued, it is consistent and logical not to artificially distinguish those grounds on the level of proportionality. In that regard, the Court held in $O y A A$, paras 63-65, that no other alternative measure was conceivable which would equally protect Finland's internal tax competence and pose a lesser restriction on freedom of 
establishment. In short, any form of cross-border group contribution, however limited, would chip away at Finland's legitimate right to tax the profits so contributed to foreign establishments. The Court did not find that the total ban on cross-border group contributions was excessive or disproportionate in a narrow sense. Consequently, the risk of tax avoidance and the need to safeguard a balanced allocation of taxing powers weigh up against the fundamental nature of the right to free movement.

The Court's proportionality analysis in $X$ Holding consists of two steps of argumentation. The first step was a preliminary remark on the benchmark against which the proportionality of the restriction was to be adjudged. The second step was the actual proportionality analysis for the restriction at issue.

As regards the first step, the Court dismissed the submission by X Holding and the Commission that a restriction against foreign subsidiaries would in principle be disproportionate in the context of a balanced allocation of taxing powers between the Member States if a more beneficial tax treatment was accorded to foreign branches than to foreign subsidiaries. Their argument was that the necessary level of protection of the balanced allocation of taxing powers had to be adjudged against the conditions the Dutch legislator considered sufficient for maintaining a balanced allocation as regards the taxation of foreign branches - i.e. a temporary relief of foreign losses with subsequent recapture $(X$ Holding, paras 36 and 37).

The Court (correctly) stipulated that foreign subsidiaries and branches are not generally in a comparable position as regards the allocation of taxing competences between the Member States pursuant to a double tax convention $(X$ Holding, para 38). It was therefore in principle lawful to apply different tax rules to both types of foreign establishments, given that consistent case law only requires equal treatment irrespective of legal personality if the national legislator otherwise aims to treat different forms of (secondary) establishments on a par ( $X$ Holding, paras 39-40). Since the Netherlands and Belgium agreed to a different allocation of the power to tax in regard to the two different forms of secondary establishments in their double tax convention, the Dutch national measures which would provide a level of protection not beyond what is necessary to maintain the balance of the allocation in regard of income made by foreign branches could not, at the outset, be assumed to be the same as the conditions which the Dutch legislator regarded adequate for foreign subsidiaries.

This first step should thus be read in the narrow sense of a preliminary point and this passage of the $X$ Holding judgment does not imply that the restriction in issue was proportional because the Netherlands had no taxing competence on the subsidiary's income; an opinion advanced in some prior research. ${ }^{726}$ The latter reading would be in direct conflict with para 24 of the judgment in which the Court held that this lack of tax competence does not imply that there would be no distortion of the Dutch legislator's tax equity choice of corporate group neutrality by making a distinction on the place of establishment to the

${ }^{726}$ Van Thiel and Vascega (2010). 
disadvantage of foreign subsidiaries. For this reason, it is plausible that it was the existence of a different allocation as such, and not the nature or effects of that difference, which persuaded the Court in finding that proportionality could not be assessed on the basis of the level of protection which the Dutch legislator held to be sufficient with regard to of branches. The assumption therefore had to be that different allocations for different legal forms, the different allocation in principle being lawful, may require different levels of protection and the respective national measures aimed at assuring the balance of each allocation have to be reviewed individually and on their own merits.

Logically, the Court's second analytical step was thus to adjudge the proportionality of the restriction against foreign subsidiaries in isolation, without reference to the tax scheme applicable to branches. Since the Court believed that, citing $O y A A$ as the only relevant precedent, any extension of the single tax entity scheme to foreign subsidiaries would enable the principal company to freely decide in which Member State (potential) losses would be subjected to tax, the Court decided to fully allow the restriction as proportionately justified ( $X$ Holding, para 41).

In para 32, to which the Court referred in para 41, the Court found that $X$ Holding, if allowed, could change the dimensions of the tax entity at will as explained in para 31 . The Court's proportionality analysis in para 41 could, in that context, be understood as implicitly rejecting the theoretical possibility that stricter rules on the formation and dissolution of a tax entity would be more proportionate than the blanket rejection of a tax entity under the conditions of the Dutch law at issue. However, that interpretation seems to read too much into paras 31 and 32. Rather, the proportionality analysis in para 41 makes clear that it was the existence of a tax entity with a foreign subsidiary which by itself would jeopardise the balanced allocation of taxing powers between the Member States. The significant freedom of the parent company to form and dissolve the entity hence only contributed further to that fundamental possibility and thus aggravated a risk that was already intolerable as such but it was not the root of the Court's reservations with X Holding's claim for a cross-border tax entity.

The Court neither recalled, nor analysed the paragraph 55 conditions of Marks \& Spencer in X Holding. This can be fully explained by the fact that the Belgian subsidiary of $\mathrm{X}$ Holding had not suffered losses (yet). But the possibility that this subsidiary would incur losses in the future was obviously a latent risk. Therefore, the possibility that future losses of the subsidiary could jeopardise the balanced allocation of taxing powers, if that subsidiary already was in a single tax entity with its parent when these losses would be incurred, could not be ruled out. This potential jeopardy was sufficient ground for the Court to justify a national provision that in principle precluded the formation of a cross-border single tax entity.

Although the potential jeopardy justified the restriction in general, there was no particular risk that this restriction would be disproportionate (unnecessary) in the circumstances of the case. This is so because losses first have to be incurred before the possibilities of their relief can be exhausted. And, nothing in the Court's judgment indicates that the Belgium subsidiary had in fact incurred 
losses. In Lidl Belgium, the Luxembourg branch of Lidl Belgium had in fact suffered losses. The restriction was consequently at risk to have disproportionate effects on the specific case of Lidl Belgium, so the Court went on to analyse the paragraph 55 proportionality conditions and applied them to the case at hand. The facts of $X$ Holding did not require a similar analysis.

The only justification applied by the Court in $X$ Holding was the balanced allocation of taxing powers. Also, in N. and ACT Group Litigation the balanced allocation of taxing powers was applied as an autonomous ground of judgment. The Court did not find a restriction against free movement in the latter case of $A C T$ Group Litigation, and consequently neither analysed (additional) justification grounds, nor their proportionality requirements. The former case of $N$. however included an extensive proportionality analysis.

In $N$. the Court found the exit tax on accrued capital gains on shareholdings justified by the need to safeguard the Netherlands' internal tax competence on that income (paras 40-47). The three conditions of proportionality in $N$. relate to the three additional sources of differential treatment that the Court identified alongside the primary discrimination of the exit tax as such ( $N$., para 35). First, in free movement situations the Netherlands obliged the taxpayer to provide guarantees in order to ensure collection of the tax at time of disposal, but not in internal relocations $(N$. , para 36). That condition was considered disproportionate because harmonising measures already safeguarded the proper collection of tax through directives enabling the Member States to exchange information and affording procedures of mutual assistance in the recovery of tax claims ( $N$., paras 51-53). Second, the obligation to make a tax declaration at the time of transfer of residence was not required for taxpayers who moved within the Netherlands ( $N$., para 38 ). This was considered a proportionate measure by the Court since any other administrative formalities or documentary evidences that Member States need from the taxpayer in order to properly determine the taxpayer's taxable income in the Member State of origin were unlikely to be less restrictive on the freedom of movement in the Court's view (N., paras 49-51). Third, realisation basis taxation in internal situations but accrual basis taxation in free movement situations was also held to be discriminatory (N., para 37$)$ and disproportionate ( $N$., para 54).

It follows from the third proportionality condition in $N$. that the balanced allocation of taxing powers may be relied on with regard to free movement situations not only if but also only to the extent that a Member State enforces a similar internal tax competence on internal situations in a consistent and systematic manner. If the taxing competence on internal situations is so defined that only realised capital gains at the time of disposal are taxed, then it would be inconsistent, and consequently disproportionately restrictive, if the principle of taxing realised income would not be applied as regards of free movement situations. Member States may safeguard their internal competence to tax by imposing a restriction on free movement but that restriction may not effectively result in a higher tax for citizens who have made use of their freedom of movement compared to the tax on internal situations. The Court however qualified the proportionality with regard to this last point further. 
The Court introduced an exception to the third proportionality condition. The Court only requires the Member State of origin to allow a tax reduction for capital losses accruing after transfer of residence 'unless such reductions have already been taken into account in the host Member State' ( $N$., para 54). The Court's reasons for including this exception are not entirely unambiguous. Whatever the true motivation may be, it is clear that there is no disproportionate burden on free movement as long as the realisation principle is observed from the taxpayer's perspective, even if it merely is the natural result from the Member States' exercise of taxing competences in parallel.

Not too much should not be read into this exception. The general rule is that the Member State of origin is accountable for ensuring that the standard of realisation basis taxation is observed. A national provision with a different effect would be considered a disproportionate restriction on paper by the Court's standards of $N$. The burden of proof is therefore on the Member State of origin to demonstrate that it would be absolved of its duty to allow a tax reduction because the host Member State has taken due account of capital losses which accrued after the citizen's transfer of residence.

The Court's judgment in $N$. leaves no room for the Member State of origin to invoke the existence of so called step-up rules in the host Member State as a complete justification for not applying realisation basis taxation as the ordinary system for both internal and free movement situations. Step-up basis taxation in the host Member State would take consistent and systematic account of capital losses accruing after the time of transfer of residence in that Member State because the acquisition value for tax accounting purposes is set at the shares' value at the time of transfer. However, the $N$. judgment specifically, and EU law as it currently stands, does not oblige the host Member States to have in force such step-up rules. ${ }^{727}$ For this reason, the Member State of origin cannot rely exclusively on the host Member State's legislation but it should establish on a case-by-case basis whether the capital losses were actually taken into account by the host Member State and the tax advantage of those losses were effectively enjoyed by the citizen. Only in this way can a possible violation of the taxpayer's rights under EU law be excluded.

The practical implications of this exception are very similar to the Court's argument in Schumacker that EU law does not oblige Member States to enable the result that a free moving Union citizen would effectively enjoy a more than equal treatment than a Union citizen who stayed in his or her Member State, see Section 4.3.5.3.3.

The proportionality analysis in National Grid Indus differs from $N$. on several points. To be clear upfront; the divergences described below do not imply that the case law is inconsistent. The judgment in National Grid Indus is not an overruling of $N$. The Grand Chamber paid great attention in distinguishing National Grid Indus from N., mainly on the third proportionality 
requirement of $N$. regarding the tax treatment in the Member State of origin of capital losses accruing after the transfer of residence.

It should be recalled that the Dutch legislator had already amended the relevant national provisions following the judgment in De Lasteyrie du Saillant to take account of reductions in value after the transfer of residence. The original national provisions as they applied to $\mathrm{Mr} \mathrm{N}$. did not provide this possibility. The judgment in $N$. might therefore be read as confirming to the Dutch legislator that the amendments were principally in line with EU law. The legal background to National Grid Indus was that the Dutch legislator did not concede that the same possibility should apply in the context of business income taxation.

The material reasons for distinguishing National Grid Indus from N. apply in principle exclusively to the specific case of National Grid Indus. The introductory statement in para 56 to that relevant passage in National Grid Indus already points this out:

56. However, in contrast to the position in $N$, the failure of the Member State of origin to take into account, in the dispute in the main proceedings in the present case, decreases in value that occur after the transfer of a company's place of effective management cannot be regarded as disproportionate to the objective pursued by the national legislation at issue in those proceedings. [italics added]

Explicit attention to the factual context of the case is also drawn in para 58 ('...in a situation such as that at issue in the main proceedings...'), in para 59 ('In those circumstances...') and, again, in para 60 ('...in a situation such as that at issue in the main proceedings...'). The clear signal is that the interpretative guidance in this material passage should not be read in a general manner. Paragraphs 61 ('Moreover...'), 62 ('It should be recalled in this connection...') and 63 ('Furthermore...') are best read as obiter dicta. The entire passage of paras 56-63 is unquestionably a ruling on the specific case of National Grid Indus. The text of the decision therefore significantly limits the use of National Grid Indus as legislative precedent. Rather, the judges in subsequent cases are left a precedent model of fact-intensive case-bound reasoning with National Grid Indus in Komarek's model. ${ }^{728}$

The potential broader legal ramifications of distinguishing National Grid Indus from $N$. and therefore the scope of National Grid Indus should become clear only with future case law. At the time that the judgment in National Grid Indus was delivered, six cases on similar exit taxes - concerning both personal income and corporation taxes-were pending before the Court. ${ }^{729}$ The Court likely could not yet oversee the consequences of National Grid Indus

${ }^{728}$ See, Section 2.3.2.1.

729 See, Commission v Spain (C-269/09); Commission v Portugal (C-38/10); Commission v Spain (C-64/11); Commission v Denmark (C-261/11); Commission v Netherlands (C-301/11); and DIVI Finanziaria SAPA di Diego délia Valle (C380/11). 
completely. The fact that the case was decided by the Grand Chamber should however make National Grid Indus an important point of reference for those pending cases. The question to be solved in those cases is consequently when the reasoning of $N$. applies and which other cases are preferably decided along the lines of National Grid Indus?

The Court mentioned explicitly in para 54 of the ruling in National Grid Indus, before giving the distinguishing grounds, that $N$. concerned national legislation to which a private individual was subject. The dispute in the main proceedings of National Grid Indus concerned corporation taxes. This poses the question whether the dividing line is the distinction between personal income taxes and corporation taxes? For these reasons, a closer view on the material reasons for distinguishing the two cases on the level of proportionality is warranted.

First, the basis for the Court's approach to proportionality in National Grid Indus is that a company is taxed on its profits from economic activities and that these profits are influenced by the valuation of the assets because depreciation expenses are accounted for in taxable income (para 57). This connection between a company's assets and its taxable profits proves material in understanding the reasons for distinguishing National Grid Indus from N. A cautious and preliminary conclusion is that a broader application of National Grid Indus will be reserved for capital gains which normally are part of taxable business income. It is plausible that the Court did not attempt to give interpretative guidance for cases that concern an accrued, but not yet realised, capital gain which is taxable as a specific item of personal income upon the transfer of residence of an individual, like the capital gain on the closely held shareholding in $N$.

The Court secondly turns to the allocation of taxing powers between the Member States in respect of those profits. It holds that the profits of a company that has transferred its place of effective management to another Member State are exclusively taxable in the host Member State. Upon this transfer, the Member State of origin loses all fiscal connection with the company, according to the Court. The host Member State will in principle take account of the fluctuations in value of the company's assets which occur after the date of transfer on the basis of the connection between the company's profits and its assets. In the Court's view, this is a logical result 'for reasons relating to the symmetry between the right to tax profits and the possibility of deducting losses' (National Grid Indus, para 58). The Court holds this allocation to be in accordance with 'the principle of fiscal territoriality linked to a temporal component', i.e. the same reason that legitimised the assessment of the tax claim on the company by the Member State of origin upon the transfer of the place of effective management.

Third and finally, the residence of the company is decisive for the question which Member State is responsible for the taking into account of taxable gains or losses relating to assets of companies (para 60). Therefore, there is no obligation on the part of the Member State of origin to take account of fluctuations in the value of the claim held by the company arising after the 
transfer to another Member State, irrespective of whether they are due to exchange rate losses which cannot be reflected in the host Member State (paras 59 and 64), or because the company did not obtain payment of the debt in full (para 55). To require otherwise would 'not only call into question the balanced allocation of powers of taxation between the Member States but also lead to double taxation or double deduction of losses' (para 59). This applies in particular between Member States in the euro zone (para 59).

This latter argument on double taxation and double taxation of losses seems not entirely convincing. The risk of double deduction of losses was accounted for in the proportionality analysis in $N$. by requiring the Member State of origin to show that the losses had already been taking into account by the host Member State. The risk of double taxation also seems, on basis of the Kerckhaert and Morres line of authority, not material-juridical double taxation is not as such a restriction on freedom of movement. In any event, double taxation is only the case when the host Member State would tax the same capital gain as assessed by the Member State of origin. For that reason, the Member State of origin could only avoid double taxation by surrendering the exact tax claim which the Court held justified in National Grid Indus. The fact that the Member State of origin would not tax capital gains which accrued after the transfer of the place of effective management was undisputed before the Court. A risk of double taxation on that basis was excluded at the outset.

Any omission on the part of the Member State of origin to take account of those post-transfer fluctuations in value cannot make the Member State of origin accountable (para 61). The disadvantage which may so arise is attributable to lawful disparities between the systems of taxation of the Member States (para 62). Furthermore, in the specific case of National Grid Indus such a disadvantage does not necessarily arise (para 63). One could read this passage as a tacit departure from the obligation in $N$. to allow a deduction of capital losses after transfer if the other Member State had not taken those losses into account. As stated above, these considerations are evidently obiter statements as far as National Grid Indus is concerned. Neither had it been established in National Grid Indus that the UK, the host Member State, had indeed failed to take account of any capital losses, not had it been established that such losses actually had arisen in the case of National Grid Indus in the first place.

The Court held on this issue in synthesis:

64. It follows from the foregoing that Article 49 TFEU does not preclude legislation of a Member State under which the amount of tax on unrealised capital gains relating to a company's assets is fixed definitively, without taking account of decreases or increases in value which may occur subsequently, at the time when the company, because of the transfer of its place of effective management to another Member State, ceases to obtain profits taxable in the former Member State. It makes no difference that the unrealised capital gains that are taxed relate to exchange rate gains which cannot be reflected in the host Member State under the tax system in force there. 
It is true that the reasoning in National Grid Indus may be applied mutatis mutandis to $N$. The individual would also lose all fiscal connection by transferring his place of residence to another Member State and it would seem equally symmetrical to leave gains and losses arising after this transfer to the fiscal jurisdiction of the host Member State only. Moreover, any omission by the host Member State to take account of capital losses accruing after the transfer at the moment of realisation may be considered the same disparity as identified in $\mathrm{Na}$ tional Grid Indus. The Court in effect conceded to the criticism expressed in the academic literature in response to $N$. It is thus possible that the Court will indeed overrule $N$. in future case law. But the judgment in National Grid Indus cannot be considered to constitute such an explicit departure from judicial doctrine. The only sure thing at the time of writing is that the principle of proportionality is assessed more strictly when it concerns private individuals $(N$.) and more weight is given to the Member State's public interest when the national measure applies to companies (National Grid Indus). Surely, this is not a judicial revolution in itself.

The second point of divergence between $N$. and National Grid Indus is the issue of immediate recovery of the tax claim upon the transfer to another Member State. In $N$. the immediate recovery was considered to be disproportionate but the Court held in National Grid Indus that immediate payment was not necessarily disproportionate. Also on this issue, the Court pointed to the specific situation of companies in National Grid Indus:

70. It follows, as the Advocate General observes in point 69 of her Opinion, that the asset situation of a company may appear so complex that an accurate cross-border tracing of the destiny of all the items making up the company's fixed and current assets until the unrealised capital gains incorporated into those assets are realised is almost impossible, and that such tracing will entail efforts representing a considerable or even excessive burden for the company in question.

71. It thus cannot be ruled out that the administrative burden that would be entailed by the annual return suggested by the Commission, which would necessarily relate to every asset in respect of which a capital gain was established at the time of the transfer of the place of effective management of the company concerned, would give rise as such, for that company, to a hindrance to freedom of establishment that would not necessarily be any less harmful to that freedom than the immediate recovery of the tax debt corresponding to the capital gain.

72. In other situations, on the other hand, the nature and extent of the company's assets would make it easy to carry out a cross-border tracing of the individual assets for which a capital gain was ascertained at the time when the company transferred its place of effective management to another Member State.

On this basis, the Court's conclusion was that, in order for the national measure to comply with the principle of proportionality, the company should at least be 
given a choice between immediate payment without undue administrative burdens and deferral of the tax recovery until the moment of realisation (para 73). The Dutch measures at issue did not offer the alternative to deferral and were therefore precluded by EU law in this regard (para 85). If the company chooses for a deferred recovery the possibilities of administrative cooperation between Member States offered by secondary EU law provides a sufficient level of protection to assure the effectiveness of supervision (paras 76-78). This is consistent with $N$.

A third, but minor, point of ambiguity is the issue of guarantees. In National Grid Indus the Court held:

74. However, account should also be taken of the risk of non-recovery of the tax, which increases with the passage of time. That risk may be taken into account by the Member State in question, in its national legislation applicable to deferred payments of tax debts, by measures such as the provision of a bank guarantee.

Although the Court found the provision of guarantees disproportionate in $N$., it is clear that those guarantees were required only in situations in which freedom of movement was exercised, but not in internal situations. The Court already considered in $N$., para 51, that the obligation to provide a guarantee doubtless facilitates the collection of tax. The above suggestion in National Grid Indus is thus best understood as a general condition for deferral. It is consequently not disproportionate to require a guarantee for all cases in which taxpayers are allowed to defer payment of tax debts, but only if such a condition also applies in internal situations.

If the degree of dissent between $N$. and National Grid Indus is balanced against the Court's reason for distinguishing, it may be concluded that National Grid Indus does not generally overrule $N$. The proportionality analysis is approached somewhat differently but the Court attributes the deviating perspective to the different nature of the national measures at issue. The assessment of tax in relation to those different gains should therefore not necessarily be similar.

\subsection{Synthesis and discussion}

The aim of this Chapter was to research the proportionality conditions of the BAOTP standard. We started with a concise review of the principle of proportionality as an important standard for the review of the compatibility of national measures with EU law in Section 8.2. We concluded that the principle of proportionality was received in the field of direct taxation through Futura and that it should not be interpreted differently in this field. We pointed out, on the basis of prior research, that a national measure that restricts freedom of movement is proportionate if it is suitable and necessary to pursue a recognised overriding reason of public interest, while not going beyond what is necessary to that end. The restriction must pursue the protection of legitimate public policy goals in a 
consistent and systematic manner and must be the least restrictive alternative available to the Member State concerned in view of the level of protection that it purports to achieve. Also, the restriction must be proportionate in the narrow sense. But, this requirement involves a delicate balancing of the different interests of Member States, of Union citizens and of the Union as a whole that enjoy constitutional protection which is inherent in the Treaties.

We continued in Section 8.3 with a research on the Court's application of the principle of proportionality in relation to restrictions which pursued the legitimate aim of preserving a balanced allocation of the power to impose taxes between the Member States. We found that the Court examines whether the restriction is necessary to protect a tax claim in relation to economic activities carried out within the territory of the Member State concerned in a consistent and systematic manner. In that regard, we recall the judgment in Amurta as discussed in Section 6.4.3. The Court held in that case that a Member State cannot invoke the BAOTP justification in relation to non-resident taxpayers if the national legislation is inconsistent and does not impose a similar tax claim on resident taxpayers.

In the context of loss relief for foreign losses, the Court applies the paragraph 55 conditions of Marks \& Spencer to assess the necessity of a restriction on freedom of establishment. These conditions attach to the circumstances in the Member State of the secondary establishment and render a tax restriction imposed by the Member State of the parent company unnecessary, thus disproportionate, when the Member State of the secondary establishment breaks with tax symmetry between profits and losses and therefore introduces inconsistencies and incoherence in the pursuit of a balanced allocation of taxing powers. It depends on the circumstances of the case whether the Court applies the paragraph 55 conditions of Marks \& Spencer, or not.

In the context of exit taxes, we found that the Court applies different conditions in relation to, on the one hand, personal capital gains $(N$.$) and capital$ gains as an element of general business income on the other hand (National Grid Indus). In $N$. the Court found an exit tax restriction upon the transfer of residence between Member States excessive if the national measure of the Member State in which the taxpayer previously resided does not ensure realisation based taxation in the end. The Court relaxed this condition in National Grid Indus, but this may be due to objective differences between the national measures in relation to the manner in which capital gains were included in taxable income. Future rulings are likely to clarify the Court's interpretation of proportionality.

We did not find evidence in the case law for a proportionality analysis in the narrow sense of tax restrictions which are justified by the BAOTP standard. Especially $O y A A$ indicates that the protection of the competence to tax in relation to activities carried out in national territory is rather absolute. The case law does not show that the Court is willing to question the necessity to preserve a balanced allocation of taxing powers in relation to the constitutional protection afforded to the free movement of Union citizens. We believe that the Court will continue to apply judicial restraint in this field and will not consider the 
proportionality in the narrow sense of restrictions insofar as they are suitable and necessary to preserve a balanced allocation of taxing powers. To decide that the need to preserve the internal competence to tax is excessive in view of the Union citizen's effective enjoyment of the fundamental freedoms would mean, in point of fact, that the Court would break radically with the basic distinction between the existence and the exercise of taxing powers under EU law. 



\title{
Chapter $9 \quad$ Revisiting Marks \& Spencer
}

\author{
9.1 Why the Court erred in Marks \& Spencer
}

\subsubsection{The error of fact on loss trafficking}

We have seen in the previous Chapters that the Court's assumption that losses could be freely transferred from other Member States to the UK if group relief was to be granted in free movement situations was imperative to justify the restriction at issue in Marks \& Spencer (C-446/03). It was material for accepting the balanced allocation of taxing powers as a justification. We know that it was not so much the import of losses to the UK that mattered because the Court even required this for some final losses. No, the key fact on which the Marks \& Spencer ruling ultimately rests is the idea that a surrender of losses by the foreign subsidiary to its UK parent company supposedly is an export of losses for taxation purposes of the Member State in which the subsidiary is established. That assumption is regrettably not consistent with the international consensus on fiscal jurisdiction. This opinion finds wide support in the literature. ${ }^{730}$

The idea that losses are transferred between states is inconceivable under the international consensus on the parallel exercise of taxing powers of states. Absent international agreements, one Member State's exercise of taxing powers does not, in any way whatsoever, affect another Member State's competence to exercise taxing powers with regard to the same taxpayer, to the same income, at the same time. This fact is the fundamental basis of the international law on taxation. And, maybe ironically, this principle would later be upheld as valid EU law by the Court in a line of authority on juridical double taxation that started with Kerckhaert and Morres (C-513/04).

The Court's reasoning for upholding the balanced allocation of taxing powers justification in Marks \& Spencer also seems inconsistent with the Court's reasoning as regards the risk of double loss relief. First, the Court argues that allowing group relief for losses of foreign subsidiaries would jeopardise a balanced allocation of taxing powers between the Member States because losses could so be transferred. Then, the Court basically reasons that the same group relief would result in losses being taken into account twice. Marks \& Spencerread together with Lidl Belgium (C-414/06) and Papillon (C-418/07) - is clearly to be interpreted as meaning that the loss would probably be taken into account at the level of the foreign subsidiary and also at the level of parent company if

${ }^{730}$ E.g., Lang (2006b), p. 57. 
EU law would require that foreign subsidiaries be given the possibility to surrender their losses to the UK parent company.

Both justification grounds are difficult to reconcile. Under the interpretation of the balanced allocation of taxing powers established in the previous Chapters and its application in Marks \& Spencer as understood with reference to that interpretation, the two risks cannot hold simultaneously. The alternatives are these. Either, losses are transferred and disappear from the tax base of the subsidiaries, and thus a risk of a double use of losses is excluded by definition. Or, these Member States can still attach tax consequences to those losses even though the subsidiaries surrendered the losses to their parent company in another Member State, and the power of the Member States of the subsidiaries to attach tax consequences to those losses is not affected. ${ }^{731}$

Maybe the Court envisaged a possibility that losses can still be transferred after having been relieved in the Member State of the subsidiary. Such a possibility, whatever the Court's thoughts were, would in theory account for both risks. But, in that case the Member State of the subsidiary still has exercised its power to attach tax consequences to those losses and the balanced allocation of the power to impose tax was consequently not jeopardised, despite a subsequent transfer.

We will probably never learn the judges' thoughts. The Court simply postulated in Marks \& Spencer that both risks existed as if by magic. The Marks \& Spencer ruling thus suffers a defect in reasoning that, without additional guidance by the Court, also cannot be mended through interpretation of subsequent rulings as we will see below. The Lidl Belgium ruling suffers the same logical defect. Also, $X$ Holding (C-337/08) is based on the false premise that losses can be actually transferred. So, what should we make of Marks \& Spencer and the BAOTP standard it established?

\subsubsection{The error cannot be mended by reinterpretation}

Would the balanced allocation of the power to impose tax between the Member States be jeopardised if the international consensus was taken as the factual basis? Put differently, let's assume that extension of the UK group relief system to foreign subsidiaries as at issue in Marks \& Spencer would not prevent those subsidiaries from claiming loss relief in the Member States in which they are established even though, as far as UK taxation of the parent company is concerned, those subsidiaries should be assumed to have surrendered their losses to their UK parent company. This excludes by definition the possibility that the power to impose tax of the Member States of the subsidiaries is jeopardised. Whether the foreign subsidiary can make use of carry-over relief in its Member State of establishment thus becomes a moot issue in this context. Would then the

731 The 2012 judgment of the Court in Philips Electronics (C-18/11) suggests this alternative. 
power to impose tax of the UK, i.e. the Member State of the parent company, be jeopardised?

Allowing a cross-border group relief would reduce the tax claim on the profits of the UK parent company against which the losses of the foreign subsidiaries are relieved. That relief is in principle a final reduction of taxes. The tax claim on the particular profits made by the parent company is definitely lost due to the loss relief. In internal situations, that reduction would be compensated by the tax claim on future profits of resident subsidiaries because resident subsidiaries cannot claim carry over relief for surrendered losses. Evidently, the UK cannot charge a non-resident subsidiary with UK corporation tax as it would with a resident subsidiary. A compensation of the loss of the tax claim at the parent company level by a subsequent charge imposed on the foreign subsidiary is not possible. Member States have no fiscal jurisdiction on companies established outside their national territory. Following Lidl Belgium, EU law also does not require a Member State to extend its jurisdiction to establishments on foreign territory.

The loss relief could however be compensated by an additional tax charge on the parent company.

Alas, a tax charge imposed on a parent company in respect of profits made by its subsidiary would be contrary to the rulings in Cadbury Schweppes (C196/04) and CFC and Dividend Group Litigation (C-201/05). Even if this additional charge would only become due if and insofar the foreign subsidiary makes a profit, the fact remains that no such charge is imposed on the parent company in internal situations. It is therefore a disproportionate restriction on freedom of establishment. Consistent case law only allows for exceptions if the foreign subsidiary should be considered a letterbox company in order to prevent tax avoidance. Consequently, it is not possible to compensate a final reduction of tax by reason of loss relief with a subsequent final charge to tax on foreign companies as a general rule.

But, let's look a bit closer at what actually happens tax-wise.

The reduction of the tax claim on the parent resulting from the loss relief is in fact an advance payment of the tax reduction that the subsidiary enjoys when it would use its losses to relieve future profits on a carry-over basis. ${ }^{732}$ By allowing the subsidiary to surrender its losses to its parent, the group of companies can enjoy the benefit of that tax reduction at an earlier moment, i.e. immediately when the loss is incurred. Such a cash-flow advantage can be effectively conferred on the corporate group by reducing the tax claim on the parent company. The taxes which would have been charged on the parent company, but which are reduced by the group relief, will now be collected from the future profits of the subsidiary. This works fine on a going concern basis because the subsidiary has to surrender its right to carry-over relief in regard of those losses. There is an explicit direct link in UK corporation tax law between

732 This explains why the subsidiaries should also surrender that right (and are so required by law) in internal situations to prevent a double use of losses. 
the tax advantage for the parent company (the group relief) and the subsequent levy on the subsidiary (due to the surrender of carry-over relief). That direct link is consistent with the aim of the system as a group taxation regime.

An alternative is to impose a negative tax on the subsidiary for the losses, i.e. an immediate refund, but this is not customary in international tax practice. However, this alternative also implies that a state would be obliged to confer a benefit even if there are no profits available within the group to offset the losses at that moment. That indeed seems to go beyond what is necessary to achieve equal treatment between corporate groups and single companies. It is consequently simpler to offset the losses of the subsidiary with profits of the parent and to deny the subsidiary all carry-over relief in regard to those surrendered losses, so that the losses are not used twice and the group effectively enjoys the same reduction twice. The system of loss relief as at issue in Marks \& Spencer made complete sense in that regard - in internal situations.

In internal situations the UK would thus never lose a tax claim; it would merely forego an interest on the tax claim of the parent company which it could have levied. In that context, it really does seem strange to require the Member State of a parent company to make an advance payment for a refund of taxes that it would not have levied anyway due to a lack of fiscal jurisdiction and irrespective of the availability of losses, simply because the subsidiary is established in another Member State. Why should the UK make an advance payment for a reduction on a tax claim that never becomes due in the UK anyway? That, actually, would have been a more precise version of the submissions of the governments that the UK had no fiscal jurisdiction on the subsidiary and that therefore the situations were not comparable. It was just badly presented perhaps because it could not convince the Court in Marks \& Spencer. But, according to the Court in Gilly (C-336/96):
48. Furthermore, as has been observed by the French, Belgian, Danish, Fin- nish, Swedish and United Kingdom Governments, if the State of residence were required to accord a tax credit greater than the fraction of its national tax corresponding to the income from abroad, it would have to reduce its tax in respect of the remaining income, which would entail a loss of tax revenue for it and would thus be such as to encroach on its sovereignty in matters of direct taxation.

It is clear that a loss relief which acts as final reduction of a tax claim on the parent company in situations in which freedom of movement has been exercised is a similar jeopardy to the 'sovereignty' (i.e. competence) of the Member State concerned. Extending the group relief as at issue in Marks \& Spencer to free movers effectively nullifies the existence of a tax claim. Thus we can uphold the judgment in Marks \& Spencer because the restriction was indeed held to be justified by the Court with reference to the BAOTP standard which was already dormant in Gilly. Other clear authorities are e.g. ACT Group Litigation (C374/04), Oy AA (C-231/05) and National Grid Indus (C-371/10).

The material problem with Marks \& Spencer is the proportionality analysis. The error on loss trafficking cannot be mended through reinterpretation of the 
proportionality analysis without changing the outcome; we are required to overrule the conditions of Marks \& Spencer, para 55, in a consistent reinterpretation. The reason is this: it is difficult to accept an obligation in EU law that requires a Member State to make an advance payment or a refund of taxes that it would never levy anyway. It seems even more unreasonable, and it is frankly illogical, inexplicable and absurd to impose such an obligation on that Member State when it has established with certainty that this tax reduction has even not become due in another Member State because the period of carry-over relief under that Member State's laws has rightfully passed. Why should the Member State of the parent company adapt its own rules to those in force in another Member State? We have seen in Chapter 6 that it is well-established case law that a Member State cannot so be required, since this is within its reserved competence to define the criteria of taxation. The paragraph 55 conditions of Marks \& Spencer constitute an unfair enrichment of the corporate group by all standards, a consequence that the Court tried to avoid by recognising the right of Member States to prevent that losses are used twice. It is an outright negation of the need to maintain a balanced allocation of taxing powers. What exactly is so proportionate about that?

In short and with the benefit of hindsight, the inevitable conclusion is that the outcome in Marks \& Spencer is wrong. That is not because the interpretation of EU law is incoherent or inaccurate - we fully accepted the balanced allocation of taxing powers as dominating EU law standard in the field of direct taxes-but because the Court evidently failed to fully understand the national legal framework and basic principles of (international) taxation that applied in the case. That failure is not to be attributed solely to the Court or its AG, but is a joint responsibility of all actors involved in the proceedings of Marks \& Spencer, including the national court who referred the preliminary questions to the Court and the national governments who submitted observations.

\subsection{Alternative solution: a system of deferral}

\subsubsection{Outline}

In contrast to the unreasonably wrong requirements of Marks \& Spencer, it would seem very reasonable to require Member States to defer the collection of tax on the parent company for the same period that its subsidiary has not yet enjoyed the tax reduction in its host Member State. That is a fully adequate measure to make sure that free movers receive an equivalent cash-flow advantage without the Member State of the parent company losing any tax claim and without running a risk that losses are used twice. The Court could - not limited by any rule of EU law-endorse such an interpretation of national legislation which is consistent with EU law pursuant to the principle of proportionality. Also in National Grid Indus the Court required that an immediate payment of taxes was disproportionate and should be replaced by a deferral system, so there is a Grand Chamber precedent directly to that effect on which the Court could rely. There is 
also no need for Union action here, so we can safely ignore the obiter comment of Marks \& Spencer, para 58 in that regard.

The approach which we will review below is essentially this: an immediate payment of the tax claim on the parent company should be replaced by a deferral system to take account of losses suffered by foreign subsidiaries if there is a national system of loss relief between those companies in internal situation. The analysis below is no more than a rather concise thought experiment (Gedankenexperiment); would a system of deferral be consistent with EU law?

A system of deferral does not presume loss relief to be a final reduction of the tax claim on current profits of the parent company, but only a deferral of the payment of the tax. Therefore, if a foreign subsidiary 'surrenders' its losses to its resident parent company then the corresponding tax claim on the profits of the parent company is not considered to be affected but recovery of that amount is merely temporarily deferred. That deferral is ended at the moment when the subsidiary becomes profitable again, and only insofar as it becomes profitable. Accordingly, the compensation does not occur by collecting tax from the foreign subsidiary, but by requiring the resident parent company to make a payment at a later moment in consideration of taxes due on past profits. Consequently, the loss relief has no effects on the assessment stage of taxation but is executed as a pure recovery measure.

Furthermore, there is no risk that losses are used twice because any carryforward relief for the subsidiary in its Member State of establishment does not entail a cash-flow advantage - it is actually a disadvantage if losses are carried over on a nominal basis. Consequently, group relief at the level parent company would adequately compensate for this disadvantage so that there is the neutrality in corporate form for which a group taxation regime aims.

Carry-back relief on a nominal value of losses actually entails a cash-flow disadvantage for the subsidiary because it reduces an amount of taxes which has already been paid in a previous period without compensation for the time-value of money. ${ }^{733}$ The deferral of taxes due by the parent company merely neutralises this disadvantage on the subsidiary by compensating for the time-value of money. The moment that the subsidiary has to pay taxes (since there are no more losses available as they have been used on a carry-back basis) is then the same moment at which the deferral for the parent ends. In synthesis, there is no 'double advantage' in the proposed system of tax deferral despite the fact that two Member States attach tax consequences to the same losses of the same subsidiary.

\subsubsection{Legality}

It should be noted that the recovery of a tax charge on past profits would probably be considered a prima facie restriction on freedom of movement by the Court's standard in Krankenheim Ruhesitz am Wannsee-Seniorenheimstatt (C-

${ }^{733}$ We presume that the Revenue does not pay interest on carry-back recaptures. 
157/07). That situation should however be clearly distinguished from the charges on the parent companies in Cadbury Schweppes and CFC and Dividend Group Litigation. In those latter two cases, the parent company was charged with a tax in respect of profits earned by its foreign subsidiary. The loss relief system of deferral discussed here only triggers collection of tax with reference to the income position of the foreign subsidiaries, but clearly concerns a charge on profits earned by the parent company itself. Cadbury Schweppes and CFC and Dividend Group Litigation do not apply here.

Serious doubt has been expressed in the literature whether the Court was right to hold that freedom of establishment was restricted in Krankenheim Ruhesitz am Wannsee-Seniorenheimstatt. ${ }^{734}$ It indeed appears that the Court misunderstood a basic aspect of corporation taxation. Contrary to the Court's holding, there is no different treatment at the level of company depending on the place of its non-incorporated secondary establishment. A company is in principle liable to tax in respect of the balance of income earned by its principal establishment and non-incorporated secondary establishments. Under the international consensus, a state is not a priori prohibited from taxing a company on income earned through a foreign secondary establishment. Therefore, the income of a foreign branch is in principle added to the tax base of a resident company in a comparable way as the income of domestic branches of that same company. Thus, losses at the level of a foreign branch in principle reduce the taxable income of a company, whereas profits increase the basis of assessment. A DTC may require exempting income made by foreign secondary establishments but this does not alter the basic design of the corporation tax to tax the balance of income of all constituent establishments of the same company. Neither is this basic design discriminatory as such, nor can it become so by reason of a superimposed obligation of relief for double taxation pursuant to a DTC. Krankenheim Ruhesitz am Wannsee-Seniorenheimstatt was not on point in this respect.

Nonetheless, assuming that there is a prima facie restriction on freedom of movement, that restriction would however be justified according to the same judgment in Krankenheim Ruhesitz am Wannsee-Seniorenheimstatt and National Grid Indus These are the relevant authorities for the conclusion that ending the deferral and collecting the tax from the parent company reflects a logical symmetry of the previously granted loss relief and protects the balanced allocation of taxing powers in a consistent and systematic manner.

It should be clearly observed that the tax advantage of deferral is granted to the same taxpayer that suffers the disadvantage, and both charges relate to the same tax. The tax advantage (deferral) and the offsetting levy (end of deferral) are established with reference to the position of the same subsidiary. The aim of the group relief system envisaged here is to award a temporary cash flow advantage to groups of companies (recall, this is only to compensate for a cash flow disadvantage that a single company business would not suffer), but not to

734 See e.g., Haslehner (2010); Meussen (2009a). 
allow groups of companies to be taxed on a lower balance of income in comparison with single company businesses. It is therefore material that the loss relief is considered a deferral and not a reduction of tax owed by the parent company. If the tax deferral would not be ended at a subsequent moment, then the Member State of the parent company cannot recover a tax claim which it may legitimately impose on economic activities carried on by the parent company within its territory. The advantage and the subsequent disadvantage cannot be dissociated from each other and are directly linked within the meaning of the well-established case law. Ending deferral thus protects cohesion of the tax system. Therefore the fact that a tax charge on the parent company becomes payable at the moment that the subsidiary becomes profitable again preserves the balanced allocation of the power to impose tax between the Member States in a consistent and systematic manner. A loss relief system based on deferral would for these reasons be lawful under EU law.

\subsubsection{Proportionality}

The next question is whether such a deferral system of group relief goes beyond what is necessary to preserve the power to impose tax, or whether it is a proportionate measure under EU law?

First, if the loss relief would ultimately amount to a final reduction of the tax claim in internal situations because the subsidiary does not become profitable again or winds up its business, it would be inconsistent to require payment in free movement situations.

Since we discuss a system of tax deferral here, the recovered tax charge may secondly not exceed the amount of taxes 'saved' at the moment of loss relief. The value of the amount of losses is to be calculated at the marginal tax rate of the parent company at the time of loss relief. The relevant basis for that valuation is the additional charge on the parent company that would have been due if there had not been a relief for the losses of the subsidiary. In view of the aim of deferral, the payable charge at the moment when the subsidiary becomes profitable again may not exceed this amount, since it is purported by design to only protect the tax claim on those previously relieved profits and not to increase it. The marginal tax rate at the time of loss relief should be considered. Any changes in rates during the period of deferral are in principle to be neglected in a consistently designed system. It is also immaterial whether the parent company realised net operating profits or suffered losses in the year in which deferral is ended since the advantage was by its nature a cash-flow advantage and it therefore does not matter whether the parent company has sufficient ability to pay based on its current income position in the year concerned. Its income in the previous year was in any case sufficient or otherwise there would not have been a deferral after all. It may be advisable to settle any deferred taxes against refunds in respect of current losses of the parent company itself that are carried back and relieved against previous profits of that 
parent company. If the refund for carry back is not enough to absorb all deferred taxes, the remainder is to be remitted to the Revenue in any case. ${ }^{735}$

Third, since the whole point of the proposal is that the Member State foregoes interest on a tax claim for which it could have required immediate payment, it would be inconsistent with that aim to calculate interest on the deferred taxes.

Fourth, a bank guarantee may be required to ensure effective recovery, but only if the Member State applies this measure generally as a condition for deferred payments of taxes, i.e. if it is already a measure that applies internally. National Grid Indus is the authority to that effect.

Fifth, there is no reason to apply special measures as long as the composition and structure of the corporate group does not change. In contrast, it is justified and proportional to end the deferral upon the moment at which the subsidiary no longer satisfies the qualifying conditions for group treatment if deferral has not yet been fully ended until that moment. The argument in support of this is that the subsidiary is no longer part of the corporate group and that there is thus no reason in continuing to apply any favourable tax rules specifically targeted at corporate groups. The termination of the qualifying relation between the parent company and its subsidiary (e.g. by reason of a sale) justifies the termination of any tax advantages which the parent has enjoyed in relation to that subsidiary.

We have observed above that, unlike the actual reasoning of the Court in Marks \& Spencer, the fact whether there is a possibility of carry-over relief in the Member State of the subsidiary, and the fact whether that relief has actually been enjoyed are moot issues in deciding to grant a deferral to the parent company. It would therefore also be inconsistent to take these circumstances into account in adjudging whether ending the deferral is proportionate to the aim of the system.

The same proportionality analysis applies, mutatis mutandis, to foreign permanent establishments, i.e. foreign branches or agencies in other Member States. The proportionality analysis in Lidl Belgium should be overruled on the

735 The following example illustrates this technical point. At $t_{0}$ the parent company made a profit of $€ 150 \mathrm{k}$, but was granted a loss relief in respect of its foreign subsidiary for an amount of $€ 100 \mathrm{k}$ as group relief at a rate of $20 \%$, resulting in a deferral of $€ 20 \mathrm{k}$ in taxes. This leaves $€ 10 \mathrm{k}(20 \%$ of $€ 150 \mathrm{k}$ minus $€ 20 \mathrm{k})$ of the tax charge payable at $\mathrm{t}_{0}$ immediatly. At $t_{1}$ the parent company made a loss of $€ 200 \mathrm{k}$, but the foreign subsidiary became profitable again — let us assume a same amount of $€ 100 \mathrm{k}$ to keep it simple. The deferral should consequently be ended in full. Assuming that the law of the Member State of the parent company allows a carry-back of losses to the previous fiscal year, the parent company may request a refund of $€ 30 \mathrm{k}$ in taxes from $\mathrm{t}_{0}$, since the basis of assessment was $€ 150 \mathrm{k}$ in $\mathrm{t}_{0}$ and this is settled againts an equal amount of losses from $t_{1}$. Due to settlement with deferred taxes, the effective refund is only $€ 10$. That is equivalent to the $€ 10 \mathrm{k}$ which was paid at $t_{0}$. An amount of $€ 50 \mathrm{k}$ $(€ 200 \mathrm{k}-€ 150 \mathrm{k})$ in losses of the parent company remains available for carry-forward relief. 
same grounds as Marks \& Spencer and X Holding. The defect in reasoning in these cases is the same.

\subsection{Synthesis and discussion}

The analysis in this Chapter was based on the finding that the Court erred in Marks \& Spencer on the issue of loss trafficking. We concluded that the principle of proportionality was not applied correctly in this hallmark case of EU law in field of direct taxation. We reviewed a system of deferral as an alternative measure which would be consistent with EU law. That thought experiment was grounded on the Court's own authorities. The Court could take the direct action against the UK as an opportunity to reverse the proportionality analysis of Marks \& Spencer. ${ }^{736}$

We have written our proposal for the sake of simplicity (and readability) for the situation of one parent company and one foreign subsidiary. This experiment sufficed to analyse the most important consequences of a system of deferral for the issue of cross-border loss relief in principle. The practical questions and technical issues of its application to actual national laws are left for future research. A little hint in that regard is that, in a situation with more foreign subsidiaries, the deferral of tax of the parent company could be established with reference to the hypothetically consolidated income of the foreign subsidiaries which meet the qualifying conditions of group treatment. Deferral would only be granted insofar as the balance of foreign economic activities actually makes a loss. That seems particularly justified for full consolidation systems like the ones at issue in X Holding and Papillon.

${ }^{736}$ European Commission (2012b). 
IV Conclusion 



\section{Chapter $10 \quad$ General Conclusions}

\subsection{Summary of conclusions}

This book aimed to establish a framework of a legal doctrine on EU law in the field of direct taxes. We did so by asking what the structure and organisation of this functional subsystem of EU law is. The research was focused on the judicial interpretation of EU law in the field of direct taxes because prior research showed that the Union exerts most regulatory control in this field through the Court's judicial governance.

The main challenge in this book was to treat EU law in the field of direct taxes, and specifically the body of case law, as the complex adaptive system that it is. Instead of a reductionist approach to the case law that focuses on the reasoning in individual judgments in a rather isolated manner and in which the structure and organisation of the legal doctrine is mainly a preconception of or induced by the researcher, we attempted to research the system of law as such. We treated it as an object of interest in its own right, and we tried to discover the structure and organisation that inheres in that system in an objective and reproducible manner. This is the main original contribution to knowledge that this book makes.

A framework of a legal doctrine on EU law in the field of direct taxes requires research in breadth and in depth. But, research resources and time required to compromise between the two in order to keep the project well defined and manageable. Therefore, Part II was primarily concerned with the breadth of EU law in the field of direct taxes and Part III went more in depth on specific topics. We analysed the complete body of case law in the field of direct taxes.

The most important idea of this book is that the body of case law was conceived as a network. This approach enabled the explicit relations between the Court's rulings to be included in the analysis. Given that the Court generally follows its interpretation of EU law of prior rulings in its subsequent case law, we presupposed that citation to precedent is a highly reliable indicator that shows how grounds of judgment evolve into judicial rules and how these rules are enforced in later case law. Chapter 2 explained this general analytical framework. In short, we believed that we could study these doctrinal structures and the way in which they organised and gave structure to the interpretation of EU law by a systematic research of citation to precedent in the body of case law. In doing so, we were able to make empirical observations on the structure and organisation of the network of case law in the field of direct taxation. 
Chapter 3 explored the properties of the body of case law in the field of direct taxes. This review of the Court's case law on the basis of aggregated meta-data on the rulings gave meaningful insight into the general development and trends of judicial decision making in this field of EU law in the period between 1983 through 2011 . We found that the case law covered many topics in direct taxation and that the broad spectrum of Treaty provisions on freedom of movement is involved. The Court also interpreted directives in the field of direct taxation but the Court's judicial review function in relation to the Treaties is by far more important in this field than the statutory interpretation function in relation to the directives. We looked at the context of the case law by researching which Member States, which national courts and what type of procedures were involved. We also observed an increase in direct actions in recent years but preliminary references are still the most important way in which the Court is invited to interpret EU law in the field of direct taxation. Also, the taxpayer rate of success has declined over the last years; a development which is in part due to the Court's introduction of the balanced allocation of taxing powers as a justification ground for direct tax restrictions on free movement. We cautiously concluded that EU law in the field of direct taxation has reached a maturity and stability that justifies the expectation that a functional subsystem with a robust identity has emerged from the body of case law.

Chapter 4 carried out a network analysis on the body of case law in the field of direct taxes. We looked at the global properties of the network of case law and discovered in Section 4.2 how it was connected as a cohesive whole. We compared it to a corresponding random network and concluded on that basis that the Court does not cite precedent randomly. Our findings suggest that the body of case law is subject to a dynamic and self-organising process like many other real networks with comparable topological structure. Despite its complexity, a cohesive structure of case law has emerged.

The next step in the research on the structure of the case law network was to analyse the organisation of the case law in different communities and subcommunities by applying computational community detection methods. We observed that the community structure of the case law network is significant and is meaningful in a legally relevant manner. The extensive qualitative analysis in Section 4.3 showed that community detection is an effective method to find distinct lines of authority in the body of case law in the field of direct taxes.

The global properties of the network showed that the Court pays disproportionate attention to a small subset of cases. We applied further insight from network science and the research continued in Section 4.4 on the idea that the resilience and resistance to change of the whole network depends on very few cases. The most important cases perform a crucial role for the overall structure and organisation of the system of EU law in the field of direct taxation. We identified these most important cases using a link analysis algorithm. The ranking of the 20 most authoritative precedents in the field of direct taxes provides valuable information to practitioners and national judiciaries and lawmakers about the most essential sources of EU law when dealing with national legislation in the field of direct taxes. 
Section 4.5 made another important contribution to the overall aim of the research. In order to establish a framework of legal doctrine on EU law in the field of direct taxation we needed to find the most important rules that have emerged from the case law. We explained how we extracted these rules from the most authoritative precedents of Section 4.4 by relying on the network structure and the granular information of legal citations. We then examined which paragraphs of the most authoritative precedents have been cited most frequently in subsequent case law. We evaluated and organised the judicial rules that we found in a separate Annex A to this book. This Annex A represents a legal doctrine on EU law in the field of direct taxation which describes its essential rules in detail. This book is the first to give an objective and reproducible research methodology for finding the acte clair rules that are representative of the body of case law on EU law in the field of direct taxes as a whole. We believe that the restatement of the case law in Annex A makes a major contribution in the interest of legal certainty in this complex field of law. This restatement is not only relevant as an academic product and teaching guide, but may also be put to immediate use in daily practice.

The core judicial rules that the research identified have given specific content to the written and unwritten general principles of EU law as they apply in the field of direct taxation. Notwithstanding that the development of judicial doctrine in the field of direct taxation was heavily influenced by and followed the paths which the Court developed outside this field, the Court has also created original rules specifically for the field of direct taxation, e.g. the cohesion of the tax system and the balanced allocation of taxing powers.

Section 4.5 demonstrated how rules of general EU law have been received in the field of direct taxation. We analysed how this field has evolved over the last 30 years to a functional subsystem of EU law that has organisationally closed and at the same time remains structurally open in order to receive innovations from the larger system of EU law. We conclude that a distinct identity of EU law in the field of direct taxation has incrementally emerged from a pathdependent process of judicial decision making, which is driven by an orientation to precedent as a first order description, and that this identity gives meaning to this functional subsystem as a unified and cohesive whole.

The research in Part II of this book supports the claim that the Court aims to construct a cohesive judicial doctrine of EU law in the field of direct taxation through a dynamic process of judicial decision making which is based on the interpretative guidance of precedent. This is consistent with the Court's Treaty mandate to safeguard the uniform interpretation and application of EU law. The research showed how network science may be used to research the structure and organisation of that legal doctrine.

The focus of our research shifted in Part III of this book. We limited the research to one standard of EU law that we suspected was of critical importance to the structure and organisation of the system as a whole; the balanced allocation of the power to impose tax between the Member States. In contrast to the breadth of Part II of this book, the qualitative analysis of the case law in Part III is a much closer reading of Court's judgments. Part III thus continued with 
an in-depth research into the evolution of the balanced allocation of taxing powers into a broad and dominating justification standard of EU law in the field of direct taxes. The rationalisation of this justification that Chapters 5 to 9 offer by embedding it directly into the basic framework of EU law and through positioning it in relation to other justifications makes the second original contribution to knowledge.

Chapter 5 explained the analytical framework for Part III. The survey of prior research showed that a detailed understanding of the balanced allocation of taxing powers was critical for a systematic exposition of the structure and organisation of EU law in the field of direct taxes. We again used a network analytical approach to the research, but the main method of analysis was qualitative in nature. We found preliminary evidence for a conceptual link between the balanced allocation of taxing powers and the justification of the need to prevent tax avoidance and other abuses of law on the basis of the results of network analysis.

Chapter 6 established a working hypothesis of the balanced allocation of taxing powers as a standard of EU law in the field of direct taxes. We used insights from computational linguistics to make a citation summary of the interpretation of this standard in the case law. The research discovered that the Court restated the standard's central idea in later case law as the legitimate right of Member States to impose taxes in relation to activities that are carried out on national territory. A detailed legal analysis of the application of this justification in the case law followed. We concluded that the legitimacy of a tax claim under EU law needs to be established according to the fiscal principle of territoriality. However, a tax claim may only be justified if it is indeed imposed in a consistent and systematic manner on all taxpayers who conduct activity within the national territory of the Member State concerned. We found evidence that the balanced allocation of taxing powers does not recognise a tax claim on foreign income as justified. But, EU law does not require that Member States surrender their competence to impose taxes on foreign income. In sum, the balanced allocation of taxing powers protects the internal competence to impose tax of the Member States.

The relations between the balanced allocation of taxing powers and other recognised justifications for direct tax restrictions on freedom of movement was the topic of research in Chapter 7.

The first conclusion was that the need to prevent the risk that losses might be used twice is a limitation to the Union citizen's right to freedom of movement as this right cannot be invoked to support a claim for undue tax advantages.

The second conclusion was that the need to prevent tax avoidance and other abusive practices is a justification that similarly pre-empts that undue tax advantages accrue to a taxpayer by improperly relying on EU law. A Union citizen may not improperly escape a legitimate tax claim on activities carried out in a Member State's territory by setting up a wholly artificial arrangement. A wholly artificial arrangement is a legal arrangement that does not reflect economic reality and is void of commercial justification. A Union citizen may also not improperly take advantage of tax disparities between the Member States 
and avoid taxes by relying on arrangements in national legislation that operate on the basis of an inherent artificiality. The protection of EU law may be withheld if the conditions of freedom of movement have not been exercised in substance in a manner that is consistent with their aim and purpose, despite compliance with the formal conditions of their application. When actions of this kind jeopardise the balanced allocation of taxing powers, the Member State may apply countervailing measures that seemingly restrict freedom of movement in order to protect their internal competence to tax, provided that such measures apply only after a case-by-case examination of objective evidence, and after the taxpayer has been given the opportunity to produce evidence to support his claim for tax benefits without undue administrative constraints. Consequently, we conclude that the overriding reasons of public interest of the need to prevent abuse and fraudulent conduct, and of the need to preserve the balanced allocation of taxing powers cannot be distinguished, on a higher level of abstraction, as regards the larger aim of government that they pursue.

The third conclusion of Chapter 7 was that the rule of the cohesion of the tax system is best conceived as a methodological tool to assess whether the underlying policy objectives of a national measure, including the need to preserve a balanced allocation of taxing powers, are pursued in a consistent and systematic manner. It therefore relates closely to the judicial principle of proportionality.

Chapter 8 researched the judicial principle of proportionality as applied to the balanced allocation of taxing powers. We demonstrated that national measures which are objectively necessary to preserve a tax claim in relation to economic activities on national territory in a consistent and systematic manner will be considered lawful as a matter of EU law. The Court will not examine the proportionality of such claims in a narrow sense. The reason for this is that an assessment of proportionality in the narrow sense is a statement about the system of law that inheres in the Treaties. This system derives its identity in the field of direct taxes from a distinction between the existence (allocation) and the exercise of the competence to impose direct taxes. This distinction not only recognises that an exercise of freedom of movement may be non-neutral in terms of tax consequences due to disparities between the tax legislation of the Member States. In addition, this distinction requires that the Treaties cannot be interpreted to nullify the existence of legitimate tax claims. Consequently, we conclude that a national measure that seemingly restricts freedom of movement, but that is nonetheless justified by the balanced allocation of taxing powers is legislation that fully coheres with the system of EU law in the field of direct taxes.

We revisited the Court's reasoning in Marks \& Spencer (C-446/03) in Chapter 9. We concluded that, although there is a factual defect in the Court's reasoning in that case, our recommendation of a deferral system for cross-border loss relief is a viable alternative to the Court's approach, which is based on a finding of final losses. Our recommendation fully recognised the balanced allocation of taxing powers as a dominating standard of EU law in the field of direct taxes. 


\subsection{Implications of the research}

This book argued that there is a cohesive system of EU law in the field of direct taxes that is structured and organised in a legally relevant manner. The theoretical case that the Court has decided its case law in the field of direct taxation on the basis of systematic inconsistencies in the interpretation of EU law appears rather weak on the basis of the empirical evidence presented in this book. We did not find evidence or indications that the legal doctrine which the Court governs is at significant variance with the principle of conferral and encroaches upon the reserved competences of the Member States.

The basic framework of the legal doctrine in this field is defined by the distinction between the existence and exercise of the reserved competence of the Member States to impose direct taxes on Union citizens. The Court recognises the competence of the Member States to define the criteria of taxation always at the outset, but the intensity of the Court's judicial review depends on the potential effects of national legislation on the exercise of freedom of movement by Union citizens in view of the aims that it pursues. However, the fundamental protection afforded by EU law to the freedom of the Union citizen is limited by the Court if that protection would undermine the freedom of the Member State to regulate the actions of its citizens to the benefit of the citizenry.

Oliver Wendell Holmes, Jr.-Justice at the US Supreme Court-famously wrote in one of his (many) dissenting opinions:

It is true $[\ldots]$ that every exaction of money for an act is a discouragement to the extent of the payment required, but that which, in its immediacy, is a discouragement may be part of an encouragement when seen in its organic connection with the whole. Taxes are what we pay for civilized society, including the chance to insure. ${ }^{737}$

In the same line, the research in this book implies that, although every tax may discourage the pursuit of economic activity, not every tax should therefore be considered a restriction on the freedom of establishment, the freedom of workers, the freedom to provide services, or the free movement of capital.

The European Union is a society that affords supra-national constitutional rights to its citizens through the Treaties on which it is founded. The union and protection of the diversity of cultures, traditions, languages and history of the several Member States is equally at the heart of this society. Therefore, also the competence of the Member States to construct a diverse and civilized society through their several direct tax systems must be assured by the Treaties.

The Court has provided this absolute assurance by developing the standard of the balanced allocation of the power to impose tax between the Member States. This justification allows the Court to see a tax charge on free moving Union citizen in its organic connection with the whole. A Member State may require 
the payment of tax from a Union citizen who has a sufficient connection to the society of the Member State because that citizen rightfully pursues economic activity or resides on the territory of the Member State as an enjoyment of his or her fundamental rights guaranteed by the Treaties. However, the Member States must also pay a price for civilized society in that the same Treaties preclude them from arbitrarily redistributing tax burdens to Union citizens who wish to enjoy their constitutional right to move and reside freely within the European Union. The Member States are required to act in a consistent and systematic manner in relation to all Union citizens and may not discriminate against the exercise of what is, in effect, a constitutional right. A tax on the exercise of constitutional rights is only a discouragement, to the Union citizen and to civilized society. Such a tax has no proper place in the European Union. This is the price that the Member States have to pay for their membership of the EU and as a tax on their reserved competences it is, using Holmes' words, 'part of an encouragement when seen in its organic connection with the whole'. That encouragement is the ever closer Union among the peoples of Europe.

With this book, we believe to have made an important contribution in rationalising the 'bewildering array of concepts' and 'red herrings' in the case law. We hope that the framework of legal doctrine in this book offers a red thread to navigate our way out of the 'labyrinth of impossibility' and ultimately leave 'Wonderland'. ${ }^{738}$ However, there are ample avenues left for future research to explore. We will now describe possible future directions of research that can build on this book.

\subsection{Avenues for future research}

The research in this book was limited by a focus on the Court's rulings only, and only those rulings that were included in the case law list that the European Commission maintains.

We have not taken into account the national courts' mandate to interpret and develop EU law. ${ }^{739}$ We justified this deliberate choice with reference to the limited aim of establishing a framework of legal doctrine. A better developed and more comprehensive legal doctrine on EU law in the field of direct taxes should factor national judicial decisions into the equation. The uniformity of EU law throughout the Union is served by a uniform treatment of the Court's precedent on the national judicial level. How do national courts receive and interpret the judicial rules that the Court has developed? Are these rules applied in a homogeneous manner, or do national courts give different meaning in different national context to the precedents of the Courts? For example, one could make citation summaries of the most important precedents of the Court for the national case law of each Member State and then compare these

\footnotetext{
${ }^{738}$ Section 1.3.

739 See generally, Claes (2006).
} 
restatements. Furthermore, are the same precedents equally important to all Member States, or do national courts weigh the Court's case law in the field of direct taxation differently?

A second limitation of the research in this book is the sample of Court cases that we used to define the body of case law in the field of direct taxes. The TFEU impacts national legislation and policy in relation to direct taxes through the prohibition on restrictions on freedom of movement, but also through the Treaty prohibition on state aid. ${ }^{740}$ Furthermore, either prohibition might apply to the same national measure. ${ }^{74}$ This book has primarily focused on the legal doctrine with regard to the Treaty provisions on freedom of movement. Future research could expand the sample and include cases on state aid in the field of direct taxation. An interesting research question is whether the Court borrows from precedents decided under the fundamental freedoms to interpret the state aids prohibition, and vice versa? To what extent is judicial interpretation in these two areas carried out in isolation, and has the Court developed common rules that apply in either context? This type of research could give insight into what extent the Court interprets the Treaty as a cohesive whole.

A third avenue for expanding the scope of legal doctrine on EU law in the field of taxation is to connect the fields of internal taxation (Article 110 TFEU), VAT law and direct taxation. Can the method of research that we applied in this book to constitutional judicial review in the field of direct taxation also be applied to constitutional judicial review in the field of indirect taxation? In other words, what is the structure and organisation of the case law on Article 110 TFEU, and how does it connect to doctrine in the field of direct taxation? As regards VAT law, the Court does not exercise a constitutional review function, but it acts as a supreme court of statutory interpretation. A network analysis of the extensive VAT case law of the Court could give further systematic insight into the judicial interpretation of the VAT directives and the principles that inhere in them.

We are well aware that the method of research in this book has not been fully tested and is work in progress. Future research should also point out its shortcomings and contribute to making it more robust. For example, we have seen in Chapter 6 that a citation summary gives more insight into a judicial rule compared to the text of its original source. An evident shortcoming of Annex A is that it is primarily based on extraction summaries of the most important authorities. Because we have identified the paragraphs of the rulings that are the source of those rules, we believe that the informative quality of Annex A could be improved by using citation summaries of those paragraphs as a basis for a restatement of the law.

Another shortcoming of our research is that we based all our inferences on a specific sample of cases. Although we already suggested above including other cases in this sample, we believe that a complete view of the network is also

${ }_{740}$ See, Luja (2003); Luja (2012); Panayi (2004).

741 Engelen (2012); Micheau (2012). 
necessary. Future research should test the validity and robustness of our conclusions on the basis of a complete network of the Court's case law.

\section{$10.4 \quad$ Final word}

We have seen that there are many possibilities to advance our knowledge through future research. In pursuit of this new knowledge, we should keep in mind that EU law in the field of direct taxes may perhaps always remain at the edge between order and chaos. It is best if we accept this complexity and work on understanding it as a natural thing, instead of aiming to destruct its existence. This is not a plea to shy away from normative judgment, but merely an encouragement to frame normative evaluations and recommendations in relation to this complexity.

The history of direct tax harmonisation and coordination has shown that centralised and strategic policy planning at the Union level is difficult to achieve in this field due to institutional rigidity. The evolution of the law has come incrementally, and will most likely also come in the future from the judicial arena as an emergent of the complex interplay and linkages between the various social agents involved and their heterogeneous preferences: the interaction between taxpayers and their advisors, their relations with the tax inspectors and governments of the 27 Member States, the intervention by the European Commission, the reactions of the national courts and the new litigation in response, and not in the least, the interaction of all of the these agents with the Court of Justice of European Union. But, from the dynamic processes of negative integration emerges an adaptive complexity which can be researched systematically. By further advancing our knowledge on these interactions and processes, we can learn how they bring about structure and organisation in the legal system. 



\title{
Annex A
}

\section{Acte clair rules in the field of direct taxes}

\author{
Section 1 \\ General principles
}

Rule 1:1 - Principle of conferral

(1) Direct taxation falls within the competence of the Member States. ${ }^{742}$

(2) In the absence of any unifying or harmonising Union measures, Member States retain the power to define, by treaty or unilaterally, the criteria for taxation of income and wealth and the connecting factors for the purposes of allocating their powers of taxation, particularly with a view to eliminating double taxation. ${ }^{743}$

Rule 1:2 - Principle of supremacy

The Member States must exercise their competence on direct taxation consistently with EU law. ${ }^{744}$

742 Schumacker (C-279/93), para 21; Wielockx (C-80/94), para 16; ICI (C-264/96), para 19; Royal Bank of Scotland (C-311/97), para 19; Verkooijen (C-35/98), para 32; Metallgesellschaft and Others \& Hoechst (Joined Cases C-397\&410/98), para 37; Manninen (C-319/02), para 19; Marks \& Spencer (C-446/03), para 29; Cadbury Schweppes (C-196/04), para 40; ACT Group Litigation (C-374/04), para 36; and Thin Cap Group Litigation (C-524/04), para 25.

743 Gilly (C-336/96), paras 24 and 30; Saint-Gobain (C-307/97), para 57; and ACT Group Litigation, para 52.

744 Schumacker, para 21; Wielockx, para 16; ICI, para 19; Royal Bank of Scotland, para 19; Verkooijen, para 32; Metallgesellschaft and Others \& Hoechst, para 37; Manninen, para 19; Marks \& Spencer, para 29; Cadbury Schweppes, para 40; ACT Group Litigation, para 36; and Thin Cap Group Litigation, para 25. 
Rule 1:3 - Principle of non-discrimination

(1) Discrimination consists of the application of different rules to comparable situations or in the application of the same rule to different situations. ${ }^{745}$

(2) The Member States must avoid all discrimination on grounds of nationality. $^{746}$

(3) The rules regarding equal treatment forbid not only overt discrimination by reason of nationality but also all covert forms of discrimination which, by the application of other criteria of differentiation, lead in fact to the same result. ${ }^{747}$

(4) The general prohibition of all discrimination on grounds of nationality laid down by Article 18 TFEU applies independently only to situations governed by EU law for which the Treaty lays down no specific nondiscrimination rules. ${ }^{748}$

(5) In relation to the freedom of establishment, the principle of nondiscrimination was implemented and specifically laid down by Article 49 TFEU. ${ }^{749}$

Rule 1:4 - Principles of nationality and territoriality

(1) Differentiation by the criterion of nationality for the purpose of allocation of fiscal jurisdiction cannot be regarded as constituting discrimination prohibited by the Treaty. ${ }^{750}$

(2) A system which is in conformity with the fiscal principle of territoriality cannot be regarded as entailing any discrimination, overt or covert, prohibited by the Treaty. ${ }^{751}$

${ }^{746}$ Wielockx, para 16; Royal Bank of Scotland, para 19; and Metallgesellschaft and Others \& Hoechst, para 37.

${ }^{747}$ Schumacker, para 26.

${ }^{748}$ Metallgesellschaft and Others \& Hoechst, para 38.

${ }_{749}$ Metallgesellschaft and Others \& Hoechst, para 39.

${ }^{750}$ Gilly, para 30.

${ }^{751}$ Futura (C-250/95), para 22. Explanatory note: The 'system' to which Futura, para 22 and, thus, Rule 1:4(2) refer is the ordinary system in international tax practice which differentiates, for the purpose of allocation of the basic scope of fiscal jurisdiction, between residents and non-residents. The Court thus only validated a different treatment of the two categories by the criterion of territoriality for the purpose of allocation of fiscal jurisdiction to determine the material scope of assessment. Futura and, thus, Rule 1:4(2) are misconceived when interpreted as allowing any other differentiation by the same criterion within the exercise of fiscal jurisdiction, whether it concerns universal jurisdiction for resident taxpayers or territorial jurisdiction for non-resident taxpayers. 
Rule 1:5 - Residence as a factor for distinction in direct taxation

(1) The taxpayers' residence may constitute a factor that might justify national rules involving different treatment for resident and non-resident taxpayers, but residence is not always a proper factor for distinction. ${ }^{752}$

(2) In relation to direct taxes, the situations of residents and of non-residents are not, as a rule, comparable in terms of Rule 1:3, in that: ${ }^{753}$

(a) income received in the territory of a Member State by a non-resident is in most cases only a part of his total income, which is concentrated at his place of residence;

(b) a non-resident' s personal ability to pay tax, determined by reference to his aggregate income and his personal and family circumstances, is more easy to assess at the place where his personal and financial interests are centred, that is, in general, the place where he has his usual abode; and

(c) in accordance with (a) and (b), international tax law, and in particular the Model Double Taxation Treaty of the Organization for Economic Cooperation and Development, recognizes that in principle the overall taxation of taxpayers, taking account of their personal and family circumstances, is a matter for the State of residence of the taxpayer. ${ }^{754}$

(3) From Paragraph 2 follows that the fact that a Member State does not grant to a non-resident certain tax benefits which it grants to a resident is not, as a rule, discrimination in terms of Rule 1:3. ${ }^{755}$

(4) Residence is not a proper factor for distinction in terms of Paragraph 1 in a case where the non-resident receives no significant income in the State of his residence and obtains the major part of his taxable income from an activity performed in the State of employment, with the result that the State of his residence is not in a position to grant him the benefits resulting from the taking into account of his personal and family circumstances. $^{756}$

${ }^{752}$ Marks \& Spencer, para 37. See, Rule 2:1(7).

${ }^{753}$ Marks \& Spencer, para 37; and Schumacker, paras 31 and 32.

${ }^{754}$ See, Rule 1:4(2).

755 Schumacker, para 34.

${ }^{756}$ Schumacker, para 36. 


\section{Section 2 \\ Restatements of the freedoms}

Rule 2:1 - Freedom of establishment

(1) Article 49 TFEU constitutes one of the fundamental provisions of EU law and has been directly applicable in the Member States since the end of the transitional period. ${ }^{7}$ ?

(2) Article 49 TFEU grants freedom of establishment to Union citizens. ${ }^{758}$

(3) Freedom of establishment includes the right of Union citizens to take up and pursue activities as self-employed persons and to set up and manage undertakings under the conditions laid down for its own nationals by the law of the Member State where such establishment is effected. ${ }^{759}$

(4) The abolition of restrictions on freedom of establishment also applies to restrictions on the setting up of agencies, branches or subsidiaries by nationals of any Member State established in the territory of another Member State. ${ }^{760}$

(5) The term controlling holdings concerns holdings in the capital of a company which have a definite influence on the company's decisions and allow to determine its activities. ${ }^{761}$

(6) National legislation which applies to controlling holdings, in or by a company established in another Member State, comes within the substantive scope of freedom of establishment; ${ }^{762}$

(7) Freedom of establishment also includes, pursuant to Article 54 TFEU, the right of companies or firms formed in accordance with the laws of a Member State and having their registered office, central administration or principal place of business (corporate seat) within the Union to pursue

757 Commission v France (Avoir Fiscal) (270/83), para 13; and Royal Bank of Scotland, para 22;

Avoir Fiscal, para 18; Saint-Gobain, para 35; Marks \& Spencer, para 30; Cadbury Schweppes, para 41; ACT Group Litigation, para 42; Keller Holding (C-471/04), para 29; and Thin Cap Group Litigation, para 36.

759 Avoir Fiscal, paras 13 and 18; Saint-Gobain, para 35; Royal Bank of Scotland, para 22; Marks \& Spencer, para 30; Cadbury Schweppes, para 41; ACT Group Litigation, para 42; Keller Holding, para 29; and Thin Cap Group Litigation, para 36.

760 Avoir Fiscal, para 13; Royal Bank of Scotland, para 22; Baars (C-251/98), para 22.

761 Baars, para 22; Cadbury Schweppes, para 31; ACT Group Litigation, para 39; and Thin Cap Group Litigation, para 27.

762 Baars, paras 21 and 22; Cadbury Schweppes, para 31; ACT Group Litigation, para 39; and Thin Cap Group Litigation, para 27. 
their activities in the Member State concerned through a subsidiary, branch or an agency: ${ }^{763}$

(a) With regard to companies, it should be noted that it is their corporate seat that serves as the connecting factor with the legal system of a Member State, like nationality in the case of natural persons; ${ }^{764}$

(b) Acceptance of the proposition that the Member State in which a company seeks to establish itself may freely apply to it a different treatment solely by reason of the fact that its corporate seat is situated in another Member State would thus deprive Article 54 TFEU of all meaning. ${ }^{765}$

Freedom of establishment thus aims to guarantee the benefit of national treatment in the host Member State, by prohibiting any discrimination based on the nationality of the Union citizen or the place in which companies have their corporate seat. ${ }^{766}$

(9) In the case of a DTC concluded between a Member State and a nonmember country, the national treatment principle requires the Member State concerned which is party to the DTC to grant to permanent establishments of companies which have their corporate seat in another Member State the advantages provided for by that DTC on the same conditions as those which apply to companies which have their corporate seat in the Member State concerned. ${ }^{767}$

(10) Even though, according to their wording, the provisions of the Treaty concerning freedom of establishment are directed at ensuring that foreign nationals and companies are treated in the host Member State in the same way as nationals of that State, they also prohibit the Member State of origin from hindering the establishment in another Member State of one of its nationals or of a company formed in accordance with its laws. ${ }^{768}$

(11) In order for national legislation to be considered to be a restriction on freedom of establishment, it is sufficient that it be capable of restricting the exercise of that freedom, and it is not necessary to establish that the legislation in question has actually had the effect of leading a national of a Member State or company to refrain from exercising that freedom. ${ }^{769}$

763 Avoir Fiscal, para 18; Saint-Gobain, para 35; Metallgesellschaft and Others \& Hoechst, para 42; Marks \& Spencer, para 30; ACT Group Litigation, para 42; Keller Holding, para 29; and Thin Cap Group Litigation, para 36.

764 Avoir Fiscal, para 18; Metallgesellschaft and Others \& Hoechst, para 42; and ACT Group Litigation, para 43. Avoir Fiscal, para 18; Metallgesellschaft and Others \& Hoechst, para 42; Marks \& Spencer, para 37; and ACT Group Litigation, para 43.

766 Avoir Fiscal, para 14; Saint-Gobain, para 35; and ACT Group Litigation, para 43.

767 Saint-Gobain, para 59.

768 ICI, para 21; Marks \& Spencer, para 31; and Cadbury Schweppes, para 42.

769 Thin Cap Group Litigation, para 62. 
Rule 2:2 - Free movement of capital

(1) The possibility granted to the Member States by Article 65(1)(a) TFEU of applying the relevant provisions of their tax legislation which distinguish between taxpayers according to their place of residence or the place where their capital is invested has already been upheld by the Court, before the entry into force of that provision. ${ }^{7}$

(2) It should be noted that Article 65(1)(a) TFEU, which, as a derogation from the fundamental principle of the free movement of capital, must be interpreted strictly and cannot be interpreted as meaning that any tax legislation making a distinction between taxpayers by reference to the place where they invest their capital is automatically compatible with the Treaty. ${ }^{771}$

(3) The derogation in Article 65(1)(a) TFEU is itself limited by Article 65(3) TFEU, which states specifically that the national provisions referred to by Article 65(1)(a) TFEU are not to constitute a means of arbitrary discrimination or a disguised restriction on the free movement of capital and payments, as defined in Article 63 TFEU. ${ }^{772}$

(4) National tax provisions of the kind to which Article 65(1)(a) TFEU refers, in so far as they establish certain distinctions based, in particular, on the residence of taxpayers, could be compatible with EU law provided that they apply to situations which are not objectively comparable in terms of Rule 1:5, or could be justified by overriding reasons in the public interest to which Rule 4:1 applies. ${ }^{773}$

(5) Inasmuch as Article 63 TFEU substantially reproduced the content of Article 1 of Directive 88/361, and even if the latter was adopted on the basis of Articles 69 and 70(1) of the EEC Treaty (Articles 67 to 73 of the EEC Treaty were replaced by Articles $73 \mathrm{~b}$ to $73 \mathrm{~g}$ of the EC Treaty, now Articles 63 TFEU to 66 TFEU) that nomenclature retains the same indicative value, for the purposes of defining the term 'movement of capital', as it did before their entry into force, subject to the qualification, contained in the introduction to the nomenclature, that the list set out therein is not exhaustive, ${ }^{774}$

(6) The same indicative value must be given to the nomenclature in interpreting the concept of direct investment. ${ }^{775}$

(7) The concept of direct investments concerns investments of any kind undertaken by natural or legal persons and which serve to establish or maintain lasting and direct links between the persons providing the capital and

\footnotetext{
${ }^{770}$ Verkooijen, para 43.

771 Verkooijen, para 44; and Manninen, para 28

772 Verkooijen, para 44; and Manninen, para 28.

773 Verkooijen, para 43; and Manninen, para 29.

${ }_{774}$ FII Group Litigation (C-446/04), para 179

775 FII Group Litigation, para 180.
} 
the undertakings to which that capital is made available in order to carry out an economic activity.

(8) According to the first section of the nomenclature, direct investments include: ${ }^{.76}$

(a) the establishment and extension of branches or new undertakings belonging solely to the person providing the capital and the acquisition in full of existing undertakings;

(b) participation in new or existing undertakings with a view to establishing or maintaining lasting economic links;

(c) long-term loans with a view to establishing or maintaining lasting economic links;

(d) reinvestment of profits with a view to maintaining lasting economic links.

(9) As regards the shareholdings in new or existing undertakings of Paragraph $8(\mathrm{~b})$, the objective of establishing or maintaining lasting economic links presupposes that the shares held by the shareholder enable him, either pursuant to the provisions of the national laws relating to companies limited by shares or otherwise, to participate effectively in the management of that company or in its control. ${ }^{777}$

Rule 2:3 - Precedence and concurrence of freedoms

(1) Legislation which primarily affects freedom of establishment should be considered in the light of Article 49 TFEU; ${ }^{778}$

(2) Legislation which is targeted only at controlling holdings primarily affects freedom of establishment in terms of Paragraph $1 .^{77}$

(3) Restrictive effects on the freedom to provide services and the free movement of capital of legislation to which Paragraph 1 applies, must be seen as an unavoidable consequence of any restriction on freedom of establishment and do not justify an independent examination of that legislation in the light of Articles 56 TFEU and 63 TFEU. $^{780}$

(4) Legislation which affects freedom of establishment, but to which Paragraph 1 does not apply, and which is also targeted to situations that come within the substantive scope of free movement of capital, may fall within the scope of both Article 49 TFEU and Article 63 TFEU. Consequently,

776 FII Group Litigation, para 181.

777 FII Group Litigation, para 182.

778 Cadbury Schweppes, para 32; FII Group Litigation, para 118; and Thin Cap Group Litigation, paras 26, and 28-33.

779 Cadbury Schweppes, para 32; FII Group Litigation, para 118; and Thin Cap Group Litigation, paras 26, and 28-33.

780 Cadbury Schweppes, para 33; and Thin Cap Group Litigation, para 34. 
such legislation must also be considered in the light of the TFEU provisions on the free movement of capital. ${ }^{781}$

\section{Section 3 Taxation of dividends}

Rule 3:1 - Competence to organise the system of dividend taxation

(1) It is for each Member State to organise, in compliance with EU law, its system of taxation of distributed profits and, in that context, to define the tax base as well at the tax rates which apply to the company making the distribution and/or the shareholder to whom the dividends are paid, in so far as they are liable to tax in that State. ${ }^{782}$

(2) As appears particularly from the third recital in its preamble, the aim of Directive $90 / 435$ is, by the introduction of a common system of taxation, to eliminate any disadvantage to cooperation between companies of different Member States as compared with cooperation between companies of the same Member State and thereby to facilitate the grouping together of companies at Union level. ${ }^{783}$

(3) The decisions which Directive 90/435 leaves in the hands of the Member States may be exercised only in compliance with the fundamental provisions of the TFEU, in particular those relating to freedom of establishment. $^{784}$

(4) The mere fact that, for holdings to which Directive 90/435 does not apply, it is for the Member States to determine whether, and to what extent, a series of charges to tax and economic double taxation are to be avoided and, for that purpose, to establish, either unilaterally or through DTCs concluded with other Member States, procedures intended to prevent or mitigate such a series of charges to tax and that economic double taxation, does not of itself mean that the Member States are entitled to impose measures that contravene the freedoms of movement guaranteed by the TFEU. ${ }^{785}$

Rule 3:2 - Inbound dividends

(1) A legislative provision of a Member State which treats income arising from the investment of capital in companies which have their corporate seat in another Member State (foreign-sourced dividends) less favourably

781 ACT Group Litigation, paras 37 and 38; and FII Group Litigation, paras 36 and 38.

782 ACT Group Litigation, para 50; and FII Group Litigation, para 47. See, Rule 1:1 and Rule 1:2.

783 FII Group Litigation, para 103.

${ }^{784}$ FII Group Litigation, para 46. See, Rule 1:2.

785 ACT Group Litigation, para 54. See, Rule 1:2. 
from a tax point of view than dividends paid by companies which have their corporate seat in the Member State concerned (nationally-sourced dividends), has the effect of dissuading the nationals or companies of the Member State concerned from investing their capital in companies in that other Member State and also has a restrictive effect on those companies in that it constitutes an obstacle to their raising of capital in the Member State concerned. ${ }^{786}$

(2) Where the Member State concerned has a system for preventing or mitigating a series of charges to tax or economic double taxation for nationally-sourced dividends, it must treat foreign-sourced dividends in the same way. ${ }^{787}$

(3) The fact that nationally-sourced dividends are subject to an exemption system and foreign-sourced dividends are subject to an imputation system does not contravene the principle of freedom of establishment, provided that: ${ }^{788}$

(a) the tax rate applied to foreign-sourced dividends is not higher than the rate applied to nationally-sourced dividends; and

(b) the tax credit is at least equal to the amount paid in the Member State in which the company making the distribution has its corporate seat, up to the limit of the tax charged in the Member State concerned.

(4) Paragraph 2 does not apply if the difference in treatment concerns situations which are not objectively comparable in terms of Rule 1:5 or is justified by overriding reasons in the general interest to which Rule 4:1 applies.

(5) The difficulties that may arise in determining the tax actually paid in the Member State in which the company making the distribution has its corporate seat is not a justification in terms of Paragraph $4 .^{790}$

Rule 3:3 - Outbound dividends

(1) In order for shareholders which are nationals of other Member States or companies which have their corporate seat in another Member State receiving dividends (foreign shareholders) not to be subject to a restriction on freedom of establishment, the Member State in which the company making the distribution has its corporate seat, is obliged to ensure that, under the procedures laid down by its national law in order to prevent or mitigate a series of liabilities to tax, foreign shareholders are subject to the same treatment as shareholders which are nationals or companies of the Member State concerned (national shareholders), if the Member State

\footnotetext{
786 Verkooijen, paras 34 and 35; and FII Group Litigation, paras 64 and 166.

787 ACT Group Litigation, para 55; and FII Group Litigation, para 46.

788 FII Group Litigation, paras 48, 52 and 57.

789 Manninen, para 29; and FII Group Litigation, para 46.

790 FII Group Litigation, para 70.
} 
concerned is in the same position, as regards the prevention or mitigation of a series of charges to tax and of economic double taxation, with regard to foreign and national shareholders. ${ }^{791}$

(2) The Member State concerned is not the same position as regards the prevention or mitigation of a series of charges to tax and of economic double taxation, with regard to foreign and national shareholders for purposes of Paragraph 1, unless the Member State concerned, unilaterally or by a convention, imposes a charge to income tax not only on national shareholders but also on foreign shareholders in respect of nationally-sourced dividends. ${ }^{792}$

(3) To require a Member State, to which Paragraph 2 applies, to ensure that nationally-sourced dividends distributed to foreign shareholders are not liable to a series of charges to tax or to economic double taxation, either by exempting those profits from tax at the level of the company making the distribution or by granting the shareholder a tax advantage equal to the tax paid on those profits by the company making the distribution, would mean in point of fact that the Member State concerned would be obliged to abandon its right to tax a profit generated through an economic activity undertaken on its territory. ${ }^{793}$

(4) It is for the national court to determine, in each case, whether the obligation of Paragraph 1 has been complied with, taking account, where necessary, of the provisions of the DTC that the Member State concerned has concluded with the State of the foreign shareholder. ${ }^{794}$

\section{Section 4 Justification}

Rule 4:1 - Rule of reason

(1) A restriction is permissible only if it is justified by overriding reasons of public interest. ${ }^{795}$

(2) It is further necessary, if a restriction is permissible in terms of Paragraph 1 , that its application be appropriate to ensuring the attainment of the objective thus pursued and not go beyond what is necessary to attain it. ${ }^{796}$

\footnotetext{
791 ACT Group Litigation, para 70;

792 ACT Group Litigation, paras 58, 68 and 70.

793 ACT Group Litigation, para 59.

794 ACT Group Litigation, para 71.

795 Futura, para 26; Marks \& Spencer, para 35; Cadbury Schweppes, para 47; and Thin Cap Group Litigation, para 64.

796 Futura, para 26; Marks \& Spencer, para 35; Cadbury Schweppes, para 47; and Thin Cap Group Litigation, para 64.
} 
Rule 4:2 - Effectiveness of fiscal supervision

(1) The effectiveness of fiscal supervision is an overriding reason of public interest to which Rule 4:1 applies. ${ }^{797}$

(2) A Member State may apply measures which enable the amount of both the income taxable in the Member State concerned and of the losses which can be carried forward there to be ascertained clearly and precisely. ${ }^{798}$

Rule 4:3 - Cohesion of the tax system

(1) The need to maintain the cohesion of the tax system is an overriding reason to which Rule $4: 1$ applies. ${ }^{799}$

(2) The formulation of the cohesion of the tax system is a matter for each individual Member State and the need to safeguard the cohesion of the tax system must, thus, be examined in the light of the objective pursued by the tax legislation in question. ${ }^{800}$

(3) For an argument based on the cohesion of the tax system to succeed, a direct link must be established between the tax advantage concerned and the offsetting of that advantage by a particular tax levy.

(4) In order to establish a direct link in terms of Paragraph 3, it is sufficient if the tax advantage and the offsetting levy relate to the same tax and one and the same taxpayer. ${ }^{802}$

Rule 4:4 - The balanced allocation of taxing powers

(1) The preservation of the allocation of the power to impose taxes between Member States is an overriding reason of public interest to which Rule $4: 1$ applies. $^{803}$

(2) The preservation of the allocation of the power to impose taxes between Member States might make it necessary to apply to the economic activities of companies established in one of those States only the tax rules of that State in respect of both profits and losses. ${ }^{804}$

\footnotetext{
${ }^{797}$ Futura, para 31.

798 Futura, para 31.

799 Bachmann (C-204/90), para 28; Commission v Belgium (C-300/90), para 21; Manninen, para 42; Keller Holding, para 40; and Thin Cap Group Litigation, para 68

${ }^{800}$ Bachmann, para 23; Commission v Belgium, para 16; and Manninen, para 43.

801 Bachmann, para 21-23; Commission v Belgium, para 14-16; Verkooijen, para 35; Baars, para 40; Manninen, para 42; Keller Holding, para 40; and Thin Cap Group Litigation, para 68.

802 Bachmann, para 21-23; Commission v Belgium, para 14-16; Verkooijen, para 57; and Manninen, para 42.

${ }^{803}$ Marks \& Spencer, para 51.

${ }^{804}$ Marks \& Spencer, para 45.
} 
(3) In effect, to give companies the option to have their losses taken into account in the Member State in which they are established or in another Member State would significantly jeopardise a balanced allocation of the power to impose taxes between Member States, as the taxable basis would be increased in the first State and reduced in the second to the extent of the losses transferred. ${ }^{805}$

Rule 4:5 - The prevention of abusive practices

(1) The prevention of abusive practices, i.e. tax avoidance, is an overriding reason of public interest to which Rule 4:1 applies. ${ }^{806}$

(2) In order for a restriction to be justified by the prevention of abusive practices, the specific objective of such a restriction must be to prevent conduct involving the creation of wholly artificial arrangements which do not reflect economic reality, with a view to escaping the tax normally due on the profits generated by activities carried out on national territory. ${ }^{807}$

(3) The establishment of a company in another Member State does not, of itself, necessarily entail an abusive practice and cannot set up a general presumption of tax avoidance, since that company will in any event be subject to the tax legislation of the State of establishment. ${ }^{808}$

Rule 4:6 - Other tax advantages

The existence of other tax advantages is not an overriding reason of public interest to which Rule 4:1 applies and therefore cannot justify unfavourable tax treatment contrary to a fundamental freedom, even supposing that such advantages exist. ${ }^{809}$

Rule 4:7 - Reduction in tax revenue

Reduction in tax revenue is not an overriding reason of public interest to which Rule 4:1 applies. ${ }^{810}$

${ }^{805}$ Marks \& Spencer, para 46.

${ }^{806}$ Marks \& Spencer, para 57; Cadbury Schweppes, para 50; and Thin Cap Group Litigation, para 72.

807 ICI, para 26; Cadbury Schweppes, paras 50 and 55; and Thin Cap Group Litigation, paras 72 and 74.

808 ICI, para 26; and Cadbury Schweppes, para 50.

809 Verkooijen, para 61.

810 Metallgesellschaft and Others \& Hoechst, para 59; Verkooijen, para 59; and Manninen, para 49. 
Rule 4:8 - Justification in relations with non-member countries

(1) It may be that a Member State will be able to demonstrate that a restriction on capital movements to or from non-member countries is justified for a particular reason in circumstances where that reason would not constitute a valid justification in terms of Rule 4:1 for a restriction on capital movements between Member States. ${ }^{811}$

(2) It is true that, because of the degree of legal integration that exists between Member States of the Union, in particular by reason of the presence of Community legislation which seeks to ensure cooperation between national tax authorities, such as Council Directive 77/799/EEC of 19 December 1977 concerning mutual assistance by the competent authorities of the Member States in the field of direct taxation (OJ $1977 \mathrm{~L}$ 336, p. 15), the taxation by a Member State of economic activities having cross-border aspects which take place within the Community is not always comparable to that of economic activities involving relations between Member States and non-member countries. ${ }^{812}$

\section{Section 5 \\ Remedies}

\section{Rule 5:1 - National procedural autonomy}

It must be stated that it is not for the Court to assign a legal classification to the actions brought before the national court by the claimants in the main proceedings. In the circumstances, it is for the latter to specify the nature and basis of their actions (whether they are actions for repayment or actions for compensation for damage), subject to the supervision of the national court. ${ }^{813}$

\section{Rule 5:2 - Right to a restitution of undue charges}

The right to a restitution of charges levied in a Member State in breach of rules of EU law is the consequence and complement of the rights conferred on individuals by Union provisions as interpreted by the Court. The Member State concerned is therefore required in principle to repay charges levied in breach of EU law. 814

811 FII Group Litigation, para 171.

${ }^{812}$ FII Group Litigation, para 170.

${ }^{813}$ Metallgesellschaft and Others \& Hoechst, para 81; and FII Group Litigation, para 201.

814 Metallgesellschaft and Others \& Hoechst, para 84; and FII Group Litigation, para 202. 
Rule 5:3 - Liability for damages

It is, in principle, for the national courts to apply the criteria for establishing the liability of Member States for damage caused to individuals by breaches of EU law, in accordance with the guidelines laid down by the Court for the application of those criteria. ${ }^{815}$

\section{Rule 5:4 - Principles of equivalence and effectiveness}

(1) In the absence of Union rules on the restitution of national charges that have been improperly levied, it is for the domestic legal system of each Member State to designate the courts and tribunals having jurisdiction and to lay down the detailed procedural rules governing actions for safeguarding rights which individuals derive from EU law, provided that: ${ }^{816}$

(a) such rules are not less favourable than those governing similar domestic actions (principle of equivalence); and

(b) such rules do not render practically impossible or excessively difficult the exercise of rights conferred by Community law (principle of effectiveness).

(2) The exercise of rights conferred on private persons by directly applicable provisions of EU law would be rendered practically impossible or excessively difficult within the meaning of the principle of effectiveness if their claims for restitution or compensation based on EU law were rejected or reduced solely because the persons concerned had not applied for a tax advantage which national law denied them, with a view to challenging the refusal of the tax authorities by means of the legal remedies provided for that purpose, invoking the primacy and direct effect of EU law. ${ }^{817}$

${ }^{815}$ FII Group Litigation, para 210. Explanatory note: The 'guidelines' are the conditions established in the line of authority following Brasserie du Pêcheur and Factortame (Joined Cases C-46/93 \& C-48/93).

${ }^{816}$ Metallgesellschaft and Others \& Hoechst, para 85; and FII Group Litigation, para 203.

${ }^{817}$ Metallgesellschaft and Others \& Hoechst, para 106. 


\section{Nederlandse Samenvatting}

\section{De Structuur en Organisatie van het EU-Recht op het Gebied van de Directe Belastingen}

Het doel van dit boek is om een concept voor een rechtsleer van het EU-recht op het gebied van de directe belastingen te ontwikkelen. De onderzoeksvraag is wat de structuur en organisatie van dit functionele subsysteem van het EU-recht is. Het onderzoek is beperkt tot het EU-recht op het gebied van de directe belastingen zoals dat uit de rechtspraak van het Hof van Justitie van de Europese Unie (het Hof) kan worden afgeleid. Deze beperking is gerechtvaardigd omdat het regelgevend toezicht van de Europese Unie ten aanzien van de nationale directe belastingen het sterkst tot uitdrukking komt in en primair wordt bepaald door de rechtspraak van het Hof.

De uitdaging van het voorliggende onderzoek was om het EU-recht op het gebied van de directe belastingen, in het bijzonder de rechtspraak, te benaderen als het complex adaptief systeem dat het is. Dit onderzoek benadert de rechtspraak namelijk niet op een reductionistische wijze. In een reductionistische benadering wordt vooral gekeken naar de motivering en de gronden van de individuele arresten en worden deze arresten op een geïsoleerde wijze benaderd. Daarbij is de structuur en organisatie van de rechtsleer van een vooropgezet kader of een persoonlijke inductie van de onderzoeker. Het voorliggende onderzoek tracht om het systeem als zodanig te onderzoeken, als een zelfstandig voorwerp van onderzoek. Het tracht zijn structuur en organisatie te bepalen op een wijze die objectief en herhaalbaar is. Dit is de belangrijkste bijdrage aan de wetenschap van dit boek.

Een concept voor een rechtsleer van het EU-recht op het gebied van de directe belastingen vereist een breed onderzoek met diepgang. Anderzijds leggen onderzoeksmiddelen en onderzoekstijd beperkingen op. Een en ander noopte tot het vinden van een balans met als doel het onderzoeksproject overzichtelijk en beheersbaar te houden. Om deze reden onderzoekt Deel II het EU-recht op het gebied van de directe belastingen in de breedte en komen specifieke onderwerpen met meer diepgang aan de orde in Deel III. Het voorliggende onderzoek analyseert de volledige verzameling van rechtspraak van het Hof op het gebied van de directe belastingen.

Het belangrijkste idee van dit boek is dat de rechtspraak als een netwerk wordt onderzocht. Deze benadering stelt het in staat om de expliciete relaties 
tussen de verschillende arresten in de analyse te betrekken. Het Hof volgt in zijn arresten bestendig de gedragslijn om de uitleg van het recht in eerdere arresten te handhaven. Daarom veronderstelt het onderzoek dat verwijzingen in een arrest naar precedenten zeer betrouwbare anwijzingen geven hoe rechtsoverwegingen evolueren naar rechtsregels en hoe het Hof deze rechtsregels vervolgens handhaaft in zijn latere rechtspraak. Hoofdstuk 2 beschouwt dit analytische raamwerk. Het raamwerk veronderstelt dat een systematische analyse van de verwijzingen naar precedenten in de rechtspraak het mogelijk maakt om de structuur en organisatie van de rechtsleer te bepalen. Op deze manier kan de structuur en organisatie van het netwerk van rechtspraak op het gebied van de directe belastingen empirisch worden waargenomen.

Hoofdstuk 3 verkent de eigenschappen van de verzameling van rechtspraak op het gebied van de directe belastingen. Dit overzicht van de rechtspraak van het Hof op basis van geaggregeerde meta-kenmerken van de arresten geeft zinvolle inzichten in de algemene ontwikkeling en richtingen van de rechterlijke besluitvorming in dit deelgebied van het EU-recht in de periode van 1983 tot en met 2011. De rechtspraak behandelt veel thema's in de directe belastingen en is gewezen op basis van de diverse verdragsbepalingen die betrekking hebben op de vrijheid van verkeer. Het Hof legt ook Richtlijnen op het gebied van de directe belastingen uit, maar zijn taak om nationale wetgeving te toetsen aan de Verdragen is verreweg belangrijker dan zijn taak om secundaire wetgeving uit te leggen. Het onderzoek geeft een beschouwing van de context van de rechtspraak aan de hand van de vragen welke lidstaten, welke nationale gerechten en welke procedures betrokken waren bij zijn totstandkoming. Wij zien in de afgelopen jaren een toename van het aantal inbreukprocedures, maar prejudiciële vragen blijven het belangrijkste middel om het Hof uit te nodigen het EU-recht op het gebied van de directe belastingen uit te leggen. Tevens blijkt, dat de mate van succes van belastingplichtigen in deze periode afnam. Deze laatste ontwikkeling kan deels worden toegeschreven aan de introductie door het Hof van de evenwichtige verdeling van heffingsbevoegdheden tussen de lidstaten als rechtvaardigingsgrond voor beperkingen van het vrije verkeer door maatregelen op het gebied van de directe belastingen. De voorzichtige conclusie van dit hoofdstuk is, dat de rechtspraak van het Hof op het gebied van de directe belastingen inmiddels zodanig volwassen en stabiel is, dat de stelling is te verdedigen, dat zich daarin een functioneel subsysteem met een robuuste identiteit heeft ontwikkeld.

Hoofdstuk 4 voert een netwerkanalyse uit op de verzameling van rechtspraak op het gebied van de directe belastingen. Na een beschouwing van de algemene eigenschappen van het netwerk van rechtspraak, legt paragraaf 4.2 bloot hoe de arresten in een samenhangend geheel met elkaar zijn verbonden. De conclusie op grond van een vergelijking met een vergelijkbaar willekeurig netwerk is dat het Hof niet op willekeurige wijze naar zijn eerdere rechtspraak verwijst. Deze bevindingen duiden erop dat de onderzochte rechtspraak onderhevig is aan een dynamisch en zelforganiserend proces zoals veel andere echte netwerken met een vergelijkbare topologische structuur. Ondanks zijn complexiteit was in de rechtspraak een samenhangende structuur te vinden. 
De volgende stap in het onderzoek naar de structuur en organisatie van het netwerk van rechtspraak is een analyse van zijn organisatie in groepen (communities) en subgroepen (subcommunities) door middel van computational community detection methoden. Deze analyse leidde tot de vaststelling van een structuur van groepen van arresten in het netwerk van rechtspraak die juridisch relevant, significant en van betekenis is. De uitvoerige kwalitatieve analyse van paragraaf 4.3 toont aan dat de gehanteerde methode een effectieve manier is om in de vaste rechtspraak op het gebied van de directe belastingen verschillende lijnen te onderscheiden.

Uit de algemene eigenschappen van het netwerk van rechtspraak komt ook naar voren dat het Hof onevenredig veel aandacht besteedt aan een relatief klein deel van arresten. Hierop vervolgt het onderzoek in paragraaf 4.3 door het toepassen van meer inzichten uit de netwerkwetenschap, zulks op basis van de gedachte dat het herstellingsvermogen bij en weerstandsvermogen tegen verandering van het netwerk afhankelijk is van slechts enkele arresten. De belangrijkste arresten vervullen een beslissende rol in de algemene structuur en organisatie van het systeem van EU-recht op het gebied van de directe belastingen. Het onderzoek identificeert deze gezaghebbende arresten door middel van een link analysis algoritme. Een rangschikking van de 20 meest gezaghebbende arresten op het gebied van de directe belastingen levert voor beroepsbeoefenaren, nationale rechters en regelgevers waardevolle kennis op over de meest essentiële bronnen van het EU-recht waar het gaat om nationale wetgeving op het gebied van de directe belastingen.

Paragraaf 4.5 levert een andere waardevolle bijdrage aan de algemene doelstelling van het onderzoek. Om tot een rechtsleer van EU-recht op het gebied van de directe belastingen te komen moeten de belangrijkste rechtsregels uit de rechtspraak worden gedestilleerd. Door gebruik te maken van de netwerkstructuur en de detailgegevens van de verwijzingen naar eerdere rechtspraak kunnen deze rechtsregels worden bepaald op basis van de meest gezaghebbende arresten uit paragraaf 4.4. De meest geciteerde rechtsoverwegingen van deze arresten werden zo op hun betekenis onderzocht en de gevonden rechtsregels werden georganiseerd in een afzonderlijke bijlage bij dit boek (Annex $A$ ). Deze bijlage vormt en beschrijft daarom, tot op het niveau van belangrijke detailregels, een concept voor een rechtsleer van het EUrecht op het gebied van de directe belastingen. Dit boek is het eerste dat een objectieve en herhaalbare onderzoeksmethode geeft om de acte clair rechtsregels te bepalen die representatief zijn voor de verzameling van rechtspraak van EU-recht op het gebied van de directe belastingen als geheel. Deze herformulering van de rechtspraak in Annex $A$ draagt bij tot rechtszekerheid in dit complexe rechtsgebied. De herformulering is niet alleen relevant als wetenschappelijk resultaat of als hulpmiddel in het onderwijs, maar kan tevens direct worden gebruikt in de dagelijkse beroepspraktijk.

De essentiële rechtsregels die het onderzoek identificeert hebben inhoud gegeven aan de geschreven en ongeschreven beginselen van het EU-recht zoals deze van toepassing zijn op het gebied van de directe belastingen. Niet alleen de de algemene rechtsleer van het EU-recht en de wegen die het Hof buiten het 
directe belastingrecht bewandelde om tot oplossingen in zijn overige rechtspraak te komen ('padafhankelijkheid') hebben grote invloed gehad op de onwikkeling van de rechtsleer op het gebied van de directe belastingen. Het Hof heeft ook nieuwe, bijzondere rechtsregels gesteld op het gebied van de directe belastingen, o.a. de samenhang van het belastingstelsel en de evenwichtige verdeling van heffingsbevoegdheden.

Paragraaf 4.5 toont aan hoe algemene rechtsregels van het EU-recht zijn opgenomen in de rechtsleer op het gebied van de directe belastingen. De analyse van de ontwikkeling van dit rechtsgebied tot een functioneel subsysteem van het EU-recht in de laatste dertig jaren laat zien hoe zijn organisatie gesloten werd, maar zijn structuur open bleef om innovaties van het algemene systeem van EUrecht te kunnen opnemen. Een eigen identiteit van EU-recht op het gebied van de directe belastingen is geleidelijk ontstaan uit een padafhankelijk proces van rechterlijke besluitvorming dat gestuurd wordt door een primaire gerichtheid op precedenten; deze identiteit makt het functionele subsysteem als een samenhangend geheel betekenisvol.

Het onderzoek in Deel II van dit boek ondersteunt de stelling dat het Hof een samenhangende rechtsleer van EU-recht op het gebied van de directe belastingen probeert te ontwikkelen door een proces van rechterlijke besluitvorming op basis van de richtsnoeren voor uitleg van precedenten. Dit is in lijn met het verdragsrechtelijke mandaat van het Hof om de eenparige uitleg en toepassing van het EU-recht te waarborgen. Het onderzoek laat zien hoe inzichten uit de netwerkwetenschap gebruikt kunnen worden om de structuur en organisatie van de rechtspraak te onderzoeken.

Deel III van het boek verlegt het zwaartepunt van onderzoek. Het voorwerp van onderzoek werd beperkt tot een EU-rechtelijke norm die vermoed werd van doorslaggevende betekenis te zijn voor de structuur en organisatie van het systeem als geheel; de evenwichtige verdeling van heffingbevoegdheden tussen de lidstaten. In tegenstelling tot de brede doelstelling van het tweede deel is de kwalitatieve analyse van de rechtspraak in het derde deel veel meer gericht op de tekst van de arresten van het Hof. In Deel III volgt een diepgaande analyse van de ontwikkeling van de evenwichtige verdeling van heffingsbevoegdheden tot een brede en overheersende rechtvaardigingsgrond in het EU-recht op het gebied van de directe belastingen. Hoofdstukken 5 tot en met 9 bieden door een rationele benadering een inbedding van deze rechtvaardigingsgrond in het fundamentele rechtskader van EU-recht en een plaatsbepaling in verhouding tot andere rechtvaardigingsgronden. Dit is de tweede belangrijke bijdrage aan de wetenschap.

Hoofdstuk 5 verklaart het analytische raamwerk van het onderzoek. Het overzicht van eerder onderzoek laat zien dat een gedetailleerde begripsvorming van de evenwichtige verdeling van heffingsbevoegdheden essentieel is om tot een systematische uiteenzetting van de structuur en organisatie van het EU-recht op het gebied van de directe belastingen te kunnen komen. Het onderzoek past opnieuw een netwerkanalyse toe, maar de primaire methode van onderzoek is kwalitatief van opzet. De voorlopige bevindingen naar aanleiding van de netwerkanalyse wijzen erop dat er een conceptueel verband is tussen de 
evenwichtige verdeling van heffingsbevoegdheden en de rechtvaardigingsgrond van de noodzaak om belastingontwijking en andere vormen van misbruik van recht te bestrijden.

Hoofdstuk 6 stelt een werkhypothese op van de evenwichtige verdeling van heffingsbevoegdheden als EU-rechtelijke norm op het gebied van de directe belastingen. Met behulp van inzichten uit de computationele taalkunde maakt dit hoofdstuk een citatensamenvatting van de uitleg van deze norm. Uit deze samenvatting volgt dat het Hof de hoofdgedachte van de norm in latere rechtspraak herformuleerde als het legitieme recht van een lidstaat om belasting te heffen van activiteiten die op zijn grondgebied worden uitgeoefend. Een uitgebreide juridische beschouwing van de toepassing van deze rechtvaardigingsgrond in de rechtspraak volgde. Een bevinding naar aanleiding van deze beschouwing is dat de legitimiteit van een belastingvordering naar EUrecht beoordeeld dient te worden op grond van het fiscale territorialiteitsbeginsel. Nochtans is een belasting pas rechtmatig indien zij daadwerkelijk op een consistente en systematische wijze wordt geheven van alle belastingplichtigen die activiteiten op het grondgebied van de betrokken lidstaat ontplooien. Het onderzoek toont aan dat de evenwichtige verdeling van heffingsbevoegheden geen rechtvaardiging vormt voor belastingheffing over buitenlandse inkomsten. Deze norm verlangt echter niet van lidstaten om afstand te doen van het recht om belasting te heffen op buitenlandse inkomsten. In één zin, de evenwichtige verdeling van heffingsbevoegdheden beschermt de interne heffingsbevoegdheid van de lidstaten.

De verhouding van de evenwichtige verdeling van heffingsbevoegdheden tot de andere erkende rechtvaardigingsgronden voor beperkingen van de vrijheid van verkeer door directe belastingmaatregelen is het voorwerp van onderzoek in Hoofdstuk 7.

De eerste conclusie van dat onderzoek is dat de noodzaak om dubbele verliesverrekening te voorkomen een inherente beperking van het recht van de Unieburger op vrijheid van verkeer meebrengt, omdat dit recht niet kan worden ingeroepen om oneigenlijke belastingvoordelen te vorderen.

De tweede conclusie is dat de noodzaak om belastingontwijking en andere misbruikpraktijken te bestrijden een rechtvaardigingsgrond is die op vergelijkbare wijze voorkomt dat aan een belastingplichtige die op onjuiste gronden de bescherming van het EU-recht inroept, oneigenlijke belastingvoordelen toekomen. Een Unieburger mag niet op onjuiste wijze, door het creëren van een volstrekt kunstmatige constructie, belasting ontwijken over activiteiten die hij of zij op het grondgebied van een lidstaat ontplooit. Een volstrekt kunstmatige constructie is een rechtsfiguur die geen verband houdt met de economische realiteit en niet op grond van zakelijke (andere dan fiscale) overwegingen kan worden gerechtvaardigd. Een Unieburger mag ook niet op onjuiste wijze voordeel genieten van de dispariteiten tussen de wetgevingen van de lidstaten en zo belasting ontwijken door gebruik te maken van nationale regelingen die inherent kunstmatig zijn ('ficties'). De bescherming van het EUrecht mag worden onthouden als de voorwaarden van de vrijheid van verkeer niet daadwerkelijk zijn uitgeoefend op een wijze die verenigbaar is met het doel 
en de strekking ervan, hoewel aan de toepassingsvereisten formeel is voldaan. Als gedragingen van deze aard de evenwichtige verdeling van heffingsbevoegdheden aantasten, mogen de lidstaten tegenmaatregelen nemen om hun interne heffingsbevoegdheid te beschermen, hoewel daarmee de vrijheid van verkeer schijnbaar wordt beperkt. De toepassing van tegenmaatregelen vereist een beoordeling van geval tot geval op basis van objectieve gegevens en de mogelijkheid voor belastingplichtigen om zonder buitensporige administratieve moeite bewijs aan te dragen ter onderbouwing van hun recht op belastingvoordelen. Om deze redenen concludeert het onderzoek dat de rechtvaardigingsgrond van de noodzaak om misbruiken en fraude te voorkomen en de rechtvaardigingsgrond van de noodzaak om een evenwichtige verdeling van heffingsbevoegdheden te waarborgen niet kunnen worden onderscheiden op een hoger abstractieniveau ten aanzien van de dwingende reden in het algemene belang die zij nastreven.

De derde conclusie van het hoofdstuk is dat de samenhang van het belastingstelsel als rechstregel het beste kan worden begrepen als een methodologisch hulpmiddel om te bepalen of een nationale maatregel de daaraan ten grondslag liggende beleidsdoelstellingen, daaronder begrepen de noodzaak om een evenwichtige verdeling van heffingsbevoedgheden te waarborgen, op een consistente en systematische wijze nastreeft. Om deze reden houdt het sterk verband met het rechterlijke proportionaliteitsbeginsel.

Hoofdstuk 8 onderzocht het rechterlijke proportionaliteitsbeginsel zoals het van toepassing is met betrekking tot de evenwichtige verdeling van heffingsbevoegdheden. Het onderzoek toonde aan dat nationele regelingen die objectief noodzakelijk zijn om op consistente en systematische wijze de belastingheffing van een lidstaat met betrekking tot op zijn grondgebied ontplooide economische activiteiten te waarborgen, verenigbaar zijn met EUrecht. Het Hof zal de proportionaliteit in de enge zin van de deze regelingen niet beoordelen. De beoordeling van de proportionaliteit in de enge zin is namelijk een uitspraak over het aan de Verdragen ten grondslag liggende rechtssysteem. De identiteit van dit systeem op het gebied van de directe belastingen wordt bepaald door een onderscheid tussen het bestaan (de verdeling) en de uitoefening van de bevoegheid om belasting te heffen. Dit onderscheid houdt niet alleen een erkenning in dat ten gevolge van dispariteiten in de belastingwetgevingen tussen de lidstaten de uitoefening van het recht op vrijheid van verkeer niet fiscaal neutraal hoeft te zijn. Het houdt ook in dat de Verdragen niet zo kunnen worden uitgelegd dat zij een legitieme belastingheffing teniet kunnen doen. Dientengevolge luidt de conclusie dat een nationale regeling die de vrijheid van verkeer schijnbaar beperkt, maar door de evenwichtige verdeling van heffingsbevoegdheden wordt gerechtvaardigd, wetgeving is die volledig coherent is met het systeem van EU-recht op het gebied van de directe belastingen.

Hoofdstuk 9 beschouwt de motivering van het Hof in de zaak Marks \& Spencer (C-446/03) opnieuw. Dit hoofdstuk presenteert een voorstel tot uitstel van invordering als een alternatief voor de benadering van het Hof met betrekking tot grensoverschrijdende verliesverrekening. Dit voorstel past binnen 
de bedoeling van het Hof op dit gebied, hoewel de motivering van het Hof in het arrest Marks \& Spencer feitelijk onjuist is en daarom niet goed te doorgronden. Het voorstel erkent de evenwichtige verdeling van heffingsbevoegdheden als overheersende EU-rechtelijke norm op het gebied van de directe belastingen volledig. 



\section{References}

Albert, R., \& Barabási, A.-L. (2002). Statistical mechanics of complex networks. Reviews of Modern Physics, 74(1): 47-97.

Albert, R., Jeong, H., \& Barabási, A.-L. (1999). Internet: Diameter of the WorldWide Web. Nature, 401(6749): 130-131.

Albert, R., Jeong, H., \& Barabási, A.-L. (2000). Error and attack tolerance of complex networks. Nature, 406(6794): 378-382.

Arendonk van, H.P.A.M. (2012). Citizens and Taxation in the EU: Fifty Years after the Neumark Report. EC Tax Review, 21(3): 144-156.

Arnull, A. (1993). Owning up to fallibility: Precedent and the Court of Justice. Common Market Law Review, 30(2): 247-266.

Arnull, A. (1998). Interpretation and Precedent in English and Community Law: Evidence of Cross-Fertilisation? In M. Adenas (Ed.), English Public Law and the Common Law of Europe (pp. 101-115). London: Key Haven.

Arnull, A. (2006). The European Union and its Court of Justice (2 ed.). Oxford: OUP.

Avi-Yonah, R., Hines, J., \& Lang, M. (Eds.). (2007). Comparative Fiscal Federalism: Comparing the European Court of Justice and the US Supreme Court's tax jurisprudence. Alphen aan den Rijn: Kluwer Law International.

Backstrom, L., Boldi, P., Rosa, M., Ugander, J., \& Vigna, S. (2011). Four Degrees of Separation. arXiv: 1111.4570v3.

Bak, T. (2006). Power-Law Distributions and the Federal Judiciary. Jurimetrics, 46(2): 139-160.

Balkin, J. (1986 ). The Crystalline Structure of Legal Thought. Rutgers Law Review, 39(1): 1-110.

Balkin, J. (1991). The Promise of Legal Semiotics. Texas Law Review, 69(7): 18311852.

Banks, K. (2008). The application of the fundamental freedoms to Member State tax measures: guarding against protectionism or second-guessing national policy choices? European Law Review, 33(4): 482-506.

Barabási, A.-L. (2005). Taming complexity. Nature Physics, 1(2): 68-70.

Barabási, A.-L. (2012). The network takeover. Nature Physics, 8(1): 14-16.

Barabási, A.-L., \& Albert, R. (1999). Emergence of Scaling in Random Networks. Science, 286(5439): 509-512.

Barabási, A.-L., Albert, R., \& Jeong, H. (1999). Mean-field theory for scale-free random networks. Physica A: Statistical Mechanics and its Applications, 272(12): 173-187.

Barents, R. (2007a). Directory of EC Case law on Competition. Alphen aan den Rijn: Kluwer Law International. 
Barents, R. (2007b). Directory on EC Case Law on State Aids. Alphen aan den Rijn: Kluwer Law International.

Barents, R. (2009a). Directory of case law on the preliminary ruling procedure. Alphen aan den Rijn: Kluwer Law International.

Barents, R. (2009b). Directory of EC case law on direct taxation. Alphen aan den Rijn: Kluwer Law International.

Barnard, C. (2010). The Substantive Law of the EU (3 ed.). Oxford: OUP.

Bastian, M., Heymann, S., \& Jacomy, M. (2009). Gephi: An Open Source Software for Exploring and Manipulating Networks. Paper presented at the International AAAI Conference on Weblogs and Social Media,. from http://www.aaai.org/ocs/index.php/ICWSM/09/paper/view/154

Bellingwout, J. (2008). Amurta : a tribute to (the late) Advocate General Geelhoed. European Taxation, 48(3): 124-132.

Bengoetxea, J. (1993). The Legal Reasoning of the European Court of Justice. Oxford: Clarendon Press.

Bettendorf, L., Van Der Horst, A., De Mooij, R.A., \& Vrijburg, H. (2010). Corporate Tax Consolidation and Enhanced Cooperation in the European Union. Fiscal Studies, 31(4): 453-479.

Bianconi, G., \& Barabási, A.-L. (2001a). Bose-Einstein Condensation in Complex Networks. Physical Review Letters, 86(24): 5632-5635.

Bianconi, G., \& Barabási, A.-L. (2001b). Competition and multiscaling in evolving networks. Europhysics Letters, 54(4): 436-442.

Bird, R.M. (2002). Why Tax Corporations? Bulletin for International Taxation, 56(5): 194-203.

Blauberger, M. (2011). With Luxembourg in mind. The remaking of national policies in the face of ECJ jurisprudence. Journal of European Public Policy, 19(1): 109-126.

Blondel, V., D. , Jean-Loup, G., Renaud, L., \& Etienne, L. (2008). Fast unfolding of communities in large networks. Journal of Statistical Mechanics: Theory and Experiment, 2008(10): P10008.

Boccaletti, S., Latora, V., Moreno, Y., Chavez, M., \& Hwang, D.U. (2006). Complex networks: Structure and dynamics. Physics Reports, 424(4-5): 175-308.

Bommarito II, M.J., Katz, D., \& Zelner, J. (2010). On the Stability of Community Detection Algorithms on Longitudinal Citation Data. Procedia Social and Behavioral Sciences, 4: 26-37.

Bommarito II, M.J., \& Katz, D.M. (2010). A mathematical approach to the study of the United States Code. Physica A: Statistical Mechanics and its Applications, 389(19): 4195-4200.

Bommarito II, M.J., Katz, D.M., \& Isaacs-See, J. (2011). An Empirical Survey of the Population of U.S. Tax Court Written Decisions. Virginia Tax Review, 30(3): 523-557.

Boulet, R., Mazzega, P., \& Bourcier, D. (2011). A network approach to the French system of legal codes - part I: analysis of a dense network. Artificial Intelligence and Law, 19(4): 333-355. 
Bourcier, D., \& Clergue, G. (1999). From a rule-based conception to dynamic patterns. Analyzing the self-organization of legal systems. Artificial Intelligence and Law, 7(2): 211-225.

Brokelind, C. (2008). The acte clair doctrine arising from the ECJ's direct tax case law from a Swedish perspective: use or misuse? In A.P. Dourado \& R. da Palma Borges (Eds.), The Acte Clair in EC Direct Tax Law (pp. 453-488). Amsterdam: IBFD.

Brokelind, C. (Ed.). (2006). Towards a homogeneous EC direct tax law. Amsterdam: IBFD.

Brown, L.N., \& Kennedy, T. (2000). The Court of Justice of the European Communities. London: Sweet \& Maxwell.

Burley, A.-M., \& Mattli, W. (1993). Europe Before the Court: A Political Theory of Legal Integration. International Organization, 47(1): 41-76.

Callaway, D.S., Newman, M.E.J., Strogatz, S.H., \& Watts, D.J. (2000). Network Robustness and Fragility: Percolation on Random Graphs. Physical Review Letters, 85(25): 5468-5471.

Caron, P. (2006). The Long Tail of Legal Scholarship. Yale Law Journal Pocket Part, 116: 38-45.

Carrese, P.O. (2003). The Cloaking of Power. Chicago: The University of Chicago Press.

Carrubba, C.J., Gabel, M., \& Hankla, C. (2008). Judicial Behavior under Political Constraints: Evidence from the European Court of Justice. American Political Science Review, 102(4): 435-452.

Cerioni, L. (2007). EU corporate law and EU company tax law. Cheltenham: Edward Elgar.

Cerioni, L. (2009). Double Taxation and the Internal Market: Reflections on the ECJ's Decisions in Block and Damseaux and the Potential Implications. Bulletin for International Taxation, 63(11): 543-556.

Cerioni, L. (2010). The "Abuse of Rights" in EU Company Law and EU Tax Law: A Re-reading of the ECJ Case Law and the Quest for a Unitary Notion. European Business Law Review, 21(6): 783-814.

Chalmers, D. (2001). The Positioning of EU Judicial Politics within the United Kingdom. In K.H. Goetz \& S. Hix (Eds.), Europeanised Politics. European Integration and National Political Systems (pp. 169-211). London: Frank Cass Publishers.

Claes, M. (2006). The national courts' mandate in the European constitution. Oxford: Hart Publishing.

Clauset, A., Newman, M.E.J., \& Moore, C. (2004). Finding community structure in very large networks. Physical Review E, 70(6): 066111.

Clauset, A., Shalizi, C.R., \& Newman, M.E.J. (2009). Power-Law Distributions in Empirical Data. SIAM Review, 51(4): 661-703.

Cohen, R., \& Havlin, S. (2003). Scale-Free Networks Are Ultrasmall. Physical Review Letters, 90(5): 058701.

Conant, L. (2007). Review Article: The Politics of Legal Integration. JCMS: Journal of Common Market Studies, 45(s1): 45-66. 
Cordewener, A. (2002). Europä̈sche Grundfreiheiten und nationales Steuerrecht. Cologne: Otto Schmidt.

Cordewener, A. (2009). Free Movement of Capital between EU Member States and Third Countries: How Far Has the Door Been Closed? EC Tax Review, 18(6): 260-263.

Cordewener, A., Kofler, G., \& Van Thiel, S. (2009). The clash between European freedoms and national direct tax law: Public interest defences available to the Member States. Common Market Law Review, 46(6): 1951-2000.

Cordewener, A., Kofler, G.W., \& Schindler, C.P. (2007a). Free Movement of Capital and Third Countries: Exploring the Outer Boundaries with Lasertec, $A$ and $B$ and Holböck. European Taxation, 47(8/9): 371-376.

Cordewener, A., Kofler, G.W., \& Schindler, C.P. (2007b). Free Movement of Capital, Third Country Relationships and National Tax Law: An Emerging Issue before the ECJ. European Taxation, 47(3): 107-119.

Cordewener, A., \& Reimer, E. (2006a). The Future of Most-Favoured-Nation Treatment in EC Tax Law - Did the ECJ Pull the Emergency Brake without Real Need? - Part 1. European Taxation, 46(6): 239-249.

Cordewener, A., \& Reimer, E. (2006b). The Future of Most-Favoured-Nation Treatment in EC Tax Law - Did the ECJ Pull the Emergency Brake without Real Need? - Part 2. European Taxation, 46(7): 291-306.

Court of Justice of the European Union (2012). Annual Report 2011 Available from www.curia.eu

Craig, P., \& De Búrca, G. (2008). EU Law: Text, Cases, and Materials (4 ed.). Oxford: OUP.

Cross, F.B., Smith, T.A., \& Tomarchio, A. (2008). The Reagan Revolution in the Network of Law. Emory Law Journal, 57(5): 1227-1258.

Cross, F.B., Spriggs, J.F., Johnson, T.R., \& Wahlbeck, P. (2010). Citations in the US Supreme Court: An empirical study of their use and significance. University of Illinois Law Review, 2010(2): 489-575.

Davies, G. (2010). Understanding Market Access: Exploring the Economic Rationality of Different Conceptions of Free Movement Law. German Law Journal, 11(7/8): 671-704.

de la Feria, R. (2008). Prohibition of abuse of (Community) law: the creation of a new general principle of EC law through tax. Common Market Law Review, 45(2): 395-441.

de Sousa de Câmara, F. (2008). The meaning and the scope of teh acte clair doctrnie concerning direct taxation: the Portugese experience and the establishment of boundaries. In A.P. Dourado \& R. da Palma Borges (Eds.), The Acte Clair in EC Direct Tax Law (pp. 371-416). Amsterdam: IBFD.

Deakin, S. (2002). Evolution for Our Time: A Theory of Legal Memetics. Current Legal Problems, 55(1): 1-42.

Den Boer, S. (2010). Freedom of Establishment versus Free Movement of Capital: Ongoing Confusion at the ECJ and in National Courts? European Taxation, 50(6): 250-258.

Denys, L.A. (2007). The ECJ Case Law on Cross-Border Dividends Revisited. European Taxation, 47(5): 221-238. 
Dibadj, R. (2008). Networks of fairness review in corporate law. San Diego Law Review, 45(1): 1-32.

Dibadj, R. (2009). Networks of heightened scrutiny in corporate law. San Diego Law Review, 46(1): 1-26.

Dodds, P.S., Muhamad, R., \& Watts, D.J. (2003). An Experimental Study of Search in Global Social Networks. Science, 301(5634): 827-829.

Dorogovtsev, S.N., \& Mendes, J.F.F. (2002). Evolution of networks. Advances in Physics, 51(4): 1079-1187.

Dorogovtsev, S.N., Mendes, J.F.F., \& Samukhin, A.N. (2000). WWW and Internet models from 1955 till our days and the "popularity is attractive" principle. arXiv:cond-mat/0009090.

Douma, S. (2006). The three Ds of direct tax jurisdiction: Disparity, discrimination and double taxation. European Taxation, 46(11): 522-533.

Douma, S. (2007). Het evenredigheidsbeginsel stricto sensu als belangenafweging tussen nationale fiscale soevereiniteit en vrij verkeer. Weekblad voor Fiscaal recht, 2007(6709): 247-253.

Douma, S. (2012a). Non-discriminatory Tax Obstacles. EC Tax Review, 21(2): 6783.

Douma, S. (2012b). Optimization of Tax Sovereignty and Free Movement. Amsterdam: IBFD.

Dourado, A.P. (2007). Portugal. In C. Brokelind (Ed.), Towards a Homogeneous EC Direct Tax Law (pp. 341-356). Amsterdam: IBFD.

Dourado, A.P., \& da Palma Borges, R. (Eds.). (2008). The acte clair in EC direct tax law. Amsterdam: IBFD.

Dubut, T. (2012). The Court of Justice and the OECD Model Tax Conventions or the Uncertainties of the Distinction between Hard Law, Soft Law, and No Law in the European Case Law. INTERTAX, 40(1): 2-12.

ECOFIN Council (1997). Council Conclusions of the ECOFIN Council Meeting on 1 December 1997 concerning taxation policy (98/C 2/01), O.J. C 2, 6/1/1997, p. 1-6.

Eden, S. (2010). The obstacles faced by the European Court of Justice in removing the "obstacles" faced by the taxpayer: the difficult case of double taxation. British Tax Review, 2010(6): 610-628.

Elkiss, A., Shen, S., Fader, A., Erkan, G., States, D., \& Radev, D. (2008). Blind men and elephants: What do citation summaries tell us about a research article? Journal of the American Society for Information Science and Technology, 59(1): 51-62.

Engelen, F. (2012). State Aid and Restrictions on Free Movement: Two Sides of the Same Coin? European Taxation, 52(5): 204-209.

Englisch, J. (2007). Grundfeiheitsbeschränkungen zwecks Wahrung der Aufteilung der Besteuerungsbefugnis. Steuer \& Wirtschaft International, 17(9): 399-408.

Englisch, J. (2010). Taxation of Cross-Border Dividends and EC Fundamental Freedoms. INTERTAX, 38(4): 197-221.

Erdős, P., \& Rényi, A. (1959). On Random Graphs I. Publicationes Mathematicae, 6: 290-297. 
Erdős, P., \& Rényi, A. (1960). The Evolution of Random Graphs. Magyar Tud. Akad. Mat. Kutató Int. Közl., 5: 17-61.

European Commission (1993). Commission Recommendation of 21 December 1993 on the taxation of certain items of income received by non-residents in a Member State other than that in which they are resident (94/79/EC), O.J. L 39, 10/2/1994, p. 22-28.

European Commission (1994). Commission Recommendation of 25 May 1994 concerning the Taxation of Small and Medium-sized Enterprises (Text with EEA relevance) (94/390/EC), O.J. L 177, 9/7/1994, p. 1-19.

European Commission (2001a). Company taxation in the Internal Market, SEC(2001)1681.

European Commission (2001b). The elimination of tax obstacles to the cross-border provision of occupational pensions, $\operatorname{COM}(2001) 214$.

European Commission (2001c). Tax policy in the European Union - Priorities for the years ahead, $\operatorname{COM}(2001) 260$.

European Commission (2003a). Dividend taxation of individuals in the Internal Market, $\operatorname{COM}(2003) 810$.

European Commission (2003b). An Internal Market without company tax obstacles: achievements, ongoing initiatives and remaining challenges, COM(2003) 726.

European Commission (2006a). Co-ordinating Member States' direct tax systems in the Internal Market, $\operatorname{COM}(2006) 823$.

European Commission (2006b). Exit taxation and the need for co-ordination of Member States' tax policies, $\operatorname{COM}(2006) 825$.

European Commission (2006c). Tax Treatment of Losses in Cross-Border Situations, COM(2006) 824.

European Commission (2007). The application of anti-abuse measures in the area of direct taxation - within the EU and in relation to third countries, $\operatorname{COM}(2007)$ 785.

European Commission (2009). Corporate taxation: Commission refers the United Kingdom to the European Court of Justice over improper implementation of an ECJ ruling on cross-border loss relief, IP/09/1461.

European Commission (2011a). Internal Market Scoreboard no. 23. Luxembourg: European Union.

European Commission (2011b). Proposal for a Council Directive on a Common Consolidated Corporate Tax Base (CCCTB), COM(2011) 121.

European Commission (2012a). CJEU Cases in the Area of, or in Particular Interest for Direct Taxation. Retrieved 27 January 2012: $\mathrm{http} / /$ ec.europa.eu/taxation_customs/common/infringements/case_law/index_en. htm

European Commission (2012b). Taxation: Commission refers UK to the European Court of Justice over cross-border loss relief, IP/12/1017.

European Parliament (2008). The impact of the rulings of the European Court of Justice in the area of direct taxation (No. IP/A/ECON/ST/2007-27). Brussels: European Parliament 
European Parliament (2011). The impact of the rulings of the European Court of Justice in the area of direct taxation 2010 (No. IP/A/ECON/ST/2010-18). Brussels: European Parliament.

Evans, T. (2004). Complex networks. Contemporary Physics, 45(6): 455-474.

Faloutsos, M., Faloutsos, P., \& Faloutsos, C. (1999). On power-law relationships of the Internet topology. SIGCOMM Comput. Commun. Rev., 29(4): 251-262.

Farmer, P. (2003). The Court's case law on taxation: a castle built on shifting sands? EC Tax Review, 12(2): 75-81.

Farmer, P. (2007). Tax law and policy in an adolescent European Union. Bulletin for International Taxation, 61(2): 42-45.

Fase, A.A. (2008). Het Rangordevraagstuk in Derdelandverhoudingen. Weekblad voor Fiscaal recht, 2008(6770): 687.

Fennelly, N. (1996). Legal Interpretation at the European Court of Justice. Fordham International Law Journal, 20(3): 656-679.

Fligstein, N., \& Sweet, A.S. (2002). Constructing Polities and Markets: An Institutionalist Account of European Integration. American journal of sociology, 107(5): 1206-1243.

Flynn, L. (2002). Coming of Age: the Free Movement of Capital Case Law 19932002. Common Market Law Review, 39(4): 773-805.

Fon, V., Parisi, F., \& Depoorter, B. (2005). Litigation, Judicial Path-Dependence, and Legal Change. European Journal of Law and Economics, 20(1): 43-56.

Fontana, R. (2007). Direct Investments and Third Countries: Things are Finally Moving ... in the Wrong Direction. European Taxation, 47(10): 431-436.

Fortunato, S. (2010). Community detection in graphs. Physics Reports, 486(3-5): 75-174.

Fowler, J.H., \& Jeon, S. (2008). The authority of Supreme Court precedent. Social Networks, 30(1): 16-30.

Fowler, J.H., Johnson, T.R., Spriggs, J.F., Jeon, S., \& Wahlbeck, P.J. (2007). Network analysis and the law: Measuring the legal importance of precedents at the U.S. Supreme Court. Political Analysis, 15(3): 324-346.

Fried, M.S. (1999). The Evolution of Legal Concepts: The Memetic Perspective. Jurimetrics, 39(3): 291-316.

Gammie, M. (2010). Non-Discrimination and the Taxation of Cross-Border Dividends. World Tax Journal, 2(2): 162-174.

Garciá Prats, F.A. (2008). The acte clair doctrine and the effective judicial protection of EC law rights in direct tax matters: the Spanish case as an example. In A.P. Dourado \& R. da Palma Borges (Eds.), The Acte Clair in EC Direct Tax Law (pp. 417-451). Amsterdam: IBFD.

Garrett, G. (1992). International cooperation and institutional choice: the European Community's internal market. International Organization, 46(2): 533-560.

Garrett, G. (1995). The Politics of Legal Integration in the European Union. International Organization, 49(1): 171-181.

Garrett, G., Kelemen, R.D., \& Schulz, H. (1998). The European Court of Justice, national governments, and legal integration in the European Union. International Organization, 52(1): 149-176. 
Geist, A. (2009). Using citation analysis techniques for computer-assisted legal research in continental jurisdictions. Unpublished Graduate thesis, University of Edinburgh, Edinburgh.

Gelter, M., \& Siems, M.M. (2012). Networks, Dialogue or One-Way Traffic? An Empirical Analysis of Cross-Citations Between Ten of Europe's Highest Courts. Utrecht Law Review, 8(2): 88-99.

Gelter, M., \& Siems, M.M. (2013). Language, Legal Origins, and Culture before the Courts: Cross-Citations between Supreme Courts in Europe. Supreme Court Economic Review, 21: forthcoming.

Genschel, P., \& Jachtenfuchs, M. (2011). How the European Union constrains the state: Multilevel governance of taxation. European Journal of Political Research, 50(3): 293-314.

Genschel, P., Kemmerling, A., \& Seils, E. (2011). Accelerating Downhill: How the EU Shapes Corporate Tax Competition in the Single Market. JCMS: Journal of Common Market Studies, 49(3): 585-606.

Genschel, P., \& Schwarz, P. (2011). Tax competition: a literature review. SocioEconomic Review, 9(2): 339-370.

Gerhardt, M.J. (2005). The Limited Path Dependency of Precedent. University of Pensylvania Journal of Constitutional Law, 7(4): 903-1000.

Ghosh, J. (2007). Principles of the Internal Market and Direct Taxation. Oxford: Key Haven.

Girvan, M., \& Newman, M.E.J. (2002). Community structure in social and biological networks. Proceedings of the National Academy of Sciences, 99(12): 7821-7826.

Goodenough, O.R. (2005). Cultural Replication Theory in Law: Proximate Mechanisms Make a Difference. Vermont Law Review, 30(4): 989-1005.

Graaf de, A.C.G.A.C. (2004). De invloed van het EG-recht op het internationaal belastingsrecht: beleids- en marktintegratie. Deventer: Kluwer.

Graetz, M.J., \& Warren, A.C. (2006). Income Tax Discrimination and the Political and Economic Integration of Europe. Yale Law Journal, 115(6): 1186-1255.

Graetz, M.J., \& Warren, A.C. (2007). Dividend taxation in Europe: When the ECJ makes tax policy. Common Market Law Review, 44(6): 1577-1623.

Graetz, M.J., \& Warren, A.C. (2012). Income Tax Discrimination: Still stuck in the Labyrinth of Impossibility. Yale Law Journal, 121(5): 1118-1167.

Granger, M.-P. (2004). When governments go to Luxembourg...The influence of governments on the Court of Justice. European Law Review, 29(1): 3-31.

Granger, M.-P. (2006). States as succesful litigants before the European Court of Justice: Lessons from 'Repeat Players' of European litigation. Croatian Yearbook of European Law and Policy, 2: 27-49.

Granovetter, M.S. (1973). The Strength of Weak Ties. American journal of sociology, 78(6): 1360-1380.

Gribnau, H. (2007). Improving the Legitimacy of Soft Law in EU Tax Law. INTERTAX, 35(1): 30-44.

Gribnau, H. (2008). Soft Law and Taxation: EU and International Aspects. Legisprudence, 2(2): 67-117.

Guare, J. (1990). Six Degrees of Separation: A Play. New York: Random House. 
Harris, P., \& Oliver, J.D.B. (2010). International Commercial Tax. Cambridge: CUP.

Haslehner, W.C. (2008). Das Konkurrenzverhältnis der Europäischen Grundfreiheiten in der Rechtsprechung des EuGH zu den direkten Steuern. Internationales Steuerrecht, 2008(16): 565-575.

Haslehner, W.C. (2010). Cross-Border Loss Relief for Permanent Establishments under EC Law. Bulletin for International Taxation, 64(1): 33-44.

Hathaway, O.A. (2001). Path dependence in the law: The course and pattern of legal change in a common law system. Iowa Law Review, 86(2): 601-635.

Heise, M. (2002). Past, Present, and Future of Empirical Legal Scholarship: Judicial Decision Making and the New Empiricism. University of Illinois Law Review, 2002(4): 819-850.

Hellerstein, W., Kofler, G., \& Mason, R. (2009). Constitutional Restraints on Corporate Tax Integration in the EU and the U.S. Tax Law Review, 62(1): 1-66.

Hemels, S.J.C. (2009). References to the Mutual Assistance Directive in the Case Law of the ECJ: A Systematic Approach. European Taxation, 49(12): 583-591.

Hemels, S.J.C., \& Rompen, J.W. (2010). Vestiging of Kapitaalverkeer: Welke Vrijheid Heeft Prioriteit? Weekblad voor Fiscaal recht, 2010(6871): 1058.

Hemels, S.J.C., Rompen, J.W., Smet, P., De Waele, I., Adfeldt, S., Breuninger, G., et al. (2010). Freedom of Establishment or Free Movement of Capital: Is There an Order of Priority? Conflicting Visions of National Courts and the ECJ. EC Tax Review, 19(1): 19-31.

Hikaka, G., \& Prebble, J. (2010). Autopoiesis and general anti-avoidance rules. Critical Perspectives on Accounting, 21(7): 545-559.

Hindelang, S. (2010). Gestufte Freiheitsverbürgung? - Art. 63 Abs. 1 AEUV (ExArt. 56 Abs. 1 EG) im Drittstaatenkontext. Internationales Steuerrecht, 2010(12): 443-448.

Hinnekens, L., \& Schelpe, D. (1992). Bachmann v. Belgium (C-204/90) and Commission v. Belgium, 28 January 1992 (C-300/90). EC Tax Review, 1(1): 5862.

Hondius, E. (2007a). General Report. In E. Hondius (Ed.), Precedent and the law. Reports to the XVIIth Congress International Academy of Comparative Law, Utrecht 16-22 July 2006 (pp. 1-24). Brussels: Bruylant.

Hondius, E. (Ed.). (2007b). Precedent and the law. Reports to the XVIIth Congress Internaltional Academy of Comparative Law, Utrecht 16-22 July 2006. Brussels: Bruylant.

International Fiscal Association (2008). New tendencies in the tax treatment of cross-border interest of corporations, Cahiers de droit fiscal international vol. 93b (e-book) Available from IBFD Tax Research Platform

Isenbaert, M. (2010). EC Law and the Sovereignty of the Member States in Direct Taxation. Amsterdam: IBFD.

Isenbaert, M., \& Valjemark, C. (2006). M\&S judgment: The ECJ caught between a rock and a hard place. EC Tax Review, 15(1): 10-17.

Itzcovich, G. (2009). Interpretation of Community Law. German Law Journal, 10(5): 537-560. 
Jacobs, F.G. (2007). Citizenship of the European Union-A Legal Analysis. European Law Journal, 13(5): 591-610.

Jans, J.H. (2000). Proportionality Revisited. Legal Issues of Economic Integration, 27(3): 239-265.

Jones, J.T. (2009). Dynamical Jurisprudence: Law as a Complex System. Georgia State University Law Review, 24(4): 873-889.

Kapteyn, P.J.G., McDonnell, A.M., Mortelmans, K.J.M., \& Timmermans, C.W.A. (Eds.). (2008). The Law of the European Union and the European Communities (4 ed.). Alphen aan den Rijn: Kluwer Law International.

Karimeri, R. (2011). A Critical Review of the Definition of Tax Avoidance in the Case Law of the European Court of Justice. INTERTAX, 39(6/7): 296-316.

Katz, D.M., Bommarito, M.J., II, Seaman, J., Candeub, A., \& Agichtein, E. (2011). Legal N-Grams? A Simple Approach to Track the Evolution of Legal Language. Paper presented at the JURIX 2011: The Twenty-Fourth Annual Conference. from http://ssrn.com/paper=1971953

Katz, D.M., Gubler, J.R., Zelner, J., Bommarito II, M.J., Provins, E.A., \& M., I.E. (2011). Reproduction of Hierarchy? A Social Network Analysis of the American Law Professoriate. Journal of Legal Education, 61(1): 1-28.

Katz, D.M., \& Stafford, D.K. (2010). Hustle and Flow: A Social Network Analysis of the American Federal Judiciary. Ohio State Law Journal, 71(3): 457-509.

Katz, D.M., Stafford, D.K., \& Provins, E. (2008). Social Architecture, Judicial Peer Effects and the "Evolution" of the Law: Toward a Positive Theory of Judicial Social Structure. Georgia State University Law Review, 24(4): 975-999.

Kavelaars, P. (2008). Grensoverschrijdende renteaftrek. NTFR Beschouwingen, 2008(12): 55.

Kelemen, R.D. (2012). The political foundations of judicial independence in the European Union. Journal of European Public Policy, 19(1): 43-58.

Kemmeren, E.C.C.M. (2008). ECJ should not unbundle integrated tax systems! EC Tax Review, 17(1): 4-11.

Kemmeren, E.C.C.M. (2009). Renneberg Endangers the Double Tax Convention System or Can a Second Round Bring Recovery? EC Tax Review, 18(1): 4-15.

Kemmeren, E.C.C.M. (2012). Double Tax Conventions on Income and Capital and the EU: Past, Present and Future. EC Tax Review, 21(3): 157-177.

Kemmerling, A. (2010). Does Europeanization lead to policy convergence? The role of the Single Market in shaping national tax policies. Journal of European Public Policy, 17(7): 1058-1073.

Kiekebeld, B.J. (2009a). Anti-Abuse in the Field of Taxation: Is There One Overall Concept? EC Tax Review, 18(4): 144-145.

Kiekebeld, B.J. (2009b). Kapitaalverkeer versus Vestigingsverkeer. NTFR Beschouwingen, 2009(12): 47.

Kingston, S. (2007). A Light in the Darkness: Recent Developmemts in the ECJ's Direct Tax Jurisprudence. Common Market Law Review, 44(5): 1321-1359.

Kleinberg, J.M. (1998). Authorative sources in a hyperlink environment. Paper presented at the Proceedings of ACM-SIAM Symposium on Discrete Algorithms.

Kleinberg, J.M. (2000). Navigation in a small world. Nature, 406(6798): 845-845. 
Knoke, D., \& Yang, S. (2008). Social network analysis. Los Angeles: Sage Publications.

Kofler, G. (2005). "Dancing with Mr D": The ECJ's Denial of Most-FavouredNation Treatment in the "D" case. European Taxation, 45(12): 530-540.

Kofler, G. (2007a). Austria. In C. Brokelind (Ed.), Towards a Homogeneous EC Direct Tax Law (pp. 59-100). Amsterdam: IBFD.

Kofler, G. (2007b). Doppelbesteuerungsabkommen und Europäisches Gemeinschaftsrecht. Vienna: Linde Verlag.

Kofler, G. (2008). Acte clair, Community precedent and direct taxation in the Austrian judicial system. In A.P. Dourado \& R. da Palma Borges (Eds.), The Acte Clair in EC Direct Tax Law (pp. 173-222). Amsterdam: IBFD.

Kofler, G. (2011). Tax Treaty "Neutralization" of Source State Discrimination under the EU Fundamental Freedoms? Bulletin for International Taxation, 65(12): 684690.

Kofler, G., \& Mason, R. (2008). Double taxation: a European switch in time? Columbia Journal of European Law, 14(1): 63-98.

Köhler, S., \& Tippelhofer, M. (2007). Kapitalverkehrsfreiheit auch in Drittstaatenfällen? Internationales Steuerrecht, 2007(18): 645-649.

Komárek, J. (2005). Federal Elements in the Community Judicial System - Building Coherence in the Community Legal Order. Common Market Law Review, 42(1): 9-34.

Komárek, J. (2010). Precedent in European Union Law: Reasoning with Previous Decisions of the Court of Justice. Unpublished D.Phil Thesis, Oxford, Oxfordshire.

Koopmans, T. (1982). Stare decisis in European law. In D. O'Keeffe \& H.G. Schermers (Eds.), Essays in European law and integration (pp. 11-27). Leiden: Kluwer.

Koopmans, T. (2003). Methods of Interpretation. In O. Wiklund (Ed.), Judicial Discretion in European Perspective (pp. 75-83). Stockhom: Kluwer Law International.

Lancichinetti, A., \& Fortunato, S. (2009). Community detection algorithms: A comparative analysis. Physical Review E, 80(5): 056117.

Landes, W.M., \& Posner, R.A. (1976). Legal Precedent: A Theoretical and Empirical Analysis. Journal of Law and Economics, 19(2): 249-307.

Lang, J., \& Englisch, J. (2006). A European Legal Tax Order Based on Ability to Pay. In A. Amatucci (Ed.), International Tax Law (pp. 251-335). Alphen aan den Rijn: Kluwer Law International.

Lang, M. (2006a). Direct taxation: Is the ECJ heading in a new direction? European Taxation, 46(9): 421-430.

Lang, M. (2006b). The Marks \& Spencer case - The open issues following the ECJ's final word. European Taxation, 46(2): 54-67.

Lang, M. (2008). ECJ case law on cross-border dividend taxation - recent developments. EC Tax Review, 17(2): 67-77.

Lang, M. (2009). Recent case law of the ECJ in direct taxation: Trends, tensions and contradictions. EC Tax Review, 18(3): 98-113. 
Lang, M. (2012). The Legal and Political Context of ECJ Case Law on Mutual Assistance. European Taxation, 52(5): 199-202.

Lang, M., \& Heidenbauer, S. (2008). Wholly Artificial Arrangements. In L. Hinnekens \& P. Hinnekens (Eds.), A Vision of Taxes Within and Outside European Borders (pp. 597-615). Alphen aan den Rijn: Kluwer Law International.

Lazer, D., Pentland, A., Adamic, L., Aral, S., Barabási, A.-L., Brewer, D., et al. (2009). Computational Social Science. Science, 323(5915): 721-723.

Lehner, M.M. (2000). The Influence of EU Law on tax Treaties from a German Perspective. Bulletin for International Taxation, 54(8): 461-470.

Leicht, E.A., Clarkson, G., Shedden, K., \& Newman, M.E.J. (2007). Large-scale structure of time evolving citation networks. Eur. Phys. J. B, 59(1): 75-83.

Lenaerts, A. (2010). The General Principle of the Prohibition of Abuse of Rights:A Critical Position on Its Role in a Codified European Contract Law. European Review of Private Law, 18(6): 1121-1154.

Leskovec, J., Kleinberg, J., \& Faloutsos, C. (2005). Graphs over time: densification laws, shrinking diameters and possible explanations. Paper presented at the Proceedings of the eleventh ACM SIGKDD international conference on Knowledge discovery in data mining, Chicago, Illinois, USA.

Liberatore, F. (2010). EU Report. In International Fiscal Association (Eds.), Death as a taxable event and its international ramifications (e-book), Cahiers de droit fiscal international vol. 95b (e-book) Available from IBFD Tax Research Platform

Lindquist, S.A., \& Cross, F.B. (2005). Empirically testing Dworkin's chain novel theory: Studying the path dependence of law. New York University Law Review, 80(4): 1156-1206.

Lloyd, A.L., \& May, R.M. (2001). How Viruses Spread Among Computers and People. Science, 292(5520): 1316-1317.

Luhmann, N. (1989). Law as a Social System. Northwestern University Law Review, 83(1/2): 136-150.

Luja, R.H.C. (2003). Assessment and Recovery of Tax Incentives in the EC and the WTO: A View on State Aids, Trade Subsidies and Direct Taxation. Antwerpen: Intersentia.

Luja, R.H.C. (2012). (Re)shaping Fiscal State Aid: Selected Recent Cases and Their Impact. INTERTAX, 40(2): 120-131.

Lupu, Y., \& Voeten, E. (2012). Precedent in International Courts: A Network Analysis of Case Citations by the European Court of Human Rights. British Journal of Political Science, 42(2): 413-439.

Mackor, A.R. (2012). Legal Doctrine As a Non-Normative Discipline. Recht en Methode in Onderzoek en Onderwijs, 2(1): 22-45.

Maduro, M.P. (1998). We, the Court: The European Court of Justice and the European Economic Constitution. Oxford: Hart Publishing.

Maduro, M.P. (2007). Interpreting European Law: Judicial Adjucation in a Context of Constitutional Pluralism. European Journal of Legal Studies, 1(2). Retrieved from http://www.ejls.eu/2/25UK.pdf 
Maduro, M.P. (2008). Preface. In A.P. Dourado \& R. da Palma Borges (Eds.), The Acte Clair in EC Direct Tax Law (pp. 1-4). Amsterdam: IBFD.

Malgram, S. (2011). Towards a theory of jurisprudential relevance ranking. Usin link analysis on EU case law. Unpublished Graduate thesis, Stockholm University, Stockholm.

Marres, O. (2011). The Principle of Territoriality and Cross-Border Loss Compensation. INTERTAX, 39(3): 112-125.

Martha, R.S.J. (1989). The Jurisdiction to Tax in International Law: Theory and Practice of Legislative Fiscal Jurisdiction. Deventer: Kluwer.

Martin Jiménez, A.J. (1999). Towards Corporate Tax Harmonization in the European Community. An Institutional and Procedural Analysis. Dordrecht: Kluwer Law International.

Mason, R. (2007). Flunking the ECJ's Tax Discrimination Test. Columbia Journal of Transnational Law, 46(3): 72-132.

Mason, R. (2008). Made in America for European Tax: The Internal Consistency Test. Boston College Law Review, 49(5): 1277-1326.

Mason, R., \& Knoll, M.S. (2012). What is Tax Discrimination? Yale Law Journal, 121(5): 1014-1116.

Masui, Y. (2004). General Report. In International Fiscal Association (Eds.), Group taxation, Cahiers de droit fiscal international vol. 93b (e-book) Available from IBFD Tax Research Platform

Mathisen, G. (2010). Consistency and Coherence as Conditions for Justification of Member State Measures Restricting Free Movement. Common Market Law Review, 47(4): 1021-1048.

Matsos, G. (2007). Greece. In C. Brokelind (Ed.), Towards a Homogeneous EC Direct Tax Law (pp. 357-380). Amsterdam: IBFD.

Mattli, W., \& Slaughter, A.-M. (1995). Law and Politics in the European Union: A Reply to Garrett. International Organization, 49(1): 183-190.

Mattli, W., \& Slaughter, A.-M. (1998). Revisiting the European Court of Justice. International Organization, 52(1): 177-209.

Meussen, G. (2008). Cross-border loss compensation and permanent establishments: Lidl Belgium and Deutsche Shell. European Taxation, 48(5): 233-236.

Meussen, G.T.K. (2009a). The ECJ's Judgment in Krankenheim - The Last Piece in the Cross-Border Loss Relief Puzzle? European Taxation, 49(7): 361-363.

Meussen, G.T.K. (2009b). Renneberg : ECJ unjustifiably expands Schumacker doctrine to losses from financing of personal dwelling. European Taxation, 19(4): 185-188.

Micheau, C. (2012). Fundamental Freedoms and State Aid Rules under EU Law: The Example of Taxation. European Taxation, 52(5): 210-214.

Miller, J.H., \& Page, S.E. (2007). Complex Adaptive Systems. Princeton: Princeton University Press.

Mingers, J. (2002). Can social systems be autopoietic? Assessing Luhmann's social theory. The Sociological Review, 50(2): 278-299.

Mirshahvalad, A., Lindholm, J., Derlen, M., \& Rosvall, M. (2012). Significant Communities in Large Sparse Networks. PLoS ONE, 7(3): e33721.

Mitchell, M. (2009). Complexity: A Guided Tour. Oxford: OUP. 
Monsenego, J. (2012). Taxation of Foreign Business Income within the European Internal Market. Amsterdam: IBFD.

Moody, J., \& White, D.R. (2003). Structural Cohesion and Embeddedness: A Hierarchical Concept of Social Groups. American Sociological Review, 68(1): 103-127.

Murphy, L., \& Nagel, T. (2002). The myth of ownership. Oxford: OUP.

Navez, E.-J. (2012). The Influence of EU Law on Inheritance Taxation: Is the Intensification of Negative Integration Enough to Eliminate Obstacles Preventing EU Citizens from Crossing Borders within the Single Market? EC Tax Review, 21(2): 84-97.

Newman, M. (2008). The physics of networks. Physics Today, 61(11): 33-38.

Newman, M.E.J. (2003). The Structure and Function of Complex Networks. SIAM Review, 45(2): 167-256.

Newman, M.E.J. (2004). Fast algorithm for detecting community structure in networks. Physical Review E, 69(6): 066133.

Newman, M.E.J. (2006). Modularity and community structure in networks. Proceedings of the National Academy of Sciences, 103(23): 8577-8582.

Newman, M.E.J. (2011). Communities, modules and large-scale structure in networks. Nature Physics, 8: 25-31.

Newman, M.E.J., \& Girvan, M. (2004). Finding and evaluating community structure in networks. Physical Review E, 69(2): 026113.

Nijkeuter, E. (2006). Samenloop van Art. 43 EG en Art. 56 EG. Weekblad voor Fiscaal recht, 2006(6661): 249.

Nijkeuter, E. (2011). Exchange of information and the free movement of capital between Member States and third countries. EC Tax Review, 20(5): 232-241.

Noe, S. (2011). Directory of EU case law on merger control. 'The Merger Brick'. Alphen aan den Rijn: Kluwer.

O'Brien, M. (2010). Taxation and the Third Country Dimension of Free Movement of Capital in EU Law: the ECJ's Rulings and Unresolved Issues. British Tax Review, 2010(6): 628-666.

O'Shea, T. (2008). Freedom of establishment tax jurisprudence: Avoir Fiscal revisited. EC Tax Review, 17(6): 259-275.

OECD (2011). Revenue Statistics 1965-2010: 2011 Edition. Paris: OECD Publishing.

Panayi, C.H.J.I. (2004). State Aid and Tax: the Third Way? INTERTAX, 32(6/7): 283-306.

Panayi, C.H.J.I. (2007). Double taxation, tax treaties, treaty-shopping and the European Community. Dordrecht: Kluwer Law International.

Pastor-Satorras, R., \& Vespignani, A. (2001). Epidemic Spreading in Scale-Free Networks. Physical Review Letters, 86(14): 3200-3203.

Paterson, J., \& Teubner, G. (1998). Changing Maps: Empirical Legal Autopoiesis. Social \& Legal Studies, 7(4): 451-486.

Peeters, B. (2012). Tackling Cross-Border Inheritance Tax Obstacles within the EU. EC Tax Review, 21(2): 54-56.

Peeters, B. (Ed.). (2005). The concept of tax, 2005 EATLP Congress, Naples (Italy). Amsterdam: IBFD. 
Peters, P.J.J.M. (2007). Meerderheidsdeelnemingen: Bestaat er een Rangorde tussen Art. 43 en 56 EG? Weekblad voor Fiscaal recht, 2007(6728): 777.

Pinto, C. (2003). Tax competition and EU law. Dordrecht: Kluwer Law International.

Pistone, P. (2002). The impact of Community law on tax treaties: issues and solutions. Dordrecht: Kluwer Law International.

Pistone, P. (2006). The Impact of European Law on the Relations with Third Countries in the Field of Direct Taxation. INTERTAX, 34(5): 234-244.

Pistone, P. (2008). The search for objective standards in the application of the acte clair doctrine to direct taxation: Some remarks from an Italian perspective. In A.P. Dourado \& R. da Palma Borges (Eds.), The Acte Clair in EC Direct Tax Law (pp. 223-274). Amsterdam: IBFD.

Posner, R.A. (2000). An economic analysis of the use of citations in the law. American Law and Economics Review, 2(2): 381-406.

Post, D.G., \& Eisen, M.B. (2000). How Long Is the Coastline of the Law? Thoughts on the Fractal Nature of Legal Systems. The Journal of Legal Studies, 29(S1): 545-584.

Poulson, M. (2012). Freedom of Establishment and the Balanced Allocation of Tax Jurisdiction. INTERTAX, 40(3): 200-211.

Prebble, J. (2011). Justice Hill and the autopoiesis of income tax law. Victoria University of Wellington Legal Research Papers No 32/2011. Retrieved from SSRN: http://ssrn.com/abstract=1107662

Qazvinian, V., \& Radev, D.R. (2008). Scientific paper summarization using citation summary networks. Paper presented at the Proceedings of the 22nd International Conference on Computational Linguistics - Volume 1.

Qazvinian, V., \& Radev, D.R. (2010). Identifying non-explicit citing sentences for citation-based summarization. Paper presented at the Proceedings of the 48th Annual Meeting of the Association for Computational Linguistics.

Radaelli, C.M. (1997). The politics of corporate taxation in the European Union: knowledge and international policy agendas. London: Routledge.

Radaelli, C.M., \& Kraemer, U.S. (2008). Governance Areas in EU Direct Tax Policy. JCMS: Journal of Common Market Studies, 46(2): 315-336.

Richards, M.J., \& Kritzer, H.M. (2002). Jurisprudential regimes in Supreme Court decision making. American Political Science Review, 96(2): 305-320.

Rixen, T. (2010). From double tax avoidance to tax competition: Explaining the institutional trajectory of international tax governance. Review of International Political Economy, 18(2): 197-227.

Roe, M.J. (1996). Chaos and Evolution in Law and Economics. Harvard Law Review, 109(3): 641-668.

Rogers-Glabush, J. (2012). IBFD International Tax Glossary (electronic edition). Amsterdam: IBFD.

Roxan, I. (2000). Assuring Real Freedom of Movement in EU Direct Taxation. Modern Law Review, 63(6): 831-876.

Ruhl, J.B. (1996). Complexity Theory as a Paradigm for the Dynamical Law-andSociety System: A Wake-Up Call for Legal Reductionism and the Modern Administrative State. Duke Law Journal, 45(5): 849-928. 
Ruhl, J.B. (2009). Law's Complexity: A Primer. Georgia State University Law Review, 24(4): 885-991.

Rust, A. (Ed.). (2011). Double Taxation within the European Union. Alphen aan den Rijn: Kluwer Law International.

Sassoli de Biachi, M. (2012). The observer effect. arXiv: 1109.3536v3.

Schaper, M.G.H. (2009). De Zaak Renneberg: Return to Sender? Maandblad Belastingbeschouwingen, 2009(2): 51-70.

Schmidt, S.K. (2000). Only an Agenda Setter? European Union Politics, 1(1): 3761.

Schmidt, S.K. (2012). Who cares about nationality? The path-dependent case law of the ECJ from goods to citizens. Journal of European Public Policy, 19(1): 8-24.

Schön, W. (2008). Loosing out on the snooker table: Cross-border loss compensation for PEs and the fundamental freedoms. In L. Hinnekens \& P. Hinnekens (Eds.), A vision of taxes within and outside European borders (pp. 813-830). Alphen aan den Rijn: Kluwer Law International.

Siems, M.M. (2008). Legal Originality. Oxford Journal of Legal Studies, 28(1): 147164.

Siems, M.M. (2010a). Citation Patterns of the German Federal Supreme Court and the Court of Appeal of England and Wales. King's Law Journal, 21(1): 152-171.

Siems, M.M. (2010b). The Web of Creditor and Shareholder Protection in 25 Countries: A Comparative Legal Network Analysis. Arizona Journal of International and Comparative Law, 27(3): 747-785.

Siems, M.M. (2011). Measuring the Immeasurable: How to Turn Law into Numbers. In M. Faure \& J. Smits (Eds.), Does Law Matter: On Law and Economic Growth (pp. 115-136). Antwerp: Intersentia.

Smit, D.S. (2005). Capital Movements and Direct Taxation: the Effects of the Nondiscrimination Principles. EC Tax Review, 14(3): 128-139.

Smit, D.S. (2006). Capital Movements and Third Countries: the Significance of the Standstill-Clause ex-Article 57(1) of the EC Treaty in the Field of Direct Taxation. EC Tax Review, 15(4): 203-214.

Smit, D.S. (2007). The Relationship Between the Free Movement of Capital and the Other EC Treaty Freedoms in Third Country Relationships in the Field of Direct Taxation: a Question of Exclusivity, Parallelism or Causality? EC Tax Review, 16(6): 252-267.

Smit, D.S. (2011). Freedom of Investment between EU and non-EU Member States and its impact on Corporate Income Tax Systems within the European Union. Unpublished Dissertation, Tilburg University, Tilburg.

Smit, D.S. (2012). EU Freedoms, Non-EU Countries and Company Taxation: An Overview and Future Prospect. EC Tax Review, 21(5): 233-247.

Smith, M., Milic-Frayling, N., Shneiderman, B., Mendes Rodrigues, E., Leskovec, J., \& Dunne, C. (2010). NodeXL: a free and open network overview, discovery and exploration add-in for Excel 2007/2010, http://nodexl.codeplex.com/: The Social Media Research Foundation, http://www.smrfoundation.org.

Smith, T. (2007). The web of law. San Diego Law Review, 44(2): 309-354.

Snell, J. (2007). Non-discriminatory Tax Obstacles in Community Law. International and Comparative Law Quarterly, 56(2): 349-370. 
Snell, J. (2010). The Notion of Market Access: A Concept or a Slogan? Common Market Law Review, 47(2): 437-472.

Snell, J. (2011). Free Movement of Capital: Evolution as a Non-linear Process. In P. Craig \& G. de Búrca (Eds.), The Evolution of EU Law (2 ed., pp. 547-574). Oxford: OUP.

Solanke, I. (2011). 'Stop the ECJ'?: An Empirical Analysis of Activism at the Court. European Law Journal, 17(6): 764-784.

Sørensen, K.E. (2006). Abuse of rights in Community law: a principle of substance or merely rhetoric? Common Market Law Review, 43(2): 423-459.

Spies, K. (2012). Influence of International Mutual Assistance on EU Tax Law. INTERTAX, 40(10): 518-530.

Staringer, C. (2007). Where does foreign loss utilization go in Europe? Steuer \& Wirtschaft International, 17(1): 5-11.

Stein, E. (1981). Lawyers, Judges, and the Making of a Transnational Constitution. American Journal of International Law, 75(1): 1-27.

Stone Sweet, A. (2004). The Judicial Construction of Europe. Oxford: OUP.

Stone Sweet, A. (2007). The Juridical Coup d'État and the Problem of Authority. German Law Journal, 8(10): 915-928.

Stone Sweet, A. (2010). The European Court of Justice and the judicialization of EU governance. Living Reviews in European Governance, 5: 2. Retrieved from http://www.livingreviews.org/lreg-2010-2

Stone Sweet, A. (2011). The European Court of Justice. In P. Craig \& G. de Búrca (Eds.), The Evolution of EU Law (2 ed., pp. 121-153). Oxford: OUP.

Stone Sweet, A., \& Brunell, T. (2012). The European Court of Justice, State Noncompliance, and the Politics of Override. American Political Science Review, 106(1): 204-213.

Stone Sweet, A., \& McCown, M. (2003). Discretion and Precedent in European Law. In O. Wiklund (Ed.), Judicial Discretion in European Perspective (pp. 84115). Stockholm: Kluwer Law International.

Strandburg, K.J., Csardi, G., Tobochnik, J., Erdi, P., \& Zalanyi, L. (2007). Law and the Science of Networks: An Overview and an Application to the 'Patent Explosion'. Berkely Technology Law Journal, 21(4): 1293-1362.

Strandburg, K.J., Csardi, G., Tobochnik, J., Erdi, P., \& Zalanyi, L. (2009). Patent Citation Networks Revisited: Signs of a Twenty-First Century Change? North Carolina Law Review, 87(5): 1657-1698.

Strogatz, S.H. (2001). Exploring complex networks. Nature, 410(6825): 268-276.

Stumpf, M.P.H., Wiuf, C., \& May, R.M. (2005). Subnets of scale-free networks are not scale-free: Sampling properties of networks. Proceedings of the National Academy of Sciences of the United States of America, 102(12): 4221-4224.

Szudocky, R. (2009). How does the European Court of Justice treat precedents in its case law? Cartesio and Damseaux from a different perspective: Part 1. INTERTAX, 32(6/7): 346-362.

Szudocky, R., \& Van de Streek, J.L. (2010). Revisiting the Dutch Interest Box under the EU State Aid Rules and the Code of Conductive: When a 'Disparity' is Selective and Harmful. INTERTAX, 38(5): 260-280. 
Tenore, M. (2010). Taxation of Cross-Border Dividends in the European Union from Past to Future. EC Tax Review, 19(2): 74-84.

Terra, B.J.M., \& Wattel, P.J. (2008). European Tax Law. Deventer: Kluwer.

Terra, B.J.M., \& Wattel, P.J. (2012). European Tax Law. Deventer: Kluwer.

Teubner, G. (1993). Law as an Autopoietic System. London: Blackwell.

Tippelhofer, M., \& Lohmann, A. (2008). Niederlassungsfreiheit vs. Kapitalverkehrsfreiheit: Analyse der jüngeren Rechtsprechung des EuGH zu den direkten Steuern. Internationales Steuerrecht, 2008(24): 857-864.

Tjon Tjin Tai, E., \& Teuben, K. (2008). European Precedent Law. European Review of Private Law, 16(5): 827-841.

Toth, A.G. (1984). The Authority of Judgments of the European Court of Justice: Binding Force and Legal Effects. Yearbook of European Law(4): 1-77.

Travers, J., \& Milgram, S. (1969). An Experimental Study of the Small World Problem. Sociometry, 32(4): 425-443.

Tribe, L.H. (1989). The Curvature of Constitutional Space: What Lawyers Can Learn from Modern Physics. Harvard Law Review, 103(1): 1-39.

Tridimas, T. (2006). The General Principles of EU Law. Oxford: OUP.

Tryfonidou, A. (2010). Further steps on the road to convergence among the market freedoms. European Law Review, 35(1): 36-56.

Ugander, J., Karrer, B., Backstrom, L., \& Marlow, C. (2011). The Anatomy of the Facebook Social Graph. arXiv: 1111.4503v1.

Ulen, T. (2002). Nobel Prize in Legal Science: Theory, Empirical Work, and the Scientific Method in the Study of Law. University of Illinois Law Review, 2002(4): 875-920.

Usher, J.A. (2008). The Evolution of the Free Movement of Capital. Fordham International Law Journal, 31: 1533-1570.

van Dam, J., \& van Eijsden, A. (2010a). The Impact of European Law on Domestic Procedural Tax Law: Wrongfully Underestimated? EC Tax Review, 19(5): 199209.

van Dam, J., \& van Eijsden, A. (2010b). Possibilities and Impossibilities for Challenging Final Tax Assessments and Decisions in Tax Cases that Contravene EC Law. EC Tax Review, 19(6): 247-258.

van der Kroon, M.G.H. (2010). Het Baarscriterium Krijgt Invulling. Weekblad voor Fiscaal recht, 2010(6847): 229.

van der Mei, A.P. (2011). The Outer Limits of the Prohibition of Discrimination on Grounds of Nationality: A Look Through the Lens of Union Citizenship. Maastricht Journal of European and Comparative Law, 18(1-2): 62-18.

Van Thiel, S. (2002). Free Movement of Persons and Income Tax Law: The European Court in Search of Principles. Amsterdam: IBFD.

Van Thiel, S. (2007a). Why the ECJ Should Interpret Directly Applicable European Law as a Right to Intra-Community Most-Favoured-Nation Treatment - Part 1. European Taxation, 47(6): 263-269.

Van Thiel, S. (2007b). Why the ECJ Should Interpret Directly Applicable European Law as a Right to Intra-Community Most-Favoured-Nation Treatment - Part 2. European Taxation, 47(7): 314-327. 
Van Thiel, S. (2008a). The direct income tax case law of the European Court of Justice: Past trends and future developments. Tax Law Review, 62(1): 143-192.

Van Thiel, S. (2008b). Justifications in Community Law for Income tax Restrictions on Free Movement: Acte Clair Rules That Can Be Readily Applied by National Courts - Part 1. European Taxation, 48(6): 279-290.

Van Thiel, S. (2008c). Justifications in Community law for income tax restrictions on free movement: Acte clair rules that can be readily applied by national courts - part 2. European Taxation, 48(7): 339-350.

Van Thiel, S., \& Vascega, M. (2010). X Holding: Why Ulysses Should Stop Listening to the Siren. European Taxation, 50(8): 334-349.

Vanistendael, F. (2005). Cohesion: the phoenix rises from the ashes. EC Tax Review, 14(4): 208-222.

Vanistendael, F. (2006a). The ECJ at the crossroads: Balancing tax sovereignty against the imperatives of the internal market. European Taxation, 46(9): 413420.

Vanistendael, F. (2006b). Halifax and Cadbury Schweppes: One Single European Theory of Abuse in Tax Law? EC Tax Review, 15(4): 192-195.

Vanistendael, F. (2007). Common (tax) law of the ECJ. EC Tax Review, 16(6): 250251.

Vanistendael, F. (2008a). Does the ECJ have the power of interpretation to build a tax system compatible with the fundamental freedoms? EC Tax Review, 17(2): 52-66.

Vanistendael, F. (2008b). In defence of the European Court of Justice. Bulletin for International Taxation, 62(3): 90-100.

Vanistendael, F. (2010). Taxation and Non-Discrimination, A Reconsideration of Withholding Taxes in the OECD. World Tax Journal, 2(2): 175-191.

Verdoner, L. (2009). The Coherence Principle under EC Tax Law. European Taxation, 49(5): 274-282.

Vermeend, W. (1996). The Court of Justice of the European Communities and direct taxes: 'Est-ce que la justice est de ce monde'? EC Tax Review, 5(2): 54-55.

Voeten, E. (2010). Borrowing and nonborrowing among international courts. Journal of Legal Studies, 39(2): 547-576.

Völker, D. (2009). Kapitalverkehrsfreiheit für Drittstaatendividenden - Widerspruch zur BFH-Rechtsprechung oder Bestätigung des BFH durch den EuGH-Beschluss vom 4. 6. 2009? Internationales Steuerrecht, 2009(20): 705-709.

Von Bogdandy, A. (2009). Founding Principles. In A. Von Bogdandy \& J. Bast (Eds.), Principles of European Constitutional Law (2 ed., pp. 11-54). Oxford: Hart Publishing.

Von Bogdandy, A. (2010). Founding Principles of EU Law: A Theoretical and Doctrinal Sketch. European Law Journal, 16(2): 95-111.

Von Bogdandy, A., Riedel, E., \& Wolfrum, R. (2006). Constitutional Principles for Europe. Recent Trends in German and European Constitutional Law (Vol. 188, pp. 1-35): Springer Berlin Heidelberg.

Wallace, M.L., Gingras, Y., \& Duhon, R. (2009). A new approach for detecting scientific specialties from raw cocitation networks. Journal of the American Society for Information Science and Technology, 60(2): 240-246. 
Wathelet, M. (2004). Direct taxation and EU law: integration or disintegration? EC Tax Review, 13(1): 2-4.

Wathelet, M. (2006). Marks \& Spencer plc v Halsey: Lessons to be drawn. British Tax Review, 2006(2): 128-134.

Wathelet, M. (2008). Tax sovereignty of the Member States and the European court of Justice: New trends or confirmations? In L. Hinnekens \& P. Hinnekens (Eds.), $A$ vision of taxes within and outside European borders (pp. 905-929). Alphen aan den Rijn: Kluwer Law International.

Wattel, P. (2007). Fiscal cohesion, fiscal territoriality and preservation of the (balanced) allocation of taxing power; what is the difference? In D. Weber (Ed.), The influence of European law on direct taxation: Recent and future developments (pp. 139-156). Alphen aan den Rijn: Kluwer Law International.

Wattel, P. (2008). Judicial constraint and the three trends in the ECJ's direct tax case law. Tax Law Review, 62(1): 205-219.

Wattel, P.J. (1996). The EC Court's attempts to reconcile the Treaty freedoms with international tax law. Common Market Law Review, 33(2): 223-254.

Wattel, P.J. (2004). Red Herrings in Direct Tax Cases before the ECJ. Legal Issues of Economic Integration, 31(2): 81-95.

Wattel, P.J. (2008). National Procedural Autonomy and Effectiveness of EC Law: Challange the Charge, File for Restitution, Sue for Damages? Legal Issues of Economic Integration, 35(2): 109-132.

Watts, D.J. (1999). Networks, Dynamics, and the Small-World Phenomenon. American journal of sociology, 105(2): 493-527.

Watts, D.J., \& Strogatz, S.H. (1998). Collective dynamics of 'small-world' networks. Nature, 393(6684): 440-442.

Weber, D. (2003). The Bosal Holding Case: Analysis and Critique. EC Tax Review, 12(4): $220-230$.

Weber, D. (2004). Abuse of Law: European Court of Justice, 14 December 2000, Case C-110/99, Emsland-Stärke. Legal Issues of Economic Integration, 31(1): 43-55.

Weber, D. (2005). Tax Avoidance and the EC Treaty Freedoms. The Hague: Kluwer Law International.

Weber, D. (2006). In search of a (new) equilibirum between tax sovereignty and the freedom of movement within the EC. Intertax, 34(12): 585-616.

Weber, D. (Ed.). (2010). Traditional and Alternative Routes to European Tax Integration. Amsterdam: IBFD.

Weber, D., \& Davits, F. (2008). The practical application of the acte éclairé and the acte clair doctrine (with reference to Netherlands direct tax law). In A.P. Dourado \& R. da Palma Borges (Eds.), The Acte Clair in EC Direct Tax Law (pp. 275-320). Amsterdam: IBFD.

Weber, D., \& Spierts, E. (2004). The "D Case": Most-Favoured-Nation Treatment and Compensation of Legal Costs before the European Court of Justice. European Taxation, 44(2): 65-71.

Weiler, J.H.H. (1991). The Transformation of Europe. Yale Law Journal, 100(8): 2403-2483.

Wiarda, G.J. (1999). Drie typen van rechtsvinding (4 ed.). Deventer: Kluwer. 
Wiklund, O. (2003). Taking the World View of the European Judge Seriously some reflections on the role of ideology in adjucation. In O. Wiklund (Ed.), Judicial Discretion in European Perspective (pp. 29-47). Stockholm: Kluwer Law International.

Wind, M. (2010). The Nordics, the EU and the Reluctance Towards Supranational Judicial Review. JCMS: Journal of Common Market Studies, 48(4): 1039-1063.

Wind, M., Martinsen, D.S., \& Rotger, G.P. (2009). The Uneven Legal Push for Europe. European Union Politics, 10(1): 63-88.

Winkels, R., de Ruyter, J., \& Kroese, H. (2011). Determining authority of Dutch Case Law. Legal Knowledge and Information Systems, 235: 103-112.

Wollenschläger, F. (2011). A New Fundamental Freedom beyond Market Integration: Union Citizenship and its Dynamics for Shifting the Economic Paradigm of European Integration. European Law Journal, 17(1): 1-34.

Wunderlich, N., \& Blaschke, C. (2008). Die Gewährleistung der Kapitalverkehrsfreiheit in Bezug auf Drittstaaten - Neuere Entwicklungen in der Rechtsprechung des EuGH. Internationales Steuerrecht, 2008(21): 754-762.

Zalasinski, A. (2007). Proportionality of Anti-Avoidance and Anti-Abuse Measures in the ECJ's Direct Tax Case Law. INTERTAX, 35(5): 310-321.

Zalasinski, A. (2008). Some Basic Aspects of the Concept of Abuse in the Tax Case Law of the European Court of Justice. INTERTAX, 36(4): 156-167.

Zalasinski, A. (2009). The Limits of the EC Concept of 'Direct Tax Restriction on Free Movement Rights', the Principles of Equality and Ability to Pay, and the Interstate Fiscal Equity. INTERTAX, 37(5): 282-297.

Zhang, L., Liu, X., Janssens, F., Liang, L., \& Glänzel, W. (2010). Subject clustering analysis based on ISI category classification. Journal of Informetrics, 4(2): 185193.

Zhu, H., Wang, X., \& Zhu, J.-Y. (2003). Effect of aging on network structure. Physical Review E, 68(5): 056121.

Zorn, N. (2010). Nochmals: Kapitalverkehrsfreiheit für Drittstaatendividenden Eine Reaktion auf den Beitrag von Dietmar Völker in IStR 2009, 705 ff. Internationales Steuerrecht, 2010(6): 190-195. 



\section{Curriculum Vitae}

Marcel Schaper was born in Heerlen, the Netherlands on 2 August 1983. He attended grammar school (VWO Gymnasium) at College Rolduc (now: Charlemagne College) in Kerkrade, the Netherlands until he started university education in 2001. In September 2006, Marcel graduated with a master degree in economics and a master of laws degree in international and European tax law (cum laude) from Maastricht University. He worked as a research assistant for Prof. Dr Rainer Prokisch during his studies. After graduation until September 2012, Marcel worked as a junior researcher in the Faculty of Law of Maastricht University. During that period he gained extensive experience in teaching courses at the Faculty of Law, as well as at the School of Business and Economics, in (tax) accounting, and international and European tax law at a bachelor and master level, in Dutch and in English. From September 2007 until September 2009, he served as one of six elected academic staff members in the University Council. From 2007 until 2010, Marcel also was the faculty representative of Maastricht University in the $\mathrm{PhD}$ Council of the Ius Commune Research School of which he has been a member since 2007. In September 2012, Marcel was appointed assistant professor of law in Maastricht University. 